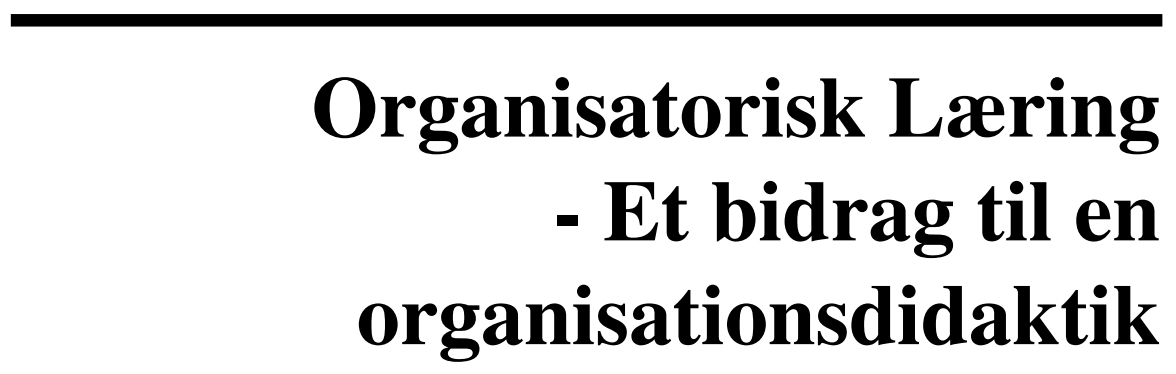





\title{
Organisatorisk Læring - Et bidrag til en organisationsdidaktik
}

\author{
Ph.d.-afhandling \\ Henrik Vardinghus-Nielsen \\ Aalborg Universitet, \\ Det Sundhedsvidenskabelige Fakultet
}


ISBN 978-87-93237-32-2 (Ebook)

ISBN 978-87-93237-33-9 (Paperback)

Published, sold and distributed by:

River Publishers

Niels Jernes Vej 10

9220 Aalborg Ø

Denmark

Tel.: +45369953197

www.riverpublishers.com

Copyright for this work belongs to the author, River Publishers have the sole right to distribute this work commercially.

All rights reserved (c) 2014 Henrik Vardinghus-Nielsen.

No part of this work may be reproduced, stored in a retrieval system, or transmitted in any form or by any means, electronic, mechanical, photocopying, microfilming, recording or otherwise, without prior written permission from the Publisher. 


\section{Indholdsfortegnelse}

Forod $x i$

Kapitel 1: Indledning og forskningsinteresse 1

Kort om empirien . . . . . . . . . . . . . . . 3

Afhandlingens overordnede tilgang ....... 5

Problemformulering ............... 8

Kapitel 2: Didaktik 9

Samfundets uddannelsessystem, pædagogik og didaktik . . . . . 9

Præsentation af pædagogik . . . . . . . . . . . 11

Didaktik . . . . . . . . . . . . . . 13

Samfundet uddannelsessystem . . . . . . . . . . . . . . 14

Uddannelsessystemets primære og sekundære funktion . . 14

Uddannelsessystemet som symbolsk generaliseret

kommunikationsmedie . . . . . . . . . . . 18

Uddannelsessystemets ydelse . . . . . . . . . . . 21

Mening .................... 23

Sproget, udbredelsesmedier og symbolsk generaliserede

kommunikationsmedier . . . . . . . . . . . 24

Didaktisk teori . . . . . . . . . . . . . . 25

Dannelse ...................... 26

Didaktiske tilgange . . . . . . . . . . . 30

Uddannelse og undervisning som kommunikation . . . . 31

Afhandlingens erkendelsesinteresse og videnskabelige

iagttagelses position . . . . . . . . . . . . 35

Organisationssociologisk positionering - et

udgangspunkt . . . . . . . . . . . . . . 37

Fænomenologisk-systemteoretisk 'approach' . . . . . . 39

Formen iagttagelse . . . . . . . . . . . . . . . . 40

Iagttagelse af organisatorisk læring . . . . . . . . . . 42

Organisation, organisatorisk læring og teknologi . . . . 44

To tilgange til organisatorisk læring $\ldots \ldots 53$ 
Kapitel 3: Organisatorisk læring

Beskrivelse af organisatorisk læring som populær organisationskoncept . . . . . . . . . . 57

Historisk udvikling af organisatorisk læring . . . . . . . 60

Sociologi, samfund og organisation . . . . . . . . 63

Argyris \& Schöns samfundsbegreb . . . . . . . . . . . . . . 66

Senges samfundsbegreb . . . . . . . . . 67

Kapitel 4: Sociologi, samfund og organisation $\quad 71$

Webers normative samfundsprojekt . . . . . . . . . . 72

Durkheims samfundsforståelse . . . . . . . . . . . . . 74

Individualisering som kompleksitetstilvækst . . . . . . 76

Luhmann samfundsforståelse . . . . . . . . . . . . . . . . . 79

Segmentært differentiereret samfundsform . . . . . . 79

Centrum-periferi differentieret samfundsform . . . . . 80

Stratifikatorisk differentieret samfundsform . . . . . . . 81

Funktionelt differentieret samfundsform . . . . . . . . 82

Samfundets udvikling som irritation af systemer . . . . 86

Styringsproblemer - kompleksitet, kontingens,

systemdifferentiering . . . . . . . . . . . . . . 88

Funktion, ydelse og refleksion . . . . . . . . . . . . 90

Organisationer som samfundets handlesystemer . . . . . 100

Funktion, ydelse, refleksion og didaktik . . . . . . . . 103

Organisationssociologisk positionering . . . . . . 103

Kapitel 5: Pædagogisk iagttagelse af organisatorisk læring $\begin{array}{ll}\text { som sprog og kommunikation } & 117\end{array}$

Organisatorisk læring og kommunikation . . . . . . . . 118

Pædagogisk epistemologisk iagttagelsesposition . . . . . . . . . 119

Habermas og kommunikation . . . . . . . . . . . . . . 121

Den ideale samtalesituation . . . . . . . . . . . 123

Kritik af den sproglige forståelse af kommunikation . . . 125

Konsensus og organisatorisk læring . . . . . . . . . . 126

Anvendeligheden af Habermas . . . . . . . . . . . 127

Luhmanns sprog og kommunikationsforståelse . . . . . . . . 128

Luhmanns sprogforståelse . . . . . . . . . . . . . 128

Luhmanns kommunikationsbegreb . . . . . . . . . . . 130

Det sociales usandsynlighed . . . . . . . . . . . . 131

Dobbelt kontingens . . . . . . . . . . . . . . . . . 132 
Kommunikation som selektion (information, meddelelse og forståelse) . . . . . . . . . . . . . 135

Kommunikationens fjerde selektion . . . . . . . . 137

Organisatorisk læring og kommunikationens fjerde selektion . . . . . . . . . . . . . . 138

Pædagogisk iagttagelse af Nonaka \& Takeuchis

kommunikationsforståelse . . . . . . . . . . . . . . 139

Analog kommunikation og tavs- og eksplicit viden . . . 139

Figurativt sprogbrug og deling af viden . . . . . . . . 141

Syntese af kommunikationsforståelser . . . . . . . . . . 142

Kapitel 6: Teorien om sociale systemer $\quad 145$

Autopoiesis og system/omverden . . . . . . . . . . . 147

Systemteoretisk læring . . . . . . . . . . . . . . . . . . . 149

Argyris og Schön - organisatorisk læring . . . . . . . . 151

Analyse af ambivalenser i organisatorisk læring . . . . . 153

Individuel og organisatorisk læring . . . . . . . . . . 154

Operativ lukning og strukturel kobling . . . . . . . . . 156

Sociale systemtyper . . . . . . . . . . . . . . . . . 158

Samfundssystemet som systemtype . . . . . . . . . 159

Interaktionssystemer . . . . . . . . . . . . . . . . 159

Sociale systemers iagttagelse af psykiske systemer personer og roller . . . . . . . . . . . . . . 162

Organisationsbegrebet $\mathrm{i}$ et sociokulturelt perspektiv . . . . . . . . . . . 165

Wengers praksisfællesskab som organisation . . . . . . . . 168

Wengers institutionsbegreb som organisation? . . . . . . 170

Opsummering af teorien om praksisfællesskaber . . . . 172

Beslutning som organisationsteoretisk begreb . . . . . . . . 175

Den tidlige beslutningsteori . . . . . . . . . 176

Organisatorisk læring og beslutning . . . . . . . . . . 178

Argyris og Schön's organisationsbegreb som

beslutning . . . . . . . . . . . . . . . . . . . 179

Systemteorien organisationsbegreb . . . . . . . . . . . . 181

Beslutningsbegreb som organisation . . . . . . . . . 182

Funktionelt ledet analyseform . . . . . . . . . . . . . . . 184

Beslutning . . . . . . . . . . . . . . 185

Organisation som fire forhold . . . . . . . . . . . . . . 189

Beslutningsprogrammer . . . . . . . . . . . . . 191 
Konditionering . . . . . . . . . . . . . . 192

Konditionering og intern differentiering . . . . . . . . 193

Ledelse . . . . . . . . . . . . . . . . . . . . . 194

Ledelsesansvar, programmer og mål . . . . . . . . . . 195

Kapitel 7: Værdier, kommunikation og organisatorisk læring 197

Organisationer, værdier og omverden . . . . . . . . . 198

Funktionel uddifferentiering og værdier . . . . . . . . . 199

Systemteoriens værdibegreb . . . . . . . . . . . . . . . 203

Formteoretisk værdibegreb . . . . . . . . . . . . . . 204

Værdier, motivation og selektion . . . . . . . . . . 206

Værdier, autopoiesis, blindhed og negation . . . . . . 207

Kultur og værdier . . . . . . . . . . . . . . . 210

Konflikt, modsigelse, værdier og læring . . . . . . . . 213

Forventninger til forventninger . . . . . . . . . . . . 218

Læring som selvtilpasning . . . . . . . . . . . . 219

Læring, struktur, hændelse og proces . . . . . . . . 221

Værdier, stabilitet, forandring og refleksion . . . . . . . 222

Værdier og beslutningsprogrammer . . . . . . . . . . 224

\section{Kapitel 8: Præsentation af empiri og organisationsdidaktisk}

\section{analysemodel 229}

Præsentation af empiri . . . . . . . . . . . . . . . . 229

Strategi for implementering af VBL . . . . . . . . . . 230

Kontakt til Kommunen . . . . . . . . . . . . . . . . . 231

Organisationsdiagram over kommunen . . . . . . . . 231

Organisationsdidaktisk analysemodel . . . . . . . . . . . 233

Funktionel analytisk form . . . . . . . . . . . . . . 234

Undervisnings- og læringsmål . . . . . . . . . . . . 235

Funktion, ydelse og refleksion . . . . . . . . . . . 235

Læring og konditioneringsprogrammer . . . . . . . 237

Organisationsdidaktiske temaer . . . . . . . . 237

Komparation - det generelle og det specifikke . . . . . . 238

Systematisering og anvendelse af empiri . . . . . . . 238

Kapitel 9: Analyse 241

Uddifferentiering af ledelse - selvledelse . . . . . . . . . . 242

Park og natur . . . . . . . . . . . . . . . . . . 243

Gartnernes refleksioner over selvledelse . . . . . . . . 244 
Indholdsfortegnelse ix

Opsummering på Park og natur . . . . . . . . . . . . . . . . . 249

Områdecentret . . . . . . . . . . . . . . . . . 252

Områdecentrets refleksioner over selvledelse . . . . . 256

Selvledelse som kilde til reduktion af og dannelse

af ny kompleksitet . . . . . . . . . . . . . 258

Reduktion af ledelseskompleksitet . . . . . . . . . . 262

Semantik om ydelsesområdet som et beslutningsproblem . . . . . . . . . . . . . 267

Læring relateret til semantik om ydelsesområdet som et beslutningsproblem . . . . . . . . . . . . 271

Reduktion af arbejds- og arbejdstidskompleksitet . . . . 272

Vidensdeling som differentieringsstrategi . . . . . . . . 274

Kompleksitetsreduktion, faglighed, autonomi og hierarki . . . . . . . . . . . . . 281

Opsummering på Områdecentret . . . . . . . . . . . . . . . . . 290

Konklusion

English Summary - Abstract 



\section{Forord}

Denne afhandling har været længe undervejs, og der er i den forbindelse en række omstændigheder, jeg gerne vil fortælle om, og ikke mindst en række mennesker, som jeg gerne vil takke.

Jeg blev i 2001 ansat som ph.d.-studerende på, hvad der dengang hed Videncenter for Læreprocesser ved Aalborg Universitet. Mit projekt var indskrevet under overskriften organisatorisk læring, og min empiri blev et værdibaseret ledelsesprojekt i en større dansk kommune. Ideen var på det tidspunkt at iagttage værdibaseret ledelse som et udtryk for organisatorisk læring. Denne ide blev aldrig realiseret, men i arbejdet med afhandlingen og sammen med kollegaer, spirede der en ide frem om, hvorvidt det var muligt at udvikle en alternativ måde at iagttage organisatorisk læring på, nærmere betegnet gennem en organisationsdidaktisk tilgang. I 2005 blev jeg ansat som adjunkt og senere lektor ved University College Nordjylland med undervisningopgaver og opgaver inden for forskningsformidling. I løbet af de næste år begyndte ideen om og motivationen for at skrive denne afhandling at spire. Derfor var det heldigt og glædeligt, at jeg i efteråret 2010 blev kontaktet af Aalborg Universitet med henblik på at gøre afhandlingen færdig. I foråret 2011 blev jeg således ansat på Det Sundhedsvidenskabelige fakultet, med placering på Institut for Læring og Filosofi. Denne ansættelse har været en slags kombinationsstilling med undervisningsopgaver og færdiggørelse af afhandlingen. Det har været hårdt, men jeg er taknemlig for, at det har kunnet lade sig gøre. Der er derfor en række mennesker, som jeg gerne vil takke.

En meget stor tak til Professor Annette Lorentsen, Institutleder på Institut for Læring og Filosofi, for din umiddelbare tro på projektet, og din fortsatte støtte til mig. En stor tak til Lone Stoustrup, Chefkonsulent på Institut for Læring og Filosofi, for at du utrætteligt og gennem mange år troede på mig og mit projekt - uden det var det aldrig blevet til noget! Tak til Professor Lars Qvortrup for altid villighed til at diskutere og læse mindre bidder af afhandlingen. Endelig en meget stor tak til min vejleder Professor Erik Laursen, der hele vejen har bakket op om min beslutning om at tage afhandlingen op igen. 


\section{xii Forord}

Slutteligt vil jeg takke vores børn Frederik og Ida for forståelse for projektet. Frederik og Ida har under hele processen spurgt interesseret til, hvordan det går, og har således været mere nærværende end deres far! Til sidst vil jeg takke min kone Maria Appel Nissen for altid at være der, tro på mig, og opmuntre mig, også når det ikke lige var så sjovt. Tak for din vilje til at kaste andre opgaver fra dig, og give dig tid til at snakke og diskutere. Tak fordi du af alle har gjort det muligt for mig at skrive denne afhandling.

April 2013, Kælderen på Mølleparkvej

Henrik Vardinghus-Nielsen 


\section{Indledning og forskningsinteresse}

Denne afhandling handler om og skriver sig ind i feltet og forskningstraditionen organisatorisk laring. Der er efterhånden skrevet og forsket temmelig meget i organisatorisk læring. De fleste er bekendte med begrebet organisatorisk laering eller den laerende organisation. Hele grundforudsætningen for at tale om organisatorisk er, at organisationer lærer! Men hvordan lærer man en organisation at lære? Eller hvordan lærer organisationer selv at lære, dvs. at lære sig selv at lære? Det er pædagogiske spørgsmål, som ikke alene kan besvares med et begreb om læring. Det indbefatter refleksioner over forholdet mellem undervisning og laering, dvs. refleksioner over, hvordan man lærer nogen noget! Med et sådant spørgsmål eller problemerkendelse skal man måske hellere tale om den padagogiske organisation! Eller den undervisende organisation! Det er sådan "noget", denne afhandling interesserer sig for og $\emptyset$ nsker at vide noget om. I denne afhandling vil der blive skrevet om den didaktiske organisation, eller mere præcist en organisationsdidaktik.

Formålet med afhandlingen er på baggrund af teoretiske og empirisk eksemplificerende analyser at diskutere, udvikle og præsentere et sociologisk og pædagogisk perspektiv på organisatorisk læring. Det er afhandlingens intention at udvikle en videnssociologisk inspireret organisationsdidaktik. Med videnssociologisk henvises der til det generelle forhold, at videnssociologien beskæftiger sig med og unders $\varnothing$ ger, hvorledes tilvejebringelse og udbredelse af viden indgår som et led i det sociale liv, herunder organisationers. Grundspørgsmålene for videnssociologien er på den ene side, hvorledes tænkning, idéer og forestillinger til enhver tid er præget af de samfundsforhold, hvori de er dannet, på den anden side, hvilken rolle viden spiller for samfundets og organisationers virkemåde og udvikling (Berger \& Luckmann 1999; Harste \& Mortensen 1996; www.denstoredanske.dk).

Der kan indenfor teorier om organisatorisk læring spores flere forskellige tilgange, som, udover at forholde sig til organisationer identificeret

som lærende individer, systemer, fællesskaber eller konstellationer, supplere 
med begreber om viden, mening, kultur eller kommunikative konstellationer (Jørgensen 2007; Wenger 2004; Elkjær 1999; 2005; Gherardi \& Nicolini 2001). Disse epistemologier kan betragtes som forsøg på at danne mere adækvate forståelser af organisatorisk udvikling, forandring og læring i organisationer. Tilgangene supplerer eller erstatter hermed det individuelle perspektiv med begreber om forskellige arenaer, hvor mening og viden konstrueres og forhandles mere eller mindre autonomt i forskellige kontekster. Hovedindsigten er således, at mening og virkelighedsforståelse tones, konstrueres eller udlægges forskelligt med henvisning til sådanne lokale og kontekstuelle meningskonstruktioner (Jørgensen 2007; Wenger 2004; Gherardi \& Nicolini 2001; Elkjær 1999; 2005; Dixon 1999; Gherardi \& Nicolini 2001).

Organisationsteorien har med begreberne om Den larende organisation og Organisatorisk laring ladet sig inspirere af begrebet om læring; Et begreb som oprindeligt stammer fra filosofien og psykologien, og som står centralt indenfor pædagogisk tænkning, teori og forskning. ${ }^{1}$ Når organisationer skal forandres og lære, kan en strategi være at benytte sig af konsulent bistand. ${ }^{2}$ En anden gammel kendt strategi er at sende medarbejderne på kursus, hvor de tilegner sig den viden og de kompetencer, som organisationen efterspørger. I forlængelse af dette forventes det, at medarbejderne efterfølgende integrerer den nye viden og de erhvervede kompetencer i organisationens arbejde, således at organisationen får det forventede udbytte. Men studier har vist, at dette ikke bare sker helt automatisk, og at organisationer oplever, at de ikke får det fulde udbytte af medarbejderkurserne, hvorfor det tværtimod kan være en god ide at have strategier for, hvordan denne nye (medarbejder) viden integreres bedst $\mathrm{i}$ forskellige former for arbejdsprocesser f.eks. gennem aktiv eksperimentering og refleksion (Larsen et al. 2006). Dette involverer ikke bare, at den enkelte medarbejder foretager prioriteringer i relation til eget arbejde, men at organisationen anerkender og prioriterer muliggørelsen af sådanne metodiske strategier for kompetence udvikling. Et andet aspekt vedrører ændrede tilgange til organisationens arbejde på baggrund af ny viden og kompetence udvikling. Den amerikanske forsker Harold J. Leavitt

\footnotetext{
${ }^{1}$ Jens Rasmussen skriver f.eks. ”Den moderne pædagogiks teoretiske grundlæggere er, uanset deres forskelligheder i øvrigt, optaget af det samme problem: Hvordan sikrer man sig, at eleven ikke kun får kendskab til det stof, der undervises i; men at han eller hun også kommer til at forstå det." (Rasmussen 1996 s. 94).

${ }^{2}$ I en rapport lavet af Lektor Kent Nielsen fra Handelshøjskolen i Århus om Viborg Amts anvendelse af de erhvervspolitiske programmer Udviklingskompas og Chef til leje konkluderes der, at de virksomheder, som har deltaget i projektet, har vist bedre præstationer end de virksomheder, der ikke har deltaget (Nielsen 2005 s. 23).
} 
tematiserede allerede i 1965 med sin dynamiske diamantmodel for forståelsen af organisationer (identificeret ved deltagere, socialstruktur, teknologi og mål) det forhold, at når der sker forandringer i én dimension i organisationen, vil det næsten helt naturligt betyde forandringer i andre dele af organisationen (Borum 1995 s. 29).

\section{Kort om empirien}

Afhandlingens empiriske genstand er et værdibaseret ledelsesprojekt i en større dansk kommune. Empirien er oprindeligt indsamlet til en afhandling der skulle handle om organisatorisk læring og værdibaseretledelse. (se evt. bilag 15) Denne problemstilling blev dog forladt til fordel for den nu foreliggende om udvikling af en organisationsdidaktik. Afhandlingens skift i problemtilgang har ligeledes betydet et skift i anvendelsen af empirien, som i denne afhandling har en mere eksemplificerende karakter, dvs. empirien anvendes til at udlede eksempler på anvendelsen af den didaktiske tilgang til organisatorisk læring. For at få indblik i empirien og dens organisatoriske ophav, vil jeg kort beskrive den i nedenstående. Empirien beskrives mere indgående i forbindelse med analysen til sidst $i$ afhandlingen.

Kommunens ledelse havde udvalgt fem værdier som alle kommunens afdelinger og ansatte skulle forholde sig til: Helhed, Ansvarlighed, Brugerorientering, Udvikling og Kvalitet. Projektet er tilrettelagt som et organisationsudviklingsprojekt, hvor medarbejderne indledningsvist deltager i et tre dages introduktionskursus, hvor medarbejdere fra forskellige afdelinger i kommunen er på kursus sammen. Efterfølgende skal medarbejderne på afdelingsplan og på baggrund af værdirefleksioner selv formulere, hvad projektet skal fokusere på og handle om i forhold til deres afdeling og i relation til deres eget arbejde. I et af dokumenterne til alle ansatte i forbindelse med kurset står der:

"Indførelsen af vardibaseret ledelse er et langsigtet projekt, fordi det indeborer, at vi alle skal til at gфre, det vi plejer på nye måder. Vi skal bruge den inspiration, som "Var med" kurserne fører med sig, til at gøre vardierne narvarende på hver arbejdsplads. Det betyder, at vi skal fortsatte med at drøfte vardierne, når "Var med" kurserne er fardige. Vi skal finde ud af, hvad vardierne egentlig betyder for os, og for den måde vi arbejder på. Det er et stort og udfordrende arbejde. Der er derfor taget initiativer, som skal hjoelpe arbejdspladserne med at komme videre. initiativerne 
skal vare med til at sikre, at (...) Kommunens vardier bliver det naturlige udgangspunkt for udførelsen af arbejdsopgaverne. De skal vare med til at støtte op om den proces, der igangsattes på arbejdspladsen, når man skal arbejde vardibaseret og drøfte sit eget vardigrundlag." (Bilag 11)

Udover introduktionskurset, som primært blev forestået af ansatte fra kommunen, der havde fået en kort instruktøruddannelse, er der ikke tale om anvendelse af det formelle uddannelsessystem. Som det fremgår af citatet skulle de ansatte selv og på afdelingsplan diskutere sig frem til, hvad projektet skulle indeholde, og hvordan man på afdelingsplan ønskede at arbejde med værdierne. Kort sagt skulle medarbejderne i fællesskab formulere, hvem der skulle lære, hvad de skulle lære, hvorfor de skulle lære, hvornår de skulle lære, og hvordan de skulle lære. Dette er i bund og grund didaktiske refleksioner og temaer.

Alle kommunens afdelinger og ansatte skal arbejde efter de samme fem værdier: Ansvarlighed, Udvikling, Helhed, Kvalitet og Brugerorientering. Som det fremgår af ovenstående citatet og af nedenstående fra Administrationsdirektøren (AD), er det et langsigtet projekt:

”AD: Der er 2 projekter i det, vi snakker om vardibaseret ledelse. Der er det vi kalder vardibaseret ledelse, som startede i august 2000 og som, jeg har nar sagt, i princippet kører indtil vores dages ende, og så er der det andet projekt, som så at sige er et redskab inde i projektet vardibaseret ledelse, det er de der Var-Med-kurser." (Bilag 2. s. 33)

Et af de væsentligste tiltag i organisationsudviklingsprojektet om værdibaseret ledelse er opfordringen til og forventningen om ledernes udvikling af egne og medarbejdernes evne til selvledelse. For at dette kan realiseres, er en ledelsesfunktion, at Lederen for den selvledende medarbejder skal "Støtte individuel og organisatorisk laering”. (Bilag 12)

Intentionerne og semantikken bag organisationsudviklingsprojektet er, at det implicerer hele organisationen (kommunen), og stort set alt er til diskussion både på den enkelte afdeling, og i forholdet mellem afdelinger i kommunen. Som administrationsdirektøren siger i nedenstående, skal de (kommunen som helhed) være én virksomhed. Det værdibaserede ledelsesprojekt fungerer med andre ord som et organisationsudviklingsprojekt, hvis funktion er at realisere organisationens intentioner om at integrere sig i sig selv. 
"AD: (...) vi er en rodfastet organisation, vi er en traditionsstork organisation, for nu at sige det positivt ikke også, der er meget 'plejer' indenfor de her 4 vagge, (...) nu har jeg snart varet her lange jo, der er meget 'plejer', og der er mange tilvante forestillinger om, hvad der er en god måde at drive kommune på. Det $\phi n s k e r$ vi selvfølgelig ikke at gфre op med $i$ den forstand, at vi siger, at det har alt sammen varet noget skrammel indtil nu, (...) men vi vil sige, at alt er til diskussion, alt skulle gerne vare under udvikling, og den vardibaserede ledelse skulle gerne vare et af midlerne til, at det også lader sig gфre at diskutere ting, (...) mine 6299 kolleger, der kunne jeg da godt berige med at gфre sådan og sådan, altså at vi prøver at få handlekompetence, $i$ begge betydninger af ordet kompetence, får handleretten og handleevnen lagt helt ned på gulvet i så vidt omfang som det overhovedet lader sig gфre, når vi stadigvaek skal vare én virksomhed." (Bilag 2. s. 31)

Organisationsudviklingsprojektets forandring og læring er ikke bare et spørgsmål, som vedrører den enkelte medarbejder, vedkommendes nære kollegaer eller afdeling men noget, som vedrører alle dele af organisationen.

\section{Afhandlingens overordnede tilgang}

Afhandlingens tese er, at organisationer ud fra et forandrings- og læringsmæssigt perspektiv ikke bare kan og skal beskrives snævert med begrebet læring, dvs. selve tilegnelsen af viden og kompetencer. For at begribe kompleksiteten, der er forbundet med forandring og læring i og af organisationer, lader afhandlingen sig som sagt inspirere af det mere almene pædagogiske begreb om didaktik. Organisationsudviklingsforhold af den karakter, hvor organisationen selv er en aktiv medspiller, som ovenfor beskrevet, vil ud fra et pædagogisk perspektiv ikke kun referere til begrebet læring som relevant, men vil også og ikke mindst referere til didaktiske refleksioner forstået som undervisningens hvad, hvorfor og hvordan (Hansen og Tams 2006; Jank \& Meyer 2010).

Afhandlingens overordnede og grundlæggende erkendelsesinteresse er derfor argumentationen for og udviklingen af en organisationsdidaktik. Og hvorfor så det? Hvorfor udvikle en organisationsdidaktik? Hertil er der to svar.

For det første handler det om videnskabens adgang til virkeligheden. Indenfor nyere videnskabsteori er man gået fra ontologi til epistemologi 
(Hagen 1997; 2006; Andersen 1999). Mens ontologi drejer sig om det værende, og om at afdække tingenes væsen eller iboende essens, har den epistemologiske tilgang fokus på erkendelse, og på hvordan man kan få eller skaffe sig viden om verden (Hagen 1997 s. 7). Troen på den ontologiske erkendelse indenfor videnskaben er blevet kritiseret i en sådan grad, at den nye videnskabsteori vender blikket mod sig selv, dvs. videnskabens begreber og teorier. Argumentet er, at videnskaben iagttager, forstår og erkender virkeligheden ved hjælp af og gennem sine teorier. I den udstrækning videnskaben $\emptyset$ nsker viden om verden, må den udvikle teorier og begreber, som gør det muligt, at iagttage det, den gerne vil iagttage. Afhandlingen argumenterer i den forbindelse for, at udviklingen af en organisationsdidaktik på den moderne systemteoris grundlag, tilbyder en anderledes og mere pædagogisk orienteret iagttagelse af organisatorisk læring i konkrete organisationsudviklingsprojekter.

Det andet svar er ikke en del af afhandlingen, men knyttet til det første svar. Det er en forhåbning om, at andre kan bruge det begrebsapparat, som afhandlingen opbygger ved udviklingen af organisationsdidaktikken. Her tænkes på to forskellige anvendelsesområder, dels som teoretisk begrebsapparat for andre, som ønsker at unders $\emptyset$ ge lignende projekter angående organisationsudvikling, dels som en model eller et begrebsapparat for andre, der mere konkret arbejder med organisationsudvikling f.eks. konsulenter og lignende. Sådanne aktører kan tage udgangspunkt i organisationsdidaktikken i arbejdet med sådanne projekter.

I forbindelse med udviklingen af organisationsdidaktikken anvendes en sammentænkning af teorier, ideer og empiriske erfaringer om og fra organisatorisk læring, videnssociologi og pædagogik. Sammentænkningsfunktionen er at fremanalysere nogle muligheder og begrænsninger, som en række grundvilkår organisationer i almindelighed må forholde sig til, og som organisationer, der $\emptyset$ nsker at arbejde med organisatorisk læring eller organisationsudvikling i særdeleshed må forholde sig til. Det er endvidere en forventning, at udviklingen af en organisationsdidaktik kan tilvejebringe et nyt teoretisk perspektiv og dermed udgøre et alternativ til andre teorier, hvis erkendelsesinteresse er forståelse og analyse af organisationsudviklingsprojekter, som indbefatter forhold af undervisnings- og læringsmæssig karakter. Organisationsdidaktikken skal som teoretisk perspektiv desuden udgøre og tilbyde en anvendelig analysestrategi eller iagttagelsesprogram til analyse af forandrings- og læreprocesser i organisationer.

Med intentionen om at udvikle en organisationsdidaktik får didaktik begrebet en central placering $\mathrm{i}$ afhandlingen, og beskrives $\mathrm{i}$ afhandlingens 
andet kapitel. Dette gøres dels for at introducere begrebet om didaktik, dels fordi det $\mathrm{i}$ afhandlingens opbygning er nødvendigt for udvikling af og begrundelsen for afhandlingens probleminteresse. Som det vil fremgå i didaktik afsnittet anvender afhandlingen den tyske sociolog og moderne systemteoretiker Niklas Luhmanns sociologiske teori om sociale systemer som tilgang $\mathrm{i}$ afhandlingen og til indkredsning af begrebet organisatorisk læring. Niklas Luhmanns systemteori fremstår som en gennemgående teori for hele afhandlingen. ${ }^{3}$ Introduktionen til didaktik er valgt som første afsnit af ovennævnte grund, men også fordi didaktik står som det centrale begreb for afhandlingens forståelse af organisation, undervisning og læring herunder de muligheder og begrænsninger, som efter afhandlingens forståelse aktualiseres, når der skal foretages organisationsudvikling, forandring eller læring. Afhandlingens opbygning og prioritering vil ikke følge hvad man måske kunne betegne en klassisk form, dvs. hvor én teori om organisatorisk læring introduceres, behandles og afsluttes. Afhandlingen handler om organisatorisk læring, hvorfor dette vil blive behandlet og diskuteret flere forskellige steder $\mathrm{i}$ afhandlingen. Afhandlingens tilgang vil primært være begrebsligt styret forstået på den måde, at forskellige afsnit og kapitler forholder sig til og er styret af begrebsdiskussioner, hvorfor nogle teorier om organisatorisk læring vil optræde spredt ud over afhandlingens forskellige afsnit og kapitler. Det vil imidlertid være forskellige aspekter, temaer og begreber fra teorierne de forskellige kapitler og afsnit forholder sig til - ikke nødvendigvis hele teorier af gangen.

\footnotetext{
${ }^{3}$ Niklas Luhmanns produktion er legendarisk (jf. Borch 2009 s. 521; Rasmussen 2000; Jönhill 1997). I tidsskriftet Soziale Systeme (1/98) angives det, at Niklas Luhmann i sin levetid nåede at udgive 72 bøger og 456 videnskabelige artikler (Moe 2003 s. 12). Posthumt er der udkommet 4 monografier, hvorfor det bliver til 76 bøger i alt.
} 
8 Indledning og forskningsinteresse

\section{Problemformulering}

Hvordan begrebsliggøres organisatorisk laring i eksisterende teorier, og hvilke muligheder/problemer er der forbundet med det i forhold til at beskrive organisationers udfordringer som 'larende organisationer' $i$ et moderne samfund, og kan man på den baggrund (og med den moderne systemteori) udvikle en organisationsdidaktik, der kan anvendes til at forstå og analysere organisatorisk laring i konkrete organisationsudviklingsprojekter?

1. Hvordan begrebsliggфr eksisterende teorier om organisatorisk laring samfund og organisation og hvilke muligheder/problemer er der forbundet med det i relation til organisatorisk laering?

2. Er det muligt på den baggrund med den moderne systemteori at udvikle en organisationsdidaktik, der kan anvendes til at forstå og analysere organisatorisk laring i konkrete organisationsudviklingsprojekter?

3. Hvordan kan man ud fra ovenstående organisationsdidaktik forstå organisatorisk laring $i$ et konkret organisationsudviklingsprojekt? 


\section{2}

\section{Didaktik}

Didaktik er en pædagogisk deldisciplin og handler i kort form om undervisningens hvorfor, hvad og hvordan, dvs. undervisningens indhold, mål, kriterier for indholdsudvælgelse, elevers udvikling og læring samt de betingelser og forhold, der kan fremme denne læring (Hansen \& Tams 2004). I det følgende lægges der an til dette kapitels formål, nemlig at beskrive samfundets uddannelsessystem, pædagogik og didaktik, og hvorledes dette kan relateres til organisatorisk læring.

\section{Samfundets uddannelsessystem, pædagogik og didaktik}

Når organisationer arbejder med organisatorisk læring, kan alle de forhold, som ovenfor gælder for at fremme elevers læring, efter min mening overføres til den organisatoriske verden. Dette betyder, at alle de refleksioner, prioriteringer og tiltag, som på forskellig vis støtter op om og retter sig mod at fremme organisationsmedlemmers læring, iagttages som produkter af og udtryk for didaktiske refleksioner og pædagogiske aktiviteter. Niels Åkerstrøm Andersen udtrykker det på denne måde.

"I det фjeblik kompetence ikke langere kun er noget eksternt givet, som uddannelsessystemet står for, men også er noget, der skal defineres internt $i$ de offentlige organisationer, igangsattes organisationskommunikationen padagogisk." (Andersen 2002 s. 24)

Det, Andersen skriver, er, at uddannelse og pædagogisk refleksion og aktivitet ikke længere er noget, som uddannelsessystemet har patent på, og som kun forekommer indenfor uddannelsessystemets traditionelle systemer og institutioner. Det er snarere et fænomen, som i takt med fremkomsten af teorier om organisatorisk læring op gennem 1990'erne, kan ses som en bestemt 
logik, der vinder indpas i samfundets organisationer (Andersen 2002 s. 3). Det forhold, at organisationskommunikationen bliver pædagogisk henviser til, at organisationens iagttagelse og forhold til sig selv ikke kun handler om produktivitet, men kodes og forgår ud fra et pædagogisk perspektiv, som i bund og grund lægger op til læring. En læring hvor:

"Omdefinitionen handlede ikke om at definere nye opgaver og roller, men om at ombryde selve forholdet mellem person og rolle. Forholdet mellem person og rolle skulle gфres til et indre selvforhold hos den enkelte medarbejder. Rollen blev at skabe og omskabe forholdet mellem sig selv og sin rolle i forhold til de stadig nye udfordringer, den enkelte så $i$ vardigrundlaget for udviklingen af plejecentret." (Andersen 2002 s. 1)

"Profilteknologien foreskriver på den måde operationer, igennem hvilke medarbejderen kan komme på afstand af sig selv, objektivere sig selv, reflektere over egne personlige kompetencer evt. sammenlignet med omverdenens forventninger, samt gå $i$ dialog om sig selv med kollegaer på en neutral og selv-distant måde. Det smarte ved spejlprofilens teknologi er dens mangedobling af selvrefleksionen. Først kommer medarbejderen på afstand af sig selv og fär forestillingen om et objektivt forhold til sig selv som ressource. Så lokkes en kollega til at lagge sine personlige indtryk af medarbejderen frem, ikke ved at sidde foran den medarbejder det hele handler om, men ved at sidde foran skarmen og besvare neutraliserede af-intimiserede enkeltspфrgsmål om vedkommendes personlighed. Til sidst kan forholdet mellem medarbejderens selv og den anden isoleres som en genstand derude, man sammen kan snakke om og reflektere sig $i$, uden fornemmelse af en blotlaggelse af sig selv, samtidig med at alt kan siges. Det hele står på et stykke papir, der ligger ude på bordet, og er fyldt med computerfortolkninger og grafer i farver, som handlede det om virksomhedens regnskabstal. Personligheden er blevet til sammenlignelige og målelige variable med både plus og minus vardier." (Andersen 2002 s. 17-18)

Kapitlet vil derfor koncentrere sig om at beskrive, hvorfor og hvordan pædagogik og didaktik er relevant i en organisatorisk kontekst. Kapitlet retter sig derfor specielt mod at modificere, udvikle og beskrive en organisationsdidaktik. Inden en egentlig organisationsdidaktik kan beskrives, starter kapitlet med at klarlægge en række pædagogiske begreber, som løbende 
reflekteres og modificeres i forhold til en organisatorisk kontekst, dvs. gør dem organisatorisk relevante.

Kapitlet starter med en kort introduktion til og definition af pædagogikkens genstandsfelt, herunder læring som pædagogikkens udgangspunkt, og didaktik som en deldisciplin indenfor pædagogikken, der har undervisningen og laeringens teori og praksis som erkendelsesinteresse og genstandsfelt. Formålet med afsnittet er at få afklaret afhandlingens forståelse af didaktik, og at muliggøre en didaktisk iagttagelse af organisatorisk kommunikation og prioriteringer i form af beslutninger. Eftersom afhandlingen ikke har selve didaktikken som sit genstandsfelt, men ønsker at bruge didaktikken til at udvikle en ny og anderledes iagttagelse af aspekter ved organisatorisk læring, vil beskrivelsen af og diskussionerne angående didaktik begrænse sig til en kort introduktion og præsentation af den didaktiske tilgang, som bliver ført videre $\mathrm{i}$ afhandlingen, dvs. den didaktik, som søges udviklet og anvendt.

Efter den korte introduktion til pædagogisk og didaktisk tænkning vil jeg præsentere samfundets uddannelsessystem, sådan som det forstås ud fra Luhmanns sociologiske systemteori. Luhmanns systemteori er valgt, fordi jeg vurderer, at den har en analytisk stærk tilgang til de begreber, jeg ønsker at inddrage $\mathrm{i}$ afhandlingen. Gennem sine refleksioner over samfundet, og det at teorien er en generel teori, dvs. en enhedsteori, giver mulighed for, at begreber, analyser og i en vis udstrækning konklusioner kan generaliseres til andre områder af samfundet - i dette tilfælde organisationer. I systemteorien er uddannelsessystemet et uddifferentieret funktionssystem i samfundet, som er specialiseret $i$ at varetage samfundets behov for uddannelse. Udfoldelsen af denne funktion sker gennem specialiseret viden om og programmer for, hvordan uddannelse kan bedrives. Dette karakteristiske ved uddannelsessystemet kan være relevant at forholde sig til og blive inspireret af, når organisationer arbejder med forandringer og organisatorisk læring, som i dette perspektiv iagttages som udtryk for didaktiske refleksioner og undervisning, dvs. en form for uddannelse.

\section{Præsentation af pædagogik}

Pædagogik kommer oprindeligt af græsk - paidagogike - og betyder opdragelseskunst. Overordnet defineres pædagogik som:

"(...) laeren om den teori og praksis, der omhandler mål, midler, sammenhange og forhindringer i relation til udvikling af vardier, viden og kunnen hos den enkelte. Set under forskellige synsvinkler 
handler padagogikken om opdragelse, undervisning og uddannelse, dvs. personlighedens dannelse i vid forstand." (Den Store Danske)

Pædagogik har i denne meget brede og generelle forståelse en altfavnende karakter, som indbefatter stort set ethvert forhold ved ethvert menneske. Forståelsen kan spores tilbage til begrebets etymologiske betydning, som udspringer fra antikkens Grækenland. Interessen for og optagetheden af pædagogiske spørgsmål går helt tilbage til den græske filosof Platon (år 427-347 f.Kr.). For Platon var menneskene af gud inddelt i tre forskellige grupper, ${ }^{4}$ og dannelse og opdragelse skulle forløbe i overensstemmelse med denne gudsbestemte orden. Filosofferne var sat til at herske, og Platons ideer om pædagogik og opdragelse vedrører hovedsageligt dem. For filosofferne var opdragelsens formål i første omgang karakteropdragelse/dannelse, og senere videnskabelig uddannelse forstået som tilegnelse af en række kundskaber (f.eks. matematik, logik og astrologi). Sammenfattede gjaldt det dog, at karakteropdragelse såvel som kundskabstilegnelse bestod $\mathrm{i}$ at indpode eleven den rette holdning og de kundskaber, som var passende til den menneskegruppe, man var placeret i, og man (eleven), forventedes at blive formet af det, vedkommende lærte (Johansen 1991 s. 259).

I det moderne funktionelt uddifferentierede samfund er det ikke muligt at indrette uddannelsessystemets efter et dannelsesideal, der som hos Platon begrundes religiøst. Det moderne samfund er grundlæggende struktureret efter helt andre principper og har helt andre forventninger til, hvad der skal læres i dets uddannelsesinstitutioner, og, som jeg senere kommer ind på, i særdeleshed i samfundets organisationer.

Som det fremgår allerede fra Platon, indeholder definitionen af pædagogik også begrebet om undervisning i form af at indpode, og en laerende, som de pædagogiske aktiviteter centrerer sig om. I 1979 skrev den første danske professor i pædagogik Knud Grue Sørensen (1902-1992) følgende:

"Der kan ikke vare tvivl om, at begrebet 'at lare' hфrer til de mest fundamentale i padagogikken, og dette hvad enten man opregner opdragelse, dannelse, undervisning eller uddannelse for at vare hovedgenstanden for det, man i padagogikken beskaftiger sig med." (Op.cit. fra Oettingen 2010 s. 21)

\footnotetext{
${ }^{4}$ De tre grupper menneskene var gudsinddelt i var "Arbejderen og bonden skulle s $\phi$ rge for den materielle velstand. Vogterne for borgernes beskyttelse, og endelig skulle filosofferne herske." (Oettingen 2010 s. 65)
} 
Ligesom det indenfor organisatorisk læring ikke giver mening at tale om organisatorisk læring uden en lærende, er det ligeledes umuligt eller indholdsløst at bedrive eller tale om pædagogik uden ideen om en lærende! Dette gælder for den sags skyld også didaktiske refleksioner i form af indhold og rammer og vilkår for undervisning, dvs. de ideer og den aktivitet, gennem hvilken eleven/medarbejderen/organisationen fors $\varnothing$ ges formet og skal lære på baggrund af. Dette gælder for alle dele af pædagogikken og derfor også for deldisciplinen didaktik. Tilsvarende vil jeg argumentere for at det samme gør sig gældende for organisatorisk læring. Ligesom indenfor uddannelsessystemet er organisationer, der har intentioner om at forandre sig (og her er det ikke nødvendigvis afgørende, at de arbejder med organisatorisk læring), nødt til at operere med ideer om hvilken forandring, der skal være tale om, såvel som ideer om vilkår for, hvordan forandringen $\emptyset$ nskes realiseret, dvs. de konkrete (undervisende) tiltag, organisationen foretager med henblik på at initiere forandringerne.

\section{Didaktik}

Didaktik kommer af græsk didáskein og betød allerede for 2.500 år siden at (be)lare, formidle eller undervise og med det formål at bibringe kundskaber (Hansen \& Tams 2006 s. 9). Betydningen er mere eller mindre den samme i dag, hvor didaktik generelt defineres som undervisningens og laringens teori og praksis, og dermed i et funktionelt differentieret samfund udgør lærerens professionsvidenskab. ${ }^{5}$ Didaktik rummer både teorier om og for undervisning (Laursen 1997 s. 61), og kan betegnes som en pædagogisering af viden, eller en metodisering af vidensmæssige problemer (Luhmann 2006 s. 156).

Med professionsvidenskab menes, at lærere (for bedst muligt at leve op til deres funktion, som udover undervisningsaktiviteter, hvor der formidles en eller anden form for viden, der gerne skulle lede til læring) med fordel kan trække på de refleksioner som muliggøres gennem didaktiske teoriers begreber og refleksion over praktiske omstændigheder, der har indflydelse på undervisnings- og læringssituationer (Jank \& Meyer 2010; Hermansen, Jensen og Krejsler 2005; Hansen \& Tams 2004; Jacobsen 1997). Selvom didaktiske tanker og refleksioner kan spores 2.500 år tilbage, stadfæstes den

\footnotetext{
${ }^{5}$ Jens Rasmussen beskriver pædagogikken udvikling ved at pege på dens brud med den førmoderne forståelse rodfæstet i religionen. Sammenfaldende med oplysningstidens fremmarch i slutningen af 1700-tallet, sker der en begyndende videnskabeliggørelse af pædagogikken og dens dannelsesideer, som er retningsgivende for pædagogiske og didaktiske refleksioner og aktiviteter (Rasmussen 2004 s. 38-40).
} 
historisk til den tjekkiske lærer, forfatter og præst Johann Amos Comenius (1592-1670) klassiske almendidaktiske værk Didactica Magna, som udkom ca. år 1630 med den meget ambitiøse undertitel Den fuldstandige kunst at laere alle alt. (se Laursen 1997). Denne blinde tro på, at alle kan lære alt, har efterfølgende fortaget sig, men didaktikken operere imidlertid stadig med den grundlæggende forståelse, at didaktiske refleksioner som mindste mål gør en positiv forskel i relation til undervisning og læring.

"Ingen underviser/opdrager kan komme af sted uden den antagelse, at han skulle have muligheder for at forandre den, som han underviser. At give afkald på kausalitet ville vare ensbetydende med at give afkald på rollen som underviser." (Op.cit. Luhmann og Schorr in Qvortrup 2001 s. 129)

\section{Samfundet uddannelsessystem}

Jeg vil her forholde mig til systemteoriens beskrivelse af samfundets uddannelsessystem. Eftersom didaktik først og fremmest er udviklet i relation til uddannelsessystemet, hvor det bidrager med selvrefleksionsprogrammer for funktionsudfoldelse og styrkelse af uddannelsessystemets ydelser, er det et godt afsæt for inspiration til, hvordan didaktik kan tænkes i relation til undervisnings-, uddannelses-, og læringstænkning indenfor organisationer. En indledende bemærkning for læsning af nedenstående er, at systemteorien i relation til uddannelsessystemet taler om uddannelseskommunikation. I nedenstående har jeg valgt at anvende samme begreb i forhold til kommunikation om organisatorisk læring, dels for at lette læsningen, og dels fordi kommunikation om organisatorisk læring er at forstå som uddannelses- eller undervisningskommunikation.

\section{Uddannelsessystemets primære og sekundære funktion}

Ifølge Qvortrups tolkning af Luhmann, er samfundets uddannelsessystems funktion i det moderne funktionelt uddifferentierede samfund differentieret i to former - en primar og en sekundar funktion henholdsvist at gøre mennesker til personer og karriereselektion (Qvortrup 2006 s. 25-28). Uddannelsessystemets primære eller basale funktion er, at gфre mennesker til personer, dvs. gøre dem kommunikerbare. Med dette menes, at samfundets kommunikation ville bryde sammen i kompleksitet, hvis vi i mødet med andre skulle forholde os til dem som hele mennesker, dvs. et menneskes samlede empiriske 
mangfoldighed (Qvortrup 2006 s. 25; Luhmann 2006 s. 56). ${ }^{6}$ I det moderne samfund er det et vigtigt kompleksitetsreducerende forhold, at mennesket forstår, at det selv og andre indgår i en mangfoldighed af forskellige sociale situationer og relationer som generaliserede personer (roller) i forskellige sociale sammenhænge, f.eks. som ekspedient, en lærer, elev, chef, kollega, nabo, kunde osv. Denne kompetence opnås dels gennem socialisering, dels gennem uddannelse, hvor den viden og de kvalifikationer og kompetencer, som skal til for at indtage og koble sig til forskellige generaliserede persontyper, tilegnes.

"Menneskerfødes. Personer opstår gennem socialisation og uddannelse. Når man holder dette for $\phi j e$, er det narliggende at relatere uddannelsens funktion til det forhold, at mennesker bliver personer. Isar i komplekse samfund kan man ikke overlade dette til socialisationen. Den virker ikke tilstraekkelig specifikt og bliver i for $h \phi j$ grad bundet til det miljф, hvor den finder sted." (Luhmann 2006 s. 65)

Ifølge Qvortrup har følgende tre kategorier siden 1700-tallet været de tre dominerende generaliserede persontyper: Man bliver et menneske for andre mennesker, en borger for samfundet og en kompetent medarbejder $i$ en privat eller offentlig virksomhed (Qvortrup 2006 s. 27). I forhold til organisatorisk læring kan man argumentere for, at alle tre persontyper er relevante, men jeg vil koncentrere mig om den sidste nemlig medarbejderen i en organisatorisk kontekst, hvilket specificeres yderligere ved uddannelsessystemets sekundære funktion - karriereselektion. ${ }^{7}$ Med karriereselektion menes, at uddannelsessystemet gennem bedømmelse (karaktergivning) og funktionel specifikation fordeler samfundsmæssige og personlige muligheder og begrænsninger med henblik på bestemte og senere karrieremuligheder.

\footnotetext{
${ }^{6}$ Luhmann skriver: ’Den form, der muliggør, at man i sammenhæng med samfundsmæssig kommunikation kan se bort fra det enkelte menneskes dynamikker, vil vi kalde $>$ person $<$. Dette begreb bliver dermed defineret gennem en forskel til de empiriske mennesker." (Luhmann 2006 s. 56)

${ }^{7}$ Jf. også Luhmann 1989 (specielt s. 100-105): "The successful completion of a program of study is important for entry into a career. Entry into a career determines advancement. In all these cases, the intentional or unintentional non-fulfillment of requirements has value for the career as well, only it is negative. Those who leave this process without completing it may decide on no career to careers since careers are a given possibility and since they are the standard instrument of inclusion by which persons are appointed to positions throughout many systems." (Ibid. s. 101-102).
} 
"Karriere betyder blandt andet, at tidligere stadier er vigtige for senere stadier. Vagten af, hvad der er relevant for karrieren, skubbes derfor over til uddannelsessystemet, også når det egentlig først er den senere karriere, der er interessant. Man må allerede stå sin prøve i skolen henholdsvis på universitetet for at skabe gunstige udgangspunkter for en senere karriere." (Luhmann 2006 s. 97)

Med begrebet om organisatorisk læring kan man argumentere for, at der opstår en ny måde at iagttage og danne mening om organisationers medarbejdere. Ifølge Andersen og Born (2001), som har beskæftiget sig med, hvordan medarbejderen i den offentlige sektor italesættes anderledes qua nye omstillingsidealer op gennem 1990'erne, handler det moderne arbejde også om at leve op til begreber som omstillingsparathed, fleksibilitet og selvudvikling. De citerer en forvaltningschef fra Aalborg for på en konference at have sagt: "Den medarbejder, der ikke er i udvikling er under afvikling." (Andersen \& Born 2001 s. 8). Dette kunne indikere, at den karriereselektion, som Luhmann taler om som uddannelsessystemets sekundær funktion, er flyttet ind som en iagttagelsesform og afledt funktion i organisationer, der arbejder med omstilling og organisatorisk læring. Med andre ord har den enkelte medarbejders vilje og evne til at omstille sig i relation til organisationens forventninger muligvis betydning for vedkommendes intraorganisatoriske karrieremuligheder. Eftersom uddannelsessystemet er et symbolsk generaliseret kommunikationsmedie (beskrives nedenfor), kunne man tilsvarende forestille sig, at den omstillingsparathed, fleksibilitet og selvudvikling, den enkelte medarbejder udviser, ikke kun giver karrieremuligheder internt i organisationen, men også kan anvendes i andre organisationssystemer, der kobler sig positivt til en moderne semantik om medarbejderen.

Som det fremgår af skemaet om samfundets uddannelsessystem opererer Luhmann med to medier nemlig barnet og livsforlфb (se f.eks. Luhmann 2006 s. 73). ${ }^{8}$ Tidligere var samfundets og uddannelsessystemets semantik, erkendelsesinteresse og aktiviteter rettet mod uddannelse/dannelse af barnet,

\footnotetext{
8" Uddannelse foreskriver ikke et livsforløb. Den kan ikke gøre fordring på at kontrollere sine elevers livsførelse. Det ville være en $>$ totalitær $<$ uddannelse og ikke forenelig med samfundsmæssig differentiering, og altså heller ikke med uddifferentieringen af uddannelsessystemet. (...) Den (red. uddannelse) kan tilbyde meget specielle uddannelser til bestemte erhverv og dermed åbne mulighederne for et livsforløb, der ikke fandtes uden en sådan uddannelse. Men heller ikke det kan ske i form af determination af fremtid adfærd, men kun som tilvejebringelse af viden, som gør det muligt at indlade sig på bestemte adfærdskrav med tilstrækkelig sikkerhed; eller at kunne finde de informationer, der er meningsfulde for adfærden i bestemte situationer." (Luhmann 2006 s. 125).
} 
men i det moderne samfund har semantikken bredt sig til også at inkludere voksne, og kan empirisk iagttages ved et stigende fokus på livslang læring, og udbydelse af forskellige former for kurser og uddannelse. ${ }^{9}$ Man kan argumentere for, at netop ideer om og udvikling af teori om organisatorisk læring, er udtryk for samme tendens nemligt at uddannelseskommunikation er rykket ind i organisationers kommunikative verden. ${ }^{10}$ Uddannelsessystemets reaktion på denne semantiske kompleksitetstilvækst har været intern differentiering og opbygning af kompleksitet, som retter sig mere specialiseret mod udvikling af viden, pædagogikker, læseplaner og kurser for voksne (jf. Illeris 2003; 2004; Illeris \& Berri 2005; Undervisningsministeriet 2007). ${ }^{11}$ Grundtanken er, at der gør sig andre og særlige vilkår gældende for voksenundervisning og -læring, end der gør for børn. ${ }^{12}$ Ifølge Illeris egen forskning er der en række tommelfingerregler (forforståelser), som det er værd at være bevidst om som forhold, der gør sig gældende for forståelsen af voksnes tilgang til uddannelse og læring:

\footnotetext{
${ }^{9}$ I relation til denne udvikling og i særdeleshed uddannelsessystemets reaktion herpå skriver Luhmann: "Det har først og fremmest forskudt uddannelsesbehovet til en stadig højere alder, det har udvandet universiteterne, det gør krav på kompetence til videreuddannelse, til voksenuddannelse og endda til bestræbelser på at tage sig af seniorer på en $>$ geragogisk $<$ måde.” (Luhmann 2006 s. 117). Geragogisk betyder 'voksen eller pædagogik for ældre'.

${ }^{10}$ Man kunne tilføje eller underbygge dette med, at de fleste organisationer har indskrevet en efteruddannelsesfunktion i deres interne organisering.

${ }^{11}$ I redegørelsen Danmarks strategi for livslang læring - Uddannelse og livslangopkvalificering for alle, til EU-Kommissionen fra april 2007, skriver daværende undervisningsminister Bertel Haarder i forordet bl.a. følgende: "Gode udviklings- og læringsmuligheder for børn, unge og voksne skal styrke den enkeltes personlige udvikling, beskæftigelse og aktive deltagelse i samfundet. Alle skal udfordres i en læringsproces, der udvikler idérigdom og glæden ved til stadighed at kunne dygtiggøre sig. Det er afgørende for at højne uddannelsesniveauet og styrke konkurrence- og sammenhængskraften i det danske samfund. Livslang læring skal fremmes $\mathrm{i}$ alle de mange sammenhænge, hvor mennesker lærer nyt og tilegner sig brugbare kompetencer. Det gælder i uddannelserne, i arbejdslivet, i folkeoplysningen og i forenings- og fritidslivet. Det er et fælles ansvar for alle. Hermed får vi de bedste forudsætninger for et dansk kompetenceløft, og at den livslange læring bliver i verdensklasse. Med denne redegørelse præsenteres Danmarks strategi for livslang læring og de initiativer og indsatsområder, der fremadrettet især prioriteres. Den er et bidrag til en realisering af de fælles målsætninger i Lissabon-strategien." (Undervisningsministeriet 2007 s. 1)

${ }^{12}$ Et eksempel på dette er den danske læringsforsker og professor i livslang læring ved Learning Lab Denmark Knud Illeris som de senere år har forsket intenst i dette område. I bogen Læring gennemgår han en række forskellige tilgange til det han selv betegner "Læring og livsforløb". Her beskriver han en række forskellige tilgange som reflekterer forhold angående læring på forskellige tidspunkter i menneskers liv, og faser. (Illeris 2006 s. 207-223)
} 
- Voksne lærer det, de vil lære, det der er meningsfuldt for dem at lære.

- Voksne trækker i deres læring på de ressourcer, de har.

- Voksne tager det ansvar for deres læring, de er interesseret i at tage (hvis de kan komme til det).

- Voksne er meget lidt tilbøjelige til at engagere sig i læring, som de ikke kan se meningen med eller ikke har nogen interesse i (Illeris 2006 s. 217: 2003 s. 101).

Illeris citerer uddannelsesforskeren Annegrethe Ahrenkiel (opr. 1998) for, at voksne har særlige strategier for, hvordan de forholder sig til uddannelse og læring, idet de som udgangspunkt for deres uddannelses- og læringsaktiviteter ikke så meget har forskellige mere eller mindre løsrevne motiver, men mere sammenhængende strategier, som er relateret til mål, der sædvanligvis er ret klare og bevidste for den enkelte (Illeris 2006 s. 217).

Relateret til afhandlingens forståelse af organisatorisk læring, forstået som både strukturelle forandringer i psykiske systemer og sociale systemer, er der to forhold, som på baggrund af ovenstående kan gøre sig gældende, og som muligvis støtter op om hinanden. For det første kan man have en hypotese om, at læring, der lever op til medarbejdernes subjektive forventninger (jf. ovenstående pointer om voksenlæring) skaber legitimitet og motivation set fra medarbejdernes side. For det andet kan man ud fra systemteoriens forståelse af organisationer som systemer, der er funktionelt relateret til deres omverden, arbejder med den hypotese, at organisationens subsystemer gennem refleksion vil fors $\emptyset g$ e at relatere og anvende læringen til styrkelse af funktionsudfoldelsen med henblik på forbedring af systemets ydelser.

\section{Uddannelsessystemet som symbolsk generaliseret kommunikationsmedie}

Ifølge systemteorien fungerer uddannelse på samfundsplan, da uddannelsessystemet er et symbolsk generaliseret kommunikationsmedie. Et generaliseret kommunikationsmedie er et medie, der, qua en række standardiserede temaer, kompleksitetsreducerer virkeligheden, og som dermed funktionelt skaber mulighed for succesrig kommunikation på tværs af samfundssystemer. ${ }^{13}$ Helt centralt og generelt tjener mediet uddannelse ligesom de andre medier, f.eks. фkonomi, politik, videnskab, religion, retssystemet, massemedier mfl., funktionelt til at transformere usandsynlighed til sandsynlighed ved

\footnotetext{
${ }^{13}$ Herunder selvfølgelig også på tværs af systemer i samfundet: sociale systemer og interaktionssystemer.
} 
at det anvender generaliseringer for at symbolisere sammenhængen mellem selektion og motivation, f.eks. uddannelsessystemets eksamensbeviser. ${ }^{14}$

Som jeg har været inde på, kan man forestille sig, at omstillingsparate medarbejdere ikke bare forbedrer karrieremulighederne i ét system, men kan anvende denne omstillingsparathed i relation til andre systemer, dvs. til personlige karrieremuligheder. Helt generelt fungerer det ved, at disse medier selekterer på forhånd (altså med tempofordel), idet bestemte træk ved virkeligheden udvælges og gøres til symbol for virkeligheden, f.eks. eksamensbeviser, omstillingsparathed osv. ${ }^{15}$

"Vigtige eksempler er: Sandhed, karlighed, ejendom/penge, magt/ret og som ansatser også religiøs tro, kunst og i dag måske civilisatorisk standardiserede "grundvardier". På meget forskellig måde og for meget forskellige interaktionskonstellationer drejer det sig $i$ alle disse tilfcelde om at konditionere kommunikationens selektion således, at den samtidig virker som motivationsmiddel, altså vare tilstrakkeligt til at sikre antagelse af selektionsforslagene." (Luhmann 2000a s. 203) ${ }^{16}$

De symbolsk generaliserede medier opererer med bincere koder, som fastlægger det pågældende systems funktion og bestemmer systemets videre operationer. For eksempel baserer det politiske system sig på koden magt/-magt, det $\varnothing$ konomiske system på betale/-betale og uddannelsessystemet er dobbelt kodet $\mathrm{i}$ bedre/værre eksamen og på formiddelbar/ikke-formiddelbar viden. Til hvert af disse delsystemer knytter sig programmer, der betegner de betingelser under hvilke, en bestemt kode kan tilskrives et sagsforhold. For eksempel anviser et politisk program, hvordan magten skal anvendes, og for uddannelsessystemets vedkommende er det programmet padagogikker og laeseplaner, der anviser, hvordan viden evt. kan formidles, henholdsvis ikke kan formidles, samt hvem

\footnotetext{
${ }^{14}$ Pointen er, at et socialt system ikke kan basere sig på eller fungere under hensyn til hvert enkelt individs praktiske erfaringer. Resultatet ville være, at intet ville kunne tages for givet, og at enhver interaktion skulle starte ved nulpunktet.

${ }^{15}$ Der er altid tidligere foretaget kompleksitetsreduktioner, der lægger sig som semantiske konstruktioner og danner kultur.

${ }^{16}$ Antallet af mulige symbolsk generaliserede medier, der optræder i samfundet er ikke givet på forhånd, eftersom de er evolutionært opnåede gennem samfundets emergente orden. I Luhmanns fremstilling tyder meget dog på, at når først et symbolsk generaliseret medie er opstået, er det om end ikke umuligt, så overordentligt svært at forestille sig dets forsvinden. Det skyldes dels dets stærke kodificering og dannelsen af sociale systemer - organisationer der er koblet til og således bidrager til opretholdelsen af denne kode.
} 
det gælder. Der findes symbolsk generaliserede medier for hvert af samfundets delsystemer, som er kendt i samfundet som helhed, og som øvrige systemer i samfundet derfor kan tage i anvendelse og drage nytte af, qua den tempofordel disse medier yder. Luhmann siger om dette:

"Den mest succesrige og mest relevante kommunikation bliver i det nutidige samfund afviklet over sådanne kommunikationsmedier, og følgelig bliver chancerne for dannelse af sociale systemer dirigeret hen til de tilsvarende funktioner.” (Luhmann 2000a s. 203)

Et tegn på at uddannelse og dermed fokus på læring har fået en betydningsfuld gennemslagskraft i det moderne funktionelt differentierede samfund kan på systemplan iagttages ved ændringer i uddannelsessystemets interne differentiering. Empirisk kan det konkret iagttages ved udviklingen af et stadigt stigende antal af nye uddannelser og efteruddannelsestiltag i de formelle uddannelsesinstitutioner. Der kan tillige iagttages dannelsen af en række andre organisationssystemer, f.eks. konsulentfirmaer og private uddannelser, der strukturelt kobler sig til og anvender tilsvarende funktionelle beskrivelser om sig selv, dvs. beskriver sig som systemer, der tilbyder uddannelse. Ligeledes kan det iagttages at flere organisationer - specielt større - har deciderede efteruddannelsesafdelinger, eller de har i det mindste indskrevet en eller anden efteruddannelsesfunktion i egne beslutningsprogrammer og organisering (f.eks. et budget og en person, hvis funktion det er at forholde sig til uddannelse/efteruddannelse).

Når Luhmann skriver, at medierne - her uddannelse - på meget forskellig måde og for meget forskellige interaktionskonstellationer konditionerer kommunikationens selektion således, at den virker som motivationsmiddel, der kan medvirke til at sikre antagelse af selektionsforslagene, så handler det om, at når spørgsmål om uddannelse tematiseres, er der større motivation/sandsynlighed for at uddannelse vælges frem for ikke uddannelse. ${ }^{17}$ Denne antagelse handler ikke bare om formel uddannelse, men tillige om kurser osv. i organisationer. ${ }^{18}$

\footnotetext{
${ }^{17}$ Dette kan også knyttes til det symbolsk generaliserede medie uddannelsessystems symbiotiske mekanisme larelyst, som handler om menneskers individuelle motivation for at lære og uddanne sig.

${ }^{18}$ Ifølge Luhmann har samfundets overgang fra stratifikatorisk differentiering til funktionel uddifferentiering betydet et samfundsmæssigt skift i inklusions- og eksklusionslogikkerne. Uddannelse er her blevet et vigtigt forhold, idet uddannelse, viden, kvalifikationer og kompetencer, som traditionelt erhverves gennem uddannelse, og symbolsk udtrykkes gennem uddannelsespapirer, samfundsmæssigt har fået en højere status og generelt spiller en mere
} 
Ud fra en systemteoretisk forståelse er det ikke sådan, at karriere udelukkende bestemmes og muliggøres gennem uddannelsessystemets formelle uddannelsessymboliseringer. "Det er ikke alle samfundsmaessige karrierer, som struktureres via formaliserede afslutninger i uddannelsessystemet." (Luhmann 2006 s. 97-98). Ved en sociologisk iagttagelse af samfundets karriereselektioner kan personer sagtens af andre veje tilegne sig viden, færdigheder og kompetencer som samfundsmæssigt efterspørges, og som derfor giver karriere muligheder. Pointen er, at uddannelsessystemet tjener en vigtig kompleksitetsreducerende funktion for samfundets $\varnothing$ vrige systemer, som de er afhængige af og trækker på, når de skal afgøre, hvem der er relevant for dem, dvs. hvem, der passer til pågældende systems funktionelle forventninger, og ikke formelle uddannelsestyper trækker på samme semantik. Uddannelse er godt, og mere uddannelse er bedre, syntes parolen at lyde, men det er selvsagt heller ikke utænkeligt, at gode eksamensbeviser i visse tilfælde kan medvirke til at diskvalificerer personer fra bestemte karrieremuligheder; Man kan hænde at blive betegnet som overkvalificeret, men sådanne tilfælde må i det moderne samfunds inklusionspolitikker betragtes som undtagelser, der bekræfter reglen!

Relateret til uddannelseskommunikation i organisationer er det interessant at iagttage, på hvilken måde uddannelseskommunikation iagttages og hvilke refleksioner, der er knyttet til uddannelseskommunikationen.

\section{Uddannelsessystemets ydelse}

Uddannelsessystemets ydelse defineres ud fra en systemteoretisk forståelse som muliggфrelse af usandsynlig kommunikation, og eksamen/(uddannelses) grad. Med hensyn til eksamen/grad henvises der til, at uddannelsessystemet har samfundsmæssigt patent på at bedrive uddannelse, udstede eksamensbeviser og tildele uddannelsesgrader til enkelt personer. Denne ydelse anvendes af andre af samfundets systemer til at afgøre personers relevans i relation til inklusion i bestemte stillinger. Med usandsynlig kommunikation henvises der til, at uddannelsessystemet underviser med henblik på læring, og læring indbefatter, at eleven, kursisten, medarbejderen, eller hvem det måtte være, både forstår og anvender kommunikationens information som præmis for egen

legitim rolle i inklusions- og eksklusionsmæssige forhold. "Empirisk set vokser mangden af kommunikationer, som uddannelsessystemet tilregner sig selv, hastigt og i uhyre stort omfang gennem uddifferentieringen. Dermed $\phi$ ges trykket fra krav, eftersom hverken lagdeling eller magt bidrager til definition af relative chancer." (Luhmann 2006 s. 138). 


\section{Didaktik}

adfærd. Men eftersom forholdet mellem undervisning og læring systemteoretisk forstås gennem den grundlæggende distinktion system/omverden (dvs. undervisning som en intentionel og specialiseret form for kommunikation i et socialt interaktionssystem, der har til hensigt at stimulere læring forstået som et psykisk system, der gennem interne operationer (f.eks. tanker og bevidsthed) ændrer sin struktur (skemaer, frames, scripts, mentale modeller) (Luhmann 2006 s. 71)) så anses det for usandsynligt, at kommunikation kan ændre psykiske systemers indre strukturering. Dette stiller undervisning overfor det grundlæggende problem om manglende kausalforbindelser mellem det sociale og det psykiske, mellem undervisning og læring - der er ingen sikkerhed for, at eleven har tilegnet sig, dvs. forstået og lært det der er undervist i, endsige anvender det som præmis for egen adfærd! Luhmann har i flere omgange beskæftiget sig med dette grundlæggende problem i forholdet mellem undervisning og læring, og beskriver det som et teknologi underskud indenfor pædagogikken. (Luhmann og Schorr 1979) Jeg vender tilbage til dette i afsnittet om Organisatorisk laring som tekniologi, men kort fortalt handler det om at pædagogikken ikke råder over f.eks. undervisningesformer/teknikker (teknologier) som sikrer at eleverne lærer det der undervises i. Eller som han selv udtrykker det: "Det (...) skyldes, at der ikke findes opskrifter på laring, der giver sikker succes." (Luhmann 2006 s. 72-73) ${ }^{19}$

Luhmann udtrykker dette forhold på følgende måde:

"Hvis man forstår individuelle mennesker som konglomerater af autopoietiske, egendynamiske og ikke-trivielle systemer, er der ikke nogen anledning til at formode, at man kan uddanne dem." (Luhmann 2006 s. 107)

Jeg beskriver senere i afsnittet hvordan forholdet mellem sociale og psykiske systemer i systemteorien beskrives med den grundlæggende difference mellem system og omverden, dvs. som to autopoietiske systemer, som er åbne gennem deres egen lukkethed, og som opererer i hvert deres medie henholdsvis kommunikation og bevidsthed. Kort sagt er den teoretiske pointe at systemerne

\footnotetext{
${ }^{19}$ I bogen om samfundets uddannelsessystem beskriver Luhmann det som at pædagogikken i form af undervisning mangler arbejdsteknologier. (Luhmann 2006 s. 73) I relation til undervisningskommunikation i mere traditionel klasse form, beskriver Qvortrup det på følgende måde: "Kommunikationen i klassevarelset kan ikke trange ind i elevernes bevidsthed. Uanset hvor højt, tydeligt og overbevisende laren taler, kan hun ikke $>$ tale ind $<i$ den enkelte elevs hoved. (...) Klassen som socialt system og eleven som psykisk system er omverden for hinanden." (Qvortrup 2006 s. 13; Se også Rasmussen 2004 s. 286-291)
} 
ikke kan gribe direkte ind i hinandens operationer - kommunikation i sociale systemer og bevidsthed i psykiske systemer.

Som nævnt ovenfor, er der ikke nogen nødvendig sammenhæng mellem at have forstået noget, og samtidig gøre det til noget, man efterlever, dvs. som præmis for egen adfærd. ${ }^{20}$ Dette forhold kan knyttes til systemteoriens forståelse af mening.

\section{Mening}

I Luhmanns termer er mening ikke meningen med noget, men mening som en selektiv hændelse i et systems selvreference. Mening konstitueres i forskellen mellem aktualitet og mulighed. På et givet tidspunkt står noget i centrum, men samtidig henviser dette noget til yderligere muligheder. Mening er altså "enheden af aktualisering og virtualisering, reaktualisering og revirtualisering som en selv-propellerende proces (konditioneret af systemet)." (Luhmann 2000a s. 105). Måden hvorpå mening dannes og kompleksitet reduceres sker i anvendelsen af information, som skal forstås som "en hoendelse, som udvaelger systemtilstande" (Luhmann 2000a s. 106). Information er altså ikke en mangde af kommunikationer, men den selektive hændelse, der udelukker muligheder. Som form er mening dermed konstituerende for et systems differencer, og har med systemets identitet og funktion at gøre: noget beskrives som meningsfuldt, og noget beskrives som meningsløst. ${ }^{21}$ Når mening på denne måde opfattes som kontingent, dvs. kunne være eller opfattes på en anden måde, og dette kobles til, at sociale og psykiske systemer forstås meningsoplevende systemer, dvs. systemer som rummer hver deres selvreferentielt og historisk opbyggede mening, så er der ikke nogen nødvendig sammenhæng mellem at have forstået noget, og samtidig gøre det til noget, man efterlever, dvs. som præmis for egen adfærd.

\footnotetext{
${ }^{20}$ Man kunne tilføje, at måske netop fordi man har forstået noget, ønsker man i nogle tilfælde ikke at gøre det til noget, man efterlever, dvs. som præmis for egen adfærd.

${ }^{21}$ Det skal understreges, at meningsløshed som beskrivelse er systemets beskrivelse. Der findes i Luhmanns terminologi ikke sådan noget som meningsløshed eftersom "For meningsforarbejdende systemer findes der dermed ikke noget meningstab. Enhver aktualiseret intention henviser til yderligere muligheder. Der med er der ikke udelukket, at jeg tonker, at noget er meningsløst, eller at kommunikationen kommunikerer, at der er indtrådt tab af mening. I sådanne tilfaelde bliver der imidlertid anvendt et helt andet, nemlig et emfatisk meningsbegreb: Mening betyder da noget $i$ retning af meningsfuld - og modsatningen så: meningslфs. For teorien om sociale systemer er mening derimod en ikke-negerbar kategori: Psykiske og sociale systemer er bundet til fanomenet mening; de kan altså ikke operere meningslфst" (Kneer \& Naseehi 1997 s. 83)
} 
"Tvartimod: "Ethvert udtalt ord fremprovokerer den modsatte mening”. Kommunikationen har kun succes, hvis ego overtager kommunikationens selektive indhold (informationerne) som pramisser for egen adfard." (Luhmann 2000a s. 200)

Det er ikke kun interessant og relevant for uddannelses- og undervisningskommunikation, at det kommunikerede forstås og anvendes som præmis for egen adfærd, f.eks. til eksamen, men i særlig grad for organisationer, som på baggrund af organisationsudviklingsprojekter forventer, at organisationsmedlemmer lærer, dvs. forstår og anvender kommunikationen som præmis for egen adfærd. For organisationers vedkommende gælder dette forhold ikke bare ligesom indenfor uddannelsessystemet forholdet mellem undervisningskommunikation i interaktionssystemer og elevers læring (klasseværelses undervisning), men også forholdet mellem subsystemer i organisationen, dvs. adskilte afdelinger.

\section{Sproget, udbredelsesmedier og symbolsk generaliserede kommunikationsmedier}

Kommunikation har altid et problem angående udbredelse: "Hvis kommunikationen overskrider kredsen af narvaerende, bliver forståelsen svarere og afvisningen lettere; hjolp til tydning og den konkrete interaktions bekraftigelsestryk mangler." (Luhmann 2000a s. 201). Løsningen af kommunikationsprocessens immanente usandsynlighed skal imidlertid findes $\mathrm{i}$ samfundets sociokulturelle evolutionsproces, der leder fra kommunikationens usandsynlighed til dens sandsynlighed. Samfundet har over tid konstrueret forskellige kommunikationsmedier, der funktionelt skaber sandsynlighed for lovende kommunikation. Luhmann skelner mellem tre forskellige medier, som muliggør, begrænser og belaster hinanden med følgeproblemer. Det drejer sig om sproget, udbredelsesmedierne og de symbolsk generaliserede kommunikationsmedier, som ovenfor er forklaret. Fælles for disse medier er deres mulighed for at skabe tempofordele i kommunikationssituationer qua ego og alters kendskab til dem.

Sproget er et medium, der er konstrueret som og er kendetegnet ved regler for tegnbrug. Sprog øger sandsynlighed for forståelse af kommunikation langt ud over det iagttagelige.(Luhmann 2000a s. 201) ${ }^{22}$ Kendskabet til

\footnotetext{
${ }^{22}$ At sproget $\emptyset$ ger forståelse langt ud over det iagttagelige skal begribes på den måde, at det med sproget er muligt at tale om noget, der ikke findes fysisk f.eks. enhjørninger, Gud og spøgelser (Luhmann 2000a s. 201f.).
} 
tegnenes kombinatorik ligger til grund for ego og alters (kommunikationsparternes) mulighed for at kommunikere i den forstand, at ensartet tegnbrug bestyrker dem $\mathrm{i}$, at de mener det samme (indtil det modsatte iagttages!). Dannelsen af udbredelsesmedierne skrift, tryk og radiofoni har bidraget til en udvidelse af kommunikationsprocessers rækkevidde, sådan at andre end de tilstedeværende i den aktuelle interaktionssituation kan nås. ${ }^{23}$ Dannelsen af udbredelsesmedierne har dog ikke en entydig tempofordel:

"Den kommunikation, der kan tjene som grundlag for yderligere kommunikation, bliver, sammenlignet med interaktions- og erindringsbunden mundtlig overlevering, udvidet umådeligt og samtidig indskraenket”. (Luhmann 2000a s. 202)

At den anden side - indskrænkning - også optræder, skal ses i lyset af, at fremkomsten af sprog og udbredelsesmedier danner nye problemer vedrørende kommunikationens succes. Sagt banalt: Mere sprog og øget rækkevidde kan tilsvarende medvirke til, at mulighederne for kommunikationens usandsynlighed accelererer. Luhmann giver selv følgende eksempel:

"Langt ind i nyere tid har man reageret på en фget usandsynlighed med forcerede anstrengelser i form af overtalelsesteknikker såsom veltalenhed som opdragelsesmål, retorik som sarlig kunstlare og disputeren som konflikt- og resultatssikringskunst. Selv opfindelsen af bogtrykket har ikke forceldet disse anstrengelser, men snarere forstarket dem."(Luhmann 2000a s. 202)

Eftersom disse teoretiske pointer gælder generelt, er dette forhold et generelt problem eller en udfordring, også selvom man skifter elever ud med organisationsmedlemmer, og undervisningskommunikation ud med forandringskommunikation i organisationer osv.

\section{Didaktisk teori}

I det følgende vil jeg kort beskrive didaktikken historisk, og hvordan den forandrer sig i relation til samfundets udvikling, samt som en disciplin, der alt efter erkendelsesinteresse er internt differentieret i en række del discipliner.

\footnotetext{
${ }^{23}$ Her kunne der passende udvides med en lang række andre udbredelsesmedier f.eks. film, fjernsyn og ikke mindst computeren.
} 
Afsnittets funktion er grundlæggende at argumenter for, hvilken didaktik afhandlingen anvender, og begrundelserne herfor.

De didaktiske teorier er blevet udviklet og modificeret i takt med samfundets sociokulturelle evolution og i relation til de historisk skiftende ideer om dannelse, som pædagogikken har været og stadig er involveret i. ${ }^{24}$ Med begrebet didaktik kan der ifølge Künzli ikke henvises til et entydigt og homogent objekt, men til mange forskellige teorier og variationer i praktiske anvendelsesformer (Künzli 2000 s. 41). Klafki mener bl.a. derfor, at pædagogisk praksis må forstås som en bestemt form for samfundsmæssig praksis, der grundlæggende betragtes som historiske produkter (Klafki 2004 s. 16). ${ }^{25}$ Det er derfor afgørende at beskrive og forholde sig refleksivt til valget af dén didaktiske tilgang, som ønskes anvendt. Dette gøres ved at begrunde og reflektere didaktiske valg med reference til pædagogiske og undervisningsmæssige forhold i relation til organisationer. Et af de vigtigste og mest diskuterede emner i relation til pædagogik, og dermed også didaktik, er målet med uddannelse(n), dvs. dannelse (Klafki 2004; Schnack 2001; Ziehe 1997; Thyssen 2006; Oettingen 2010; Jank \& Meyer 2010).

\section{Dannelse}

I forhold til uddannelsessystemet kan man ifølge Oettingen skelne mellem dannelse $\mathrm{i}$ et førmoderne og et moderne perspektiv. Som vi så det hos Platon, var det vigtigste uddannelsesmæssige dannelsesmål karakteropdragelse, forstået som en intakt meningstydning, hvor det enkelte menneskes plads i samfundet var udpeget. Dannelse og dannelsesprocesser var således teleologisk bestemt, dvs. orienteret efter en fast overleveret meningstydning, retning og orden (Oettingen 2010 s. 65). Men med henvisning til det moderne funktionelt uddifferentierede samfund giver det ikke mening at operere med

\footnotetext{
${ }^{24}$ Didaktikken opstår og udvikles som en konsekvens af samfundets stigende opmærksomhed på og behov for uddannelse og undervisning, dvs. gennem en stærkere kobling mellem undervisning og læring. Som deldisciplin af pædagogikken vedrører pædagogiske diskussioner ligeledes didaktikken. Et relativt nutidigt eksempel er Henrik Windinges artikel om, hvordan f.eks. et nyt politisk forlig om folkeskolen i 2006 har haft betydning for didaktikken (Windinge 2006 s. 122-144). Et andet eksempel er Ole Thyssens artikel Vardier og dannelse i folkeskolen, som er en slags idehistorisk analyse af skolen, der belyser historiske og nutidige betydninger for dannelsestænkning og pædagogik (Thyssen 2006 s. 36-56).

${ }^{25}$ Hertil kunne man tilføje er didaktik såvel som pædagogik discipliner, der trækker på mange andre vidensformer psykologi, filosofi, sociologi, фkonomi, politiske, kulturelle og institutionelle forhold, osv., og følgelig er under indflydelse af udviklinger inden for disse discipliner.
} 
en ide om, at mennesket skal dannes til en fast plads i samfundet. Med reference til Luhmann og Schorr (1979) betegner Qvortrup dannelse som en kontingensformel (Qvortrup 2004 s. 284).

"Almendannelse er med et sociologisk udtryk en 'kontingensformel'. Den er den formel, uddannelsessystemet bruger, når der ikke er noget $i$ samfundet, der giver et holdepunkt for, hvad skolen overordnet set skal levere, og det er den formel, samfundets borgere bruger, når de taler om uddannelsessystemets ydelser." (Qvortrup 2004 s. 285)

I et moderne funktionelt uddifferentieret samfund er der ligesom til uddannelsessystemet også et utal af forventninger til organisationer og deres forskellige organisationsmedlemmer, hvorfor det er umuligt at stabilisere et fast dannelsesideal for, hvad en organisation og dens medlemmer skal vide noget om og kunne.

Tværtimod skal vi i et uddannelsesmæssigt perspektiv dannes, så vi selv lærer at bestemme over vores liv, hvilket betyder at dannelse i det moderne samfund må forstås som både emancipation (frigørelse) og participation (deltagelse) (Oettingen 2010 s. 67). ${ }^{26}$ Paulsen definerer således med reference til Luhmann (2006 s. 212), at uddannelsessystemets semantik om dannelse handler om læring; at tilegne sig laeringsevne, at laere at lare, hele livet (stofuafhængighed) (Paulsen 2008 s. 210). Dette dannelsesideal er på mange måder i overensstemmelse med det dannelsesideal, som kan findes indenfor en række teorier om organisatorisk læring, som koncentrerer sig om at optimere organisationens forandrings- og læringsevne, dvs. at lære at lære (Argyris \& Schön 1978; 1996; Senge 2000; Schein 1996; 2010).

Et problem i den henseende er, at nogle af disse organisatoriske læringsteorier, der opererer med dette dannelsesmål, fokuserer på at identificere læringsbarrierer af social og psykologisk karakter, og spørgsmålet er, om det er et tilstrækkeligt dannelsesmål for organisationer? Min påstand er, at der ikke findes organisationer hvis funktionelle bestemmelse er at laere at laere! Organisatorisk læring må betegnes som en form for middel, beredskab eller kompetence, der skal gøre organisationer robuste over for forandringerne i dets omverden. Eller som Thyssen formulerer det:

\footnotetext{
${ }^{26}$ Ifølge Oettingen må dannelse i det moderne samfund tænkes som en vekselvirkning mellem mennesket og verden. Mennesket må formgive dets eksistens i samvirkning med fællesskabet eller det sociale og relateret til uddifferentierede systemer. Oettingen taler også om, at mennesket skal kunne forstå og anvende flere perspektiver, f.eks. det politiske, etiske og religiøse. (Oettingen 2010 s. 65-110).
} 
"Laring bliver et led i en forfinet sensibilitet over for forandring og tilpasning til forandring." (Thyssen 1996 s. 104)

Spørgsmålet er, hvordan man finder ud af, hvad en organisations dannelsestænkning består i, dvs. hvad er målet for læringen?

I en refleksion over det moderne samfundsforandringsinerti skriver Thyssen om organisationers reaktionsmønster som et spørgsmål om organisatoriske selviagttagelsesprocesser, hvor organisationer reflekterer over, om de lever op til egne og omverdenens forventninger.

"Tvangen til fornyelse fører til en tvang til refleksion. Når både mål og midler vurderes $i$ stadig nye lys, er det aldrig givet hverken hvad der skal gøres eller hvordan det skal gøres. Og da organisationer er markedets aktфrer, tvinges de til en selviagttagelse, som munder ud i en uophфrlig lareproces." (Thyssen 1996 s. 111)

Det, Thyssen er inde på, kan udlægges som at organisationer iagttager sig selv ud fra et spørgsmål om ikke-viden. Hele grundideen med læring er at tilegne sig viden, som gør det muligt at handle anderledes. For at gøre dette muligt, må organisationen muliggøre andre og nye iagttagelser af sig selv, dvs. fokus på ikke-viden, altså hvad organisationen ikke ved. Dette sætter en refleksions- og beslutningsproces i gang, som handler om i hvilken udstrækning, man ønsker at gøre denne iagttagede ikke-viden til viden eller grundlag for fremtidige beslutninger. I forhold til konkrete medarbejdere udtrykker Niels Åkerstrøm Andersen det som pædagogisering af medarbejderens selvforhold:

”(...) at medarbejderens selvforhold bliver kodificeret padagogisk. Medarbejderen forventes at forholde sig til sig selv som objekt for laring i koden bedre/dårligere dannelsesmassigt." (Andersen 2002 s. 26)

Der kan lægges to betragtninger på Andersens udlægning. For det første vil jeg argumentere for, at koden viden/ikke-viden kommer før bedre/dårligere, idet man først må have en ide om, hvad bedre/dårligere handler om: Man må have alternativer, og de fremkommer gennem refleksionen viden/ ikke-viden. For det andet vil jeg argumentere for, at dette ikke bare handler om, at medarbejderens selvforhold kodificeres anderledes, dvs. relationen mellem organisation og medarbejder, men at det også indbefatter organisationen som sådan, dvs. organisationens selvforhold. Med dette menes, at organisatoriske muligheder og begrænsninger med hensyn til forandring og læring skal ses i 
et bredere organisatorisk perspektiv hvilket betyder, at en organisations eget eller egne forhold til dens forskellige subsystemer (f.eks. afdelinger) bliver relevant ud fra den betragtning, at organisatoriske subsystemer er afhængige af hinanden, og derfor udgør forskellige muligheder og begrænsninger for hinanden. Det er dermed den organisatoriske kommunikation, der kodificeres anderledes. Spørgsmålet er bare hvilke muligheder og begrænsninger, der viser sig ved organisationsudviklingsprojekter? Hvilke spørgsmål rejser sig i den forbindelse?

Eftersom denne søgen efter ikke-viden er noget, som er afhængigt af processer, refleksioner og beslutninger i den enkelte organisation, er det et grundlæggende empirisk spørgsmål, dvs. forudsætter empiriske undersøgelser. Herigennem vil det også være muligt at afgøre, om organisationen i sin interne differentiering arbejder efter samme dannelsesmål, eller om subsystemerne, f.eks. på grund af funktionelle forskelle, arbejder efter forskellige dannelsesmål, og hvad det evt. betyder for organisationens interne konditionering mellem afdelinger (subsystemer).

I dag vil man i relation til organisationer, og med reference til samfundets funktionelle differentiering og arbejdsmarkedets generelle inklusionsmæssige fokus på kvalifikationer og kompetencer, vende Platons forståelse om, så kundskabsformer (kvalifikationer og kompetencer) kommer før karakteropdragelse/almen dannelse. ${ }^{27}$ Med uddifferentieret henvises til, at dannelse formuleres forskellige i relation til forskellige mål, og ud fra et systemteoretisk perspektiv forløber målformuleringer i sociale systemer gennem reflekterende selvrefererende processer i forhold til sociale systemers selvforståelser.

\footnotetext{
${ }^{27}$ Den norske uddannelsesforsker og -teoretiker Petter Aasen udtrykker det på denne måde: "Et vellykket pedagogisk prosjekt $i$ et samfunn innebærer at individet tilegner seg kunnskaper, verdier og ferdigheder som gir mestrings- og handlingsgrunnlag i forhold til de krav, utfordringer og muligheter som individet møter gjennom livet." (Aasen 1997 s. 38). Der har de senere år været en række diskussioner om kompetencebegrebet i relation til et organisatorisk perspektiv. En kritik har været at kvalifikationer og kompetence indenfor en del af organisations- og ledelsesteorien beskrives med statiske og dualistiske forståelser af grundforholdet mellem individ og omverden, dvs. som en individuel kompetence. Ifølge en række forskere er dette et udtryk for en reduktionistisk forståelse, som ikke fanger, at kompetence i organisationer må ses som et intersubjektivt fænomen og en proces, hvor deltagere i arbejdsprocesser udvikler forståelser af deres arbejde gennem deres interaktive mestring af dette (Andersen, Jensen \& Prahl 2000). Denne nye tilgang eller forståelse af kompetence laver imidlertid ikke om på, at det stadig er kompetencer og kvalifikationer, der er i fokus i organisationer på det moderne arbejdsmarked, men udtrykker blot, at de iagttages og beskrives på andre måder.
} 
Jeg kommer senere ind på hvordan man ud fra en didaktisk og organisationsteoretisk tilgang kan gøre sig antagelser om disse selvbeskrivelser eller selvforståelsers retning i organisatoriske refleksionsprocesser. I det følgende vil jeg beskrive hvilken didaktik afhandlingen tager udgangspunkt i og hvorfor.

\section{Didaktiske tilgange}

Op gennem historien har samfundets gradvise uddifferentiering, specialisering og professionalisering af uddannelse og undervisningsaktiviteter resulteret i en intern differentiering i uddannelsessystemet, som har resulteret i udviklingen af forskellige didaktikker relateret til særlige uddannelses- og undervisningsaktiviteter. Der findes således i dag en lang række forskellige didaktikker fagdidaktikker, områdedidaktikker, aldersdidaktikker, didaktikker for sarlige opgaver, naturvidenskabsdidaktik, laringsforskning, undervisningsforskning osv. (Jank \& Meyer 2010; Hansen \& Tams 2006). Jeg vil ikke gå gennem didaktikkens mange forskellige udviklinger, teorier og modeller, ${ }^{28}$ men blot konstatere, at der ikke findes én entydig teoretisk definition af, hvad didaktik er, men en række mere eller mindre forskellige didaktiske modeller og teorier, som overordnet inddeles i to kategorier nemlig fagdidaktik, og almendidaktik. ${ }^{29}$ Ifølge Jank og Meyer kan fagdidaktik defineres på følgende måde:

"Fagdidaktikker er sarlige videnskaber, der udforsker og strukturerer forudsatninger, muligheder, konsekvenser og granser for laering og undervisning inden for et fagligt felt i eller uden for skolemassige sammenhange." (Jank \& Meyer 2010 s. 34)

Deres definition på en almendidaktisk model er videre:

1. En almendidaktisk model er en pædagogisk teoribygning til analyse og modellering af didaktisk handlen i og uden for skolemæssige sammenhænge.

\footnotetext{
${ }^{28}$ Det ses ikke som denne afhandlings opgave at forholde sig til, beskrive endsige analysere de mange forskellige didaktiske teorier og modeller, som i årenes løb har været fremme. Skulle man være nysgerrig i den henseende henvises til følgende: (Schnack 2001; Jank \& Meyer 2010)

${ }^{29}$ Der tales også om en tredje gruppe af didaktikker, nemlig særdidaktikker, som hører under fagdidaktikker. Eftersom dette område vurderes at ligge udenfor denne afhandlings fokus, vil det ikke blive beskrevet yderligere.
} 
2. en almendidaktisk model har til opgave at afdække forudsætninger, muligheder, følger og grænser for undervisning og læring på en teoretisk sammenhængende og praktisk anvendelig måde.

3. en almendidaktisk model kan i sin teoretiske kerne i reglen indordnes under en videnskabsteoretisk position (nogle gange også flere). (Jank \& Meyer 2010 s. 37)

Ifølge Klafki er der især to traditioner, som har gjort sig gældende nemlig materialdannelse og formaldannelse. Den materiale dannelse lægger vægt på dannelseseffekten et bestemt indhold har på personen - man påvirkes og præges som person af indholdet. Formaldannelse fokuserer på træningen af personlige evner og psykologiske funktioner uden forbindelse til et indhold, f.eks. at tænkeevnen forbedres gennem arbejdet med matematik (Klafki 2004 s. 15).

Som det tidligere er blevet beskrevet, kan teorier om organisatorisk læring ses som et særligt forskningsområde indenfor organisationsteorien. Et område, som til forskel fra tidligere teoriers mekaniske beskrivelser af organisationer, der lagde vægt på fast struktur, stabilitet og klare regler, i højere grad iagttager og beskriver organisationer som dynamiske systemer, hvis norm eller imperativ er, at de skal lære og i visse tilfælde 'lære at lære'. Denne afhandling lægger sig i forlængelse af rækken af didaktikker, som vedrører et bestemt undervisningsområde, nemlig undervisning i, og hvis indhold er relateret til, organisationer. Som udgangspunkt for udviklingen af en organisationsdidaktik tages der udgangspunkt i den almene didaktik. Den almene didaktik er mest velegnet til dette formål, fordi organisationer som udgangspunkt ikke består af et bestemt fag. Den didaktiske tilgang, som her søges, er af mere generel karakter, idet den som udgangspunkt skal kunne bruges til alle former for organisationer.

\section{Uddannelse og undervisning som kommunikation}

Som der tidligere er blevet argumenteret for, så forekommer der undervisningskommunikation i organisationer, men hvad er undervisning? I nedenstående vil jeg med reference til Luhmanns systemteori definere uddannelse og undervisning som kommunikation, hvilket bevirker at uddannelse og undervisning ikke kun er relateret til og foregår i f.eks. det officielle uddannelsessystem, men som relateret til kommunikationens funktion og intention, dvs. foregår alle mulige steder. Uddannelse og undervisning er med andre ord særlige former for kommunikation. 
Når man anvender en didaktisk iagttagelsesform, så søger man efter at iagttage organisatorisk kommunikation, som kan betegnes undervisningskommunikation, og det helt store spørgsmål er så: Hvad er organisatorisk undervisningskommunikation? Med udgangspunkt i Luhmanns definition af uddannelse som noget, der ikke er situeret i det formelle uddannelsessystem, men relateret til kommunikationens funktion og intention kan man sige, at "Alle kommunikationer, der bliver aktualiseret med henblik på uddannelse, gaelder for at vare uddannelse." (Luhmann $2006 \mathrm{~s}$. 81). Tilsvarende kan man med reference til hans definition af undervisning sige at undervisningskommunikation er kommunikation, som har intentioner om at forandre personer! (Luhmann 2000a s. 250; 1997 s. 628).

I denne afhandling bliver undervisnings- og uddannelseskommunikation så til organisatorisk kommunikation, som har intentioner om ikke kun at uddanne og forandre personer men også organisation(er). Eftersom didaktik defineres generelt som undervisningen og læringens teori og praksis, eller kort sagt som teorier og refleksioner om undervisning eller undervisningens hvad, hvorfor og hvordan (Dale 1999; Hansen \& Tams 2006; Jank \& Meyer 2010), så rummer didaktikken andre og flere elementer end bare konkret kommunikation, som har intentioner om forandring af personer. Afhandlingen tager udgangspunkt i Jank \& Meyers (2010) definition af almen didaktik. Denne er som sagt udviklet til at pege på de temaer, som findes relevante for uddannelses og undervisningsplanlægning indenfor uddannelsessystemet:

\section{Didaktiske spørgsmål i relation til læring}

1. Hvem skal lære?

2. Hvad skal læres?

a. Hvor kommer indholdet fra?

b. Hvilke kriterier skal ligge til grund for udvælgelsen?

c. Hvem skal træffe beslutningerne?

3. Af hvem skal der læres?

4. Hvornår skal der læres?

5. Med hvem skal der læres?

6. Hvor skal der læres?

7. Hvordan skal der læres?

a. Spørgsmålet om metoder.

8. Ved hjælp af hvad skal der læres?

a. Læremidler - computer, bøger, supervision, kollegaer osv. 


\section{Hvorfor skal der læres?}

a. F.eks. dannelsesmål.

b. Læringsmål. (Jank \& Meyer 2010 s. 20-30)

Man kan argumentere for, at alle temaerne i ovenstående didaktik også er relevante i organisatoriske sammenhænge. Det skal jeg ikke afvise, at de kan være. Det vil formentlig være afhængigt af organisationsudviklingsprojektets karakter, hvorvidt alle ovenstående temaer er relevante at forholde sig til, eller den konkrete erkendelsesinteresse i f.eks. et forskningsprojekt. Jeg vælger i afhandlingen at afgrænse temaerne til læringens: Hvem, hvad, hvornår, hvorfor og hvordan.

I den udstrækning en organisation $\emptyset$ nsker at udvikle og forandre sig, dvs. lære, vurderes det som helt afgørende, at der som en slags mindste mål er klarhed over, hvem der skal lære, hvornår der skal læres, hvorfor der skal læres, hvordan der skal læres, og ikke mindst hvad der skal læres. Ud fra en didaktisk iagttagelse af organisationer som ønsker udvikling, forandring og læring betegnes netop disse temaer som en slags grundvilkår der må være ideer om og en vis klarhed over. Eftersom didaktikken er udviklet indenfor samfundets uddannelsessystem er de didaktiske refleksioner knyttet til samfundets forventninger i relation til netop uddannelsessystemets funktion sådan som det er fors $\varnothing$ gt opstillet i nedenstående skema. Skemaet er inspireret af Qvortrup (1998) og Hagen (2006), men modificeret i relation til Luhmanns bog om samfundets uddannelsessystem (2006), hvor flere begreber afviger fra Qvortrups tidligere angivelser. Det drejer sig helt konkret om medium, kode og funktion. Der ud over er kategorierne refleksion og funktionssystem hentet fra Hagens skema (2006).

Mens uddannelsessystemets egenkompleksitet først og fremmest er udviklet i relation til samfundets forventninger til uddannelse af enkelt personer, som foregår i dertil indrettede skoler og uddannelsesinstitutioner, så må man formode at det forholder sig anderledes for organisationers vedkommende. Det er derfor ikke muligt direkte at overføre skemaet for uddannelseskommunikation til området for organisationer. Organisationer er slet og ret et andet genstandsområde, som fordrer at skemaet udfyldes ud fra teoretisk og empirisk viden om organisationer, så det mere adækvat forholder sig til disse områder. Som det senere fremgår i afhandlingen, iagttages og begribes organisationer ud fra den moderne systemteori, sådan som den er udviklet af sociolog og systemteoretiker Niklas Luhmann (2000a; 2000b). Ifølge den forståelse kan organisationer ikke forstås som bestående af enkelt individer, personer eller mennesker, kort sagt psykiske systemer, men som 
34 Didaktik

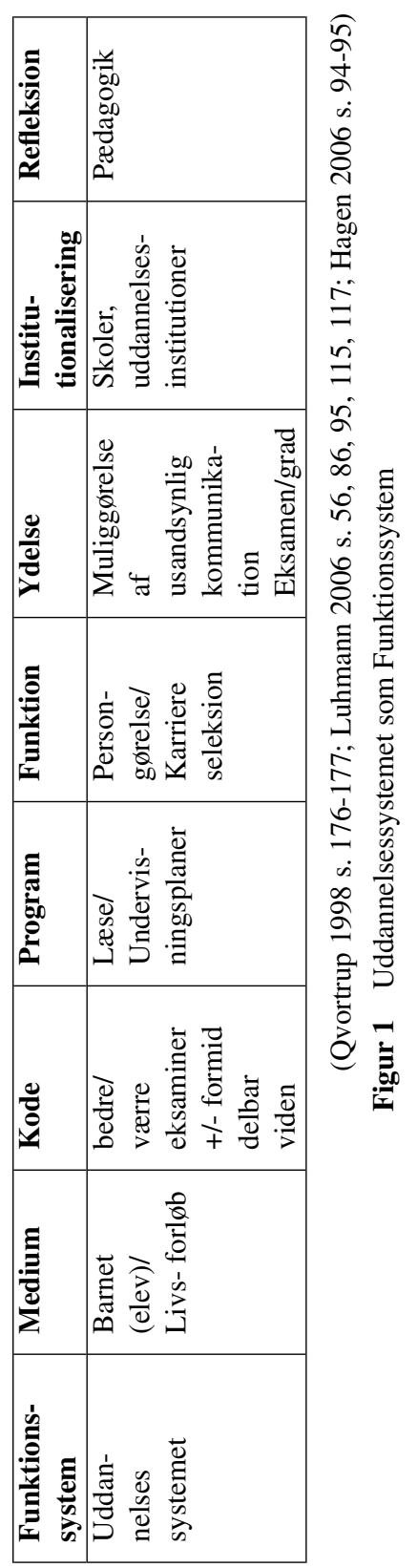


bestående af beslutninger. "Decisions is not understood as a psykological mechanism, but as a matter of communication, not as a psykological event in the form of an internally conscious definition of the self, but as a social event." (Luhmann 2003a s. 32) Organisationssystemer beskrives tværtimod som et særligt selvstyrende socialt system, der består af og reproducerer sig selv ved beslutningskommunikation (Luhmann 2000b; 2003a). I afhandlingen begribes organisationer som internt differentierede beslutningssystemer, der hver især konstruerer mening i relation til egne interne kriterier, hvorfor organisatorisk udvikling, forandring og læring ikke begribes udelukkende med henvisning til enkelt individer (psykiske systemer), men må forstås i henvisning til organisationssystemets beslutningskommunikation og herunder interne differentieringer (subsystemer). Netop dette forhold er en erkendelsesinteresse for afhandlingen i relation til forståelsen af organisatorisk læring og udviklingen af en organisationsdidaktik, der kan bruges som analysemodel til empiriske iagttagelser af organisatorisk læring.

\section{Afhandlingens erkendelsesinteresse og videnskabelige iagttagelses position}

En grundantagelse for afhandlingen er, at erkendelsesinteressen for teorier om organisatorisk læring er organisatorisk forandring og laring. Som afhandlingens empiriske genstand såvel som for andre organisationer, der arbejder med organisatoriske udviklingsprojekter, fusioner, udvikling af medarbejderes kompetencer eller lignende, vil det som oftest være relevant retrospektivt at få viden om hvorvidt og i hvilken udstrækning, der i relation til intentionerne bag organisationsudviklingsprojektet er sket læring eller forandringer, herunder hvorfor og hvorfor ikke. ${ }^{30}$ Selvom man kan argumentere for at teorier om organisatorisk læring havde deres storhedstid i 1990'erne (jf. Cohen \& Sproull 1996; Prange 1999; Easterby-Smith \& Araujo 1999; Gherardi \& Nicolini

\footnotetext{
${ }^{30}$ I det hele taget har der gennem en årrække været mere og mere fokus på forskellige former for evaluering koblet til begreber om organisatorisk læring (jf. Dahler-Larsen 2009 - specielt kap. 2.). Det Kommunale og Regionale Evalueringsinstitut (KREVI) skriver bl.a. under overskriften Hvordan kan organisationer omsætte evalueringer til læring?: "Hvis organisationen skal blive klogere og dermed en bedre problemløser, skal den beskæftige sig med problemer på organisationsniveau og ikke på enkeltsagsniveau. Hvis forvaltningen eller institutionen skal lære eller arbejde med kvalitetsudvikling bør den

- bruge evalueringer aktivt

- etablere et læringsrum tæt på praksis

- have ledelse og medarbejde til at deltage i dette læringsrum
} 
2001; Jacobsen \& Thorsvik 2008), og selvom den danske organisationsforsker med speciale i organisatorisk læring Bente Elkjær allerede i 1999 skrev artiklen "Det er laenge siden, at nogen har talt om den laerende organisation" (1999a), så bruges teorier og begreber om læring i organisationer stadig til under skiftende overskrifter at udvikle viden og erfaringer på baggrund af forskellige organisationsudviklingsprojekter (jf. Christensen 1997; 2000; Jørgensen \& Rasmussen 2005; Dahl mfl. 2005; Høyrup \& Ellström 2007; SCKK \& Holt Larsen 2007) Interessen for teorier om organisatorisk læringen finder således ikke alene sin berettigelse i organisationers praktiske anvendelse som organisationsudviklingsprojekt, ${ }^{31}$ men tillige ved at forskere og andre generelt anvender teorierne om organisatorisk læring som epistemologier til undersøgelse af forandring og læring i organisationer, dvs. til forskning, erfarings- og vidensudvikling vedrørende organisationsudviklingsprojekter af enhver karakter. ${ }^{32}$

Indenfor organisatorisk læring kan man på den baggrund udskille to tilgange eller perspektiver. På den ene side er der perspektivet organisatorisk læring i praksis, dvs. organisationers praktiske anvendelse af og erfaringer med organisatorisk læring som organisationsudviklingsprojekt. På den anden side er der teorier om organisatorisk læring, dvs. epistemologier om organisatorisk

- have lederen eller en ekstern konsulent til at fungere som vejleder i læringsrummet

- have ledelse og medarbejdere til at italesætte deres læring." (KREVI \& Eriksen 2009 s. 4)

\footnotetext{
${ }^{31}$ F.eks. udgav DEA, NOCA og Mannaz A/S, der er en sammenslutning af konsulentbureauer og netværksorganisationer, som henvender sig til private og offentlige organisationer, i 2010 guiden "Effektive laeringsformer - der skaber bedre laringsformer for din virksomhed", hvori de skriver: "Vakst er et centralt tema for mange virksomheder, og det satter laring, udvikling og innovation på dagsordenen. Nøglen til at skabe vakst er kompetente og innovative medarbejdere, som evner at udvikle, udveksle og anvende viden. Det stiller krav til virksomhederne om at sikre laringsveje, der mest effektivt og bedst muligt udvikler de menneskelige ressourcer $i$ virksomhederne. Mange HR-afdelinger og ledelser har valgt at se på nye muligheder for effektiv laring og udvikling internt $i$ virksomhederne. Det handler ikke bare om laring og udvikling, der g $\phi r$ den enkelte medarbejder mere kompetent. Men derimod om organisatorisk laring, der skaber bedre resultater for den enkelte virksomhed." (Mannaz 2010 s. 4). Guiden er skrevet på baggrund af input fra en ekspertgruppe indhentet ved møder og individuelle interviews samt interviews med HR-personer og medarbejdere i ekspertgruppens virksomheder. De har desuden gennemført en større spørgeskemaundersøgelse blandt HR-personer samt foretaget deskresearch og litteraturstudier.

${ }^{32}$ Teorier om organisatorisk læring kan måske nok ses som et modefænomen der har haft sin tid (jf. Røvik 1998), men på trods af dette kan man argumentere for, at de er relevante at beskæftige sig med, fordi de er indrettet efter, dvs. har som genstand at fremanalysere, forhold vedrørende læring og forandring i relation til organisationer.
} 
læring. Som der er blevet argumenteret for i indledningen af afhandlingen, og som det vil fremgå i det efterfølgende, er det i første omgang den sidste nemlig teorier om organisatorisk laring som epistemologier, der er i fokus. Senere i afhandlingen analyseres et konkret organisationsudviklingsprojekt; et værdibaseret ledelsesprojekt fra en større dansk kommune. Empirien har to funktioner, der er forbundet med hinanden. For det første bruges den til at lave en egentlig empirisk analyse med den i afhandlingen teoretisk udviklede organisationsdidaktik. Den empiriske analyse fungerer efterfølgende som empirisk grundlag for den videre udvikling af organisationsdidaktikken, dvs. de empiriske iagttagelser indskrives i organisationsdidaktikken.

\section{Organisationssociologisk positionering - et udgangspunkt}

Afhandlingen første afsnit handler om at positionere afhandlingen indenfor sociologiske eller sociologisk inspirerede teorier om organisatorisk læring som epistemologier. Men hvorfor interessere sig for teorier, og ikke bare empirisk unders $\emptyset$ ge om der er sket ændringer, læring eller ny erkendelse og organisatoriske forandringer? Gherardi og Nicolini beskriver ud fra et sociologisk perspektiv dette med begrebet om refleksion og viden:

"The concept of reflexivity is tied closely to participation in that reflexivity occurs when the flow of experience is interrupted and the subject reflects on knowledge. Reflexivity refers to ways of seeing that act back on and reflect existing ways of seeing; reflexivity gives rise to the institutionalization of knowledge. The principal feature of reflexivity is that reflection produces the setting that contains its objects as well as its expected and unexpected outcome. In other words, reflexivity ensures that the social production of that area of studies known as 'organizational learning' will produce the very phenomenon that it studies." (Gherardi \& Nicolini 2001 s. 35)

Det Gherardi \& Nicolini tematiserer her er videnskabens refleksive opmærksomhed på sig selv som et spørgsmål om viden. Ikke bare viden som viden om noget, men viden som $g \phi r$ en forskel! Fordi den anvendte viden selv producerer den genstand, som den studerer! Tilgangen er videnskabsteoretisk eller videnskabsfilosofisk, dvs. et udtryk for en metavidenskabelig disciplin, der studerer det videnskabelige grundlag for videnskabelig aktivitet, erkendelse og forudsætninger. Den fors $\emptyset$ ger så at sige at gå bag om videnskabelige teorier, begreber og forklaringer for at klarlægge og analysere de forudsætninger, de bygger på (Gilje \& Grimen 2002 s. 9). Tilgangen tematiserer det vigtige i 
ikke bare at gøre virkeligheden til genstand for iagttagelse, men i at vende blikket indad, dvs. stille skarpt på og gøre videnskabens teorier (om f.eks. organisatorisk læring) til genstand for iagttagelse, da netop disse teorier er medskabere af den virkelighed de selv studerer! Et andet forhold, som Gherardi \& Nicolini ikke tematiserer, er det forhold, at teorier og iagttagelse altid vil have blinde pletter - et synspunkt, som den tyske sociolog Niklas Luhmann har givet en radikal formulering. Hans påstand er, at man ikke kan skille iagttageren og det iagttagede ad. Det iagttagede er altid formet af en bestemt måde at iagttage på, og det udgør et erkendelsesteoretisk problem, der aldrig kan overskrides. Luhmann formulerer selv dette problem på en kryptisk måde:

"Et system kan kun se, hvad det kan se. Det kan ikke se, hvad det ikke kan se. Og det kan heller ikke se, at det ikke kan se, hvad det ikke kan se." (Luhmann 1995c s. 101)

Med Luhmann i tankerne kan en teori ses som et system af begreber og forståelser, der samtidig står for en særlig virkelighedsopfattelse, og som dermed både producerer det, den selv studerer, men også har sine egne blinde pletter, dvs. er blind overfor de forhold, den ikke har begreber til at iagttage. Det er denne analytiske tilgang til teorier om organisatorisk læring, som i det følgende vil blive yderligere begrundet, specificeret og anvendt.

Det spørgsmål, som Gherardi \& Nicolini rejser, besvares af to forskellige men relaterede veje - en videnskabsteoretisk og en sociologisk. Funktionen af den videnskabsteoretiske refleksion består i at være springbræt, dvs. danne baggrund for den sociologiske analyse. I kort form tager den videnskabsteoretiske tilgang udgangspunkt i refleksionen over videnskabelige teoriers funktion, dvs. forholdet mellem teori og virkelighed. Der kan ud fra forskellige videnskabsteoretiske tilgange peges på, at videnskabelige teoriers funktion udgør videnskabens optik, forforståelse/fordomme, eller som man indenfor nyere konstruktivistiske tilgange betegner videnskabens konstruktion af virkeligheden (jf. Gadamer 2004 s. 264-271; Hagen 1997; 1999; 2006 s. 52-64; Gilje \& Grimen 2002). Allerede Immanuel Kant (1724-1804) var inde på karakteren og betydningen af dette epistemologiske forhold (Kant 2002) Hans berømte udsagn: Das Ding-an-sich og Das Ding-für-uns, betoner erkendelsens grænser, dvs. det forhold, at det ikke er muligt, at operere ud fra en naiv realisme ${ }^{33}$ med en ontologisk antagelse om, at man kan erkende og erfare

\footnotetext{
33" Naiv realisme, erkendelsesteoretisk position, if $\varnothing$ lge hvilken virkeligheden er, som vi sanser den. Der er således ikke noget skel mellem verden, som den virkelig er, og den måde, hvorpå
} 
verden eller virkeligheden, som den er i sig selv (Das Ding-an-sich - verden, som den er i sig selv). Man må tværtimod operere ud fra den grundlæggende epistemologiske forståelse, at enhver sansning, forståelse og fremtrædelse af verden er et produkt af, hvordan vi oplever verden (Das Ding-für-uns verden, som vi oplever den). Den tyske systemteoretiske ${ }^{34}$ sociolog Niklas Luhmann udtrykker det på følgende måde, og ud fra antagelsen og begrebet om selvreferentielle systemer.

"Den gamle opfattelse var, at videnskaben var henvist til en rationalitet, der kom den i møde i genstanden. Denne opfattelse er opgivet af transcendentalfilosofien $i$ den udformning, der foreligger som ontologi. Den blev erstattet af tesen om, at realiteten ikke kan erkendes $>$ an sich $<$, en tese som korrelerer med inkluderingen af selvreference $i$ 'subjektet'. Reobjektiviseringen af selvreferentielle systemer, som gennemfores her, erklarer ikke denne tese for falsk, men generaliserer den snarer: Ethvert selvreferentielt system har kun den omverdenskontakt, som den selv muliggør, og ingen omverden $>$ an sich $<$.” (Luhmann 2000a s. 141)

\section{Fænomenologisk-systemteoretisk 'approach'}

I analysen af organisatorisk læring tages der udgangspunkt $i$ et fænomenologisk-systemteoretisk approach baseret på Niklas Luhmanns systemteori, som grundlæggende er inspireret af fænomenologi og anden ordens kybernetik (Luhmann 1989 s. 23). ${ }^{35}$ Tilgangen knytter sig til den videnskabsteoretiske forestilling om, at "Objektivitet er den vrangforestilling, at man kan gøre iagttagelser uden en iagttager." (Foerster \& Pörksen 2003 s. 126). Fokus bliver derfor på hvordan iagttagere iagttager!

Edmund Husserl (1859-1938), der betegnes som fænomenologiens grundlægger, forsøgte at beskrive grundlaget for al erkendelse. Husserl tog

den fremstår for os. Mere avancerede former for realisme afviser, at der skulle være en sådan direkte og sikker adgang til virkeligheden." (Den Store Danske)

${ }^{34}$ Der findes mange forskellige systemteorier, som epistemologisk adskiller sig fra hinanden. Når der i afhandlingen skrives systemteori eller henvises til systemteori, sker det altid i en henvisning til systemteori, sådan som den er formuleret af den tyske sociolog Niklas Luhmann. For en indføring i, og diskussion af forskellige systemteorier henvises der til Kneer og Nassehi (1997) specielt kapitel 2.

${ }^{35}$ Anden ordens kybernetik i denne form er grundlæggende inspireret og udviklet af den $\emptyset$ strigsk-amerikanske fysiker og filosof Heinz von Foerster, specielt bogen Observing System, Seaside 1981. 
udgangspunkt i en tese om, at al erkendelse forekommer i bevidstheden. Dét, som viser sig i denne erkendelse, kaldes fanomener. Fænomen betyder det som kommer til syne, og fænomenologi kan derfor betragtes som læren om det, som viser sig for bevidstheden, sådan som det forekommer at være, men ikke nødvendigvis som det i virkeligheden er (Rasmussen 1996 s. 99). Omsat til systemteori betyder den fænomenologiske indsigt, at de fænomener, videnskaben studerer, skabes af de begreber og teorier, som tages i anvendelse (jf. Gherardi \& Nicolini 2001). Tilgangen beskrives analytisk som en 2. ordens tilgang, dvs. en tilgang der har som ideal og erkendelsesinteresse at beskrive, hvordan andre beskriver og forholder sig til et givent fænomen, her begreber om organisatorisk laering. Kort sagt, at iagttage andres iagttagelser som iagttagelser med det formål at beskrive, hvad de med deres iagttagelser iagttager. Tilgangens forskningsmæssige funktion og dermed dens legitimitet er at give mulighed for erkendelsesgevinster, dvs. tilvejebringe andre iagttagelser.

Eftersom videnskabens iagttagelse eller tilgang til verden sker gennem begreber og teorier (Hagen 1997; 2006; Gherardi \& Nicolini 2001), er det i relation til ovenstående videnskabsteoretiske refleksion afgørende at være bevidst om netop disse begreber og teorier, og det mener jeg denne epistemologiske tilgang er velegnet til. Epistemologisk iagttages teorier og begreber som konstruktioner, dvs. som måder at iagttage og skabe mening på. Eftersom iagttagelsesbegrebet spiller en så central rolle i afhandlingen, vil jeg her forholde mig til, og beskrive hvordan iagttagelsesbegrebet forstås indenfor systemteorien.

\section{Formen iagttagelse}

Med inspiration fra den engelske matematiker George Spencer Browns bog Laws of Form (opr. 1969) præciserer og konsoliderer Luhmann sit distinktionsteoretiske iagttagelsesbegreb. ${ }^{36}$ Spencer Brown starter bogen med udsagnet

\footnotetext{
${ }^{36}$ Luhmann begynder først for alvor at referere til Spencer Brown i slutningen af 1980' erne - nærmere bestemt 1988 (se Borch 2000 s. 106). Dette betyder imidlertid ikke, at referencer til Luhmanns tidligere arbejder ikke passer, snarere er der tale om, at Spencer Browns distinktionskalkule tilfører Luhmanns systemteori en præciserende radikalisering, som leverer den teoretiske retfærdiggørelse af Luhmanns distinktionsteoretiske systemantagelser (se Borch 2000 s. 105). Som det fremgår af følgende citat flugter Luhmanns senere distinktionspræciseringer med hans tidligere skrifter: "Iagttagelse vil $i$ denne sammenhang (altså på den almene systemteoris niveau) blot sige håndteringen af forskelle. Kun for psykiske systemers vedkommende forudsattes bevidsthedsbegrebet (man kunne også sige, at iagttagelser giver anledning til fremkomsten af systemets eget medium, bevidsthed). Andre systemer må erhverve deres egne muligheder for iagttagelse. Selviagttagelse er altså følgelig
} 


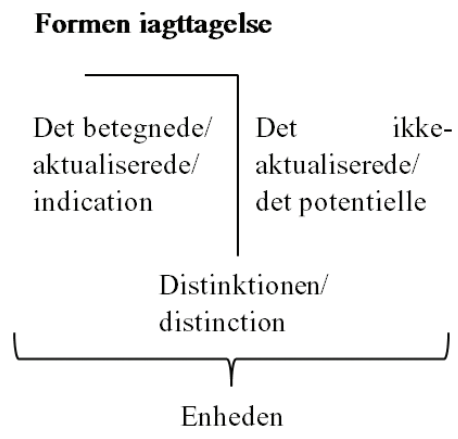

Figur 2

Draw a distinction! (Spencer Brown 1971 s. 3). Med dette menes, at for at kunne se, må verden kløves ved hjælp af en distinktion (distinction), der resulterer i en betegnelse (indication), og som er det en iagttager ser - det aktualiserede (Luhmann 2000a s. 105). ${ }^{37}$ En iagttagelse er således en indikation inden for rammen af en distinktion, eller enheden af distinktionen mellem det betegnede/det potentielle, dvs. enheden i det distinktionen adskiller.

Det, enheden af distinktionen giver mulighed for at se, er distinktionens inderside, dvs. det betegnedelaktualiserede, mens den anden side det ikkeaktualiserede eller potentielle, træder i baggrunden som umarkeret. Det man ser, er altså indersiden af distinktionen - det betegnede - og det man ser med er distinktionen. Ydersiden, som også er skabt af distinktionen, er det ikke-aktualiserede, dvs. det, som er udelukket eller ikke markeret gennem distinktionen. Ydersiden (det ikke-aktualiserede) udgør dermed noget potentielt muligt, eller som Luhmann udtrykker det - placeret i en tilstand af momentan inaktualitet (Ibid. 105). Iagttagelser af denne art eller form kaldes første ordens iagttagelser. Et væsentligt træk ved første ordens iagttagelser er, at distinktionen, som ligger til grund for iagttagelsen, er usynlig i iagttagelses $\varnothing j$ eblikket (blind plet), men kan gøres synlig eller bevidst med en anden ordens iagttagelse. Et eksempel på dette kunne være: Jeg er i biografen, og ser en film, jeg oplever, er god, men jeg kan ikke samtidigt med, at jeg ser filmen (dvs. i oplevelsen) begrunde hvorfor, jeg oplever den som god. Det kræver en anden ordens iagttagelse - en refleksion.

indføringen af system/omverdensdifferencen i systemet, som konstituerer sig ved hjolp af denne selviagttagelse (...)” (Luhmann 2000a s. 75).

37,'Iagttagelse vil i denne sammenhæng (altså på den almene systemteoris niveau) blot sige håndteringen af forskelle.” (Luhmann 2000a s. 75). 
En anden ordens iagttagelse er iagttagelse af distinktionen i første ordens iagttagelsen, dvs. anden ordens iagttagelsen ser det, som første ordens iagttagelsen ser med, eller distinktionen som ligger til grund for iagttagelsen af det aktualiserede (Hagen 2006 s. 59). Ligesom distinktionen i første ordens iagttagelsen er kontingent, dvs. kunne være foretaget anderledes, gælder det samme for anden ordens iagttagelsens distinktion, idet også denne ser med en distinktion, hvorfor første ordens iagttagelsen er anden ordens iagttagelsens konstruktion. Med denne distinktionsanalytiske tilgang sikres ikke ontologi (som det også fremgår af fænomenologien), forstået som adgang til det værende, men til en forståelse af, at alle iagttagelser, uanset hvem der foretager dem, er kontingente konstruktioner (se f.eks. Hagen 2006 s. 57-64; Qvortrup 2001 s. 94-98). Kybernetikeren Heinz von Foerster betegner denne form for erkendelse som en processologi (Foerster \& Pörksen 2003 s. 12).

Denne analytiske tilgang kan derfor beskrives som en form for iagttagelses epistemologi, eller som Hagen kalder den: epistemologisk konstruktivisme (Hagen 2006 s. 57), hvor alt, hvad der kan iagttages, iagttages som iagttagelser, herunder også anden ordens iagttagelser, dvs. iagttagelser af iagttagelser. I afhandlingen sættes der fokus på, at begreber og teorier ikke er egenskaber ved verden, men betegnes som de iagttagelsesinstrumenter, forskeren ser med, og som giver anledning til erkendelser om verden, knyttet til og styret af de anvendte begreber og teorier, der fungerer som distinktioner for iagttagelser.

\section{lagttagelse af organisatorisk læring}

Den videnskabsteoretiske lære af systemteoriens iagttagelsesbegreb er, som også Gherardi og Nicolini pointerer, nemlig en opfordring til refleksion, dvs. bevidsthed om anvendte teoriers indvirkning på forståelse og fortolkning af verden og virkelighedsbeskrivelsen. I denne afhandling drejer det sig om, hvordan videnskabelige teorier om organisatorisk læring giver teoristyrede analytiske muligheder og begrænsninger ved iagttagelse af empiri, såvel som organisationsudvikling. ${ }^{38}$

På baggrund af ovenstående videnskabsteoretiske refleksion, kan afhandlingens positionering yderlige specificeres og begrundes. ${ }^{39}$ Forskningsinteressen fokuserer i første omgang på forholdet mellem samfund og organisation

\footnotetext{
${ }^{38}$ Et eksempel på denne tilgang er Silvia Gherardi og Davide Nicolinis artikel ”The Sociological Foundations of Organizational Learning" (2001). Dette er en artikel som gennemgår fem forskellige sociologiske traditioners tilgange og epistemologiske refleksioner knyttet dertil.

${ }^{39}$ Det skal for klarhedens skyld nævnes at den egentlige sociologiske positionering af afhandlingen finder sted i slutningen af kapitel 4 . Her positioneres afhandlingen i relation til fem forskellige sociologiske tilgange til organisatorisk læring.
} 
og de begreber og refleksioner, som organisatorisk læringsteori knytter hertil. Forskningsinteressen stiller skarpt på og fors øger at iagttage de begrundelser interessen for lærende organisationer anvender koblet til teori om det moderne samfund. Jeg ønsker ikke her at inddrage og gennemgå større mængder af litteratur om, hvorfor læring har fået en fremtrædende plads indenfor organisationsteorien, men nøjes med at konstatere begrundelserne som er nært knyttet til samfundets forandring, og den hastighed med hvilken forandringerne finder sted.

"Ett stort intresse för förandringen som tema stämmer väl överens med dagens debatt om det postindustrielle samhället. (...) Modernanister förklarar behovete av nya organisatoriske former i termer av förändringar $i$ omvärlden, och dessa uppfattningar har sin grund i förutsägelser om snabba och kontinuerliga förändringar av produkter, marknader, teknologier och samhällen. För att hålla jämna steg med detta måste organisationer vara byggda för förändring, och organisationsforskare kommer att behöva dynamiska modeller för att beskriva och förklara dem." (Hatch 1997 s. 383)

"Disse historier om hastige andringer i omgivelserne lokker os til mere generelt at forudsige, at de fremtidige miljфer vil favorisere organisationer, som evner at vare fleksible, og som hurtigt kan tilpasse sig de forandrede vilkår. Organisationer, som ikke tilpasser sig, synes dømt til at forsvinde, når verden omkring dem andrer sig. Dette har medfort megen begejstring for at designe organisationer, der magter at lare, at tilpasse sig de forandringer, som de udsattes for." (March 2005 s. 297)

Man kan læse Hatch's udlægning som et produkt af modernisters iagttagelse af samfundet, men det er ikke bare modernister, som står frem med dette argument. Tværtimod kan det genfindes hos mange andre, og det udbygges eller gendrives gennem henvisning til samfundets øgede internationalisering og globalisering, samt den $\emptyset$ gede betydning af informations- og kommunikationsteknologi osv. (Jacobsen og Thorsvik 2002 s. 337-338). ${ }^{40}$ Tematiseringen af samfundets forandringer udlægges og genfindes hos en

\footnotetext{
${ }^{40}$ Begrundelserne for, hvorfor organisatorisk læring er kommet på dagsordenen falder typisk i to kategorier, nemlig praktiske årsager og af teoretiske grunde (Hildebrandt \& Brandi 1998 s. 17-19). De praktiske grunde hænger sammen med ændringer i forholdet mellem organisationer og deres omgivelser, dvs. nye udfordringer, krav, forventninger, ny teknologi, nye markeds- og konkurrencevilkår, ny viden som alt sammen betyder konstante forandringer.
} 
række sociologer og organisationsteoretikere (Scott 2003; Qvortrup 1998; 2001; March 1995; 2005; Luhmann 1997a; 1998; Giddens 1996; Senge 2000). At organisationer skal have opbygget og indbygget et mere eller mindre permanent forandringsberedskab, og at dette kræver mere eller mindre eksplicitte modeller, anskues i afhandlingen som organisationsteoriens svar på de samfundsmæssige forandringer.

\section{Organisation, organisatorisk læring og teknologi}

I dette afsnit tematiseres organisatoriske tiltag, herunder organisatorisk læring, med et samlet begrebet om teknologi. Teknologi kan overordnet defineres som forhold, hvor noget anvendes med det formål at transformere mere eller mindre bestemte input til mere eller mindre bestemte output. (Luhmann 1997a s. 517-536; 2008 s. 83-100). Set i det perspektiv er teknologi grundlæggende knyttet til organisering. Ud fra den antagelse, at organisatoriske og organiserende tiltag foretages med henblik på at forandre, og i nogle tilfælde at styre, større eller mindre dele af en organisations handleområde, kan der være erkendelsesgevinster ved at have begreber for, hvilke muligheder og begrænsninger forskellige former for organisering (teknologi) stilles overfor. Når teknologibegrebet knyttes til organisering, åbner det blikket for, at se teknologi som et grundlæggende element i organisationers måde at fungere og forandre sig på. De anvender teknologier som led i egen organisering dvs. på sig selv.

De teoretiske grunde handler om organisationers interne forhold eller strukturering i forhold til de ydre forhold. Statens Center for Kompetence- og Kvalitetsudvikling har udgivet hæftet "Laringsmiljø i staten Hvad, hvorfor og hvordan? - et inspirationshafte om laring på jobbet." Heri fremgår det, at Statens organisationer iagttages som nært knyttet til forandringer i deres omverden f.eks."

- Den politiske dagsorden - bl.a. ønsker om modernisering og effektivisering af den offentlige sektor, politiske beslutninger som kommunalreformen samt reformer på ministerområder

- Internationalisering - bl.a. europæisk samarbejde, som betyder harmonisering af nationale lovgivninger og bestemmelser, samt globalisering, hvor information og påvirkninger flyder over landegrænser

- Den teknologiske udvikling - bl.a. internet og e-mails, hvor data kan distribueres og deles mere enkelt, hvilket kan betyde effektivisering af den offentlige forvaltning både internt og i forhold til brugerne

- Samarbejdspartnere, konkurrenter og leverandører - bl.a. ved at indgå i samarbejder og nedbryde traditionelle barrierer

- Forventninger og krav fra brugerne - bl.a. et øget fokus på brugerperspektivet i staten, idet forventninger og krav fra brugerne er blevet mere individualiserede, og service skal rumme et aspekt af valgfrihed." (Larsen 2007 s. 35). 


\section{Det forskellige som sammenligneligt}

Både interessen for og studiet af organisation, organisering, rationalitet, ledelse, værdier og kommunikation, samt relationerne mellem disse elementer, har på forskellige tidspunkter og med varierende styrke optaget organisationsforskningen. Fra at være et område domineret af økonomisk tænkning, rationalitet og ingeniørvidenskab, har organisationsforskningen op gennem de sidste 100 år integreret tankegods fra et utal af andre videnskabelige discipliner f.eks. psykologi, sociologi, antropologi, kultur antropologi, biologi, semiotik, kybernetik m.m. (se f.eks. Røvik 1998; Morgan 1993; Hatch 1997; Scott 2003). Organisationsforskning er derfor i dag et interdisciplinært og tværvidenskabeligt felt, som mange forskellige professioner, institutioner og fag leverer bidrag til.

Indenfor de seneste ca. 30 års har organisationsforskningen, og specielt den del som interesserer sig for organisatorisk udvikling og forandring, både nationalt og internationalt været centreret omkring begreber som læring, viden, Human Ressource, kvalifikationer og kompetencer, værdier og etik (se f.eks. Nonaka \& Takeuchi 1995; Senge 2000; Argyris \& Schöen 1978 \& 1996; Thyssen 1997a; Andersen, Jensen og Prahl 2000; Fisher \& Lovell 2003; Armstrong 2006; Easterby-Smith, Burgoyne \& Araujo 1999; Easterby-Smith \& Lyles 2005). Organisationsforskningens historie har været præget af en lang række organisationskoncepter, som i kortere og længere perioder har gjort sig gældende - både rent forskningsmæssigt og i form af konkrete redskaber, som organisationer har brugt til udvikling af sig selv. Når man f.eks. taler om organisationspsykologi, organisatorisk læring, New Public Management, værdibaseret ledelse eller etisk regnskab, er det så et udtryk for henholdsvis psykologiens, uddannelsestænkningens, økonomiens eller filosofiens kolonialisering af organisationsteorien og samfundets organisationer, eller kunne der evt. være en alternativ forklaring? Spørgsmålet er i den forbindelse, om man kan finde en slags fælles betegnelse for dem, som siger noget andet, end at det er koncepter? I det følgende vil der blive argumenteret for, at organisationsudviklingskoncepter, herunder organisatorisk læring, kan iagttages og beskrives som teknologier.

"I en organisatorisk sammenhong handler teknologi om måder, hvorpå et system gennem strukturerede arbejdsprocesser kan andre genstande for dets handlinger $i$ en på forhånd fastlagt retning, dvs. frembringe årsag-virkningskceder.” (Qvortrup 2006 s. 17) 


\section{Organisatoriske teknologibegreber}

I overensstemmelse med Goodman og Sproull (1990) og Weick (1990) anvendes begrebet teknologi som samlet betegnelse for organisationskoncepter, der er indskrevet med det formål at dele eller hele organisationen skal handle anderledes, og hvor teknologi betegner det middel eller den metode, der er valgt med henblik på at transformere organisatorisk input til et andet output. På et overordnet plan kan teknologibegrebet tematisere og præcisere aspekter af tiltag, beslutninger, procedurer og organisationskoncepter, der bruges til prioritering og styring af organisationer, herunder hvordan organisatorisk læring kan forstås som organisatorisk teknologi.

Anvendelsen af teknologibegrebet til iagttagelse og forståelse af, hvad der sker i organisationer, er ikke af nyere dato. Goodman og Sproull (1990) argumenterer for, at det moderne samfunds organisationer fra begyndelsen har anvendt (naturvidenskabelige) teknologier til fremme af bestemte organisatoriske og samfundsmæssige formål. "The industrial revolution used technology to extend human physical capability. The computer or information revolution will extend our mental capacity. Technology may change the basic way we think about organizational forms." (Ibid. s. xi). Som det fremgår, kan indførelsen og anvendelsen af teknologi iagttages som noget, der har implikationer for både mennesker og hele måden, vi tænker organisationer og organisering på. For eksempel definerer Hulin \& Roznowski (1985) teknologi i relation til organisationer således:

"We define technology as the physical combined with intellectual or knowledge processes by which materials in some form are transformed into outputs used by another organization or subsystem within the same organization." (Ibid. s. 47)

Denne definition udvider begrebet fra at omhandle naturvidenskabelige teknologier til også at omhandle kvalifikationer, udstyr og ikke mindst viden, der bruges strategisk til organisatoriske transformationsprocesser med henblik på mere eller mindre bestemte output, dvs. opnåelse af bestemte mål (Weick 1990 s. 3). En anden definition er:

"Technology is a family of methods for associating and channeling other entities and forces, both human and nonhuman. It is a method, one method, for the conduct of heterogeneous engineering, for the construction of a relatively stable system of related bits and pieces with emergent properties in a hostile or indifferent environment." (Law 1997 s. 115) 
Denne definition inkluderer ud over materielle ting også mennesker som noget, der med en planlagt metode som teknologi i en eller anden udstrækning kan formes. Definitionen betoner desuden, at der kan være kritiske aspekter og organisatorisk modstand ved anvendelsen af en teknologi. En tredje definition er:

"Technology refers to a body of knowledge about the means by which we work on the world, our arts and our methods. Essentially, it is knowledge about the cause and effect relations of our actions (...) Technology is knowledge that can be studied, codified, and taught to others." (Berniker 1987 s. 10)

Denne definition lægger vægt på teknologi som viden, der tages i anvendelse med intentionen om strategisk at påvirke og med henblik på opnåelse af helt bestemte effekter, dvs. opnåelse af bestemte mål.

En lignende forståelse findes hos den franske idehistoriker Michel Foucault, der arbejder med at sammenknytte viden og teknologi som strategisk kan tages i anvendelse i relation til opnåelse af bestemte mål. Foucault identificerer og beskriver fire forskellige disciplinære magtteknologier, der opererer mere eller mindre usynligt i relation til disciplinering af subjekter:

"1) technologies of production, which permits us to produce, transform, or manipulate things; 2) technologies of sign systems, which permit us to use signs, meanings symbols, or signification; 3) technologies of power, which determine the conduct of individuals and submit them to certain ends or domination, an objectivizing of the subject; and 4) technologies of the self, which permit individuals to effect by their own means or with the help of others a certain number of operations on their own bodies and souls, thoughts, conduct, and the way of being, as to transform themselves in order to attain a certain state of happiness, purity, wisdom, perfection, or immortality." (Foucault 1988 s. 18)

Ifølge Gherardi \& Nicoloni (2001) kan en Foucaudiansk læsning af specielt den managementorienterede del af organisationsteoriens brug af begreber om organisatorisk læring ses som brugen af magtteknologier med det formål at disciplinere og kontrollere organisationsmedlemmer i relation til organisationens strategiske bestræbelser (Ibid. s. 44).

Luhmann operer også med et teknologibegreb, der ligesom ovenstående definitioner ser teknologi som naturvidenskabelige, som viden og som 
bestemte organiseringsformer, der alle kan anvendes i forsøg på at fremme mere eller mindre bestemte mål. Til forskel fra ovenstående definitioner har Luhmann imidlertid mere blik for forskellige teknologiers muligheder og begrænsninger relateret til dels den konkrete teknologis beskaffenhed, dels til teknologiers koblinger til andre systemer. ${ }^{41}$ Teknologier iagttages som noget, der organisatorisk indsættes med henblik på transformation af organisatoriske områder, dvs. som måder til styring og forandring af organisationer i mere eller mindre bestemte retninger.

\section{Systemteoriens teknologibegreb}

I denne afhandling anskues organisatorisk læring som teknologi. ${ }^{42}$ Ligesom i ovenstående definitioner trækker teknologi ifølge Luhmann på antagelsen om kausalitet, altså kvalificerede antagelser om årsags-virkningsforhold (Luhmann 1990c s. 228; 2000b s. 364; 2007 s. 90). Teknologi er forhold, hvor noget anvendes med det formål at transformere bestemte input til mere eller mindre bestemte output (Luhmann 1997 s. 517-536; 2008 s. 83-100). Ifølge Luhmann må man skelne mellem tekniske systemer (kausale teknologier) og meningssystemer (skemabaserede teknologier) (Luhmann 2007 s. 9; se også Oettingen 2007 s. 33) ${ }^{43}$ Som jeg senere kommer ind på, er denne skelnen afgørende i forhold til fors $\emptyset \mathrm{g}$ på at styre og forandre organisationer.

\section{Tekniske systemer og meningssystemer som teknologier}

Tekniske systemer er kausale teknologier, der opererer ud fra antagelsen om, at det er muligt at skabe en kausal sammenhæng mellem input og output.

\footnotetext{
${ }^{41}$ Det er altid en overvejelse, hvilke teoretikeres teknologibegreb, man skal inddrage og medtage, og det kan selvfølgelig ikke afvises, at andre tilgange kunne have bidraget med andre indsigter. Men i henhold til præcis begrebsdefinition henholdes bl.a. til, hvad Niels Åkerstrøm Andersen, der igennem en årrække har beskæftiget sig indgående med netop Luhmann og Foucault, skriver om f.eks. Foucaults teknologibegreb: "Hvordan vi skal forstå teknologi, springer Foucault imidlertid let og elegant uden om." (Andersen 2002 s. 14). For yderligere uddybninger af ligheder og forskelle mellem Luhmanns og Foucaults begreber om teknologi og styring i relation til organisationer se Thygesen \& Andersen 2007.

${ }^{42}$ Begrebet er systemteoretisk udviklet af Niklas Luhmann og pædagogen Karl Eberhard Schoor (1979) (jf. Oettingen 2010 s. 39; Qvortrup 2006 s. 16). Luhmann har ikke lavet et samlet skrift om hans forståelse af teknologi, men han har beskæftiget sig med det i forskellige bøger og artikler samt i relation til forskellige områder. Nogle eksempler på, hvor teknologibegrebet defineres og anvendes er f.eks. Luhmann \& Schorr 1979; 1990c; 1990d; Luhmann 2000b s. $364 ; 2008$ s. $83-100 ; 1997$ s. $517-535 ; 2007$ s. $90-95$.

${ }^{43}$ I Die Gesellschaft der Gesellschaft anvender Luhmann begreberne om fast koblede systemer (kausale), og løst koblede systemer (meningssystemer) (Luhmann 1997 s. 517-535).
} 
De er kendetegnet ved at være simplificerede og lukkede kausalforløb, hvor udefrakommende forstyrrelser ideelt set kan isoleres, således ønskede effekter kan beregnes, reproduceres og gentages ved samme operation. Hvis en sådan teknologi ikke producerer det forventede output, ligger fejlen i selve det tekniske system. Fejlen kan efterfølgende identificeres og korrigeres, hvis man vel og mærke behersker maskinens tekniske struktur. ${ }^{44}$ Med inspiration fra kybernetikkeren Heinz von Foerster bruger Luhmann begreberne trivielle maskiner og ikke-trivielle maskiner. Tekniske systemer som kausale teknologier betegnes trivielle maskiner, dvs. maskiner, hvor en input-impuls transformeres til output ud fra en bestemt regel, således at maskinen altid arbejder og frembringer et bestemt resultat, hver gang man fodrer den med information (Luhmann 2007 s. 92; 2008 s. 87). Hvis der ønskes et andet output, kan maskinen "programmeres" med en anden regel, og således producere et andet output. Trivielle maskiner består altså af faste koblinger og kan beskrives ud fra skematikken om beregnelige årsags-virkningsforhold, hvor et bestemt input fører til beregneligt output. Begrebet kan anvendes indenfor det sociologiske område f.eks. indenfor områder af jura eller bureaukratiske organisationers sagsbehandling, hvor en sag (input) skal afgøres med henvisning til gældende regler (teknologi) som resulterer i en forventelig afgørelse (output). Her vil det give problemer, hvis outputtet influeres af eller afgøres med henvisning til f.eks. sagsbehandlerens eller dommeres sindstilstand, dvs. udefrakommende forstyrrelser af det forventelige kausale forl $\varnothing$ b, der leder til sagens afgørelse. ${ }^{45}$ Trivielle maskiner skal fungere pålideligt, og samfundet har i dagligdagen brug for og er afhængig af pålideligheden af organisationers og andre menneskers måder at fungere på (Luhmann 2007 s. 94). Oversat til

\footnotetext{
$44 "(. .$.$) the inside of the form, what is called technology, is a functioning simplification in$ the medium of causality. We could also say that within the simplified area strict (functioning under normal circumstances, recurrent) couplings are established. This is, possible only if interference by external factors is to a large extend excluded. Technology can therefore also be understood as the extensive causal clousere of an operational area. The result of technicalization is thus the more or less successful insulation of causal relations with the consequence that (1) processes become controllable, (2) resources become amenable to planning, and (3) faults (including wear and tear) can be located and attributed." (Luhmann 2008 s. 87).

${ }^{45}$ Luhmann giver selv følgende eksempel: "Hver gang der indgives et bestemt input, kommer der en bestemt skelnen ud. Hvis fx betingelserne for en skilsmisse er opfyldt, så bliver agteskabet oplфst. Man ville ikke tolerere, hvis en domstol sagde: Nu har vi opløst så mange agteskaber; for engang skyld vil vi nu afvise en klage, dvs. hvis domstolen af kedsomhed eller anden sindsstemning, som udspringer af dens egne aktiviteter, pludselig reagerede anderledes, end man forventer udefra." (Luhmann 2007 s. 93).
} 
organisationers operationsmåder kan de områder og sagsbehandlinger, hvor der forventes bestemte output på baggrund af bestemte input, betragtes som anvendelser af organisatoriske trivial teknologier.

Meningssystemer fungerer under helt andre forudsætninger end tekniske systemer/teknologier. Mens tekniske systemer er kausale teknologier (forudsigelige trivielle maskiner bestående af fast koblede elementer, der leder til styrbare output), betegnes meningssystemer som ikke-trivielle systemer/maskiner/teknologier, dvs. som løst koblede elementer. Ikke-trivielle maskiner kendetegnes ved at have indbygget en selvreferentiel sløjfe, således at de anvender deres eget output som input. Ikke-trivielle maskiners anvendelse af deres umiddelbare historiske tilstand, som hele tiden ændrer sig ved hver operation, betyder, at sådanne maskiner råder over et praktisk taget uendeligt, eller i hvert fald ikke-kalkulerbart repertoire af reaktionsmuligheder, hvilket betyder, at de ikke kan beregnes, dvs. de er upålidelige qua deres grad af uberegnelighed (Luhmann 2006 s. 102). Autopoietiske systemer, f.eks. mennesker eller psykiske systemer, kan beskrives som ikke-trivielle maskiner, idet de anvender deres egen tilstand, tanker og meninger og løbende stiller spørgsmål som Hvem er jeg? Hvad har jeg lige gjort? Hvilket humør er jeg $i$ ? Hvor interesseret er jeg? Nu kom jeg lige til at tonke på noget, hvad mener jeg så nu? - for først derefter at producere outputtet (Luhmann 2007 s. 93). Til forskel fra trivielle maskiner har psykiske systemer evnen til processuelt at forandre sig selv, hvorfor de betegnes ikke-kausale teknologier.

Psykiske systemer eller meningssystemer orienterer sig ved hjælp af viden og orienteringsskemaer (se Oettingen 2007 s. 33), og som vidensteknologi anvendes de til løsning af forskellige opgaver. Ligesom ved kausalteknologier, hvor et problem/opgave (input) søges transformeret til et bestemt output, anvendes f.eks. professioner som teknologier: syge sendes til lægen (lægeviden som teknologi), jurister skal afgøre samfundsmæssige stridstilfælde (juridisk viden som teknologi), lærere skal lære elever et givent pensum (pædagogisk viden som teknologi) osv.

I forhold til organisationer er det interessante, at fast koblede regelsæt, f.eks. regelbaserede bureaukratiske procedurer, IT systemer, offentligt ansattes indberetningspligter osv., er afhængige af koblinger til løst koblede elementer (meningssystemer) (se f.eks. Luhmann 2008 s. 91). Dette fordrer standardisering af menneskelig adfærd og dermed fors $\emptyset \mathrm{g}$ på at udelukke muligheder for eller tilfælde af, at mennesker gør noget andet end det forventede eller foreskrevne (Luhmann 2008 s. 93).

Med teknologibegrebet kan organisationer forstås som sammenblandinger af koblinger mellem løst og fast koblede elementer, eller mellem kontrollerede 
rum og det ukontrollerede (Luhmann 2008 s. 94). Relevante spørgsmål bliver i den forbindelse: Hvilken teknologi er velegnet til løsning af et givet problem, dvs. hvordan skal teknologien udformes for at transformere et (mere eller mindre) bestemt input til et (mere eller mindre) bestemt output? Næste spørgsmål bliver så hvordan organisationen vil håndtere dette? Kan der være brug for en indbygget processuel refleksivitet, dvs. organisatorisk læring, over teknologens udformning, der potentielt kan tage højde for koblingen til løst koblede elementer som gennem egen tilvirkning ændrer sig selv, og derved genererer et stadigt foranderligt input? Dvs. efter devisen: Man har et standpunkt, til man tager et nyt. ${ }^{46}$

\section{Organisation som teknologi}

Når det gælder organisationer, står man ifølge Luhmann overfor det problem, at på trods af en given teknologis forventning om en fast årsagssammenhæng mellem elementer ikke kan forhindre det forhold, at teknologiers indvirkningen på organisationer er afhængig af meget forskellige omstændigheder, hvorfor anvendelsen af tilsyneladende ens eller samme teknologier kan give forskelligt udfald.

"Definition als feste Kopplung kausaler Elemente darf nicht darüber hinwegtäuschen, dass in den Auswirkungen auf Organisationen höchst unterschiedliche Sachverhalte vorliegen." (Luhmann 2000b s. 364)

Med andre ord er de omstændigheder, som opstår i mødet mellem fast og løst koblede elementer ud fra et forskningsmæssigt og ikke mindst læringsmæssigt perspektiv interessant. Dette skyldes at interferensvirkningerne i mødet mellem fast og løst koblede elementer kan være nærmest umulige at forudse, og kun kan afdækkes gennem urimeligt grundige tests (Luhmann 2008 s. 89$).{ }^{47}$

\footnotetext{
${ }^{46}$ Ordene faldt i et interview (1977) med Jens Otto Krag ved Ekstra Bladet efter folketingsvalget 1966 som svar på, hvordan han så hurtigt kunne ændre sin opfattelse af et samarbejde mellem Socialdemokratiet og Socialistisk Folkeparti (SF). Citatet er på den ene side blevet kanoniseret som udtryk for politik, når det er værst: Når det nye standpunkt blot er et middel til at nå magten og de mål, man ønsker sig. På den anden side er citatet taget til indtægt for det fornuftige $\mathrm{i}$ at tage fornyet stilling til realiteten, hvis grundlaget for det oprindelige standpunkt er ændret (Wikipedia).

${ }^{47}$ Luhmann bruges selv Gutenbergs trykpresse som et eksempel på en fast koblet teknologi, der endte med at være den formentlig vigtigste faktor i bidraget til en ny radikalitet i samfundet, nemlig at folk begyndte at spørge "Hvordan?" (Luhmann 2008 s. 85).
} 


\section{Didaktik}

Som organisationsteknologi er organisatorisk læring en teknologi, hvor vægten lægges på transformation og en opfordring til ikke-trivialitet. Medarbejdere, afdelinger osv. i organisationen opfordres til at anvende deres egen refleksionssløjfe, og indfører dermed deres output som input og lærer, og kan efterfølgende implementere denne læring/viden i organisationens organiseringer og beslutningskredsløb. Pointen er at denne form for læring ikke kan foregå efter en standard eller styres fuldkomment, og potentielt føre til mindre standardisering af menneskelig adfærd. Det må forventes, at transformationerne af mere eller mindre bestemte input transformeres til mere eller mindre bestemte output, hvorfor den organisatoriske viden om dens egne årsags-virkningsforhold resulterer i mere kompleksitet. Denne form for teknologi bidrager til at reducere kompleksitet men skaber også ny kompleksitet. Teknologien er med til at genere organisatorisk viden, som altid rummer et element af usikkerhed og uoverskuelighed med hensyn til, hvordan den egentligt virkede, dvs. at viden om egen årsags-virkningsforhold ikke nødvendigvis mindskes, men bliver mere usikker? Jf. at professionsviden er forbundet med risiko / opererer på usikker grund. Organisatorisk læring opfordrer grundlæggende til flere løse koblinger, og den øger derfor potentielt sin egen uforudsigelighed. Analytisk set er det et interessant aspekt, hvilke forhold ikke-trivialiseringen af organisationen og dens ansatte gør til genstand for iagttagelse.

Teoretisk betyder dette, at en organisation som ønsker at være lærende, må reservere tid og ressourcer på processuelt at indsamle og bearbejde information om, hvad der sker, og reflektere over fremtidige implikationer for organisationens virkemåde. Og jo mere komplekse organisationer, jo mere kompleks bliver denne opgave.

Efter denne gennemgang af teknologibegrebet relateret til organisationer, vender jeg tilbage til begrebet om organisatorisk læring, og spørgsmålet om hvordan det organisationsteoretiske svar er begrebsliggjort? Og hvilke output der på et generelt plan forventes på baggrund af organisatorisk læring?

Ifølge Andersen og Born (2001) kan det forøgede fokus på udvikling, læring og omstilling i samfundets organisationer lidt kritisk og ironisk betegnes som omstilling til omstilling. ${ }^{48}$

\footnotetext{
${ }^{48}$ Social filosoffen Ole Thyssen udtrykker det på følgende måde i forhold til organisationer: "Laring bliver et led i en forfinet sensibilitet over for forandring og tilpasning til forandring." (Thyssen 1996 s. 104). Det fremstår i den udlægning nærmest som en række tautologier; at lære at lære, omstilling til omstilling, forandring til forandring!
} 
"Omstilling synes at vare blevet et selvstandigt ideal. Det synes $i$ dag ikke at handle så meget om omstilling til noget bestemt, men om omstilling til omstilling. Dette omstillingsideal er gennem 1990'erne fordoblet, så omstilling er blevet et ideal for den offentlige sektor som sådan, for den enkelte offentlige organisation samt for den enkelte medarbejder. Honnфr-ordene er forandringsparathed, fleksibilitet og selvudvikling." (Andersen \& Born 2001 s. 7-8)

Andersen og Borns bemærkning kan knyttes til en væsentlig indholdsmæssig dimension og et slags slagord for organisatorisk læring nemlig, at organisationen og dens ansatte skal være bedre til at laere at lare (Argyris \& Schön 1978, 1996; Senge 2000). Det er således ikke længere tilstrækkeligt, at organisationer tilegner sig ny viden, kvalifikationer og kompetencer. Teorier om organisatorisk læring indfører en ny diskurs eller et nyt tema for organisationer ved at fokusere på og arbejde med forøget viden om faktorer, som ligger bag eller til grund for læring, dvs. organisationens læringskompetence. ${ }^{49}$ Dette $\emptyset$ ger behovet for teori om, hvordan dette kan forstås, og, set ud fra et mere praktisk perspektiv, hvordan dette kan realiseres, dvs. et program for, hvordan organisationer kan designes, så de opnår denne eftertragtede læringskompetence.

\section{To tilgange til organisatorisk læring}

I relation til dette kan der identificeres to forskellige tilgange, som hver især lægger vægten forskellige steder: en individualistisk orienteret tilgang, og en sociologisk, sociokulturel eller socialpsykologisk tilgang.

A. Den individualistiske fokuserer på individet og psykiske mulighedsbetingelser i forhold til læring. ${ }^{50}$ Denne tilgangs forståelse af organisatorisk læring kan i store træk opsummeres i nedenstående beskrivelse.

\footnotetext{
${ }^{49}$ Dvs. faktorer, som henholdsvis fremmer eller hæmmer organisatorisk læring, f.eks. modstand mod læring i form af psykologiske forsvarsmekanismer. Argyris kalder disse for defensive rutiner, som er udtryk for individets behov for at have en følelse af kontrol, og kan på den måde ses som individuelle immunstrategier over for forandring. (Argyris 1990a; 1990b; 1997).

${ }^{50}$ Som Bente Elkjær (1999) pointerer, så begribes læring i den vestlige verden som oftest med reference til individuel kognition (se også Säljö 2003 s. 59). Den svenske professor i pædagogisk psykologi Roger Säljö skriver, at "Hvis kognitivismen i dens amerikanske aftapning har haft en relativt begranset indflydelse på vores opfattelse af laring og udvikling, kan man sige det stik modsatte om den schweiziske forsker Jean Piaget. Hans betydning som teoretiker for, hvordan undervisning skal udфves, og for vores syn på laring og udvikling kan nappe overvurderes." (Säljö 2003 s. 61). Piagets udgave af konstruktivismen (og andre kognitive traditioner) betegner Säljö som individualistisk konstruktivisme (Ibid.: 72). For mere udførlige beskrivelser af teorier
} 
"Organisationer kan ikke lare. Det er alene mennesker der kan lare. En organisation er ikke noget vasen eller en selvstondig aktør med en egen bevidsthed. En organisation er relationer, som er etableret mellem mennesker gennem indgåelse af kontrakter, der betyder, at menneskerne som en helhed udgфr et socialt system, der samarbejder for at nå bestemte mål. Når organisationer satter mål, er det $i$ realiteten mennesker, der satter mål." (Jacobsen \& Thorsvik 2002 s. 334; se også Kim 1993; Leymann 1989; Simon 1991; Argyris \& Schön 1978; 1996; Duncan \& Weiss 1979; March \& Olsen 1988; Swiringa \& Wierdsma 1994)

Ud fra en sociologisk betragtning kan man beskrive den individuelt orienterede tilgang som udtryk for en slags metodologisk individualisme; En tilgang som mener, at alle sociale fænomener, deres strukturer og ændringer, i princippet kan forklares ud fra individuelle egenskaber, intentioner, tanker, handlinger og individuel interaktion, hvorved de indskriver sig med en helt bestemt forståelse i sociologiens tilgang til micro/macro forhold. "They concieve of society as being held tegether by the actions of individuals at the microlevel, and they reject the idea of society as a macrostructure existing above and beyond individuals." (Gherardi \& Nicolini 2001 s. 38). Dette kan ses i ovenstående citat ved at Når organisationer satter mål, er det i realiteten mennesker, der satter mål. Så henvises der grundlæggende til, at mennesker i organisationer har en fælles forståelse og rettethed mod de samme mål. Dette betyder, at det er meget svært at skelne mellem individuelle egenskaber og sociale strukturer, og på hvilken måde f.eks. makrostrukturer er summen af mikrostrukturer og individuelle handlinger (Korsnes, Andersen og Brante 1997 s. 202-203).

Den sociologiske, sociokulturelle eller socialpsykologiske tilgang fors $\emptyset \mathrm{ger}$ at overskride den individualistiske ved at lægge vægten på forskellige former for sociale dynamikker, som nogen der har afgørende indflydelse på, og dermed betydning for væsentlige forhold vedrørende organisatorisk læring.

B. Den sociologiske, sociokulturelle, socialpsykologiske forholder sig til det sociales betydning for organisatorisk læring. Med henvisning til f.eks. social position (hierarki) og socialdynamiske struktureringsformers betydning for meningsdannelse og udvikling af ideer, anses det sociale som en væsentlig aktør eller faktor med betydning for læring. Som repræsentanter for den sociologiske eller mere socialt orienterede tilgang

om kognition og deres betydning for generelle udviklinger indenfor læringsteorien se Illeris 2000; Hermansen 1998; Bisgaard 1998. 
begrunder Gherardi \& Nicolini denne på følgende måde. En begrundelse som samtidig er en slags kritik af ovenstående individualistiske tilgang.

"The concept of participation highlights the fact that learning does not take place solely or principally in the minds of individuals but rather stems from the participation of individuals in social activities. Working and organizing are social practices engaged in through a set of activities situated in specific contexts of interaction. Organizational learning-in-organizing, because working, learning, and organizing are not distinct activities within a practice. The concept of participation, therefore, gives access to the study of organizational learning that takes place in action and through action." (Gherardi \& Nicolone 2001 s. 35; se også Wenger 2004; Jorgensen 2007; Cangelosi \& Dill 1965; Fiol \& Lyles 1985; Levitt \& March 1988; Huber 1991; Weick \& Roberts 1993)

En forskel mellem de to perspektiver kan f.eks. ses ved, at den individuelt orienterede, ser organisationer som enkelt individer med en fælles rettethed mod de samme mål, mens det i den sociologiske handler om participation of individuals in social activities, dvs. at mennesker samarbejder og handlingskoordinerer i social aktivitet, og at den sociale meningsdannelse kan have relationer til macro forhold i det moderne samfund.

Spørgsmålet er, hvordan og i hvilken udstrækning disse to teoretiske perspektiver forholder sig til og kan fungere som adækvate svar på de samfundsmæssige forandringer, der identificeres som kilden til, at organisationer i dag skal have et permanent forandringsberedskab, dvs. skal have eller må tilegne sig evnen til at lære. Eller udtrykt anderledes: Reflekteres organisatorisk læring i relation til individuelle forhold (som f.eks. grundlæggende antagelser, mentale skemaer, psykiske barrierer), eller også som samarbejdsformer og meningstilskrivning i organisationens sociale grupperinger? Herunder i hvilken udstrækning og på hvilken måde macromæssige eller blot samfundsmæssige forhold inddrages og medreflekteres i relation til den sociale meningsdannelse i organisationer.

I næste kapitel vil jeg præsentere og diskutere forholdet mellem samfund og organisation, og til sidst præsentere afhandlingens forståelse af forholdet. Det er også i næste kapitel at afhandlingen positionerer sig indenfor organisatorisk læring. 



\section{Organisatorisk læring}

I dette kapitel vil jeg først beskrive begrundelser for hvorfor organisatorisk læring fremstår som et populært organisationskoncept, efterfulgt af en kort beskrivelse af konceptets historiske udvikling. Dernæst et afsnit om forholdet mellem sociologi, samfund og organisationer, som fors øger at perspektive at hvad der læres i organisationer kan relateres til samfundet. Efterfølgende tages der fat i to teorier om organisatorisk læring - Argyris \& Schön samt Peter M. Senges Den Femte Disciplin, med henblik på at få en forståelse af disse teoriers forståelse af forholdet mellem organisation og samfund, dvs. organisationens omverden. Dette gøres med henblik på at perspektivere en af afhandlingens pointer, nemlig at nogle teorier om organisatorisk læring har begrænsede eller relativt svage forståelser af det samfund som organisationer er situeret i. En af afhandlingens gennemgående pointer er at det moderne samfundsform har afgørende indflydelse på organisationer, herunder forhold vedrørende organisatorisk læring

\section{Beskrivelse af organisatorisk læring som populær organisationskoncept}

Den amerikanske fremtidsforsker, forfatter og foredragsholder John Naisbitt publicerede i 1982 bogen Megatrends. Ten New Directions Transforming Our Lives, hvor han udpegede 10 megatrends eller udviklingstendenser, som han mente, kom til at præge samfundet og i særligt grad organisationer i fremtidens samfund. Naisbitts udviklingstendenser som f.eks. globalisering af $\varnothing$ konomien, mere decentralisering og netværkstænkning, uddifferentiering af organisatoriske ydelser (f.eks. hjælp til selvhjælp, forskellige borgere skal have forskellige ydelser osv.), fra repræsentativt demokrati til mere borger inddragelse og medbestemmelse, og i det hele taget en differentiering og uddifferentiering af befolkningens valgmuligheder, er alle tendenser, som efterfølgende har kunnet iagttages som centrale 
udviklings- og forandringstemaer for private såvel som offentlige organisationer (s. f.eks. Finansministeriet $2003^{51}$; Finansministeriet $1983^{52}$; Klausen 2001; Jørgensen \& Melander 1999).

Næsten 20 år senere i 1998 publicerede den norske organisationsforsker Kjell Arne Røvik bogen Moderne organisationer - Trender I organisasjonstenkningen ved tusenårsskiftet. If $\varnothing l g e$ Røvik kan man på globalt og lokalt plan iagttage et udvalg af organisationsopskrifter, koncepter eller styringsværktøjer, som de fleste moderne organisationer i dag må eller potentielt kommer til at forholde sig til. Der er tale om organisationsopskrifter, som er ude at rejse, og som har sin tid; de dukker op, spredes hurtigt til mange og gerne forskellige typer organisationer verden over for så senere at blive fortrængt af andre og nye ideer (Røvik 1998 s. 11). Disse organisationsopskrifter betegner Røvik som institutionaliserede standarder eller institutionaliserede organisationsopskrifter.

"At en oppskrift er $>$ institusjonalisert $<$ betyr at den innenfor en periode av mange blir oppfattet og gjerne omtalt som den riktige, den hensiktsmessige, den effektive, den moderne - og sogar den naturlige måten å organisere på." (Røvik 1998 s. 13)

\footnotetext{
${ }^{51} \mathrm{VK}$ regeringen har gennem en årrække udgivet forskellige publikationer, som indeholder mange af de tanker, som Naisbitt skriver om i 1982. Et eksempel er publikationen om Reformprogrammet "Velfærd og valgfrihed" fra 2002, hvor det bl.a. hedder: "Det falles ansvar for at lose en rakke velfardsopgaver skal i fremtiden kombineres med en personlig frihed til at valge mellem forskellige lфsninger. Regeringen vil gennemfore et reformprogram, \& "Velfard og valgfrihed", hvor borgerne fär frihed til at valge mellem forskellige offentlige og private lфsninger på en rakke serviceområder". I en anden publikation fra Finansministeriet - En mere borgernar service (2002) - hedder det "Det frie valg handler ikke kun om at effektivisere den offentlige sektor. Frit valg giver borgerne mulighed for at påvirke og deltage $i$ at forme den offentlige sektor. Samtidig giver det borgeren muligheden for et bedre møde med den institution, som varetager opgaven." (Finansministeriet 2003 s. 2).

${ }^{52}$ Fra begyndelsen af 90'erne har der eksisteret et lovmæssigt krav om brugerbestyrelser knyttet til en række områder af den offentlige sektor (Finansministeriet 1983) Dette krav var en følge af den tidligere borgerlige regerings program for modernisering af den offentlige sektor og blev først formuleret i forhold til skoleområdet (1990) og senere i forhold til gymnasie(1991), dagpleje- og daginstitutionsområdet (1993) (Floris \& Bidsted:1996:163-164). I 1995 var der således knyttet brugerbestyrelser til alle organisationer indenfor ovennævnte områder, og man kan derfor med rimelighed tale om, at denne organisationsform i løbet af forholdsvis kort tid har vundet stor udbredelse og i dag berører mange personer og institutioner.
} 
Ifølge Røvik er årsagerne til at specielt den lærende organisation er blevet en institutionaliseret standard for mange forskellige typer af organisationer følgende:

"En viktig årsak er sannsynligvis at dette konseptet er så pass tvetydig at det appellerer til ulike posisjoner og interesser $i$ virksomhedetene. Dels er begrebet laering i seg selv et helt usedvanlig positivt ladet begreb, et symbol på de fleste verdier vi feirer, som f.eks. fornuft, utvikling, frihet, forandring osv. Et argument for en mer laerende organisasjon er derfor som oftest et nokså uangripelig og uimotståelig argument. Dels appellerer slagordet om den larende organisasjon til det enkelte individ i organisasjonen. Det presenteres som et tilbud til den enkelte om at få vare reflekterende og kreativ, kort sagt, om å få utvikle seg selv. Dels appellerer de også til ledelsen og dens фnske om å få gjennomført nфdvendige markedstilpasningerr så raskt som mulig med minst mulig motstand. Og her er selvsagt den språklige innpakning vigtig. En organisasjonsendring som defineres som en laeringsprosess gir lett positive assosiasjoner og kaller på kollektiv oppslutning, $i$ motsetning til atskillig mer brutale begreber som $>$ omstilling $<$ og $>$ snu-operasjon< som let utlфser motstand." (Røvik 1998 s. 251)

Populariteten kan altså tilskrives nogle strømninger eller forventninger, som allerede ligger i forvejen i samfundet, og som de fleste derfor kan tilslutte sig. ${ }^{53}$

\footnotetext{
${ }^{53}$ Udvikling, omstilling, forandring og læring kan man påstå altid har fundet sted. Men bevidstheden om og fokus på netop udvikling, omstilling, forandring, og ikke mindst læring i relation til nærsagt hvilket som helst aspekt af samfundet, synes i dagens samfund at være relevant. På Danmarks Radios hjemme side læste jeg en artikel med overskriften: Forceldre bakker op om krav til paedagoger (04. aug. 2011 11.04 Indland). Artiklen handler om, at den på dette tidspunkt fungerende Socialminister Benedikte Kiær (K) mente, at der skal være mindre fri leg og mere styret leg i landets daginstitutioner. Hertil svarede formand for forældrenes landsorganisation FOLA Lars Klingenberg: "Jeg tror sagtens, man kan arbejde paedagogisk aktivt med børnene uden det behфver at blive "skoleagtigt" ", og han fortsætter med reference til børnenes liv i institutionerne, at han og andre gerne så at" (...) padagogerne er meget aktive i forhold til at bibringe børnene de kompetencer, som de har så hårdt brug for(...)" (dr.dk 04. aug. 201111.04 Indland). Socialministeren bebudede på den baggrund, at hun ville lægge op til en reform af pædagoguddannelsen, således at den i højere grad giver mulighed for at specialisere sig i småbørn, og at de læreplaner, som alle daginstitutioner i dag selv formulerer, i fremtiden skal rumme fælles, landsdækkende mål, der sikrer børnene mere læring. Dette er et opgør med en meget lang tradition, og afføder selvfølgeligt højlydte indlæg og protester, men er et eksempel på at 'plejer er død'!
} 


\section{Historisk udvikling af organisatorisk læring}

Helt generelt kan man sige, at interessen for og studiet af organisation, organisering, rationalitet, ledelse, værdier, kommunikation samt relationerne her imellem på forskellige tidspunkter og med varierende styrke har optaget organisationsforskningen i dens lidt over hundredårige historie. Organisationsteorien er gået fra at være en forskningsdisciplin domineret af $\varnothing$ konomisk tænkning, rationalitet og ingeniør videnskab, til op gennem historien at lade sig inspirere af og inkorporere tankegods fra et utal af andre videnskabelige discipliner f.eks. psykologi, sociologi, antropologi, kultur antropologi, biologi, semiotik, kybernetik o.a. (se f.eks. Røvik 1998, Morgan 1993, Hatch 1997, Scott 2003). Forskning i og udvikling af organisationer og organisationsteori er derfor i dag et interdisciplinært og tværvidenskabeligt forskningsfelt, som mange forskellige professioner, institutioner og forskningsdiscipliner opererer og udvikler teorier inden for. Dette gælder ligeledes teorier om organisatorisk læring.

Som jeg senere vil beskrive i kapitel 4 Sociologi, samfund og organisation, kan udviklingen af og interessen for organisatorisk læring knyttes sammen med samfundets sociokulturelle udvikling fra segmentær differentiering til centrum-perifær differentiering, over stratifikatorisk differentiering til det moderne samfunds funktionelt differentierede samfund. Dette er et samfund, som gennem sine interne differentieringsprocesser producerer et komplekst samfund, dvs. et samfund, der kontinuerligt skaber et utal af kontingente iagttagelser og meningstilskrivninger, som grundlæggende leder til kommunikationens asymmetrisering, dvs. kendetegnet ved, at samme fænomen kan iagttages forskelligt, og derfor tilskrives forskellig mening. ${ }^{54}$

At det samme kan iagttages, forstås og beskrives forskelligt gælder i lige så høj grad organisatorisk læring. Interessen for organisatorisk læring er på ingen måde af nyere dato. Det har som Mary jo Hatch (1997) og Kim (1993) skriver, altid interesseret organisationsteorien og været et af dens temaer. Der

\footnotetext{
${ }^{54}$ For eksempel iagttager og tilskriver politiske partier mening forskelligt til det samme fænomen. Forståelsen af eller meningen om et fænomen, udspringer ikke fra fænomenet, men forekommer på baggrund af interne konstruktioner i det iagttagende system. F.eks. er en forbrydelse ikke i sig selv en forbrydelse (en ontologisk kriminel handling), men kun en forbrydelse i relation til det juridiske systems interne program, i form af henvisning til og refleksion over gældende love og retsnormer. Dette betyder imidlertid ikke, at man ikke kan iagttage forbrydelsen ud fra en $\varnothing$ konomisk, moralsk, etisk, politisk, religiøst osv. tilgang. Blot at det i det moderne samfund er tilforordnet det juridiske system at afgøre om, og hvornår der er tale om en forbrydelse, og at dette sker med reference til interne kriterier i det juridiske system, og som i sidste ende er politisk bestemt.
} 
er mange udlægninger af, hvornår ideer og begreber om organisatorisk læring vinder indpas indenfor organisationsteoretisk litteratur. Nogle mener, at det sker i 1960'erne (Hatch 1997), mens andre sporer konceptet eller interessen tilbage til 1950'erne (Prange 1999 s. 24; Elkjær 2005a s. 36), men der er relativ bred enighed om, at den ekspanderer og kulminerer i 1990'erne med udgivelse af et rekord stort antal artikler og bøger om emnet (Prange 1999; Easterby-Smith \& Araujo 1999; Cohen \& Sproull 1996; Gherardi \& Nicolini 2001; Elkjær 2005a; Easterby-Smith \& Lyles 2005). ${ }^{55}$

Den danske organisationsforsker Bente Elkjær udtrykker det således:

"Organisatorisk laering eksisterer i dag som et internationaltforskningsfelt indenfor organisationsforskningen med egne konferencer, egne tidsskrifter samt adskillige temanumre om organisatorisk laering i diverse tidsskrifter foruden som oversigtsvarker." (Elkjar 2005a s. 36)

Selvom interessen har været stor, er der som sagt ikke konsensus om, hvornår interessen blev udviklet, hvor mange teoretiske perspektiver eller skoler organisatorisk læring kan inddeles i, eller ud fra hvilke kriterier inddelingen skal foretages. Prange skriver at de multiple måder organisatorisk læring er blevet klassificeret og anvendt må forstås som en 'organisatorisk lærings jungle', som efterhånden er blevet tæt og uigennemtrængelig (Prange 1999 s. 24).

Der findes altså mange forskellige måder at systematisere og inddele teorier om organisatorisk læring (se f.eks. Hatch 1997; Gherardi \& Nicolini

\footnotetext{
${ }^{55}$ Så vidt jeg kan se, er det muligt at spore begrebet om organisatorisk læring på følgende måde. Ifølge Prange (1999) er det specielt med Cyert og March's bog "A behavioral theory of the firm" (opr. 1963), at organisationsteorien begyndte mere systematisk at arbejde med teorier om organisatorisk læring. Andre stadfæster det til Argyris og Schön's "Organizational Learning: a Theory of Action Perspective" (opr. 1978), som er den første bog, der anvender organisatorisk læring i titlen. Der er dog relativ bred enighed om, at Peter Senge's bog, "The Fifth Discipline - the Art and Practice of the Learning Organization" (2000: opr. 1990) for alvor sætter begrebet på dagsordenen både i forskningsverdenen og i samfundet som sådan (Prange 1999; Easterby-Smith \& Araujo 1999; Cohen \& Sproull 1996; Qvortrup 1998a; Elkjær 2005a). Den stigende interesse for organisatorisk læring i 90'erne kan ses ved en oversigtsartikel, der viste, at der blev skrevet lige så mange internationale artikler om organisatorisk læring i 1993 som i løbet af 1980'erne (Jacobsen og Thorsvik 2002 s. 331). Indenfor de seneste ca. 30 år har den organisatoriske forskning og specielt den del som interesserer sig for organisatorisk læring både nationalt og internationalt været centreret omkring begreber som læring, viden, Human Ressource, kvalifikationer og kompetencer, værdier og etik (se f.eks. Nonaka \& Takeuchi 1995; Senge 2000; Argyris \& Schöen 1978 \& 1996; Thyssen 1997a; Andersen, Jensen og Prahl 2000; Fisher \& Lovell 2003; Armstrong 2006; Eastereby-Smith \& Lyles 2005).
} 
2001; Prange 1999; Easterby-Smith \& Lyles 2005). For eksempel skriver organisationsforskeren Mary jo Hatch at interessen for organisatorisk læring i 1960 'erne startede med ideer udviklet i relation til organisationsteoriens interesse for, hvad hun betegner det modernistiske perspektiv, hvor organisationer i kybernetisk forstand beskrives som åbne systemer (1997 s. 405). Dette har ifølge Hatch efterfølgende udviklet sig, så feltet i dag kan inddeles i to forskellige retninger: en modernistisk og en postmoderne. Den modernistiske retning er inspireret af naturvidenskabens begreb om refleksive kybernetiske systemer, som kan blive bevidste om sig selv, og derved ændre sig, dvs. lære at lære. Det postmodernistiske perspektiv beskriver hun som mere inspireret af det kunstneriske end af det videnskabelige område ved overvejende at være inspireret af lingvistik og litteraturteori, hvor organisationer ses som socialt konstruerede symbolproducenter med sprogligt indbyggede forståelser (ibid. s. 405-406).

Jeg ønsker ikke at indlede en længere diskussion om inddelinger og kategoriseringer, men har i denne sammenhæng valgt at det i første omgang er relevant at sondre mellem forskningsstyrede tilgange med et 'akademisk approach', og management styrede tilgange, hvis erkendelsesinteresse er mere normativt og designstyret (opr. fra Tsang 1997).

De to forskellige tilgange eller approaches betegnes typisk henholdsvist organisatorisk laering og den laerende organisation. Kort fortalt beskrives Organisatorisk laring (OL) som udtryk for forskningsstyrede interesser, hvor fokus er på individuelle og kollektive læreprocesser i og mellem organisationer (Elkjær 1999a; 1999b; 2005b; Qvortrup 1998; Prange 1999; Tsang 1997; Vera \& Crossan 2005). Hovedspørgsmålet for dette såkaldte 'akademiske approach' er, hvordan organisationer lærer, og herunder til dels hvad OL er som fænomen, samt på hvilken måde begrebet om organisation kan rumme og redegøre for fænomenet.

Den laerende organisation (DLO) beskrives på den anden side som en normativt og praksisorienteret approach, ofte refereret til som managementtilgangen (se f.eks. Christensen 1997 \& 2000; Røvik 1998: Easterby-Smith mfl. 1999; Elkjær \& Lysgaard 1998; Eastereby-Smith \& Lyles 2005). Det styrende hovedspørgsmål for denne tilgang er hvordan organisationer bringes på læringssporet, dvs. fokus er på designet af organisationer, således at de bliver bedre til at lære, og derved forbedrer deres handlekompetence.

Begrundelsen for anvendelse af sondringen mellem Ol og DLO udspringer dels af at det er en alment anvendt måde at inddele feltet på, og dels af afhandlingens eget dobbelte formål. På den ene side er formålet, og det er det primære for afhandlingen, at udvikle en analytisk tilgang til organisatorisk 
læring der skal muliggøre iagttagelse af aspekter af organisatorisk læring som andre teorier ikke gør. Aspekter som afhandlingen vil argumentere for er vigtige for forståelsen af kompleksiteten af organisatorisk læring. Dette formål ligger indenfor den forskningsstyrede tilgang. Det andet formål skal ses $i$ et mere praktisk og operationelt perspektiv hvis ambitionen er at konsulenter, organisationsudviklere, ledere, medarbejdere og andre som involveres i organisationsudviklingsprojekter skal kunne trække på og anvende nogle af de indsigter afhandlingen forsøger at komme med bud på. Ambitionen er altså at afhandlingens tematiseringer efterfølgende kan anvendes normativt i relation til designstyring af organisationsudvikling. Denne efterfølgende ambition ligger således indenfor den management styrede tilgang.

\section{Sociologi, samfund og organisation}

Hvorfor interessere sig for forholdet mellem sociologi, samfund og organisation, når man beskæftiger sig med organisatorisk læring? Hvad har det, der læres, og den måde det læres på, egentlig med sociologi, samfund og organisation at gøre? Er det ikke et pædagogisk eller nærmere didaktisk spørgsmål? Til det sidste spørgsmål kan man i den udstrækning pædagogik tentativt kan bestemmes som den disciplin, der interesserer sig for refleksionen over forholdet mellem undervisning og laering svare jo! Men samtidig er det jo et lettere kortfattet svar, eftersom de forhold, som er bestemmende for læringens $h \mathrm{vad}$, og didaktiske forhold vedrørende eventuel undervisning, ikke er noget som alene kan besvares pædagogisk, men må støtte sig til, eller slet og ret besvares med henvisning til f.eks. sociologiens genstand, nemlig samfundet.

De to første spørgsmål er straks mere krævende og fordrer - for at kunne blive besvaret - en sociologisk beskrivelse af samfundet. Kigger man på sociologiens, f.eks. Giddens definition af samfund, er det tydeligt at se, at organisationer betragtes som vigtige elementer i samfundet:

"... en samling eller et system af institutionaliserede adfardsmåder. "Institutionaliserede" adfardsmåder vil sige tros- og adfardsformer, der gentages - eller med den moderne samfundsteoris terminologi reproduceres socialt - over lang tid og store afstande."

(Giddens 1995 s. 17)

Når Giddens taler om institutionaliserede adfærdsmåder og social reproduktion, inkluderer det ikke bare kulturelt baserede normative værdiorienteringer og samfundsmæssige strukturer med indflydelse på individuel adfærd og 
meningsdannelse, men også samfundets organisationer som elementer i denne proces - eller sagt på en anden måde: Samfundet indvirker på organisationer, og omvendt. ${ }^{56}$ I Giddens perspektiv vil organisatorisk læring betyde ændringer i en organisations institutionaliserede adfærdsformer, dvs. social reproduktion af en anden art.

Selvom de fleste er enige $i$, at der er et betydningsfuldt forhold mellem organisation og samfund, og at omverdenen i form af samfundet ofte bruges som udgangspunkt for at igangsætte ændringer og udviklingsprojekter i organisationer (March 2005 s. 296) ${ }^{57}$, så peger Nielsen og Vallentin (2003) på, at organisationsteoriens sociologiske samfundsforståelse ofte er yderst begrænset.

"Moderne organisationsteori undgår $i$ vidt omfang at bruge et samfundsbegreb. Organisationsteoriens analyseenhed er som regel den enkelte organisation eller et netvark eller felt af sammenkoblede organisationer, mens samfundet som helhed er fravarende. I det omfang samfundsmassige betragtninger inddrages, er det med henblik på at beskrive organisationer, ikke samfundet som sådan." (Nielsen \& Vallentin 2003 s. 161)

Med reference til Robert K. Merton peger de på, at organisationslitteraturen er præget af middle range teorier, der ikke forholder sig til samfundets makroniveau, men "... alene fokuserer på de sociale og mentale strukturer og processer, der gфr sig galdende i og omkring private virksomheder og offentlige organisationer." (Ibid. s. 161-162). Nielsen og Vallentin betegner med reference til organisationsteoretikeren W. Richard Scott (2003) (se også

\footnotetext{
${ }^{56}$ Lars Bo Kaspersen skriver i den forbindelse om Giddens sociologi: "Giddens hævder, at de sociale organisationsformer, der udvikles i Europa fra begyndelsen af 1600-tallet, og som siden er blevet verdensomspændende, er helt unikke i forhold til tidligere tiders samfundsformer. Disse organisationsformer og dermed det moderne udvikles, siger Giddens, i et samspil med en række overordnede institutionelle dimensioner, nemlig kapitalisme, industrialisme, nationalstatens overvågning og informationskontrol samt militærets og militærindustriens udvikling. At indfange kompleksitetens i dette samspil er ifølge Giddens en nødvendighed for en ny sociologisk teori, der skal kunne begribe vores samfund." (Kaspersen 1995 s. 121).

${ }^{57}$ March skriver: "Stort set alle organisationsteorier antager, at ændringer i omgivelserne har en tendens til at bliver omsat i organisatoriske ændringer. (...) Derfor formodes specifikke ændringer i omverdenen at ville medføre specifikke ændringer i organisationerne, når de forsøger at overleve og gøre sig attraktive i deres konkurrenceprægede miljøer. For eksempel hævdes det tit, at de øgede globale forbindelser og anvendelsen af moderne informationsteknologi vil medføre en større brug af ikke-hierarkiske netværk til at koordinere aktiviteterne." (March 2005 s. 296)
} 
Mejlby, Nielsen \& Schultz 1999) derfor organisationsteorien som en disciplin eller forskningstradition, der historisk set har udviklet sig fra en forståelse af organisationer som lukkede systemer til åbne systemer igennem hvilken omverdenen har fået mere forklaringskraft, dvs. har et omverdens begreb. Men omverdens begrebet relaterer og begrænser sig til en organisations relevante omverden og omverdensrelationer (Ibid. s. 162), dvs. opererer uden et egentligt samfundsbegreb. Scott beskriver det på følgende måde i relation til den tidlige organisationsteori:

"... early rational system theorists did not take much notice of the effects of the larger social, cultural, and technological context on organization structure or performance. Attention was concentrated on the internal features of organizations." (Scott 2003 s. 55)

Hertil bemærker Scott, at siden udviklingen af forståelsen af organisationer som åbne systemer, kan organisationsforskere ikke længere ignorere betydningen (the effects) af organisationers omverden (environment) og dens indflydelse på organisationer. Han opfordrer derfor til udvikling af forståelser og konceptualiseringer af organisationers omverden. Og med en nærmest humoristisk bemærkning skriver han "it is not very helpful to regard the environment as simply 'everything else'." (Scott 2003 s. 125).

For afhandlingen er spørgsmålet, hvordan teorier om organisatorisk læring forholder sig til deres omverden i form af samfundet? I det følgende vil jeg først tage udgangspunkt i to alment refererede men forskellige teorier, som ligeledes repræsenterer to forskellige bud, nemlig Argyris \& Schön og Peter M. Senges forståelse af samfund eller organisationens omverden. Analysen postulerer ikke, at det fremanalyserede gælder alle teorier om organisatorisk læring, men på baggrund af analysen af de to teorier at perspektivere det forhold som Scott og Nielsen \& Vallentin er inde på også kan iagttages indenfor teorier om organisatorisk læring, samt hvordan det kan tage sig ud, dvs. er begrebsliggjort. Analysen danner således en form for baggrund for at perspektivere og fremkomme med et alternativ, som netop betoner vigtigheden af at teorier om organisatorisk læring kan drage fordel af at have et samfundsbegreb.

Tilsidst positioneres afhandlingen i relation til Gherardi og Nicolinis metateoretiske artikel 'The Sociological Foundations of Organizational Learning' (2001). 


\section{Argyris \& Schöns samfundsbegreb}

Argyris og Schön (1978; 1996) forholder de sig meget selektivt og begrænset til organisationens omverden. Deres tilgang til organisatorisk læring er udpræget psykologisk, hvor organisatorisk læring iagttages som individuel læring i en organisatorisk kontekst. For Argyris \& Schön er organisatorisk læring processen hvor organisations medlemmer gennem fejlfinding og identificering af anomalier korrigerer ved at restrukture organisationens theory-inuse, dvs. organisationsmedlemmernes individuelle teorier (mentale modeller) for handling i relation til organisatoriske arbejdsopgaver (Argyris \& Schön 1978 s. 2; se også Prange 1999 s. 28). Spørgsmålet er hvordan organisationens omverden gøres relevant i relation til ændring af organisations medlemmernes theory-in-use. Arguris og Schöns henvisning til organisationens omverden eller samfundet sker primært gennem en økonomisk iagttagelse, hvilket giver en ide om hvordan de vurderer viden, refleksioner, teorier og analyser af organisationers omverden. Den $\emptyset$ konomiske iagttagelse beskriver organisationer i et konkurrerende marked, hvor organisationer adopterer eller ændrer strategier med henblik på at få konkurrencefordele på markedet. Ifølge Argyris og Schön betragter disse økonomiske analyser organisationer ud fra en 'black box' tilgang, hvilket refererer til et lineært kausalitetsforhold mellem system (organisation) og omverden, dvs. en black box som en ubekendt maskine, hvorom man antager, at den er determinerbar, men den determinerende mekanisme er unddraget iagttagelse (Glansville i Kneer \& Nassehi 1997 s. 28). Men ifølge Argyris \& Schön medinddrager disse $\emptyset$ konomiske analyser ikke hvad der sker i de enkelte systemer (organisationer og deres afdelinger) og kan derfor ikke se og medinddrage refleksioner over, hvad der sker i systemet (organisationen), dvs. hvordan systemet organiserer forholdet mellem input og output, så afskriver de denne iagttagelsesform som relevant for organ-

isatorisk læring, og i forlængelse heraf også alle mulige andre iagttagelser fra omverdenen.

"All such distant theories of organizational behaviour, operate at high levels of social aggregation, may make useful contributions to economic theory or even to policy analysis. What they do not do or seek to do is to describe and explain the processes within an organization that give rise to patterns of activity seen, in the aggregate, as the organization's knowing, thinking, remembering, or learning." (Argyris \& Schön 1996 s. 5-6)

Argyris og Schön beskriver organisatorisk læring som noget, der foregår i organisatioer. Dette kan der etableres bred enighed om, men spørgsmålet er 
om de vil forholde sig til sociologiske teorier på samme måde som de gør med henvisning til $\varnothing$ konomiske teorerier og analyser fordi de også opererer med en udefra tilgang til organisationer, som f.eks. at beskrive organisationers omverdensvilkår. Hvis man skal følge deres ressonnement kan man udlede, at $\mathrm{i}$ den udstrækning en teori eller analyse ikke forholder sig til specifikke intraorganisatoriske forhold, dvs. en organisations interne organisering, viden, interaktionen mellem ansatte, måde at tænke på, forsvarsmekanismer, hukommelse og læring, kort sagt identificering og beskrivelse af organisationsmedlemmernes theory-in-use, så er de formentlig ifølge Argyris og Schön ikke egnede til at sige noget om organisatorisk læring. Det skal hertil siges at det ikke er Argyris \& Schöns intention, hensigt eller erkendelsesinteresse at beskæftige sig med samfundet, men med interorganisatoriske forhold ud fra en psykologisk tilgang til organisatorisk læring. Det er imidlertid afhandlingens intention at argumentere for at organisationer er situeret $i$ et samfund, og at dette samfunds måde at sætte muligheder og begrænsninger for organisationerne, kan medvirke til en anden og mere kompleks forståelse af organisatorisk læring.

\section{Senges samfundsbegreb}

Peter M. Senges systemtænkning i form af Den femte disciplin går i hans egen beskrivelse ud på at se helheder. For Senge består en organisations omverden af forskellige national stater, organisationer, markeder, netværk, miljø udfordringer osv. (Senge 2000 s. 68-69), og har stort set alle karakter af at fungere som erfaringsbaserede 'Best practice' eller 'worst case scenario' eksempler, som en organisation ved at reflektere over, kan bruge til at optimere sin læring. Det er ikke muligt i Senges teori at finde en egentlig samfundsbeskrivelse eller forståelse af sociologisk karakter, og man kan derfor konkludere det samme som Nielsen og Vallentin (2003) gør angående organisationsteorien som sådan. Men til forskel fra Argyris og Schön som decideret afskriver analyser og viden fra omverdenen, så forholder Senge sig til organisationers omverden, i form af informationsoverload, der overstiger mulighed for organisatorisk absorption og større mulighed for indbyrdes forbundenhed, end der kan håndteres, og at de samfundsmæssige forandringer har nået et stadie, som ingen kan følge med længere. Ifølge Senge er det et grundvilkår for organisationer, at de overvældes af kompleksitet forstået som flere muligheder end, der kan realiseres, hvilket fører til systemsammenbrud (Senge 2000 s. 67). Senge beskriver denne omverdenskompleksitet i to forskellige former; detalje kompleksitet og dynamisk kompleksitet (ibid. 
s. 69-70). Detalje kompleksitet er kendetegnet ved, at der indgår en række variable, som der i en vis udstrækning kan laves konsekvensberegninger på, dvs. det er muligt på forhånd at have en relativ god ide om konsekvenser eller følger af en eller anden handling. Dynamisk kompleksitet er derimod kendetegnet ved situationer, hvor sammenhængen mellem årsag og virkning ikke fremgår så klart, og hvor effekten over tid ikke er helt så indlysende. Senge beskriver det som når en handling har én slags konsekvenser lokalt, og nogle helt andre i en anden del af systemet, så er der tale om dynamisk kompleksitet. (Ibid. s 70). Samfundet eller organisationens omverden kommer således til syne for organisationen som enten beregnelig eller uberegnelig. Senge har som sagt ikke en samfundsbeskrivelse af sociologisk karakter, men man kan udlede, at han mener at samfundet er gået fra at bestå af detalje kompleksitet, til i det moderne samfund i højere grad at bestå af dynamisk kompleksitet. Dette ligger til grund for hans argumentation for systemtænkning, hvor det drejer sig om at identificere omverdenens dynamiske kompleksitet og at se de vigtigste samspillende faktorer bag et problem, fordi det fører til nye indsigter i, hvad det er muligt at gøre.

"Systemtcenkningspraksis begynder med en forståelse af det simple koncept, der hedder feedback, og viser, hvordan handlinger kan forstarke eller modarbejde (afbalancere) hinanden. Den praksis vokser til en forståelse og genkendelse af strukturtyper, der kommer igen gentagne gange." (Senge 2000 s. 71)

Systemtænkningen transformerer herved en organisations omverden eller samfundets uberegnelighed til en højere grad af beregnelighed, hvilket adskiller Senges teori fra Argyris og Schön, idet de primært ser samfundet gennem en $\varnothing$ konomisk optik, som udelukkende handler om konkurrerende markeder, hvor organisationer adopterer eller ændrer strategier med henblik på konkurrence fordele, dvs. en vidensform som ifølge dem er uegnet til iagttagelse af og forståelse for intraorganisatoriske forhold. For Argyris \& Schön er organisatorisk læring udelukkende et intraorganisatorisk anliggende, og de afviser derfor enhver analyse, som ikke har dette som sit anliggende, hvorfor de må siges et svagt begreb om samfundet. Senge derimod iagttager det moderne samfund bestående af umiddelbar uberegnelig dynamisk kompleksitet, som organisationer gennem systemtænkning kan transformere til en højere grad af beregnelig. Dermed har Senge heller ikke noget egentligt samfundsbegreb, men et begreb om dynamisk kompleksitet. Man kan sige, at mens Argyris og Schön mere eller mindre lukker øjnene for samfundet, 
og dermed afviser relevansen af samfundet for organisatorisk læring, så introducerer Senge med sit systemtænkningsbegreb en form for fornyet rationalistisk tilgang til organisatorisk tænkning og handling, hvor organisationer bliver i stand til at tage beslutninger med beregnelige konsekvenser. Denne tænkning står på mange måde i kontrast til og ignorerer Simons begreb fra 50'erne om bounded rationality, som opererer med, at der er tre uundgåelige begrænsninger vedrørende organisatorisk beslutningstagen: 1) informationer foreligger kun i begrænset omfang og er ofte upålidelige, hvorfor foreliggende oplysninger om mulige alternativer og deres konsekvenser er tvivlsomme, 2) det menneskelige sind har kun begrænset kapacitet til at vurdere og behandle de oplysninger, der er til rådighed, og 3) kun en begrænset mængde af tid er til rådighed for at træffe en beslutning. (March 2005 s. 65-67). Spørgsmålet i relation til Senge er også, om det overhovedet giver mening at betragte relationen mellem samfund og organisation som noget organisationer gennem systemtænkningens styringsrationalitet, kan styre?

Jeg vil ikke gennemgå flere teorier om organisatorisk læring med henblik på at vise deres forståelse af samfundet eller mangel på samme, men mere generelt henvise til, at det ikke er usædvanligt at se forståelser som nedenstående blandt teorier om organisatorisk læring.

"I det sen-eller postmoderne samfund er et hastigt forandringsmilj $\phi$ et vilkår, som alle tyder organisationer er underlagt, og som $n \phi d v e n d i g g \phi r$ en kontinuerlig stillingtagen til forandringer planlagte som ikke planlagte. Med en stadig stigende andringstakt $i$ arbejdslivet bliver det en stadig mere omfattende opgave at lede forandringsprocesserne $i$ de enkelte organisationer. Både overordnede og medarbejdere stiller krav om, at lederen skal kunne gennemføre forandringsarbejdet, så medarbejderne bliver $i$ stand til at mestre fremtidens krav; f.eks. storre internationalt fokus, tvaerfagligt samarbejde i organisationen, højere vidensniveau samt evne til at samle og distribuere viden organisationsmedlemmerne imellem." (Elting 2009 s. 165)

Det forandringsmiljø Elting er inde på beskrives som et generelt organisatorisk problem i det sen-, post- eller bare moderne samfund. I den udstrækning vi accepterer, at det forholder sig sådan, er et relevant spørgsmål, hvorfor det forholder sig sådan? Og hvad menes der egentligt? Og hvad der er grunden eller grundene til, at det forholder sig sådan? Man kunne hertil bemærke, at i den udstrækning det er en udbredt forståelse indenfor organisationsteorien, 
at samfundet er sådan noget, der forandrer sig, så bliver organisationsteoriens svar forandring, dvs. tilpasning (adaption), til den samfundsmæssige forandring! Og potentielt sammenbrud eftersom ingen organisation kan tilpasse sig samfundet! Dette ville betyde, at organisationen blev samfundet! Et sådant svar - forandring for forandringens skyld - syntes i relation til det moderne samfunds pluralitet at være et fattigt svar, eller et ikke-svar, eftersom det ikke giver mening at forandre sig i relation til alle forandringer! Det er klart at, i den udstrækning organisationer kun står til ansvar overfor sig selv og sin egen overlevelse, bliver retningsgiveren for forandringen organisationen selv. Spørgsmålet er, om det er muligt ved en refleksion over forholdet mellem samfund og organisation at udvikle en mere præcis eller mere retningsgivende forståelse for organisatorisk læring i relation til de forhold en organisation står overfor i forhold til det moderne samfunds forandringer? Man kunne have den tese, at det gennem en sociologisk forståelse af samfundet vil være muligt at udvikle en mere kompleks forståelse af samfundets forandringer end Senges enkle begreb om dynamisk kompleksitet? Eller end Argyris og Schöns afvisning af $\varnothing$ konomien som en faktor, der har relevans for hvorfor og hvordan organisationer skal forandre sig? Man kunne i den forbindelse tilføje at netop $\varnothing$ konomi, og en viden om $\varnothing$ konomi kan være vigtig for organisationer, og tillige have konsekvenser for interne prioriteringer i organisationer, herunder at forklare bevæggrunde for anvendelse af begrebet om organisatorisk læring. Hertil kunne man tilføje at økonomi ikke er det eneste omverdens forhold! Omverdenen eller samfundet består ikke bare af økonomi! Organisationer kan ikke nøjes med at begrunde sig økonomisk, men skal ofte også kunne forholde sig til politiske, etiske og moralske, økologiske, religiøse, retslige, dvs. juridiske forhold, mediemæssige forhold og dagsordener osv.

For at få en forståelse af dette, vil jeg i det følgende foretage en sociologisk beskrivelse, refleksion og analyse af samfundet som jeg vil relatere til de overordnede implikationer for organisationer i det moderne samfund. 


\section{Sociologi, samfund og organisation}

Dette afsnit vil diskutere og belyse forholdet mellem organisation og samfund ud fra specielt tre forskellige sociologiske tilgange; Max Weber, Emile Durkheim og Niklas Luhmann. Afsnittet afsluttes med en positionering af afhandlingen i relation til fem sociologiske traditioner indenfor organisatorisk læring, som Gherardi \& Nicolini (2001) på baggrund af Collins (1994) fire sociologiske traditioner, har fremanalyseret og opererer med.

For dels at diskutere og belyse forholdet mellem organisation og samfund, som jeg påpegede $\mathrm{i}$ indledningen, og for at få en forståelse for, hvorfor organisationer i tiltagende grad anvender dét den norske organisationsforsker Kjell Arne Røvik kalder organisationsopskrifter, og hvad det er for nogle grundlagsproblemer eller spørgsmål organisationer forsøger at løse, og hvilke muligheder og begrænsninger der er knyttet hertil, vil jeg se på, hvordan sociologien forholder sig til samfundsudviklingen og dens generelle implikationer for samfundets organisationer.

Til dette formål vil jeg anvende to forskellige sociologiske klassikere nemlig Emile Durkheim (1858-1917) og Max Weber (1864-1920). Durkheim bruges til at sige noget om de grundlæggende forandringer som samfundsudviklingen fra en samfundstype til en anden har af betydning for samfundet og dets organisationer, individualisering og arbejdsdeling herunder implikationer for videnproduktion. Weber bruges til noget af det samme, men også til at beskrive den måske mest succesrige og udbredte organisationstype nemlig bureaukratiet, og dens betydning for udviklingen af det moderne samfund, og ikke mindst hvorfor den er kommet under kraftig kritik i de sidste mange år. Bureaukratiet bruges som eksemplarisk case på den historiske udvikling i forholdet mellem samfund og organisation, men også for at beskrive og reflektere de mere generelle problemstillinger, som jeg vil hævde, alle organisationer i det moderne samfund i varierende grad er konfronteret med.

Interessen for organisationer kædes inden for sociologien sammen med udviklingen og forandringen af samfundet (Weber 2003; Giddens 1995; 
Luhmann 1982; 1997; Beck 1997). ${ }^{58}$ Allerede de sociologiske klassikere Emile Durkheim og Max Weber reflekterede over forholdet mellem organisation og samfund. Mens Durkheims samfundsanalyse viste, hvordan samfundets primære differentieringsform havde implikationer for samfundets organisering, arbejdsdeling, individualitet og vidensproduktion, så anvendte Weber sin mere normative og værdiorienterede samfundsanalyse til at foreslå, hvordan en bestemt organiseringsform - bureaukratiet - kunne bruges til at fremme bestemte interesser, som han mente, var centrale for udviklingen af det moderne samfund.

\section{Webers normative samfundsprojekt}

Max Weber betoner betydningen af konkrete organisationers indretning som essentiel for udviklingen af det moderne samfund. For Weber var indførelsen af retssamfundet i Tyskland i starten af det 20 århundrede snævert knyttet til hans sociologiske ideer om staten, og et juridisk legaliseret og sikret universelt borgerskab med borgerrettigheder. Webers udgangspunkt markerer således et opgør med et førmoderne stratifikatorisk og lagdelt samfund domineret af feudalistiske, patriarkalske og patrimonialistiske herredømme former (Weber 2000 s. 73-88; Collins 2000 s. 102-111). For at dette projekt kunne lykkedes, var Weber fortaler for indførelsen af hans egen organisatoriske idealtype bureaukratiet. Trods den efterhånden udbredte kritik af bureaukratiet som organisationstype, er der bred enighed om, at den bureaukratiske organisationstype, $\mathrm{i}$ betydningen et rationelt autoritetssystem, har været afgørende for udviklingen af den moderne vestlige stat. Bureaukratiet skulle i følge Weber udformes i maskinens billede som middelrationelle, regelorienterede og upersonlige konstruktioner (Borum 1995 s. 12). I stedet for at tjene egennytte interesser skulle embedsmanden referere til et rationelt og legalt autoritetssystem. Det, der gør bureaukratiet overlegent i forhold til andre organisationstyper, er ifølge Weber:

"Den afgørende årsag til, at den bureaukratiske organisation har vundet frem, har fra starten varet dens rent tekniske overlegenhed $i$ forhold til en hvilken som helst anden form for organisation. Forholdet mellem en fuldt udviklet bureaukratisk mekanisme og disse andre organisationsformer er akkurat det samme som forholdet mellem en maskine og de ikke-mekaniske produktionsmåder. Pracision, hurtighed, entydighed, aktkundskab, kontinuitet,

\footnotetext{
${ }^{58}$ Andre har argumenteret for, at stororganisation (large- scale organisation) er et decideret uundværligt træk ved det moderne samfund (Giddens 1995 s. 37).
} 


\begin{abstract}
diskretion, ensartethed, streng underordning, reduktion af friktion samt faglige og personlige omkostninger-alle disse faktorer er iden strengt bureaukratiske forvaltning, og sarligt i dens monokratiske form med skolede embedsmand, forøget til det optimale sammenlignet med enhver kollegial eller ares- og bierhvervsmassig form for forvaltning. Såfremt det drejer sig om komplicerede opgaver, er betalt bureaukratisk arbejde ikke bare mere pracist, men i praksis endda ofte billigere, end hvis arbejdet udføres som et formelt set vederlagsfrit aereserhverv." (Weber 2003 s. 81)
\end{abstract}

For Weber var det afgørende, at staten og dens bærende offentlige forvaltninger og institutioner skulle designes, så de opfyldte to hovedformål. I et tidsligt perspektiv skulle de operere med en vis træghed overfor pludselige forandringer i omverdenen, og i et sagligt perspektiv ud fra andre kriterier i sagsbehandlingen end det omkringliggende samfund, således at semantiske og strukturelle former forbundet med feudalsamfundets hegemoni blev begrænset til et absolut minimum. Alt sammen var nødvendigt, for at staten ikke kom til at tjene personlige og nepotistiske interesser. For Weber lå svaret som sagt $\mathrm{i}$ opbygningen af organisationer som bureaukratier. Men netop bureaukratiets udprægede fokus på eksplicitte og præskriptive beskrivelser af det strukturelle ledelseshierarki, arbejdsdeling, upersonlig og regelbaseret adfærd og formaliserede avancement regler (Weber 2000 s. 105-115), som var så afgørende for Weber, idet det kunne tjene som bolværk mod pludselige samfundsmæssige forandringer og interessemæssige indgreb af mere personlig karakter (Se Weber 2000 s. 105-153), er i det moderne samfund blevet dets akilleshæl. ${ }^{59}$ Dette er der flere grunde til, men ud fra en sociologisk og læringsteoretisk tilgang er netop Webers ideal om bureaukratiet som en lukket enhed, der fungerer og danner mening i relation til interne kriterier og regler de-koblet det omkring liggende samfunds meningsdannelse, problematisk, og kan resultere i integrations- eller adaptionsproblemer. Disse forhold kan relateres til samfundsforståelsen. Som baggrund eller afsæt for sin bureaukratiske idealtype tager Weber udgangspunkt i en iagttagelse af samfundet som uhensigtsmæssigt styret af feudalistiske, patriarkalske og patrimonielle herredømme (magt)

\footnotetext{
${ }^{59}$ Metaforisk sagt skulle bureaukratiet fungere som en regelbaseret $\varnothing$ i samfundet, dvs. et system som opererede i henhold til egne internt baseret kategorier, regler og procedurer for sagsbehandling. Selvom bureaukratiet som organisationsform historisk set har været og stadig er vidt udbredt og accepteret, både indenfor det offentlige såvel som det private, er den ud fra et forandringsperspektiv blevet kritiseret for dens begrænsninger qua sin lukkede, strukturelle og regelbaserede karakter (Scott 2003).
} 
former, som for Weber er uacceptable og uforenelige med hans ideer om staten og et juridisk legaliseret og sikret universelt borgerskab med borgerrettigheder. For Weber er den mest rationelle og legitime herredømme form den, som er sikret gennem retsgrunde, dvs. juridisk, fordi netop denne herredømmeforms legitimitet (målrationel legitimitet) bygger på en foreskreven ordens legalitet konstitueret og sikret gennem demokratiske principper. Borgerne vælger politikerne, som formulerer love, som bureaukratiet bl.a. er med til at udmønte. Borgerne styrer m.a.o. selv, hvem de vil styres af, hvorfor dem som styrer er $i$ besiddelse af eller har opnået (demokratisk reguleret) legitimitet.

Man kan hævde, at bureaukratiet i Webers udlægning måske nok kan fungere som en fornuftig indretning i relativt stabile samfund, hvor forandringer forekommer langsomt, men i samfund som beskrives i forandrings inertiens vold (Thyssen 1996), og hvor viden, teknologi, menneskelige ressourcer og kvalifikationer, konkurrencen om medarbejdere, semantikken om individet osv. antager nye historiske former, fremstår bureaukratiet med sit rigide fokus på formelle regler, embedsmandshierarki og arbejdsdeling som et ideal eller en konstruktion, der er ude af stand til at tilpasse sig samfundets forventninger og krav. Eller som Luhmann skriver: "(...) netop bureaukrati er som bekendt et system med meget ringe følsomhed over for forstyrrelser." (Luhmann 2000a s. 445). Den legitimitet med hvilket bureaukratiet skulle indføres, nemlig realiseringen af det universelle borgerskab og indførelsen af legale borgerrettigheder, vendes i det moderne samfund imod det. Man kan hævde, at bureaukratiet overhales indenom, eller - i den udstrækning det iagttages som grundlag for fremkomsten af det refleksivt moderne menneske - selv er skyld i kritikken (Giddens 1996; 1997; Beck 1994).

Som det fremgår, kan man ud fra en sociologisk refleksion se Webers udformning af bureaukratiet, ikke for bureaukratiets og regelbaseringens skyld, men som en organisationsform fremkommet gennem en analyse af og refleksion over samfundets grundlæggende form. Bureaukratiet skulle tjene, hvad man kan betegne et højere formål, nemlig muliggørelsen af et retssamfund. Man kan også sige, at i relation til statens institutioner og organisationer var og er bureaukratiets overordnede funktion muliggørelsen og opretholdelsen af bl.a. retssamfundet.

\section{Durkheims samfundsforståelse}

Begrundet i samfundets ændrede arbejdsorganisering opfatter Durkheim udviklingen af samfundet fra førmoderne til moderne som en overgang fra segmentær til funktionel differentiering, og som en overgang fra mekanisk 
til organisk solidaritet. Dette er en overgang der grundlæggende ændrer vilkårene for individets individualitetsmuligheder. Durkheim beskriver dette ved forholdet mellem solidaritet og social orden (Guneriussen 1996 s. 76-79; Rasborg 1996 s. 57-69). Førmoderne samfund beskrives som segmentære, dvs. homogene samfund, hvis mest typiske træk er overskuelighed og et afgrænset fællesskab, hvor individer er knyttet sammen ved en fællesbevidsthed. Nærheden, ligheden og stabiliteten i de samfundsmæssige forventninger til individet har i sådanne simple fællesskaber været afgørende for mulighederne for individualitet, arbejdsdeling og forandring.

"De sociale molekyler, der kun kan haenge sammen på denne ene måde, kan ikke optrade som en enhed, medmindre de savner enhver egenbevagelse, således som det er tilfaldet med de uorganiske legemers molekyler. Dette er grunden til, at vi foreslår, at denne form for solidaritet betegnes som mekanisk solidaritet." (Op.cit. fra Rasborg 1996 s. 60)

Forandring og mulighed for individualitet er i sådanne samfund meget begrænset, eftersom individet betragtes som et kollektivt væsen, der i enhver henseende refereres til som en del af en større helhed, dvs. hele fællesskabet (segmentet). Rasborg betegner ligefrem disse samfund som individualitetsbegrænsende, idet der er tale om en social tilstand, hvor personligheden nærmest forsvinder, hvor vi ikke længere er "os selv" men derimod et "kollektivt væsen". (Rasborg 1996 s. 60). I segmentære samfund var det enkelte menneskes rolle og handlinger tæt knyttet til andre som tandhjul, der griber ind $\mathrm{i}$ hinanden, hvorfor forandringer har været set som trusler mod helheden - stabilitet og status quo har været comme il faut!

"Mens den første form for solidaritet [den mekaniske solidaritet] indebarer at individerne ligner hinanden, forudsatter den anden [den organiske solidaritet]at de adskiller sig fra hinanden. Den førstncevnte type er kun mulig, for så vidt som den individuelle personlighed er absorberet af den kollektive personlighed, hvorimod den sidstnavnte kun er mulig, hvis enhver har et virkefelt, der er helt hans eget, og han dermed har en personlighed.... Det er givet, at på den ene side er vi hver iscer langt mere afhangige af samfundet, jo mere arbejdet er delt, mens på den anden side den enkeltes aktivitet tilsvarende er mere personlig, jo mere specialiseret den er." (Op.cit. fra Rasborg 1996 s. 61) 
Dette er Durkheims definition på det moderne samfund. Et funktionelt differentieret samfund kendetegnet ved stigende specialisering, som grundlæggende ikke bare fremmer individualitet, arbejdsdeling og forandring, men ligefrem er afhængig af det og forventer det. Helt konkret uddifferentierer samfundet en række samfundsmæssige funktioner til fremvoksende professioner og organisationer, samt specialiserer og uddifferentierer videnproduktion. Dette betyder, at samfundets interne og gensidige afhængighed - den samfundsmæssige interdependens, mellem mennesker og organisationer - øges. For spørgsmål angående læring, viden og organisationer har dette en lang række vidtgående konsekvenser, som jeg senere skal komme ind på, men grundlæggende skaber det moderne samfund semantiske præferencer og strukturer, der forventer og hylder uddifferentiering, dvs. nytænkning, og samlet set resulterer i en tilvækst i samfundets samlede kompleksitet. På samme tid $\varnothing$ ger interdependensen. På niveauet for samfundet sætter disse forhold en kædereaktion af kompleksitetsreducerende strategier i gang, hvilket i udpræget grad op gennem det 20. århundrede har kunnet iagttages indenfor organisationsteorien i form af forskellige organisationsudviklingskoncepter, som jeg senere kommer ind på.

\section{Individualisering som kompleksitetstilvækst}

Individualiseringen af samfundet er nært knyttet til dels den samfundsudvikling, Durkheim beskrev, og dels udviklingen af de vestlige samfund som retssamfundet, hvor borgere har lige rettigheder over for staten og hinanden. Ifølge Luhmann kan dette ses som et udtryk for samfundets sociokulturelle evolutionsproces, som på en og samme tid (simultant) er en binding til og en emancipation fra historien (Luhmann 1982 s. 74). For Luhmann er dette et historisk element $i$ overgangen fra et stratifikatorisk samfund til et - i lighed med Durkheims forståelse - funktionelt differentieret samfund, hvor vurderingen og iagttagelsen af den enkelte ikke forløber i relation til familiær baggrund og klasse (stand), men hvor specialiserede organisationssystemer i det moderne samfund involverer en abstraktion fra indifference til multiple aspekter af konkrete individers liv (Luhmann 1982 s. xx). Systemer ekskluderer med andre ord mennesker som psyke-organiske enheder, hvorfor intet menneske er komplet indkapslet i dem, men må i tilfælde af inklusion forstås ud fra et rollebegreb, og derfor forskelligt i relation til forskellige systemer (kontekster). (Jönhill 2012 s. 69-70) Intet menneske kan leve sit liv i tilknytning til ét system, men må i det moderne samfund forstås som afhængigt af inklusion i mange forskellige systemer på en og samme tid. 
Dette er udtryk for samfundsmæssig, organisatorisk og individuel autonomi og interdependens. Mennesket er interdependent (afhængig) af inklusion i en mangfoldighed af forskellige systemer, som hver især iagttager den enkelte gennem hver deres optik f.eks. i rollen som kunde i banken, i brugsen, forælder til børn på skolen, kursist på et efteruddannelseshold osv. Organisationer og mennesker er gensidigt afhængige af at samfundets systemer tilvejebringer og giver mulighed for en mangfoldighed af ydelser. På den anden side er der en relativ autonomi, da organisationer og mennesker i det moderne samfund selv kan bestemme en række forhold f.eks. hvor man vil handle, hvem der skal ansættes, hvor man ønsker at være ansat osv.

Ifølge Ziehe (1989) og Giddens (1997) betyder overgangen til det moderne samfund en indvarsling til en ekstrem samfundsdynamik, som har konsekvenser for en lang række forskellige områder, f.eks. meningsdannelse, individualitet, refleksivitet, organisationer osv. Giddens beskriver den ligefrem som en "løbsk verden" (1997 s. 27), fordi de sociale forandringers hastighed, deres omfang og dybdegående betydning for sociale praksisser og adfærdsformer, forøges. ${ }^{60}$ Dette leder til en generel opløsning af tidligere normer, moralkodeks og traditioner, som resulterer i forøget refleksivitet, formbarhed og individualisering, der på den ene side frisætter det enkelte mennesket fra de gamle kulturelle normer og traditioner, på den anden side binder friheden til selvstændig handling og udvikling, dvs. handlingstvang. Dette leder ifølge Ziehe og Giddens til et livslangt og refleksivt identitetsarbejde, hvor vi gennem livet skal opfinde vores liv på ny. ${ }^{61}$ Ifølge Ziehe (1997) vælger mennesket i det moderne samfund ud fra en subjektiveret tilgang til

\footnotetext{
${ }^{60}$ Giddens mener, at samfundet befinder sig i en fase mellem modernitet og postmodernitet præget af, hvad han kalder en radikalisering af moderniteten. Radikaliseringen af moderniteten består i en opløsning af evolutionismen, den historiske teleologis forsvinden, anerkendelsen af en gennemgribende, konstitutiv refleksivitet og opløsning af Vestens privilegerede position, som fører os ind i et nyt og urovækkende erfaringsunivers, hvis følger kan mærkes alle vegne. Til at betegne og forklare denne transformation af samfundet fra det moderne til det postmoderne anvender Giddens selv tre dominerende, og som han siger sammenhængende kilder til modernitetens dynamik: 1) Adskillelsen af tid og rum, 2) Udviklingen af udlejringsmekanismer (disembedding-mekanismer), 3) Den refleksive tilegnelse af viden (Giddens 1996 s. 51; for en uddybning se Kaspersen 1995 s. 121-127).

${ }^{61}$ Denne forståelse eller analyse peger i en helt modsat retning end den f.eks. Etienne Wenger advokerer for i sin sociale læringsteori. Wenger mener, at det er samfundssystemernes ansvar at give folk identitet. F.eks. skriver han om sin egen datter, og hendes gymnasietid, hvor hun er meget optaget af spørgsmålet om, hvem hun er - et spørgsmål, som gymnasiet ikke hjalp hende med at finde svar på. "Godt nok laerte hun en hel masse. Hun laerte algebra og trigonometri og samfundsfag, men hun oplevede det som spild af tid i forhold til hendes egentlige spфrgsmål om, hvem hun er." (Wenger 2009 s. 62).
} 
verden, dvs. i relation til, hvad det enkelte menneske selv finder meningsfuldt. Mennesker italesættes af politikere og organisationer som forbrugere, der agerer på et marked (Lyon 1995), hvor organisationer i en vis udstrækning må indrette sig på at sælge sig selv, idet det moderne menneske ser sine valg som noget, der skal passe ind i deres eget refleksive identitetsarbejde og selvrealisering (Giddens 1996; 1997).

"Det er et dybt ironisk spil, samfundet spiller med individerne og sig selv: Først tvinger samfundet individerne til selvbestemmelse; de bliver "overladt til autonomi (...) Individerne - eller Luhmannsk sagt: semantikken om individet - overtager så selv de naste trin $i$ kaden, tilegner sig individualitetsvaerdien som udsprunget af individet, tror, at den er en art indre naturgiven vardi, og bebrejder samfundet, at det ikke tilbyder nok mulighed for eller ligefrem forhindrer individualitet." (Mortensen 1996 s. 34).

I relation til samfundets organisationer betyder denne individualisering, at det moderne menneske i visse tilfælde opererer ud fra parolen: samfundet, herunder organisationer skal indrette sig efter mig og ikke omvendt! Denne kompleksitet i form af frihed til selvbegrundelse, dvs. til at forfølge det meningsfulde for den enkelte, gælder ikke kun forbrugere og borgere, men tillige organisationers ansatte. ${ }^{62}$ Ansatte har også forventninger til, hvad der passer dem. Det er selvsagt strukturelle forskelle i hvilke muligheder og begrænsninger, mennesker har i relation til at anvende eller hævde deres frihed i almindelighed og i forhold til organisationers forventninger til dem, ligesom der er individuelle forskelle; Nogle mennesker er mere frihedselskende end andre, og har derfor brug for forandring, mens andre kan bruge semantikken om frihed til at hævde deres ret til ikke at ville forandre sig.

I lighed med Senges definition af samfundet som (dynamisk) komplekst betegner Luhmann det moderne samfund som et komplekst samfund. Men til forskel fra Senge har Luhmann en forklaring eller en teori om samfundets kompleksitet, der er relateret til beskrivelsen af samfundets grundlæggende differentieringsprincip på makroniveau. Dette betyder, at kompleksitet i

\footnotetext{
${ }^{62}$ Med reference til Luhmann beskriver Niels Mortensen dette forhold mellem individ og samfund således: "Luhmann formulerer udviklingen i forholdet mellem individ og samfund som et stigningsforhold, således at der samtidig sker en vækst i på den ene side omfanget af og kompleksiteten i de samfundsmæssige systemer og på den anden side i individernes frigørelse fra de faste sociale bindinger." (Mortensen 1996: s. 32). Individets mulighed for individualitet ses som en naturlig konsekvens af samfundets funktionelle uddifferentiering, og den finder sted på samfundsplan såvel som i relation til organisationer.
} 
Luhmanns forståelse ikke bare er overload, der leder til dysfunktion, således som Senge hævder, men som noget der har en form nemlig differentieringens form. Jeg vil i det følgende beskrive Luhmanns forståelse af samfundets udvikling med særligt henblik på at beskrive, hvordan samfundets primære differentieringsform på makroniveau har indflydelse på en række forhold vedrørende samfundets organisationer, herunder organisatorisk læring.

\section{Luhmann samfundsforståelse}

Ud fra en teori om sociokulturel evolution skelner Luhmann overordnet mellem fire primære samfundsformer, som historisk set er emergeret. Det drejer sig om en segmentcert-, centrum-periferi-, stratifikatorisk- og funktionelt differentieret samfundsform (Luhmann 1982 s. 232-238; 1997 s. 634-776). ${ }^{63}$ Samfundsformerne skal opfattes som typificeringer, hvor fokus er på den primaere differentieringsform. Strukturelle og semantiske former fra andre differentieringsformer er således ikke udelukket, som Nils Mortensen er inde på i bogen Det paradoksale samfund (2004; se også Jönhill 2012 s. 32), men kan forekomme som måder at danne mening på indenfor alle områder af samfundets kommunikationer. ${ }^{64}$ Samfundets primære differentieringsform har ifølge Luhmann afgørende betydning for samfundets meningsdannelse, interne differentiering, uddannelsestænkning og kompleksitet.

\section{Segmentært differentiereret samfundsform}

I lighed med Durkheim opererer Luhmann med en segmentær samfundsform (arkaiske samfund) karakteriseres ved en uddifferentiering i ens delsystemer; f.eks. stammer, klaner, landsbyer, familier osv. Inklusionsformen

\footnotetext{
${ }^{63}$ At det netop er disse fire former, som kan identificeres, kommer ikke af en indre logik, hvor den ene samfundsform naturligt og logisk afløser den anden som den eneste mulige, men af samfundsformer, der i kraft af de historiske mulighedsbetingelser har sat sig igennem: "(...) we can rely on the "Golden weiser principle", which states that specific structural problems can have only a limited number of possible solutions." (Luhmann 1982 s. 233).

${ }^{64}$ Specielt de flydende overgange, hvor en samfundsform afløser en anden, er karakteriseret ved anvendelsen af strukturelle og semantiske former fra flere samfundsformer. Et eksempel på dette forhold er, at der i nutidens funktionelt differentierede samfund kan spores anvendelser af socialsemantiske former fra det stratifikatorisk differentierede samfund i familier og organisationer, f.eks. i form af hierarki, eller hvor nogle ser sig for "fine" til at kommunikere med bestemte personer, ud fra en betragtning om, at disse personer iagttages som rangerende lavere i social forstand - f.eks. økonomisk.
} 
betyder, at personer kun kan deltage i et delsystem (segment) af gangen. "Et liv uden inklusion $i$ et segment er $i$ praksis umuligt." (Luhmann 2002 s. 124). ${ }^{65}$ Samfundets grænser er med andre ord segmentets grænser, og iagttagelse af andre segmenter forløber over forskellen os/dem. Hvert medlem indgår multifunktionelt $\mathrm{i}$ opretholdelsen af forskellige samfunds- og/eller levefællesskabsfunktioner, ${ }^{66}$ og kompleksitetsopbygningen er begrænset ved mundtlig overlevering i interaktive situationssekvenser. Meningsdannelse opererer ud fra en lukket form, dvs. den begrænser sig til de iagttagelser segmentet historisk selv har muliggjort, accepteret og overleveret. Et segment fungerer i den forstand kommunikativt lukket og omnipresent ved i al væsentlighed at referere til sig selv som system, og ved at det reproducerer sin helhed i hver enkelt interaktion. Den segmentære samfundsform beskrives derfor følgelig som den mest simple af de fire samfundsformer. (Kneer \& Nassehi 1997 s. 126). Oplæring og uddannelse har fundet sted som socialisation, og samfundets forventninger til læring har sammenlignet med i dag været særdeles begrænset. Enhver form for nytænkning, innovation og forandring skal ses i relation de til strukturelle muligheder og begrænsninger interaktionsformen $\mathrm{i}$ et sådant samfundssystem har givet mulighed for, dvs. med fravær af abstrakte regeldannede forventninger til konditionering af handlinger (Luhmann 2002 s. 124). Forandring er således foregået kontekstbundet og i direkte relation til praktiske gøremål, og har som grundlag for segmentets erfaringsdannelse været underlagt de tilstedeværendes erindring og segmentets kommunikative vedligeholdelse f.eks. i form af fortællinger.

\section{Centrum-periferi differentieret samfundsform}

Centrum-periferi diffentieringensformen forløber over en samfundsmæssigt observeret forskel i bosted (territorial), f.eks. forskellen mellem byen som centrum og landet som periferi, og en hierarkisk differentieringsform der forløber over forskellen; civiliseret/ikke civiliseret. (Luhmann 1997 s. 666; Baraldi 1999 s. 66-67) Centrum udgøres af de bosteder eller byer der regnes for vigtige af samfundet, og som rummer samfundets betydeligste

\footnotetext{
65,'Dette gælder dog ikke ubetinget. Fra Island berettes der om mangeårig overlevelse af fordrevne forbrydere i det ugæstfrie bjergland. Der fandtes åbenbart tilstrækkeligt med frit græssende får." (Luhmann 2002 s. 124 note 11).

${ }^{66}$ Habermas opererer med en lignende forståelse: "Den segmentære differentiering, der forlфber via udvekslingsrelationer, фger et samfunds kompleksitet ved hjalp af en horisontal sammenkædning af elementer, der er struktureret på en ensartet måde." (Habermas 1996 s. 337).
} 
magt-og vidensinstitutioner og instanser, f.eks. kongen, bureaukratiet, militæret, uddannelsessteder, handelscentre, betydelige religiøsecentre osv., og disse står i forskel til periferien som typisk udgøres af segmenter. (Luhmann 1997 s. 666) Centrum/periferi differentieringen betyder videre en forskel i kompleksitetsopbygning. Mens segmenterne i periferien opererede som i ovenstående beskrivelse, dvs. ved at oplæring og uddannelse fandt sted som socialisation, og forventninger til læring og forandring har været særdeles begrænset, så giver byernes centrering af de vigtigste kommunikationscentre som følger med magten i form af bureaukratiet, militæret, uddannelsessteder, handelscentre, religiøsecentre osv. muligheder for opbygning, udbydelse og anvendelse af en helt anden form for kompleksitet. Centrum udviker ligeledes interne differentieringer, f.eks. hierarkiske magt- og økonomiske forskelle ligesom en stærkere rolledifferentiering og arbejdsdeling gradvist udvikles. (Luhmann 1997 s. 663)

\section{Stratifikatorisk differentieret samfundsform}

Ved overgangen til den stratifikatoriske samfundsform skabes der nye muligheder og begrænsninger med hensyn til samfundets meningsdannelse, interne differentiering, uddannelsestænkning og kompleksitet.

Stratifikatorisk differentierede samfund er karakteriseret ved en kompleksitetsreducerende lededifference om ulige sociale lag, som iagttager samfundskommunikation med henblik på forskellen for oven/for neden. Personer er tilforordnet et bestemt socialt lag/klasse, der lukker sig om sig selv, og som primært er reguleret gennem endogamisk inklusion/eksklusion. Individualitet erhverves via henvisning til social status (Luhmann 2002 s. 124-125). Den altovervejende sociale semantik er, at social mobilitet foregår indenfor ens stand eller opad stratifikatorisk set. Interaktionsformen er positionel, dvs. man omgås og kommunikerer med andre i overensstemmelse med sin position. Enhver kender sin plads - sin stand - og forventes at kommunikere i overensstemmelse hermed, bl.a. fordi konsekvenserne af ikke at kommunikere og handle i overensstemmelse med stratificeringen kan have fatale konsekvenser i form af forskellige former for ringeagtelse, eksklusion, straf og sanktionering. Forskellige lags værdiorienteringer behandledes m.a.o. ikke som funktionelle ækvivalente på samfundsplan. Den stratifikatoriske kompleksitetsreducerende kløvning af samfundets kommunikationer opererede ved på forhånd at udpege udfaldet af kommunikation; det var ikke afgørende at have sagligt ret men hvem, der sagde hvad. Saglighed var således underlagt social positionering. Samfundets forventningsnorm var, 
at socialdimensionen var udslagsgivende, dvs. at den, som stod фverst i hierarkiet, havde og fik ret.

Det stratificerede samfund giver mulighed for opbygning og håndtering af en helt anden form for kompleksitet end det segmentære samfund. Stratifikationen producerer forskelle i rolleforventninger, arbejdsdeling og specialisering, og får betydning for emergensen af forskellige værdier knyttet til samfundets forskellige lag. Herremandens, bondens eller håndværkerens forestillinger og viden er knyttet til hver deres særlige referenceramme. Selvorganisering og realitetskonstruktioner, semantikker om socialisering, samt forventninger til dannelse er knyttet til standen eller klassen. En af de betydningsfulde uddifferentieringer og specialiseringer er et begyndende uddannelsessystem, som har været forbeholdt samfundets $\emptyset$ vre lag, men som senere i det funktionelt uddifferentierede samfund udbredes til resten af samfundet (Luhmann 2006).

\section{Funktionelt differentieret samfundsform}

Ifølge Luhmann forløber den mest adækvate beskrivelse af nutidens samfund via begrebet om funktionel differentiering. Samfundet iagttages f.eks. ikke som et standsmæssigt og hierarkisk system, hvor dem der rangerer øverst i hierarkiet har definitionsret over dem længere nede i systemet, men som et system hvis kommunikation mest udpræget forløber via funktionsbestemmelser.

Ifølge Luhmann har de vestlige samfund siden det 16. århundrede forandret deres primære organisering fra stratifikatorisk differentiering til funktionel differentiering. Funktionel differentiering er dét, der ifølge Luhmann indfanger nutidige vestlige samfunds grundform og grundproblematikker (Kneer \& Nassehi 1997 s. 146):

"The functional differentiation of society is at the very core of Luhmann's general theory of society. It signifies the distinct way in which modern society has evolved. It is an historical achievement of society itself that is preceded by other modes of differentiation" (John Bednarz in Luhmann 1990b s. 2)

Dette kan konkret iagttages ved, at samfundet i dag er differentieret i en række uens men ligestillede og funktionelt equavivalente delsystemer, f.eks. politik, økonomi, ret, videnskab, kærlighed, religion, uddannelse, kunst og massemedier. (se f.eks. Luhmann 1997 s. 557-569; Borch 2011 s. 80-87; Hagen 2006 s. 93-98) Disse delsystemer er kendetegnet ved deres funktionelle 
relation til samfundet, ${ }^{67}$ og de opererer autonomt på baggrund af egne symbolsk generaliserede medier. Listen af delsystemer eller funktionssystemer er ikke endelig eller fastlagt, men et empirisk spørgsmål, dvs. relateret til samfundets sociokulturelle evolution. ${ }^{68}$ (Luhmann 1997 s. 565-566)

Den sociokulturelle evolution har selvstændiggjort disse medier ved at de tager form af bincere koder, som fastlægger det pågældende systems funktion og som har indflydelse på systemets videre operationer. For eksempel baserer det politiske system sig på koden magt/-magt, det $\varnothing$ konomiske system på betale/-betale, og uddannelsessystemet er dobbelt kodet med bedre/værre for eksaminer, og med formiddelbar/ikke formiddelbar med hensyn til viden. Til hvert af disse delsystemer knytter sig programmer, som betegner de betingelser under hvilke, en bestemt kode kan tilskrives et sagsforhold. For eksempel anviser et politisk program, hvordan magten skal anvendes. I uddannelsessystemet anviser en undervisningsplan et program for hvad, og evt. hvordan og hvornår elever eller studerende skal undervises, og dermed også hvad de forventes at skulle lære.

'Samfundet' som begreb henviser dermed til ét samfund, ${ }^{69}$ som er internt differentieret $\mathrm{i}$ en række forskellige men lige specialiserede lukkede

\footnotetext{
${ }^{67}$ Denne differentiering skete naturligvis ikke fra den ene dag til den anden og var heller ikke forårsaget af noget udefra kommende. Dannelsen af et funktionelt differentieret samfund er sket i form af flere usamtidige overgange som samfundets svar på en kompleksitetstilvækst i egne handlingsområder. Allerede fra slutningen af det 16. Århundrede, tegnede der sig politiske delsystemer, men en egentlig funktionel differentiering af samfundet satte sig først for alvor igennem ved århundredeskiftet. Netop derfor betegner Gorm Harste 17-1800 tallet som modernitetens urknald (Harste 1997).

${ }^{68}$ Listen af funktionssystemer er ikke endelig, idet den relaterer sig til samfundets sociokulturelle evolution. Der er f.eks. forskere, som argumenterer for at det moderne samfund viser tegn på at f.eks. sport kandiderer til at være et funktionssystem. (se f.eks. Thyssen 2000b; Tangen 1997). I forlængelse af Luhmann spørger Roar Hagen til, om samfundet er ved at udvikle et medicinsk system sygdomsbehandlingssystemet der altså kan betragtes og beskrives som et funktionssystem. (Hagen 2006 s. 94-97; Luhmann 1993 s. 183) Andre igen betragter og beskriver socialhjælpen som et af samfundets funktionssystemer. (Baecker 1994; Moe 1998)

69"'Samfund er følgelig det omfattende socialsystem, som indeholder alt det sociale, og som følge heraf ikke kender nogen social omverden. Hvis noget socialt opstår, hvis en ny slags kommunikationspartnere eller kommunikationstemaer dukker op, vokser samfundet med disse. De forøger samfundet. De kan ikke eksternaliseres, ikke behandles som forhold i dets omverden, for alt det, der er kommunikation, er samfund. (...) I dette system findes der ingen unddragelser fra denne konsekvens, selv negationen er, (...), inkluderet i systemet og tjener, om ikke til opretholdelsen af strukturer, så dog til opretholdelsen af den autopoietiske reproduktion. Man kan derfor også betegne samfundet som en selvsubstitutiv orden, fordi alt det, der må ændres eller erstattes ved det, må erstattes i det." (Luhmann 2000a s. 470-471) Kursiveringen er vendt om i forhold til originalen.
} 
funktionssystemer, der med hver sine koder og programmer henviser til bestemte områder af den samfundsmæssige kommunikation. De så at sige afsøger verden for information gennem egen semantik. Samfundt er det omfattende socialsystem, som indeholder alt det sociale, og som derfor ikke kender nogen social omverden. (Luhmann 2000a s. 470) I kommunikativ forstand kan samfundet derfor kort og godt defineres som det omfattende social system af alle handlinger der kan nås af hinanden kommunikativt eller som summen af tilgængelige kommunikationer, men er i øvrigt ikke muligt at beskrive under nogen form for reciprocitet: Det enkelte delsystem, f.eks. uddannelsessystemet, er qua generaliseringer i kommunikationsformer selvstændiggjort og opererer i forskel til samfundets $\varnothing v$ vrige systemer ${ }^{70}$ det være sig eksternt i forhold til samfundets $\emptyset$ vrige delsystemer og sociale systemer, og internt qua en differentiering i forskellige subsystemer og organisationer (institutionaliseringer).

"The structurally imposed non-substitutability of function systems does not exclude interdependencies of every kind. A flowering economy is also a political blessing - and vice versa. This does not mean that economy could fulfil a political function, namely, to produce collectively binding decisions (to whose profit?). Instead, the non-substitutability of functions (i.e., the regulation of substitution by functions) is compensated by increasing interdependencies. Precisely because function systems cannot replace one another they support and burden one another reciprocally. It is their irreplaceability that imposes the continual displacement of problems from one system into another. The result is a simultaneous intensification of independencies and interdependencies (dependencies) whose operative and structural balance inflates the individual systems with an immense uncontrollable complexity." (Luhmann 1989 s. 110)

Samfundets generelle uddifferentiering kan generelt beskrives som en tilvækst i uafhængigheder (independencies) og gensidige afhængigheder

\footnotetext{
${ }^{70}$ For hvert af disse delsystemer gælder, at de fungerer uden at stille spørgsmål ved kodens enhed. Gjorde de det, ville det forekomme, som et paradoks idet det ville blive synligt, at koden selv skaber dét, de ser i verden. Systemet fungerer som om verden var, sådan som den bliver iagttaget af det pågældende system: I det $\varnothing$ konomiske system danner koden tro/ikke tro således ikke mening, ligesom at agtelse/ikke agtelse ikke er den kode hvorefter det politiske system grundlæggende orienterer sig. Dette udelukker som bekendt ikke, at forretningsmanden banker under bordet, eller at politikeren udtrykker sig i moralske termer. Blot sprænger disse iagttagelser ikke den grundlæggende kode, hvorefter et givet system orienterer sig.
} 
(interdependencies) samt kompleksitet karakteriseret ved en forøget mulighed for kommunikationens asymmetrisering. Med reference til det moderne samfunds polykontekstualitet udtrykker Kneer og Nassehi forholdet som at "... man må i det moderne samfund hele tiden regne med, at andre iagttagere betragter ens iagttagelse som blot én blandt mange iagttagelser." (Kneer og Nassehi 1997 s. 147). Organisationsteoriens 'grand old man' James G. March er i relation til organisatoriske handlinger inde på noget af det samme:

"En handling, der er fornuftig set ud fra organisationens synspunkt ( $f x$ ved at maksimere sandsynligheden for organisationens overlevelse), vil ofte vare mindre fornuftig set med det enkelte

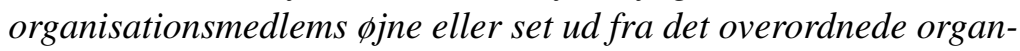
isationsmiljøs perspektiv.” (March 1995 s. 179)

Ethvert forhold kan og bliver beskrevet ud fra et utal af iagttagelsesperspektiver, hvilket f.eks. massemedierne flittigt anvender og ernærer sig ved. ${ }^{71}$ Netop kommunikationens asymmetrisering får samfundets kompleksitet til at stige, hvilket har betydet, at nogle mener, at samfundet er gået fra at være moderne til at være postmoderne (Lyotard 1982; 1984). Tesen er at samfundet ikke længere er bundet af historien (religionen og andre store fortællinger), hvilket karakteriserede moderniteten, som netop var moderne til forskel fra, men i relation til traditionen. For postmodernisterne har samfundet med andre ord overskredet og befinder sig på den anden side af og i en periode, der ligger efter eller adskiller sig fra det moderne, hvorfor samfundet betegnes postmoderne (Rasmussen 1996 s. 23). Postmodernisternes slagord "anything goes" henviser i systemteoretiske termer til kommunikationens asymmetrisering, idet den samfundsmæssige kommunikation i mange tilfælde ikke positionerer sig i relation til historisk set traditionelle meningskonstellationer og semantikker. "The point is that we are not in a phase of 'posthistoire' but, on the contrary, in a phase of turbulent evolution without predictable outcome." (Luhmann 1997c s. 8). I den systemteoretiske beskrivelse af kompleksitetstilvæksten tilskrives religionens fald og det stratificerede samfunds funktionelle uddifferentiering en central rolle, fordi det har muliggjort et stigende utal af iagttagelses- og meningsdannelsesformer på samfundsplan.

\footnotetext{
${ }^{71}$ Se f.eks. Luhmann 2002. Luhmann skriver i forbindelse med massemedier, at de kan beskrives ved anvendelse af koden $+/$ - information, og adskiller sig fra hinanden ved anvendelsen af forskellige journalistiske kriterier (programmer). Massemedier bidrager i den forstand til en fordobling af realiteten - noget sker, hvorefter massemedierne former det skete i relation til sin kode og sit eget program.
} 
If function systems are operationally closed systems, their differentiation will produce more independencies and more dependencies at the same time - more independencies because of their operational closure and their highly selective structural couplings, and more dependencies because society can maintain its present achievements only if all the function systems operate and reproduce themselves at an adequate level. The world society has reached a higher level of complexity with higher structural contingencies, more unexpected and unpredictable changes (some people call this 'chaos') and, above all, more interlinked dependencies and interdependencies. This means that causal constructions, (calculations, plannings) are no longer possible from a central and therefore 'objective' point of view. They differ depending upon observing systems, that attribute effects to causes and causes to effects, and this destroys the ontological and the logical assumptions of central guidance. We have to live with a polycentric, polycontextural society. (Luhmann 1997 c s. 8)

\section{Samfundets udvikling som irritation af systemer}

For Luhmann beskrives det moderne samfundets asymmetriserede kommunikation - opbud af forskellige iagttagelses perspektiver og iagttagelsesmuligheder - med et samlet begreb om irritationer, eller sagt på en anden måde, så irriterer det moderne samfund sig selv. ${ }^{72}$ Særligt interessant for denne afhandling, er at i særlig grad organisationer har samfundets funktionssystemer som omverden, hvorfor der fra samfundets side af er knyttet forventninger til dets organisationer. ${ }^{73}$

"Die Verwirklichung funktionaler Differenzierung als Primärform gesellschaftlicher Differenzierung ändert auf tiefgreifende Wiese

\footnotetext{
${ }^{72}$ Ifølge Luhmann indbefatter samfundet alt socialt, og eftersom organisationer betegnes sociale systemer befinder organisationer sig i samfundet, men er samtidig uddifferentieret fra samfundet, dvs. er ikke det samme som samfundet. Organisationer er således grundlæggende paradoksale, idet de både er en del af samfundet og uddifferentieret fra samfundet, og derfor har samfundet som sin omverden.

${ }^{73}$ Luhmann opererer med en række forskellige systemtyper; levende systemer, mekaniske systemer, sociale systemer og psykiske systemer (Luhmann 2000a). Med samfundet som omverden henvises der særligt til sociale og psykiske systemer, eftersom disse betragtninger vedrørende irritationer i særlig grad vedrører netop disse to systemtyper, som begge har samfundet som omverden.
} 
die Umweltverhältnisse der Systeme, und zwar sowohl des Gesamtsystems Gesellschaft alt auch seiner Teilsysteme. Zur Darstellung dieser Veränderung benutzen wir, strukturelle Kopplungen voraussetzend, den Begriff der Irritation. Die These ist, das der Übergang $z u$ dieser Differenzierungsform die Irritierbarkeit der Gesellschaft steigert, ihre Fähigkeit, auf Veränderungen der Umwelt rasch zu reagieren, zunehmen läßt, zugleich aber dies mit einem weitgehenden Verzicht auf Koordination der Irritationen bezahlen muß. Auf die Unkoordiniertheit der Irritationen kann die Gesellschaft dann wiederum nur irritiert reagieren, und nicht etwa durch eine zentral überwachte Lösung des Problems der Überirritation. Denn wäre eine solche zentrale Planung und Steuerung möglich, würde das sehr rasch die Irritabilität der Gesellschaft auf das Format der Informationsverarbeitungskapazität der entsprechenden Stelle (und man kann eigentlich nur an Organisation denken) einschränken und den Vorteil wiederaufgeben, der mit der Steigerung von Irritabilität gewonnen war. (Luhmann 1997a s. 789)

Ifølge Luhmann er det moderne samfund differentieret i en sådan grad, at det er ustyrligt, uoverskueligt og intransparent for enhver, og eftersom samfundets vigtigste funktioner og ydelser er uddifferentieret til området for organisationer, får de generelt problemer angående (selv)styring i forhold til omverdenens ukoordinerede forventninger/irritationer til funktionsudfoldelse og ydelse. Som Luhmann skriver, er der netop ikke en central instans eller et system, som kan overvåge, styre, koordinere og reducere samfundets irritationer. Hertil kan man svare, at organisationsteoriens svar på koordinering af irritationer (forandringer) er læring. Systemteoriens svar på dette kompleksitetsproblem er også læring i forståelsen systemers opbygning af egenkompleksitet. Kun kompleksitet kan reducere kompleksitet. For at reducere kompleksitet må et system forøge sin egenkompleksitet; ved at muliggøre flere tilstande i systemet, forøger systemet potentientialet for at reagere på udfordringerne fra omverdenen. Det laver imidlertid ikke om på, at alt dette leder til en art irritationsspiral, hvor sociale systemers ukoordinerede irritation leder til fornyet ukoordineret irritation fra andre af samfundets sociale systemer.

"In modern society, functional systems, above all, have the possibility of self-steering. Society itself has delegated all the problems and therefore does not possess any agencies that could, as a super 
function of perception, perceive all the functions. Although all steering takes place within society and therefore always executes the autopoiesis of society (i.e. communicates) there is, in the strict sense of the word, no self-steering of society on the level of the entire system.” (Luhmann 1997b s. 49-50)

Samfundets styring er i det moderne samfund uddifferentieret til samfundets organisationssystemer, der ud fra Luhmanns systemteori forstås som selvstyrede sociale systemer baseret på kommunikative netværk af beslutninger om beslutninger, og for hvem samfundets/omverdenens irritationer resulterer i grundlæggende problemer med at styre sig selv, dvs. grundlæggende problemer vedrørende beslutninger om f.eks. hvem skal ansættes, organisationens struktur; hierarki, heteraki eller teamledelse, hvilken viden er der brug for, hvilket marked skal der satses på, udlicitering eller outsourcing osv. osv.

\section{Styringsproblemer - kompleksitet, kontingens, systemdifferentiering}

Ifølge Luhmann må nutidige styringsproblemer altså begribes ud fra den grundlæggende forskel mellem systemer og deres omverden. Forskellen mellem system/omverden kan beskrives med et begreb om kompleksitet:

"Vi betegner en sammenhangende mangde af elementer som kompleks, når hvert element på grund af immanente indskrankninger $i$ elementernes tilslutningskapacitet ikke til enhver tid kan sammenknyttes med ethvert andet. Begrebet "immanent indskrankning" henviser til elementernes indre kompleksitet, som på den ene side ikke står til rådighed for systemet, som på den anden side muligg $\phi r$ deres "enhedsduelighed"." (Luhmann 2000a s. 61)

Differentieringen af samfundet har medført to forhold og er i sig selv et svar på disse. For det første har den medført og er opstået på baggrund af en forøgelse af samfundsmæssig kompleksitet. For det andet har denne samfundsform, og især iagttagelsen af den kompleksitetstilvækst den medfører, skabt kontingens. At noget er kontingent betyder, at det:

"hverken er nфdvendigt eller umuligt [...] Begrebet betegner følgelig noget givet (noget erfaret, forventet, tankt eller fantaseret) med henblik på noget muligt andet; det betegner genstande indenfor horisonten af mulige varianter" (Luhmann 2000a s. 146-47). 
Med andre ord: "Kontingens betyder fravar af umulighed og fravar af nфdvendighed. Det betyder med andre ord alternativer." (Thyssen 1997 s. 19; Luhmann 2000a s. 146) ${ }^{74}$, og kan direkte relateres til iagttagelsen af, at samfundet ikke tilbyder et privilegeret udkigspunkt, én sandhed, én bestemt orden eller helhed, men at alt afhænger af, hvordan man iagttager samfundet. Med henblik på at mestre denne variation, dvs. at opretholde og fortsætte egne operationer (for organisationers vedkommende at muliggøre beslutninger), må systemer selektere mellem flere mulige iagttagelser. Noget gøres aktuelt, noget andet stilles i baggrunden. At noget gøres aktuelt kan også bero på, at den aktuelle variation træder i baggrunden, men i det omfang kompleksiteten forstyrrer systemet og synliggør dets manglende korrespondance med omverdenen, må systemet forandre sig, dvs. lære. Måden, hvorpå det sker, er ved den særlige selektion, hvor "relationssammenføjninger $i$ en kompleks sammenhoeng rekonstrueres igennem en anden sammenhang med farre relationer" (Luhmann 2000a s. 63) - altså gennem kompleksitetsreduktion. Dette er at betragte som systemdifferentiering og resultatet er systemdannelse. Systemdannelse stabiliserer systemets iagttagelse i en ny form, men det skal bemærkes, at denne stabilitet er midlertidig - i Luhmanns termer (tilsyneladende paradoksalt) dynamisk - eftersom "Enhver andring af et system er også en andring af andre systemers omverden; enhver kompleksitetstilvakst på et sted $\emptyset$ ger omverdenskompleksiteten for alle andre systemer." (Luhmann 2000a s. 220). Kompleksitetsreduktion i form af systemdifferentiering indebærer dermed altid muligheden for ny kompleksitet eller iagttagelsen af ny variation. ${ }^{75}$ Hermed bliver det tydeligt, at Luhmann opererer med en anderledes og mere kompleks forståelse af samfundet end Senge. Hvis man følger Senges systemtænkning er det i en vis udstrækning muligt at kontrollere og forudsige konsekvenserne af bestemte organisatoriske prioriteringer og handlinger, mens det hos Luhmann er et grundlæggende kontingent forhold, dvs. hverken nødvendigt eller umuligt m.a.o. kunne være anderledes. Mere præcist er systemteoriens svar på kompleksitet ikke udvikling af systemtænkning i form af nye mentale skemaer som hos Senge, som ud fra systemteorien betegnes omverden for sociale systemer, men at sociale systemers iagttagelse af kompleksitet danner baggrund for en intern

\footnotetext{
74" Begrebet fremkommer gennem udelukkelse af nфdvendighed og umulighed. Noget er kontingent, når det hverken er nфdvendigt eller umuligt; når det altså kan vare sådan, som det er (var, vil blive), men også kunne vare muligt på en anden måde." (Luhmann 2000a s. 146)

${ }^{75}$ Begreberne variation, selektion og stabilisering er kernebegreberne i Luhmanns evolutionsteori (Moe 1999).
} 
differentiering i organisationer med henblik på at reducere omverdenskompleksitet og dermed at løse et problem vedrørende iagttagelse. Set i lyset af dette kan man tale om, at nutidige styringsproblemer opstår på baggrund af og kun kan håndteres som et problem vedrørende 1) iagttagelse af kompleksitet, 2) selektion, og 3) manglende mulighed for at forudsige konsekvenserne af denne selektion.

Problemer med at styre samfundet som samlet system kan altså direkte lokaliseres til et samfund, hvis form udstyrer systemerne med et grundlæggende styringsproblem: Funktionssystemer og organisationer er selvstyrende systemer, dvs. kan styre sig selv, men ikke samfundet som total system. I relation til organisationssystemer betyder dette, at den samfundsmæssige kompleksitet og kontingens leder til et problem vedrørende iagttagelse.

Organisatorisk læring som organisationsdidaktik ses i denne afhandling som et forsøg på et svar på netop dette problem vedrørende iagttagelse. Organisatorisk læring har på baggrund af denne samfundsanalyse til formål - ikke at styre - men at udstyre organisationer med mere komplekse evner eller former til at lære, dvs. at lære at lære nye måder til iagttagelse af sig selv og organisationens omverden, og integrere disse nye iagttagelsesformer i organisationens iagttagelsesprogrammer. Spørgsmålet er så, om systemteorien har nogle bud på, hvordan dette kan foregå i relation til organisationer?

\section{Funktion, ydelse og refleksion}

I dette afsnit vil jeg argumentere for anvendelsen af begreberne funktion, ydelse og refleksion som velegnede til besvarelse af spørgsmålet: Hvilke begreber har systemteorien i relation til potentielt at udstyre selvstyrende organisationssystemer med iagttagelsesmuligheder, som kan lede til mere komplekse evner til at laere, $d v$ s. at lare at lare nye måder til iagttagelse af sig selv og omverdenen, og til potentielt at integrere disse nye iagttagelsesformer i organisationens iagttagelsesprogrammer? Som jeg kommer ind på anvender Luhmann ikke selv begreberne til iagttagelse og beskrivelse af organisationer, men der vil blive argumenteret for, at denne form for anvendelse er mulig i relation til organisationer samt beskrevet, hvordan de relateres hertil. Dette kræver en lidt længere systemteoretisk udredning, hvor der er behov for en længere systemteoretisk udredning, som klargør begreberne til afhandlingens anvendelsesformål.

For at svare på spørgsmålet tages der udgangspunkt i funktionsbegrebet i relation til funktions-og organisationssystemer, og hvordan disse systemer er forbundet til hinanden. Dette gøres med henblik på at forstå og afklare 
funktionsbegrebets relatering til funktionssystemer, hvordan man kan forstå funktionsbegrebet som et alment begreb i relation til organisationer, samt hvordan begreberne funktion, ydelse og refleksion vurderes som velegnede til iagttagelse af organisatorisk kommunikation med henblik på organisatorisk læring.

\section{Funktion og funktionssystemer}

Luhmann anvender mest eksplicit begreberne funktion, ydelse og refleksion til iagttagelse og beskrivelse af samfundets funktionssystemer (Luhmann 1992 s. 635; 1997 s. 757). I forhold til forståelsen af samfundet som totalsystem spørger Luhmann hvilke muligheder for observationssystemer, der opstår, når det kommer til dannelsen af subsystemer, og han peger på fremkomsten af de uddifferentierede funktionssystemer; ret, økonomi, politik, uddannelse osv. som subsystemer, der betjener sig af tre grundoperationer og iagttagelsesmuligheder, nemlig funktion, ydelse og refleksion. ${ }^{76}$

"Aus rein logischen Gründen sind drei Möglichkeiten gegeben, nämlich (1) die Beobachtung des Gesamtsystems, dem das Teilsystem angehört, (2) die Beobachtung anderer Teilsysteme in der gesellschaftinternen (oder auch: anderer Systeme in der externen) Umvelt, und (3) die Beobachtung des Teilsystems durch sich selber (Selbstbeobachtung). Um diese verschiedenen Systemreferenzen unterscheiden zu können, wollen wir die Beobachtung des Gesamtsystems Funktion, die Beobachtung anderer Systeme Leistung und die Beobachtung des eigenen Systems Reflexion nennen." (Luhmann 1997 s. 757)

Funktion har potentiale til at simplificere systemer, da funktionsorientering kan frembringe redundans og lade forskellige måder at opfylde en funktion forekomme som funktionelle ækvivalente, dvs. en art systemisk bevidsthed om, at der kan forefindes forskellige løsningsmuligheder for samme problem (Luhmann 2000a s. 350).

Funktionssystemer er knyttet til samfundets sociokulturelle evolution og forståelsen af det moderne samfund som funktionelt uddifferentieret (Luhmann 2000a s. 525-530). Funktionssystemer er kommunikationsmedier, der opererer på samfundsniveau, og som hver især har monopol på funktionelt at varetage bestemte opgaver, f.eks. økonomi, ret, uddannelse,

\footnotetext{
${ }^{76}$ I relation til samfundets uddannelsessystem behandles dette mere specifikt i Luhmann \& Schorr 2000c s. 41.
} 
kunst osv. Funktionssystemer udfører én funktion i relation til samfundet funktionssystemet $\phi$ konomi forholder sig udelukkende til samfundet ud fra en $\emptyset$ konomisk betragtning, og funktionssystemet uddannelses svar på et hvilket som helst samfundsspørgsmål er; mere eller bedre uddannelse (Luhmann og Schnoor 2000c). Den sociokulturelle evolution har som tidligere beskrevet selvstændiggjort disse funktionssystemer gennem dannelse af symbolsk generaliserede kommunikationsmedier, der tager form af bincere koder, som fastlægger det pågældende systems funktion. Funktion knytter sig således til funktionssystemets system/omverdens difference, dvs. iagttagelsen af det samfundsmæssige totalsystem, og dette har afgørende betydning for systemets videre operationer (Luhmann 1997. s. 757). Luhmanns fokus på sammenhængen mellem funktion og funktionel differentiering, betyder at man umiddelbart kan betragte Luhmanns forståelse af funktionsbegrebet som en slags egenskab der alene kan knyttes til funktionssystemer, og dermed til samfundets funktionelle differentiering i samfundssystemer.

De enkelte funktionssystemer fungerer funktionelt ækvivalent og i forskel til samfundets $\emptyset$ vrige funktionssystemer som selvstændiggjorte, selvstyrende og ligestillede systemer, der ikke kan blande sig i hinanden; $\varnothing$ konomien ikke kan bestemme og afgøre, hvad der er videnskabeligt sandt, eller hvad der juridisk set er lovligt/ulovligt (Luhmann 1997b s. 52; 1989 s. 110). ${ }^{77}$ Ingen videnskabelig analyse, hvad enten den er sand eller ej, kan ved brug af egne frembringelser ('achievements') styre og ændre det politiske systems forventninger, fordi det politiske system er et selvstyrende funktionssystem, der selv afgør hvad, hvorfor, og hvordan noget er relevant (Luhmann 1997b s. 42). Med andre ord kan videnskaben ikke tage politiske (kollektivt bindende) beslutninger, ligesom at politikere ikke kan afgøre, hvad der er henholdsvis sandt/ikke sandt (Se f.eks. Luhmann 2009 s. 190). Funktionssystemer kan ikke kommunikere med deres omverden, dvs. med hinanden eller med andre systemer (Luhmann 1997 s. 842-843), men de kan koble sig strukturelt til hinanden: "Faktisch sind alle Funktionssysteme durch strukturelle Kopplungen miteinander verbunden und in der Gesellschaft gehalten." (Luhmann 1997a s. 779). ${ }^{78}$ Denne kobling er kun mulig via organisationer, hvorfor organisationer har afgørende betydning

\footnotetext{
$77 "(. .$.$) every functional system orients itself by its own code. No steering attempt can$ eliminate these distinctions or bridge them." (Luhmann 1997b s. 52)

${ }^{78}$ Faktisk er der i tilfældet samfundsinterne koblinger mellem funktionssystemer ikke bare tale om strukturelle koblinger, men om operative koblinger, fordi mediet kommunikation er det samme på tværs af systemerne. Operationelle koblinger kan imidlertid ikke erstatte strukturelle koblinger. De kondenserer og opdaterer den gensidige irritation og giver mulighed for hurtigere
} 
for funktionssystemer. ${ }^{79}$ Organisationer kan nemlig kommunikere med deres omverden, og de er derfor afgørende for funktionssystemernes udbredelse på samfundsplan (Luhmann 1997a s. 834). Dette betyder imidlertid ikke, at organisationer på samme måde som funktionssystemer kan beskrives ved at operere med én funktionsbeskrivelse. Et relevant spørgsmål er derfor, hvordan funktionsbegrebet er relevant i relation til organisationer?

I forhold til organisatorisk kommunikation beskriver Luhmann to aspekter: kommunikations-temaer og kommunikations-funktioner (Luhmann 2000b s. 59). Mens kommunikations-temaer differentierer (adskiller og hierarkiserer) og strukturerer kommunikationen sagligt, socialt og tidsligt ${ }^{80}$, dvs. kommunikationens hvad, hvem og hvornår, så beskrives kommunikationens funktion i forhold til organisationers beslutninger på følgende måde: "Die funktionen der Kommunikation beziehen sich dagegen aufdie Autopoiesis des System, des heißt auf die Ermöglichund weitere kommunikation." (Luhmann 2000b s. 60). Kommunikationen er således først og fremmest knyttet funktionelt til organisationssystemets opståen og autopoiesis som det, der muliggør yderligere kommunikation af og om beslutninger: "(...) Organizationen entstehen und sich reproduzieren, wenn es zur Kommunikation von Entscheidungen (...)" (Ibid. s. 63). Denne beskrivelse af organisationssystemer gælder i forhold til det operative niveau, men ikke i relation organisationssystemets forståelse af system/omverdens differencen og interne meningsmæssige kompleksitetsopbygning, som det ellers er tilfældet for funktionssystemer. Derfor er denne forståelse af kommunikationens funktion ikke i sig selv tilstrækkelig til forståelse af en organisations forståelse af sig selv og dens omverden. ${ }^{81}$

og bedre koordineret indsamling af efterretninger i de involverede systemer (Luhmann 1997a s. 788).

${ }^{79}$ Det er ved de strukturelle koblinger, at funktionssystemer stiller kompleksitet til rådighed for hinandens autopoiesis og kan bidrage til hinandens interne kompleksitetsopbygning.

${ }^{80}$ Dette er en henvisning til tre differencer, som Luhmann kalder meningsdimensioner. Det drejer sig om sagsdimensionen, tidsdimensionen og socialdimensionen (Luhmann 2000a s. 115). Disse dimensioner er meningsuniverselle, og de kan derfor kaldes verdensdimensioner, idet en henvisning til disse finder sted i forhold til alt, som forekommer (genstande, temaer etc.): "Ved al mening, den vare sig positivt eller negativt formuleret, er disse tre meningsdimensioner tilgangelige som former for yderligere henvisning. Den primare dekomposition af mening overhovedet ligger da i disse tre dimensioner, og alt yderligere bliver til et spørgsmål om deres rekombination." (Luhmann 2000a s. 116).

${ }^{81}$ Luhmann skriver ikke særligt meget om funktionsbegrebet i relation til organisationer og slet ikke i relation til organisationssystemers system/omverdens differencer. I sin posthumt udgivne bog om organisationer Organisation und Entscheidung (Luhmann 2000b), er der f.eks. i Index kun angivet en reference til funktionsbegrebet, nemlig side 59. Heller ikke hans store 


\section{Forskelle mellem funktionssystemer og organisationer}

Eftersom samfundets mest betydningsfulde kommunikation finder sted i reference til funktionssystemer, opererer de mest betydningsfulde organisationer indenfor disse; banker som organisationsformer i funktionssystemet $\varnothing$ konomi, politiske partier/organisationer i funktionssystemet politik, og skoler eller universiteter som organisationsformer i samfundets uddannelsessystem osv. (Luhmann 1997 s. 840-841).

Ud over ovennævnte grunde adskiller organisationer og funktionssystemer sig fra hinanden på mindst tre punkter, hvilket er afgørende for forståelsen af funktionsbegrebets relevans i forhold til organisationer:

1. For det første kan organisationer ikke overleve ved udelukkende at anvende ét funktionssystems iagttagelsesformer. Organisationer danner ikke kun mening i relation til ét funktionssystems kode og program, men anvender flere forskellige funktionssystemers kode og programmer til iagttagelse af sig selv og deres omverden. Bankerne skal f.eks. også kunne iagttage sig selv og omverdenen ud fra den juridiske kode osv. Dette får Niels Åkerstrøm Andersen til at betegne organisationer som polyfone systemer, dvs. systemer, som koder deres beslutningskommunikation i relation til en flerhed af funktionssystemer (Åkerstrøm 2003). Jönhill skriver desuden, at organisationer bygges hen over funktionssystemernes grænser (Jönhill 1997 s. 180). Selvom organisationer anvender en flerhed af funktionssystemer, er den enkelte organisation ifølge Luhmann dog tilforordnet ét funktionssystem som dets primat (Luhmann 1997a s. 841), dvs. ét funktionssystem har forrang som det vigtigste referencesystem organisationen opererer i forhold til. ${ }^{82}$

2. For det andet er organisationer selvstyrende autopoietiske systemer, som producerer og reproducerer sig selv gennem beslutninger, medlemskab og beslutningsprogrammer (Luhmann 2000b; 2003 s. 32). Dette er en afgørende forskel i forhold til funktionssystemer, som ikke opererer med inklusions- og eksklusionskriterier for medlemmer (Luhmann 2000b s. 391), og ikke kan kommunikere med deres omverden eller tage beslutninger. Funktionssystemers kommunikation trækker på organisationers anvendelse af dem som medier for kommunikation, hvorved

samfundsteori Die Gesellschaft der Gesellschaft rummer diskussioner og referencer om den funktionelle metode (Luhmann 1997a).

${ }^{82}$ Det er f.eks. sjældent at se en bank konvertere og blive til et politisk parti, en uddannelsesinstitution eller vice versa. Dette betyder imidlertid ikke, at banker ikke anvender uddannelsessystemets kode og programmer osv., eller i visse tilfælde støtter bestemte politiske partier. 
både funktions- og organisationssystemer udvikles og reproduceres. Som selvstyrende systemer beslutter organisationer selv anvendelsen af funktionssystemenes koder og programmer, dvs. hvordan

3. For det tredje kan intet funktionssystem finde sin enhed i én organisation. Et funktionssystems kommunikation, kode og programmer er ikke reserveret bestemte organisationer, men handler om en given kommunikations kodning. Uddannelseskommunikation finder sted på både universitetet, $\mathrm{i}$ folkeskolen, $\mathrm{i}$ hjemmene såvel som i samfundets organisationer. Politisk kommunikation er ikke reserveret til politikere og det politiske systems organisationer. Ligesom f.eks. medicinsk behandling ikke kun finder sted på sygehuset (Luhmann 1997a s. 841). ${ }^{83}$ Udtrykt anderledes flugter organisationers system/omverdens differencer ikke med funktionssystemers, dels fordi de ikke gælder som enhed for et funktionssystem, dels fordi organisationer koder deres kommunikation i relation til flere forskellige funktionssystemer, og ikke mindst fordi organisationssystemer i teorien om selvreferentielle autopoietiske systemer anskues som selvstyrende (autopoietiske) systemer.

For at vende tilbage til funktionsspørgsmålet betyder ovenstående, at man i forhold til organisatorisk kommunikation må skelne mellem på den ene side kommunikation kodet i relation til funktionssystemer, ${ }^{84}$ på den anden side kommunikation, der ikke er kodet i relation til funktionssystemer, dvs. iagttager anderledes. Pointen med dette er, at organisatorisk kommunikation ikke kan reduceres til kun at være kodet i overensstemmelse med funktionssystemer, men kan være kodet på utallige andre måder. Som Jönhill skriver i relation til funktions forventninger til ledelse, så ”(...) har besluts- och styringsteorin påvisat att organisationer i princip är själstyrande cirkuläre system, där ledningens främsta funktion är att observera och implementera organisationens program." (Jönhill 2012 s. 31-32).

Analyser af organisatorisk kommunikation må derfor åbne op for andre analyser end dem, der er knyttet til funktionssystemer, dvs. må også kunne analysere kommunikationer, der ikke nødvendigvis er kodet i relation til funktionssystemer. I den forbindelse er systemteoriens funktionelle analysemetode relevant, idet den er en teoriteknisk tilgang til systemteoretiske

\footnotetext{
${ }^{83}$ Man kan sige, at hvert funktionssystem på organisationsplan er internt differentieret i en række forskellige organisationsformer - for uddannelsessystemet i forskellige universiteter, forskellige skoler osv.

${ }^{84}$ Dvs. hvornår, hvordan og i forhold til hvad en organisation anvender de forskellige funktionssystemers koder og programmer.
} 
analyser generelt. Det er netop denne tilgang som afhandlingen benytter til begrundelse af, hvorfor og hvordan begreberne funktion, ydelse og refleksion anvendes til iagttagelse af organisatorisk kommunikation med henblik på en mulig styrkelse af systemets evne til at lære.

\section{Den funktionelle analysemetode}

Den funktionelle analysemetode til empiriske analyser adskiller sig i en vis udstrækning fra Luhmanns egen anvendelse af funktionsbegrebet i relation til funktionssystemer. ${ }^{85}$ Ved funktionssystemer tilskrives funktionsbegrebet en slags egenskab ved systemet, og er tæt knyttet til Luhmanns analyse af nutidens samfund som funktionelt uddifferentieret. Roar Hagen er inde på noget af det samme angående Luhmanns brug af funktionsbegrebet i relation til funktionssystemer. Hagen beskriver dette som indikerende en rest af funktionalisme, som den kan genfindes hos f.eks. Parsons: "Når Luhmann (1997:755) betegner forholdet mellom delsystem og hele samfunnet med begrepet funksjon, mener han noe mer enn det som ligger i en ekstern, komparativ betraktning. Det er en rest av funksjonalisme $i$ den nye systemteorien $i$ den forstand at det $\stackrel{a}{ }$ peke på funksjoner også er et bidrag til forklaring - både av det systemet som har funksjonen og av den helheten det loser et problem for, i dette tilfollet samfunnet. (Hagen 2006 s. 133).

Den anden forståelse ligger i anvendelsen af funktionsbegrebet som alment analytisk begreb og i relation til systemteoriens erkendelsesteoretiske intention om at fremanalysere funktionelle ækvivalenser. ${ }^{86}$ I forhold til den funktionelle analyse metode skriver Luhmann:

"I denne forstand er den funktionelle metode i sidste ende en sammenlignende metode, og dens indføring i realiteten tjener til at åbne det eksisterende for sideblik til andre muligheder. Endelig relaterer den relationer til relationer: den relaterer noget til et perspektiv på

\footnotetext{
${ }^{85}$ Luhmann har ikke publiceret et samlet skrift eller større artikel, hvor den funktionelle analysemetode udfoldes i relation til hans senere teoretiske udvikling med introduktionen af begrebet autopoiesis, og den senere større vægt på formbegrebet fra George Spencer Brown. Man må derfor finde referencer til den funktionelle analyse metode forskellige steder i hans omfattende værk. Luhmann referer selv til to meget tidlige artikler Funktion und Kausalität (opr. 1962) og Funktionale Methode und Systemtheorie (opr. 1964), som f.eks. er publiceret i Soziologische Aufklärung 1 (1991; opr. 1970) se Luhmann (2000a s. 93 fodnote 110 \& 112).

${ }^{86}$ Her kan man sige, at Luhmann anvender funktionsbegrebet specifikt i relation til forståelsen af funktionssystemer og deres betydning for forståelsen af det moderne samfund, mens den funktionelle analysemetode angiver en epistemologisk tilgang til empiriske analyser generelt.
} 
et problem for at kunne relatere det til andre problemlфsninger." (Luhmann 2000a s. 93)

Her anvendes funktionsbegrebet som analytisk epistemologi, dvs. i et anden ordens perspektiv, forstået på den måde, at anden ordens iagttagelsen anvender, dvs. tillægger (epistemologisk) empirien en funktionel intention (se Luhmann 2000a s. 91-97; 1997 s. 1125). Dette betyder, at kommunikation analyseres ud fra den analytiske præmis, at den identificerer funktionelle relationer med henblik på funktionel forklaring i relation til et systems system/omverdens difference. Luhmann betoner i den forbindelse også, at den funktionelle metode, ud over at være en ren metodeafgørelse, er en erkendelsesteori (Luhmann 2000a s. 97). Han vedgår, at den funktionelle analyse udgør et inkongruent perspektiv ved ikke at beskrive systemers egen oplevelse af sig selv men i overensstemmelse med videnskabens anvendelse af begrebslige abstraktioner, rekonstruerer empiriske genstande, således at mere kompleksitet bliver synlig end den, der er tilgængelig for det iagttagede (empiriske) system (Luhmann 2000a s. 95). Det vil sige, at den funktionelle analyse ifølge Luhmann bliver et princip for videnskabelig systemanalyse (Luhmann 2000a s. 351). Dvs. at videnskaben ikke er genspejlinger af en ydre realitet, men viser tilbage til en observatør, som ser, betragter eller opfatter noget på en særlig måde. (Hagen 1997; 2006). Ud fra den epistemologiske spørgeform, dvs. hvorfor iagttager en iagttager det iagttageren iagttager? kan man sige, at den funktionelle analysemetode udtrykker systemteoriens analytiske epistemologi idet den trækker på funktionel tilskrivning til empirien, dvs. rekonstruerer empiriske iagttagelser ud fra den præmis, at de iagttages som udfyldende en funktion i relationen mellem et system og dets omverden.

Det er ikke denne afhandlings ærinde at gå langt ind i de historiske anvendelser og udviklinger af den funktionelle metode. Det skal dog nævnes, at Luhmann beskriver og anvender en anderledes tilgang til funktionsbegrebet end de tidlige antropologer Bronislaw Malinowski og Alfred Radcliffe-Brown, og sociologer Robert K. Merton og Talcott Parsons (se Knudsen 2010; Jönhill 1997 s. 98-112; Kneer og Nassehi 1997 s. 39-44). Luhmann vender sig specielt mod den struktur-funktionalistiske tilgang som findes hos Parsons, hvor systemers strukturer forudsættes, hvorfor der spørges til hvilke funktionelle ydelser, der skal tilvejebringes for at sikre et socialt systems beståen (Kneer og Nassehi 1997 s. 40). Parsons tilgang benævnes derfor også som kausalfunktionalisme, da den fremstiller en direkte sammenhæng mellem bestemte systembidrag og et systems opretholdelse (Kneer og Nassehi 1997 s. 43). Eftersom Luhmann ikke mener, at det moderne samfund, således som Parsons 
forudsætter, frembyder fælles strukturer (værdikonsensus i form af fælles normativ orientering), arbejder han ud fra en funktions-strukturalistisk tilgang til systemer. Det vil sige, at de kollektive norm- og værdimønstre (bestemte strukturer i form af et 'shared symbolic system', jf. Parsons fire-funktions-skema; AGIL-skemaet) ikke forudsættes af Luhmann - hverken på samfundsplan eller for andre sociale systemer (se f.eks. Luhmann 2000a s. 144). For Luhmann dannes sociale systemer, når forskellige kommunikationer henviser til hinanden. Luhmanns tilgang kan derfor beskrives som ækvivalensfunktionalisme, dvs. et systems tilskrivning af sammenhæng mellem problem og løsning, og kan dermed relateres til niveauet for et systems forventninger om, hvorvidt noget kan fungere som løsning på et problem. Luhmann udtrykker det på den måde, at systemer, der relaterer deres operationer til differencen mellem system og omverden, kan orientere sig efter funktionelle ækvivalenser, dvs. de kan være opmærksomme på, at konkrete løsninger på problemer kunne være anderledes (Luhmann 2000a s. 219).

\section{Videnskab, organisationer og funktionelle ækvivalenser}

Luhmanns funktionelle tilgang knyttes sammen med 2. ordens kybernetikkens opløsning af den empiriske virkelighed i former af kompleksitet, kontingens og selektion. Enhver selektion iagttages som et funktionelt svar på et problem, dvs. som problemløsning, men eftersom enhver selektion (problemløsning) iagttages som kontingent (kunne være foretaget anderledes), muliggør denne analytiske tilgang sammenligning mellem forskellige problemløsninger. Eller som Luhmann udtrykker det: "Relationen mellem problem og problemløsning bliver således ikke taget op for sin egen skyld, men som ledetråd for spфrgsmålet om andre muligheder, som ledetråd for efters $\phi g n i n g e n$ af funktionelle akvivalenter." (Luhmann 2000a s. 91). Videnskabens funktion bliver i denne udlægning at muliggøre refleksion, idet den forholder sig til den empiriske virkelighed, som kendetegnet ved variation og alternativer. Eller udtrykt anderledes: Et problem kan løses på såvel en som en anden måde! Appliceret på organisationer betyder dette, at et hvilket som helt svar (løsning) på et hvilket som helst problem lige så godt kunne være faldet anderledes ud og samlet set, at der findes en variation af forskellige problemløsninger. Qua forståelsen af organisationer som autopoietiske systemer iagttages og henføres problemløsninger netop som systemets eget produkt, dvs. som systemets valgte måde at anskue og løse et problem. En variation af problemer og problemløsninger henviser dermed også til en generel antagelse om variation og forskelle mellem systemer. 


\section{Organisation, funktion, ydelse og refleksion}

For at komme tilbage til spørgsmålet: Hvilke begreber har systemteorien $i$ relation til potentielt at udstyre selvstyrende organisationssystemer med iagttagelsesmuligheder som kan lede til mere komplekse evner eller former til at lare, dvs. at lare at lare nye måder til iagttagelse af sig selv og omverdenen, og potentielt integrere disse nye iagttagelsesformer $i$ organisationens iagttagelsesprogrammer? I forlængelsen af ovenstående afsnit, er svaret begreberne funktion, ydelse og refleksion. Funktion er knyttet til system/omverden-distinktionen og har med systemets iagttagelse af hele samfundssystemet at gøre. Ydelse har med systemets iagttagelse af eller forhold til andre systemer at gøre. Refleksion er knyttet til systemets selviagttagelse, dvs. refleksion vedrører systemets forhold til sig selv (Luhmann 1982 s. 238; 1997 s. 757). Funktion og refleksion retter sig altså primært mod systemets - her det organisatoriske systems - egen selvreference og selvkontrol, hvor ydelse retter sig mod iagttagelsen af omverdenen af øvrige systemer - det være sig sociale eller psykiske systemer. Denne tredeling i funktion, ydelse og refleksion gælder alle systemtyper, og mere specifikt i relation til interorganisatoriske forhold, dvs. organisationer og deres subsystemer (afdelinger) så står en afdeling i en organisation $i$ et forhold til hele organisationen (funktion), til andre afdelinger (ydelse) og til sig selv (refleksion) (se Hagen 2006 s. 131).

Hvorvidt en organisation løser det initierende problem vedrørende iagttagelse gennem en differentiering til hhv. funktions-, ydelses- eller refleksionsområdet afhænger af, i hvilket omfang den aktuelle differentieringsform er kommet til udfoldelse. Lars Qvortrup beskriver nutidige samfund som hyperkomplekse. ${ }^{87}$ Hyperkompleksitet kan beskrives som "kompleksitet af 2. orden, dvs. som kompleksitet der henviser til sig selv" (Qvortrup 1998 s. 30) og følgende betegner et hyperkomplekst samfund, herunder dets grundlæggende måde at organisere sig på:

"Et hyperkomplekst samfund kan ikke overskues fra noget enkelt observationspunkt (det vare sig eksternt eller internt), men må iagttages fra en flerhed af observationspunkter med hver deres iagttagelseskode. En stor del af disse iagttagelser er iagttagelser af iagttagelser: Af andres og/eller af egne iagttagelsesoperationer. Dette karakteriserer hvad jeg kalder den polycentriske tidsalder" (Qvortrup 1998 s. 30)

\footnotetext{
${ }^{87}$ I relation til beskrivelsen af det moderne funktionelt uddifferentierede samfund anvender Luhmann selv i Die Gesellschaft der Gesellschaft begrebet hyperkompleksitet (se Luhmann 1997 s. 891-892).
} 
Med begrebet hyperkompleksitet antager Qvortrup således, at den funktionelle differentiering nu er kommet til en sådan udfoldelse, at dér, hvor vi aktuelt kan iagttage en stigende differentiering og dermed også en kompleksitetstilvækst, er i henhold til ydelses- og refleksionsområdet (i relation til funktionssystemer se Luhmann 1997 s. 759). Det er netop målrettetheden vedrørende refleksionsområdet, der betegner et systems læringskompetence. Tesen er med andre ord, at systemers iagttagelse af kompleksitet aktuelt danner baggrund for en intern differentiering med henblik på at reducere omverdenskompleksitet $o g$ at dette i særlig grad sker i relation til og målrettet på refleksion. Dette handler alment om at løse et problem vedrørende iagttagelse og for organisationers vedkommende om muligheden for at træffe og at lære af beslutninger.

Man kan på den baggrund mere præcist tale om, at organisationer kontinuerligt udfordres af et iagttagelsesproblem, frem for af sammenbrud som slutresultat for organisationer, således som Senge hævder. Udfordringen kan beskrives som en organisations problem med at iagttage sig selv som en helhed $i$ relation til andre mulige og relevante iagttagelsesmåder. Konkret kommer dette særlige refleksionsproblem til udfoldelse som et problem med at iagttage egne beslutninger. Set i lyset af dette er organisationsudviklingsprojekter et

svar på et problem vedrørende et systems selviagttagelse og iagttagelse af systemer i dets omverden, hvor organisationsudviklingsprojektet forventes at gøre det muligt for det organisatoriske system at udvikle, afprøve og derigennem lære nye måder at iagttage egne iagttagelser af sig selv og andre systemer.

I denne generelle udlægning kan organisatorisk læring forstås som et organisationssystems muliggørelse og selektive anvendelse af andre og nye iagttagelser af sig selv, dvs. integration af nye iagttagelseskriterier som grundlag for beslutningstagen. Hermed menes, at uanset om man arbejder med organisatorisk læring, værdibaseret ledelse, organisationskultur, anvendelse af ny teknologi, Total Quality Management, New Public Management, indførelse af ny lovgivning, nye eksamensformer osv., så kan det helt generelt beskrives som anvendelsen af nye måder at iagttage organisationen og dens beslutninger og arbejdsopgaver på. Dette er vel at mærke iagttagelsesformer, som skal omsættes til beslutninger, der efterfølgende leder til anderledes kommunikation/handlinger.

\section{Organisationer som samfundets handlesystemer}

Der er generel enighed blandt sociologier om, at et væsenskendetegn ved det moderne samfund er fremvæksten af organisationer (Luhmann 1982; 1997; Giddens 1995 s. 101-102; 1997). 
"The increasing prevalence of organizations in everyday arena of social life is one indicator of their importance. Another, rather different index of their significance is the increasing frequency with which organizations are singled out as the source of many of the ills besetting contemporary society." (Scott 2003 s. 5)

Organisationer spiller i den henseende en afgørende rolle i og for samfundet, og ikke mindst for dets udvikling på godt og ondt! For at fungere er samfundet dybt afhængig af organisationer, og for at kunne realisere ovennævnte ændringer og transformationer må samfundet relatere disse til dets prægivne systemer, dvs. dets organisationer (Luhmann 1982 s. 75). Luhmann kalder ligefrem organisationssystemer for samfundets handlesystemer, idet de til forskel fra samfundssystemet er kendetegnet ved at varetage bestemte og vigtige samfundsmæssige funktioner.

"It is beyond question, in any case, that only organizations are capable of producing the motivational generalization and the behavioural specification required in several of modern society's most important functional domains." (Luhmann 1982 s. 76)

Med denne placering i og for samfundet bliver organisationerne helt naturligt adressat for samfundets nye og stadigt stigende, ukoordinerede og forskellige forventninger (asymmetriserede kommunikation), som kan deles op $i$ to forskellige forventningstilskrivninger. På den ene side drejer det sig om omverdenens/samfundsmæssige forventninger om en vis form for stabilitet, struktur og kontinuitet, og på den anden side om forventninger om muliggørelse af omverdens/samfundsmæssige ændringer og transformationer. I dette krydsfelt kan organisationers problem som sagt beskrives som et problem vedrørende iagttagelse, selektion, koordinering og beslutning. Organisationer skal være $\mathrm{i}$ stand til at iagttage kompleksiteten af samfundets forskellige forventninger og afgøre hvilke, der er relevante/ikke relevante for organisationen og ikke mindst hvordan. Samtidigt skal organisationer også motivere og specificere, hvad det betyder for individer som omverden (de ansatte).

Som jeg tidligere har været inde på, er den typiske begrundelse for organisatorisk læring relateret til samfundets forandringer. ${ }^{88}$ Men teoriers

\footnotetext{
${ }^{88}$ Allerede i 1994 skriver Hildebrandt og Johnsen i indledningen til en bog om ledelse og udviklingen af vilkår og viden relateret hertil: "Dansk ledelsesforskning har sin egen identitet. Den er påvirket af udviklingstendenser og forskning $i$ andre lande. Men den er primart praget
} 
refleksioner over karakteren af samfundets forandringer, og den måde de samfundsmæssige iagttagelser får relevans i relation til organisatorisk læring, er forskellige. Argyris \& Schön betragter samfundet ud fra en økonomisk iagttagelse, som de mener ikke har relevans for intraorganisatoriske forhold, og dermed kan man argumentere for at deres samfundsforståelse ikke er særligt udfoldet. Senge betragter organisationens omverden/samfundet som dynamisk kompleksitet, der i udgangspunktet er kontingent og uberegnelig med hensyn til kontrol og styring af konsekvenserne af, men som gennem hans systemtænkning kan transformeres til variable, der kan kontrolleres og håndteres. Luhmanns sociologiske systemteori har et væsentligt anderledes syn på samfundet, organisationer og muligheder for styring og kontrol. For systemteorien er samfundet komplekst og kontingent, og genuint ustyrligt fra en hvilken som helt position og organisation (system). Forholdet mellem organisation og samfund beskrives gennem den grundlæggende system/omverdensdifference og henviser til, at omverdenen altid er mere kompleks end systemet. Dette betyder, at et systems mulighed for reduktion af omverdenskompleksitet ligger i opbygning eller udvikling af en højere grad af egenkompleksitet. Jo mere komplekst et system er, desto flere muligheder har det for at reagere på en passende måde i forhold til udfordringerne fra omverdenen (Kneer \& Nassehi 1997 s. 46). Dette laver dog ikke om på den grundlæggende definition af kompleksitetsforholdet mellem system og omverden, nemlig at omverdenen altid er mere kompleks end systemet. Tværtimod betyder kompleksitetstilvæksten i et system - som for dette system betyder mulighed for reduktion af systemets omverdens kompleksitet - samtidig en tilvækst i andre systemers omverden. I den forbindelse kan man opstille følgende formel:

Løsning af kompleksitetsproblemet $=$ systemisk kompleksitetsreduktion gennem kompleksitetstilvækst $=$ forøgelse af andre systemers omverdens kompleksitet $=$ forøgelse af samfundets samlede kompleksitet!

En anden væsentlig forskel mellem hhv. Luhmanns, Argyris \& Schöns, og Senges teorier er, at Luhmann iagttager organisationssystemer i et system/omverdens forhold, dvs. at et systems operationer i form af beslutninger altid står i et relationelt forhold til omverdenen i form af samfundet.

af aktuelle problemstillinger i dansk erhvervsliv og i offentlige virksomheder og af selvstandige danske forskningsopgaver. Der foregår en hastig udvikling på ledelsesområdet. Modeller og løsninger, der var relevante og anvendelige i går, skal man under tiden vare forsigtige med $i$ morgen, fordi forudsatningerne er andret, og fordi der er kommet ny viden." (Hildebrandt \& Johnsen 1994 s. 5). 


\section{Funktion, ydelse, refleksion og didaktik}

Den systemteoretiske tilgang til forholdet mellem organisation og samfund betyder at man kan betragte organisationer som systemer, der betjener sig af tre grundoperationer med henblik på at mestre kompleksitetsproblemet nemlig funktion, ydelse og refleksion.

Funktion er knyttet til system/omverden-distinktionen og har med systemets iagttagelse af hele samfundssystemet at gøre. Ydelse har med systemets iagttagelse af eller forhold til andre systemer at gøre. Refleksion er knyttet til systemets selviagttagelse, dvs. refleksion vedrører systemets forhold til sig selv (Luhmann 1982 s. 238; 1997 s. 757). Funktion og refleksion retter sig altså primært mod systemets - her det organisatoriske systems - egen selvreference og selvkontrol, hvor ydelse retter sig mod iagttagelsen af omverdenen af øvrige systemer - det være sig sociale eller psykiske systemer. Denne tredeling i funktion, ydelse og refleksion gælder alle systemtyper, og mere specifikt i relation til interorganisatoriske forhold, dvs. organisationer og deres subsystemer (afdelinger) så står en afdeling i en organisation i et forhold til hele organisationen (funktion), til andre afdelinger (ydelse) og til sig selv (refleksion) (se Hagen 2006 s. 131).

Funktion og refleksion retter sig altså primært mod systemets - her det organisatoriske systems - egen selvreference og selvkontrol, hvor ydelse retter sig mod iagttagelsen af omverdenen af øvrige systemer - det være sig sociale eller psykiske systemer. Organisatoriske refleksioner over funktion og ydelse kan tilsammen give retning til den pædagogiske didaktiks begreber om: Hvem der skal laere? Hvad der skal lares? Hvornår der skal lares? Hvorfor der skal lares? og Hvordan der skal laeres?

\section{Organisationssociologisk positionering}

På baggrund af ovenstående afsnit om afhandlingens sociologiske forståelse af forholdet mellem organisation og samfund vender jeg nu tilbage til positioneringen i relation til de fem sociologiske traditioner, som Gherardi og Nicolini (2001) opererer med.

Silvia Gherardi og Davide Nicolini beskriver fem sociologiske epistemologier inden for organisatorisk læring som fem forskellige traditioner, der hver især har sine egne karakteristika. De fem sociologiske traditioner betoner epistemologisk bestemte normative interesse områder, der ikke bare beskriver deres indbyrdes uenigheder og forskelligheder, men også af netop denne grund potentielt tilfører empiriske analyser og konklusioner elementer af 
deres eget perspektiv. De fem sociologiske tilgange består af elleve diskursive positioneringer eller narrativer (se nedenstående figur 3).

I det følgende vil afhandlingens tilgang blive beskrevet i relation til de fem traditioner med vægt på at identificere forskelle og ligheder. Afslutningsvist beskrives en sjette tilgang, nemlig afhandlingens.

I kapitlet om Sociologi, samfund og organisation blev der taget udgangspunkt $\mathrm{i}$ to klassiske sociologiske teorier repræsenteret ved henholdsvis Max Weber og Emile Durkheim, hvilket gav anledning til et mere komplekst bud på forståelsen af det moderne samfund givet af den tyske sociolog Niklas Luhmanns. Niklas Luhmanns teori kan ses som en sociologisk teori, der trækker på både Weber og Durkheims klassiske teorier. Hans systemteori er dog ikke en decideret videreførelse af Weber og Durkheim men udgør et selvstændigt bud på forståelsen af det moderne samfund og dets organisationer. Som det fremgår nedenfor kan afhandlingens tilgang ikke placeres entydigt $\mathrm{i}$ nogle af de fem traditioner, men kan i stedet siges at anvende elementer fra flere forskellige traditioners tilgange.

\begin{tabular}{|l|l|}
\hline Sociological traditions & Narratives of organizational learning \\
\hline The tradition of conflict & $\begin{array}{l}\text { - Organizational learning as the ideology of particular } \\
\text { power groups } \\
\text { - Organizational learning as a policy of mobilizing } \\
\text { resources of power and conflict } \\
\text { - Organizational learning as an attempt to manage } \\
\text { the tension between substantial and formal } \\
\text { rationality }\end{array}$ \\
\hline $\begin{array}{l}\text { The rational-utilitarian } \\
\text { tradition }\end{array}$ & $\begin{array}{l}\text { - Organizational learning as a problem-driven search } \\
\text { - Organizational learning as the activation of an exchange } \\
\text { network }\end{array}$ \\
\hline The Durkhemian tradition & $\begin{array}{l}\text { - Organizational learning as an ecology of learning } \\
\text { - Organizational learning as a dependent variable } \\
\text { cultural codes }\end{array}$ \\
\hline The microinteractionist & $\begin{array}{l}\text { - Organizational learning as the transmission of } \\
\text { knowledge within occupational communities }\end{array}$ \\
\hline tradition & $\begin{array}{l}\text { Organizational learning as a label producing } \\
\text { and produced by a socially constructed } \\
\text { reality }\end{array}$ \\
\hline
\end{tabular}

(Gherardi \& Nicolini 2001 s. 46)

Figur 3 


\section{The Tradition of Conflict}

Ifølge Gherardi \& Nicolini kan den sociologiske konflikttradition hovedsagligt identificeres ved og opgøres af tre forskellige diskursive positioner; 1) Organizational learning as the ideology of particular power groups, 2) Organizational learning as a policy of mobilizing resources of power and conflict, og 3) Organizational learning as an attempt to manage the tension between substantial and formal rationality. Ifølge denne tradition iagttages samfundet grundlæggende baseret på konflikt mellem forskellige grupperinger og i fraværet af synlige kampe mellem disse, foregår der en domineringsproces, hvor bestemte magtgrupperinger anvender viden i forsøg på at fremme deres egne overbevisninger overfor andre grupperinger. Tesen er, at den samfundsmæssige udvikling har flyttet den eksterne kontrol fra f.eks. det politiske ind i organisationerne, således at kampe og konflikter, der finder sted her, ses som maskerede politiske kampe. Denne maskering kan f.eks. tage form af organisatorisk læring. Magtgrupperinger, som anvender organisatorisk læring til fremme af egne interesser på bekostning af andre, er f.eks. ledelse, HRafdelinger, konsulenter osv., der legitimerer deres handlinger og prioriteringer under dække af organisatorisk læring. På den måde ses organisatorisk læring som viden/kapital, der i samfundet og organisationer kan veksles og indgå i personer og gruppers sociale stratificeringsstrategier på bekostning af andre. Den viden, som favoriseres med organisatorisk læring, betegnes som formel rationalitet, og den står overfor substantiel rationalitet. Formel rationalitet er et udtryk for den viden og de regler, procedurer osv., som anvendes til ledelse af organisationer, og dens modsætning er substantiel rationalitet, der betegner den viden og læring, som organisationsmedlemmer genererer gennem erfaringsdannelse, og som ikke lader sig omsætte til ledelse af organisationer. I overensstemmelse med perspektivet favoriserer organisatorisk læring den formelle rationalitet, således at ledelsesniveauet kan hævde deres legitimitet. Ifølge perspektivet er problemet, at store dele af viden (substantiel rationalitet) udelukkes eller går tabt - en viden som ifølge denne forståelse burde inddrages, ikke mindst fordi netop denne viden er udtryk for organisatorisk læring (Gherardi \& Nicolini 2001 s. 36-37).

\section{Systemteoretisk iagttagelse af The Tradition of Conflict}

Den epistemologiske iagttagelse, som ser organisatorisk læring som et udtryk for bestemte gruppers ideologi anvendt til mere eller mindre usynligt at undertvinge og udgrænse andre grupper og deres erfaringsbaserede læring, ligger fjernt fra systemteorien. For systemteorien vil resultatet eller outputtet af organisatorisk læring være et empirisk spørgsmål. Derudover vil 
systemteorien iagttage forskellige (grupper), f.eks. professioner som producerer og anvender viden, som en gruppe af ansatte tilknyttet forskellige systemer, som ikke direkte kan blande sig i og tage beslutninger for andre systemer. Ideen om på forhånd at fastlægge noget som en gruppe, og at generalisere denne gruppes vidensmæssige intentioner og eventuelle virkninger i forskellige systemer, vil set ud fra et systemteoretisk perspektiv skulle fastlægges empirisk. Systemteorien vil iagttage dette ud fra et differentieret perspektiv, både når det gælder forskellige organisationer, og en organisations interne differentiering, samt i forhold til organisationsansatte. ${ }^{89}$ Systemteoriens differentieringstilgang handler ikke om mere eller mindre magt, men en kompleksitetsstigning der kan lede til potentielle konflikter og modsigelser.

Ud fra et systemteoretisk perspektiv betyder det som beskrevet ikke, at der ikke kan opstå modsigelser og konflikter i konkrete organisationsudviklingsprojekter. Tværtimod er der stor sandsynlighed for, at dette kan opstå. Der kan mindst udpeges tre grunde til dette. For det første forstås organisationssystemer og deres interne differentiering som autopoietiske systemer, der funktionelt er relaterede forskelligt til omverdenen. De vil derfor iagttage og meningslægge det samme forskelligt, hvorved uenigheder kan opstå f.eks. om, hvad der er økonomisk eller pædagogisk forsvarligt, eller om, hvordan disse to hensyn skal vægtes. For det andet gælder det samme for en organisations ansatte, idet ansatte forstås som autopoietiske psykiske systemer, der genererer mening i relation til hver deres indre meningsstrukturering. For det tredje er de fleste organisationer opbygget med en vis form for hierarki, hvor ledere har funktionen at skulle tage beslutninger for større eller mindre dele af organisationen, herunder de ansatte. I den udstrækning, at nogen er uenig $i$ en leders beslutninger, kan det føre til uenigheder, modsigelser og konflikter mellem organisationens subsystemer og ansatte. Systemteoretisk kan man heller ikke som udgangspunkt sige, at organisatorisk læring fører til, at bestemte gruppers erfaringsdannelse (substantiel rationalitet) udgrænses, i den betydning at denne gruppe nægtes adgang til organisationens beslutninger og beslutningsprogrammer. Tværtimod kunne man forestille sig en gruppe som formet set ikke har magt til at omgøre beslutninger, kan have megen uformel magt (læs: protest og modmagt). Men det vil være et empirisk

\footnotetext{
${ }^{89}$ Dette kan iagttages som et epistemologisk udtryk for en nul-sum-spil forstået på den måde, at mængden af magt og indflydelse er konstant, hvorfor mere magt til en gruppe nødvendigvis må betyde, at andre grupper mister magt og indflydelse. Dette harmonerer dårligt med en systemteoretisk forståelse, hvor ændringer i et system automatisk betyder kompleksitetsmæssige ændringer i andre systemers omverden. Systemteoretisk vil man derfor betragte dette som udtryk for et stigningsforhold i kompleksitet.
} 
spørgsmål, hvorvidt og i forhold til hvilke organisatoriske temaer bestemte erfaringer (kommunikative iagttagelser) kommer til at gøre en forskel i relation til organisationens beslutninger. I et givet organisationsudviklingsprojekt vil de enkelte subsystemers beslutningsprocesser og konkrete beslutninger være afgørende for, hvilke iagttagelser der kommer til at gøre eller ikke gøre en forskel. Eftersom organisationer ikke kan vælge alt, og derfor må selektere, vil nogle tiltag til organisationsudvikling få virkninger, mens andre ikke vil få en videre færd.

The tradition of conflict opererer med forståelsen: Organizational learning as an attempt to manage the tension between substantial and formal rationality. Her henviser konflikt traditionen til, at den individuelle læring, som fremkommer gennem rationel eksperimentering, og at forestillinger om konsekvenser af handlinger ikke altid kan oversættes til organisationen rutiner, regler osv. Systemteoretisk vil man sige noget af det samme ved at sociale og psykiske systemer er omverden for hinanden og opererer i hvert deres medie, hvorfor det er nærliggende at forestille sig, at mennesker ikke altid kan forklare, hvordan eller hvorfor de gør, når de gør, som de gør. Samtidig er ideen om, at organisatorisk læring handler om at søge efter meningsfulde udvekslinger mellem sociale og psykiske systemer et grundvilkår i systemteorien. Sociale organisationssystemer er i et systemteoretisk perspektiv dybt afhængige af mennesker forstået som psykiske systemer.

\section{The Rational-Utilitarian Tradition}

Den rationelle-utilitaristiske traditions grundforståelse hviler på antagelsen om, at samfundet holdes sammen gennem individers handlinger på mikroniveau og forkaster ideen om, at samfundet som en makrostruktur overhovedet eksisterer ovenover eller løsrevet fra individer. Traditionen er på sin vis paradoksal, idet den på den ene side trækker på ideen om rational choice, hvor individuelle handlinger forstås som motiveret af en maksimering af egne interesser, på den anden side trækker på utilitarisme, der interesserer sig for rationalitetens begrænsninger, dvs. betragter handlinger i lyset af, hvorvidt de producerer nytte eller velfærd for et givent fælleskab. Samlet er forståelsen, at individet rationelt motiveres og handler i overensstemmelse med ideen om, at alt skal fungere på den bedst mulige måde. Tilgangen tager på den måde udgangspunkt i den rationelle, bevidste læring og søgen efter løsninger på problemer relateret til standardprocedurer for handling i og for et fællesskab. Organisatorisk læring resulterer i udvekslingsnetværk af viden og kompetencer, der tjener som input i produktionsprocesser, og som organisationer henter eksternt i form af mennesker og teknologier, der 
er i besiddelse af og producerer den $\varnothing$ nskede viden. Organisatorisk læring forstås som økologisk læring, dvs. læring, der foregår i distribuerede og multifaceterede rutiner snarere end i hjernen på de ansatte. Organisationer lærer ved tidligere erfaringer, som refortolkes ind i rutiner, regler, procedurer, konventioner, strategier og teknologi, der guider organisationsmedlemmernes adfærd. Viden betragtes i vid udstrækning som tavs og ligger i organisationens teams af individer med fælles erfaringer, men hver især med partiel viden om, hvad der konstituerer en bestemt rutine (Gherardi \& Nicolini 2001 s. 37-39)

\section{Systemteoretisk iagttagelse af The Rational-Utilitarian Tradition}

Som det er fremgået tidligere opererer systemteorien til forskel fra den rationelle-utilitaristiske tradition med en makro forståelse af samfundet, hvilket har afgørende betydning for samfundets mezzo og mikroniveau, jf. de fire samfundsformer. Det moderne samfund som funktionelt uddifferentieret har betydning for organisationer og deres opbygning (interne differentiering), for udviklingen af specialiserede professioner, der kan anvende funktionssystemernes kode og programmer, og for overnationale økonomiske og juridiske bestemmelser, der har konsekvenser i form af forskellige muligheder og begrænsninger for organisationer og mennesker. I forhold til begrebet om rationelle-utilitaristiske handlinger er systemteoriens udgangspunkt, at de grundlæggende antagelser bag dette begreb i bund og grund ikke holder givet kompleksiteten i verden. ${ }^{90}$ Luhmann mener grundlæggende ikke, at beslutningstagere kan være rationelle aktører, eller at organisationer er eller kan være mere rationelle end individer. Systemteoretisk er der to grunde til dette. Den ene er, at rationelle aktører i valget af handlingsalternativer skal kunne estimere hvilke handlinger, der gør størst nytte, og for at kunne afgøre dette, er de afhængige af at kunne overskue konsekvenserne af handlingsalternativerne. Dette giver ikke mening givet samfundets kompleksitet og mangfoldigheden af forskelligt iagttagende systemer, jf. begrebet om kommunikationens asymmetrisering. For det andet implicerer rationalitetsbegrebet, at der er overensstemmelse mellem handlingsaktørens forståelse og selve handlingen, men ifølge systemteorien beskrives forholdet mellem bevidsthed og kommunikation (handling) som et system/omverdens forhold. Handlingsaktørens forståelse finder sted i det psykiske systems bevidsthed, og handlingen finder sted som kommunikation i et socialt system, hvor forståelsen af kommunikationen er knyttet til det sociale systems kommunikative processer, og ikke til det psykiske systems bevidsthedsoperationer. Organisatorisk læring som

\footnotetext{
${ }^{90}$ For en generel fremstilling og kritik af rational choice tilgangen se (Hagen1996 s. 213-228), samt Hagen (1999; 2006).
} 
$\varnothing$ kologisk læring vil systemteoretisk begribes på en lidt anderledes måde. Viden vil være knyttet til organisationens kommunikative netværk, erfaringer, beslutninger og beslutningsprogrammer, de ansatte psykiske systemer, og den kompleksitet, de vælger at forstyrre kommunikationen med, samt i hvilken udstrækning den vinder tilslutning i det sociale system.

Ud fra begreberne om funktion og ydelse og refleksioner er det meget sandsynligt, at organisationssystemers kommunikation empirisk er orienteret mod oplevede problemer som i The rational-utilitarian tradition. Da systemteorien forstår organisatorisk læring som ændringer i organisationers beslutningsprogrammer, trækker den på lignende forståelser som i The rational-utilitarian tradition, der med begrebet Organizational learning as an ecology of learning forstår læring som distribueret via rutiner og forståelser i netværk snarer end i individuelle kognitive hjerner. Forskellen består som nævnt ovenfor i den rationalitet og forudsigelighed, som aktører og organisationer tilskrives.

\section{The Durkheimian Tradition}

Inspirationen fra Durkheim til organisatorisk læring fokuserer på to forhold. Det ene forhold er analyse af organisatorisk læring som en afhængig variabel, således at man ser efter de (makrostrukturelle) betingelser, der fremmer eller hæmmer læring. Det andet forhold er begrebsliggjort som en socialiseringsproces til specifikke kulturelle koder (mikrostrukturelle forhold). Den makrostrukturelle analyse leder efter samfundets normative integration af individer, dvs. i hvilken udstrækning og på hvilken måde, den organiske solidaritet på samfundsplan giver individet adgang til fællesskabets ritualer og praksisser. Den mikrostrukturelle analyse leder efter de strukturelle forhold i organisationers fælles hverdagspraksis, som normativt integrerer individet til den specifikke organisatoriske konteksts kulturelle forventninger. Dette kan f.eks. være til accept af den hierarkiske orden og kontekstens moralske interaktionsforventninger, til de uddannelses- og socialiseringsformer individer konfronteres med, til muligheder og begrænsninger i relation til at eksperimentere med udvikling af nye kompetencer, og til sidst til socialisering som kendskab til egne og andres affective former, således adfærd falder inden for fælleskabets forventninger (Gherardi \& Nicolini 2001 s. 39-41).

\section{Systemteoretisk iagttagelse af The Durkheimian Tradition}

I forhold til den makrostrukturelle analyse opererer systemteorien ikke med normativ integration. I følge systemteorien håndteres samfundets kompleksitet ved dannelsen af funktionssystemer og organisationer, dvs. gennem 
systemdifferentiering, og psykiske systemer befinder sig i omverdenen af disse differentieringer. For organisatorisk læring betyder den makrosociologiske analyse fra et systemteoretisk perspektiv, at organisationers omverden er kompleks og kontingent, samt at den funktionelle uddifferentiering betyder, at de fleste organisationer opererer inden for et funktionssystem, men tillige er stillet overfor forventninger om anvendelse af andre funktionssystemers koder og programmer til iagttagelse af sig selv og omverdenen. I følge Jönhill er mennesket som person altid inkluderet i det moderne samfund som samlet system men er ekskluderet fra alle de systemer, vedkommende ikke er medlem af. Personer er således altid både inkluderet og ekskluderet i forskellige systemer (Jönhill 2012 s. 88). Idet ikke hele mennesker men personer inkluderes i organisationssystemer, betragtes de som løst koblede. Koblingen foregår via rollefunktioner, og disse varierer fra system til system. Der er således ikke ét system med ansvar for samfundsmæssig integration, hvorfor man ikke på niveauet for organisationssystemer kan tale om normative integration, men i stedet må tale om inklusion. På mikroniveau opererer systemteorien heller ikke med normativ integration men med funktion som primær differentieringsform i relation til inklusion. Integration som inklusion omhandler, i hvilken udstrækning personer kan leve op til og håndtere de funktionelle forventninger, der er knyttet til bestemte roller f.eks. rollen som medarbejder i et bestemt ansættelsesforhold.

\section{The Microinteractionist Tradition}

Den mikrointeraktionistiske tradition er etnometodologisk og har fokus på de nære og dynamiske interaktioner mellem mennesker. Læring forstås som situeret indenfor social interaktion i et netværk af kollektiv adfærd i en arbejdsmæssig kontekst. Tilgangen trækker på en konstruktivistisk epistemologi, hvor ideer om samfundet, viden, virkeligheden, organisatorisk læring osv. konstitueres i og af medlemmernes fortolkende praksisser og forhandlinger, og hvor sproget spiller en afgørende rolle som medie for de heterogene og fragmenterede sociale konstruktioner arbejdskonteksten producerer (Gherardi \& Nicolini 2001 s. 41-43).

\section{Systemteoretisk iagttagelse af The Microinteractionist Tradition}

Der kan peges på nogle forskelle og ligheder mellem den mikrointeraktionistiske tradition og systemteoriens forståelse af organisatorisk læring. Til forskel fra den mikrointeraktionistiske tradition opererer systemteorien med en makroforståelse af samfundet; en forståelse som sætter forskellige muligheder og begrænsninger for organisationers håndtering af sig selv både 
i forhold til forventninger fra omverdenen, og i forhold til dens interne differentiering, herunder organisatorisk læring. Mens systemteoriens beskæftiger sig med både samfunds-, organisations- og interaktionssystemer, synes den mikrointeraktionistiske tradition udelukkende at interessere sig for interaktionen, og dens produktion af viden osv. i en arbejdsmæssig kontekst. For systemteorien er der et lignende fokus på interaktioners produktion af kommunikation, mening og forståelse som et eget realitetsområde, men meningsproduktionen vil altid forstås $i$ et relationelt forhold til en organisatorisk kontekst og samfundet. Et organisatorisk system er ikke blot en arbejdskontekst, og eksisterer ikke i et tomrum for sig selv men står i relation til andre systemer i dets omverden, og må derfor forstås som indstiftet med en række forventninger, som kan analysers funktionelt, dvs. at meningsproduktionen og særligt systemets beslutninger fortolkes i forhold til systemets operationelle differentiering mellem system og omverden. Organisationssystemers kommunikation og beslutninger analyseres ud fra præmissen om, at de udfylder en funktion i relationen mellem et system og dets omverden.

Eftersom organisationer beskrives som sociale systemer bestående af kommunikation, begribes organisatorisk læring som ved den The microinteractionist tradition som socially constructed reality.

\section{The postmodern tradition}

Ifølge Gherardi og Nicolinis inddeling af sociologiske traditioner indenfor organisatorisk læring beskrives kommunikative teorier om organisatorisk læring primært inden for kategorien postmoderne tradition med den begrundelse, at disse epistemologier karakteriserer samfundet som kontingent og uden det før-moderne og moderne samfunds store fortællinger.

"(...) the constructed nature of people and reality, emphasizing language as a system of distinctions which are central to the construction process, arguing against grand narratives and large-scale theoretical systems, such as Marxism, or functionalism, emphasizing the power-knowledge connection and the role of expertise in systems of domination, emphasizing the fluid and hyperreal nature of the contemporary world and the role of mass-media and information technologies, and stressing narrative/fiction/rhetoric as central to the research process. (Op.cit Alvesson and Deetz 1996: 192; in Gherardi \& Nicolini 2001 s. 43-44)

Som det tidligere er fremgået, vil man ud fra Luhmanns systemteori iagttage samfundet som funktionelt uddifferentieret, og af den grund ikke betegne 
det som postmoderne. Her er det underforstået, at enhver iagttagelse af samfundet forløber ud fra en forestilling om samfundet, som igen efterfølgende leder til bestemte udledninger om samfundet. I systemteoretiske termer kan diskussionen om samfundet som moderne eller postmoderne dermed henføres til teorien om anden ordens kybernetik og må derfor anskues som en diskussion centreret om, hvilket iagttagelsespunkt iagttagelsen af samfundet forløber ud fra. Spørgsmålet om, hvorvidt samfundet er moderne eller postmoderne, er derfor ikke så meget en diskussion om samfundet som en bestemt ontologisk entitet, som det er muligt at trække følgeslutninger af, men om hvilke kategorier eller begreber, som ligger til grund for iagttagelsen af samfundet, og hvilke iagttagelsesmuligheder denne iagttagelsesform giver. Alene distinktionen i bestemmelsen af et "før" og et "efter" implicerer et historisk iagttagelsesperspektiv, som samfundet ikke selv har produceret, men som viser tilbage til de kategorier og begreber, iagttagelsen forløber ud fra.

Et eksempel på, hvor den postmoderne tradition og systemteorien adskiller sig fra hinanden, er i forståelsen af videnskabens rolle, når det kommer til organisatorisk læring. Den postmoderne tradition ser samfundet som bestående af en række forskellige samfund ('specific social communitys') med hver deres diskursive praksis. Forskning ses som et samfund ('community'), hvis diskursive praksis består i at eksaminere, hvordan organisatorisk læring som socialt objekt er udformet og opstået med henblik på at synliggøre, hvordan denne vidensgenstand er ustabil, ufuldstændig, og altid åben for nye fortolkninger (Gherardi \& Nicolini 2001 s. 45). Videnskabens rolle er ikke at afdække sandheden ('discovering the truth'), men at udsætte den videnskabelige viden for ikke dogmatiske tanker, dvs. at udfordre konventionelle forståelser, rutiner, statiske meninger og aksiomer indenfor normal videnskab (Gherardi \& Nicolini 2001 s. 44). I den postmoderne tradition iagttages samfundet som bestående af et utal communities med hver deres diskursive praksis, og eftersom videnskab iagttages som et community på lige fod med andre communities, og viden knyttes til magt, iagttages videnskabens produktion af viden som noget, der indgår i de forskellige communities generelle kamp om sandheden, dvs. magten til at definere andres definitioner.

Systemteorien forstår samfundet som internt uddifferentieret i en række uens men ligestillede funktionssystemer, f.eks. politik, økonomi, ret, videnskab, religion, uddannelse osv., som hver især opererer autonomt med hver deres binære koder, der fastlægger det pågældende systems funktion, og hver især råder over programmer, der betegner de betingelser under hvilke, en bestemt kode kan tilskrives et sagsforhold. Videnskaben opererer i mediet sandhed med koden +/- sandhed, og anviser med sit program af teorier og 
metoder, hvordan videnskaben skal anvendes. Teorier er interne konstruktioner, som videnskaben anvender til iagttagelse af verden, og som indgår i videnskabens løbende refleksion over egne udsagn, og hvorvidt de kan regnes for sande. Her adskiller videnskaben sig fra andre funktionssystemer, som anvender andre koder og programmer. Jura forholder sig ikke til, og kan ikke afgøre, hvorvidt noget er sandt eller ej, men hvorvidt noget ud fra en juridisk betragtning er lovligt/ulovligt. Systemteorien adskiller sig på den måde fra den postmoderne tradition ved sit funktionsbegreb og beskrivelsen af samfundet som funktionelle differentieret. Videnskaben er forskellig fra men sammenlignelig med de andre funktionssystemer. De er som tidligere beskrevet ligestillede, men uens ved deres funktionelle relatering til samfundet som samlet system. Den postmoderne tradition opererer ikke med en sådan beskrivelse, men iagttager samfundets forskellige communities som ligestillede, dvs. som vidensproducerende diskursive praksisser, der indgår i et magtkredsløb.

"Obviously, it has nothing to do with the structural drift or the evolution of modern society. Moreover, its description remains ambiguous. Perhaps it is an autological description, that is, a description that applies to itself. The description that includes its own performative "speech activity". If this is meant by "post modernity", the term cannot say what it means, because this would lead to a confusion of constative and performative components of communication and in consequence - i.e., to its deconstruction." (Luhmann 2000c s. 40)

Den postmoderne pointe om, at nutidens samfund er anderledes end tidligere samfundstyper, forstås i afhandlingen med begrebet om kommunikationens asymmetrisering. Dette vil sige, at samfundet har nået et kompleksitetsniveau, der muliggør et stigende utal af iagttagelses- og meningsdannelsesformer på samfundsplan. Selvom Luhmann ikke vil betegne det moderne samfund som postmoderne, kan der drages nogle paralleller mellem systemteorien og de teorier og, som Gherardi \& Nicolini beskriver som postmoderne: ideen om, at viden er historisk betinget og produceret i og af sociale kontekster, samt at disse kontekster kan forholde sig forskelligt til viden. I den postmoderne tradition beskrives dette som at "(...) organizational learning is viewed as a discursive practice." (Gherardi \& Nicolini 2001 s. 45), og derfor varierer organisatorisk læring fra organisation til organisation. Systemteoriens forståelse af meningsproduktion vil ikke være uenig i at man 
kan tale om diskursive praksisser, men i at de er så frit flydende, dvs. hvad der gælder som viden - hvad der anses som betydningsfuldt, er afhængig af det sociale systems iagttagelseskriterier herunder hvorvidt det sociale system tilslutter sig, eller afviser det iagttagede.

\section{Afhandlingens organisationssociologiske position}

I afhandlingen anvendes Luhmanns systemteori som primær teori, og den betegnes som operativ eller epistemologisk konstruktivisme (Rasmussen 2004; Hagen 2006). Eftersom organisationer beskrives som sociale systemer bestående af kommunikation, begribes organisatorisk læring på samme måde som i The microinteractionist tradition som socially constructed reality. Ud fra begreberne om funktion og ydelse og refleksioner er det tilsvarende sandsynligt, at disse empirisk er orienteret mod oplevede problemer, som i The rational-utilitarian tradition. Da systemteorien forstår organisatorisk læring som ændringer i organisationers beslutningsprogrammer, trækker den på lignende forståelser som findes i The rational-utilitarian tradition, der med begrebet Organizational learning as an ecology of learning forstår læring som distribueret via rutiner og forståelser i netværk snarer end i individuelle kognitive hjerner. The tradition of conflict opererer med forståelsen Organizational learning as an attempt to manage the tension between substantial and formal rationality. Her henvises der til, at den individuelle læring, som fremkommer gennem rationel eksperimentering, og at forestillinger om konsekvenser af handlinger ikke altid kan oversættes til organisationen rutiner, regler osv. Ud fra et systemteoretisk perspektiv er sociale og psykiske systemer omverden for hinanden og er desuden systemer, der opererer i hvert deres medie, hvorfor det er nærliggende at forestille sig, at mennesker ikke altid kan forklare, hvordan og hvorfor de gør, når de $\mathrm{g} \varnothing \mathrm{r}$, som de gør. Men hele ideen om, at organisatorisk læring også kan handle om at søge efter meningsfulde udvekslinger af mening mellem det sociale og det psykiske system ligger ud fra et systemteoretisk perspektiv, som et grundvilkår i forhold til organisatorisk læring. Sociale organisationssystemer er i et systemteoretisk perspektiv dybt afhængige af mennesker forstået som psykiske systemer. The tradition of conflict opererer også med forståelsen Organizational learning as a policy of mobilizing resources of power and conflict. I stedet for at iagttage dette som et magt spil, vil systemteorien iagttage dette ud fra et differentieret perspektiv, både når det gælder forskellige organisationer, og en organisations interne differentiering, samt i forhold til organisationsansatte. Systemteoriens differentieringstilgang handler ikke alene om mere eller mindre magt, men en kompleksitetsstigning der kan lede til potentielle konflikter og modsigelser. 
Dette kan systemteoretisk have tre grunde: 1) Systemer er funktionelt relateret forskelligt til omverdenen, og vil derfor iagttage og meningslægge forskelligt hvorved uenighed kan opstå. 2) Ansatte er ligeledes selvstændigt meningsopererende systemer hvorfor det samme vil gælde for dem. 3) Organisationer er opbygget med en vis form for hierarki, hvor ledere har funktionen at skulle tage beslutninger for større eller mindre dele af organisationen, herunder de ansatte. I den udstrækning afdelinger og ansatte ikke er enige kan modsigelser og konflikter opstå. Men disse aspekter er systemteoretisk noget som kun kan afgøres empirisk, og altså ikke kan udpeges på forhånd.

Afhandlingens tilgang ser i skematisk form og i forhold til Gherardi og Nicolini fem traditioner, og deres særkende, ud som i nedenstående skema.

\begin{tabular}{|l|l|}
\hline $\begin{array}{l}\text { Den Luhmannske systemteo- } \\
\text { retiske tilgang }\end{array}$ & $\begin{array}{l}\text { - Organizational learning as a policy of mobilizing } \\
\text { resources of power and conflict }\end{array}$ \\
- Organizational learning as an attempt to manage the \\
tension between substantial and formal rationality \\
- Organizational learning as a problem-driven search \\
- Organizational learning as an ecology of learning \\
- Organizational learning as a socially constructed \\
reality
\end{tabular}

Figur 4 (egen tilvirkning) 



\section{Pædagogisk iagttagelse af organisatorisk læring som sprog og kommunikation}

Kommunikation kommer fra det latinske ord communicare, og det betyder etymologisk at gøre noget foelles.

"Kommunikation: Kommunikation er det medium, hvorigennem vores virkelighed bliver social. Uden kommunikation ville der kun vare individuelle virkeligheder. Vi kunne ikke tale om kultur, fallesskab, samfund eller historie uden kommunikation (Dewey 1916; Bruner 1996). Vores konstruktioner ville udelukkende vare individuelle. Laring ville ligeledes vare meget begranset, fordi vi ikke ville kunne lare af andre. Kommunikation er således altafgфrende $i$ forhold til at tale om virkeligheden som socialt konstrueret. Integreret $i$ kommunikationen er således fakta, logik og vaerdier. Det er med andre ord igennem kommunikationen, at vi har adgang til fakta, logik og vardier. Kommunikation er således et spфrgsmål om liv eller d $\phi d$ for organisationen (Gergen, Gergen et al. 2004)." (Jorgensen 2007 s. 13)

Det er store ord og betydninger som tillægges kommunikation, og dens rolle og relevans for forståelsen af virkeligheden helt generelt! Som det vil fremgå gennem kapitlet, anvender afhandlingen en kommunikativ tilgang til organisationer og organisatorisk læring, herunder pædagogiske og didaktiske aktiviteter.

Selvom der gennem en årrække har været fokus på kommunikation ikke bare i relation til organisationer, men i forhold til samfundsmæssig og sociologisk teoretisering og forskning, er kommunikation ikke et entydigt begreb, som der er konsensus om, hvordan skal udlægges. Afhængig af epistemologi udlægges kommunikation forskelligt, og dette har 
konsekvenser for virkelighedsiagttagelsen, herunder forståelsen af organisationer, og afhandlings erkendelsesinteresse for pædagogisk didaktiske begrebsdannelser.

Med henblik på at afklare og beskrivelse afhandlingens grundlæggende forståelse af kommunikation som grundlæggende analyseenhed, tages der udgangspunkt $\mathrm{i}$ to forskellige kommunikations epistemologier, nærmere betegnet den tyske sociolog og filosof Jürgen Habermas teori om kommunikativ handlen, og Niklas Luhmanns sociologiske systemteori om sociale systemer bestående af kommunikation.

Ligeledes trækkes og suppleres der undervejs i kapitlet med pædagogiske indsigter fra andre organisationsteorier, der anvender kommunikative tilgange til iagttagelse af organisatorisk læring.

\section{Organisatorisk læring og kommunikation}

Når organisationer skal forandre sig og lære, indgår kommunikation som et naturligt og centralt element. Hvordan skulle man ellers forestille sig, at læring kunne forekomme? Begreber og koncepter som omstrukturering, sidemandoplæring, arbejdspladslæring, ændring af mentale modeller, opbygning af fælles visioner, teamlæring, distribueret kognition, læring i læringsrum, læring i praksis fællesskaber, udveksling og forhandling af viden eller single-, doubleog triple loop learning er umulige at forestille sig uden kommunikation. I det hele taget er kommunikation et vigtigt og helt afgørende element $\mathrm{i}$ alle organisationers daglige koordination, beslutningstagen samt interne og eksterne kommunikation med kunder, brugere og andre aktører.

En første afgrænsning for dette afsnit er, at der er flere som abonnerer på eller skriver, at de opererer med en kommunikativ tilgang til organisatorisk læring, men ved nærmere eftersyn reelt ikke gør det. F.eks. er Jacobsen og Thorsvik nogen af de organisationsteoretikere, som anerkender og betoner vigtigheden af kommunikation. De skriver, at det grundlæggende er umuligt at tale om organisatorisk læring uden kommunikation (Jacobsen \& Thorsvik 2002 s. 233). Man kan i den forbindelse undre sig over, at de ikke forholder sig til, hvad kommunikation er, dvs. beskriver og udlægger et kommunikationsbegreb, herunder hvilke muligheder og begrænsninger et sådant begreb eventuelt kunne have for udvikling, deling, udveksling og forhandling af viden i relation til organisatorisk læring. En anden organisationsteoretiker, som også betoner kommunikationsbegrebet i relation til organisatorisk læring, er Elkjær (2005). Med reference til Argyris og Schön beskriver Elkjær organisatorisk læring som kommunikation (Ibid. s. 38-40). Argyris og Schön opererer imidlertid ikke selv 
med et kommunikationsbegreb men med en handlings- og adfærdsteoretisk tilgang til organisatorisk læring (theory of action) (Argyris \& Schön 1978; 1996). ${ }^{91}$

Afsnittet vil argumentere for anvendelse af et komplekst kommunikationsbegreb, som kan anvendes til forståelsen af kommunikation i organisationer, og som kan tematisere væsentlige aspekter ved undervisningskommunikation, hvorfor afsnittet afgrænser sig til og koncentrere sig om teorier, som faktisk anvender sproglige og kommunikative tilgange til organisatorisk læring.

Med udgangspunkt i afhandlingens teoretiske forståelsesramme - Niklas Luhmanns sociologiske og kommunikationsteoretiske systemteori - hvis grundlæggende forståelse er, at det sociale, herunder organisationer som systemer, består af kommunikation, har afsnittet også den funktion at positionere afhandlingen indenfor den retning, som beskæftiger sig sprogligt og kommunikativt med organisatorisk læring.

I et lidt videre perspektiv vil der i de teoretiske gennemgange af Luhmanns systemteori blive argumenteret for, at den sociologiske systemteori har begreber, der er særligt velegnede til at beskrive og analysere pædagogiske og læringsteoretiske problemstillinger i relation til organisationer.

\section{Pædagogisk epistemologisk iagttagelsesposition}

Eftersom afhandlingens forskningsmæssige erkendelsesinteresse er at udvikle en forståelse af, hvordan organisatorisk læring kan beskrives og reflekteres inden for rammerne af en pædagogisk inspireret organisationsdidaktik, vil iagttagelsen og analysen af teorier, der forstår og beskriver organisatorisk læring ud fra en kommunikativ epistemologi, foregå med henblik på udledning af erkendelser og indsigter, som kan bruges hertil. Der arbejdes således ud fra den grundlæggende antagelse om, at teorier om organisatorisk læring - ud over læringsaspektet (som er en del af pædagogikken), og uden at de nødvendigvis bruger begrebet pædagogik - rummer og anvender, hvad jeg vil betegne som pædagogiske anvisninger, forestillinger og ideer.

Som ovenfor beskrevet er det ikke en ny erkendelse eller epistemologi for organisationsteorier om og forskning i organisatorisk læring at forholde sig til

\footnotetext{
${ }^{91}$ Med reference til Argyris og Schön skriver Elkjær at: "I de uproduktive lærende organisationer, som der er flest af, er defensive kommunikationsformer i højsædet. De defensive kommunikationsformer blokerer for fri og åben udveksling af information og viden, og er den største hindring for produktiv organisatorisk læring. Mens omvendt produktivt lærende organisationer er kendetegnet ved, at antagelser og formodninger om dette eller hint testes gennem en kommunikationsform, der er åben herfor." (Elkjær 2005a s. 39).
} 
dem ud fra sproglige og kommunikative tilgange. ${ }^{92}$ F.eks. tildeler organisationsforskerne Weick og Westley (1996) sproget og sprogforståelsen en helt central placering i forhold til organisatorisk læring. For Weick og Westley er sproget kilden til både social og psykisk refleksion. Tilsvarende knytter de sproget tæt til læring, som de, i lighed med Nonaka og Takeuchi (1995), mener, sker gennem social interaktion, hvor sproget er både midlet/redskabet og vidensbasen eller lageret (repository).

I det følgende tages der udgangspunkt $\mathrm{i}$ en af de teoretikere, som har arbejdet mest indgående med kommunikation og sprog i relation til forståelsen af det sociale nemlig den tyske sociolog og filosof Jürgen Habermas. Grunden til, at Habermas er valgt, er, at han repræsenterer og på mange måder står som en af de helt afgørende og uomgængelige skikkelser for det, der betegnes den kommunikative vending indenfor sociologien og filosofien. Med den kommunikative vending refereres der til et brud med en århundrede lang tradition for at tage udgangspunkt i og udlede præmisser for menneskets handlinger med udgangspunkt i subjektets bevidsthed, mentale aktiviteter eller tankevirksomhed, for i stedet at tage udgangspunktet i og teoretisere over kommunikation (Eriksen \& Weigård 2003 s. 61). Man kan sige, at netop den kommunikative vending er et grundlæggende opgør med handlingsbegrebet, som f.eks. anvendes af Argyris og Schön, såvel som et opgør med ideen om, at organisatorisk læring kan begribes alene som et udtryk for individers motiver, tanker osv., sådan som er tilfældet ved den sociologiske rationelt-utilitaristiske tradition (Gherardi \& Nicolini 2001 s. 37-39). The rational-Utilitarian Tilsvarende er den et opgør med den individualistiske tilgang, som tidligere i afhandlingen blev beskrevet som udtryk for metodologisk individualisme. Ligesom Luhmanns teori er Habermas' teori sociologisk, og begge er udtryk for sociologiens kommunikative vending og tilgang til sin genstand. Begrundelsen for anvendelsen af Habermas er - udover hans relevans ud fra et kommunikationsteoretisk perspektiv - at han i forvejen anvendes som kommunikativ tilgang til organisatorisk kommunikation. For eksempel bruges han i relation til beskrivelse, forståelse og analyse af forandringsledelse, visionsledelse, vidensledelse, værdibaseret ledelse og strategisk ledelse. (jf. Morsing \& Schultz 2006; Bordum 2003; 2009; 2010).

Udgangspunktet er Jürgen Habermas sprogligt orienterede kommunikationsforståelse. Dernæst præsenteres Niklas Luhmanns systemteoretiske

\footnotetext{
${ }^{92}$ Der har gennem en årrække været fokus på at koble organisation og kommunikation med hinanden, f.eks. har det danske forlag Samfundslitteratur siden år 2000 publiceret en række udgivelser inden for serien "Den kommunikerende organisation".
} 
forståelse af sprog og kommunikation, og til sidst forholder jeg mig til Nonaka og Takeuchis teori om The Knowledge-creating company. Undervejs inddrages Weick og Westleys sproglige tilgang til organisatorisk læring.

\section{Habermas og kommunikation}

Habermas baserer blandt andet sin socialfilosofiske samfundsteori på et kommunikationsbegreb - kommunikativ handlen - som rummer en særlig sprogforståelse. ${ }^{93}$ I kraft heraf ses Habermas som et udtryk for en kommunikationsteoretisk vending indenfor filosofien og socialvidenskaben (kommunikationsparadigmet) (Pahuus 1989).

For Habermas er kommunikation på samme måde som for Nonaka og Takeuchi (1995), Jørgensen (2007), Luhmann (1997; 2000a) og Weick og Westley (1997) tæt knyttet til sproget. Habermas refererer helt generelt til sprogbrugere som kommunikativt handlende.

Habermas' udgangspunkt er, at mennesket helt generelt indgår i den sociale samtale situation (interaktion) ud fra to grundlæggende intentioner, nemlig at blive enige med og at forstå hinanden. I tilknytning til ontologien om konsensus og forståelsesorienteringen tillægger Habermas sproget en særlig kommunikativ funktion, betegnet: opnåelse af gensidig forståelse. Begrundelse for dette finder han indlejret eller indbygget i sproget. "Indbyrdes forståelse er iboende det menneskelige sprog som dets telos." (Habermas

\footnotetext{
${ }^{93}$ Habermas socialfilosofiske teori tager udgangspunkt i et begreb om kommunikativ handlen og kan ses som udtryk for et grundlagsskift - et paradigmeskift - indenfor filosofien ved bl.a. at være et opgør med erkendelsesteoretiske funderinger af filosofien i et bevidsthedsparadigme (Descartes, Hume, Kant, Schütz, Luckmann, Husserl). For Habermas er det ikke tilstrækkeligt med en bevidsthedsmæssig procedure - en bevidsthedsindstilling, hvor man ved hjælp af fornuften tænker sig til, hvordan man bør kommunikere og handle, sådan som det ses hos Kant (Kant 2002). I stedet er det nødvendigt med sproglig dialog, dvs. en betoning af sprogets og kommunikationens udvidede rolle (Geist 1996 s. 50). Ifølge Uwe Geist kan forskellen illustreres ved en sammenligning mellem Kants kategoriske imperativ og grundsætningen i Habermas' diskursetik: "Du skal kun handle efter den maxime, der er således, at du samtidigt kunne фnske at den blev gjort til en generel lov (Kant) og Kun de normer kan gфre krav på gyldighed, som alle de som det angår, som deltagere $i$ en praktisk diskurs kan (eller ville kunne) tilslutte sig (Habermas 1983:103).” (Geist 1996 s. 50). William Outhwaite skriver om samme: "Habermas (...) forsøg på at fundere en diskursetik, som han betragter som én af de rekonstruktive videnskaber, at den "står og falder med to antagelser, at (a) normative gyldighedskrav har en kognitiv betydning og kan behandles på samme måde som sandhedskrav, og at (b) begrundelsen af normer og påbud krcever gennemførelsen af en real diskurs og i sidste ende ikke er mulig monologisk, $i$ form af en argumentation, der gennemspilles hypotetisk $i$ ånden." (Outhwaite 1997 s. 65).
} 
1996 s. 211). ${ }^{94}$ Men ifølge Habermas lever menneskers kommunikation i det moderne samfund ikke altid op til denne forståelsesorientering, ${ }^{95}$ hvorfor han udvikler et metodisk og socialfilosofisk diskursbegreb, betegnet den ideale samtale situation, og som består i fire universelle gyldighedskrav til samtalen. ${ }^{96}$

$$
\begin{aligned}
& \text { at udtrykke sig forståeligt - (krav om forståelighed) } \\
& \text { at fremsatte noget som skal forstås, - (krav om sandhed) } \\
& \text { at gфre sig forståelig herved, - (krav om gyldighed) } \\
& \text { at komme til forståelse med hinanden. - (Krav om oprigtighed) }
\end{aligned}
$$

(Habermas 1989 s. 112)

Overordnet set er Habermas' socialfilosofiske ide, at man ved overholdelse af gyldighedskriterierne får $\emptyset$ get mulighed for at indrette et godt samfund herunder gode sociale relationer. For Habermas er det universelle krav, og de gælder i den udlægning ikke kun for diskussioner på samfundsplan, eftersom f.eks. et godt samfund ikke kun udspringer af politiske diskussioner, men i ligeså høj grad er relateret til menneskers hverdagsliv, og de beslutninger og prioriteringer som finder sted i samfundets organisationer (noget Habermas i relation til f.eks. penge og magt kalder systemverdenen). I organisatorisk sammenhæng vil denne kommunikationsform medvirke positivt til, hvad

\footnotetext{
${ }^{94}$ Organisationsforskerne Weick og Westley trækker ligesom Habermas i deres sprogforståelse på nogen af de samme forståelser, ved at sproget tildeles en selvstændig rolle eller funktion nemlig som noget, der generelt repræsenterer viden i sig selv, og for organisationer i en vis udstrækning også repræsenterer dens ophobede viden (Weick \& Westley 1996 s. 446).

${ }^{95}$ Påstanden er, at en kontrafaktisk struktur ligger til grund for og bærer den faktiske samtale (Thyssen 1991 s. 113). Men disse sondringers realisationsmuligheder er ifølge Habermas korrumperet af det moderne samfunds differentierings- og individualiseringsprocesser, hvor systemer og personer ikke kommunikerer med hinanden i en forståelsesorienteret hensigt, men med henblik på opnåelse af en form for egennytte. Habermas mener derfor, at der gældende for alle personer - de kommunikativt handlende - må indsættes visse regler i samtalesituationer, som det er hensigtsmæssigt at overholde, nemlig ovennævnte gyldighedskriterier. Ideen er, at langt de fleste sociale og psykiske misforståelser kan elimineres eller delvist nedtones, hvis de kommunikativt handlende i samtalen overholder netop disse universelle krav, som gælder for kommunikation i betydningen forståelsesorienteret handlen.

${ }^{96}$ Disse universelle gyldighedskrav anvendes tillige i udviklingen af Habermas etiske teori. Tesen for diskursetikken er; "at enhver kommunikativt handlende i udførelsen af en hvilken som helst talehandling må stille universelle gyldighedskrav, og forudsætte at disse indfries. For så vidt han overhovedet vil deltage i en forståelsesproces, kan han ikke komme uden om at stille de følgende og netop disse universelle krav" (Habermas 1989 s. 111-112).
} 
man kunne betegne fornuftbetonet vidensudveksling. ${ }^{97}$ Man kunne udlede, at den fornuftbetonede tilgang til kommunikation har læring indbygget $\mathrm{i}$ kommunikationsforståelsen. For at komme lidt tættere på en forståelse af, hvad Habermas mener, og hvordan denne kommunikationsforståelse metodisk skal gribes an, vil jeg i det følgende forholde mig til at hans teoretisering over, hvad han selv kalder den ideale samtalesituation.

\section{Den ideale samtalesituation}

Habermas anvender ovennævnte gyldighedskriterier til konstruktion af et filosofisk ideal for samtaler - at føre en diskurs. ${ }^{98}$ Diskursbegrebet henviser

\footnotetext{
${ }^{97}$ Habermas teori kaldes da også for en filosofisk samfundsteori, fordi han af filosofisk og demokratisk vej fors øger at rekonstruere og institutionalisere den fornuftige samtales grundformer som en overordnet normativ idealrationalitet med konsekvenser for det sociale (Nørager 1998 s. 28 \& 35). Hans teori udspringer af et generelt opgør med den samfundsmæssige og videnskabelige erodering af et konsistent og gennemgribende fornufts begreb, og retter sig mod en undersøgelse af nødvendige og formelle betingelser for kommunikation og forståelse (Thyssen 1991 s. 112). Når samfundet og videnskaben ikke længere kan finde og begrunde fornuften som gennemgribende kraft, dvs. som handlingsanvisende, ved strukturering af mening og samhandling, finder Habermas af filosofiens vej det hensigtsmæssigt at installere universelle kommunikative kriterier, der kontekstuelt giver mulighed for delvist fornuftsbaserede beslutninger ved at alle berørte parter sikres lige mulighed for meningsudveksling. Ved delvist fornuftsbaserede beslutninger forstås, at fornuften for det første ikke kan etableres ontologisk, dvs. med universel gyldighed, og for det andet, at en given fornuft er kontekstafhængig, idet den formentlig kun kan gøre sig gældende som fornuft i den kontekst, hvori den er fremkommet.

${ }^{98}$ At diskurs er en ideal samtalesituation løftet ud af den normale verden signalerer, at den kan være et kontrafaktisk ideal, og at diskurssamtalen, når den tentativt finder sted, betegnes og forvaltes anderledes end almindelig dagligdags kommunikativ handlen. Habermas forståelse af diskurs adskiller sig væsentligt fra diskursbegreber i diskursteorier. Her betragtes diskurs som en sarlig sproglig fremstilling eller en samtale og dermed "en bestemt måde at tale om og forstå verden (eller et udsnit af verden) på" (Jørgensen \& Phillips 1999:9). Diskurs kan ikke defineres entydigt: "Discurro med den afledede form discursus er latin og betyder lobe frem og tilbage med en undertone af lidt forvirring og uden egentligt retning. Herfra kommer det til at betyde først ordveksling, argument(ation) og senere både samtale og drøftelse og også fremstilling, afhandling og pradiken. Endelig kommer så en ny betydning. Diskurs bliver til rammen for talen, sproget, fremstillingen og forståelsen, dvs. den falles horisont, der muligg $\phi r$ at begreberne signalerer det samme for diskursens deltagere. Diskurs kan både vare en satning, en rakke satninger i en samlet fremstilling, en ramme for fremstillingen og også skabelsesprocessen af denne samlende ramme." (Bredsdorff 2002 s. 63). Diskursteorien idemæssige rødder kan spores tilbage til den tidlige lingvistik og sprogvidenskab. "Lingvisten og strukturalismens grundlagger Ferdinand de Saussure (1857-1913) фnskede at losrive sprogvidenskaben (lingvistikken) fra andre videnskaber, f.eks. psykologien og sociologien, og etablere den som en selvstandig videnskabelig disciplin (Saussure 1970:30-32, Madsen
} 
til en grundlagsdiskussion, der typisk fremkommer eller burde fremkomme i situationer, hvor tvivlen angående bestemmelsen af forhold vedrørende et fænomen bliver presserende.

Grundtesen for diskursbegrebet er, at fordi fornuften som universelt ontologisk fænomen er blevet forkastet, er den eneste måde at finde frem til, hvad der er sandt og rigtigt, tilbundsgående samtaler, hvor enighed tilstræbes. Den ideale eller diskursive samtalesituation betegner netop denne bestemte måde at kommunikere: at problematisere og at diskutere et udsagns gyldighed, og at fastlægge normer for gyldighed (Geist 1996 s. 51). Diskursbegrebet omhandler og beskriver en samtale som en løsrivelse fra den daglige kommunikative handlen - fra verden og dermed som en frakobling af socialdimensionens hierarkisering og magtforhold. Ved frakoblingen af socialdimensionen gøres alle lige, og kommunikationen og de kommunikativt handlende kan koncentrere sig om sagen vedrørende forståelsen af det artikulerede samt dets sandhed og rigtighed. Sandhed, rigtighed og forståelse finder ifølge Habermas sin løsning udtrykt $\mathrm{i}$ ideen om det bedre arguments ejendommelige tvangslфse tvang. Ifølge Thyssen kan den ideale samtalesituation siges at være rettet mod forståelse, og ikke mod opnåelse af noget udenfor samtalen (Thyssen 1991 s. 113). Idet vi overbevises af det bedre arguments argument, nærmer samtalen sig konsensus, som sætter betingelser for videre kommunikativ handlen. ${ }^{99}$ Den

1970:13) Ifølge Saussure måtte sproget ses som et selvstcendigt, autonomt og arbitrart "system", der ikke er afledt affanomener udenfor sprogetf.eks. bevidsthed, sociale fanomener eller materielle ting. Sprogets elementer (begreber, ord, tegn), f.eks. "bil", får deres betydning ved deres relation til andre elementer eller mere pracist ved deres forskellighed fra andre sproglige elementer f.eks. "mad". Sproglige elementer henter således deres betydning ved strukturen af relationer til andre sproglige elementer." (Nissen \& Vardinghus-Nielsen 2007 s. 163).

${ }^{99}$ Grunden til, at vi trods vores forskelligheder faktisk kan se, erkende og sande et argument som bedre, finder sin løsning i livsverdenens meningshorisont. "Faktisk er kommunikative ytringer altid indlejret $i$ verdensrelationer på en og samme gang. Kommunikativ handlen støtter sig til en kooperativ tydningsproces, hvor deltagerne relaterer sig samtidigt til noget $i$ den objektive, den sociale og den subjektive verden, også når de i deres ytringer tematisk kun fremhaver en af de tre komponenter. På denne måde anvender taler og tilhører tre-verdensreferencesystemet som en fortolkningsramme, indenfor hvilken de opnår falles definitioner af deres handlingssituation. De tager ikke blot reference til noget $i$ verden, men relativerer deres ytring $i$ forhold til den mulighed, at dens gyldighed bestrides af en anden aktør. Forståelse betyder kommunikationsdeltagernes enighed om en ytrings gyldighed; indforståelse betyder den intersubjektive anerkendelse af de gyldighedsfordringer, som taleren fordrer for denne ytring." (Habermas 1996 s. 285). Livsverdenen er et filosofisk erkendelsesteoretisk (Husserl) og kulturelt begreb, som betoner, at vi i tilgangen til verden anvender indforstået baggrundsviden af fælles normer. 
ideale samtale står således udelukkende i sagens tjeneste - sigtet er forståelse og indforståelse (Thyssen 1991 s. 113).

\section{Kritik af den sproglige forståelse af kommunikation}

Der kan fremføres en del kritik af Habermas socialfilosofiske og sprogligt funderede kommunikationsbegreb. En kritik er, at man kan beskrive Habermas' kommunikationsteori som en teori, der leder naturligt over i kommunikativ rationalitet. Grunden til dette er, at Habermas grundlæggende forstår de kommunikativt handlende som fornuftige eller rationelle i samtale situationer.

"Når fornuften hverken er en substans eller en foreliggende kendsgerning, men derimod en egenskab, bliver den identisk med "fornuftighed", og så kan man lige så godt først som sidst sige "rationalitet",". (Nørager 1998 s. 11)

Et andet kritik punkt er, at Habermas ikke udvikler et teoretisk og empirisk adækvat begreb om kommunikation, der kan beskrive og forstå, hvordan hverdagskommunikation reelt foregår. Det er et normativt begreb om, hvordan kommunikation burde være, hvis analytiske konsekvens bliver, at empirisk kommunikation udlægges som kritisabel, i den udstrækning den ikke lever op til de kriterier, som Habermas selv har opstillet. Et tredje kritik punkt er at ideen om kommunikativ rationalitet baserer sig på kommunikation som handling, hvor det med reference til individet giver mening at tale om succesfuld og usuccesfuld kommunikation, forstået som overførsel af information (Luhmann 2002b s. 160). Habermas' ide om, at sproget i sig selv har en iboende forståelsestrang, kan diskuteres. Med dette tillægges sproget selvstændige konsensussøgende egenskaber, og man spørger, om dette er muligt? Eller sagt på en anden måde, er det ikke snarere sprogbrugerne, dvs. mennesket, som overvejende opererer ud fra en konsensustilgang i interaktion med andre? Et andet forhold er, om vi som mennesker helt intuitivt kan se og anerkende det bedre arguments argument? Dette vil være afhængigt af, at vidt forskellige menneskers indre meningsstruktureringer må være styret af en eller anden fælles transcendental fornuftsreference. Denne kritik ligger i forlængelse af den ovenfor præsenterede og udledte fra Nørager. Luhmann kritiserer Habermas for at antage, at kommunikation sigter efter konsensus og enighed. Men man kan også kommunikere med henblik på dissensus. Man kan f.eks. have et ønske om at argumentere uden, at det er mere rationelt at søge konsensus end dissensus. Det afhænger af parter og 
temaer (Luhmann 2002b s. 162). Sidste kritikpunkt vedrører kommunikationens moralske binding af kommunikationsparterne. Habermas mener, at individet er bundet af gyldigheden af kommunikationens indhold således, at den bliver handlingsanvisende. Luhmann mener imidlertid, at man empirisk kan iagttage, at der kommunikeres, og at parterne efterfølgende går ud og handler anderledes, hvorfor det er en teoretisk misforståelse at operere med et kommunikationsbegreb, som baserer sig på ideen om, at kommunikationens meningsindhold afhænger af, at parterne gør den til præmis for egen adfærd. For Luhmann er dette, som jeg vil beskrive senere, to forskellige forhold (selektioner) (Luhmann 2000a s. 188). ${ }^{100}$

\section{Konsensus og organisatorisk læring}

Ud fra et lærings- og innovationsperspektiv kritiserer William S. Isaacs, som er organisationsforsker og direktør for et dialog projekt på MIT’s Organizational learning Center, søgen efter konsensus, som i bund og grund er den Habermas argumenterer for.

"In consensus building, people seek some rational means to limit options and focus on the ones that are logically acceptable to most people. Often, the purpose of a consensus approach (the root of the word means 'to feel together') is to find a view that reflects what most people in a group can 'live with for now'. This assumes that shared action will arise out of a shared position. This assumption is questionable. While consensus approaches may create some measure of agreement, they do not alter the fundamental patterns that led people to disagree at the outset. Consensus approaches generally do not have the ambition of exploring or altering underlying patterns of meaning”. (Isaacs 1993 s. 26)

For organisationer, som $\emptyset$ nsker at være lærende, er det vigtigt at sikre et frit flow af meningsudvekslinger, og eftersom konsensus modvirker eller

\footnotetext{
${ }^{100}$ Luhmann mener, at ideen om at det meddelte skal fungere som præmis for egen adfærd, ligger uden for en elementær kommunikationssituation. "Man må hos adressaten skelne mellem forståelsen af kommunikationens selektionsmening og antagelsen eller forkastelsen af selektionen som pramis for adressatens egen adfard." (Luhmann 2000a s. 188). Man kan med andre ord sagtens forstå noget, som man kunne har kunnet forstå gennem f.eks. en kommunikationssituation, men dette bevirker ikke, at man handler i overensstemmelse med meddelelsens indhold. Det er risikabelt at ryge, drikke, spise for fedt osv., men hvis en kommunikation er afhængig af, at den enkelte, som har forstået dette handler i overensstemmelse med dette, er der meget 'kommunikation', som ikke kan betegnes 'kommunikation'!
} 
begrænser dette, dvs. ikke har ambitioner om at udforske eller ændre underliggende mønstre af mening herunder konfliktende meninger, virker det ifølge Isaacs begrænsende herpå. Man kan spore en lignende argumentation hos Weick og Westley (1996), som skriver, at det optimale for organisatorisk læring er en juxtaposition, dvs. en vekselvirkning mellem udforskning og udnyttelse, der som moment repræsenterer en krydsning (intersection) af double-loop læring (forstået som: discovery, exploration, proactive learning, revolutionary learning, frame breaking), og single-loop læring (forstået som: exploitation, adaption, habitformation, deviation reduction, reactive learning, evolutionary learning) (Weick \& Westley 1996 s. 445). Muliggørelsen af disse to læringsformer er som hos Isaacs afhængig af sikringen af et frit flow af meningsudvekslinger.

\section{Anvendeligheden af Habermas}

Selvom der kan rejses en del kritik af Habermas kommunikationsforståelse for at være for normativt orienteret, er der efter min mening også pointer som ud fra en pædagogisk, læringsorienteret og didaktisk tilgang kan iagttages som konstruktive refleksioner. I forhold til Habermas' diskursbegreb sættes der fokus på, at det ud fra en motivations- og opbakningsmæssig betragtning er en god ide at invitere sagens berørte parter. I en organisatorisk sammenhæng vil dette sige at involvere de parter, som læring eller ændringer vedrører, for at få deres viden og begrundelser i spil. Selvom Habermas kan kritiseres for hans fokus på konsensus som slutprodukt, opererer hans diskursbegreb med lignende og mere præciserende forståelser af Weick \& Westleys begreb om juxtaposition, idet diskursbegrebet omhandler og beskriver en samtale som en løsrivelse fra den daglige kommunikative handlen - fra verden - og dvs. i en frakobling af socialdimensionens hierarkisering og magtforhold. Ved frakoblingen af socialdimensionen og magtforhold gøres alle lige, og kommunikationen og de kommunikativt handlende kan koncentrere sig om sagen vedrørende forståelsen og udviklingen af viden om det fænomen eller tema, som diskuteres. Dette forhold kan vise sig vigtigt i organisationer, som ønsker at være lærende. Organisationssystemer er - $\mathrm{i}$ varierende grad - hierarkiske systemer, hvor socialdimensionen og magtforhold kan have negativ betydning for et frit flow af meningsudvekslinger, dvs. kommunikative bidrag. Man kan selvfølgeligt hævde, at det baserer sig på en kontrafaktisk forestilling at frakoble socialdimensionen, men dette udlukker ikke, at man gør sig bestræbelser derpå. Alternativet virker under alle omstændigheder ikke mere tillokkende. I stedet for som Habermas at tilskrive 
forståelsesorienteringen til sproget, kan man tilskrive mennesket den. Organisationer kan i socialdimensionen forsøge at skabe et kommunikativt 'miljø' i lighed med Habermas diskursbegreb, som baserer sig på tillid til at alle frit kan komme til orde, og at kommunikative ytringer ikke tages ilde op, og f.eks. resulterer i sanktioner overfor medarbejderne. Til sidst kan man sige, at organisationer ikke er grundlæggende afhængige af, at dens medlemmer skal være enige, men snarere at organisationsmedlemmerne sagligt har forstået, hvad der forventes af dem, så det bliver muligt for dem at handle derefter.

\section{Luhmanns sprog og kommunikationsforståelse}

I nedenstående vil jeg præsentere, hvordan Luhmann forstår sprog som medie og form på én og samme tid. Derefter præsenteres teoriens kommunikationsforstålse som enheden af forskellen mellem en treledet selektionsproces bestående af information, meddelelse og forståelse, samt kommunikationens fjerde selektion om tilslutning og afvisning af, hvorvidt informationen gøres til præmis for egen adfærd. Under kommunikationsforståelsen beskrives desuden begrebet om dobbelt kontingens relativt indgående. Dette skyldes, at begrebet om dobbelt kontingens er afgørende for forståelsen af systemteoriens kommunikationsbegreb, og for teoriens grundlæggende distinktion mellem system og omverden og herunder adskillelsen af, hvad der betegnes psykiske og sociale systemer. I forhold til sidstnævnte er tankegangen, at autopoietiske systemer opererer i hvert deres medie; sociale systemer består af og opererer i mediet kommunikation, mens psykiske systemer består af og opererer i mediet bevidsthed. Som det vil fremgå i senere kapitler er begrebet om dobbelt kontingens ligeledes vigtigt for forståelsen af forholdet mellem mennesker og organisationssystemer, herunder et teoretisk bud på det meget omdiskuterede og på mange måder uafklarede forhold mellem individuel og organisatorisk læring.

\section{Luhmanns sprogforståelse}

Ifølge systemteorien er sproget det grundlæggende medie for samfundet, organisationers og interaktioners kommunikation, og det formentlig vigtigste medie for pædagogik.

"Das grundlegende Kommunikationsmedium, das die reguläre, mit Forsetzung rechnende Autopoiesis der Gesellschaft garantiert, ist die Sprache.” (Luhmann 1997 s. 205) 
Sproget indskrives i rækken af kommunikationsmedier, som samfundet gennem sin sociokulturelle evolution har konstrueret. ${ }^{101}$ Fælles for disse medier er deres mulighed for at skabe tempofordele i kommunikationssituationer qua ego og alters (kommunikationsparternes) kendskab til dem.

Luhmann beskriver sproget som både medie og form. Medie henviser, til at sproget stiller uhyre omfattende men alligevel begrænsede muligheder parat, hvorfra kommunikation kan udvælge former, når den temporært lægger sig fast på bestemt indhold udtrykt i sætninger (Luhmann 2002 s. 86). Sproget er et medium, der er konstrueret som og er kendetegnet ved regler for tegnbrug, ${ }^{102}$ og dermed funktionelt skaber mulighed for opbygning og udveksling af kompleksitet, som systemer kan bruge til at forklare sig overfor hinanden, dvs. hvad der menes, hvordan noget føles, hvad nogen tror, hvordan man forstår, koordinerer osv. Selvom andre medier som f.eks. kropssprog, tegning/illustrationer, musik osv., anvendes i pædagogiske sammenhænge, er sproget det mest udbredte af den simple grund, at det er langt hurtigere at bruge og mere komplekst, dvs. differentieret, og derfor i højere grad og på mere præcis vis giver mulighed for kompleksitet i form af forklaringer, anvisninger, refleksion og feedback på f.eks. læringsmål.

"Måske er sproget det mest rammende eksempel på den samfundsmassige brug afforskellen mellem medium og form. Det består af en temmelig stor mangde ord samt af nogle kombinationsregler, altså en grammatik. Ordene er imidlertid ikke mediets former, men derimod dets elementer, der forudsattes som ikke yderligere oplфselige elementer ved brug af mediet. Sproget bliver forst til formdannelser når der dannes satninger, for kun satninger artikulerer kommunikation. At lare sprog sker derfor ikke på den måde, at der først laeres ord, dernaest kombinationsregler og endelig dannes satninger. Sproget bliver snarere laert umiddelbart som enheden $i$ differencen mellem medium og form. Man forsфger at danne

\footnotetext{
${ }^{101}$ Disse medier skaber funktionelt sandsynlighed for lovende kommunikation. Luhmann skelner mellem tre forskellige medier, som muliggør, begrænser og belaster hinanden med følgeproblemer. Det drejer sig om sproget, udbredelsesmedierne og de symbolsk generaliserede kommunikationsmedier.

${ }^{102}$ Kendskabet til tegnenes kombinatorik ligger til grund for ego og alters mulighed for at kommunikere i den forstand, at ensartet tegnbrug bestyrker dem i, at de mener det samme (indtil det modsatte iagttages!). Sprog øger sandsynlighed for forståelse af kommunikation langt ud over det iagttagelige, f.eks. er det med sproget muligt at tale om noget der ikke findes fysisk f.eks. enhjørninger, Gud og spøgelser. (Luhmann 2000a s. 201f.)
} 
former (satninger, satningsakvivalente udråb) og - når dette har kommunikativ succes - efterhånden at udvide det repertoire, der står til rådighed. På denne måde opstår sprogkompetence som evne til selektiv, situationstilpasset omgang med mediet." (Luhmann 2006 s. 108-109)

Med sproget som medie gives der uendelige muligheder for formdannelser. For eksempel kan et fænomen, der skal læres, forklares på mange forskellige måder (ækvivalente former), hvilket ofte iagttages og opfattes som et udtryk for en særlig pædagogisk kompetence. Jo flere forskellige måder, nogen kan forklare det samme, jo bedre pædagog! Indtræffer forståelsen ikke med den ene forklaring, må man prøve med en anden! Og ved alle forsøg på forklaringer, er der tale om både medie og form på en og samme tid. Men sprog er ikke kommunikation. Sproget bruges til at kommunikere med. Sproget er et yderst differentieret medie med et utal af ord, som åbner for uendelige kombinationsmuligheder og uendelige måder, hvorpå man kan udtrykke sig. ${ }^{103}$ I den forstand beskriver og betegner Luhmann sprogets funktion som værende et forståelses- og udbredelsesmedie og ikke et kommunikationsmedie. I det følgende vender jeg mig derfor mod at forklare systemteoriens kommunikationsforståelse.

\section{Luhmanns kommunikationsbegreb}

Nogle af de første videnskabelige teorier om kommunikation var udarbejdet af ingeniører (f.eks. Shannon \& Weaver) og havde fokus på transport af information fra en afsender, og på, hvordan afsenderen, helst så uforstyrret som muligt, kunne overføre et budskab til en modtager (se f.eks. Fiske 1990; Eide \& Eide 2007). ${ }^{104}$ Problemet med det gamle transportparadigme er, at det bygger på en antagelse om, at information skulle være det samme for afsender som for modtager: ${ }^{105}$

\footnotetext{
${ }^{103}$ Eller sagt på en anden måde; jo flere ord, man har til rådighed, jo mere differentieret kan man udtrykke sig.

${ }^{104}$ En forklaring kan være, at de gamle kommunikationsforståelser i højere grad var udviklet med henblik på ikke bare forståelse og beskrivelse af kommunikation, men også med henblik på at gøre sig overvejelser om, hvordan man ud fra en teknisk naturvidenskabelig tilgang skulle sikre udbredelse af kommunikationen til mennesker udenfor en snæver interaktiv sammenhæng, dvs. overvejelser om, hvordan massekommunikation rent teknisk var muligt.

${ }^{105}$ Dette er selvsagt en umulighed, eftersom transport betyder, at noget flyttes fra et sted til et andet, hvilket i sin yderste ontologiske konsekvens dermed skulle betyde, at når nogen
} 
"Overførselsmetaforen er ubrugelig, fordi den implicerer for meget ontologi. Den suggerer, at afsenderen overgiver noget, som modtageren modtager. Det passer ikke, allerede af den grund at afsenderen ikke giver noget bort $i$ den forstand, at han selv mister noget. Den samlede metaforik, der angår det at besidde, at have, at give og modtage, denne samlede tingsmetaforik er uegnet til en forståelse af kommunikation.” (Luhmann 2000a s. 180).

At nogle kommunikationsteorier tilføjer kontekstforståelse eller beskriver kommunikation som en proces mellem mindst to parter, hvor der produceres og udveksles betydning, hjælper ikke. ${ }^{106}$ Disse beskrivelser har f.eks. svært ved at forklare misforståelse, og de må derfor forlade sig på håbet om, at gentagelse af kommunikationen tilstrækkelig mange gange i sidste ende vil føre til en forståelse. En kommunikationsteori må derfor beskrives og organiseres på en radikalt anderledes måde. Luhmanns bud på en sådan reorganisering har omfattende konsekvenser for, hvordan man kan begribe kommunikation. Udgangspunktet for at tale om kommunikation og sociale systemers tilblivelse er ikke forståelse og kan ikke begribes ud fra en overførselsmetafor, men må grundlæggende begribes ud fra det sociales usandsynlighed.

\section{Det sociales usandsynlighed}

Her vil jeg uddybe den dobbelt kontingente situations betydning for sociale systemers opståen og fortløbende kommunikative reproduktion.

Hvordan er det sociale muligt? På hvilken måde dannes et socialt system, herunder organisationssystemer? Luhmanns svar er paradoksalt: det sociales usandsynlighed er dét, der sandsynliggør det. Eftersom systemer er omverden for hinanden, og fordi ethvert system har foretaget sine egne kontingente valg, betegnes kommunikationssituationen som dobbelt kontingent. Kommunikation er en $\mathrm{n}$ uhyre kompleks situation, fordi mulighederne er ufattelige, og fordi en løsning er nødvendig. Denne antagelse er fundamental dels fordi den vedrører den teoretiske konstruktion af det sociale som mulighed, dels fordi den danner basis for hele teorien om sociale systemer. Problemet i den dobbelt kontingente situation er adfærdsafstemningen, fordi den anden fra begge positioner er ufattelig. Hvem skal starte? Hvilket sprog og hvilken

fortæller sine erindringer selv skulle miste dem samtidig med, at de blev nogle andres (Jf. desuden Qvortrup 1996 s. 131-133, Luhmann 2000a s. 180-181).

${ }^{106}$ Et eksempel på en sådan kommunikationsforståelse findes i (Alrø \& Kristiansen 1992 s. 20). 
kode skal vælges for at kommunikere? Luhmann beskriver løsningen som et "order from noise principle." (Luhmann 2000a s. 145). ${ }^{107}$ Den ene bevidsthed kan ikke komme i kontakt med en anden, ${ }^{108}$ og må grundlæggende reducere den anden gennem kommunikation, dvs. forestille sig en modtager eller kommunikationspartner. Dette er et grundlæggende problem, som ethvert socialt system og organisationssystem er henvist til at håndtere, og løsningen bliver kommunikation.

\section{Dobbelt kontingens}

Fra den tidligere definition af kontingens som noget der hverken er umuligt eller $n \phi d v e n d i g t$, og ud fra den grundlæggende distinktion system/omverden, bestemmes den situation, hvor to eller flere systemer skal interagere med hinanden som dobbelt kontingent (dette gælder både psykiske og sociale systemer). Begge systemer fremstår fra hver sin position som kontingente over for hinanden, dvs. mulige på andre måde. Dobbelt kontingens forholder sig med andre ord til den ubestemte valgsituation, som to parter, der ønsker at kommunikere med hinanden, står i. Situationer af dobbelt kontingens kræver derfor "et mindstemål af gensidig iagttagelse og et mindstemål af forventninger, der er baseret på gensidigt kendskab" (Luhmann 2000a s. 148), men eksponerer altid kompleksitet for de involverede og fordrer derfor kompleksitetsreduktion.

Luhmann har "hentet" begrebet om dobbelt kontingens fra sociologen Talcott Parsons, men som vi skal se, omfortolker Luhmann begrebet. For Parsons er begrebet om dobbelt kontingens præget af et grundlæggende fokus på orden i studiet af sociale fænomener, som bevirker, at problemstillingen centreres om, hvordan adfærdsforventninger kan generaliseres, dvs. hvordan institutioner sikrer orden. Institutioner er hos Parsons ikke lig organisationer men det kulturelle systems værdiorienteringer, hvis samfundsmæssige funktion tilskrives en integrativ og kompleksitetsreducerende funktion ved at værdiorienteringernes moralske modus (moral mode of value-orientation) integreres i samfundets sociale systemer (organisationer) og internaliseres i personsystemer (mennesker) (Bakken 2000 s. 339). Dette bevirker, at en del af kompleksiteten reduceres ved at kommunikationens parter - ego og alter deler en kulturelt overleveret værdikonsensus, som et "shared symbolic system" af normativ karakter (Parsons \& Schils 1951 s. 51).

\footnotetext{
${ }^{107}$ Luhmann er her inspireret af Heinz von Foersters beskrivelser af selvorganiserende systemer.

${ }^{108}$ Med mindre man tror på telepati.
} 
I forhold til Parsons' konstruktion af dobbelt kontingens iagttager Luhmann to grundlæggende problemer. Det første problem er, at Parsons ikke kan forklare, hvordan det sociale er opstået i første omgang, idet han starter begrebet så at sige midt $\mathrm{i}$, eller efter en samfundsmæssig konstruktion af normer og værdier. Problemet er ikke løst idet Parsons ikke forklarer selve konstitutionen af sociale systemer, men forudsætter den og binder den til en allerede forhåndenværende kulturel kode, som om den i sig selv skulle kunne forklare dens egen opståen og funktion (Luhmann 2000a s. 144).

"Hvis man stiller sig ved evolutionens nulpunkt, er det til at begynde med usandsynligt, at ego overhovedet forstår, hvad alter mener - $i$ og med at deres kroppe og bevidstheder er adskilte og individualiserede" (Luhmann 2000a s. 199).

Det andet problem er, at denne normative konstruktion af samfundet fungerer alt for reduktionistisk som forklaringsmodel af det moderne samfunds kommunikative asymmetrisering og den variation, som kan findes i moderne organisationer. Nærmere bestemt udlægger Parsons forklaringsmodel for rigide strukturelle begrænsninger for sociale systemers emergens, der ikke kan forklare den autonomi og pluralitet i meningskonstruktioner, som kendetegner det moderne samfund.

"This theoretical precommitment to "normative integration", moreover, forces us to say that even a slave, even a criminal, and even a hippie "ultimately recognize and accept" the prevailing values of society.” (Luhmann 1982 s. 74)

Ifølge Luhmann er problemet i den dobbelt kontingente situation stadig som hos Parsons adfærdsafstemningen, fordi den anden fra begge positioner (dobbelt) er ufattelig og mulig på utallige måder (kontingent). Hvem skal starte? Hvilket sprog og hvilken kode skal vælges for at kommunikere? Den dobbelt kontingente situation opstår, når to meningsoplevende systemer forsøger at kommunikere. Den drejer sig om den situation, hvor den anden fra begge positioner er ufattelig, og hvor "begge parter erfarer dobbelt kontingens og ved at ubestemmeligheden af en sådan situation for begge parter $i$ enhver aktivitet, som finder sted, får strukturdannende betydning" (Luhmann 2000a s. 148).

Luhmann beskriver løsningen som et "order from noise principle." (Luhmann 2000a s. 145). Den ene bevidsthed kan ikke komme i kontakt med en anden og må grundlæggende reducere den anden gennem kommunikation; 
dvs. forestille sig en modtager eller kommunikationspartner. Dette er et grundlæggende problem, som alle sociale og psykiske systemer er henvist til at håndtere.

Med inspiration fra Parsons benytter Luhmann begreberne alter og ego til at betegne kommunikationens to parter, men i modsætning til Parsons forudsætter Luhmann ikke nogen form for forudgående værdikonsensus eller overensstemmelse mellem ego og alter. Alter er egos egen konstruktion. I en interaktion modtager ego ikke information fra alter men konstruerer selv en distinktion for informationen og for, hvordan den meddeles:

"Alter bestemmer forst fors $\phi$ gsvis sin måde at forholde sig på $i$ en endnu uklar situation. Han begynder med et venligt blik, en gestus, en gave, og afventer, om og hvorledes ego modtager den foreslåede situationsdefinition. Ethvert følgende skridt er så i lyset af denne begyndelse en handling med kontingensreducerende, bestemmende effekt - det vare sig positiv eller negativ." (Luhmann 2000a s. 145).

Kommunikationen kan begynde sin færd eller - lige så væsentligt - afbrydes. I den udstrækning kommunikationen fortsætter, dannes et socialt system. Om dette sociale system og ego/alters position i dette siger Luhmann:

"De forbliver adskilte, de smelter ikke sammen, de forstår ikke hinanden bedre end før; de koncentrerer sig om det, som de kan iagttage ved den anden som system-i-omverden, som input og output, og laerer $i$ givet fald selvreferentielt $i$ hver deres eget iagttagelsesperspektiv. Det som de iagttager, kan de fors $\phi$ ge at $\phi v e$ indflydelse på gennem deres egen handlen og ved feedback lare yderligere. På denne måde kan en emergent orden opstå, en orden som er betinget af kompleksiteten i de systemer, som gør denne orden mulig, men den er ikke afhangig af, om denne kompleksitet også kan beregnes eller kontrolleres. Vi kalder denne emergente orden for et socialt system." (Luhmann 2000a s. 150) $)^{109}$

\footnotetext{
${ }^{109}$ Kneer \& Nassehi har en et godt eksempel på, hvordan sociale og psykiske systemer er selvreferentielt lukkede for hinanden, og derfor ikke kan tilregnes samme konstruktioner, dvs. samme og fælles forståelser. Som jeg senere skal komme ind på er virkeligheden hverken en social eller en psykisk konstruktion men systemrelativ, dvs. både/og. "Hvem har ikke gjort den erfaring, at den samtale, man deltager $i$, og det, man samtidig tanker på, kan gå helt forskellige veje? (...) Kommunikationen skaber fra det ene фjeblik til det naste en ny tilslutningskommunikation, og de bevidsthedssystemer, der deltager i kommunikationen, skaber fra det ene фjeblik til det naste deres egne følgetanker, uden at de to forskellige typer netvark forlфber parallelt eller overlapper hinanden.” (Kneer \& Nassehi 1997 s. 76-77).
} 
Ud fra en systemteoretisk betragtning er psykiske og sociale systemer opstået og udviklet ad co-evolutionens vej (Luhmann 2000a s. 318-319), dvs. de er medvirkende til udvikling af hinandens kompleksitet, og her har sproget som beskrevet ovenfor en særlig funktion. Systemteorien skelner imidlertid, som jeg skal uddybe nedenfor, mellem medierne sprog og kommunikation.

Men hvordan begriber Luhmann mere specifikt kommunikation og dermed de nærmere betingelser for kommunikationens opståen og videre færd?

\section{Kommunikation som selektion (information, meddelelse og forståelse)}

Som det fremgår foroven, kan tanker ikke kommunikere. Ingen tanker kan komme i berøring med andre tanker, hvilket ville betyde tankeoverføring eller telepati. Det er derimod dét, der er kommunikeret, der kommunikerer altså kommunikationen. En organisation er derfor, som tidligere beskrevet, et autopoietisk system baseret på kommunikation. Hvis kommunikation $i$ et socialt system foregår selvreferentielt autopoietisk, og hvis psykiske systemer betragtes som omverden for sociale systemer (da der ikke kan være tale om input eller output af tanker og forestillinger fra de psykiske systemer), som alligevel er afhængig af deres tilstedeværelse, hvordan er det da muligt at beskrive kommunikation? Ifølge Luhmann er kommunikation en trecifret opmorksomhedsakt (Luhmann 2000a s. 183) eller en selektionsproces (Kneer \& Nassehi 1997 s. 85), der som en emergent enhed er en syntese af tre selektionsydelser eller komponenter:

1. information

2. meddelelse

3. forståelse

Selektion betyder udvælgelse blandt flere muligheder:

"Hvis man går ud fra meningsbegrebet, er det for det første klart, at kommunikation altid er en selektiv hoendelse. Mening tillader ingen andre valg end at valge. I den til enhver tid aktuelle henvisningshorisont, som kommunikationen først selv konstituerer, griber den ud efter noget og lader andet ligge. Kommunikation er processeren af selektion. [...] Den selektion, som aktualiseres i kommunikationen, konstituerer sin egen horisont; den konstituerer allerede det, som den valger, som selektion, nemlig som information. Det som den meddeler, bliver ikke blot udvalgt, det er allerede selv et udvalg, og det bliver derfor meddelt." (Luhmann 2000a s. 181) 
Den første selektion består altså i, at adressanten ${ }^{110}$ udvælger noget ud fra en horisont af muligheder - dette og ikke noget andet - hvorefter det udvalgte bliver til information. ${ }^{111}$ Den udvalgte information har flere meddelelsesmuligheder: Den kan meddeles mundtligt, skriftligt, via gestik osv. Sidst men ikke mindst kan informationen i kommunikationssituationen forstås af adressaten på den ene eller den anden måde som tilslutning/afvisning af kommunikationen. ${ }^{112}$ Kravet om forståelse er ensbetydende med kriteriet om, at kommunikationen er gennemført. Luhmann siger: "Vi går ud fra, at tre selektioner må syntetiseres, for at kommunikationen tilvejebringes som emergent haendelse." (Luhmann 2000as. 182). Herefter vil være muligt for to eller flere forskellige psykiske systemer at deltage i en ud fra kommunikationen at aflæse tilsyneladende meningsfyldt interaktion. ${ }^{113}$

"I hvert fald er enhver enkeltkommunikation rekursivt sikret i dens mulighed for og kontrol af at blive forstået som tilslutningssammenhang for yderligere kommunikation, ellers ville den slet ikke forekomme". (Luhmann 2000a s. 184)

Forståelsestesten af kommunikationen er altid medløbende og testes ved den efterfølgende tilslutningsadfærd. At forståelsestesten er medløbende betyder, at den 1) foregår udelukkende i kommunikationen og dermed 2) ikke kan henføres til det/de implicerede psykiske system(er). Dette er yderst væsentligt: En sådan forståelse af kommunikation, har stor betydning for både det psykiske system samt for sociale systemer i almindelighed, idet der ikke kan være tale om en fælles ækvivalent forståelsesorienteret betydningsdannelse internt i forskellige selvreferentielle og historisk betingede meningssystemer, som det f.eks. antages inden for transportparadigmet. Tilsvarende har det stor betydning for forståelsen af organisatorisk læring, som i denne forståelse må betegnes genuin social læring, dvs. ændringer i sociale kommunikative

\footnotetext{
${ }^{110}$ Indenfor den transportparadigmatiske kommunikationsforståelse identificeres adressanten som afsenderen af information, men her hører ligheden også op, som vi skal se.

${ }^{111}$ Information er i følge systemteoretikeren Gregory Bateson: en forskel som g $\phi r$ en forskel (Bateson 1984 s. 95).

${ }^{112}$ Adressaten er, hvad der indenfor den transportparadigmatiske kommunikationsforståelse identificeres som modtageren af information. Derudover er der intet grundlag for sammenligning.

${ }^{113}$ At der kun er tale om en tilsyneladende meningsfuld kommunikation skyldes, at man aldrig kan vide, om den anden har forstået, hvad man mener. Mere grundlæggende refererer det til psykiske systemers autonomi som autopoietiske systemer, hvilket medfører at enhver operation henvises til systemet selv. Ækvivalent betydningsdannelse er en umulighed.
} 
systemer. Bevidsthed eller tanker kan ikke deltage i kommunikationen; det er kommunikationen, der kommunikerer. Information, meddelelse og forståelse er en konstruktion i kommunikationsprocessen og ikke en operation hos bevidsthedssystemet (Kneer \& Nassehi 1997 s. 87). Selv om det umiddelbart ser ud som om, at den anden har forstået, hvad man siger, kan man ikke vide, om det er tilfældet. Kommunikation i Luhmanns terminologi muliggør ikke sådan noget som en 'intersubjektiv forståelse'.

Endelig er forståelsesselektionen den selektion, der lukker kommunikationen om sig selv. Eftersom den er kommunikationens egen, og altid medløbende forståelsestest af sig selv i kommunikationen, er det den selektion, som gør kommunikationen til et lukket autopoietisk socialt system. Det er ved opfyldelsen af netop disse tre selektioner som kommunikationens enhed, og ikke andet, at systemteorien beskriver kommunikation som noget, der kommunikerer.

Kommunikation bliver altså i Luhmanns termer et forhold af dobbelt kontingens: en højst usikker affære. Gevinsten er, at man med et sådant udgangspunkt får et redskab til at gå problemorienteret til værks. Når man tager udgangspunkt i kommunikationens usandsynlighed, sætter man fokus på sociale og psykiske systemers problemer med være og at blive lærende, og for sociale systemers og organisationssystemers vedkommende i det hele taget at blive sociale systemer.

Som det tidligere er beskrevet er læring pædagogikkens mest grundlæggende begreb. For organisationer, som ønsker at være lærende, er det ikke tilstrækkeligt, at de tror eller forudsætter, at medlemmerne eller at organisationens forskellige subsystemer har forstået, dvs. foranlediger sig på den kommunikative forståelsesselektion. Det bliver i stedet afgørende at undersøge om subsystemerne og medlemmerne faktisk har forstået, dvs. lært det af organisationen intenderede. I modsatte fald kan organisationen ikke vide om organisationsændringer i overensstemmelse med dens forventninger kan realiseres. En opgave for organisationen bliver derfor at skabe opmærksomhed om og mulighed for feedback på det tillærte i forhold til det forventede, dvs. funktion, ydelse og refleksion. Dette forhold kommer jeg nærmere ind på i afsnittet om didaktik.

\section{Kommunikationens fjerde selektion}

Udover at kommunikationen er en syntese af de tre selektioner information, meddelelse og forståelse, hvor forståelse er kriteriet for og har en kontrolfunktion i kommunikationen, muliggør den en fjerde selektion nemlig 
tilslutning/afvisning af den meddelte meningsreduktion. Denne selektion er en tilslutningshandling, som ligger udenfor enheden af en elementcer kommunikation, men som er forudsat af denne. Tilslutningshandlingen henføres til, om adressaten vælger at antage eller forkaste selektionen som pramis for egen adfærd (Luhmann 2000a s. 188), og henviser dermed til spørgsmålet om kommunikativ succes forstået som vellykkede selektionskoblinger. Denne fjerde selektion er udenfor, og derfor ikke en forudsætning for kommunikationen. Kommunikation kan være forstået og dermed realiseret, men resulterer ikke nødvendigvis i adfærdsændring. Personer siger ja (dvs. forstår), men kan gøre noget andet eller det modsatte.

\section{Organisatorisk læring og kommunikationens fjerde selektion}

Ovenstående er ud fra en systemteoretisk forståelse af organisationer som kommunikative systemer en meget vigtig pointe. Organisationsmedlemmer kan kommunikere, at de forstår, men kan efterfølgende gøre noget ganske andet. I den forståelse er organisationer ikke kun kommunikative systemer, men systemer, der - for ikke at blive overbelastet af f.eks. mistillidskompleksitet - er afhængige af, at deres medlemmer ikke bare forstår, men knytter an til og anvender kommunikationens selektioner som præmis for egen adfærd, dvs. tilslutning. Ud fra en pædagogisk didaktisk tilgang, og for organisationer som arbejder med læring, og dermed forventer, at organisationens medlemmer på baggrund af organisatoriske beslutninger ændrer handlingsmønstre, er netop dette forhold afgørende. En del teorier om læring og organisatorisk læring fokuser på dette forhold; at organisationsmedlemmer af forskellige grunde ikke altid følger organisatoriske beslutninger. Teorierne opererer med forskellige og som oftest psykologiske begreber og forklaringer for, hvad Illeris under en samlet betegnelse kalder 'barrierer mod læring' (Illeris 2006 s. 165-184). Dette kan mere præcist være forsvarsmekanismer, ubevidst inkompetence eller modstand mod læring (Argyris \& Schön 1978; 1996; Argyris 1990; Senge 2000; Chaize 1994). Ud fra en systemteoretisk tilgang kan en mulig anden forklaring være, at et socialt subsystem i organisationen ikke knytter an til organisatoriske forventninger om forandring produceret $i$ andre af organisationens subsystemer, fordi det i forhold til dets egen selvforståelse ikke giver mening i relation til systemets funktion, dvs. dets egen forståelse og fortolkning af, hvordan relationen til omverdenen skal forstås, og hvad det er sat i verden for at gøre, samt ydelse, dvs. forståelse og fortolkning af forholdet til andre omverdens systemer. 
Efter denne præsentation af den sociologiske systemteoris kommunikationsforståelse vil næste afsnit koncentrere sig om præsentation af Nonaka og Takeuchis kommunikationsforståelse. Dette er en forståelse, som har særligt fokus på, hvordan vidensudveksling og -udvikling kan realiseres i organisationer.

\section{Pædagogisk iagttagelse af Nonaka \& Takeuchis kommunikationsforståelse}

En af de organisatoriske læringsteorier, som har fokus på samt beskriver og anvender en kommunikativ tilgang til organisatorisk læring, er Nonaka og Takeuchi. Udgangspunktet for Nonaka og Takeuchis teori om The Knowledgecreating company er et fors $\emptyset \mathrm{g}$ på at forklare, hvorfor japanske organisationer har mere succes end vestlige. Dét, de kommer frem til, er et argument og en teori om, at det skyldes de japanske organisationers evne til at skabe og distribuere viden til deres produkter, services og systemer (Nonaka \& Takeuchi 1995 s. 3). Dermed kan man sige, at et af deres væsentligste argumenter ikke så meget er af læringsmæssig karakter, men af pædagogisk undervisningskarakter karakter, idet de udpeger bestemte undervisningsmæssige retningsliner eller refleksioner, som er væsentlige for distribution eller formidling af viden forstået som særlige omgangsformer for kommunikation. Helt konkret interesserer Nonaka og Takeuchi sig for og udvikler begreber, der kan optimere vidensdeling og distribution af viden i organisationer, og eftersom væsentlige elementer af deres teori handler om, at nogen skal lære noget af nogle andre, kan de betragtes som udtryk for pædagogiske refleksioner eller retningslinjer.

\section{Analog kommunikation og tavs- og eksplicit viden}

Nonaka og Takeuchis teori om The Knowledge-creating company fokuserer på, hvordan vidensudvikling og vidensinteraktion mellem tre niveauer individet, gruppen og organisationen - kan forklares og forstås. Dette gøres med reference til Michael Polyanis (opr. 1966) teori om og distinktion mellem tavs viden (Tacit knowledge) og eksplicit viden (Explicit knowledge) (Nonaka \& Takeuchi 1995 s. 59-61). Nonaka og Takeuchi beskriver vidensudvikling i meget positive termer og som en helt afgørende konkurrencemæssig ressource for organisationer, hvorfor de interesserer sig for at forklare transformationer mellem de to vidensformer tavs viden og eksplicit viden. De er af 
den overbevisning, at personers information om og deling af tavs viden sker og kan styrkes og optimeres ved anvendelse af analog kommunikation.

"Sharing tacit knowledge between individuals through communication is an analog process that requires a kind of simultaneous processing" of the complexities of issues shared by the individuals." (Nonaka \& Takeuchi 1995 s. 60)

Ud fra en systemteoretisk iagttagelse er analog kommunikation i Nonaka og Takeuchis udlægning en form for interpersonel kommunikation og dermed et kommunikationsmedie, som udover at involvere sprog også støtter sig til de kommunikerendes ansigtsudtryk, kropssprog, stemmeleje og -føring. At det er et kommunikationsmedie skal ses i lyset af forståelsen enheden af medie og form, og i så henseende er det et forholdsvist upræcist medie. For eksempel foregår meget kropssprog ubevidst, og skal som regel eller ofte oversættes eller tolkes for at give relativ præcis mening. Eller sagt på en anden måde, så er ikke alt kropssprog tydeligt og muligt at afkode, og som analogt kommunikerende ved man heller ikke nødvendigvis altid, hvad man afsender. En undtagelse herfra er selvfølgeligt tegnsprog, der er et veludviklet kommunikationsmedie, men som kræver en høj grad af kendskab, og som de færreste mestrer. Ud fra denne iagttagelse virker det som om, at Nonaka og Takeuchi lægger mere vægt på de positive og effektiviserende elementer af de analoge kommunikationsog forståelsesformer, end de mere uforståelige, utydelige og svært afkodelige aspekter, som dette medies former er behæftet med. Hvad betyder f.eks. et træk på skulderen? Dermed ikke sagt, at analog kommunikation ikke har en relevans, eller kan spille en konstruktiv medierende rolle i bestemte kommunikative sammenhænge. De fleste er bekendte med situationer, hvor f.eks. kropssprog eller toneleje enten passer eller ikke passer sammen med det sagte, hvilket i den ene form medvirker til understregning (bekræftelse) af det sagte, og modsat kan medvirke til en form for mistænkeliggørelse af det sagte. I undervisningsmæssige sammenhænge, hvor nogen skal lære noget, kan det være vigtigt at være bevidst om og at anvende de analoge kommunikationsformer, således at de illustrerer eller underbygger undervisningens tematiseringer. Ud fra en systemteoretisk betragtning vil den analoge kommunikationsform imidlertid være sekundær til en sprogligt medierende, der er mere kompleks. Den sprogligt medierede kommunikation er mere præcis i sine formgivninger qua kommunikationsparternes kendskab til mediets former, og qua dette medies større muligheder for at mediere komplekse og varierende forklaringer. Det sproglige medie er ligeledes i interaktive sammenhænge mere velegnet til præcist at fungere til feedback angående f.eks. misforståelser. 


\section{Figurativt sprogbrug og deling af viden}

Nonaka og Takeuchi anvender et kommunikationsbegreb, som knytter sig til sproget (language), for at forklare, hvordan disse transformationer i organisationen og mellem organisationsmedlemmerne sker og ikke mindst, hvordan de kan optimeres undervisningsmæssigt, med det formål at producere læring:

"Figurative language, which is especially prominent in product development, can take the form of metaphor or analogy. A metaphor or an analogy (...) is a distinctive method of perception. It is a way for individuals grounded in different contexts and with different experiences to understand something intuitively through the use of imagination and symbols. No analysis or generalization is needed." (Nonaka og Takeuchi 1995 s. 13, se også s. 66)

Effektiv vidensdeling, både når det gælder tavs og eksplicit viden, kan ske gennem eller via en kommunikationsforståelse, der i første omgang handler om særligt metaforisk inspirerede sprogliggørelser, som på tværs af kontekster og uafhængigt af individuelle erfaringer tilskrives at blive forstået intuitivt, eller som de skriver: No analysis or generalization is needed. Ved anvendelse af metaforer støttet af analoge kommunikationsformer bliver kommunikationen ud fra et undervisningsmæssigt perspektiv særligt effektiv eller optimal, idet det mere eller mindre automatisk eller intuitivt antages at producere læring. Udviklingen, distributionen, delingen og anvendelsen af viden i organisationer bliver på den måde et spørgsmål om anvendelse af bestemte former for sprogbrug i interaktionistiske sammenhænge, som er det eneste sted, hvor der er mulighed for, at analog kommunikation kan understøtte det sagte.

Ud fra en systemteoretisk forståelse kan man imidlertid spørge, hvorvidt det alene er anvendelsen af metaforer og analogier - figurativ sprogbrug - der i sig selv sikrer forståelsen af det mente? Og sker det nødvendigvis mere intuitivt end ved andre sprogligt medierede formgivelser, således at det $\mathrm{g} \emptyset \mathrm{r}$ figurativt sprogbrug mere velegnet til pædagogiske formål? Forståelsen af metaforer og analogier er ud fra en systemteoretisk tilgang afhængig af systemers kendskab til deres afkodning, dvs. af systemers kendskab til generaliserede semantiske former. Semantik eller semantiske former relaterer sig til det forhold, at for at kunne håndtere en række forskellige tematiseringer opbygger systemer kompleksitet i form af meningsfulde former som en slags "... forråd af til rådighed stående regler til meningsforarbejdning." (Op.cit. Kneer \& Nassehi 1997 s. 124). Disse koordinerende meningsfulde former, "... som står til rådighed for hurtig og hurtigt forståelig optagelse i konkrete kommunikative 
processer." (Luhmann 2000a s. 205), kalder Luhmann for temaforråd. Eller som han udtrykker det: "Vi kalder dette temaforråd for kultur, og -hvis det er reserveret til kommunikationsformål - semantik" (Luhmann 2000a s. 205), og "Med semantik forstår vi derfor en høj grad af generaliseret mening, som er disponibel relativt uafhaengigt af situation." (Op.cit. Kneer \& Nassehi 1997 s. 124).

I den udstrækning, at noget skal forstås på tværs af kontekster, må det således basere sig på generaliserede semantiske eller kulturelle former, som står til rådighed for hurtig forståelse i konkrete kommunikative processer, og forståelse i den sammenhæng kan altså ikke alene forklares ved anvendelse af bestemte medierede formgivninger som f.eks. metaforer eller analogier. Eksempelvis skal man vide, hvordan en analogi, dvs. det at forklare noget ved hjælp af noget andet, skal udlægges. Det samme gør sig gældende for metaforen, hvor karakteristika ved et objekt overføres på et andet objekt, der som oftest er u-relateret! For eksempel "jeg er hundesulten", hvor ens egen sult relateres med et alment accepteret karakteristikum ved hunde.

\section{Syntese af kommunikationsforståelser}

Afhandlingens kommunikationsforståelse baserer sig på Luhmanns forståelse som grundlæggende skelner mellem sprog og kommunikation. Kommunikation er en treledet selektionsproces bestående af information, meddelelse og forståelse mens sproget er et forståelsesmedie, som kan antage en utal af former. Når der er tale om beslutningskommunikation tilføjes kommunikationens fjerde selektion, nemlig at organisationsmedlemmer skal gøre selektionen til præmis for egen adfærd.

Med Luhmann og Habermas' teorier, der begge er repræsentanter for sociologiens kommunikative vending, er der præsenteret to meget forskellige kommunikationsteorier, som hver især vægter noget forskelligt. I denne afhandling ligger Luhmanns kommunikationsforståelse til grund for forståelsen af det sociale som systemer bestående af kommunikation. Dette betyder, at forståelse og mening konstrueres i og af lukkede selvreferentielle autopoietiske systemer. I den sammenhæng har Luhmann fokus på kommunikationens usandsynlighed, og derfor på sandsynligheden for misforståelser psykiske systemer imellem, mens Habermas overvejende opererer med en forståelses og konsensusorienteret tilgang. I afhandlingen gøres begge forståelser gældende forstået på den måde, at misforståelsesdimensionen hos Luhmann nedtones eller modificeres med hensyn til, i hvilken udstrækning kommunikationsparterne kender hinanden, har kendskab til det/de temaer, som står centralt 
i kommunikationen, tilhører samme kultur, dvs. har kendskab til fælles temaforråd, og af den vej har kendskab til generaliseret mening i form af semantik(ker), og kan genere kommunikationsmiljøer. Dette fjerner ikke sandsynligheden for mis- eller ikke-forståelser, men reducerer under givne forhold sandsynligheden i mere almen forstand.

Nonaka og Takeuchi lægger i deres forståelse op til et fokus på, hvad jeg vil betegne en pædagogisk tilgang til kommunikationens sprogliggjorte retoriske former. Med begreberne om analog kommunikation og figurativ sprogbrug henvises der til det forhold, at vidensdeling og udvikling af viden er afhængig af kommunikationsparternes forståelse, og at denne kan fremmes gennem en pædagogisk anlagt sprogbrug st $\varnothing t t e t$ af understøttende kropssprog, og gennem brugen af forskellige forklaringer og sprogligg ørelser. Som Nonaka og Takeuchi er inde på, kan det bestemt ikke afvises at den nære interaktion psykiske systemer i mellem, øger sandsynligheden for at eventuelle misforståelser eller svært forståelige forhold, har bedre betingelser, end hvis parterne skulle kommunikere gennem f.eks. skrift.

I næste kapitel præsenteres, diskuteres og beskrives teorien om sociale systemer, som baserer sig på ovenstående kommunikationsbegreb. 



\section{6}

\section{Teorien om sociale systemer}

Luhmann starter sin bog Sociale systemer - grundris til en almen teori, med: "Udsagnet $>$ der findes systemer $<$ udsiger (...) blot, at der findes forskningsgenstande, som udviser kendetegn, der retfardigg $\phi r$ anvendelsen af systembegrebet (...)” (Luhmann 2000a s. 37). Hermed lægges en analytisk distance til den empiriske verden, som betyder, at systemteorien ikke i ontologisk forstand hævder, at verden består af systemer, men at den kan betragtes med et systembegreb, dvs. som bestående af systemer.

Luhmanns sociologiske systemteori er en såkaldt 'grand theory, ${ }^{114} \mathrm{dvs}$. en teori med universelle fordringer, der potentielt omhandler og har begreber til forståelse og analyse af alt socialt, inklusivt sig selv (Luhmann 2000a s. 39). Det er en stor teori med mange begreber, som uophørligt henviser til og betinger hinanden; teorien afgrænser så at sige ikke sig selv! Ved brug af Luhmanns systemteori står man derfor altid overfor en række valg: Hvilke begreber skal valges og bringes i anvendes? I hvilken rakkefølge? Og ikke mindst, Hvordan afgranser man sig?

Jeg har, som det er fremgået ind til videre, valgt en fremstillingsform, hvor begreber er blevet introduceret undervejs, som de indgår i afhandlingens afsnit. Dette kapitel, som introducerer nogle af systemteoriens grundbegreber, kan betragtes som et egentligt teoriafsnit. Afsnittet omhandler Luhmanns organisationsbegreb, og de begreber, som vurderes at have betydning for udviklingen af en organisationsdidaktik ud fra anvendelsen af Niklas Luhmanns sociologiske systemteori.

Luhmanns særlige erkendelsesinteresse er selvskabende systemer, dvs. systemer, der har mulighed for at skabe og ændre sig selv, og dermed deres relationer til omverdenen. Systemer kaldes selvreferentielle systemer,

\footnotetext{
${ }^{114}$ Begrebet grand theory kommer fra den amerikanske sociolog C. Wright Mills som i bogen The Sociological Imagination (1959) refererede til Talcott Parsons systemteori. I den danske oversættelse af Luhmanns grundbog 'Sociale systemer - Grundrids til en almen teori' anvendes begrebet superteori (Luhmann 2000a s. 39).
} 
og deres operationsmodus betegnes med begrebet om autopoiesis. Niklas Luhmann er sociolog og interesserer sig for at udvikle en teori om det sociale - samfundet. Ifølge Luhmann kan samfundet iagttages og analyseres med tre forskellige sociale systemtyper - interaktionssystemer, organisationssystemer og samfundssystemet. I nedenstående introducerer jeg kort til disse tre systemtyper, hvorefter de uddybes og relateres til organisationsbegrebet, og hvordan de har implikationer for udviklingen af afhandlingens organisationsdidaktik.

\section{Tre sociale systemtyper}

1. Interaktionssystemer: Kommer $\mathrm{i}$ stand ved at de tilstedeværende handler, dvs. kommunikerer, og som mulighed skal kunne sanse hinanden.

2. Organisationssystemer: Sociale systemer kan betegnes som organiserede, når medlemskabet er knyttet til særlige betingelser. Organisationssystemers overordnede funktion er muliggфrelsen af handlingsforl $\phi$, som ikke kan forventes $i$ omverdenen.

3. Samfundssystemer: Samfundssystemet er det mest omfattende system, idet samfundet er mere end summen af alle interaktions- og organisationssystemer. Dette forhold henviser til, at der i samfundssystemet optræder en mangfoldighed af handlinger, som ikke bliver frembragt af interaktions- eller organisationssystemer (Kneer og Nassehi 1997 s. 46-48).

Disse tre forskellige systemtyper og psykiske systemer, som jeg forklarer senere, udviser samme kendetegn med hensyn til operationsmodus; et kendetegn, der indfanges af begrebet autopoiesis. Med den begrebslige abstraktion system gøres system- og autopoiesis begrebet derfor til almene begreber, og muliggør på den måde sammenligninger, idet man herved får mulighed for at kigge efter ligheder/forskelle mellem forskellige systemers kompleksitets håndtering af forholdet mellem system/omverden og forholdet mellem problem og løsning (Luhmann 2000a s. 37). Systemteorien rummer derfor potentialer og muligheder for komparation. I afhandlingen betyder det, at det gennem anvendelsen af de samme begreber gør det muligt at sammenligne, hvordan to forskellige systemer håndterer det at skulle laere på baggrund af et organisationsudviklingsprojekt. Sagt på en anden måde, så giver det mulighed for at iagttage det ene henholdsvis det andet systems måde at håndtere det samme. 


\section{Autopoiesis og system/omverden}

Luhmann henter begrebet om autopoiesis (grask auto: "selv" og poiein: "at skabe") fra de chilenske biologer Humberto Maturana og Francisco J. Varela, som 'opfandt' begrebet til at forklare, hvordan liv i sin simpleste form - en celle - kunne forklares (Maturana \& Varela 1987). Luhmann overfører begrebet til sin almene systemteori som en betegnelse for systemers operationsmodus ved systemdannelse, produktion og reproduktion, dvs. til at beskrive sociale og psykiske systemers operationsmodus. Følger man Luhmanns teoretiske optik, må man antage, at der findes sociale systemer, der opererer autopoietisk, dvs. selvreferentielt, på basis af meningsgenererende kommunikation. Det betyder, at de har “(...) evne til at kunne frembringe relationer til sig selv og til at kunne skelne disse relationer fra relationer til deres omverden." (Luhmann 2000a s. 49). Denne specifikke operationsmåde, som baserer sig på den grundlæggende distinktion system/omverden, betegner Luhmann som autopoietisk. Systemer er autopoietiske:

"(...)når de selv producerer og reproducerer de elementer, hvoraf de består, gennem de elementer hvoraf de består. Alt hvad sådanne systemer anvender som enhed, dvs. deres elementer, deres processer, deres strukturer og sig selv, bliver først bestemt gennem netop sådanne enheder $i$ systemet. Eller med andre ord: der forekommer hverken input af enheder $i$ systemet, eller output af enheder fra systemet. Det betyder ikke at der ikke forekommer relationer til omverdenen, men disse relationer ligger på et andet realitetsniveau end selve autopoiesisén.” (Kneer \& Nassehi 1997: op.cit.63).

Systemet trækker så at sige et skel mellem sig selv og en omverden, som det selv konstruerer, så det i første omgang som mulighed kan kende forskel på sig selv og omverdenen. Autopoietiske systemer kan ikke hente deres strukturer som færdige produkter udenfor systemet, men må opbygge dem gennem sine egne operationer (Luhmann 1997 s. 45). Dette skel betyder, at aktiviteter i systemet stilles under andre betingelser end aktiviteter udenfor systemet.

Grunddistinktionen i systemteorien udspringer af kompleksitetsmæssig asymmetri i forskellen mellem system/omverden. Omverdenen er altid mere kompleks end systemet, og et system kan kun gøre sig operationsduelig overfor omverdenen gennem opbygning af intern kompleksitet, dvs. kompleksitetsreduktion gennem kompleksitetsopbygning. Sagt på en anden måde: kun kompleksitet kan reducere kompleksitet (Luhmann 2000a s. 64). 
"Ikke noe system kan opprettholde seg selv ved hjelp av punktfor-punkt forhold til sin omverden, det vil si at det ikke kan samle $>$ tilstrekkelig variasjon $<$ for å kunne bringe det i overensstemmelse med sin omverden. Hvert system må altså redusere omverdensmessig kompleksitet - hovedsakelig ved å begrense selve omverdenen og å iaktta den på en kategorisk preformet måte. På den andre siden er differansen mellom system, og omverden et premiss for reduksjonen av kompleksitet, sidan reduksjonen kun kan utføres innenfor systemet, både for selve systemet og for dets omverden. (Luhmann 2009 s. 31)

Omverdenen er et systemrelativt produkt skabt af systemet selv, og hvert system har derfor hver sin systemskabte omverden.

Udover på samfundsplan at kunne iagttages at forøgelsen af kompleksitet er nært knyttet til systemdannelse og -differentiering, så kan det samme fænomen iagttages og beskrives i relation til organisationer. Et fænomen som har implikationer for afhandlingens beskrivelse af organisatorisk læring, og dermed udviklingen af en organisationsdidaktik. Mens systemdannelse som beskrevet i ovenstående handler om hvordan systemer helt generelt dannes, så betegner systemdifferentiering sociale systemers interne systemdannelse, dvs. udvikling af subsystemer.

"Systemdifferentiering er intet andet end gentagelsen af differencen mellem system og omverden inden for systemer. Det samlede system benytter derved sig selv som omverden for sine egne delsystemdannelser og opnår derigennem på delsystemernes nivueau højere sandsynligheder gennem forstarkede filtervirkninger over for omverdenen, som det $i$ sidste ende ikke er muligt at kontrollere. Derefter består et differentieret system ikke alene af et vist antal dele og forbindelser mellem dele. Det består snarer af et mere eller mindre stort antal operativt anvendelige system/omverdensdifferencer, som gennem forskellige skaringslinier rekonstruerer det samlede system som enhed af delsystem og omverden. Differentiering bliver så behandlet efter det generelle monster for systemdannelse, og spфrgsmålet om, $i$ hvilke former og for hvilken grad af kompleksitet systemdifferentiering er mulig, kan bindes tilbage til den udgangsdifference, som konstituerer det samlede system." (Luhmann 2000a s. 42) 


\section{Systemteoretisk læring}

Taler man om, at et system skal ændres, taler man i samme nu om noget, der minder om læring. I Luhmanns systemteoretiske termer betyder læring, at et system skal lære at iagttage sig selv og omverdenen med nye kriterier/koder (med nye forståelser og på nye måder). Hvilke konsekvenser det kan få, når man med teorien om sociale systemer arbejder med "(...) det eksplosive stof, selvreference..." (Luhmann 2000a s. 550), dvs. begrebet autopoietiske systemer, vil jeg beskrive i det følgende.

"'Learning" should be understood as an aspect of autopoiesis, i.e., as a change of structure within a closed system (and not: as adaption to a changing environment)" (Luhmann 1990a s. 18).

Når et system lærer noget, sker det ikke som en aktivitet for at genoprette ligevægten i systemet eller overfor omverdenen (se f.eks. Rasmussen 1996 s. 118-121). Forholdet mellem system og omverden er bestemt ved asymmetri, dvs. omverdenen er altid mere kompleks end systemet, hvorfor der aldrig kan komme ligevægt i dette forhold. Det giver derfor ikke mening at tale om systemers tilpasning/adaption til omverdenen. Med henvisning til organisationssystemer er begrebet om f.eks. tilpasning utopisk og kontraproduktivt fordi, hvor går grænsen for tilpasning? Man kan hævde, at i moderne funktionelt differentierede organisationssystemer er hele ideen med den funktionelle differentiering, at organisationssystemets forskellige subsystemer funktionelt er sat i verden for at kunne reducere forskellige former for kompleksitet. Den juridiske afdeling skal ikke tilpasse sig og iagttage sig selv som skole, rengøringsafdeling eller gartnere, der servicerer kommunens grønne områder men som et system, der måske nok har med disse arbejdsområder at gøre, men ud fra en juridisk iagttagelse. Et system ændrer sig på sine egne præmisser jf. begrebet om autopoiesis, som beskriver og iagttager systemer som operationelt lukkede, dvs. åbenheden er relateret til og sker kun som en intern operation, altså som et produkt af systemets egen lukkethed. Det er systemets egen fortolkning af "utilpassethed", der ligger til grund for identifikationen af områder, som det findes relevant at ændre sig på og formålet er at "mestre" omverdenens kompleksitet, dvs. opbygge tilstrækkelig og kvalificeret intern kompleksitet til at kunne leve op til egne forventninger. Eller som Luhmann skriver: "Kun kompleksitet kan reducere kompleksitet" (Luhmann 2000 s. 64) Ifølge Luhmann er det, der kan ændres, et systems strukturer. "Kun strukturer holder det, som er kontinuerligt 
(og dermed forandringsmuligt), relativt konstant." (Luhmann 2000 s. 403). Luhmann skelner her mellem to forskellige strukturelle forventningstyper.

"Forventninger, der er parate til laering, stiliseres som kognitioner. Man er parat til at andre dem, hvis realiteten viser andre, uventede sider. (...) Derimod bliver forventninger, der er uvillige til laering, stiliseret som normer. De bliver kontrafaktisk fastholdet $i$ tilfalde af skuffelse." (Luhmann 2000a s. 375-376)

Det, Luhmann her tematiserer, er, at systemer ikke nødvendigvis ændrer sig på grund af rationelle argumenter, pragmatiske løsningsforslag og lignende fra omverdenen, men ændrer sig i relation til egne interne kriterier, som måske nok kan syntes fremmedartede for andre systemer. Som udeforstående kan man ikke altid forstå eller forklare, hvorfor et system ikke ændrer sig i relation til f.eks. et bestemt tema. Eller som han udtrykker det; indimellem støder man på det forhold, at et system, som på trods af gentagne gange at være blevet skuffet i sit forehavende, og som til trods for, at andre eventuelt har fors $\varnothing \mathrm{gt}$ at fortælle om en alternativ tilgang til løsning af problemet, alligevel, og på trods, altså kontrafaktisk holder fast i f.eks. et bestemt handlemønster:

"Man kan kun tale om forandring i relation til strukturer. (...) Kun strukturer holder det, som er kontinuerligt (og dermed forandringsmuligt), relativt konstant. Strukturer garanterer på trods af hoendelsernes irreversibilitet en vis reversibilitet af forholdene. Et system kan lare på forventningernes niveau, ikke på handlingernes niveau; på forventningernes niveau kan det oplфse det, som tidligere er fastlagt, her kan det tilpasse sig ydre eller indre forandringer. Strengt taget (men af praktiske og sproglige grunde vil vi ignorere denne konvention) kan man derfor ikke sige, at $>$ et system $<$ andrer sig, da systemet består af elementer, som ikke kan andres, nemlig hondelser. På den anden side bliver systemer identificeret ved deres strukturer, og disse kan andres. For så vidt er det da også berettiget at sige, at systemer aendrer sig, hvis deres strukturer andrer sig, for når alt kommer til alt, er det noget, som hører til systemet (og netop det som gфr systemets autopoietiske reproduktion mulig), der andrer sig." (Luhmann 2000a s. 403-404)

Som det efterhånden er beskrevet flere gange skelner Luhmann ikke bare generelt mellem systemer som hver især selvreferentielle, dvs. systemer der er operativt lukkede, og derfor autopoietiske. Han skelner også mellem systemer 
der opererer i forskellige medier. Sociale systemer herunder organisationer er autopoietiske systemer der opererer i mediet kommunikation, og psykiske systemer i mediet bevidsthed. Denne skelnen mellem forskellige systemer som operativt lukkede, har hvad nogle måske vil kalde vidtrækkende konsekvenser for en af de større diskussioner indenfor teorier om organisatorisk læring, nemlig diskussionen om eller forståelsen af forholdet mellem individuel og organisatorisk læring. Jeg vil i nedenstående tage udgangspunkt i denne diskussion, og senere komme med en systemteoretisk udlægning af hvordan dette forhold kan beskrives og forstås.

Først startes med en præsentation af Argyris og Schöns begreb om organisatorisk læring, og afsnittet ender ud i en beskrivelse af hvad jeg betegner en ambivalens inden for dele af teorier om organisatorisk læring.

\section{Argyris og Schön - organisatorisk læring}

Argyris og Schön iagttager organisationer med et dobbelt blik. På den ene side taler de om a theory of action, som henviser til de bevidste og ubevidste prioriteringer og handlinger, som organisationen foretager, dvs. de fælles forståelser eller grundlæggende antagelser og regler, organisationen er konstitueret af, og som individerne er bærer af. På den anden side taler de om en organisations theory in use. Denne kan udledes ved en iagttagelse af organisationens bevidste og ubevidste (tacit) praksis, dvs. dens beslutninger og handlinger. Den analytiske pointe bliver, at individ og organisation smelter sammen til en enhed. Organisationen er individerne, og individerne er organisationen, når handlinger kan begrundes i og henføres til kollektivet/organisationen. Den naturlige konsekvens af denne sammensmeltning bliver, at Argyris og Schön ser individet som den enhed, der kan lære på organisationens vegne, idet det er den organisatoriske aktør, som kan spørge og handle på baggrund af organisationens theory in use.

Med begrebet om organisatorisk læring skelner de grundlæggende mellem produkt og proces. Produkt henviser til, hvad der er lært som tilegnelse af ny information eller viden (knowledge), og proces henviser til, hvordan der læres, dvs. hvordan eller hvad det er for en aktivitet som proces, der udføres, når der læres.

"The generic schema of organizational learning includes some informational content, a learning product, a learning process which consists in acquiring, processing, and storing information; and a 


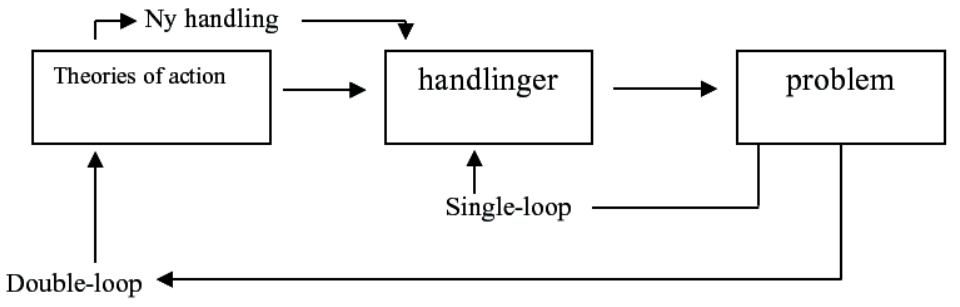

(Mary Jo Hatch 1997 s. 372)

Argyris og Schön forklarer selv single- og double-loop-learning på følgende måde:

Figur 5 Argyris \& Schön - Single- \& double-loop-Learning

learner to whom the learning process is attributed." (Argyris \& Schön 1996 s. 3)

Kardinalpunktet eller katalysatoren for igangsættelse af en læreproces udspringer af et læringsorienteret individs oplevelse af tvivl (doubt), der stammer fra en "problematic situation", som forklares ved en diskrepans mellem koblingen intention (deliberate thought) og handling (action), og resultatet af disse to komponenter, leder til en undersøgelse (inquiry) af diskrepansens grunde (Argyris \& Schön 1996 s. 11). Dette udtrykker de således:"Organizational learning involves the detection and correction of error." (Argyris \& Schön 1978 s. 2).

Denne læringsforståelse syntes meget rationalistisk og kognitivt betinget, eftersom det antages at læring foregår ved et individs kognitive erkendelse af et konkret problem, som efterfølgende søges løst gennem en rationelt orienteret erkendelses og kommunikations proces, der munder ud i en fornyet handlingsstrategi (theory in use).

En sådan løsning (correction) kan ifølge Argyris og Schön differentieres i to forskellige strategier eller læreprocesser, som de kalder henholdsvis Singleloop-learning og Double-loop-learning. Disse to læreprocesser er illustreret i nedenstående figur.

Argyris og Schön forklarer selv single- og double-loop-learning på følgende måde:

Single-loop-learning:" When the error detected and corrected permits the organization to carry on its present policies or achieve its present objectives, then that error-detection-and-correction process is single-loop learning." (Argyris \& Schön 1978 s. 2-3) 
Double-loop-learning:"Double-loop learning occurs when error is detected and corrected in ways that involve the modification of an organizations' underlying norms, policies, and objectives." (Argyris \& Schön 1978 s. 3)

I modellen ses hvordan individ og organisation ses som det samme idet modellen er udtryk for en beskrivelse af organisationen som både individets single- og double-loop-leaning. Det er individet, der ved brug af organisationen og sin egen sammensmeltede theory in use, foretager organisatoriske handlinger, som resulterer i et problem, der udløser en undersøgelse, som enten kan resultere i single- eller double-loop learning. Dette er udtryk for et paradoks, som Argyris og Schön selv er delvist klar over, nemlig at individet og den individuelle læring på samme tid er både organisationen og individet selv.

"There is something paradoxical here. Organizations are not merely collections of individuals, yet there is no organization without such collections. Similarly, organizational learning is not merely individual learning, yet organizations learn only through the experience and actions of individuals." (Argyris \& Schön 1978 s. 9)

\section{Analyse af ambivalenser i organisatorisk læring}

Dette paradoks og andre kan genfindes i forhold til andre begreber indenfor organisatorisk læring. For eksempel er begrebet ambivalens blevet brugt i samme betydning. Begrebet ambivalens kommer af latin: ambi (begge sider) og valens (værdi). Indenfor litteraturen er Hamlets monolog "at være eller ikke at være" et godt eksempel på ambivalens. Kigger man på litteraturen om organisatorisk læring, kan den metaforisk beskrives som en tilgang, der opererer med en række ambivalenser, idet den opretholdes af en række forståelser, der fremstilles som lige gode eller lige dårlige. ${ }^{115}$

De amerikanske organisationsteoretikere Karl E. Weick og Frances Westley har med henvisning til følgende forståelse: "To learn is to disorganize and increase variety. To organize is to forget and reduce variety." (Weick \& Westley 1996), kaldt organisatorisk læring et oxymoron, dvs. et begreb, der

\footnotetext{
${ }^{115}$ Under alle omstændigheder fremstår organisatorisk læring ikke som et sammenhængende paradigme i Kuhnsk forstand, men bærer tværtimod præg af de mange forskellige faggrupper og interesser, som har beskæftiget og stadig beskæftiger sig med den. Og det i en sådan grad, at den som felt måske bedst kan betegnes som tværdisciplinær. Dette kan i en vis udstrækning kædes sammen med organisationsteoriens historie.
} 
modsiger sig selv. ${ }^{116}$ Lignende paradokser, ambivalenser eller uafklarede definitioner kan genfindes i litteraturen om organisatorisk læring, f.eks. at organisatorisk læring er individuel læring og/eller kollektiv læring (se Argyris \& Schön, 1996; Levitt \& March, 1988; Normann, 1985; Weick \& Westley, 1996; Wenger 2004).

Jeg mener, at grunden til, at noget beskrives som paradokser eller med ambivalens $i$ en henvisning til begreber og forståelser, der fremstilles som lige gode eller lige dårlige, skyldes uklarheder med hensyn til begrebsafklaring og begrebsdefinitioner. I næste kapitel vil jeg beskrive den sociologiske systemteori, sådan som den er udviklet hos Niklas Luhmann. Jeg mener Luhmanns systemteori tilbyder begreber som er virksomme til forståelser angående organisatorisk læring, og som kan afparadoksere eller overskride ambivalenserne. Som det vil fremgå opererer Luhmann også med paradoksbegrebet i relation til organisationer, men til forskel fra Argyris og Schön har Luhmann begreber for paradokser og for hvordan f.eks. teoretiske paradokser kan afparadokseres.

\section{Individuel og organisatorisk læring}

Jeg har tidligere skrevet, at man ud fra en sociologisk betragtning kan beskrive den individuelt orienterede tilgang som udtryk for en slags metodologisk individualisme; En tilgang som mener, at alle sociale fænomener, deres strukturer og ændringer, i princippet kan forklares ud fra individuelle egenskaber, intentioner, tanker og handlinger (se f.eks. Jacobsen \& Thorsvik 2002 s. 334; se også Kim 1993; Leymann 1989; Simon 1991; Argyris \& Schön 1978; 1996; Duncan \& Weiss 1979; March \& Olsen 1988; Swiringa \& Wierdsma 1994). Begrundelsen for diskussionen, eller hvad man kunne betegne en slags ambivalent og uløst tilgang til forholdet mellem individuel og organisatorisk læring mener jeg systemteorien har et alternativt bud på. Et bud, som i stedet for at smelte individuel og organisatorisk læring sammen og betragte det som udtryk for det samme, så skelner systemteorien mellem læring i psykiske systemer (individuel læring), og sociale systemers læring (organisatorisk læring). Jeg har tidligere $\mathrm{i}$ afsnittet om kommunikation beskrevet dobbeltkontingens som det forhold, at systemer qua deres autopoietiske operationsmodus fra

\footnotetext{
${ }^{116}$ Hertil kunne man tilføje, at grunden til, at de ser det som et oxymoron, er fordi de ser det som et nul sum spil! Det vil sige at ud fra en matematisk kalkule bliver en forøgelse minus en tilsvarende reduktion til nul. Spørgsmålet er, om det overhovedet giver mening, at tale om organisatorisk læring som et nul sums spil, eller om det findes en anden og måske bedre forklaring?
} 
hver sin position er ufattelige for hinanden. Jeg har ligeledes beskrevet, at systemteorien med sit kommunikationsbegreb skelner skarpt mellem ikke bare systemer i generel forstand, men specifikt mellem sociale og psykiske systemer. Sociale og psykiske systemer er ikke bare lukkede, selvreferentielle og autopoietiske systemer, men tillige systemer som opererer i hvert deres medie. Sociale systemer opererer i og reproducerer sig selv ved hjælp af mediet kommunikation, og psykiske systemer opererer i og reproducerer sig selv ved hjælp af mediet bevidsthed. Sociale systemer kan ikke tænke, og psykiske systemer kan ikke kommunikere (Luhmann 1995d s. 122). Dette betyder ud fra et systemteoretisk perspektiv, at det individuelle og det organisatoriske er skilt ad, og at læring i et organisationssystem ikke automatisk kan ses som udtryk for læring i et psykisk system og vice versa. Læring er de operationer, der medfører tilstandsforandringer i ét systems autopoiesis, hvor visse af disse kan karakteriseres som 'her og nu'-viden, der enten genbenyttes og kondenseres til erfaring - eller ikke-genbenyttes og glemmes (Luhmann 1997d s. 181). Systemteoretisk er læring altså ét systems strukturelle ændringer af sig selv gennem dets egne selvreferentielle operationer, dvs. autopoiesis. Og eftersom et systems autopoiesis kun kan operere indenfor et systems egne grænser, kan læring i ét system ikke tilskrives også at være læring i et andet system. Dette betyder imidlertid ikke, at der ikke kan være tale om læring i to eller flere systemer på en og samme gang, og at systemernes læring kan ligne hinanden. Systemteoriens grunddistinktion er system/omverden hvilket betyder, at systemer ikke bare er relateret til omverdenen, men afhængige af omverden for at deres autopoiesis kan operere. Sociale systemer, herunder organisationssystemer er afhængige af psykiske systemers bevidsthed: "It should be noted only as a precaution that this naturally does not mean that communication is possible without life and consciousness." (Luhmann 2002b s. 157) Kommunikation og bevidsthed er evolutionært koblet til hinanden. "The evolution of social communicarion is possible only in a constantly operative link with states of consciousness." (Luhmann 2002c s. 173) Kommunikation og bevidsthed(er) udvikles i en slags co-evolution, hvor de bruger hinanden som medie til opbygning af egenkompleksitet.

"Just as visual and auditory perception use light and air precisely because these cannot be seen or heard as media, so communication uses the mind as a medium precisely because communication does not thematize the mind in question.” (Luhmann 2002c s. 175)

Organisationssystemer er således strukturelt koblet til psykiske systemers bevidsthed i et forhold der kan beskrives som gensidig afhængighed. Det er 
derfor evident, at kommunikation kun kan forekomme indenfor en omverden bestemt af de muligheder (conditions) og afhængig af de begrænsninger (limitations) som er sat af denne omverden. (Luhmann 2002b s. 161) Dette kommer f.eks. til udtryk gennem organisationers søgen efter ansættelse af medarbejdere som forventningsvis har den viden og de kompetencer der kræves for at bestride bestemte stillinger, og til at udføre bestemte funktioner og ydelser for systemet. Eller udtrykt på en anden måde, så må der være en vis form for overensstemmelse mellem viden og kompetencer psykiske og sociale systemer i mellem. Dette forhold vil jeg beskrive nærmere med begreberne om operativ lukning og strukturel kobling.

\section{Operativ lukning og strukturel kobling}

Operativ lukning vedrører og henviser til det forhold at systemer der opererer autopoietisk reproducerer sig selv gennem deres egen produktion. Intet fra omverdenen slipper ind i systemet. Systemet er så at sige kun åbent for omverdenen gennem sin egen lukning. Dette forklares med at autopoietiske systemers åbning altid sker i en selvhenvisning, altså i relation til systemets historisk opbyggede kompleksitet. (Luhmann 2006 s. 50-51) Men hvordan kan sociale og psykliske systemer så anvende hinanden? Hvordan kan relationen mellem bevidsthed og kommunikation beskrives når de respektive systemer

forstås som operativt lukkede systemer, og hinandens omverden? Spørgsmålet er mere præcist hvordan forholdet mellem kommunikation og bevidsthed kan forstås. Det er netop det forhold som ud fra systemteorien gør det muligt at operere med en alternativ forståelse til forholdet mellem individuel og organisatorisk læring.

Ifølge system teorien kan kommuniaktion og bevidsthed ikke gribe ind i hinanden - de realiseres i hvert deres selvreferentielt lukkede system, og hvert deres medie. Systemer kan ikke gribe ind i hinanden autopoiesis, men de kan koble sig strukturelt, dvs. stille kompleksitet tilrådighed for hinanden. En jurist kan stille sin juridiske viden og kompetencer tilrådighed for f.eks. et organisationssystem, ligesom en mekaniker, pædagog, gartner, læge osv. Det betyder ikke at den enkelte jurist, mekaniker, pædagog, læge osv. smelter sammen med, og bliver til organisationen. De forbliver psykiske systemer i organisationens omverden, men systemer som organisationen kan trække på i relation til løsning af dets opgaver. Ligesom sociale organisationssystemer er afhængige af psykiske systemer, er psykiske systemer også afhængige af sociale systemer. Psykiske systemer er afhængige af inklusion til sociale systemer i relation til at få adgang til opgaver, hvor de får mulighed for at 
anvende bestemte sider af sig selv, f.eks. er læger afhængige af ansættelse i bestemte lægelige stillinger for få adgang til at aktualisere og anvende bestemte vidensformer og kompetencer osv. Man kan her tilføje, at jo mere specialiseret et socialt system er, jo mere er det afhængigt af psykiske systemer med en helt særlig viden og kompetencer, og vice versa. Systemer danner med andre ord strukturer, der passer til bestemte omverdener. (Luhmann 2006 s. 52)

Strukturel kobling henviser altså til at systemer er henvist til hinanden, og grundlæggende gensidigt afhængige af hinanden. Systemerne kan anvende hinandens kompleksitet i egen autopoiesis, og til opbygning af strukturel egenkompleksitet (læring). Systemerne kan ikke kausalt gribe ind i hinanden, men de kan forsøge at påvirke hinanden, f.eks. kan et psykisk system fors $\emptyset$ ge at gøre sin viden, mening eller andet gældende i en kommunikationssituation, men det betyder ikke, at kommunikationen kommer til at forløbe efter det psykiske systems bevidsthedsmæssige hensigter og forestillinger - bevidstheden kan ikke kausalt kontrollere kommunikative forløb.

I et undervisningsforløb kan psykiske systemer persipere, iagttage og koble sig til undervisningskommunikationen med henblik på opbygning af ny egenkompleksitet. Sociale systemer f.eks. organisationssystemer, kan koble sig strukturelt til psykiske systemer, og i den udstrækning systemet ændrer sine strukturer for beslutningstagen ved hjælp af de psykiske systemers kommunikative bidrag, er der sket en organisatorisk forandring (læring). Men bare fordi en strukturel forandring finder sted i et organisatorisk system betyder det ikke også, at det psykiske system nødvendigvis har ændret sig. Tværtimod kan det jo være at den organisatoriske forandring er commonsence for det psykiske system. Eller sagt på en anden måde: det psykiske system kan tænke, at den organisatoriske forandring har det (psykiske system) længe tænkt på skulle finde sted. Man kan ligeledes forestille sig, at den samme (ovenstående) organisatoriske forandring for et andet psykisk system fremkommer som noget nyt. Hvad der er nyt for nogen, er ikke nødvendigvis nyt for andre! Systemteoretisk udtrykt er forandringer i ét system ikke samtidigt, eller nødvendigvis udtryk for forandringer i andre systemer. Læring og forandring er systemteoretisk relateret til forandringer i ét system, og derfor altid system relativt. Det giver derfor ingen mening at tale om at individuel, eller organisatorisk læring er, eller kan være udtryk for det samme. Organisatorisk læring er strukturelle forandringer i sociale systemer, mens individuel læring er strukturelle forandringer i psykiske systemer. Individuel læring er bevidsthedmæssige forandringer i et psykisk system, og organisatorisk læring er kommunikative forandringer i et socialt system. 


\section{Sociale systemtyper}

For Luhmann er der som sagt tre forskellige sociale systemtyper. I det følgende vil jeg uddybende beskrive disse systemtyper, hvordan de er afhængige af hinanden, og hvordan de adskiller sig fra hinanden.

Fælles for alle sociale systemer er, at de som mindste elementer består af kommunikation, og at de opererer selvreferentielt og autopoietisk, dvs. at de i henvisning til sig selv udskiller sig fra omverdenen og selvreferentielt producerer og reproducerer de elementer, de består af. Imidlertid er de som systemdannelser forskellige i deres reproduktion, og kan derfor ikke reduceres til hinanden (Luhmann 1982 kap. 4.). Et socialt systems opbyggede kompleksitet i form af kommunikation åbner systemet overfor omverdenens kommunikation, men fordi dette foregår selvreferentielt sker det eksklusivt i relation til systemets egen opbyggede kompleksitet, hvorfor systemets åbning på samme tid logisk må betegnes som en lukning. ${ }^{117}$ Et systems opbyggede kompleksitet giver mulighed for kommunikation, og eftersom systemet benytter sig selv sin egen kompleksitet - til at kommunikere med, fremkommer åbningen mod omverdenen kun gennem systemets samtidige lukning om sig selv. Et socialt systems kommunikation producerer, reproducerer og vedligeholder derved systemets system/omverden-difference, eftersom enhver kommunikation forgår i systemet som en kommunikativ difference til omverdenen. Dette er et vigtigt, når det drejer sig om læring, fordi det hermed bliver muligt præcist at skelne mellem f.eks. hvem der skal lære og hvem, der ikke skal lære.

Netop fordi systemteoriens grunddistinktion for udskillelse af tre sociale systemtyper bestemmes af systemtypens kommunikative mulighed for kompleksitets håndtering (Luhmann 1982 kap. 4.), bestemmes systemtyper ikke af antal person eller deres privilegier, men af systemtypens særlige omgang med dobbeltkontingens og kompleksitetsreduktionsmæssige muligheder og begrænsninger (Luhmann 2000a s. 467; 1997 s. 813). Som det vil fremgå af nedenstående, er systemtyperne adskilte men afhængige af hinanden i deres muligheder for produktion og reproduktion. Tilsvarende vil det fremgå, at de på en lang række punkter unddrager sig sociologiens klassiske forestillinger om hierarkier.

\footnotetext{
${ }^{117}$ Dette gælder også et systems iagttagelse af sig selv, eftersom systemet for at iagttage sig selv medbenytter sig selv for at udskille sig selv fra sig selv.
} 


\section{Samfundssystemet som systemtype}

Samfundssystemet er som enhed det mest omfattende og komplekse sociale system, idet det indeholder alt socialt (det autopoietiske socialsystem par excellence) (Luhmann 2000a s. 471.). Eftersom kommunikation bestemmes som det sociales mindste element, kan kommunikation ikke eksternaliseres til en anden social omverden, hvorfor enhver kommunikation (i et hvilket som helst interaktions og organisationssystem) betragtes som både produktion, reproduktion og forøgelse af samfundets samlede kompleksitet (Luhmann 2000a s. 470). ${ }^{118}$ Som beskrevet $\mathrm{i}$ indledningen bestemmer Luhmann det moderne samfunds grundlæggende form som funktionelt differentieret, ${ }^{119} \mathrm{og}$ som et globalt samfund defineret ved alle de kommunikationer, der er indenfor kommunikativ rakkevidde. Samfundet er det omfattende socialsystem, indenfor hvilket alle kommunikationer forekommer, produceres og reproduceres som meningsfulde horisonter for videre kommunikation (Luhmann 1990a s. 176); meningsfulde horisonter, som samfundets organisations- og interaktionssystemer kan knytte an til og vælge som udgangspunkt for egen autopoietiske kompleksitetsopbygning.

"Die Gesellschaft zieht die Grenzen der sozialen Komplexität, weil sie die Möglichkeiten beschränkt, die in der Kommunikation erfa $\beta t$ und aktualisiert werden können. Jede Differenzierung besonderer sozialer Systeme vollzieht sich in der Gesellschaft." (Baraldi mfl. 1999 s. 63)

I forlængelse heraf er interaktioner og organisationer differentieringer og betragtes som systemer i samfundssystemet, fordi de består af kommunikation, og derfor ikke kan eksternaliseres til en anden social omverdenen (Luhmann 1990a s. 176.).

\section{Interaktionssystemer}

Interaktionssystemers grunddistinktion er nærværende/fraværende, og de opstår, når nærværende psykiske systemers gensidige iagttagelse af hinanden

\footnotetext{
${ }^{118} \mathrm{Da}$ enhver kommunikation foregår i samfundet, er samfundssystemet det eneste socialsystem, som ikke har nogen social omverden. Dette betyder dog ikke, at samfundssystemet er uden omverden, blot er det ikke en social omverden. Samfundssystemets omverden er f.eks. psykiske systemers bevidsthed, biologiske systemer, den fysiske verden osv. Alt, hvad der ikke kan bestemmes som socialt - som kommunikation - er omverden for samfundet.

${ }^{119}$ Samfundet defineres derved anderledes end når det defineres ved et begreb om kultur, nationalstat eller lign.
} 
forsøger at løse dobbeltkontingensproblemet gennem kommunikation. Alle der ikke er nærværende betragtes som fraværende, dvs. som omverden for systemet (Luhmann 1997 s. 814).

Interaktioner er karakteriseret ved at være kommunikative systemer, som er strukturelt begrænsede i tid (man kan ikke sidde over for sin kollega eller kæreste(r) i al evighed), og rum (der er grænser for hvor højt man kan råbe) og i behandling af kompleksitet, fordi systemet tvinges ind i en sekventielform, hvor kun én kan tale af gangen, og hvor kun et begrænset antal temaer, som må følge hinanden, kan behandles (Luhmann 1982 s. 71-73; 1997 s. 814-815). På grund af disse begrænsninger fremstår interaktionssystemer som sårbare, idet de let opløses ved modsigelser og konflikter, der kan resultere i en gåen hver for sig. ${ }^{120}$ Interaktionssystemer fungerer efter den grundlæggende system/omverdens difference, som betyder, at interne kommunikationer iagttages som handling, og eksterne kommunikationer (handlinger) iagttages som oplevelse (Baraldi mfl. 1999 s. 84).

Udover systemtypernes forskellige håndtering af dobbeltkontingens og kompleksitetsreduktion/tilvækst er et centralt aspekt med relevans for beskrivelse og distinktion mellem systemtyperne tid eller nærmere betegnet forholdet mellem variation og stabilitet.

"Man kan forstå et vigtigt aspekt vedrørende forholdet mellem samfund og interaktion, nemlig tidsaspektet, med begrebet episode. Interaktioner er episoder i den samfundsmassige proces. De er kun mulige på grund af den sikkerhed, der opnås ved, at samfundsmaessig kommunikation er forlфbet allerede før episodens begyndelse, således at man kan forudsatte aflejringer fra forudgående kommunikation; og de er kun mulige, fordi man ved, at samfundsmassig kommunikation også er mulig efter episodens afslutning. Interaktionens begyndelse og afslutning er kun casurer i samfundets autopoiesis. De tjener til at opnå strukturer, som ikke kan gфres kongruente med samfundet og dog udstyrer samfundet med kompleksitet ved at bygge differencer ind $i$ det. Interaktionen bringer således samfundet $i$ stand ved, at det bliver aflastet fra nodvendigheden af at vare samfund. Kun ved hjolp af denne difference kan samfundet selv opnå kompleksitet og interaktionen selv opnå en usandsynlighed, der er rig på forudsatninger. Kun ved hjalp af denne difference er

\footnotetext{
${ }^{120}$ Systemteoretisk foregår dette ved, at kommunikationer attribueres til personers ansvar og intentionalitet: man kan vide, hvem der har sagt hvad, og beslutte at handle eller lade være i overensstemmelse hermed (Baraldi mfl. 1999 s. 83)
} 
evolutionen af usandsynlig kompleksitet mulig." (Luhmann 2000a

s. 469)

Selvom interaktionssystemer rent kompleksitetsteoretisk fremstår som en enslydende eller entydig kategori, vil de empirisk set være meget forskellige i henvisning til tema(er), kommunikative bidrag og kommunikationssammenhængens brug af særligt strukturerende kommunikative regler. Udtrykt på en anden måde: Samtaler er af varierende varighed, og nogle er mere komplicerede eller sværere at forstå og deltage i end andre!

Interaktionssystemer kan iagttages som systemer, der er præget af koordineret selektivitet. Kort sagt kan et interaktionssystem (og det er her påstanden, at det $\mathrm{g} \emptyset \mathrm{r}$ de fleste) begrænse kommunikativ kompleksitet ved konditionering, dvs. i interaktionen kan anvendes forskellige restriktioner (begrænsninger), som kan betyde, at der er nogle, der får mere eller mindre direkte indflydelse på interaktionssystemets særlige måde at kommunikere på. Langt de fleste interaktionssystemer er præget af en slags forstrukturering (omverdensdifferencer), f.eks. samfundets forventninger til, hvordan kommunikation med naboen over hækken bør foregå, eller kommunikationen mellem medarbejder og leder, til forskel fra medarbejder og medarbejder, medarbejder og kunde osv. System/omverdensdifferencen og autopoiesis betyder, at det er op til systemet selv at afgøre, i hvilken udstrækning omverdensdifferencer får strukturerende betydning for systemets kommunikation. ${ }^{121}$

Fordi interaktionssystemer behandles som en anden systemtype, der er løst koblet til omverdenen i form af organisationer og samfund, kan interaktioner indstille sig på og operere ud fra anderledes begrænsninger end samfundet og organisationer. Interaktionssystemer er derfor ud fra et læringsperspektiv interessante, fordi organisatorisk læring altid vil have sin oprindelse i interaktionssystemer. Interaktionssystemer kan udvikle og eksperimentere med meningsdannelse, dvs. udvikle nye iagttagelsesformer få goe ideer!Jeg kommer tilbage til dette efter forklaringen af systemteorien organisationsforståelse. ${ }^{122}$

\footnotetext{
${ }^{121}$ Her er der ikke tale om et enten-eller men snarer et både-og, eftersom de fleste kommunikative sammenhænge både producerer nye og reproducerer gamle regler for kommunikationen.

${ }^{122}$ Det skal dog siges, at det primært gælder større kompleksitetstunge organisationer med flere subsystemer og mange ansatte, fordi sådanne komplekse organisationer f.eks. typisk er præget af bureaukratiske regler, hierarki, mange forskellige funktionelt relaterede ansatte, mange forskellige beslutninger og beslutningstagere osv. Det er herunder teoretisk muligt, at jo færre ansatte, der er i en organisation, jo større er muligheden for at nærme sig en række af de karakteristika, som hører til bestemmelsen af interaktionssystemet angående udvikling og afvikling af kommunikative konditioneringer.
} 
Ved at betragte interaktionssystemer som systemer i deres egen ret, med deres egen autopoiesis, egne regler, kommunikationer og erfaringer gives der mulighed for fremkomst af anderledes iagttagelser end dem, en organisation med sin autopoiesis genererer. Interaktionssystemer fungerer på den måde som både virkeliggørelse af organisationer og samfund, så at sige nedefra. Interaktionssysmer er hvad man kunne betegne velegnede til at eksperimentere med kommmunikative iagttagelser. Interaktionssystemer kan f.eks. oprettes med den funktion at genere nye iagttagelser af og for organisationen. En organisation kan så vælge eller fravælge gennem sin beslutningsproces i hvilken udstrækning iagttagelserne skal knyttes til organisationen, og efterfølgende knytte iagttagelserne til sin egen autopoiesis.

Både samfundet og organisationer er afhængige af interaktionssystemer, fordi denne systemtype danner det minimale område for produktion af kommunikation, og fordi interaktioner udgør de sociale systemer, hvor der eksperimenteres med udviklingen af nye forståelser. Dette betyder imidlertid ikke, at organisationer og samfund kan reduceres til interaktion. Samfundet er altid også forudsætning og samtidig omverden for interaktion. Enhver interaktion baserer sig på en høj grad af kompleksitet udviklet i andre systemtyper - samfundet og/eller organisationer.

\section{Sociale systemers iagttagelse af psykiske systemer - personer og roller}

I forbindelse med rollebegrebet i relation til organisationer trækker Luhmann på sin samfundsteori, og han slutter, at samfundets generelle differentieringsform har indflydelse på den måde, som vi er inkluderet i og ekskluderet fra systemer i samfundet. Han taler om en generel abstraktion fra indifference til difference, fra samfundssystemers totale inklusion af individet som psykoorganisk enhed, til samfundets henvisning til multiple aspekter ved livet af konkrete individer (Luhmann 1982 s. xx). ${ }^{123}$ Dette betyder, at organisationssystemer på samme tid inkluderer med henblik på udfyldning af en bestemt funktionelt defineret rolle for organisationen, og samtidigt ekskluderer individet som psyko-organisk enhed (Luhmann 1982 s. xx).

Til forskel fra tidligere tiders samfund - det segmentære og det stratificerede - hvor der blev opereret med en inklusionsform i samfundssystemet ud fra et generelt princip om indifference, er vi i dag overtrådt til en mere

\footnotetext{
${ }^{123}$ Bare for at der ikke skal opstå en misforståelse, så er grunden til at der xx i referencen, fordi det $\mathrm{i}$ bogen ER side $\mathrm{xx}$ !
} 
kompleks og selektiv form, som på en og samme tid opererer med en systembestemt inklusions- og eksklusionsform. I den segmentære samfundsform, som var karakteriseret ved en uddifferentiering i ens delsystemer - stammer, klaner, landsbyer, familier osv. - var individet multifunktionelt relateret til systemet og inkluderet indifferent. Denne inklusionsform kan forklares ved den etymologiske betydning af individbegrebet, som på latin hedder individuum og betyder noget udelt eller udeleligt (Lübcke 1995 s. 211).

I det stratifikatorisk differentierede samfund er uddifferentieringen karakteriseret ved ulige sociale lag og bevirker, at interaktion er positionelt bestemt. Man omgås mennesker i overensstemmelse med den position, man har. Man tilhørte en bestemt social klasse, og denne udgjorde et lag, der lukkede sig om sig selv, og som primært var reguleret gennem endogamisk inklusion/eksklusion. ${ }^{124}$ Som vi har set, opereres der i tidligere samfundsformer med en indifferent form af individet eller mennesket, som betyder "hele" mennesket som en psyko-organisk størrelse, der er indkapslet i et tilforordnende samfundssystem (segment eller lag), hvilket adskiller sig drastisk fra den måde, som organisationer i det moderne samfund forholder sig til individet på.

Med henvisning til det moderne samfunds uddifferentiering udskifter Luhmann indifferens begrebet med et differens begreb, som først og fremmest udskifter det holistisk orienterede psyko-organiske individbegreb med et personbegreb. Grundpræmissen for dette er, at "Individer kan ju inte fördelas existentiellt på funktionssystem." (Op.cit. Jönhill 1997 s. 190) i det moderne samfund. Igen kan denne inklusionsform, som Luhmann mener det moderne samfundet opererer ud fra, forklares ved den etymologiske betydning af begrebet person, som på latin hedder persona, og betyder maske, karakter og rolle (Lübcke 1995 s. 335, se også Thyssen 1995 s. 46-48).

Samfundets generelle uddifferentiering har betydet, at individet ikke længere på samme måde som tidligere behøver at være bange for samfundets integrative forventninger til normalitet, f.eks. standens forventninger til ægteskab, beskæftigelse osv. (Luhmann 1982 s. 79). Individets eksistens i det moderne samfund er tværtimod præget af skiftende inklusions- og eksklusionsforhold i relation til forskellige sociale systemers forventninger, og baserer sig grundlæggende på samtidig inklusion i mange forskellige funktionssystemer: kunde i banken, forælder til barn i skolen, stemmeberettiget ved folketingsvalg, lønmodtager på arbejdet osv. Eksklusion fra

${ }^{124}$ Endogamisk betyder ægteskab mellem medlemmer af samme stamme eller slægt. 
et samfundssystem betyder ikke automatisk eksklusion fra en række andre systemer.

"The organizational regulation of behavior, moreover, can make enormous headway when organizations have been differentiated from each other and from the rest of society. This allows them to be indifferent to the other social roles of their members, for instance, to religious belief, political activity, family condition, or neighborly relations." (Luhmann 1982 s. 79)

Inklusion i en organisation sker med andre ord i relation til en forud bestemt forventningsbestemt og højst selektiv systemintern konstruktion, som giver en række mulige muligheder (accessible possibilities) og krav (Luhmann 1982). ${ }^{125}$

Kun som kommunikation fremtræder det psykiske system som person for det sociale system, dvs. bliver iagttagelig. Med andre ord: "Personer er ikke systemer, men identifikationspunkter i kommunikationen." (Kneer \& Nassehi 1997 s. 91). Personer optræder på den måde som strukturer, dvs. som generaliserede forventninger til adresseret og adresserende kommunikation. I et organisationssystem tilskrives personer roller som f.eks. kommunaldirektør, socialrådgiver, kantinepersonale, lærer osv. Dette har den afgørende kompleksitetsreducerende funktion, at organisationen og andre ved, hvem de skal adressere bestemte kommunikationer til, og hvem de kan forvente bestemte kommunikationer fra. ${ }^{126}$

I næste afsnit vil starten på afhandlingens organisationsbegreb blive påbegyndt og diskuteret.

\footnotetext{
${ }^{125}$ Thyssen udtrykker det således: "Masken er systemets eget produkt. Den tager form af funktion. Hvad der ligger bag masken er uvedkommende. Derfor vækker det kritik, hvis homoseksuelle ikke må være politibetjente. Rollen som betjent er ikke defineret seksuelt." (Thyssen 1995 s. 46)

${ }^{126}$ Pointen med Luhmanns beskrivelse er netop, at det psykiske system ikke i sig selv indtræder i kommunikationen, men netop kun gør det som det personificerede psykiske system. Måden, hvorpå det sociale system tilskriver personer værdi i systemet, vil derfor aldrig være ækvivalent med psykiske systemers kompleksitet. At roller synes at tvinge sig igennem, skyldes dermed heller ikke, at det sociale system siver ind i det psykiske system men nærmere det forhold, at roller reducerer kompleksitet og dermed har og giver tempofordel. Såfremt et socialt system skulle orientere sig efter psykiske systemer som individer, ville kompleksiteten blive uoverstigelig og resultere i dysfunktion og potentielt systemets kollaps. Problemet ville helt konkret være, at systemet aldrig ville vide, hvem der taler og med hvilket perspektiv: taler en person ud fra det forhold, at hun er kvinde, leder, pedel eller noget helt andet? Omvendt må systemet forholde sig til og i mere eller mindre grad kæmpe med det forhold, at det ikke kender sin omverden, og at reduktion af kompleksitet medføre ny kompleksitet.
} 


\section{Organisationsbegrebet i et sociokulturelt perspektiv}

Ligesom indenfor organisationsteorien er der store forskelle på, hvordan organisationsbegrebet defineres indenfor teorier, som anvendes til forskning i organisatorisk læring. En af de teorier, som de senere år har vundet indpas som alternativ til andre tilgange til læring og organisatorisk læring er Lave og Wengers teori om situeret læring (mesterlære): Situated learning - Legitimate peripheral participation (opr. 1991) (se Dahl mfl. 2002; Elkjær 1999b; 2005; Nielsen 2008; Eastereby-Smith \& Lyles 2005; Gherardi \& Nicolini 2001). ${ }^{127}$ Teorien er relevant at beskæftige sig med fordi den er relativt udbredt indenfor feltet organisatorisk læring, og dens tilgang til organisatorisk læring er at det skal forstås som en social proces. Fokus for denne analyse vil imidlertid primært være på teoriens organisationsbegreb, dvs. hvordan den forstår organisation. Denne teori:

"... reprcesenterer et sociokulturelt perspektiv (...) et mere socialt og kollektivt syn på, hvordan menneskelige forestillinger og menneskelig viden skabes og videreføres. Udvikling er - i et sociokulturelt perspektiv-socialisation til en verden af handlinger, forestillinger og samspilsmønstre, som er kulturelle, eksisterer $i$ og gennem kommunikation og derfor er forskellige i forskellige samfund og miljøer.” (Säljö 2003 s. 72)

I stedet for en enhedslig forståelse af viden har teorien et differentieret syn på, hvad viden er, og hvordan viden skal forstås og gøres gældende i bestemte sammenhænge, hvilket man kan argumentere for harmonerer med organisationers interne differentiering i afdelinger, organisationers forskellige verdener eller miljøer af handlinger, forestillinger og samspilsmønstre. Teorien fremhæves ofte som et godt alternativ, fordi den til forskel fra andre medreflekterer og betragter læring ud fra en sociokulturel epistemologi, ${ }^{128}$ hvor læring ikke bare ses isoleret som individuel læring, der ofte associeres med kognitiv

\footnotetext{
${ }^{127}$ I Danmark er der flere forskere, som anvender tilgangen til forskning i læring indenfor mange forskellige kontekster (se Pedersen 2003; Nielsen 1999; Nielsen \& Kvale 1999; 2003).

${ }^{128}$ Med henvisning til Lave og Wengers teori om mesterlære skriver Säljö, at de: ”...giver en interessant beskrivelse af, hvordan mesterlæren fungerer som pædagogisk miljø. (...) Da individets identitet og selvopfattelse er en væsentlig del af læringen, skabes der en loyalitet mellem eleven og faget, mellem mesteren og lærlingen. Sidstnævnte er tvungent til at acceptere mesterens autoritet, eftersom denne legemliggør den position, som lærlingen selv vil komme til at nyde godt af. Allerede denne beskrivelse viser os nogle vigtige aspekter ved den måde, hvorpå læring har logik og opbygning, som adskiller sig fra produktion.” (Säljö 2003 s. 46-47).
} 
teori, f.eks. Piaget (Säljö 2003; Elkjær 2005a): ${ }^{129}$ "Teorien om praksislaring bringer laring ind $i$ den sociale verden og begriber laring $i$ arbejdslivet som en social og relationel aktivitet." (Elkjær 2005a s. 51; 2005b). Bramming skriver, at Wenger ønsker at udvikle denne læringsforståelse organisatorisk. (Bramming 2001 s. 84). Det er derfor interessant og relevant at se på, hvordan den sociale, grænsesættende og relationelle verden i form af organisation bringes ind og reflekteres i teorien. ${ }^{130}$ De fleste vil betragte organisationer som sociale enheder, systemer, konfigurationer eller lignende, og det er derfor interessant at se om, og hvordan en sociokulturel teori om læring reflekterer organisatoriske forholds muligheder og begrænsninger i relation til læring i organisationer. Specielt i lyset af, at den, til forskel fra mere kognitivistisk orienterede epistemologier, tilskrives at have bedre begreb om det sociales betydning for læring.

På det læringsteoretiske område har teorien imidlertid været udsat for en del kritik. (se Rasmussen 1999; 2004; Munk 2002). Dette er en kritik, som i det væsentligste har koncentreret sig om vurdering af teoriens læringsteoretiske konsistens, hvorvidt den hviler på acceptable præmisser, og hvilke uddannelsesmæssige konsekvenser, der kan drages af teorien (Munk 2002 s. 113-125). ${ }^{131}$ Teoriens organisationssociologiske karakter har imidlertid ikke været diskuteret, dvs. forholdet mellem organisatoriske mikroprocesser og makroprocesser og dermed refleksioner over forholdet mellem organisation, praksisfællesskab og samfund. Eftersom organisationer i vid udstrækning accepteres som sociale konstellationer, er det interessant om og hvorvidt teorien om praksisfællesskaber reflekterer dels et konsistent

\footnotetext{
129"Mens den udgave af konstruktivismen, som Piaget (og andre kognitive traditioner) repræsenterer, kan siges at være en individualistisk konstruktivisme, repræsenterer et sociokulturelt perspektiv således et mere socialt og kollektivt syn på, hvordan menneskelige forestillinger og menneskelig viden skabes og videreføres." (Säljö 2003 s. 72).

${ }^{130}$ Ifølge Jens Rasmussen kan man slet ikke betegne mesterlare som situeret laring som en teori, hvorfor han omtaler den som en ide. Med reference til Merete Munks bog om mesterlære (Munk 2002 kap. 4), mener Rasmussen ikke, at den lever op til elementære kriterier for teori, dvs. spørgsmål om konsistens mellem elementer og begreber osv. (Rasmussen 2004 s. 378). På trods af, at jeg erklærer mig enig med Rasmussen og Munk, vælger jeg alligevel at kalde den en teori, eftersom den gængse reception af den foregår gennem betegnelsen teori. Desuden anvendes den indenfor forskning som en teori.

${ }^{131}$ Jeg mener, at den kritik som både Munk (2002), og Rasmussen (1999; 2004) har rettet mod ideen om praksisfællesskaber og mesterlæren på det læringsteoretiske område er af en sådan karakter, at teorien rent læringsteoretisk må forkastes. Jeg vil af den grund ikke beskæftige med det læringsteoretiske i teorien, men som det fremgår af teksten udelukkende med det organisatoriske.
} 
organisationsbegreb, dels hvorledes teorien som sociokulturel epistemologi reflektere organisationers udfordringer i et moderne differentieret samfund? Spørgsmålet om refleksionen over praksisfællesskaber i det moderne samfund, er ikke et forhold som teorien i sig selv interesserer sig for hvorfor denne diskussion eller udlægning af teorien, skal iagttages som en dagsorden afhandlingen bringer på banen.

Mens Lave og Wengers første bog om Situated Learning i al væsentlighed handler om og er en reaktion på og kritik af det vestlige samfunds skolastiske institutionalisering af undervisning og læring, rummer den ikke så mange tanker om læring i moderne organisationer. Aktuel forskning i organisatorisk læring tager derimod udgangspunkt i og anvender Etienne Wengers bog fra 1998 med titlen Praksisfallesskaber - laring, mening og identitet. Bogen tager på en helt anderledes måde empirisk udgangspunkt i og reflekterer og teoretiserer over arbejde og organisationer i nutidens vestlige samfund. De to udgivelser er også forskellige, idet der indenfor mesterlæren skelnes mellem to forskellige tilgange: en personcentreret, og en decentreret tilgang. I den personcentrerede tilgang fokuseres der på relationen mellem mesteren og den nytilkomne, mens der i den decentrerede tilgang fokuseres på relationen mellem den nytilkomne og det sociale praksisfællesskab. Sidstnævnte passer bedre til forskning i organisatorisk læring, eftersom der i organisationer ikke altid eller sjældent vil være en person som meningsfuldt kan betegnes mester i den forståelse som ligger i mesterlæretankegangen. Jeg har derfor valgt at tage udgangspunkt i denne. ${ }^{132}$

Wenger dedikerer eller fæstner ikke teorien om praksisfællesskaber til en bestemt profession, gruppe, arbejdsfællesskab, branche eller lignende. ${ }^{133}$ Teorien er da også i Danmark blevet brugt til at beskrive, reflektere og forske i så forskellige fænomener som musikalsk mesterlære (Nielsen 1998; 1999), socialarbejdere og kompetence udvikling i socialt arbejde (Keller 2004; 2009), ledelse og læring som teoretisk studie af kompetence i praksis (Bramming 2001), studier i sundhedsfaglige praksisfællesskaber - sygeplejersker og lægers læring (Just 2005), social læring og fælles praksis i forhold til lederes læring (Moesby-Jensen 2010).

\footnotetext{
${ }^{132}$ Etienne Wengers teori om praksisfællesskaber er udover inspiration fra samarbejdet med antropologen Jean lave grundlæggende inspireret af den russiske psykolog og ophavsmand til den kultur historiske skole Lev Semyonovich Vygotsky (1896 - 1934), og John Seely Brown og Paul Duguids (1991) begreb om organisatorisk læring og praksisfællesskaber.

${ }^{133}$ Et godt eksempel på, de forskellige områder teorien om mesterlære bruges indenfor er Klaus Nielsen og Steiner Kvales bog "Mesterlare - Laring som social praksis" (1999). Bogen indeholder en række artikler, som har både empiriske og teoretiske udgangspunkter.
} 


\section{Wengers praksisfællesskab som organisation}

For Wenger er begrebet praksisfællesskaber afgørende for forståelsen af organisationer, som han ser som sociale institutionelle designs rettet mod praksis (Wenger 2004 s. 274). Som jeg læser det, har Wenger to begreber for, hvad man kunne betegne organisation, dels et begreb om praksisfællesskab, dels et institutionsbegreb. Teoriens karakter med en vægtning af de to begreber som struktureringsprincipper i en organisation gør, at begge begreber skal beskrives for at kunne forholde sig til teoriens begreb om det, man mere traditionelt betegner som organisation.

"Både institutionelt design og praksis er selvstandige struktureringskilder. De interagerer og påvirker hinanden, men de bevarer deres egen integritet som kilder til struktur. (...) En organisation er (...) et møde mellem to kilder til struktur: institutionens designede struktur og praksis'emergente strukturer." (Wenger 2004 s. 278)

Et praksisfællesskab er konstitueret på ontologien om, at vi som mennesker er sociale væsener, der finder mening gennem vores engagement og deltagelse i aktiviteter og handlinger sammen med andre, og at vores deltagelse er baseret på og under indflydelse af en socialt defineret meningsfuldhed $i$ et givet fællesskab: et praksisfællesskab. Ifølge Wenger er praksisfællesskaber alle vegne, og vi er alle på en og samme gang medlemmer af mange forskellige praksisfællesskaber. De er en integreret del af vores dagligliv (Wenger 2004 s. 16-17). ${ }^{134}$ Praksisfællesskaber er endvidere defineret ved et begreb om praksis, konstitueret ved tre relationelle dimensioner: 1) gensidigt engagement, 2) fallesvirksomhed, 3) falles repertoire. ${ }^{135}$ (Wenger $2004 \mathrm{~s} .90$ ). I et praksisfællesskab er handling altid situeret i en social praksis/kontekst,

\footnotetext{
${ }^{134} \mathrm{Ud}$ fra definitionen af praksisfællesskaber er det svært at se, hvilke sociale former, der ikke kan defineres som et praksisfællesskab. Sagt på en anden måde kan alt socialt samvær og interaktion defineres som et praksisfællesskab. Ifølge Wenger må man skelne mellem et fællesskab og et praksisfællesskab (Wenger 2004 s. 89), men der er meget svært at se, hvordan man skal skelne. Wenger skriver selv om praksisfællesskaber: "De er så uformelle og så almindelige, at de sjaldent kommer direkte i fokus, men af samme grund er de også ganske velkendte.(...) De fleste praksisfallesskaber hedder ikke noget og udsteder ikke medlemskort." (Wenger 2004 s.17),

${ }^{135}$ De tre dimensioner er yderligere specificeret ved en række begreber, som jeg ikke finder afgørende at forholde mig til i diskussionen af relationen mellem et praksisfællesskab og organisation. Disse er kort: 1) gensidigt arrangement - engageret forskellighed, at gøre ting sammen, relationer, social kompleksitet og opretholdelse af fællesskab, 2) faelles virksomhed -
} 
som er historisk struktureret og meningsbestemt. De tre dimensioner indgår i forståelsen og definitionen af et praksisfællesskab ud fra den forståelse, at medlemmer af praksisfællesskabet deltager med et gensidigt engagement, bedriver fallesvirksomhed og koordinerer handlinger ud fra et falles repertoire (Wenger 2004 s. 61, 89-94). Praksisfællesskabsbegrebet er således i og for sig et overbegreb for viden, kompetencer og handling, idet viden, handling og kompetencer ud fra en decentreret tankegang, hvor der skelnes mellem individet og det sociale fællesskab, ikke er noget der udelukkende kan/skal tilskrives individet, men forstås som et produkt af en historisk struktur og en konkret social praksis/kontekst, dvs. socialt produceret af praksisfællesskabet.

"To take a decentered view of master-apprentice relations leads to an understanding that mastery resides not in the master but in the organization of the community of practice of which the master is part." (Lave \& Wenger 1994 s. 94)

Medlemskab af et praksisfællesskab defineres ikke ved, at personer kender hinanden, arbejder sammen, er del af en gruppe, et team eller et netværk, men ved gensidigt engagement (Wenger 2004 s. 90-91). ${ }^{136}$ Dette betyder, at mennesker, der arbejder med (er engageret i) samme emne - det være sig rødvinssmagning, skadesbehandling, at lave sko osv. - alle er medlem af samme praksisfællesskab af den simple grund, at de deler en form for fælles gensidigt engagement omkring en fallesvirksomhed på hvilken baggrund, de har en eller anden grad af falles repertoire. ${ }^{137}$ Et praksisfællesskab er

forhandlet virksomhed, gensidig ansvarlighed, fortolkninger, rytmer, lokal reaktion, og 3) falles repertoire - historier, artefakter, stile, værktøjer, handlinger, begivenheder, diskurser, begreber (Wenger 2004 s. 90).

${ }^{136}$ Det skal imidlertid tilføjes, at det er meget svært at se hvor og hvordan Wenger helt præcist definerer et praksisfællesskab, men som han selv udtrykker det, kan følgende være tegn på dannelse af et praksisfællesskab: "1. vedvarende gensidige relationer - harmoniske eller konfliktbetonede 2. falles måder at engagere sig $i$ samarbejde på 3. den hurtige strøm af information og udbredelse af innovation 4. fravar af indledninger, som om samtaler og samspil blot var fortsattelser af en vedvarende proces 5. meget hurtig formulering af et spфrgsmål, der skal diskuteres 6. vaesentlig overlapning i deltagernes beskrivelser af, hvem der horer til 7. viden om, hvad andre ved, hvad de kan, og hvordan de kan bidrage til en virksomhed 8. gensidigt definerende identiteter 9. evnen til at vurdere egnetheden af handlinger og produkter 10. specifikke redskaber, reprasentationer og andre artefakter 11. lokaltradition, falles historier, indforstået vittigheder, vidende latter 12. jargon og genveje til kommunikation såvel som letheden ved at producere nye 13. sarlige stile, der genkendes som udtryk for medlemskab 14. en falles diskurs, der afspejler et bestemt perspektiv på verden" (Wenger 2004 s. 149).

${ }^{137} \mathrm{Et}$ praksisfællesskabsgrænser er tidsligt dynamiske og ændres i takt med udviklingen af en given praksis, hvorfor jeg forstår en given grænse som et empirisk spørgsmål. Dette 
således ikke et arbejdsfællesskab, men defineret ved 'viden om' eller 'erfaring med' et eller andet. Jeg tolker det sådan, at mennesker der har erfaring med og viden om noget, men som ikke nødvendigvis kender hinanden og potentielt har meget forskellige erfaringer med og viden om dette noget, alle tilhører og er medlemmer af samme praksisfællesskab. Et praksisfællesskab er altså nærmere et 'videns og erfaringsfællesskab', og kan af ovennævnte grunde ikke forstås som en organisation i traditionel forstand, hvor det er muligt at definere om en person er medlem eller ej, og hvor opgaver er definerede arbejdsopgaver. Et praksisfællesskab er ikke en afgrænset enhed i medlemsforstand, men refererer nærmere til en eller anden form for tænkt videns og interessefællesskab. ${ }^{138}$

\section{Wengers institutionsbegreb som organisation?}

Som jeg skrev tidligere opererer Wenger også med et institutionsbegreb ${ }^{139}$ forstået som et socialt design rettet mod praksis. ${ }^{140}$ Wengers institutionsbegreb

laver imidlertid ikke om på selve definitionen af et praksisfællesskab, dvs. den teoretiske grænsesætning, som er den, jeg efterspørger. For yderligere uddybning af praksisfællesskabers grænser, herunder grænser til andre praksisfællesskaber, samt hvordan de samspiller med hinanden se Wenger 2004 kap. 4.

${ }^{138}$ Følgende citat er inde på noget af det samme, nemlig at praksisfællesskab ikke er sammenligneligt med en organisation. De betegner det som et netværk, men eftersom mennesker ikke nødvendigvis har kendskab til hinanden, vil jeg betvivle, at man kan tale om et netværk. "En anden form for stфtte udefra kan henfфres mere direkte under den eksplorative cendringsstrategi, ved at denne ikke ser organisationen som en afgranset størrelse, men som en del af et storre institutionelt felt. Centralt er ideen om akt $\phi r e r$ som varende deltagere i st $\phi r r e ~ n e t v a r k$, som går på kryds og tvaers af organisationers granser, men ikke desto mindre eksisterer som ressourcer og potentiale i forbindelse med nye ideer, tiltag og viden i organisationen. Antallet og kvaliteten af disse netvark eller "praksisfallesskaber" (Wenger, 1998), som medarbejdere og ledere deltager $i$ ofte afgørende for deres fleksibilitet og de roller, som de vil kunne påtage sig $i$ virksomheden, (...)" (Dahl mfl. 2002 s. 12).

${ }^{139} \mathrm{Jeg}$ bruger begrebet institution i stedet for organisation, eftersom det er det, Wenger bruger mest for det man traditionelt vil forbinde med organisationsbegrebet. Organisationsbegrebet bruges til at reflektere over forholdet mellem institutionelle strukturer og praksisfællesskabers strukturer (se Wenger 2004 s. 278).

${ }^{140}$ I Lave og Wengers første bog om praksisfællesskaber opererer de ikke med et organisationsbegreb, men med et begreb om institutioner og 'official agenda', som f.eks. en skole eller uddannelsesinstitution, og som de har et kritisk blik på (se Lave \& Wenger 1994 s. 61, 104). Det samme gør sig gældende i Wengers bog om Praksisfællesskaber. "En stor del af vores institutionaliserede undervisning og uddannelse opfattes derfor som irrelevant for dem, som prøver at laere, og de fleste af os kommer ud af denne behandling med en følelse af, at det er kedeligt og besvarligt at lare, og at vi ikke rigtigt er skabt til det.” (Wenger 2004 s. 13). 
svarer til det, der traditionelt betegnes organisation, hvor opgaver er definerede arbejdsopgaver. Institutioners design fører forskellige praksisser sammen, så institutionerne kan udføre deres arbejde. Institutioner er således dybt afhængige af praksisfællesskaber, eftersom det er praksisfællesskaberne, der har viden, handlekompetence og engagementet fra mennesker. ${ }^{141}$

"Institutionalisering skal vare i 'praksis' tjeneste. (...) Institutionalisering kan ikke $i$ sig selv få noget som helst til at ske. Praksisfallesskaber er det >virkelige arbejdes $<$ sted." (Wenger 2004 s. 277)

En institution kan anskues som en mere eller mindre heterogen samling af praksisfællesskaber (Jørgensen 2005 s. 169). ${ }^{142}$ Det er svært at udlede, hvordan institution skal begribes, da Wenger taler om institutioner i to forskellige betydninger, dels betegnes traditionelle uddannelsesinstitutioner, religion, videnskab og jura som institutioner (se Wenger 2004 s. 13, 157), dels betegnes institution som socialt designede strukturer rettet mod praksis (Wenger 2004 s. 278). Wenger anvender en væsentlig anderledes sprogbrug ved definitionerne af design sammenholdt med når han definerer praksisfællesskab. Design defineres som en pal i jorden, og tingsliggjort design som 'kun' et enkelt strukturerende element, og han sammenligner institutionsdesign med et computerprogram osv., mens praksis struktur er emergent, dvs. dynamisk osv. Det virker som om han har en bias i forholdet mellem institution og praksisfællesskab. Man kan efter min mening også diskutere, om det er overhovedet giver mening at tale om organisation i denne form, f.eks. kunne man sige at al koordinering mellem medlemmer af en organisation både formelt og uformelt, er udtryk for organisation, dvs. institutionsdesign. Dette vil ikke i enhver henseende nødvendigvis kunne beskrives i de termer, Wenger anvender. Det virker meget upræcist og forvirrende, at Wenger omtaler to så forskellige forhold, som grundlæggende er vidt forskellige, med samme begreb, og det $g ø r$ det empirisk meget svært at arbejde med begrebet. Eftersom

\footnotetext{
${ }^{141}$ Wenger betragter praksisfællesskaber som mere eller mindre autonome i forhold til institutionaliseringer. "1) De forhandler deres egen virksomhed, selv om de undertiden konstruerer en reaktion, der svarer til de institutionelle forskrifter. 2) De opstår, udvikles og opløses i overensstemmelse med deres egen læring, selv om de kan gøre det som reaktion på noget, der sker i organisationen. 3) De skaber deres egne grænser, selv om deres grænser til tider kan være kongruente med institutionelle grænser." (Wenger 2004 s. 274).

${ }^{142}$ Jørgensen bruger begrebet organisation, mens jeg, som det fremgår af afsnittet, mener det er mere præcist i relation til teorien om praksisfællesskaber at bruge begrebet institution.
} 
det særligt er organisationsbegrebet jeg interesserer mig for, vælger jeg at koncentrere mig om sidstnævnte.

"Institutioner definerer roller, kvalifikationer og fordelingen af autoritet-men medmindre de institutionelle roller kan virkeliggфres som identiteter i praksis, vil de sandsynligvis ikke vare forbundet med det daglige arbejde.

Institutioner fastlagger ansvarsrelationer gennem fundats, formål og målesystemer - men hver praksisfallesskab definerer også sit eget ansvarssystem. Ja, et institutionelt ansvarssystem vil sandsynligvis ikke vare sarligt effektivt, hvis det ikke integreres $i$ kompetencedefinitionen for de praksisfallesskaber, det skal indordne.

Institutioner tilbyder et repertoire af procedurer, kontrakter, regler, processer og politik - men fallesskaber skal inkorporere disse institutionelle artefakteri deres egen praksis, hvornår de skal følges, og hvornår de skal ignoreres.” (Wenger 2004 s. 278)

\section{Opsummering af teorien om praksisfællesskaber}

Uden at henvise eller referere til andre organisationsteoretikere anvender Wenger en række begreber f.eks. roller, kvalifikationer, autoritet, regler osv., som kan genfindes indenfor mange forskellige organisationsteorier herunder traditionel organisationsteori, f.eks. Weber (2003). Det uddybes imidlertid ikke, hvordan begreberne skal forstås, og de er ikke entydigt defineret, så det er muligt at udlede, hvordan de kan bruges empirisk. For eksempel fremstår det uklart, hvordan begreberne mere konkret spiller ind i forhold til de praksisfællesskaber, som de ifølge Wenger skal servicere. Den svage begrebsdefinition $g \varnothing r$, at teorien ikke er særlig præcis i forhold til at beskrive udfordringer vedrørende organisatorisk læring, hvorfor der i afhandlingen vil blive søgt efter andre teorier som har et mere udfoldede og præcise begreber til dette formål. Det samme forhold gør sig gældende for roller, kvalifikationer og autoritet, som heller ikke er defineret således, at man kan forstå hvad der menes med begreberne. Man kunne spørge: Autoritet til hvad? Som tidligere nævnt er Wengers institutionsbegreb tvetydigt, da det henviser to meget forskellige forhold, hvilket gør det svært at arbejde med empirisk.

Ud fra et systemteoretisk perspektiv er et krav til en teori, at den skal kunne skelne, og for at kunne skelne, må dens begreber være defineret så 
tilpas tydeligt, at det er muligt dels at diskutere dens praktiske anvendelse i relation til en empirisk virkelighed, dels hvordan dens begreber kan give anvisninger på, hvordan de empiriske iagttagelser skal relateres til teoriens forståelser.

Som det er beskrevet i teorien om praksisfællesskaber er der ikke nødvendigvis nogen overensstemmelse mellem den interne differentiering i praksisfællesskabet og interne differentieringer i institutionens design, hvorfor interne differentieringer i organisationen bliver uklare, og som i et organisationsteoretisk perspektiv er af vital betydning for forståelsen af forholdet mellem praksisfællesskaber og institutionens design. Når roller, kvalifikationer og autoritet samt forhold vedrørende interne differentieringer i organisationen fremstår uklart, fremstår det som uklart, hvordan teorien forholder sig til det tilfælde, hvor f.eks. to personer med samme uddannelse, dvs. personer som må være i praksisfællesskab med hinanden, er ansat i to forskellige afdelinger i organisationen. Ville sådanne personer forholde sig primært til praksisfællesskabets strukturerende princip, eller primært til det institutionelle designs struktureringsprincip? Ud fra et systemteoretisk perspektiv vil et praksisfællesskabs meningsdannelse interne differentiering i f.eks. hierarki osv. være relateret til organisationens og dens subsystemers beslutninger - både officielle og uofficielle. Det er derfor ikke så meget den konkrete persons viden der er afgørende, men personens rolle og de funktionelle forventninger som er knyttet hertil. En sådan tilgang vurderes som mere tidsvarende til hvordan moderne organisationer med mange afdelinger afdelinger, som udfører forskellige funktioner for organisationen fungerer.

Wenger lægger en ontologisk potentiel spænding og konflikt mellem institutionelle designs og praksisfællesskabers interne interesser. Som tidligere beskrevet oprerer den tradionelle konflikt tilgang indenfor sociologien (Gherardi \& Nicilini 2001), også med en ontologisk forståelse af konflikter indenfor organisationer. Men til forskel fra magt perspektivet som konflikt tilgangen opererer med, forholder teorien om praksisfællesskaber sig primært til praksisfællesskaber, og deres læring, hvorfor det kan konkluderes, at organisatorisk læring kan forstås som ændringer af et praksisfællesskabs tilgang til sin egen praksis, og i takt med dette at det institutionelle bør ændre sig således det understøtter praksisfællesskabets ændringer. Praksisfælleskabstilgangen ligner her mere den systemteoretiske ved at have fokus på vidensudvikling/organisatorisk læring, dvs. forøgelse af kompleksitet, og konsekvenserne af dette kan være at et subsystem/praksisfælleskab etablerer forventninger om organisatoriske ændringer. 
I relation til spørgsmålet om i hvilken udstrækning teorien om praksisfælleskaber rummer betragtninger over omverden/samfundet, så er det ikke et spørgsmål teorien forholder sig til. Teorien forholder sig til at der findes forskellige praksisfælleskaber, og at der potentielt kan være forskelle på praksisfælleskabernes erkendelsesinteresser både internt i en organisation, og mellem praksisfællesskaber situeret i forskellige organisationer. Ud af dette kan interesse forskelle og potentielt konflikter opstå. Systemteoretisk kan dette på samfundsplan f.eks. perspektiveres til de forskelle samfundets funktionssystemer er indstiftet med, nemlig at de er ligestillede, men forskellige i deres funktionelle relation til samfundet, eksemplificeret ved forskellige iagttagelseskoder og programmer. Internt i organisationer kan det systemteoretisk forklares med begrebet om intern differentiering i afdelinger med forskellige funktionelle forventninger, som hver i sær kunne udgøre et praksisfællesskab i den udstrækning man empirisk vil kunne iagttage at medlemmerne deler en form for fælles gensidigt engagement omkring en follesvirksomhed på hvilken baggrund, de har en eller anden grad af falles repertoire. Systemteoretisk vil dette dog udgøre et empirisk spørgsmål, og ikke noget der kan forudsættes på forhånd.

Kigger man på moderne organisationer er det tydeligt, specielt jo større de er, at de er internt differentieret i mindre enheder, afdelinger osv. Det er også tydeligt, at differentieringen er udtryk for en form for specialisering i Durkheims/Luhmanns forstand. Praksisfællesskaber kan indplaceres i den optik, idet de kan forstås som fællesskaber, der gennem viden og kompetencer i praksisfællesskabets sociale deltagelsesdynamik har tilegnet sig viden og kompetencer som en form for opøvelse $\mathrm{i}$ håndtering af bestemte problemstillinger, dvs. viden og kompetencer, der gør dem i stand til at løse bestemte opgaver, som organisationer har brug for, men som eksisterer uafhængigt af organisationens internt differentierede organisering.

Wenger anvender begreberne legitim og perifer deltagelse som stammer fra bogen Situated learning, som han skrev sammen med socialantropologen Jean Lave. Begreberne beskriver, som Elkjær er inde på, at læringen folder sig ud som både en proces og resultatet, og at adgangen til at deltage derfor bliver det helt afgørende i teorien. Begreberne kan også sociologisk iagttages som forskellige og processuelt gradvist skiftende roller. Jean Lave skriver selv at:

"Vi er omgivet af deltagerbaner i overflod, af personer, der deltager i forskellige praksisfallesskaber på forskellige måder og er 
forskellige fra hinanden på måder, der peger på bevagelsesbaner $i$ hver deres retninger. Sociale institutioner arrangerer deltagerbaner eller kanaler, hvorigennem der kan foregå bevagelse (...)” (Lave 1999 s. 50)

Spørgsmålet er om dette er et udtryk for læring, eller om det er en anden måde at skrive og udlægge det, som optog den symbolske interaktionistisk Erwin Goffman og hans analyser af og teoretiseringer over dynamiske rollespil som en helt naturlig del af det at interagere i hverdagen sammen med andre mennesker (Goffman 1992). Deltagerbaner (trajectories of participation) forstås som en retning eller bane, som en deltager (lærende) følger i processen frem mod fuld deltagelse. Rasmussen kalder dette en symmetriseringsformel, dvs. en formel, der udligner asymmetrien mellem det sociale praksisfællesskab og den lærende (deltageren) (Rasmussen 2004 s. 215). De fleste kender til, at ens egen eller andres identitet kan ændre sig over tid - deltagende lærende eller ej, men hvad der er interessant i en organisatorisk sammenhæng er, hvordan teorien forholder sig til f.eks. ansættelsen af en ny leder, og om teorien vil forholde sig til dette ud fra symmetriseringsformelen? En ny leder ansættes med en form for magt, autoritet eller større beføjelser end andre ansatte til at tage beslutninger i og for den organisatoriske kontekst. Hvordan vil teorien om praksisfællesskaber forholde sig til dette fænomen? Det kan være svært at se. I ovennævnte situation handler det ikke om, hvorvidt deltagere i et praksisfællesskab bryder sig om lederen eller ej. Det drejer sig om, at lederen har beføjelser og organisatorisk legitimitet til at definere forhold i og for praksisfællesskabet, og dette må derfor anses som et vigtigt anliggende at forholde sig til for en teori om praksisfællesskaber, f.eks. ledelsesbeslutningernes implikationer for læring.

\section{Beslutning som organisationsteoretisk begreb}

Uanset hvilken tilgang man vælger til organisationer og deres måde at fungere på, synes det umuligt at undgå et begreb om beslutninger. Organisationer må hele tiden foretage beslutninger i deres fors $\emptyset \mathrm{g}$ på at være organisationer. Selv det ikke at foretage en beslutning kan iagttages som en beslutning om ikke at ville beslutte (Thyssen 2000a s. 40-41). Beslutningsbegrebet har også historisk set haft en fremtrædende plads indenfor organisationsteorien, og ligesom alle andre videnskabelige paradigmer har også organisationsteoriens forskellige 
beslutningsteorier været under indflydelse af rationalitetens ophøjede status i starten af det 20 århundrede, som meningsform par excellence. ${ }^{143}$

\section{Den tidlige beslutningsteori}

Jeg vil i det følgende pege på to grundlæggende og væsentlige kriterier, som har haft stor indflydelse på den teoretiske udvikling af den tidlige beslutningsteoris begreber om ledelse og organisation, nærmere betegnet hierarki og rationalitet. Jeg vil argumentere for, at disse to begrebers betydningstilskrivning giver et uhensigtsmæssigt syn på organisationer, idet de gør sig blinde for en række væsentlige aspekter vedrørende organisationer, og at dette har afgørende betydning for afhandlingens fokus på didaktik og laering

I den tidlige beslutningsteori som også kaldes neo-klassisk beslutningsteori (Enderud 2003 s. 14), iagttages organisationer i første omgang ud fra en socialstrukturel iagttagelse af organisationer som stratifikatoriske eller hierarkiske systemer. Øverste lag i den hierarkiske struktur sættes lig ledelsen, og beslutningsbegrebet knyttes eksklusivt til de aktiviteter, som forestås på dette plan. Herved fremstår organisationer som logisk opbyggede og hierarkiske systemer, hvor arbejdsdeling og informationsstrømme er fastlagt

\footnotetext{
${ }^{143}$ Et klassisk eksempel er en af organisationsteoriens pionerer ingeniøren Frederick Winslow Taylor, som 1911 i bogen The Principles Of Scientific Management præsenterede en af de første reelle teorier om organisationer, udviklet inden for stålindustrien. Teorien var stærkt påvirket af datidens tro på rationalitet som udgangspunkt for videnskabelige teorier om organisering af arbejde. Scientific management går også meget betegnende under navnet det rationelle perspektiv eller den mekaniske organisationsforståelse (Morgan 1986; Scott 2003; jo Hatch 1997) i kraft af dens brug af teknisk rationalitet ved udformningen af funktionelt begrundede strukturer og processer til opnåelse af specifikke forudbestemte mål. Organisatorisk set ordnes og tilpasses menneskelige handlinger hinanden rationelt som tandhjul i en maskine, og en organisationen ses som et middel eller instrument, der kan tilpasses, så den mest effektivt tjener en given målopfyldelse. Rationaliteten fungerede som en uantastelig værdi, og var uløseligt forbundet med den i alle henseender bedst mulige løsning i bestemmelsen af arbejdets udformning. Tilgangen havde generelle grænsende til universalistiske præstationer for $\varnothing j \mathrm{je}, \mathrm{og}$ tjener som et godt eksempel på rationalitetens selvforståelse. En selvforståelse som forudsatte, at alting kunne og skulle styres og kontrolleres. "This paper was originally prepared for presentation to The American Society of Mechanical Engineers. The illustrations chosen are such as, it is believed, will especially appeal to engineers and to managers of industrial and manufacturing establishments, and also quite as much to all of the men who are working in these establishments. It is hoped, however, that it will be clear to other readers that the same principles can be applied with equal force to all social activities: to the management of our homes; the management of our farms; the management of the business of our tradesmen, large and small; of our churches, our philanthropic institutions, our universities, and our governmental departments." (Taylor 1998 s. iv).
} 
således, at de følger den hierarkiske struktur (Weber 2003). Den øverste ledelse tager beslutninger, som gradvist siver ned gennem hierarkiet for til sidst at blive udført af hierarkiets nedre lag. Udover at ledelsesbegrebet knyttes til beslutningsbegrebet, knyttes det yderligere til et begreb om rationalitet: ${ }^{144}$ "From the rational system perspective, organizations are instruments designed to attain specific goals." (Scott 2003 s. 33). Ledere tager ikke bare beslutninger, de tager rationelle beslutninger, dvs. beslutninger, som er optimale ud fra et spørgsmål om maksimering i forhold til organisationens målsætning. ${ }^{145}$ Tilgangen fokuserer på organisationens formelle struktur, og den tilskriver ledelse evnen til via rationalitetsbegrebet at kunne styre og kontrollere organisationen ved hjælp af præskriptive beskrivelser af arbejdsgange, regler, jobfunktioner osv.

Dette er kernen i den neo-klassiske beslutningsteoris tilgang til organisationer, som begreber om didaktik og læring må relateres til. Denne rationelle idealmodels logisk deduktive karakter har været udsat for kritik blandt andet fra den adfardsbaserede teori, som tager empirisk udgangspunkt i, hvordan beslutninger rent faktisk træffes (Enderud 2003 s. 16). ${ }^{146}$ Den adfardsbaserede teori er overvejende induktivt empirisk baseret og lægger vægten

\footnotetext{
${ }^{144}$ Retningen tager udgangspunkt $\mathrm{i}$ det rationalitetsprægede begreb om economic man, udviklet indenfor $\varnothing$ konomisk teori (Enderud 2003).

${ }^{145}$ Den rationelle idealmodel er baseret på følgende forudsætninger om beslutningstageren:

1. Han har en klar og stabil målsatning, dvs. han ved, hvad han vil. Beslutninger kan rangordnes transitivt $\mathrm{i}$ forhold til en værdimæssig præferenceskala, så det er muligt at vurdere nytten af en beslutning i forhold til målopfyldelse, dvs. A $>B>C$, og ikke $C>A$.

2. Beslutningstageren har fuld viden (information) om alternativer og alle konsekvenser, herunder sammenhængen mellem alternativer og alle deres konsekvenser.

3. Beslutningstageren antages at maksimere eller optimere sin nytte, målsætning osv. Det betyder, at han altid vælger det alternativ, som giver den største målopfyldelse, givet at alle alternativer koster ham lige meget i penge eller andre former for opofring, eller at han vælger det billigste alternativ, dvs. minimerer omkostningerne, hvis alle alternativer giver lige stor målopfyldelse (Enderud 2003 s. 30-31).
}

${ }^{146}$ To af de kendteste eksempler på kritik af den neo-klassiske idealmodel er Lindbloms begreb om Muddling through (1959), og Cohen, March og Olsens Garbage can model (1972). Politologen Charles E. Lindbloms (1959) studier af beslutningsprocesser i offentlige organisationer viser, at disse bedst kan betegnes som en Muddling through, dvs. som kunsten at rode sig igennem (Enderud 2003 s. 103). Ifølge Lindblom kan beslutningstagere, det være sig personer eller organisationer, ikke betegnes som rationelle aktører, men som nogen, der med små skridt prøver sig frem i et forsøg på at reducere usikkerhed og at undgå alvorlige varige fejltagelser. For yderligere eksempler på adfærdsbaserede beslutningsmodeller (se Enderud 2003 s. 29-138). 
på beskrivelse og analyse af "faktiske" beslutningsprocesser, modsat den neoklassiske model, som primært fokuserede deduktivt på input og output, hvorfor processen for så vidt har været en "sort kasse", man ikke har vidst eller villet vide særligt meget om (Enderud 2003 s. 16-17). Den adfardsbaserede teori har vist, at den neo-klassiske idealmodel ikke har noget hold i den virkelighed, den forsøger at sige noget om. Idealmodellen må m.a.o. betegnes som umulig at anvende.

Udgangspunktet for den neo-klassiske model er metodisk individualisme, hvor man forestiller sig, at beslutninger kan henføres til et individs (beslutningstagerens) egenskaber, intentioner, tanker, præferencer og handlinger. Beslutningstagere fremstilles som rationelle aktører, der tager rationelle beslutninger ud fra den præmis, at grundlaget for beslutning er transparent, og at det ikke byder på problemer at beskrive og bedømme alternativer.

\section{Organisatorisk læring og beslutning}

I det følgende vil jeg tage udgangspunkt i, hvad Elkjær (2005) kalder Beslutningstagning som lareproces. Med beslutningstagning som lareproces henvises der til en tilgang indenfor organisatorisk læring, der tager udgangspunkt i beslutningsteorier, og som kigger på beslutningstagen som udgangspunkt for og som udtryk for en læreproces. Elkjær begrunder tilgangen med, at der er behov for at se på og forstå, hvordan organisatorisk læring støtter beslutningstagning i organisationer (Elkjær 2005a s. 37). Argyris og Schön repræsenterer en sådan beslutningsteoretisk tilgang til organisatorisk læring, og de definerer i starten af bogen 'Organizational learning II' organisatorisk læring på følgende måde:

"The generic schema of organizational learning includes some informational content, a learning product; a learning process which consists in acquiring, processing, and storing information; and a learner to whom the learning process is attributed. Learning may be attributed to an agent insider or outside the organization, or even to the information itself, as one says that "new ideas invade an organization." We may also speak of the particular kind of learning that consists of "unlearning:" acquiring information that leads to subtracting something (an obsolete strategy, for example) from an organizationś existing store of knowledge." (Argyris \& Schön 1996 s. 3-4) 
Som udgangspunkt for tematisering og udvikling af organisatorisk læring rummer definitionen mange af de væsentligste temaer og begreber, de fleste teorier om organisatorisk læring er bygget op om: information (viden, indhold), det aktuelt larte, tilegnelsesprocessen, den larende, eventuel aflaring, en organisations indre og ydre og information i form af nye ideer der tilflyder organisationen udefra.

De færreste teorier om organisatorisk læring vil være uenige, $i$ at netop disse temaer og begreber er relevante for teori om organisatorisk læring. Ligesom en række af dem kan genfindes indenfor afhandlingens didaktiske temaer:

Hvem? - a learner to whom the learning process is attributed.

Hvad? - some informational content,

Hvornår? - må forventes at ske gennem beslutningsprocesser.

Hvorfor? - må forventes at ske gennem beslutningsprocesser.

Hvordan? - a learning process which consists in acquiring, processing, and storing information.

\section{Argyris og Schön's organisationsbegreb som beslutning}

Argyris og Schön anvender et organisationsbegreb, der er inspireret af organisationsteoriens begreb om beslutning, organisatorisk grænsesætning og hierarki (se f.eks. Weber 2003; Enderud 2003; Elkjær 2005a). Ifølge Argyris og Schön opstår og konstitueres en organisation, når et kollektiv af individer beslutter sig for og 'indordner' sig efter følgende betingelser eller konditioner:

"1. devise agreed-upon procedures for making decisions in the name of the collectivity, 2. delegate to individuals the authority to act for the collectivity, and 3. set boundaries between the collectivity and the rest of the world." (Argyris \& Schön 1996 s. 8)

"By establishing rule-governed ways of deciding, delegating and setting boundaries of membership, a collectivity becomes an organization capable of acting." (Argyris \& Schön 1996 s. 9)

Kort sagt opstår en organisation ved, at individers præferencer og interesser gennem en forhandlingsproces gøres fælles. Organisation muliggøres gennem kollektive beslutningsprocesser, hvor der fastsættes regler for, hvordan der kan handles, og hvor der besluttes på kollektivets/organisationens vegne. Til forskel fra teorien om praksisfællesskaber kan man med dette organisationsbegreb tydeligt se, hvem der er medlem af organisationen, dvs. hvem beslutninger 
vedrører (organisationsmedlemmerne), og at det er organisationen, som gennem beslutninger beslutter organisationens hierarki dvs. hvem der skal være leder og hvilke beføjelser, der følger med. Dette organisationsbegreb gør det ligeledes tydeligt, hvem besluttet læring vedrører, og hvordan dette afgøres. Eftersom beslutningsbegrebet får en så central placering hos Argyris og Schön, kan man med reference til Elkjær (2005) kalde Argyris og Schön's teori om organisatorisk læring for en teori om beslutningstagning som laereproces. Selvom Argyris og Schön anvender organisationsteoriens begreb om beslutning, trækker de ikke nødvendigvis på de samme rationalitets epistemologier i relation til beslutningstagen som gennem tiden har været under voldsom kritik (se f.eks. Enderud 2003: Hagen 1996 s. 213-228). Beslutningstagningens processer er for Argyris og Schön relateret til deres forståelse af organisationen som et polis - det oldgræske begreb for bystat i politisk betydning.

Ideen om at knytte den empiriske interesse til organisatoriske beslutningsprocesser virker logisk i forhold til epistemologien om organisationer som beslutningssystemer. Det er organisationens beslutninger, som udgør organisationens særlige måde at være organisations på, og det er følgelig her man kan iagttage hvilke kommunikationer, der medvirker til forandring af organisationen. Det er bl.a. her organisationens læring kan iagttages. Jeg vil imidlertid hævde, at polis tankegangen og den kommunikationsform, der er forbundet hermed, er en beskrivelse, som ikke modsvarer moderne organisationers funktionsmåde. Ud fra et systemteoretisk perspektiv er organisationer ikke politiske systemer, men systemer som gennem intern differentiering opbygger egenkompleksitet til at modsvare omverdenens kompleksitet. En af måderne, hvorpå de kan reducere kompleksitet er gennem intern differentiering (specialisering) og/eller hierarki. Man kan diskutere med ledelsen og fremføre argumenter i forhold til hvilke kriterier, der skal ligge til grund for organisationens beslutninger, men dette er ikke nødvendigvis eller kun at forstå som en politisk kodet kommunikation, dvs. som udtryk for magt eller magtspil. Ud fra et systemteoretisk perspektiv er kommunikation i organisationer langt mere komplekst kodet. Tværtimod forholder organisationer sig til sig selv og omverdenen ud fra en flerhed af iagttagelsesperspektiver f.eks. økonomiske, etiske, politiske, professionsfaglige, videnskabelige, juridiske, uddannelsesmæssige, ansattes individuelle forhold osv., dvs. der foregår multikodet kommunikation (Jf. Andersen 2001; Qvortrup 1998a; 2001; Paulsen 2008; Thyssen 2008). Man kunne forestille sig, at der f.eks. er mere $\varnothing$ konomisk kodet kommunikation i $\varnothing$ konomiafdelingen, end i en børnehave! 
I næste afsnit introduceres og beskrives systemteoriens organisationsbegreb, som er den tilgang afhandlingen anvender. Organisationsbegrebet knyttes undervejs til didaktiske og læringsmæssige overvejelser.

\section{Systemteorien organisationsbegreb}

Som organisationsteoretisk grundlag for afhandlingen organisationsdidaktik og analyse af empiriens værdibaserede ledelses projekt anvendes organisationsteoretiske begreber hentet fra Niklas Luhmanns systemteori. Luhmanns organisationsbegreb er, udover begreber fra den generelle teori om selvreferentielle autopoietiske systemer, især inspireret af organisationsteoretikerne Max Weber, Herbert Simon, James G. March og Karl Weick. Den traditionelle organisationsteoris fokus på og anvendelse af rationalitetens teoretiske præmisser til iagttagelse af organisationer kritiseres stærkt af Luhmann. Mens den adfærdsbaserede tilgang gør det fra et empirisk perspektiv, henviser Luhmann til samfundets uoverskuelige kompleksitet, hvilket i bund og grund gør rationalitetsbegrebet i ovennævnte forstand et umuligt begreb. Luhmann har kun en humoristisk bemærkning til overs for det organisationsteoretiske rationalitetsbegreb med bemærkningen om, at hvis definitionen af organisationer skal forløbe over rationalitetsbegrebet "vil patienten d $\emptyset$ " (Luhmann 2003 s. 312). Systemteorien opererer med et paradoksalt beslutningsbegreb, ${ }^{147}$ som grundlæggende element i organisationer. ${ }^{148}$ Der vil i nedenstående blive argumenteret for, at Luhmanns organisationsteori udgør et nyt, anderledes og mere frugtbart udgangspunkt for analyser af organisatorisk læring.

Luhmann startede som organisationsteoretiker i slutningen af 50'erne (Se Baecker 2003), faktisk er hans doktorafhandling fra 1964 Funktionen und Folgen formaler Organisation om organisationer, men han har siden slutningen af 60'erne koncentreret sig mest om udviklingen af en universel

\footnotetext{
${ }^{147}$ For en teoretisk gennemgang af Luhmanns paradoksale beslutningsbegreb se (Luhmann 2003 s. 35-61; Andersen 2003 s. 235-258; eller 2001).

${ }^{148}$ Luhmann mener ikke, at det traditionelle rationalitetsbegreb, som er blevet anvendt indenfor organisationsteorien, kan opretholdes, hvilket han har gjort opmærksom på i flere artikler og bøger (Luhmann 2000a; 2000b; 2003) Ligesom Weick, der betegner rationalitetsbegrebet som et oxymoron dvs. et begreb der modsiger sig selv (Weick \& Westley 1996), mener Luhmann, at rationalitetsbegrebets søgen efter korrespondance i organisationers operationer er en vildfarelse, som derfor altid ender $i$, at organisationen iagttages som i underskud af rationalitet, hvorefter medicinen bliver tilsætning af mere rationalitet. Det er på den måde, at man skal forstå hans humoriseren over, at hvis definitionen af organisationer skal forløbe over rationalitetsbegrebet "vil patienten $d \emptyset "$. (Luhmann 2003 s. 31)
} 
sociologisk teori, som behandler en mangfoldighed af sociologiske temaer. Sideløbende med dette arbejde har han med jævne mellemrum skrevet artikler om organisationer, og posthumt er Organisation und Entscheidung (2000b), der kan betegnes som hans organisationsteoretiske hovedværk, blevet udgivet. Uanset om man taler om hans generelle universelle teori eller om hans organisationssociologiske teori, er der ikke tale om en fiks og færdig opskrift klar til anvendelse for empirisk forskning. Luhmann udvikler en organisationsteori som et forslag til en ny semantik om organisationer, der begrebsligt kan håndtere mere kontingens og kompleksitet, og hvor abstraktionen er så høj, at praksis ikke kan genkende sig selv i teorien (Thyssen 2003 s. 266). Det er derfor i høj grad op til en selv at finde de begreber, som er relevante i relation til ens problemstilling, og at fremskrive begreberne $\mathrm{i}$ en form, som giver dem empirisk relevans. Nedenstående afsnit om organisation som beslutning er udtryk for det bud på begreber, der fremstår som relevante i relation til problemstillingen.

I nedenstående vil jeg beskrive, hvordan systemteoriens organisationsbegreb kan beskrives, for dernæst at relatere det til et begreb om didaktik og læring, nærmere betegnet hvilke muligheder og begrænsninger begrebet om didaktik og læring kan henføres til i organisationer.

\section{Beslutningsbegreb som organisation}

Ideen om at gøre beslutning og beslutningsprocesser til genstand ved organisationsanalyser er ikke ny. Ifølge Harald Enderud kan der som tidligere nævnt (groft sagt) skelnes mellem to forskellige retninger eller hovedstrømninger indenfor beslutningsteori - den neo-klassiske teori og den adfardsbaserede teori (Enderud 2003 s. 14).

Lindbloms model af Muddling through kan opstilles som en 10-punktsliste (Enderud 2003 s. 104; opr. Hirschman \& Lindblom i Emery 1969 s. 357-359):

1. Forsøg på at forstå det problem, der skal besluttes om, er begrænset til en politik, som ligger nær opad den eksisterende.

2. I stedet for at tilpasse midler til mål, vælges mål som passer til de midler, som står til rådighed.

3. Kun få alternative midler betragtes.

4. Mål vurderes i forhold til midler og deres konsekvenser lige så vel som det modsatte.

5. Mål og midler vælges samtidigt.

6. Nye mål opdagers til stadighed, og gamle mål tages op til fornyet overvejelse. 
7. Problemer finder sjældent deres endelige løsning, men må stadigt tages op til ny behandling.

8. Beslutninger er mere en flugt fra forskellige onder end en bevægelse hen imod mål.

9. Kun få konsekvensdimensioner betragtes.

10. Analyser og udformning af politik er adskilte aktiviteter, der foregår i stort antal hos forskellige beslutningstagere samtidigt.

Garbage can modellen opererer med de samme anarkiske forudsætninger som Lindbloms model. Men modellerne adskiller sig fra hinanden ved at beslutningsudfaldet i Lindbloms model er relativt forudsigeligt, mens det $\mathrm{i}$ Garbage can modellen er mere uforudsigeligt. ${ }^{149}$ Garbage can modellen viser, at ideen om organisationer som fornuftige eller rationelle ikke kan opretholdes. Den henviser til, at beslutningsprocesser er komplekse og tilfældige processer uden styring og faste referencepunkter. I stedet for at være udtryk for styrede, rationelle og kalkulerede situationer forstået som én proces, er beslutningssituationer sammensat af fire variable eller input-strømme (del-processer), som resulterer i at overblik ikke kan opretholdes, og at beslutningssituationer styres af tilfældigheder.

De fire strømme, som så at sige "flyder" gennem organisationen, er:

1. En strøm af beslutningssituationer (choice opportunities); situationer eller anledninger, hvor man forventer, at organisationen producerer noget, som den bagefter kan kalde en beslutning. Eksempler: årlig budgetlægning, fastlæggelse af markedsstrategi, ansættelse af ny direktør, udarbejdelse af nye stillingsbeskrivelser, love eller anordninger, punkter til dagsorden til møder.

2. En strøm af problemer, dvs. uløste spørgsmål, konflikter, følelser eller holdninger, som søger et forum at komme til udtryk i. problemer kan være latente (ligge og vente på en anledning), være under behandling eller allerede løst.

3. En strøm af lфsninger, f.eks. innovationer, nye teknikker, egnede medarbejdere til en ledig stilling (at vi har manden). Man forestiller sig, at løsninger søger efter problemer, ligesom problemer søger efter løsninger. Man kan tænke sig, at løsninger "lurer på" en beslutningsanledning for at komme frem i lyset.

4. En strøm af deltagere, som kan beskrives ved den mængde energi (evt. tid, dygtighed etc.) de har til disposition i et givet tidsrum. Vi kan se på denne,

\footnotetext{
${ }^{149}$ Ifølge Enderud er Garbage can modellen mere ægte anarkisk end Lindbloms model, eftersom uforudsigeligheden i Garbage can modellen er større (Enderud 2003 s. 112).
} 
ofte knappe energi som noget der er med til at koble problemer, løsninger, beslutningsanledninger og deltagere sammen, ved at den anvendes til at indsamle eller fortolke information, teste løsninger, bygge koalitioner etc. (Enderud 2003 s. 112-114).

Luhmanns beslutningsteori og organisationsbegreb følger i store træk en række af de kritiske pointer, som f.eks. Simon og Lindblom fremfører overfor teorier om rationel beslutningsadfærd. Luhmanns kritik er imidlertid ikke af empirisk art men teoretisk. Så selvom Luhmann peger på nogle af de samme pointer, når det gælder beslutningsadfærd, så adskiller han sig imidlertid, da hans udgangspunkt for kritik af rationalitetsbegrebet ikke kun ligger i beslutningstageres adfærd, manglende kognitive kapacitet eller begrænsede informationskilder. (Lindblom 1959). Luhmanns udgangspunkt er, at begrebet om rationalitet $\mathrm{i}$ bund og grund er et umuligt begreb givet kompleksiteten $\mathrm{i}$ verden. Luhmann mener grundlæggende ikke, at beslutningstagere kan være rationelle aktører, eller at organisationer er eller kan være mere rationelle end individer.

\section{Funktionelt ledet analyseform}

I stedet for det ontologiske spørgsmål: Hvad er en organisation? spørger Luhmanns teori ud fra en epistemologisk tilgang: Hvordan er det muligt at forstå en organisation?, ${ }^{150}$ hvilket fordrer en iagttagelse af grundlaget for organisering. En systemteoretisk analyse er en funktionelt ledet analyse, dvs. en analyseform, som søger en beskrivelse af det, som analyseres, ud fra dets funktionelle relatering til omverdenen. En funktionel analyse søger ikke en beskrivelse af, hvor godt, nyttigt eller fornuftigt noget er, men hvordan det, der studeres, udfylder en funktion i relationen mellem det studerede (systemet) og dets omverden. ${ }^{151}$

En kommune iagttages $\mathrm{i}$ denne form som et system indenfor velfærdsstatskonstruktionen, hvis primære funktion kan beskrives som

\footnotetext{
${ }^{150}$ Se f.eks. Andersen 2001.

${ }^{151}$ For en uddybning af funktionsbegrebets forskellige begrebsligg ørelse og anvendelse indenfor sociologien se Jönhill 1997 s. 98-112. Anders la Cour har i sin Ph.d. afhandling beskæftiget sig med systemteoriens funktionsbegreb og fremskriver syv forskellige funktionelle metoder, som der kan henvises til, når man arbejder med systemteori. (Cour 2002 s. 24-28)
} 
tilvejebringelse af velfærdsstatslige ydelser, eftersom det er den funktionsudfoldelse, samfundet forventer af pågældende system. ${ }^{152}$

Som det vil fremgå i det følgende, forfølges denne funktionelle analyseform ikke blot på institutions-/systemniveau, men i relation til alle de temaer, som organisationens kommunikation gør til genstand for iagttagelse.

\section{Beslutning}

Grundlaget for organisationers operationsmåde sættes lig et begreb om beslutning, og beslutningens grundlæggende funktion er absorption af selvskabt usikkerhed (Luhmann 2003b s. 45-48; Thyssen 2000a s. 18). Organisationer befinder sig i et konstant beslutningspres, som betyder at de hele tiden må vælge deres næste tilstand ud fra et begrænset sæt af alternativer (jf. bounded rationality, se Luhmann 2003b s. 42-43).

Enhver beslutning foretages ud fra et begrænset sæt af kontingente alternativer, hvorfor den defineres som transformation af kontingens. Før en beslutning træffes, foreligger der en række muligheder, også selvom mulighederne er begrænsede. Hvis ikke der var forskellige muligheder før beslutningen, som kunne have indflydelse på beslutningens udfald, kan man slet ikke tale om en beslutning. Ethvert udvalg af alternativer før en beslutning er kontingent, fordi det kun repræsenterer et begrænset udvalg af de mulige variationer, som kunne være anlagt for beslutningen. Beslutningen transformerer så at sige kontingens til en fikseret form. (Luhmann 2003a s. 37).

"Before the decision, several possible decisions exist, thus the possible space of open possibilities is limited. After the decision, the same contingency exists in a fixed form: the decision could have been made differently - it is now contingent upon itself." (Luhmann 2003a s. 37)

Organisationssystemer er:"(...) systems made up of decisions, and capable of completing the decisions that make them up, through the decision that make them up." (Luhmann 2003a s. 31). ${ }^{153}$ Organisationssystemers grundlæggende

\footnotetext{
${ }^{152}$ En kommune er ikke bare én organisation men er funktionelt opdelt i mange forskellige subsystemer eller suborganisationer, der hver især varetager en særlig funktion indenfor den kommunale sektor f.eks. børnepasning, administration af forskellige sociale ydelser, pleje af ældre, vedligeholdelse af parker og veje osv.

${ }^{153}$ En organisation eksisterer så længe autopoiesis fortsætter ved at beslutninger reproduceres ved beslutninger. Stopper denne proces, stopper de operationer organisationen reproduceres ved, og organisationen "dør".
} 


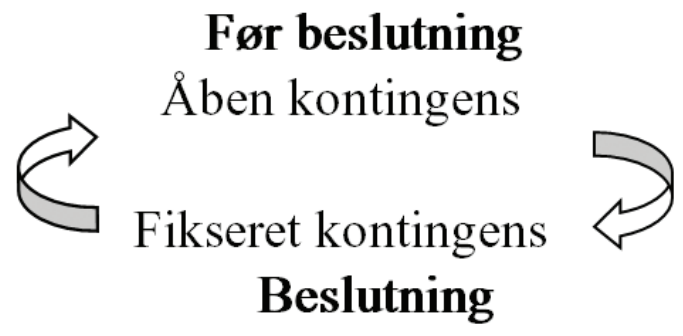

Figur 6 (egen tilvirkning)

funktion er at foretage beslutninger, som - i overensstemmelse med systemteoriens generelle begreb om autopoiesis som systemers operationsmodus betyder, at tidligere beslutninger danner informationsgrundlag for nye og fremtidige beslutninger. Beslutninger indgår på den måde $\mathrm{i}$ et rekursivt og cirkulært netværk, hvor beslutninger henviser til hinanden på kryds og tværs. ${ }^{154}$ Beslutninger er organisationers sidste ikke opløselige elementer, og dem som opmærksomheden rettes imod ved organisationsanalyser af enhver form og art. ${ }^{155}$

I henvisning til, at beslutninger ikke bare er kortvarige begivenheder $\mathrm{i}$ tid og rum, ${ }^{156}$ men er knyttet til det generelle medie mening og den mulige dekomposition i tre meningsdimensioner sag, social og tid, kan beslutninger iagttages som kommunikation med særlige sociale forventninger. Disse forventninger kan deles i tre: 1) Sagsdimensionen: faktuelle forventninger rettet mod verdens indretning, 2) Socialdimensionen: sociale forventninger rettet mod kommunikationsdeltagerne i systemet, og andre systemer i omverdenen, og 3) Tidsdimensionen: temporale forventninger rettet mod fremtiden. Således muliggør og begrænser beslutninger organisationens og medlemmernes forventninger til hinanden om hvad der skal ske, hvordan og hvornår, og hvad de kan forvente sig af fremtidige beslutninger. Beslutninger indstiller forventninger til senere beslutninger (Andersen 2001 s. 10).

\footnotetext{
${ }^{154}$ En organisation starter ved en beslutning om at "lave" en organisation, som herefter danner grundlag for senere beslutninger i organisationssystemet f.eks. Hvad skal vi beslutte at lave? Hvordan skal vi gribe det an? Hvem skal ansættes? Skal vi have et logo? En kantine og i hvilken farve?

${ }^{155}$ At beslutning er organisationers sidste ikke opløselige elementer henviser til, at beslutninger er kommunikation og derfor ikke kan reduceres til bevidsthed. For uddybning heraf, se afsnittet om kommunikation.

${ }^{156} \mathrm{En}$ beslutning som en særlig form for kommunikation forsvinder i samme moment, den opstår. I den udstrækning, at den genaktualiseres, får den strukturdannende funktion.
} 
Et koncept om værdibaseret ledelse eller organisatorisk læring giver ligesom andre koncepter om organisationsforandring anledning til forventninger om f.eks. bedre, mere optimale, humane og rationelle beslutninger. ${ }^{157}$ Systemteorien giver imidlertid ikke anledning til at forvente dette. Rationalitetsbegrebets historiske relevans indenfor organisationsteorien er velkendt, men ifølge system teorien kan et begreb om rationalitet, sådan som det har været udlagt indenfor organisationsteorien ikke opretholdes, og det er der flere grunde til (Se Luhmann 1997; 2000b; 2003a; 2003b). Systemteoretisk er en beslutning et paradoks (Luhmann 2000b s. 123-151; 2003a s. 35-61), og Andersen beskriver det som tredobbelt (Andersen 2001 s. 12-13; 2003b s. 235-258). ${ }^{158}$

1. Kun spфrgsmål, der principielt er ubesluttelige, kan besluttes (von Foerster 1992; Luhmann 2000b s. 132; Luhmann 2003a s. 36). Paradokset består i, at ingen beslutning kan finde sin endelige bestemmelse, hvorfor paradokset består i tvangen til frihed. (Andersen 2001 s. 12). Et klassisk rationalitetsbegreb forudsætter verdens og samfundets transparens, så det er muligt at kalkulere eller beregne sig frem til den bedst mulige beslutning gennem afvejning af mål og midler. Dette er ikke muligt, eftersom det ville betyde, at systemet (organisationen) var verden eller samfundet, og at den kunne overskue alle nutidige og fremtidige muligheder og mulige fremtidige udfald. En organisation, hvor kompleks den end måtte være, kan kun iagttage og operere i forhold til verden ud fra et begrænset repertoire at muligheder, ellers ville den drukne i kompleksitet. ${ }^{159}$ Således kan organisationer ikke rationelt og med fuldkommen sikkerhed analysere sig frem til, hvem der skal ansættes, hvad der skal investeres i, eller hvordan der skal prioriteres (Andersen 2001 s. 12). Enhver prioritering er en internt konstrueret og anvendt prioritering, fremkommet som en beslutning om fremtidige forventninger.

\footnotetext{
${ }^{157}$ Alt andet vil være nærmest utænkeligt, for hvem forventer, at en værdi om ansvarlighed eller brugerorientering i udgangspunktet refererer mere til uansvarlighed og ingen brugerorientering. Eller sagt på en anden måde, nogen må tro på, at forandring er til det bedre.

${ }^{158}$ Følgende ordnede gennemgang af beslutningens tredobbelte paradoksi er inspireret af Andersen 2001; 2003b s. 235-258.

159"'Distinktionen mellem beslutningspræmisser og beslutninger har fra begyndelsen haft en helt specifik betydning. Den tjener til at indsnævre området af mulig beslutningsrationalitet. Det kommer til udtryk med begrebet om "bounded rationality". Hvor stort dette felt er, er optil databearbejdnings- og beslutningsteknik at gøre. (...) Hvis man opløste den samlede verden i variabler og korrelerede hver enkelt med de andre, eller hvis man på markedet forudsatte, at alle priser påvirker priser, da ville erkendelses- og beslutningsmulighederne blive overbebyrdede." (Luhmann 2003a s. 42)
} 
2. Beslutninger indstiller sociale forventninger til fremtiden, men traffes altid bagud. En beslutning har kommunikationens form. Den muliggøres bagfra, ved at fremtidige beslutninger knytter an til den, og beslutter hvorvidt en tidligere beslutning stadig er gældende, eller må udskiftes med en anden beslutning, som så indgår i samme rekursive proces forløb (Luhmann 2003a s. 43). En beslutning kan således ikke selv bestemme, om den er en beslutning. Det må andre beslutninger gøre. "Det andet paradoks består altså $i$, at det er den kommunikative markering af at en beslutning er gennemført, der g $\phi r$ en beslutning til en beslutning." (Andersen 2001 s. 13).

3. Hvad en beslutning er, er $i$ sig selv en beslutning (Andersen 2001 s. 13). Ved et generelt universelt beslutningsbegreb må der åbnes for, at beslutninger kan foretages på mange forskellige måder. Beslutningsbegrebet må give plads til, at ikke kun nogle beslutninger gælder som beslutninger, men at alle tænkelige beslutningsformer kan inkluderes. Organisationer beslutter selv, hvornår noget kan kaldes en beslutning, og hvem der kan beslutte, at en beslutning er en beslutning, og dette er et empiriske spørgsmål, fordi kriterierne kan variere fra organisation til organisation. Det paradoksale består $\mathrm{i}$, at beslutninger må beslutte sig selv, og denne beslutning er selvfølgelig ligesom alle andre beslutninger paradoksalt funderet (Andersen 2001 s. 13).

Som det ses af ovenstående, opereres der med et grundlæggende bredt fænomenologisk og konstruktivistisk inspireret beslutningsbegreb. En beslutning er, hvad der i en given kontekst refereres til, eller behandles som en beslutning, dvs. med reference til det system, som selv er organiseret som et beslutningssystem. "A decision is thus everything a system regards as decision." (Luhmann 2003a s. 35).

Beslutningsbegrebet refererer dermed ikke udelukkende til "besluttede" beslutninger som f.eks. nedskrevne regler, procedurer og mål, men implicerer i lige så høj grad den række af mere eller mindre kulturelt betingede, symbolske og ikke-bevidste former og elementer, som en iagttager kan iagttage indgår i organisationens rekursive reproduktion, dvs. måde at være organisation på. Kulturbegrebet, som op gennem 80'erne og 90'erne havde stor bevågenhed indenfor organisationsteorien, inkluderes i systemteoriens organisationsbegreb via muligheden for særlige "kulturelle" måder at tage beslutninger på. Kultur, forstået som udtryk for særlige forventninger til kommunikation, kan være indflydelsesrige på organisationers måde at konstituere sig omkring beslutningskommunikation. I relation til beslutningsbegrebet kommer kultur 
til syne som særlige reproducerede måder at tage beslutninger på. Analytisk kan dette spores ved iagttagelse af de beslutningsformer, som det kan iagttages har indflydelse på, hvordan beslutninger tages, og hvornår en beslutning i organisationen iagttages som en beslutning. Gentages beslutningsformerne over tid, dvs. indgår i organisationens autopoietiske reproduktion, kan de siges at have en konstitutiv indvirkning på organisationens måde at være organisation på. Dette gælder også selv om de for de psykiske systemers vedkommende fungerer som ikke-bevidste reproduktionsformer. Systemteoretisk er det ikke så vigtigt om beslutninger hjælpes på vej af kulturelle former, eller om ethvert beslutningsforhold fremkommer qua "bevidste" overvejelser over, hvordan beslutninger bliver til beslutninger. Systemteoretisk er det interessante, hvordan beslutninger bliver til beslutninger, og hvilken mening beslutningerne selekterer, dvs. hvilke forventninger, beslutninger er udtryk for. På den måde iagttages kultur ikke som noget, der ligger udenfor beslutningsbegrebet men som noget, der kan være udslagsgivende for, hvordan beslutninger tages. ${ }^{160}$

\section{Organisation som fire forhold}

I systemteoretiske begreber er der fire fundamentale forhold, som karakteriserer en organisation: ${ }^{161}$

1. Medlemskab og grænse: En organisation beslutter sin grænse ved at afgøre, hvem beslutninger gælder, og hvad medlemskab vil sige.

2. Programmer: En organisation har altid definerede kriterier og mål, som sætter grænser for kommunikation og leder den i retning af, hvad der

\footnotetext{
${ }^{160}$ Hvorvidt disse kulturelle former er positive eller negative er ikke noget systemteorien har eller giver et bud på. Positive og negative bedømmelser tilskrives en empirisk iagttager. Systemteorien forholder sig kun til at foretage anden ordens iagttagelser, dvs. beskrive iagttagelser af iagttagelser.

${ }^{161}$ I sin organisationsdefinition er Luhmann inspireret af Max Weber, som definerer det moderne embedsmandssystems specifikke funktionsmåde ved seks distinktioner (Weber 2003 s. 63-112): 1). Der er et princip om faste kompetenceområder for udøvelse af myndighed, 2) Der er et princip om embedshierarki og tjenesteveje, dvs. et fastlagt system af over- og underordning af myndighederne, 3) Den moderne embedsførelse beror på dokumenter (akter), som betyder, at embedsudøvelsen er $\emptyset$ konomisk og meningsmæssigt adskilt fra privatlivs sfæren, 4) Embedsvirksomheden forudsætter en indgående faglig skoling, 5) Arbejdstiden er fastlagt og lægger som udgangspunkt beslag på al embedsmandens arbejdskraft, 6) Embedsmændene udøver deres embede i overensstemmelse med generelle, mere eller mindre faste og mere eller mindre udtømmende regler, som kan læres (Weber 2003 s. 63-65). De fire fundamentale organisatoriske karakteristika er fremkommet ved en kondensering af Andersen 2003 s. 253 og Jönhill 2003 s. 25-26.
} 
skal besluttes - kriterier der vedrører temaer og deres henvisning til sag, social og tid.

3. Differentiering: For at realisere deres programmer har en organisation personer i bestemte stillinger og dvs. roller, som udgør den sociale beslutningspræmis.

4. Beslutninger: En organisation fungerer og opretholder sin funktion ved at foretage og anvende sine egne beslutninger selvreferentielt.

Den sidstnævnte - beslutninger - knytter de tre andre forhold til sig, idet spørgsmål om medlemskab, programmer, steder og ansatte og beslutninger alle fremkommer som besluttede forhold. Beslutninger fungerer rekursivt, dvs. viser tilbage til og anvender tidligere beslutninger, som grundlag for nutidige beslutninger.

1. Organisationer muliggør sig selv ved i socialdimensionen at skelne mellem medlemmer og ikke medlemmer af organisationen. ${ }^{162}$ Personer bliver medlem af organisationer gennem organisationers beslutning om ansættelse.

2. Personer forventes at kommunikere i overensstemmelse med rolledefinitionen, og rollekonstruktionen. Personer optræder som generaliserede forventningsstrukturer til hvilken kommunikation, der forventes fra personen og hvilken kommunikation, der skal adresseres til personen

3. Til beskrivelse af hvad medlemskab vil sige, anvender Luhmann rollebegrebet som en generel henvisning til, at organisationer ikke ansætter 'hele mennesker', men inkluderer med henblik på udfyldning af på forhånd bestemte funktioner. Inklusion i en organisation sker m.a.o. i relation til en forudbestemt forventningsbestemt og højst selektiv systemintern konstruktion, som giver en række mulige muligheder (accessible possibilities) og krav. ${ }^{163}$ (Luhmann 1982; 2000a s. 371). Rollebegrebet anvendes funktionelt til reduktion af kompleksitet ved at organisationen

\footnotetext{
162"'Organization systems are always formed if it is taken for granted that a decision can be made about joining and leaving the system and if rules can be developed for taking this decision. This assumption can also be formulated in connection with the problem of contingency. Organization assumes that the role of members in the system is contingent, i.e. that a nonmember could become a member but also that members could become non-members, in other words, that there is a recruitment pool of possible members and that it is possible for members themselves to leave or be dismissed." (Luhmann 1979 s. 174).

${ }^{163}$ Eller som Thyssen udtrykker det: "Masken er systemets eget produkt. Den tager form af funktion. Hvad der ligger bag masken er uvedkommende. Derfor vækker det kritik, hvis homoseksuelle ikke må være politibetjente. Rollen som betjent er ikke defineret seksuelt." (Thyssen 1995 s. 46).
} 
og andre via rollen ved, hvem de skal adressere bestemte kommunikationer til, og hvem de kan forvente bestemte kommunikationer fra. ${ }^{164}$

Beslutningsbegrebet henviser til, at beslutninger ikke kun er noget, der foretages og praktiseres på ledelsesniveau, men fungerer som en generel aktivitet forbundet med medlemskab af organisationen.

\section{Beslutningsprogrammer}

For at kunne koordinere kommunikation og håndtere kompleksitet anvender organisationer beslutningsprogrammer og mål, som selv er udtryk for beslutninger (Luhmann 2000b s. 257). ${ }^{165}$ Beslutninger er elementer, der knyttes sammen med andre beslutninger og danner strukturer, der igen angiver muligheder og begrænsninger for kommunikation i organisationen (Luhmann 2000 b s. 275). Programmet indeholder og er udtryk for de grænsedragninger mellem system og omverden, som organisationen har besluttet skal gælde for netop denne organisation, hvilket har konsekvenser for hvilken kommunikation, der interesserer den og i så tilfælde, hvordan denne interesse kan udfoldes. ${ }^{166}$ Her reparerer vi biler, det der skal du til snedkeren med. Beslutningsprogrammer er på den måde et udtryk for organisationers forventningsdannelse og tjener som det program for iagttagelse, som en organisation iagttager sig selv og omverdenen med. Et beslutningsprogram kan ikke sammenlignes med en regel, hvor der kun er en mulighed, men beslutningsprogrammer kan indeholde regler. På et mere generelt plan er funktionen af

\footnotetext{
${ }^{164}$ Pointen med Luhmanns beskrivelse er netop, at det psykiske system ikke i sig selv indtræder i kommunikationen, men netop kun gør det som det personificerede psykiske system. Måden hvorpå det sociale system tilskriver personer værdi i systemet vil derfor aldrig være ækvivalent med psykiske systemers kompleksitet. At roller synes at tvinge sig igennem skyldes dermed heller ikke, at det sociale system siver ind i det psykiske system, men nærmere det forhold, at roller reducerer kompleksitet og dermed har og giver tempofordel. Såfremt et socialt system skulle orientere sig efter psykiske systemer som individer, ville kompleksiteten blive uoverstigelig og resultere i dysfunktion og potentielt systemets kollaps. Problemet ville helt konkret være, at systemet aldrig ville vide hvem der taler og med hvilket perspektiv: taler en person ud fra det forhold, at hun er kvinde, leder, fysioterapeut eller noget helt andet? Omvendt må systemet forholde sig til og i mere eller mindre grad kæmpe med det forhold, at det ikke kender sin omverden og at reduktion af kompleksitet medføre ny kompleksitet.

${ }^{165}$ Beslutningsprogrammer ligger derfor indenfor det generelle beslutningsbegreb, som beslutninger for fremtidige beslutninger.

${ }^{166}$ Som eksempler på beslutningsprogrammer kan nævnes en studieordning, behandlingsprocedurer osv. Men også samværsformer om, hvordan vi kommunikerer med hinanden osv.
} 
beslutningsprogrammer et forventningsbaseret råderum indenfor hvilket, der er store variationsmuligheder. For eksempel kan ydelsen af omsorg til ældre foregå på mangfoldige måder.

Et beslutningsprogram kan mere præcist beskrives som besluttede præmisser for fremtidige beslutninger.

En organisation kan karakteriseres ved at stå overfor et konstant kompleksitetspres - et konstant beslutningspres - Hvem skal undervise i fysik og hvornår? - Hvad skal de фkonomiske midler bruges til eller ikke bruges? Hvor skal der gфres rent? osv. En organisation kan derfor grundlæggende ses som et socialt system, som via beslutninger forsøger at reducere kompleksitet. ${ }^{167}$ Alt, hvad en organisation gør, kan derfor ses som beslutninger, der forsøger at reducere kompleksitet.

\section{Konditionering}

Man kan under et kalde dette for kommunikationens konditionering. Konditionering henviser til et systems internt koordineret selektivitet, og henviser under et til netop dette særlige systems kompleksitetsopbygning, herunder dets særlige måde at give sin egen kompleksitet relevans. Selvom om begrebet konditionering af Luhmann i nedenstående udlægning anvendes til at begribe, hvordan organisationssystemer håndterer kompleksitet, kan det også bruges til at sige noget væsentligt om, hvordan interaktionssystemer internt håndterer kompleksitet og opbygger strukturer. Intern konditionering er regelstyring af anden grad.

"Systemer er ikke blot relationer (i flertal!) mellem elementer. Det indbyrdes forhold må på en eller anden måde vare reguleret. Denne grundform benytter grundformen konditionering. Det vil sige, at en berstemt relation mellem elementer kan bliver realiseret under den forudsatning, at noget andet er tilfaeldet eller ikke er tilfaldet. (...) Konditioneringer, som er succerige i den forstand, at det, som er muligt gennem dem, også opstår, virker da som begransninger (constrains). Selv om de er indført kontingent, kan man ikke give afkald på dem, uden at det, som de har gjort muligt, bortfalder." (Luhmann 2000a s. 59-60)

\footnotetext{
${ }^{167}$ Kompleksitet betyder systemteoretisk noget andet, end at noget er indviklet eller uoverskueligt. Det betyder slet og ret, at der findes flere muligheder, end der kan realiseres.
} 


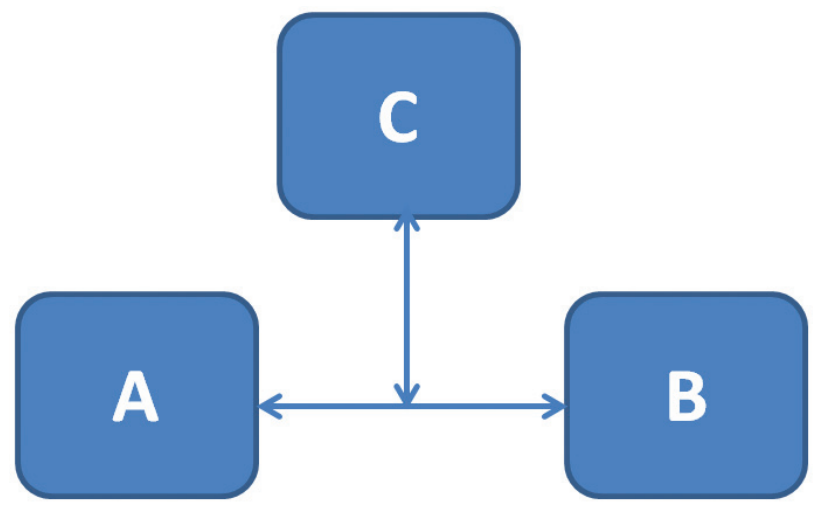

Figur 7 Konditionering (egen tilvirkning)

"Først konditionering giver overhovedet en organisation, (...) "begrebets kerne udgфres af (...) konditionering. Så snart relatio-

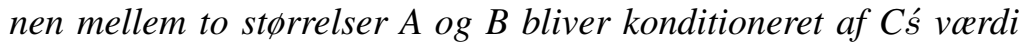
eller status, har vi fat på en nфdvendig komponent af begrebet "organisation". Således er teorien om organisation delvis forbundet med teorien om funktioner med mere end en variabel." (Qvortrup 1996 s. 186)

\section{Konditionering og intern differentiering}

For at kunne håndtere kompleksiteten, forstået som muliggørelsen af alle de forskellige beslutninger, som konstant må tages for at organisationen fungerer, er organisationer internt differentieret i specialiserede del- eller funktionelt relaterede subsystemer, som hver især varetager en bestemt funktion for organisationen, f.eks. sekretariatet, pædagogisk råd, ledelsen, lærerne, rengøringen osv. Hvert af disse subsystemer kan igen være internt differentieret f.eks. er lærerne differentierede i fag, ledelsen i en rektor og nogle inspektører, sekretariatet er differentieret i sekretariatsledelse og varetagelse af bestemte funktioner, f.eks. regnskab. En organisation iagttages derfor som enheden af en række internt og funktionelt relaterede sub-enheder, som hver især er afhængig af hinandens kompleksitetsreduktioner. Eller sagt med andre ord: alle er afhængige af hinandens beslutninger. ${ }^{168}$

\footnotetext{
${ }^{168}$ Funktionel differentiering betyder dels autonomi og dels afhængighed. Lærerne har tid til undervisning, fordi administrationen administrerer, ledelsen har tid til ledelse, fordi andre
} 
Eftersom en organisation ikke kan realisere alt på én og samme gang, men er underlagt en række begrænsninger (f.eks. økonomiske, juridiske, tidslige, saglige, sociale osv.), og fordi en organisation kan beskrives som polykontekstuel (Andersen 2001 s. 23), dvs. den består af forskellige internt og funktionelt relaterede subsystemer og personer-interessenter-som hver især udlægger organisationen forskelligt, foregår der en konstant kommunikativ brydning af interesser i forhold til de prioriteringer, som bestemte interessenter har. ${ }^{169}$ Interessenter betyder derfor på én og samme gang to forskellige ting for organisationen. På den ene side kan organisationen ikke overleve uden sin differentiering, fordi den hjælper organisationens generelle kompleksitetsreduktion. På den anden side producerer interessenterne kompleksitet internt $\mathrm{i}$ organisationen, fordi de hver især iagttager og danner mening om organisationens temaer forskelligt. ${ }^{170}$ Lærerne vil f.eks. gerne have indkøbt nye undervisningsmidler ud fra den begrundelse, at de ønsker at kunne varetage deres undervisningsfunktion bedre, men de(n) økonomiansvarlige afslår ud fra den begrundelse, at der ikke er midler til det.

\section{Ledelse}

I systemteoriens organisationsforståelse har ledelsesfunktionen en central plads. ${ }^{171}$ Ledelsen kan betegnes som adressat for kommunikation til organisationen, både fra omverdenen og fra interne organisatoriske interessenter.

Ledelse defineres som repræsentationen af organisationens helhed $\mathrm{i}$ organisationen (Andersen 2001 s. 23).

"Ledelse skal foretage den paradoksale operation at vare en del, som indfører systemets helhed $i$ hele systemet og altså reprasenterer systemet $i$ systemet. Den skal traffe beslutninger, som forpligter

tager sig af andre opgaver osv. Funktionel differentiering frig ør ressourcer og $\varnothing$ ger autonomien, fordi hver enkelt kan koncentrere sig om og strukturere egen funktionsudfoldelse, men $\emptyset$ ger samtidig netop afhængigheden af, at andre udfører deres arbejde.

${ }^{169}$ En interessent definerer Thyssen som en part, der påvirker og påvirkes af organisationens beslutninger. En interessent er en "part", som har en interesse, og en part er ikke nødvendigvis en person (Thyssen 1997 s. 192-193).

${ }^{170}$ Intern differentiering er derfor en organisations befrielse og forbandelse på en og samme tid.

${ }^{171}$ Når ledelse nævnes her, refereres der ikke til lederen som den individuelle person Frank, Birthe eller Line, men til abstraktionen ledelse som en funktion i organisationen. Enhver sammenligning med en bestemt leder her i teoriafsnittet eller i det senere analyseafsnit må stå for læserens egen regning, eftersom en sådan personificering i relation til den teoretiske begrebsliggørelse må henføres som en misforståelse. 
hele systemet. De traffes $i$ organisationen og drejer sig om organisationen." (Thyssen 1997 s. 78)

Funktionen ledelse er den funktion, der på baggrund af organisatoriske beslutninger, har fået formel hjemmel til at beslutte på vegne af organisationen. For at ledelse ikke skal drukne i kompleksitet, kan ledelsen reducere beslutningskompleksiteten ved at uddelegere eller internt differentiere ledelse, dvs. overdrage beslutningskompetencen på en række områder til andre personer og/eller subsystemer i organisationen. Beslutningsforhold vedrørende bestemte temaer adresseres herefter til den, der har fået beslutningskompetencen på området. Begrebet ledelse refererer dermed ikke længere til den $\emptyset$ verste ledelse i organisationshierarkiet, men som noget, der foregår mange steder. ${ }^{172}$

Som det fremgår af ovenstående forstås ledelse som noget, der involverer mange personer og foregår mange steder, og som noget, der via beslutninger er relateret til den overordnede ledelses centrale funktion som beslutningstagere par excellence i organisationen. Den $\emptyset$ verste ledelse har det overordnede ansvar for organisationens funktionsudfoldelse, ${ }^{173}$ men $\mathrm{i}$ mange moderne organisationer er ledelse uddelegeret, hvorfor mange af organisationens beslutninger blive taget af dem, som er tilforordnet beslutningskompetencen i relation til bestemte organisatoriske temaer.

\section{Ledelsesansvar, programmer og mål}

Ledelsens funktion er ligesom alt andet $i$ en organisation under indflydelse af de beslutningsprogrammer og mål, som organisationen har besluttet at arbejde efter og hen imod. En ledelse kan derfor ikke beslutte hvad som helst, men må agere ledelse indenfor de rammer, som beslutningsprogrammer og mål giver. Ledelsens funktion er at lede organisationen til realisering af sine mål, og dette gøres ved hjælp af de beslutningsprogrammer, som organisationen anvender. (Thyssen 1997 s. 77-81)

Når en organisation beslutter et organisationsudviklingsprojekt, er det et ledelsesansvar - i al sin mangfoldighed - at lede organisationen mod dens mål via beslutningsprogrammerne. Hertil er ledelsen afhængig af organisationens

\footnotetext{
${ }^{172}$ Den $\varnothing$ verste ledelse er imidlertid ikke for tid og evighed fritaget fra at skulle forholde sig til beslutninger på uddifferentierede områder. Den øverste ledelse som sidste adressat for beslutninger i organisationen kan f.eks. blive inddraget i beslutninger, hvis der kommunikeres utilfredshed med beslutninger hos den uddifferentierede beslutningskompetente på området.

${ }^{173}$ Hvorfor ethvert organisatorisk forhold kan henføres til den overordnede ledelse og/eller dens beslutninger også på trods af uddelegering af beslutningskompetencen.
} 
differentiering og medarbejdernes ressourcer, som den i overensstemmelse med nye beslutningsprogrammer og mål ændrer, så de funktionelt giver mulighed for realisering af målene. ${ }^{174}$

Systemteoretisk udtrykt ligger fokus i denne afhandling på, hvordan ændringer i beslutningsprogrammerne, qua organisationsudviklingsprojektet, ændrer organisationens iagttagelse, forventninger til og beskrivelse af dens medarbejdere, differentiering og opgaver.

Beslutningen om organisationsudviklingsprojektet, i det her tilfælde VBL, er en beslutning, som inkluderer og vedrører hele organisationen. Beslutningen udsætter organisationen for et kompleksitetspres. Alle i organisationen er berørt af beslutningen ved, at en række arbejdsprocesser og -rutiner muligvis skal omstruktureres og omformuleres, så de passer til de nye forventninger der besluttes som kriterier for beslutninger, beslutningsprogrammer og konditionering af organisationen, dvs. hvor organisations muliggør beslutninger fremadrettet.

Ud fra et organisatorisk perspektiv er det derfor interessant at iagttage, hvorfor og på hvilken måde organisationen funktionelt og organisatorisk håndterer kompleksiteten $\mathrm{i}$ relation til VBL, dvs. hvilke temaer, der er fremkommet og hvilke organisatoriske strategier og metoder, der er initieret som fors $\emptyset \mathrm{g}$ på at reducere den kompleksitet, som temaerne på baggrund af organisationsudviklingsprojektet udfolder.

\footnotetext{
${ }^{174}$ Får en organisation grundlæggende problemer med at opfylde sine mål, som af en eller anden grund syntes urealistisk sat, kan den vælge at ændre målene, så de bliver mere realistiske i forhold til medlemmernes ressourcer, beslutningsprogrammerne og den interne differentiering.
} 


\section{Værdier, kommunikation og organisatorisk læring}

Dette kapitel fokuserer på at skabe en forbindelse mellem værdibaseret kommunikation og organisatorisk læring og tjener på den måde til at skabe en teoretisk overgang til analysen af afhandlingens empiri. Som tidligere beskrevet består afhandlingens empiri af interviews, der forholder sig til et organisationsudviklingsprojekt om værdibaseret ledelse i en større dansk kommune. Kapitlet har karakter af at være en teoretisk analyse, der forholder sig til, hvordan det ud fra en refleksion over Niklas Luhmanns systemteori er muligt at forstå værdibaseret kommunikation som noget, der kan initiere og føre til organisatorisk læring. Kapitlet er udelukkende teoretisk og sigter på at reflektere og strække teorien til det yderste i refleksionen over forholdet mellem værdier, organisation og organisatorisk læring.

For at få en bedre forståelse af forholdet mellem værdikommunikation $i$ organisationer og organisatorisk læring vil jeg tage eksplicit udgangspunkt i, hvordan værdier forstås ud fra afhandlingens primære teoretiske inspirationskilde, nemlig Niklas Luhmanns sociologiske systemteori, og derved fors $\varnothing$ ge en begrebslig afklaring af værdibegrebet specielt i relation til organisationer. I første omgang rejser det spørgsmålet om, hvordan det er muligt at forstå værdiers muligheder og begrænsninger i det moderne samfund beskrevet som funktionelt differentieret, og dernæst hvordan det er muligt at forstå værdier i relation til værdikommunikation i organisationer generelt. Et andet spørgsmål er: Hvilken funktion værdier kan tilskrives i organisationer? På baggrund af de forventninger, som kommunen har til, at værdier kan og skal afløse regelbaserede forventninger til organisationen, spørges der grundlæggende til, hvilken funktion værdier ud fra systemteorien har eller kan have i moderne organisationer, herunder hvorvidt værdier kan erstatte organisationers regler og beslutningsprogrammer for koordination, meningsdannelse og handling, så det er muligt for organisationer at handle 
værdibaseret, eller om værdier må reserveres en mere begrænset plads i organisationers handlingskoordinerende kommunikationer. Det overordnede og vigtigste spørgsmål for afsnittet er et teoretisk fors $\emptyset \mathrm{g}$ på at perspektivere og udlede, på hvilken måde et organisationsudviklingsprojekt om værdibaseret ledelse kan iagttages som et udtryk for organisatorisk læring og hvorvidt det involverer didaktiske refleksioner eller overvejelser i organisationen.

I afhandlingen iagttages og knyttes værdier sammen med et begreb om organisatorisk forandring og læring, hvorfor det overordnede spørgsmål for afsnittet er en teoretisk afklaring af relationen mellem værdier og organisation med specielt fokus på, hvilke muligheder og begrænsninger værdibaseret kommunikation kan have for organisatorisk læring. Jeg starter med en kort introduktion til hvordan forholdet mellem organisation, værdier og omverdenen har været beskrevet inden for dele af organisationsteorien.

\section{Organisationer, værdier og omverden}

For organisationer er det ikke ligegyldigt, om deres ansatte kan blive enige eller ej. Her er samarbejde, koordinering og en hvis grad af "konsensus" eller intern integration (Schein 1993 s. 57) angående situationsbestemmelse og sagsbehandling et væsentligt anliggende, hvilket f.eks. 80'ernes og 90'ernes fokus på intra-organisatoriske forhold forsøgte at reflektere og lære organisationerne ved hjælp af kulturbegreber (Schultz 1993; Schein 1993; Hatch 1993). Men ovenstående er ikke blot relevante temaer for interne forhold. Enhver organisation er også afhængig af gode relationer til sin omverden, hvilket f.eks. begrebet om den politiske forbruger aktualiserede. For stor afstand eller diskrepans i meningsdannelse mellem organisation og omverden kan give alvorlige problemer, hvorfor organisationer i takt med, at omverdenen ændrer sig må reflektere over sig selv i henvisning til andre systemer. Dette forhold er ofte indenfor organisationsteorien beskrevet ved psykologiens begreb om assimilation, adaption eller blot tilpasning til omgivelserne/samfundet (Schein 1993; Scott 2003; Parsons 1951; March 1994 \& 1995; Mejlby mfl. 1999). I denne forståelse orienterer organisationer sig mod institutionelle normer, regler og værdier, som findes i omgivelserne, idet det er disse institutioner, der i vid udstrækning er bestemmende for, hvordan organisationer bør se ud. Organisationer legitimerer således sig selv ved en adaptiv proces, hvor omverdenen assimileres, dvs. integreres i organisationens interne meningsdannelse, så der opnås en højere grad af overensstemmelse mellem organisation og omverden. I en moderne version er denne tilgang særligt udbredt indenfor ny-institutionalismen, hvor organisationssystemer beskrives som 
omverdensdeterminerede, idet organisationer for at bevare legitimitet må fungere som en slags spejling af omverdenens regler, normer og værdier (Peters \& Pierre 1998). Konkret mener March (1994 \& 1995), at omgivelserne består af institutionaliserede koder og kulturer, der definerer regelsæt for, hvordan organisationer og deres medlemmer bør agere.

Ud fra et didaktisk perspektiv på organisationer og deres forhold til værdier, vil denne tilgang betyde, at en organisations værdiorienterede 'pensum', forstået som undervisningens og læringen hvad, kan identificeres ved en iagttagelse af organisationens omverden, dvs. samfundet. Tilgangen til værdier ud fra Niklas Luhmanns systemteori er, som det i det følgende vil fremgå, væsentligt anderledes.

\section{Funktionel uddifferentiering og værdier}

I den systemteoretiske beskrivelse af værdier relateres værdibegrebet til samfundets primære differentieringsform. Værdiers muligheder og begrænsninger er direkte relateret forholdet mellem social struktur og semantik. ${ }^{175}$ Systemteoretisk er tesen, at det moderne funktionelt uddifferentierede samfund stiller sig anderledes over for værdier end tidligere samfundsformationers socialstruktur, og at spørgsmålet bedst kan besvares med henvisning til begreberne om kompleksitet og strukturel kontingens (Luhmann 1996 s. 61; Luhmann 1995).

Dette skal ses i forskel til stratificerede samfunds socialstruktur, hvor værdier var relateret til og opererede i relation til samfundets hierarkiske stratificering og dets forskellige lag, som hver især formulerede egne værdiforståelser, og som var i difference til andre lag. Forskellene var, at samfundets stratificering bet $\varnothing \mathrm{d}$, at de $\varnothing$ vre lag kunne gøre sine værdier strukturelt gældende for de nedre lag og ikke omvendt. Værdier kunne samfundsmæssigt gøres strukturelt gældende ud fra distinktionen foroven/for neden. I et stratifikatorisk differentieret samfund handlede det om, hvem der sagde hvad, og ikke hvad der blev sagt (socialdimensionen til fordel for sagsdimensionen).

\footnotetext{
${ }^{175}$ Luhmann har hvad jeg vil kalde et meget indifferent forhold til værdier, og det kan der være flere grunde til. En grund kan være det forhold, at værdier har en tendens til at operere med ontologiske antagelser indenfor moral og anden normativ teori. En anden grund kan være, at han ikke anså værdier som noget, der har en særlig stor relevans som analytiske kategorier for samfundets måde at være samfund på. Samfundet er ikke et værdisamfund men er funktionelt uddifferentieret, hvorfor samfundets og dermed også værdiers muligheder og begrænsninger i første omgang grænsesættes ud fra funktionelle begrundelser.
} 
I det funktionelt uddifferentierede samfund forøges samfundets kompleksitet ved, at selektiviteten og ustabiliteten i relationer mellem enheder i samfundet forøges og resulterer i nedbrydning af semantiske traditioner og fremkomsten af nye. Traditionelle differentieringer, ideologier og semantikker, som tidligere ikke var til kommer under pres ved, at der stilles spørgsmålstegn ved deres indre logik, så de i dag fremstår som kontingente.

"(...) one might say that all connections are now described as contingent. They are temporally contingent in that they are no longer determined by the past, by an immutable Nature, by social origin; they are objectively contingent in that they could always be different; and they are socially contingent in that they no longer depend on consensus (keyword: democratic). (Luhmann 1996 s. 64)

Pointen i denne udlægning om værdier i det moderne funktionelt uddifferentierede samfund er, at samfundets overgang fra en socialstruktur til en anden - fra stratificering til funktionel differentiering - resulterer i en generel nedbrydning af det stratificerede samfunds socialstruktur, som betyder en stigningen i kompleksitet, der leder til strukturel og værdimæssig kontingens. Værdier i det moderne funktionelt differentierede samfund forstås systemteoretisk som kontingente, dvs. defineret ved negation af nødvendighed og umulighed (Luhmann 2000a s. 146). ${ }^{176}$ Værdier fremstår på den måde som paradoksale, fordi de på den ene side fungerer som krav til løsninger, og på den anden side ikke sagligt, tidsligt eller socialt kan gøre krav på sine krav. Forsøg på at begrunde værdier - det være sig lokalt eller globalt - bevæger sig ind i en uendelig regres. Religion og stand er ikke længere faste referencepunkter, der kan henvises til, og få værdidiskussioner til at stoppe, fordi deres værdier ikke kan diskuteres.

Værdier i det moderne samfund opererer ikke som mere eller mindre givne og overordnede hegemoniske former, samfundet generelt refererer til, koordinerer og danner mening efter. Det moderne samfunds styringsform kan ifølge Luhmann ikke forklares efter et overordnet princip, hvorfra totaliteten kan overskues. Han forklarer samfundet som en emergent orden, altså en orden, der hele tiden udvikler og forandrer sig i et samspil mellem dets

\footnotetext{
${ }^{176}$ I overensstemmelse med systemteoriens konstruktivistiske perspektiv har værdier selvfølgeligt til alle tider været kontingente i teoretisk forstand, men dette tjener mest som en selvfølgelighed. Det interessante her er ikke den teoretiske beskrivelse af værdier som kontingente, men hvordan samfundet opererer i relation til et begreb om værdier.
} 
delområder, der ikke er underlagt en overordnet styring (Rasmussen 2004 s. $33 ; 1996$ s. 26). ${ }^{177}$

Konsekvensen af dette kan beskrives ved et begreb om samfundsmæssig kontingenserfaring (Harste 1997; Ziehe 1989), dvs. en erfaring, der kan iagttages i samfundets kommunikation om værdier som nogle, der kunne være anderledes, og som leder til og empirisk kan iagttages som værdikonflikter. Begreber som den politiske og/eller $\emptyset$ kologiske forbruger, dyrenes befrielsesfront osv. er eksempler på, hvordan personers værdier fremtræder som generaliserede værdiorienteringer, der opererer i værdimæssig opposition til andre værdiinteresser, dvs. kan iagttages som og muligvis udvikle sig til værdikonflikter.

På et mere empirisk og analytisk plan betyder denne værdiforståelse, at det ikke er muligt at vurdere en handlings rigtighed ud fra vurderingen af handlingen, eftersom dette måtte forudsætte en logisk rangordning af værdier (intersubjektiv konsensus), som f.eks. transitivitet i forhold til en mangfoldighed af værdier, sådan som det f.eks. beskrives hos Parsons (1951a). Ifølge Parsons kan handlinger vurderes ved hjælp af AGIL skemaet, som udgør en taksonomi hvor det - ud fra en generel orientering og handlingskorrigerende adfærd i relation til hvad han kalder ultimate values - giver mening mere eller mindre entydigt at vurdere en handlings acceptable/uacceptable former (Parsons 1935). Ved Luhmanns relatering af værdier til samfundets samlede kompleksitet i meningshenvisninger får værdier og værdibestemmelser det problem, at et begreb om værditransitivitet fremstår som et umulighedsbegreb. Transitivitetsbegrebets problem i det globaliserede moderne funktionelt differentierede samfund er, at det opviser mange forskelligartede og kontradiktoriske henvisninger til fortolkningen af værdier i forbindelse med forskellige temaer. I forbindelse med transitivitet skriver Luhmann:

"Hvis man ville opnå information om rigtigheden af en handling ud fra vurderingen, måtte man forudsatte en logisk randordning, $f x$ transitivitet $i$ forhold til en mangfoldighed af vardier $-f x i$ den betydning at opretholdelsen affrihed er vigtigere end opretholdelsen af fred, opretholdelse af fred vigtigere end kultur, kultur

\footnotetext{
${ }^{177}$ Rasmussen skriver at dette ligner postmodernistiske forklaringer på samfundets meningsdannelse. "Hans (Luhmanns) tankegang ligner i en vis forstand postmodernisternes opfattelse af, at der ikke gives nogen samlende og koordinerende instans for de samfundsmæssige aktiviteter, men det fører ham ikke til postmodernisternes konklusion, at anything goes." (Rasmussen 2004 s. 33; se også 1996 s. 26). Kursivering er vend om i forhold til originalen.
} 
vigtigere end profit - og så altså ikke, at profit er vigtigere end frihed." (Luhmann 2000a s. 372; se også Luhmann 1997 s. 799-800)

Transitivitetsbegrebet strider altså mod Luhmanns beskrivelse og forståelse af samfundsformen som funktionelt differentieret. Samfundet består af ligestillede funktionssystemer såvel som organisationer og interaktioner som autonome, selvreferentielle og autopoietiske systemer. Ifølge Luhmann må man derfor på alle niveauer for forventningsdannelse opgive ideen om fastlæggelsen af rigtigheden af bestemte handlinger, eftersom al handling kan vurderes ud fra positive og negative synsvinkler (Luhmann 2000a s. 372; 1996 s. 65). Eller som han udtrykker det: "Man har blot værdier for hånden - eller i munden." (Luhmann 2000a s. 372).

Luhmanns udgangspunkt er, at der ikke findes et sted i samfundet, hvorfra essensen af præmisser for korrekt handling flyder, og hvorfra det er muligt (universelt) at værdisætte og iagttage eller dømme rigtigheden af handlinger. Rigtigheden af en bestemt handling foreligger ikke substantielt og ontologisk. Rigtigheden af en handling er derimod lokaliseret til og fastlægges af en iagttager, det være sig et psykisk system, eller et socialt system. ${ }^{178}$ Hvorvidt en iagttager tilslutter sig eller afviser en udlægning er afhængigt af hvilke forventninger, der er knyttet til iagttagelsen.

"(...) it is not possible to transcend differences of values or of a priori assumptions - even those witch are of a political, religious, aesthetic, erotic, capitalist or scientific kind. And if these differences cannot be resolved, the question of a unity behind the distinction

\footnotetext{
${ }^{178}$ Dette fænomen kan iagttages udfoldet i avisers læserbreve, i politiske diskussioner, i forældres forskellige måder at opdrage deres børn osv. I de senere år er temaet og diskussionerne om udlicitering af traditionelle velfærdsstats ydelser, som f.eks. hjemmehjælp, rengøring osv. et eksempel på, hvordan forskellige iagttagere konstruerer fænomenet om udlicitering ud fra forskellige kriterier. Hvorvidt udlicitering er godt eller skidt fortaber sig i iagttagerens iagttagelseskriterier. Samfundets uddifferentierede funktionssystemer er et godt eksempel på, hvordan forskellige iagttagere ud fra forskellige iagttagelseskriterier kommer frem til vidt forskellige udsagn. For det juridiske system iagttages udlicitering ud fra forskellen lovligt/ulovligt, i det $\varnothing$ konomiske system ud fra forskellen om, hvorvidt det er en god forretning underforstået, om det kan betale sig/ikke betale sig, og for de enkelte partier indenfor det politiske system iagttages det ud fra forskellen om, hvorvidt det er noget, man i overensstemmelse med sit partiprogram, dvs. ideologiske overbevisning, kan opnås valger opbakning/ikke valger opbakning til, så man kan komme i regeringen. Afgørelsen om, hvorvidt udlicitering er godt eller skidt, rigtigt eller forkert og dermed også, om det er noget man bør efterstræbe, afhænger af hvilken enhed af forskel iagttagelsen af udlicitering forløber ud fra.
} 
between being and validity, of the unity of a world in which this distinction takes on a categorical importance, cannot even be raised." (Luhmann 1996 s. 64)

Ud fra denne refleksion over systemteoriens forståelse af værdier i det moderne funktionelt uddifferentierede samfund giver det ikke mening at operere med en ide eller forståelse om, at en organisation, der ønsker at være ledet af værdier, kan finde svaret på, hvordan en værdi skal forstås og have strukturerende 'virkning' i organisationen i samfundet. Værdier foreligger ikke i fast strukturerede former, som der er samfundsmæssig konsensus om, men må forstås som kontingente, dvs. mulige at udlægge på forskellige måder og med forskelligt indhold. Ud fra et didaktisk perspektiv er læringens $h v a d$ ikke noget, som kan defineres ved en iagttagelse af organisationens omverden $\mathrm{i}$ form af samfundet. For at komme nærmere en forståelse af læringens hvad, vil jeg starte med at definere, hvordan værdier forstås ud fra den moderne systemteori.

\section{Systemteoriens værdibegreb}

Når nu det ikke er muligt at henvise til et sted i samfundet, hvor enheden af samfundet er givet, og når ideen om overordnede værdistrukturer ordnet hierarkisk og transitivt som henvisningskategori må opgives er spørgsmålet, hvordan vi skal forstå værdier og ikke mindst, hvordan de kan beskrives teoretisk?

Ifølge systemteorien er værdier og værdipræferencer lokaliseret til samfundets generelle uddifferentiering, dvs. til samfundets subsystemer: interaktionssystemer, organisationssystemer, og omverden af psykiske systemer. På det psykiske plan opererer værdier som mere eller mindre bevidste forventningsstrukturer om ønskværdige forestillinger med hensyn til hvilke kriterier der skal gælde i valget mellem handlingsalternativer (Luhmann 2000a s. 372). Værdier er: "... generelle, individuelt symboliserede synspunkter, der indeborer at foretrakke sarlige tilstande eller hondelser." (Luhmann 2000a s. 372), og kan i den udstrækning, de gøres til genstand for iagttagelse, dvs. fremtræder som kommunikation, tjene som informationsressource for sociale systemers kommunikation. Det sociale system må så via tilslutning/afvisning beslutte hvilke og på hvilken måde, at præferencer knyttet til værdier gøres gældende som konditionering af fremtidig kommunikation. I tilfælde af et socialt systems tilslutning til værdipræferencer, henvises der ikke til noget fælles, eftersom psykiske systemer ikke nødvendigvis determinerer sig selv i

reference til sociale systemers præferencer, men til at præferencerne gælder 
som (nye) muligheder og begrænsninger for reproduktion af det sociale systems fremtidige kommunikationer, og forventninger til kommunikative bidrag fra psykiske systemer. I den udstrækning sociale organisationssystemer reproducerer kommunikation, som er "accepteret" af omverdenen af psykiske systemer, kan værdiers ydelse beskrives som reproduktion af kommunikation, der giver en psykisk samhørigheds- og fællesskabsfølelse. Og dette på trods af at bevidsthedssystemer ikke er tilgængelige for hinanden, og som enhver social forms refleksivitet på grundlag af dobbelt kontingensen, ikke kan indfange (Baraldi mfl. 1999 s. 207), fordi kommunikation aldrig kan nedbrydes til psykiske systemers strukturer eller elementer.

I den udstrækning det iagttages som en belastning for et system at iagttage sig selv eller sin omverden struktureret på en væsentlig anderledes måde end systemet selv, må det forudsættes at systemet forsøger at påvirke/irritere egen eller omverdenens kommunikation, så den bliver acceptabel. Netop fordi værdiers funktion kan beskrives som handlingskoordinerende, synes de af flere grunde at være oplagte til at initiere forandring, hvilket vil blive beskrevet i nedenstående. Men først fordres en præcision af systemteoriens værdibegreb, dels fordi dette har relevans for den senere analyse af organisatorisk kommunikation, hvor der må kunne skelnes mellem værdikommunikation som enten tilsluttes eller afvises, og dels for en præcisering af systemers værdikommunikation i relation til omverdenen.

\section{Formteoretisk værdibegreb}

En mere præcis begrebsbestemmelse af værdibegrebet og dets funktionsmåde kan med henvisning til systemteorien som form- og differensteori i George Spencer Browns (1969) forståelse beskrives, som enheden af forskellen acceptabelt/uacceptabelt. Formanalytisk kan værdier beskrives således:

Hvad der i relation til en værdi anses som acceptabelt henholdsvis uacceptabelt henviser til kommunikationens præferencer for, hvad der udpeges som acceptabelt/uacceptabelt. ${ }^{179}$ Værdi distinktionen er et systems eget produkt en intern forskel - som selv producerer forskellens to sider, dvs. udpeger hvad der er acceptabelt/uacceptabelt. Det værdifulde knytter sig til forskellens inderside som acceptable meningsformer for videre operationer, mens ydersiden forkastes som udgangspunkt for reproduktion. I overensstemmelse med systemteoriens systemrelative konstruktivistiske karakter er hvad der er

\footnotetext{
${ }^{179}$ Vi bemærker os at "Formanalysen er (...) analysen af kommunikationsbetingelserne givet en bestemt forskel, og formanalysens ledeforskel er: den markerede side/den umarkerede side." (Andersen 1999 s. 130)
} 


\section{Accept}

\section{Ikke accept}

\section{Værdi}

Figur 8 Formteoretisk værdibegreb

acceptabelt henholdsvis uacceptabelt ikke en egenskab ved den iagttagede genstand, men knyttet til den forskel som anvendes til iagttagelse. Værdien ansvarlighed eller brugerorientering siger ikke i sig selv noget om, hvordan man skal iagttage, hvad der er udtryk for ansvarlighed eller brugerorientering. Hvad der anses som ansvarligt eller acceptabelt, kan ikke henføres til det iagttagede, men viser tilbage til enheden i forskellen for iagttagelse. Ansvarlighed reproduceres på indersiden af forskellen, men tilskrives mening eller relevans via ydersiden. Eller sagt på en anden måde, det giver kun mening at tale om ansvarlighed, hvis der samtidigt er noget, som kan bestemmes som uansvarligt, dvs. uacceptabelt.

Værdier relaterer sig således til den grundlæggende distinktion system/ omverden, hvor det acceptable knyttes til systemets inderside og anvendes til videre operationer, mens det uacceptable henvises til omverden, dvs. fravælges som reproduktions mulighed af systemet selv. Værdier er således en forskel i systemers forventningsfastlæggelse, og dette er et fælles træk ved alle værdier (Thyssen 1997 s. 225).

\begin{tabular}{|l|l|l|l|l|l|l|}
\hline $\begin{array}{l}\text { Institutiona- } \\
\text { lisering }\end{array}$ & Medium & Kode & Program & Funktion & Ydelse & Refleksion \\
\hline $\begin{array}{l}\text { Alle system } \\
\text { typer }\end{array}$ & Værdier & $\begin{array}{l}\text { Acceptabelt/ } \\
\text { uaccept- } \\
\text { abelt }\end{array}$ & $\begin{array}{l}\text { Kultur } \\
\text { seman- } \\
\text { tik }\end{array}$ & $\begin{array}{l}\text { Handlingskoor- } \\
\text { dinering } \\
\text { (kontingen- } \\
\text { sudelukkelse) }\end{array}$ & $\begin{array}{l}\text { Fællesskabs- } \\
\text { følelse }\end{array}$ & $\begin{array}{l}\text { Iagttagelse } \\
\text { af en værdis } \\
\text { produktion } \\
\text { af noget } \\
\text { uaccept- } \\
\text { abelt }\end{array}$ \\
\hline
\end{tabular}

Figur 9 (egen tilvirkning) 
Ud fra denne forståelse af værdier kan læringens hvad og dermed organisatorisk læring defineres ved at søge efter beslutningskommunikation, der er udtryk for nye forskelle eller distinktioner for acceptabel kommunikation, dvs. nye kriterier for organisationens beslutninger og meningsdannelse.

\section{Værdier, motivation og selektion}

Kommunens valg af værdier kan betragtes ud fra et spørgsmål om motivation og selektion. Værdien om f.eks. ansvarlighed skal ideelt set få de ansatte til at kommunikere om og handle ansvarligt - det modsatte giver ikke mening. Værdier kan derfor betragtes som attraktive, fordi de på en eller anden måde symboliserer forholdet mellem motivation og selektion af kommunikation og handlinger som f.eks. ansvarlige. Et spørgsmål i den forbindelse er, i hvilken udstrækning værdier symboliserer et mere eller mindre entydigt forhold mellem motivation og selektion? Eller anderledes udtrykt: hvilke muligheder og begrænsninger er der knyttet til værdier i relation til konsensus om selektioner forbundet til dem?

Værdier har mange ligheder med Luhmanns begreb om symbolsk generaliserede medier, idet de tilskrives at motivere til bestemte selektioner, og derfor kan virke handlingskoordinerende. Symbolsk generaliserede medier definerer Luhmann på følgende måde.

"Vi vil betegne medier som symbolsk generaliserede medier, hvis de anvender generaliseringer til at symbolisere sammenhoengen mellem selektion og motivation, dvs. hvis de fremstiller selektion og motivation som en enhed. (...) På meget forskellig måde og for meget forskellige interaktionskonstellationer drejer det sig $i$ alle tilfalde om at konditionere kommunikationens selektion således, at den samtidigt kan virke som motivationsmiddel, altså vare tilstraekkelig til at sikre antagelse af selektionsforslagene." (Luhmann 2000a s. 203)

I kommunen skal de fem værdier anvendes i mange forskellige kommunikative sammenhænge, hvorfor man kan sige, at de nødvendigvis må udlægges som generaliseringer, der skal symbolisere sammenhængen mellem selektion og motivation, således at de på meget forskellig måde, og for meget forskellige interaktionskonstellationer forventes at konditionere kommunikationens selektion således, at den samtidigt kan virke som motivationsmiddel, altså 
være tilstrækkelig til at sikre f.eks. de ansattes antagelse af selektionsforslagene. På den måde virker værdier funktionelt handlingskonditionerende, men ifølge Luhmann er værdier ikke lige så præcise i deres program som de symbolsk generaliserede medier. Værdier er mere diffuse (Luhmann 1997 s. 799-800). Hertil kan man sige, at i den udstrækning et system konditionerer værdier for handling på systemplan, kan de fungere som symbolsk generaliserede medier, men kun på system plan, ikke for omverdenen/samfundet som det er tilfældet med de symbolsk generaliserede medier. I en kommune, som består af en række uddifferentierede subsystemer, der hver især skal formulere deres systemrelative fortolkning af værdier, er det forventeligt, at de er forskelligt formuleret, dvs. værdikonditioneringen fungerer systemrelativt, men ikke på tværs af systemer. Værdier kan derfor beskrives som paradoksale ved på den ene side at fungere handlingskonditionerende, dvs. give organisatoriske tempofordele, men på samme tid være dys-konditionerende, når de negeres som konditionering af andre systemer. Ud fra et lærende perspektiv kan værdier ligeledes beskrives som kontraproduktive, qua hvad jeg betegner for deres sejlivede karakter. Dette beskriver jeg i nedenstående.

\section{Værdier, autopoiesis, blindhed og negation}

Luhmann peger på, at værdier har en tendens til at overleve næsten alt, selv død og ødelæggelse og andre destruktive hændelser (Luhmann 1996). Værdier er blinde for verden omkring dem, fordi de virker ud over en faktisk indtræden af deres virkninger (Bakken 2000 s. 351). Ved en historisk iagttagelse af samfundet findes talrige eksempler på, hvorledes dogmatiske politiske, ideologiske, kulturelle og religiøse forestillinger på paradoksal vis trækker et blodig spor op gennem historien, uden at værdierne er blevet forkastet. ${ }^{180}$ I det følgende vil jeg fremskrive tre forskellige bud på, hvorfor og hvordan værdier kan beskrives som sejlivede.

- De er blinde overfor deres faktiske virkninger.

- Deres operationsmodus er at sammenligne med autopoiesis.

- De er svære at være imod.

Værdiers blinde karakter er beskrevet i ovenstående, og beskrives derfor ikke yderligere, men gives en underbyggende forklaring af de to andre "sejlivede" pointer. Værdier fungerer som iagttagelsesformer, der tilskriver verden mening i relation til enheden af forskellen der anvendes til iagttagelse.

\footnotetext{
${ }^{180}$ Tænk bare på en værdi som naeste karlighed, som på trods af forkastelige hændelser stadig har tilslutning og opbakning.
} 
Værdier er abstrakte forestillinger, der virker handlingsorienterende ved at udpege, hvad der er acceptabelt/uacceptabelt. Når værdier én gang er blevet introduceret som valide iagttagelsesformer, er de meget sejlivede, fordi deres operationsmodus har mange ligheder med begrebet om autopoiesis, hvor iagttagelser anvendes til reproduktion af sig selv. Værdier genbekræfter og geninstallerer således sig selv, idet enhver iagttagelse ud fra en værdi anvendes til at underbygge værdiens egen relevans. Ligesom de symbolsk generaliserede medier opererer værdier ved og ernærer sig ved både opfyldelse og negation, dvs. både indersiden og ydersiden af sin egen forskel. ${ }^{181}$ Det symbolsk generaliserede kommunikationsmedie dannelse, som opererer ud fra enheden af forskellen mellem bedre/værre (Luhmann 2006 s. 69 og 86), anvender iagttagelser af forskellens begge sider til at fremhæve sin egen relevans. Iagttages dannelse, f.eks. en bedre eksamen, vurderes det som godt, og iagttages ikke dannelse, f.eks. en værre eksamen, er svaret, at der må mere dannelse til. Uddannelsessystemets svar på alle spørgsmål er altid mere (ud)dannelse. Det samme gælder for værdier. En værdi om ansvarlighed kan aldrig acceptere forskellens yderside. Hvad, der henregnes som uansvarligt, kan ikke samtidigt være ansvarligt, hvorfor uansvarlighed aldrig kan fungere som et svar eller løsning på et spørgsmål om ansvarlighed. Dette er der et logisk svar på. Ansvarlighedens to sider spejler sig i hinanden ved, at ansvarlighed får mening og relevans ved sin egen negation. Findes uansvarlighed ikke, kan værdien ikke gøre en forskel og vil forsvinde, fordi den mister sin relevans sin funktionalitet. Forskellens to sider konstituerer hinanden via forskellen. Tillades de begge, ophæves forskellen, og begreberne bliver uvirksomme. Eller som Andersen udtrykker det: "Kun én side afforskellen kan markeres ad gangen. Markeres begge sider samtidigt aflyses forskellen." (Andersen 1999 s. 110).

Ligesom uddannelsessystemets operationsmåde, hvor en hvilken som helst iagttagelse anvendes til bekræftelse af sin egen relevans, udviser værdier samme træk. Værdier reproducerer sig selv via sig selv, uanset om de iagttager sin egen opfyldelse eller negation.

\footnotetext{
${ }^{181} \mathrm{Et}$ andet godt eksempel på dette paradoks er sundhedssystemet, hvis iagttagelsesforskel kan bestemmes som enheden af forskellen mellem rask/syg. Aldrig har sundhedsvæsenet læger, medicin, kirurgiske færdigheder osv. - været så raffinerede og udviklede, som de er i dag. Ikke desto mindre har der på intet tidspunkt i historien været så mange syge. Ole Thyssen går så langt som til at sige, at samfundet opererer ud fra en inerti om vækst. (Thyssen 1997 s. 67). Alting vokser og vokser trods en grundlæggende bestræbelse på at modarbejde sin egen eksistens. Sundhedsvæsenet - må vi tro på - forsøger at gøre folk raske.
} 
Den tredje og sidste sejhedskategori omhandler, at værdier er svære at være imod. Luhmann peger på, at den, som negerer en værdi, står overfor en større opgave end den, som har introduceret værdien, og at dette er et generelt træk ved værdier.

"Empirically, one can observe how communication with values is practised on the operative level. It is striking that the communication is not about values. Rather, the validity of values is assumed. Values are treated as tacit knowledge. This protects them from contradiction. To contradict them, one needs first to elicit an overt profession of a value, so that one can say, 'I do not agree.' For communication requires references clearly stated within the communication. Someone who states their values explicitly provokes contradiction. For all communication is set up in such a way that the information transmitted can be accepted or rejected." (Luhmann 1996 s. 65)

Man kan tilslutte sig eller negere værdier, men fordi validiteten af værdier forudsættes, er det ikke selve værdien som negeres men fortolkningen og anvendelsen af værdien, som resulterer i meningsforhandling. Værdiers abstrakte, kontingente og løst koblede karakter giver ingen information om på hvilken måde, værdien sætter grænser for kommunikation. En værdi har intet program, som forbinder værdien med verden, dvs. anviser, hvordan den skal bruges: "(..) im Namen des Friedens kann man alles mögliche tun, und die Annahme, Friedens sei ein universeller Wert, beruhigt nicht einen einziger Menschen." (Baraldi mfl. 1999 s. 208). Det er først den efterfølgende kommunikative proces, hvor kommunikationens selektion som tilslutning/afvisning af forskellige kommunikative bidrag finder sted, der giver værdien en form, der er virksom, dvs. kommunikativt fylder værdien med meningsmæssigt indhold. Ifølge Luhmann tildeles værdier en begrænset rolle som alternativ til organisationers beslutningsprogrammer, fordi de ikke selv opererer med et program. Der er snarer tale om, at værdier kobler sig spørgende til organisationers beslutningsprogrammer ved at initiere refleksioner over beslutningsprogrammers funktionelle relation til systemets ydelser. Selve negeringen af forholdet om, hvorvidt en værdi skal være gældende eller synes valid, kræver mere konkrete præference anvisninger, som ikke betyder negering af værdien, men at værdien kan bringes til anvendelse på forskellige måder. 


\section{Kultur og værdier}

Værdier er nært knyttet til kulturbegrebet, hvor sociale omgangsformer og meningstilskrivning i vid udstrækning opererer på et intuitivt og ikke bevidst plan som gensidige forventninger. ${ }^{182}$ Luhmann definerer kultur på følgende måde:

"(der)... findes (...) et mellemliggende krav, der formidler mellem interaktion og sprog - en slags forråd af mulige temaer, som står til rådighed for hurtig og hurtigt forståelig optagelse i konkrete kommunikative processer. Vi kalder dette temaforråd for kultur, og - hvis det er reserveret til kommunikationsformål - semantik. Seriфs bevaringsvardig semantik er følgelig en del af kulturen, nemlig den del, som overleverer begrebs- og idehistorien til os. Kultur er ikke nødvendigvis et normativt meningsindhold, men snarer en meningsfastlaggelse (reduktion), som gør det muligt at skelne mellem passende og ikke passende bidrag, eller korrekt og

\footnotetext{
${ }^{182}$ Et system må forholde sig til en større eller mindre variation af temaer, hvoraf nogle relaterer sig til systemets funktion, og andre ikke gør det. For at kunne håndtere og koordinere en lang række forskellige tematiseringer opbygger systemet selektivt meningsfulde former som en slags ". . forråd af til rådighed stående regler til meningsforarbejdning." (Kneer \& Nassehi, 1997, s. 124). Disse koordinerende meningsfulde former, "... som står til rådighed for hurtig og hurtigt forstå lig optagelse i konkrete kommunikative processer." (Luhmann 2000a s. 205), kalder Luhmann for temaforråd. Han siger: "Vi kalder dette temaforråd for kultur, og - hvis det er reserveret til kommunikationsformål - semantik." (Luhmann 2000a s. 205) "Med semantik forstår vi derfor en høj grad generaliseret mening, som er disponibel relativt uafhangigt af situation." (Kneer \& Nassehi, 1997 s. 124). I både konstitueringen og det videre mulige forl øb for sociale systemer gælder det om at udvikle nye former for indsnævring af vilkårlighed. Sociale systemer må fortløbende kompleksitetsreducere omverdenen med henblik på at fortsætte og konditionere egne operationer. I ethvert socialt system - og herunder også afdelinger - kan dette kun ske i form af mening. "Systemer, der opererer meningsfuldt, må vise på en meningsfuld måde, altså sagligt, tidsligt og socialt, hvad, hvornår og af hvem, noget kan forventes eller ikke kan forventes i systemet." (Kneer \& Nassehi 1997 s. 124). At et system opbygger sin egen semantik angående forskellige temaer er selvfølgelig en kommunikativ proces, der forløber over tid som fortløbende selektioner. Alt, hvad systemet vælger, bruges til at konditionere og dermed opbygge systemets indre kompleksitet, og det fungerer som en slags kommunikative 'rationaler', som systemet anvender til rekursivt at måle og veje fortløbende kommunikation. Sags-, tids- og socialdimensionen samler sig i meningsfulde former, som systemet iagttager sig selv og omverdenen gennem. De fungerer som koder for kommunikationen. En afdeling har over tid udviklet bestemte meningshenvisninger i relation til bestemte temaer, som systemet gentagne gange skal forholde sig til. Meningsformer, der bliver strukturdannende, bliver til semantik.
} 
ikke korrekt temabrug i temarelateret kommunikation." (Luhmann 2000a s. 205)

Kultur og semantik er snævert forbundne og fungerer som meningsfulde former, der koordinerer tematiseringer som en slags forråd af til-rådighed-stående regler for meningsforarbejdning (Vardinghus-Nielsen \& Nissen, 2002 s. 156). For sociale systemer (og kultur) fungerer værdier som reproduktionskriterier for kommunikation, som ikke direkte er kommunikeret. (Luhmann 2000a s. 244). Kultur konditionerer kommunikation og adfærd mellem personer, som ud fra kendskab til kulturens koder er "klar" over, hvad der er forventeligt/ikke forventeligt i forskellige situationer. ${ }^{183}$ På den måde reducerer kultur kompleksitet ved at strukturere handlingshorisonten. ${ }^{184}$ Men kultur kan i lige så høj grad være med til at forøge kompleksitet, når forventninger skuffes, og her opstår der et problem angående løsning.

"The problem here is that there are many values and that there are no (so-called transitive) relationships of precedence between

\footnotetext{
${ }^{183}$ For kultur se f.eks. Ole Thyssen - Intuitiv og refleksiv kultur i (Thyssen 1994 s. 87-110).

${ }^{184}$ Dette kulturelle konditioneringsbegreb skal ikke forveksles med begrebet om vellykket socialisering, sådan som det forekommer hos Berger og Luckmann, hvor vellykket socialisering henviser til overensstemmelse mellem individets indre subjektive strukturering og den objektive virkeligheds sociale strukturering. "Med vellykket socialisering mener vi opbygningen af en høj grad af symmetri mellem den objektive og den subjektive virkelighed." (Berger \& Luckmann 1999 s. 189). Ifølge Berger og Luckmann begribes forholdet mellem individ og samfund som et dialektisk forhold, dvs. interaktion mellem den objektive virkelighed (samfundet), og individet fungerer ved at produktet virker tilbage på producenten. Individer fødes og internaliserer gradvist samfundets normer, ideer og begreber, som efterfølgende eksternaliseres via individernes handlinger. "Samfundet er et menneskeligt produkt. Samfundet er en objektiv virkelighed. Mennesket er et socialt produkt." (Berger \& Luckmann 1999 s. 79). Jens Rasmussen peger på den samme teoretiske fremstilling ved Vygotskys virksomhedsteoretiske læringsteori. Det sociale går forud for det individuelle, hvorfor Vygotsky anser individuel tænkning for overvejende at være et biprodukt af det sociale. Det psykiske er internaliseret socialitet (Rasmussen 2004 s. 230-231). Systemteoretisk er der ikke nogen tvingende og nødvendig relation mellem det sociales reproduktion og det psykiske systems reproduktion, dvs. mellem det sociales reproduktion forstået ved et begreb om kulturelle former, og det psykiske systems indre strukturelle strukturering. Psykiske og sociale systemer er omverden for hinanden. Psykiske systemer opererer i mediet bevidsthed, mens det sociale opererer i mediet kommunikation, hvorfor referencen for reproduktion er forskellig. Det psykiske system reproducerer sig selv i reference til sig selv (sin egen indre strukturering), ikke i reference til det sociale, og vice versa. Et psykisk system kan være bekendt med og operere ud fra forskellige sociale kodninger, så kulturens koder (værdier) fungerer og opererer som underforståede kriterier for meningsdannelse, dvs. skjult fra kommunikationen. Dette betyder ikke, at det psykiske er et biprodukt af det sociale, men at det er et produkt eller en form skabt af sig selv.
} 


\section{Vardier, kommunikation og organisatorisk laring}

them. Each value merely precludes its antithesis (and not always even that). ${ }^{185}$ The resolution of collisions between values is thus unregulated. But decisions are only needed in the case of value collisions. From this itfollows that the values are not able to regulate decisions. They demand a consideration of the relevant values, but a conclusion does not follow from this as to which values are decisive in cases of conflict and to which are set aside. All values may count as necessary, but all decisions remain, nevertheless, and for that very reason, contingent. We therefore have before us the figure of necessary contingency, well-known from the theology of Creation. And that is nothing other than a logically unambiguous paradox; for contingency is defined by the negation of necessity and impossibility." (Luhmann 1996 s. 65-66)

Luhmann har ikke meget tiltro til, at værdier kan anvendes til at løse værdikonflikter. Jeg vælger at tolke det som en generel henvisning til empiriske analyser af, hvordan værdikonflikter, trods deres uløselighed, løses. Men relateret til en organisatorisk kontekst mener jeg, at organisationens hierarkiske form kan fungere som konflikt "løser". Funktionen ledelse har besluttet "mandat" til at skære igennem ved uenighed og konflikt, så organisationens beslutningsproces kan køre videre. ${ }^{186}$ Ledelse kan transformere konfliktens uløselighed fra usandsynlighed til sandsynlighed.

Men hvad der under alle omstændigheder er interessant er hvilke muligheder og begrænsninger, der læringsteoretisk ligger i at skuffelser udtrykkes kommunikativt, dvs. når de resulterer i modsigelse og konflikt. I det følgende vil jeg beskrive, hvordan systemteorien begriber modsigelse, konflikt, dysfunktion og konflikters parasitære karakter, for dernæst at relatere disse begreber til begreber om værdier og læring.

\footnotetext{
${ }^{185 "}$ For example, when the valuelopposite value distinction is re-imported into value, as when war/peace distinction reinterprets peace as the just of war; or when the freedom/unfreedom distinction turns into freedom as the exclusion by natural law of licentia ( = unrestricted freedom out of freedom), etc." (Luhmann 1996 s. 69).

${ }^{186}$ En ledelses beslutning om løsning af en konflikt henviser til organisationens løsningsmodel, og ikke til organisationsmedlemmerne som psykiske systemer. Konflikten løses kommunikativt, ikke psykisk, idet man ikke kan generalisere fra kommunikationsløsningen til de psykiske systemers enighed heri.
} 


\section{Konflikt, modsigelse, værdier og læring}

I forbindelse med værdier vil jeg beskrive modsigelse som en bestemt form, sådan som den udfolder sig i sociale systemer. ${ }^{187}$ En modsigelse betragtes $i$ almindelighed som en logisk fejl, som kan undgås (Luhmann 2000a s. 417). I stedet for udelukkende at se modsigelser som et resultat af logisk inkonsekvens, en fejl eller som noget dårligt, spørger Luhmann til modsigelsens funktion. Ifølge meningsbegrebet er den modsatte mening altid medrepræsenteret i enhver meningsoplevelse som uaktualiseret mulighed, og derfor er enhver iagttagelse og "Enhver mening [...] egnet til modsigelse, eller kan udvikles til en modsigelse." (Luhmann 2000a s. 421). Modsigelse er således altid til stede som en mulig form, og den har ifølge Luhmann ”(...) en dobbelt funktion i alle selvreferentielle systemer, nemlig som blokering og en udløsning, som standsning af den iagttagelse, der stфder på modsigelser, og som udløsning af tilslutningsoperationer, der netop er relaterede hertil, og som netop derigennem er meningsfulde." (Luhmann 2000a s. 419).

Luhmann skelner mellem to forskellige modsigelser. Den ene er den interne modsigelse i systemet, som produceres af systemet selv (mellem personer), og den anden er den eksterne modsigelse, som kommer til syne som en kommunikation fra omverdenen, der forstyrrer systemets forventningshorisont. Begge vedrører systemets selvreproduktion, idet modsigelser udfordrer systemets opnåede meningsbestemthed (selvreference) og gør den ubestemt ved at introducere konkurrerende distinktioner. Men netop dette, som jo fordrer selektion, giver adgang til nye selvreferencer. Sagt med andre ord: systemer lever med og af den fortløbende håndtering af modsigelser, for på den anden side af modsigelsen - $\mathrm{i}$ håndteringen af den - ligger muligheden for at skabe konditioneringer og opbygge egenkompleksitet. Den destabilisering, som en modsigelse bidrager med, er altså ikke lig med dysfunktionalitet. Luhmann taler om, at modsigelsen tjener som "immunsystem" i systemet. Den

\footnotetext{
${ }^{187}$ Modsigelser kan også fungere eller optræde i psykiske systemer, men da jeg allerede har fravalgt at beskæftige mig med psykiske systemer, vil jeg blot referere til, hvad Luhmann skriver om forskellen mellem psykiske og sociale systemers måder at håndtere modsigelser på: "Kun i psykiske systemer består modsigelsens enhed $i$, at man er bevidst om modsigelsen $i$ umuligheden af, at to modsigende ting eksisterer sammen, og at man reflekterer dette som "ren" bevidsthed. Bevidstheden kan håndtere modsigelsen ved at tilregne den til sig selv og på den måde kontrollere sit realitetsforhold, men det bliver i givet fald en operativ option. I så fald specialiserer bevidstheden sig til at opnå erkendelse $i$ klassisk stil. Man er imidlertid også vidende om mange andre muligheder for at inderligg $\emptyset$ re modsigelser på, og "eksternalisering" af modsigelsen er en af dem." (Luhmann 2000a s. 423).
} 
"(...) tjener som alarmsignaler, der cirkulerer i systemet, og som kan aktiveres overalt under sarlige betingelser." (Luhmann 2000 a s. 431) "Modsigelser har derigennem egenskaber, der fremmer de egenskaber, som et immunsystem kraver, fordi de muliggфr, men ikke fremtvinger elimineringen af afvigelser." (Luhmann 2000a s. 429)

"Modsigelser tjener til at reproducere systemet ved den dertil $n \phi d v e n d i g e$ reproduktion af ustabiliteter, som kan, men ikke $n \phi d-$ vendigvis må satte immunsystemets mekanismer $i$ gang med at operere. Den generelle funktion ved ustabilitet forklarer imidlertid ikke endnu modsigelsens sarligt tilspidsede karakter, lige så lidt som den tilstrakkeligt forklarer, hvorfor konflikter opstår." (Luhmann 2000a s. 429)

Jeg vil kort behandle konflikt og dysfunktion men i begrænset udstrækning, da disse er særlige tilfælde af kommunikation. Som udgangspunkt kan man imidlertid sige, at i det tilfælde, hvor modsigelse ikke bliver håndteret selvreferentielt i form af selektion og konditionering, opbevares den som en kompleks størrelse, der i mere eller mindre grad vil forstyrre systemet, når aktuel kommunikation ikke mere kan håndteres inden for denne kompleksitets grænser. Modsigelsen kan da resultere i yderligere forstyrrelser, der på et tidspunkt tvinger til selektion på den måde, at for så vidt systemet ikke forandrer sig, dvs. lærer, vil det trues af dysfunktion.

Dysfunktion kan relateres til den grundlæggende forskel mellem system/omverden. I det omfang at forskellen mellem systemets forventninger og omverdenens ikke kan anvendes, men hovedsageligt bliver problematisk på den måde, at den overstiger muligheden for fortsættelsen af egne operationer, er det netop et problem for systemet. Imellem dysfunktion og modsigelse ligger muligheden for konflikt. En konflikt kan opstå enten internt i systemet eller eksternt i forhold til øvrige systemer. Luhmanns tese er, at sandsynligheden for konflikt $\emptyset$ ges i takt med forøgelsen af kommunikationsmuligheder, og dermed har konflikt med kompleksitet og kontingens at gøre. ${ }^{188}$ Håndteringen af en given modsigelse må betragtes som en særlig form for kompleksitet, der kræver selektion: Systemet må vælge, hvad der skal tilhøre systemet på hvilken måde, og hvad der skal blive eller forblive omverden. På denne

\footnotetext{
${ }^{188}$ Det funktionelt uddifferentierede samfund som et globalt samfund giver mulighed for et utal af kommunikationsmuligheder, hvorfor sandsynligheden for konflikt og modsigelse anses som øget i forhold til tidligere samfunds social struktur.
} 
måde er system/omverden distinktionen på spil i enhver håndtering af en modsigelse som problemet med at fastlægge, hvad som gælder: "Kompleksitet i denne forstand betyder selektionstvang, selektionstvang betyder kontingens og kontingens betyder risiko." (Luhmann 2000a s. 62). I konfliktens univers kommer kompleksitet, kontingens og risiko til udtryk på følgende måde:

"Når det gjelder kompleksitet, vil det uttrykke seg som konflikt angående oppfatningen av seg selv og oppfatningen av omverdenen (conflict of perceptions). Når det gjelder kontingens, vil systemet møte konflikt på det operative plan, dvs. konflikt angående handlingsalternativer (conflikt of options).” (Moe 1995 s. 107-108)

Det særlige ved konflikten er, at den er udarbejdet efter den dobbelt kontingente situations mønster og tager form som "(...) den operative selvstcendiggørelse af en modsigelse gennem kommunikation." (Luhmann 2000a s. 449). Der er derfor kun tale om konflikt, når forventninger kommunikeres, og ikkeaccepten af kommunikationen bliver kommunikeret: Jeg gør ikke, hvad du $\emptyset$ nsker, når du ikke gør, hvad jeg ønsker, og hvis du siger et, gør jeg noget andet. Konflikt er derfor ikke, som man måske ofte iagttager det, afbrydelse eller svigt af kommunikation, og den fører derfor ikke nødvendigvis til dysfunktion. Konflikt er et særligt socialt system, der tjener til nej'ets opretholdelse. Det er ikke et delsystem men et system, der eksisterer parasitært som "(...) højt integrerede socialsystemer, fordi der er en tendens til, at al handling $i$ konteksten af et modstandsforhold bringes ind under modstandsforholdets synsvinkel [...] Den trakker handlinger, der indholdsmoessigt er nok så heterogene, sammen under den negative dobbeltkontingens' synsvinkel..." (Luhmann 2000a s. 451). Konfliktens parasitære karakter er typisk ikke anlagt på symbiose men tenderer snarere "(...) mod at absorbere vartssystemet gennem konflikten, i det omfang konflikten laegger beslag på al opmarksomhed og alle ressourcer." (Luhmann 2000a s. 452). Derfor vil konflikter, afhængigt af et systems egenkompleksitet og dermed dets ressourcer, i den grad kunne belaste og forstyrre systemet, således at det trues af dysfunktion som problemet med at fortsætte egne selvreferencer.

Ud fra en læringsteoretisk tankegang er uenighed iagttaget som modsigelse og konflikt i forbindelse med et projekt om værdibaseret ledelse ikke udtryk for noget entydigt negativt. Det kan tværtimod forholde sig omvendt. Uenighed kan være et udgangspunkt for forandring og dermed læring. Iagttagelsen af forandring kædes som oftest sammen med en normativ vurdering af, hvorvidt 
en forandring er positiv eller negativ, dvs. ud fra mål for forandring. Denne sammenblanding eller forveksling mellem læring og indholdsmæssig retning for læring er meget udbredt, og er selvsagt meget naturlig, eftersom læring, det være sig i organisationer, det politiske system eller i uddannelsessystemets undervisningssammenhænge altid forløber ud fra intentioner om læring af hvad, altså som en forestilling om målet for læringen, og hvad det skal gøre godt for. Men vurderende forestillinger om læring udspringer ikke fra en læringsiagttagelse, men ud fra en iagttagelse af læring ud fra normativt vurderende kriterier, ikke fra om der er sket læring eller ej.

Modsigelser og konflikter kan være belastende for psykiske og sociale systemer, fordi de kræver tid og opmærksomhed, dvs. lægger beslag på ressourcer, som kunne være brugt anderledes. Dette betyder imidlertid ikke, at der kan sættes lighedstegn mellem belastningens og/eller læringens karakter, for selvom modsigelse og konflikt kan være en belastning for psykiske systemer ved aktivering af negative affektive følelser og deraf afledte reaktioner, er der ingen nødvendig overensstemmelse mellem de psykiske systemers interne reaktioner og læring på den ene side, og læringsmæssige effekter i det organisatoriske system på den anden side. Som vi så i ovenstående, kan modsigelse og konflikt udmønte sig i forandringer i et socialt systems forventningsstrukturer, og det kan derved være udgangspunkt for og resultere i læring desuagtet hvad, der sker i de psykiske systemer.

Kommunikation knytter an til og opererer med reference til kommunikation, ikke til psykiske systemers bevidsthed, følelser, tanker og forestillinger. Psykiske systemers uenighed og affektive reaktions mønster kan blive en belastning for sociale systemer i den udstrækning, de optræder som en begrænsning eller endnu værre amputering af det sociale systems kommunikation, dvs. opererer som en psykisk lokaliseret begrænsning for forandring og dermed læring i det sociale system (Argyris \& Schön 1978 \& 1996; Argyris 1990a; 1990b). ${ }^{189}$

\footnotetext{
${ }^{189}$ Ifølge Argyris og Schön kan forsvarsmekanismer præge arbejdet med organisatorisk læring, og denne prægning vil ud fra en systemteoretisk iagttagelse blive iagttaget som beslutninger. (Argyris \& Schön 1978; 1996; og Argyris 1990a; 1990b). Deres begreb om styrende vardier (at have ensidig kontrol, at vinde og ikke tabe og at holde negative følelser tilbage) og begrebet om handlingsstrategier (at forsvare, overtale, sælge og bruge ansigtsreddende mekanismer fører til uhensigtsmæssige organisationsmæssige forsvarsrutiner (Argyris 1990b s. 36). Disse forsvarsmæssige rutiner iagttages som positive ved at forhindre forlegenhed og truende situationer, men samtidigt opfattes de som negative for organisatorisk læring, da de bremser og blokerer for forandring og udvikling af individers handlemuligheder. I den negative version iagttages forsvarsrutiner som anti-lærende, overbeskyttende og selvlukkede (Argyris 1990 s. 36). I den udstrækning disse forsvarsrutiner kan iagttages som nogle, der reproduceres i
} 
Negation iagttaget som modsigelse og konflikt iagttages som en forstyrrelse af et systems forventningsstrukturer og kan som hændelser være medvirkende til, at forventningsstrukturer enten ændres eller fastholdes som udgangspunkt for videre kommunikative operationer. Negation kan på den måde tjene som mulighed for læring, idet negation frembringer verden på en anden måde for systemet, end systemet formår via sine egne beslutningsstrukturer. Et system må beslutte, hvorvidt negationens "tilbud" om nye iagttagelsesformer skal danne udgangspunkt for nye selvreferencer og forventningsstrukturer, dvs. lære og dermed ændre sig, eller forkaste dem som mulige reproduktionsformer.

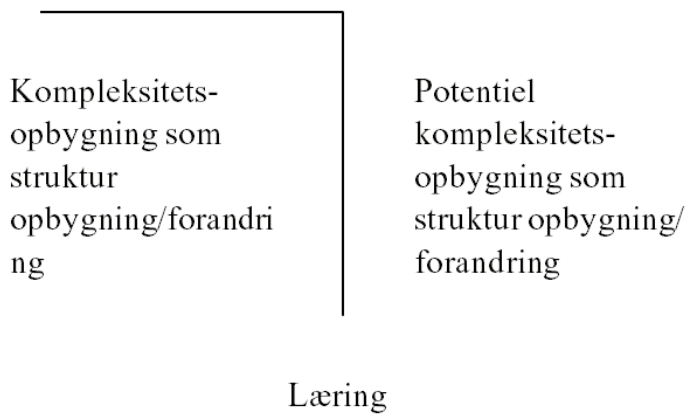

Figur 10

Værdier i og for organisationer er forbundet med et systems kommunikative forventningsstrukturer, som angiver og selekter mellem forventelige og ikke-forventelige kommunikationer. Hvad der er forventeligt, skabes der systemisk tilslutning til, mens det ikke-forventelige afvises. Introduktion til værdier i organisatorisk kommunikation sætter kommunikative refleksionsprocesser i gang og må forventes at producere en række kommunikative bidrag om hvilke kriterier, der skal ligge til grund for værdiernes kobling til organisationens beslutningsprogrammer og konditioneringer, dvs. refleksion over, hvad der skal læres, og her kan der findes andre og mere eller mindre subtile forventninger, som gør sig gældende. F.eks. peger flere undersøgelser på, at organisationer opererer med forventninger til medarbejdernes kontinuerlige udvikling og omstilling uden nødvendigvis præcist at angive hvilken

organisationens organisering, dvs. gentages over tid, iagttages de som bevidste eller ubevidste beslutninger om særlige måder at reagere organisatorisk på. Enhver omgangsform iagttages som kontingent, dvs. kunne være anderledes, hvorfor organisationens "accept" af særlige forsvarsrutiner iagttages som en organisatorisk form der, som Argyris \& Schön påpeger, på samme tid kan have positive og negative aspekter knyttet til sig. 
omstilling og udvikling, der er tale om (Andersen \& Born 2001; Rennison 2003). Forventningsstrukturer kan være en funktion af værdier, dvs. fungere som symbol eller udtryk for en værdi, mens selve værdien er en abstraktion, der viser sig som kriterier for kommunikation om, hvad der er acceptabelt henholdsvis uacceptabelt (Parsons 1952 s. 12; Luhmann 2000a s. 372-374). Teoretisk kan man ikke sige noget om, hvad der skabes tilslutning til eller afvises. Man kan blot henvise til, at blikket må holdes åbent for, hvorledes et systems strukturer fremtræder som kognitive strukturer (forandringsvillige strukturer), eller normative strukturer (ikke forandringsvillige strukturer), og på den måde må man forsøge at beskrive, hvad der fastholdes og hvad der ændres (se Luhmann 2000a s. 375-376). ${ }^{190}$ Som vi har set i ovenstående, opererer systemteorien ikke med et begreb om teoretisk definerbare eller transitive værdier, fordi det med henvisning til samfundets emergente menings- og vidensproduktion ikke anses som muligt. Systemteorien opererer i stedet med, hvad man kunne kalde et åbent, fænomenologisk og empirisk baseret værdibegreb, hvor en værdi er, hvad en iagttager tillægger en værdi, og dette gælder både psykiske og sociale systemer. ${ }^{191}$ I den udstrækning psykiske og sociale systemer ønsker deres værdier gjort gældende, må de kommunikeres, så de dels bliver iagttagelige for andre iagttagere, dels kan indgå i kommunikative processer, hvor de muligvis gøres gældende for et socialt systems strukturelle forventningsdannelse. Spørgsmålet om hvorvidt et system gennemgår strukturelle forandringer i relation til et projekt om værdibaseret ledelse er et spørgsmål, som udelukkende kan besvares ved indhentning af data fra det pågældende system. Afhandlingens didaktiske spørgsmål om læringens hvad, hvordan, hvorfor, hvornår og hvem, er med andre ord empiriske spørgsmål.

\section{Forventninger til forventninger}

Selvom teorien om autopoietiske selvreferentielle systemer teoretisk tildeler systemer en høj grad af autonomi, opererer systemteorien ud fra grunddistinktionen system/omverden, som sætter symbolske grænser for meningsdannelse, dvs. forventninger til forventninger. På et abstrakt plan er det

\footnotetext{
${ }^{190}$ Man kan som (subjekt) psykiske eller socialt system være mere eller uenig i en struktur opbygning og/eller forandring, men dette betyder ikke, at strukturopbygningen eller forandringen ikke er udtryk for læring, blot at en anden (normativ) iagttagelse, f.eks. via en værdi, vurderer strukturforandringen/opbygningen som enten acceptabel eller uacceptabel.

${ }^{191}$ Psykiske og sociale systemer som autonome, selvreferentielle og autopoietiske systemer opererer teoretisk med udgangspunkt i hver deres "individuelle" forventningsstrukturer som udtryk for særlige måder at iagttage på.
} 
selvfølgeligt muligt for et system at operere med forventninger, som systemet finder tjener systemets interesser bedst. Men et system er altid et system med en omverden af andre systemer med hver deres forventninger, som i tilfælde af skuffelse kan blive aktiveret som f.eks. sanktioner over for systemet. Der er f.eks. grænser for, hvad der er $\emptyset$ konomisk og juridisk muligt. Det samme gælder for psykiske systemers vedkommende, hvorfor et begreb om personalepleje, høje lønninger til personer med særlige eftertragtelsesværdige kvalifikationer og kompetencer, sociale og etiske regnskaber osv. prioriteres højt i organisationers kommunikation. Organisationers forventningsstrukturer har væsentlig indflydelse på sociale og psykiske systemers selektioner, fordi motivationen for succesrig selektion, dvs. positiv tilslutning, er snævert forbundet med forventningsstrukturernes relation til omverdenen af sociale og psykiske systemer. ${ }^{192}$

\section{Læring som selvtilpasning}

I systemteorien begribes læring som tilpasning, og i overensstemmelse med begrebet om autopoiesis er læring altid et produkt af et socialt systems egen ændring af egne kommunikative strukturer. Læring er derfor ikke tilpasning til omverdenen som determinant for læringen, men er i enhver henseende udtryk for selvlæring. Systemer i omverdenen kan ikke ændre et selvreferentielt systems strukturer. Et selvreferentielt system er strukturelt åbent, dvs. kan iagttage omverdenen, men er operativt lukket ved operativt at knytte an til og benytte sine egne strukturer til meningsproduktion. Et autopoietisk system producerer selv dets egne elementer og dermed også sine egne strukturforandringer.

"Ingen direkte kausale indgreb fra omverdenen mod systemet er mulige uden systemets egen medvirken. Netop derfor giver systemet sin egen struktur kausalitet. Det er formen og betingelsen for al tilpasning. (...) Al strukturforandring, det vare sig tilpasning til omverdenen eller ej, er selvtilpasning." (Luhmann 2000a s. 408-409)

Ved læring som selvtilpasning skelnes der mellem to former for tilpasning - omverdenstilpasning og selvtilpasning - hvor selvtilpasning fungerer som overbegreb. ${ }^{193}$ Omverdenstilpasning forløber via differencen

\footnotetext{
${ }^{192}$ Etisk og sociale regnskaber, $\varnothing$ kologiske udmeldinger, bæredygtig produktion og destruktion osv., er alle begreber og koncepter, som residerer på niveauet for forventninger.

${ }^{193}$ I relation til at teorien om sociale systemer er en evolutionsbaseret teori, opererer Luhmann med et begreb om morfogenese, som oprindeligt er et biologisk begreb, der henviser til
} 
system/omverden, dvs. når et systems oplevelse af omverdenens kompleksitet gøres til genstand for systemets strukturelle forandringer. Organisationssystemer, som består af strukturer samlet i beslutnings- og formålsprogrammer, kan ændre disse ved at lægge iagttagelser af omverdenens kompleksitet til grund for konstruktion og anvendelse af nye kriterier for beslutningstagen og oprettelse af nye mål. Dette kunne f.eks. består i beslutningen om, at en organisation ikke bare skal fokusere på profit, men også skal tage hensyn til miljø og ligestilling, altså forene profitkravene med andre hensyn (Moe 2003 s. 234; Qvortrup 1998a s. 201-226). Selvtilpasning på den anden side forløber via differencen element/relation, dvs. ændring (reduktion) af systemets egen kompleksitet via tilpasning af forholdet mellem elementer og relationer (som kan være en følge af tilpasning til omverdenen) (Luhmann 2000a s. 409; Moe 2003 s. 234). ${ }^{194}$ Organisationssystemer anvender en række konditioneringer af interne forhold, som f.eks. kommunikationskanaler, beslutningskompetence knyttet til særlige stillinger, forhold mellem medarbejdere og medarbejdere og ledere, mellem subsystemer (afdelinger), principper for sagsbehandling osv. Disse interne relationer mellem organisationens forskellige elementer betragtes som reduktionslinjer i samarbejdets struktur, og disse kan kollidere, hvorved der produceres (negativ) intern kompleksitet. Et bureaukratisk system kan f.eks. iagttage sig selv som unødvendigt og besværligt konditioneret i sin sagsbehandling, dvs. kan sagsbehandle på en måde, som påfører systemet selv unødvendig kompleksitet (måske også omverdenen) (se Luhmann 2000a s. 410). Også en særlig konstellation af medarbejdere og/eller ledere kan producere negativ kontingens, hvad der typisk refereres til som samarbejdsvanskeligheder. Samarbejdsvanskeligheder er et meget bredt begreb, som dækker over alt lige fra problemer relateret til personers problematiske forhold til hinanden, til hændelsers negative udfald over tid.

udviklingen af organismers struktur. "Hvis vi skiller mellom anatomi pg morfologi, så handler anatomi om systemets endelige struktur, mens morfologien handler om den evolutive utvikling av systemets relasjoneringer. Morfogenesen viser altså ikke tilforholdet system/omverden eller element/relasjon, men til differansen mulig/umulig (eller tillatt/forbudt), dvs. til det et kodert, egendynamisk system kan utvikle seg til og det som det umulig kan bli. Et sosialsystem kan for eksempel umulig utvikle en hjerne (og tenkning), men det kan derimot utvikle det som kommunikasjon gjør mulig. Grensen går ved det som kommunikasjon unulig kan bli. Ellers er det så å si ingen grenser for hva kommunikasjon kan utvikle seg til." (Moe 2003 s. 235). Se også (Luhmann 2000a s. 410).

194"'Man kan formode, at tilpasningsprocesser i bureaukratiske organisationer i vidt omfang følger denne typus for selvtilpasning, fordi der her forlanges en høj, bestandig korrekturnødvendig grad af finafstemning, og fordi de promoverer en høj sensibilitet for ubetydelige forskelle." (Luhmann 2000a s. 410). 


\section{Læring, struktur, hændelse og proces}

Forhold vedrørende stabilitet og forandring forgår altid ud fra en temporal iagttagelse af et systems strukturer, idet ændringer eller forandringer altid foregår på et systems strukturelle plan. ${ }^{195}$ "Man kan kun tale om forandring i relation til strukturer. (...) Kun strukturer holder det, som er kontinuerligt (og dermed forandringsmuligt), relativt konstant." (Luhmann 2000a s. 403). Men strukturer kan ikke forandre sig selv - hertil kræves hændelser. For at forklare, hvordan strukturforandring kan finde sted, skelner Luhmann mellem struktur og proces. Struktur defineres som relationer mellem elementer, og netop fordi relationer kan ændres - et forhold kan ophøre, man har et standpunkt til man tager et nyt osv. - er strukturer grundlæggende reversible, fordi de er kontingente. ${ }^{196}$ Strukturer er udtryk for et systems normalforståelser, dvs. forståelser, som reproduceres over tid, men en struktur kan ikke ændre sig selv - hertil kræves hændelser. ${ }^{197}$

Hændelser er irreversible og refererer til, når noget sker, f.eks. en kommunikation eller en handling og produkterne af disse - pengene er brugt, du kom ikke som aftalt, der er en bule i bilen, som ikke var der før osv. - sket er sket, og det kan ikke laves om. ${ }^{198}$ (Se Luhmann 2000 s. 83). Proces er et systemisk udtryk for temporal irreversibilitet ud fra distinktionen før/efter. En proces er en serie af hændelser, som er temporalt bundet til hinanden, dvs. som systemet logisk forbinder med hinanden på en særlig måde, så hændelser følger hinanden, altså hvordan hændelser udløser bestemte operationer. ${ }^{199}$ (se Luhmann 2000a s. 84). Når et system f.eks. skal tage beslutninger, følger

\footnotetext{
${ }^{195}$ Alt ændrer sig, hvis bare tidsspandet eller det tidskontinuum iagttagelsen forløber ud fra, er tilstrækkeligt bredt anlagt. "Hvad der forandres, og hvor dybt forandringen griber ind, er blot et spфrgsmål om det tidsrum man har for фje." (Luhmann 2000a s. 403).

${ }^{196}$ "'Strukturer forholder tiden reversibelt, fordi de holder et begrænset repertoire af valgmuligheder åbne. Man kan ophæve eller ændre dem eller ved deres hjælp opnå sikkerhed for ændringer i andre henseender." (Luhmann 2000a s. 83).

197",Change refers to a difference in structure, the difference occurring over time and being initiated by factors outside that structure." (Guy E. Swanson in Luhmann 2000a s. 403).

198" Processer markerer (...) tidens irreversibilitet. De består af handelser. De kan ikke forløbe baglans." (Luhmann 2000a s. 83). Man kan selvfølgeligt forsøge at skjule, at noget er sket ved at benægte det, eller ved at undlade at meddele det, men det laver ikke fundamentalt om på, at det er sket.

199 "'Processer (...) kommer i stand ved, at konkrete selektive hændelser opbygges tidsmæssigt efter hinanden, knytter sig til hinanden, dvs. indbygger forudgående selektioner eller forventelige selektioner som selektionspræmisser i enkeltselektionen. Forselektionen af det, som det er muligt at vælge, bliver erfaret som gældende, hvad angår struktur, men som konkrete hændelsers sekvenser, hvad angår processer.” (Luhmann 2000a s. 84).
} 
det logisk ud fra systemets procesforståelse, at når f.eks. lederen er blevet hørt, kan andre inddrages, eller at plejen af ældre er indrettet således, at efter morgenbadet følger logisk hårtørring osv. For en Kommune er projektet om værdibaseret ledelse en hændelse, og spørgsmålet er, hvordan dette håndteres, dvs. relateres til strukturer og processer internt i kommunens forskellige afdelinger og organisationer, og det er det, som undersøges ud fra en didaktisk tilgang.

\section{Værdier, stabilitet, forandring og refleksion}

Som omtalt tidligere opererer værdier ved siden af, dvs. på et intuitivt og ikke-bevidst plan, og skjult fra kommunikation, når kommunikation forløber i overensstemmelse med værdiernes forventningsstrukturer. Forløber kommunikation i difference til værdiernes forventningsstrukturer, er det muligt, at de aktiveres og reagerer ved at komme til syne i kommunikationen, som anderledes præferencer for meningsdannelse. Sammenholdes værdibegrebet med et spørgsmål om stabilitet og forandring, kan værdier tjene begge formål. I situationer med en vis grad af forventningsstrukturel overensstemmelse kan værdier have en præserverende og stabiliserende karakter, da reproduktion af status quo forventes og accepteres. I situationer med diskrepans eller differens mellem værdimæssige forventningsstrukturer kan der forekomme processer som f.eks. diskussion om gældende præferencer for meningsdannelse, som kan resultere i enten bekræftelse af den eksisterende struktur eller restrukturering og destabilisering af en ny struktur, dvs. resultere i læring.

I et læringsperspektiv kan værdier grundlæggende komme til syne på to forskellige måder alt efter hvilken side af forskellen, det iagttagede tilskrives. Dette kan beskrives ved begrebet om refleksion, dvs. iagttagelser, som forløber over forskellen mellem det iagttagede og i en henvisning til andre potentielle muligheder. Refleksion betegner den specifikke form for et systems selviagttagelse, som forløber over differencen mellem system/omverden, dvs. hvor det er systemet som enhed der er genstand for iagttagelse (Luhmann 2000a s. 508 og 520). Der er også en anden form for selvrefleksion, som forløber over differencen mellem element/relation. I begge tilfælde er der tale om en re-entry af differencer i systemet. Refleksionen over system/omverdens differencen betegner den iagttagelse, hvor det er systemet, der som enhed er tema for kommunikationen. Systemet foretager en re-entry af differencen mellem system/omverden i systemet, og tematiserer derved andre mulige måder at være system på. (Luhmann 2000a s. 508 og 520). 
Tilskrives det iagttagede indersiden af forskellen, dvs. plussiden, iagttages det som i indifference til værdien. Tilskrives det ydersiden af forskellen, dvs. minussiden, iagttages det som i difference til værdien. Mere empirisk beskrevet viser værdiiagttagelser tilskrevet ydersiden, at det iagttagede er i difference til værdiens ideer, visioner og ønsker. Her er der mulighed for læring, hvis det iagttagede ændres i overensstemmelse med værdiernes forventningsstrukturer om ønskede tilstande, så det indskrives på indersiden fra differens til indifferens. Tilskrives det iagttagede indersiden, dvs. iagttages som indifferent til værdiers forventningsstrukturer, betragtes det ikke som et læringspotentiale, hvor ændringer er påkrævet. Der er snarer tale om en slags status quo, da iagttagelsen vurderes i overensstemmelse med værdiens generelle forventningsdannelse.

Hvorvidt noget $\varnothing$ nskes ændret eller ikke ændret er et rent empirisk spørgsmål overladt til de værdimæssige forventningsstrukturer, som er kontingente qua kompleksiteten på det generelle forventningsniveau for værdier. I systemteorien kan ethvert system teoretisk set operere med hver sine forventningsstrukturer, hvorfor et system som en Kommune, der består af en række subsystemer, må forventes at operere med mange forskellige præferencer konstruktioner i relation til f.eks. samme værdi. Værdier, eller forståelsen af en værdi er systemrelativt konstrueret.

Ved iagttagelse ud fra værdier synes der umiddelbart at ligge en styringsmæssig tempofordel gemt, dels fordi de, i den udstrækning de fortolkes "ens", afstemmer og strukturerer handlingshorisonten, dels ved at de fungerer på et generelt plan. Dette skyldes at værdier ikke er reserveret til en særlig sag eller et særligt fænomen, men kan anvendes frit til iagttagelse af hvad som helst. Det er, som man siger, ikke genstanden, der betinger, hvordan den vil/skal iagttages men iagttageren, som bestemmer, hvordan genstanden iagttages. En værdi om f.eks. ansvarlighed kan således bruges til iagttagelse af, hvad iagttageren $\emptyset$ nsker at iagttage med denne værdi, og alt efter hvad der iagttages, kan ansvarlighed betyde noget forskelligt. Selvom der således synes at være en række mulige fordele forbundet med iagttagelse ud fra værdier, så er der imidlertid også en række problemer forbundet hermed. Nærmere betegnet er dette problemer vedrørende iagttagelse. Det ene, som jeg har været inde på, handler om værdiernes mangel på transitivitet, dvs. indordning $\mathrm{i}$ et hierarkisk rangforhold. Det andet handler om sociale og psykiske systemers autonomi i meningsdannelse. Det tredje handler om værdiers manglende handlingsanvisende aspekter.

Manglen på en transitiv rangordning af værdier betyder, at det ikke er muligt med henvisning til et værdihierarki logisk at deducere sig frem til 
hvilken værdi, der skal henvises til som 'ultimativt' gældende i en given sag. Værdier kan i en kommunikationsproces anvendes som "sonder", der kan eksperimenteres med for at se. om mere konkrete forventninger fungerer $\mathrm{i}$ en konkret situation (Luhmann 2000a s. 373). Ligesom iagttagelsen af en sag kan forløbe via forskellige præferencer, kan iagttagelser forløbe via de samme eller forskellige værdier blot med hver deres præferencer. Herved ledes der til indbyrdes kontrastering og risiko for uenighed, snarer end tempofordele forstået som overensstemmelse i præferencer og dernæst strukturering af handlinger. En værdikommunikationen kan ende i en værdi mod værdi, eller præference mod præferencediskussion. Værdier må således håndteres på afvekslende vis, dvs. opportunistisk (Luhmann 2000a s. 373). Anvendelsen af værdier som præferencer i kommunikative sammenhænge kan altså ligeså vel, som vi så det i kommunikationsbeskrivelsen, ende i "konsensus", som i dissensus. Værdier giver ikke sig selv. De må forhandles og diskuteres.

En empirisk analyse må således holde iagttagelsen åben for hvilke præferencer, der knyttes til bestemte værdier og må være åben for, at der kan være tale om flere forskellige præferencer - også indbyrdes konflikter, knyttet til den samme værdi.

Selvom værdier har knyttet særlige forventninger om ønskværdige fremtidige mål til sig, indeholder de ikke i sig selv tilstrækkelig kompleksitet til alene at klare opfyldelsen af målene. Et ønske om fred i verden er ikke tilstrækkeligt til at få fred eller anderledes udtrykt: værdien fred kan ikke i sig selv svare på spørgsmålet: Hvordan fred? For at besvare dette spørgsmål, er værdien henvist til og gjort afhængig af de forskellige muligheder, der er i samfundet, for at få fred. For det første må den selvfølgelig overbevise om det gode i værdien, dernæst er den grundlæggende afhængig af andre systemers bidrag, dvs. deres funktion og ydelse. Det politiske system må gøre fred til en kollektivt bindende beslutning, og freden må indskrives i det juridiske systems tekster. Religiøse trosretninger må overbevises om at betragte og praktisere fred som noget hævet over andre elementer i deres tro osv. På området for organisationer er værdier ligeledes afhængig af en række forhold, som ligger udenfor begrebets egen kompleksitet, f.eks. forskellige beslutningsprogrammer, særlige former for viden osv.

\section{Værdier og beslutningsprogrammer}

Organisationer er i det moderne samfund de systemer, der dels frembringer, dels løser samfundets generelle problemer, hvorfor det er de systemer, samfundets generelle problemer kan adresseres til. Det kan iagttages, at 
organisationer har været og til stadighed er genstand for positiv og negativ kritik relateret til værdibaserede forventningsdannelser. Klassiske eksempler er den politiske forbruger, ligestilling mellem kønnene, krav om dyre velfærd, $\varnothing$ kologisk eller anden produktions bevidsthed, forskellige former for sociale forpligtigelser, etiske investeringer osv., som qua succes til at genere organisationer $\mathrm{i}$ - set fra organisationens perspektiv - negativ retning har opnået en hvis relevans i organisationers kommunikation. Kort sagt, når samfundet anvender et utal af værdier til at koordinere og iagttage sig selv med, er organisationer genstand for selv samme værdiers irritationer i form af iagttagelsesforskelle om acceptabelt/ikke acceptabelt adfærd og meningsdannelse. Organisationer indenfor det velfærdsstatslige område, dvs. organisationer hvis primære funktion er forbundet med tilvejebringelsen af en lang række velfærdsstatslige ydelser, er følgelig udsat for samme pres. På et overordnet teoretisk plan kan organisationers generelle problem relateres til et problem vedrørende iagttagelse, nærmere betegnet den kompleksitetsmæssige asymmetri vedrørende system/omverdens differencen og det generelle kontingensproblem: intet system rummer tilstrækkeligt konditioneret kompleksitet (ressourcer) til at modsvare omverdenens kompleksitet, og enhver form for konditioneret kompleksitet iagttages som kontingent. Selv kommuner, som består af en lang række subsystemer/organisationer specialiseret til at varetage og håndtere mange forskellige kommunikationer, kan ikke fraskrive sig dette problem. Der er snarer tale om et paradoks, da det forholder sig lige omvendt. Kompleksitet og kontingens indgår $i$ et gensidigt stigningsforhold til hinanden: I takt med enhver opbygning af organisatorisk kompleksitet stiger kontingensen tilsvarende, fordi kompleksiteten kunne være anderledes på en anden måde. Eller sagt på en anden måde, jo flere funktionelle relationer en organisation etablerer til samfundet, jo flere områder og temaer er der at være uenige om - jvf. kommunikationens asymmetrisering.

Enhver organisation er følgelig tvunget ud i en række kompleksitetsreduktioner, og det kan kun foregå ved at vælge, hvilket sætter en kædereaktion i gang. Når noget vælges, opstår der kontingens, fordi valget blot er ét i favør af en lang række andre potentielle muligheder. Dette leder til risiko, da det potentielle - fravalget - kunne vise sig som et bedre alternativ, noget som kun fremtiden kan vise. Det store spørgsmål er derfor, hvad der vælges? Og hvorfor netop dette vælges? Systemteoretisk kan dette kun afgøres ved en epistemologisk tilgang, dvs. ved iagttagelser af anden orden, hvor man iagttager, hvorledes en iagttager, iagttager. 
Kommunikation om værdier finder primært sted som en refleksion over, om det man er sat i verden for at gøre - ens funktion, gøres godt nok, og aktualiserer på denne måde forskellens anden side, nemlig om det kunne gøres anderledes som regel i forståelsen "bedre". Iagttagelsesformen kunne beskrives som en iagttagelse ud fra distinktionen tilstraekkeligt/utilstraekkeligt, eller godt nok/ikke godt nok.

Men for at dette skal give mening fordres refleksion. En sådan refleksion anvender dels den funktionelle begrundelse, dvs. systemets relation til samfundet, og den funktionelle udmøntning af funktionen forstået som den ydelse, som systemet tilvejebringer til andre systemer i omverdenen.

Dette lægger et alvorligt pres på forventningerne til de ydelser, som organisationer skal leve op til, og organisationer i en global og omskiftelig verden kan få problemer med at honorere disse forventninger. ${ }^{200}$ Under sådanne idealiserede forventninger til organisationers beslutningsprogrammer, og i og med det pres de producerer på alle de beslutninger en organisation foretager, betyder det, at beslutningsprogrammer må være formuleret meget komplekst, kunne ændres og være ustabile i detaljen (Luhmann 2000a s. 373).

Generelt set iagttages organisationer i systemteorien som kontingente konstruktioner. De kunne være mulige på en anderledes måde, hvorfor organisationer altid iagttages som udtryk for et systems selektive måde at muliggøre sig selv og omverdenen på. Organisationer er autopoietiske systemer, som i overensstemmelse med sig selv producerer og reproducerer de elementer og strukturer, som de består af (Kneer \& Nassehi 1997 s. 63). De er iagttagende systemer, og deres iagttagelser er forbundet med organisationens egen historiske kompleksitetsopbygning i form af beslutninger relationelt ordnet i strukturer og samlet i beslutningsprogrammer, som udgør organisationens iagttagelsesprogram, dvs. beskriver organisationens særlige mulige måder at iagttage sig selv og omverdenen på. Beslutningsprogrammer udgør en organisations iagttagelses- og beslutningskriterier.

Erfaringer, viden, hierarki, organiseringer, kompetencer, kvalifikationer, medarbejdere, ledelse, brugere, service osv. er alle begreber, der kan ses som udtryk for en organisations interne relatering af dens erfaringer og viden, og kan forstås som beslutninger om, hvad der gælder henholdsvis ikke gælder som information for systemisk meningsproduktion og fremtidige

\footnotetext{
${ }^{200}$ Tænk bare på bureaukratiet, hvor alt var nedskrevet, og hvor ingen handlinger kunne finde sted med mindre de var beskrevet i organisationens beslutningsprogrammer. Sagsbehandling var omstændeligt og ressourcekrævende, fordi bureaukratiets hierarki skulle udføre sin kontrollerende myndighedsfunktion. I forbindelse med afvigende sager har netop den bureaukratiske model for organisationer vist sig yderst ufleksibel (se Luhmann 2000a s. 410).
} 
beslutningstagen. Funktionen af beslutningsprogrammer kan beskrives som tematiske programmer for kompleksitetsreduktion, der giver retning til, hvordan organisationen skal udføre sin funktion og tilvejebringe ydelser til systemer i dets omverden. Beslutningsprogrammerne angiver organisationens generelle og specifikke kriterier for beslutningstagen, og de er således udtryk for de muligheder og begrænsninger, som organisationens forventningsstrukturer operere indenfor. Beslutningsprogrammer er organisationens mulige iagttagelsesprogrammer, som den anvender til at iagttage sig selv og omverdenen med, og de anviser hvad og hvem organisationen er interesseret i og hvordan og hvornår, den er interesseret. Beslutningsprogrammer fungerer som information for fremtidige beslutninger, og dermed sætter beslutningsprogrammerne grænser for fremtidige beslutninger. Her kan vi tilbyde den og den service, på den og den måde, og hvis du er medlem, kan du få rabat. Hvorvidt en særlig pleje tilbydes, om medarbejderne skal bære særligt arbejdstøj, eller om brugeren tages med på råd, er forhold der alle er et udtryk for besluttede forhold, som refererer til organisations beslutningsprogram(er). Mere præcist er det utal af beslutningsprogrammer, som en organisation benytter sig af, udtryk for organisationens forventninger til medarbejderne, som beslutninger vedrører, og de angiver hvilke temaer, der er relevante og på hvilken måde.

Et organisationssystem anvender og opererer med et utal af beslutningsprogrammer knyttet til den række af temaer, der er relevante indenfor organisationen. Beslutningsprogrammer kan f.-eks. være en vagtplan på et plejehjem, forskellige former for inklusions- og eksklusionskriterier for brugere og ansatte, regler og procedurer for pleje, brugen af organisationens hierarki, graden af uddifferentierede beslutningskompetencer knyttet til bestemte medarbejdere eller medarbejdergrupper osv. Beslutningsprogrammer er således udtryk for organisatoriske kompleksitetsreduktioner, der i den udstrækning de giver forventelige anvisninger på, hvad der forventes, øger organisationens interne redundans. ${ }^{201}$ Men udover at beslutningsprogrammer er beslutningsanvisende, fungerer de også som vejledninger for evaluering af korrektheden af beslutninger. Det kan være et målprogram rettet mod et bestemt output, men også betingelsesprogrammer, som sætter grænser for spillerummet for korrekte beslutninger i forbindelse med et bestemt input (Luhmann 2003 s. 45).

\footnotetext{
${ }^{201}$ Således er bureaukratiet et klassisk eksempel på en organisationsform med en høj grad af indre redundans. Bureaukratiet opererer netop i udpræget grad ved regler for beslutningstagen og adfærd, som øger forudsigeligheden og dermed forventningerne for input, behandling og output.
} 


\section{Vardier, kommunikation og organisatorisk laring}

Beslutningsprogrammers temporalitet betyder, at det er i tilknytning til netop dem, at organisatorisk læring kan spores. Hvis der kan findes eventuelle differencer mellem fortidige og nutidige konstruktioner af beslutningsprogrammer, kan der siges at have fundet en læring sted, og den læring kan så efterfølgende tilskrives særlige begivenheder - i dette tilfælde Værdibaseret ledelse. Denne tilskrivning kan imidlertid også være til diskussion, eftersom attribuerings- eller kausalitetstilskrivning til disse forandringer foretages af en iagttager med begrænsede iagttagelsesmuligheder, og det "synlige" bevis fortaber sig i al den kompleksitet og kontingens, som ethvert forsøg på iagttagelse af forandring er forbundet med. Dette forhold bliver særligt relevant, når det sociale iagttages som kommunikation, der er kendetegnet ved at forsvinde i samme $\varnothing$ jeblik, det opstår. Et relevant spørgsmål bliver da at forsøge en sporing af den kommunikation, som resulterede i forandringen, og helt specifikt at unders $\varnothing \mathrm{ge}$ om forandringskommunikationen kan tilskrives kommunikation om Værdibaseret ledelse. 


\section{8}

\section{Præsentation af empiri og organisationsdidaktisk analysemodel}

I dette kapitel præsenteres afhandlingens empiri samt afhandlingens analysemodel i form af de temaer, som gøres til genstand for iagttagelse ud fra en didaktisk tilgang til organisatorisk læring. Analysemodellens funktion er at konditionere de didaktiske begreber til et program for, hvordan analysen af empirien er struktureret og praktisk operationaliseret, dvs. et program for analyse.

\section{Præsentation af empiri}

I dette afsnit beskrives afhandlingens empiri $\mathrm{i}$ form af Kommunes Værdibaserede ledelsesprojekt (VBL). Baggrunden for VBL er at byrådet i kommunen d. 28. maj 2001 vedtog en ny strategi og et nyt arbejdsgrundlag med henblik på en modernisering af ledelsesgrundlaget i kommunen som helhed. Under "Rammebetingelser" for udviklingsprojektet stod der at:

Den nye ledelsesform består af 2 centrale forudsætninger, der er udtrykt i:

- en vision

- et værdigrundlag med 8 ligeværdige kerneværdier (Bilag 14)

De otte værdier var: ansvarlighed, dialog, effektivitet, rummelighed, udvikling, helhed, kvalitet og brugerorientering (Nyhedsbrev fra direktionen nr. 11. 26/11 2001). Men blev på et tidspunkt af ledelsen reduceret til fem værdier, som er de fem værider alle kommunens afdelinger og ansatte skulle forholde sig til. De endelige værdier var: helhed, ansvarlighed, brugerorientering, udvikling og kvalitet.

Ud fra en politisk beskrivelse blev Visionen og værdigrundlaget iagttaget som en ny ledelsesform for hele organisationen/Kommunen: 
Det er vigtigt, at der skabes gode forudsatninger for de grundholdninger, der bør vare "pejlemarker" for udførelsen af jobbene og for den ånd Byrådet lagger vagt på bør gennemsyre det daglige arbejde (mangler ref?).

Processen med Var Med forventedes ud fra den politiske beskrivelse at imødekomme et oplevet udefra $\varnothing$ get pres i form af en stigende organisations- og systemeffektivisering, samt krav om medarbejdereffektivitet i det offentlige, dvs. kommunen. Projektet blev ligeledes iagttaget ud fra en $\varnothing$ konomisk optik, idet det forventedes, at udviklingsprojektet kunne skabe en mere lønsom ressourceudnyttelse, hvilket søgtes styret/realiseret gennem uddelegering af beslutningskompetencer til medarbejderne. Dette gjaldt f.eks. i forhold til kommunens igangværende organisationsudvikling i form af intern kontraktstyring, lønsumsstyring og modernisering af personalepolitikken (Kommune, 2001 s. 10). VBL-projektet skulle således forløbe sammen eller sideløbende med andre organisations- og styringsprojekter.

\section{Strategi for implementering af VBL}

I slutningen af 2001 var direktionen i kommunen på et tre dages seminar. I februar 2002 kom de første ledere på kursus, og senere samme måned var byrådet af sted. Fra april 2002, hvor de første medarbejdere startede og ca. 11/2 år frem, forventedes det, at alle ca. 6000 medarbejdere $\mathrm{i}$ kommunen havde været afsted på tre dages VBL-kursus. ${ }^{202}$ VBL-kurserne forventedes at svare til ca. 18.000 arbejdsdage, og fordi kurserne blev lavet i samarbejde med handelsskolen i kommunen, var det muligt at lave dem under loven om arbejdsmarkedsuddannelser, hvilket betød at staten gav lønrefusion. Kommunens udgift var derfor kun været tidsforbruget. For at skåne det daglige arbejde, så kommunens forskelle afdelinger osv. ikke skulle lukkes ned, blev kurserne gennemført som tværfaglige kurser. Et kursus bestod således af ca. 20 medarbejdere fra forskelle afdelinger i kommunen, og blev forestået af 20 udvalgte medarbejdere og ni lærer fra handelsskolen - med én til to instruktører/undervisere pr. hold. Instruktørerne var uddannet af det konsulentfirma, som i samråd med kommunens $\varnothing$ verste ledelse havde udformet organisationsudviklingskonceptet og undervisningsmaterialet.

\footnotetext{
${ }^{202}$ Grundet sygdom og andre forhindringer har det dog været nødvendigt at lave enkelte kurser som rækker ud over de berammede $1 \frac{1}{2}$ år.
} 


\section{Kontakt til Kommunen}

Mit kendskab til og kontakt med kommunen opstod gennem et tilfældigt møde med en tidligere bekendt. Vedkommende fortalte, at kommunen havde indledt et Værdibaseret ledelsesprojekt, og henviste mig til en person i personaleafdelingen, som jeg tog telefonisk kontakt til. Det første og indledende møde afholdes d. 5. februar 2002, hvor vi aftalte at lave et samarbejde. Jeg fik efterfølgende i samråd med Aalborg Universitets juridiske afdeling udfærdiget en samarbejdskontrakt (bilag 15). Kontrakten blev underskrevet af Kommunens Kommunaldirektør, og gav mig adgang til at indsamle den empiri, som jeg mener at have brug for til min afhandling, dvs. dokumenter, observationer, interview, deltagelse i introduktionskurser, medarbejder- og afdelingsmøder osv.

Nedenstående er en kort beskrivelse af mine møder med forskellige personer og afdelinger i kommunen.

- 17. april 2002 - møde i personaleafdelingen i kommunen.

- 28-30. maj 2002 - deltager jeg i et tre dages introduktionskursus i VBL.

- 18. september 2002 - møde med personaleafdelingen i kommunen.

- D. 7. marts 2003 -interview med leder af personaleafdelingen i Kommunen.

- D. 13. marts 2003 - møde på personaleafdelingen i Kommunen.

- D. 16. september 2003 - interview med økonomi direktøren i Kommunen.

- D. 2. oktober 2003 - møde med personaleafdelingen i Kommunen.

- D. 9. oktober 2003 - interview med lederen af plejehjem.

- D. 10. oktober 2003 - interview med afdelingslederen af Områdecentret.

- D. 4. november 2003 -fokusgruppeinterview med ergo- og fysioterapeuter fra Områdecentret.

- D. 7. november 2003 - deltager i og optager et personalemøde mellem ergo- og fysioterapeuter fra Områdecentret.

- D. 10. december 2003 - deltager i og optager et møde mellem ergo- og fysioterapeuterne på Områdecentret.

- D. 17. december 2003 - fokusgruppeinterview med ergo- og fysioterapeuterne på Områdecentret.

- D. 8. juni 2004 - fokusgruppeinterview med gartnerne.

\section{Organisationsdiagram over kommunen}

Nedenfor er et organisationsdiagram over den kommune, som udgør afhandlingens empiri. Af anonymiseringsmæssige grunde er navne på personer streget over med sort. De to afdelinger, hvorfra empirien stammer og som 
232 Prasentation af empiri og organisationsdidaktisk analysemodel

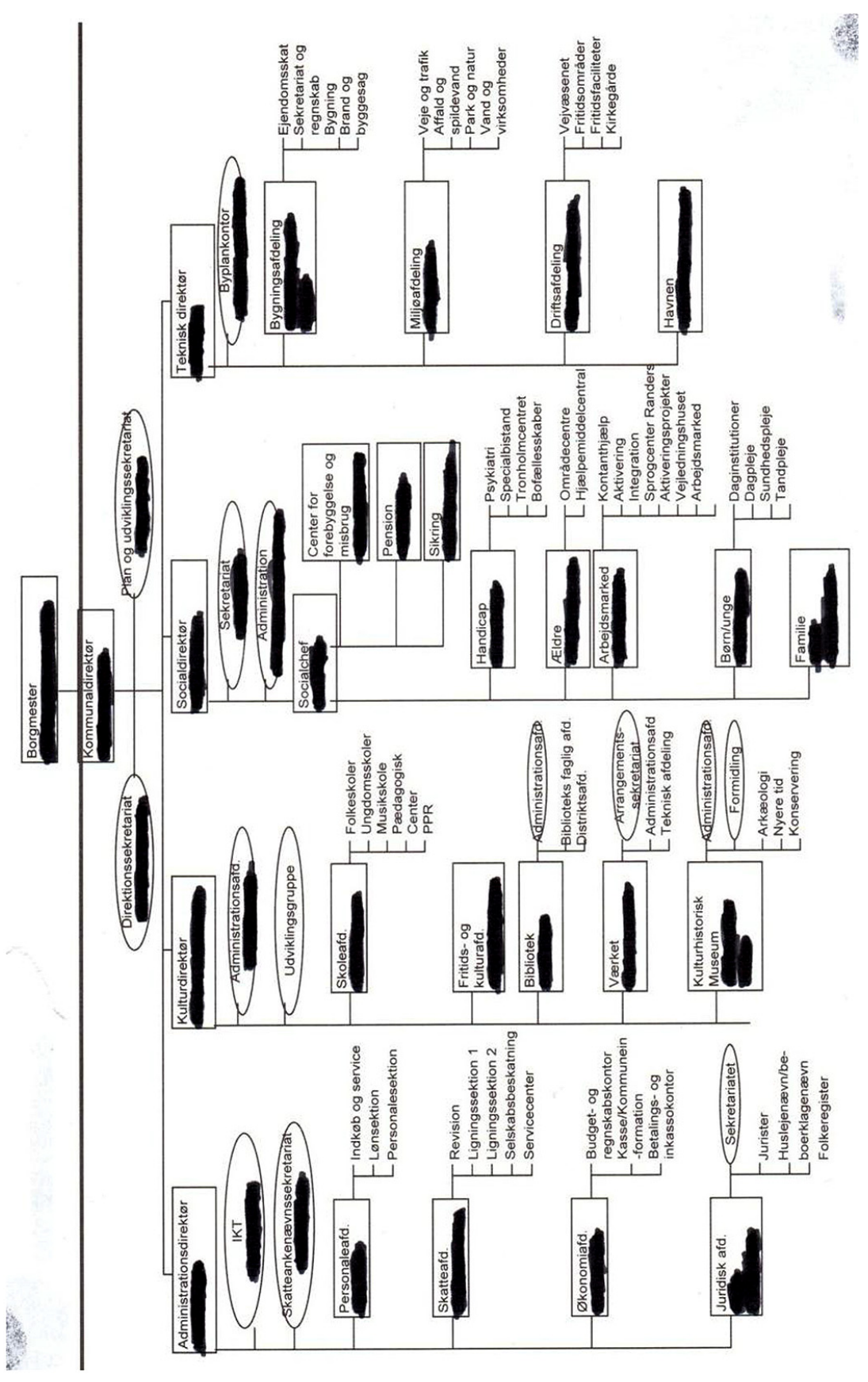


bliver gjort til genstand for analyse er Områdecentret, som findes nede i tredje søjle fra venstre. Områdecentret hører under socialdirektøren og befinder sig under aeldre området. Den anden afdeling er Park og natur og befinder sig i diagrammet yderst til højre. Denne afdeling hører under den tekniske direktør og er en del af Miljøafdelingen.

\section{Organisationsdidaktisk analysemodel}

Det er Kommunen som organisation, der er analysens genstand, og den indsamlede empiri forstås som forskellige organisatoriske subsystemers systemrelative perspektiver på bestemte dele og arbejdsområder i kommunen. Som det er fremgået er der produceret en del empiri til afhandlingen, men det er ikke alt som anverndes, inddrages og analyseres på. De bilag som indgår i analysen refererer til to forskellige systemperspektiver. Systemperspektiverne og de bilag som referes til er:

Park og natur: Bilag; 5 og 6 .

Områdecentret: Bilag; 3, 4, 7, 8 og 10.

Bilagene består af individuelle interview, fokusgruppeinterview eller personalemøder (se eventuelt indholdsfortegnelsen i bilagsmappen). Ud fra en systemteoretisk betragtning udgør et interview et interaktionssystem oprettet med det formål at kommunikere om et organisationssystems kommunikation og beslutninger, mens optagelser og udskrifter af personalemøder kan betragtes som genuin organisatorisk kommunikation, fordi det repræsenterer et organisationssystems aktuelle kommunikation. Der vil i analysen ikke blive skelnet mellem disse to datatypers validitet, dvs. i hvilken udstrækning de er forskellige $\mathrm{i}$ forhold til hvorvidt f.eks. data fra personalemøder er mere valid end interview data. I stedet for at behandle de forskellige empiriindsamlinger forskelligt alt efter om de er udtryk for, hvad man kunne betegne genuin organisatorisk kommunikation (personalemøder), eller kommunikation om et bestemt organisationssystem, har jeg valgt at ligeeller sidestille empiriindsamlingerne, således at kommunikation vedrørende ét bestemt organisationssystem slås sammen og behandles som samlet udtryk for kommunikation i relation til ét systemperspektiv.

Begrundelsen for valget af empiriindsamling stammer tilbage fra projektets oprindelige erkendelsesinteresse som var at analyse værdibaseret ledelse i en større organisation (se evt. bilag 15). Intentionen var at indsamle empiri fra hvad man kunne kalde de yderste led i organisationen, dvs. subsystemer 
af kommunen som ikke havde f.eks. forvaltningsopgaver hvor det handler om at beslutte hvordan andre subsystemer skal forvaltes. Intentionen var, at finde subsystemer som skulle bruge værdierne til beslutninger i relation til eget arbejde og arbejdsområde. Her mente jeg at et plejehjem, et områdecenter og et en afdeling i Park og natur (gartnere) var gode udgangspunkter. Udvalgt til den konkrete analyse blev Park og natur, og Områdecentret. Dette dels fordi jeg havde hvad jeg vil betegne 'gode' og i en vis forstand dækkende data, dvs. interterview med både leder og medarbejdere, og dels fordi de to afdelinger arbejder med meget forskellige områder. Park og natur arbejder med grønne arealer, mens Områdecentret arbejder med mennesker.

I overensstemmelse med ovenstående empiriske refleksioner opereres der derfor i analysen med to forskellige systemperspektiver, som først analyseres særskilt og dernæst bringes sammen i en sammenlignende, dvs. komparativ, analyse (se mere under afsnittet komparativitet).

\section{Funktionel analytisk form}

Som tidligere beskrevet anvendes der med inspiration fra Luhmanns systemteori en funktionelt ledet analytisk tilgang til empirien. Luhmann betegner den funktionelle analyseform som en strategi, der:

"... anvender relationer med det formål at forstå det eksisterende som kontingent og det forskelligartede som sammenligneligt. Den relaterer det givne, det vare sig tilstande eller hoendelser, til per-

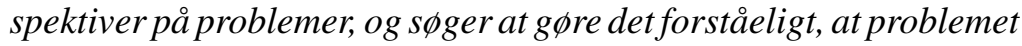
kan løses på såvel en som på en anden måde. Relationen mellem problem og problemløsning bliver således ikke taget op for sin egen skyld, men som ledetråd for spørgsmålet om andre muligheder, som ledetråd for efters $\phi$ gningen af funktionelle akvivalenter" (Luhmann 2000a s. 91)

I den funktionelle analyse iagttages empirien ud fra et funktionelt perspektiv, som dels betyder, at de empiriske iagttagelser er intereserede i, på hvilken måde kommunikationer relaterer sig til funktionsforhold for systemet, og dels at kommunikationen om forandring og læring iagttages ud fra et spørgsmål om problem og problemløsning (ydelse). Erkendelsesgevinsten er sammenligning, dvs. komparativitet, da det bliver muligt at sammenligne de forskellige systemers anvendelse af samme koncept; nemlig VBL. 


\section{Undervisnings- og læringsmål}

Ud fra en didaktisk tilgang er læringsmål afgørende i relation til tre henseender; dels for overvejelser angående undervisningens tilrettelæggelse, dvs. alle efterfølgende undervisningsrefleksioner og prioriteringer, dels for undervisningens intenderede læring i form af strukturforandringer i både sociale og psykiske systemer, og endelig for evalueringer af læringsudbyttet.

Eftersom VBL-projektet for Kommunen ikke rummer konkrete foreskrevne læringsmål (jf. afsnit om værdier) men har uddelegeret formuleringen af disse til organisationens forskellige subsystemer, er den analytiske bestræbelse at fremanalysere subsystemernes kommunikation om hver deres systemrelative formulerede læringsmål.

Ud fra den grundlæggende distinktion mellem system og omverden iagttages først systemets interne distinktioner i form af tilslutning og afvisning af kommunikerede temaer. Dette gøres med henblik på at identificere de temaer, der er udtryk for systemets nye måder at iagttage sig selv på, og som vinder indpas i systemet, dvs. får en videre kommunikativ færd i systemet. Temaerne ses som systemets egen produktion af nye forventninger til sig selv, og tjener funktionelt som fremtidige besluttede læringsmål for det pågældende system.

Ud over en iagttagelse og beskrivelse af tilsluttede temaer for organisatoriske læringsmål, analyseres det sociale systems kommunikative konstruktion af mening i relation til hvert tema. Dette gøres med henblik på at forstå det enkelte sociale systems selvreferentielle formgivning og konditionering af de tilsluttede temaer, nærmere bestemt hvilken mening systemet konstruerer i relation til temaerne. Tilslutningen til og formgivningen af temaerne tjener funktionelt til at angive det enkelte sociale organisationssystems forståelse af, hvad der skal undervises $i$, laeres og evalueres. Formgivningens funktion kan beskrives som det sociale systems fremtidige forventninger til sig selv og til organisationssystemets medarbejdere; forventninger, som er fremkommet på baggrund af det enkelte sociale systems iagttagelse, dvs. refleksioner over sig selv.

Det centrale spørgsmål bliver derfor i første omgang: Hvilke temaer vinder tilslutning/afvisning $i$ det enkelte sociale systems kommunikation, og på hvilken måde giver det sociale system dem og dermed sig selv form?

\section{Funktion, ydelse og refleksion}

Systemteorien opererer med en grundlæggende distinktion mellem system og omverden. Et system iagttages altid i relation til sin egen omverden, som det grundlæggende er strukturelt relateret til. Ovenstående tematiseringer og 
formgivninger iagttages derfor funktionelt som systemrelationelle, kontingente og iagttagelsesstrukturelle selektioner til reduktion af omverdenens kompleksitet. I fors $\varnothing \mathrm{g}$ på at 'mestre' dette problem vedrørende iagttagelse af omverdenskompleksiteten betjener systemer (organisationer) sig af tre grundoperationer, nemlig funktion, ydelse og refleksion. Funktion er knyttet til system/omverden-distinktionen og har med systemets iagttagelse af hele samfundssystemet at gøre. Ydelse har med systemets iagttagelse af eller forhold til andre systemer at gøre. Refleksion er knyttet til systemets selviagttagelse, dvs. refleksion vedrører systemets forhold til sig selv (Luhmann 1982 s. 238; 1997 s. 757). Funktion og refleksion retter sig altså primært mod systemets - her det organisatoriske systems - egen selvreference og selvkontrol, hvor ydelse retter sig mod iagttagelsen af omverdenen af $\varnothing$ vrige systemerdet være sig sociale eller psykiske systemer. Denne tredeling i funktion, ydelse og refleksion gælder alle systemtyper, og mere specifikt i relation til interorganisatoriske forhold, dvs. organisationer og deres subsystemer (afdelinger) så står en afdeling i en organisation i et forhold til hele organisationen (funktion), til andre afdelinger (ydelse) og til sig selv (refleksion) (se Hagen 2006 s. 131).

I analysen bliver systemernes tematiseringer og formgivninger analyseret ud fra, hvorvidt de retter sig mod funktionsområdet eller ydelsesområdet. Ud fra et organisationsdidaktisk perspektiv er den kommunikation (ovennævnte temaer), som vedrører ændring af eksisterende forhold og forståelser særligt interessant, det være sig i relation til funktions- eller ydelsesområdet. Der vil derfor være særligt fokus på de refleksioner, som relaterer sig til disse to områder, dvs. refleksioner, der enten tager udgangspunkt i funktionsområder som refleksioner over systemets selvreference og selvkontrol, eller refleksioner over ydelsesområdet, dvs. kommunikationer, der tager udgangspunkt i iagttagelsen af systemer i omverdenen.

Analysen vil også anvende en tilgang til kommunikastion baseret på forståelsen af semantik eller semantiske former som relaterer sig til det forhold, at for at kunne håndtere en række forskellige tematiseringer opbygger systemer kompleksitet i form af meningsfulde former som en slags "... forråd af til rådighed stående regler til meningsforarbejdning." (op.cit. Kneer \& Nassehi 1997 s. 124). Disse koordinerende meningsfulde former, ". . som står til rådighed for hurtig og hurtigt forståelig optagelse i konkrete kommunikative processer." (Luhmann 2000a s. 205), kalder Luhmann for temaforråd. Eller som han udtrykker det: "Vi kalder dette temaforråd for kultur, og -hvis det er reserveret til kommunikationsformål - semantik" (Luhmann 2000a s. 205), og "Med semantik forstår vi derfor en høj grad af generaliseret mening, som er 
disponibel relativt uafhcengigt af situation." (Op.cit. Kneer \& Nassehi 1997 s. 124).

I den udstrækning, at noget skal forstås på tværs af kontekster eller temaer, må det basere sig på generaliserede semantiske eller kulturelle former, som står til rådighed for hurtig forståelse i konkrete kommunikative processer. De semantiske former et system benytter som udtryk for sine generaliserede forståelser til et område eller tema, kan være udslagsgivende for systemets begrundelser for hvorfor det vælger som det gør. Et systems semantik kan derfor være vigtig for forståelsen af systemets til og fravalg relateret til beslutninger.

\section{Læring og konditioneringsprogrammer}

Ud fra et systemteoretisk perspektiv iagttages og beskrives organisationer som konditionerede systemer, dvs. systemer, der på basis af selvreferentialitet har opbygget og til stadighed opbygger kontingente strukturelle repertoirer af muligheder og begrænsninger for selektion. Konditioneringers systemiske funktion er grundlæggende at reducere omverdenskompleksiteten, og at gøre det muligt for systemer at vælge, handle og beslutte. Dette gøres ved at konditioneringer i mere eller mindre præcis form angiver, hvordan og hvad der er interessant, dvs. under hvilke betingelser bestemte muligheder foretrækkes frem for andre muligheder samt hvordan. Ved læring forstås helt generelt ændringer i systemers forventningsstrukturer, som for organisationers vedkommende kan beskrives som ændringer i systemets konditioneringsprogrammer.

I overensstemmelse med afhandlingens erkendelsesinteresse i problemformuleringen og med afsæt i ovenstående beskrivelse af funktion, ydelse og refleksion som analytiske tilgange til genstandsfeltet, søges der i analysen efter kommunikation, som vedrører eller kan iagttages som kommunikation, der omhandler ændringer i systemets konditioneringsprogrammer, dvs. forventningsstrukturelle forandringer i, hvordan systemerne indsnævrer eller udvider systemets forståelse og repertoire af handlemuligheder relateret til funktionsog ydelsesområdet.

\section{Organisationsdidaktiske temaer}

I overensstemmelse med afsnittet om organisationsdidaktik og ovenstående analyser af temaer og deres formgivning, samt refleksioner over konditioneringsprogrammer relateret til funktions- og ydelsesområdet, fokuseres der på kommunikation, som omhandler nedenstående didaktiske temaer. Den 
didaktisk analytiske tilgang søger at bidrage med viden om organisationssystemernes egen kommunikation om og egne refleksioner vedrørende didaktiske spørgsmål. Dette gøres med særligt henblik på at genere empirisk viden til udviklingen af en organisationsdidaktik.

Didaktiske spørgsmål i relation til læring

- Hvem skal lære?

- Hvad skal læres?

- Hvornår skal der læres?

- Hvor skal der læres?

- Hvordan skal der læres?

- Hvorfor skal der læres?

\section{Komparation - det generelle og det specifikke}

Der er mulighed for, at nogle temaer aktualiseres i alle tre organisationssystemer, og at nogle temaer kun bliver aktuelle $\mathrm{i}$ et af systemperspektiverne. Der vil også være mulighed for, at der på et generelt plan skabes konditioneringer og meningshenvisninger, der kan henføres til f.eks. en anvendelse af samme medier eller koder, ligesom det er givet, at der også vil være mulighed for, at hvert systemperspektiv i henhold til overordnede generaliserede kommunikationsformer genererer specifikke iagttagelser. Ønsket er at tilføre analysen muligheden for komparation, og derfor anvendes distinktionen generel/specifik. Som et led i arbejdet med at opbygge analysen, blev der samtidigt med kodningen af datamaterialet konstrueret en liste af temaer, som kan relateres til hvert systemperspektiv. I analysen anvendes det til at henvise til henholdsvis det generelle og det specifikke. Når et tema vinder indpas i to eller flere systemperspektiver, undersøges under hvilke meningshenvisninger og i anvendelsen af hvilke medier, at temaet gives form i hvert systemperspektiv, og der sammenlignes ud fra en iagttagelse gennem distinktionen generel/specifik. Når et tema kun vinder indpas i et systemperspektivs kommunikation, undersøges det ligeledes under hvilke meningshenvisninger og i anvendelsen af hvilke medier, dette særlige tema gives form, og såfremt det er muligt undersøges det også,om kommunikationen kan fortælle, hvorfor dette gælder specifikt for dette system.

\section{Systematisering og anvendelse af empiri}

Inden jeg går i gang med analysen, vil jeg kort forklare, hvordan jeg har systematiseret empirien. Som udgangspunkt har jeg udskrevet tre personalemøder, de individuelle interviews samt fokusgruppeinterviewene. 
Jeg har valgt at udskrive al den kommunikation, jeg har haft adgang til, men har valgt kun at udskrive den verbale kommunikation. Den samlede udskrift findes i bilagene 1-10. I analysen selekterer jeg bidrag fra kommunikationen i henhold til de konstruerede lister, jeg tidligere nævnte. I analysen betyder det, at der forekommer udvalg af bidrag, hvor den samlede kommunikationsproces, hvorfra disse bilag er udvalgt, strækker sig over væsentlig længere tid. Her henvises der til sider i bilagsmappen, og jeg vil meningskondensere, hvad der sker i tiden mellem de udvalgte bidrag.

Til sidst skal det blot nævnes, at medarbejderne er anonymiserede. Derfor beskrives personerne ud fra deres roller i forkortede former. Dette sker på følgende måde:

$\mathrm{LR}=$ Lederen af Kommunens personaleafdeling

$\mathrm{MB}=$ Administrationsdirektør

$\mathrm{L}=$ Leder af pågældende afdeling

$\mathrm{M}=$ Medarbejder i pågældende afdeling

$\mathrm{H}=$ Henrik Vardinghus-Nielsen (Interviewer) 



\section{9}

\section{Analyse}

Inden analysen starter skal nogle overordnede betragtninger og disponeringer for den klargøres. Analysen skal ses i relation til afhandlingens tredje spørgsmål i problemformuleringen, nemlig:

På hvilken måde er en sådan organisationsdidaktik meningsfuld i forhold til at forstå og analysere organisatorisk laring i et konkret organisationsudviklingsprojekt?

Dette indikerer, at analysen vigtigste fokus ikke er at præsentere en full scale analyse af kommunens VBL-organisationsudviklingsprojekt. Analysens funktion er at vise på hvilken måde, en organisationsdidaktik kan give mening som epistemologi til analyse af et organisationsudviklingsprojekt. Ud fra den overordnede betragtning er analysen mere eksemplificerende med henblik på at vise, hvordan en sådan analyse kan se ud, herunder selvfølgeligt også at komme med en udlægning på, hvad der empirisk kan iagttages med en sådan analyseform, dvs. analysere på væsentlige aspekter af VBL som organisationsudviklingsprojekt. Analysen er delt op i to overordnede dele. Den ene del analyserer afdelingen/subsystemet Park og natur, og den anden del analyserer afdelingen/subsystemet Områdecentret. De to afdelinger præsenteres nærmere i starten af den konkrete analyse af dem. Der er imidlertid forskel i længden og kompleksiteten af de to analyser, og det vil jeg kort præsentere hvorfor.

Den korteste og mindst komplekse analyse er den af Park og natur, og det skyldes for det første at jeg har færre data derfra (to interviews, ét med lederen og en medarbejder, samt et fokusgruppeinterview med afdelingens gartnere). For det andet at det valgte hovedtema for analyserne selvledelse, og de pointer som knyttes sig hertil er mindre komplekse hos Park og natur.

Analysen af Områdecentret er væsentligt længere og mere kompleks, hvilket for det første skyldes, at jeg har langt mere empiri herfra (ét interview med afdelingslederen, ét fokusgruppeinterview med centrets terapeuter og tre personalemøder) For det andet skyldes det, at de temaer og beslutninger, som 


\section{Analyse}

knytter sig til selvledelse på Områdecentret, har en mere kompleks karakter, hvilket vil fremgå analyserne.

\section{Uddifferentiering af ledelse - selvledelse}

Ud fra en didaktisk iagttagelse af organisationsudviklingsprojektet om Værdibaseret ledelse (VBL) konditioneres analysen efter den enkelte afdelings egne formulerede laringsmål for både det sociale system, og medarbejderne i form af psykiske systemer. I overensstemmelse med organisationsudviklingskonceptet er det uddelegeret til den enkelte afdeling selv at formulere, hvordan værdier skal forstås og formuleres, dvs. hvad der på den pågældende afdeling udkrystalliserer sig af forventninger i relation til dem og hvilke beslutninger, der skal tages i relation til værdikommunikationen og refleksionerne.

Som beskrevet i Organisationsdidaktisk analysemodel til empirisk analyse er læringens Hvad organisationens/afdelingens egen formulering af forventninger til, hvad der skal læres, og dette forventes at blive afgørende for alle efterfølgende undervisningsrefleksioner og prioriteringer, som kan udledes af det empiriske materiale. Afhandlingens empiriske analyser tager derfor udgangspunkt i læringens $h v a d$, og knytter efterfølgende de andre didaktiske begreber i form af forventningerne til læringens; hvem, hvornår, hvorfor og hvordan, til læringens hvad.

I analysen kalder jeg lærings hvad for laeringsmål, og med henblik på komparation analyseres først Park og natur, efterfulgt af Områdecentrets formulering af læringsmål.

I dokumenterne fra det tre dages introduktionskursus til værdiarbejdet, som alle medarbejdere i kommunen har været på, står der bl.a., at et af målene for VBL er, at det gerne skulle lede til medarbejdernes selvkontrol/laring, og at midlet eller mediet hertil er selvledelse. Selvledelse står dermed som et centralt medie for udviklingen af kommunens afdelinger i relation til VBLprojektet, hvilket - som det vil fremgå i analysen - stemmer godt overens med de undersøgte afdelingers tematiseringer i forlængelse af deres VBL-

diskussioner. Det fremgår ligeledes, at det er en ledelsesopgave, at ledere skal lære, hvordan de leder selvledende medarbejdere, således at de støtter op om, dvs. funktionelt muliggør, intentionerne bag organisationsudviklingsprojektet VBL.

Afhandlingens forståelse af VBL-projektets funktion er, at organisationens værdirefleksioner potentielt skal genere nye iagttagelser af organisationens 
måde at være organisation på. Dette betyder, at værdidiskussionerne i kommunens forskellige subsystemer består $\mathrm{i}$ at generere nye iagttagelser af organisationen, som kan inspirere til at tage nye beslutninger for organisationens konditionering. Værdidiskussionernes funktion bliver på den måde at genere ideer til nye konditioneringer, som grundlæggende ændringer af organisationen måde at være organisation på, og de udstikker på den måde nye forventninger til kommunen generelt og i forhold til de forskellige subsystemer, hvilket i sidste ende er afhængig af organisatorisk og individuel læring.

Hvordan dette kommer til syne skal vi se i den første indledende analyse af Park og natur.

\section{Park og natur}

Hos Park og natur lavede ledere og medarbejdere et program for, hvordan medarbejderne efter det tre dages obligatoriske kursus i Var Med skulle mødes en tre til fem timer umiddelbart efter kurset, hvor der var mulighed for at "laesse af" (s. 110), dvs. fortælle om deres indtryk af kurset. Derefter skulle medarbejderne gruppevis og skriftligt forholde sig til, hvad de tænkte i forhold til de fem kerneværdier. Disse beskrivelser blev efterfølgende samlet for at blive læst igennem og skulle endelig resultere i en samlet beskrivelse af, hvordan man i subsystemet for gartnerne skulle forstå og forholde sig til værdierne. Ifølge den medarbejder, som sammen med lederen skulle sammenskrive beskrivelserne var det gennemgående tema at:

"M: (...) det kendetegner noget vi ikke er i dag, nogle pejlemarker for fremtiden, det er noget vi фnsker at blive bedre til, eller det er et sted vi фnsker at gå hen. Ud af det, der er der måske 5 procent hvor man kan give det et flueben i dag og sige, at under den norm der, der er vi i dag, resten det er nogle sigtepunkter, så det kan man også laese ud af det, hvad фnsker kollegerne, medarbejderne bredt, skal kendetegne virksomheden fremover. (...) L: Det er så vores forslag til, at det kan vare driftsafdelingens vardinormsat." (s.111)

Det var herefter meningen, at værdiformuleringerne skulle afløse de tidligere regler. Man ønskede med andre ord at gå fra ydre og hierarkisk styret regel konditionering til selvreferentielt defineret værdikonditionering af gartnernes arbejde. 


\section{Analyse}

I et didaktisk perspektiv er det formulering af læringsmål for sig selv, kendetegnet ved refleksion over det systemet og medarbejderne ikke er og gør i dag, men har en forventning om at kunne eller blive i fremtiden. Det er dermed formulering af læringsmål for fremtidig konditionering, og konditionering af læringsmål for fremtiden.

\section{Gartnernes refleksioner over selvledelse}

Et af de temaer, der fremstod som helt centrale for gartnerne som subsystem var uddelegering af ledelse, dvs. selvledelse. I interviewet med lederen kommer de ledelsesmæssige refleksioner til udtryk på nedenstående måde.

"L: Jamen det er at give los. Fordi det er dem der har haft magten, det er dem der har skullet forvalte de ressourcer, isar medarbejderressourcer, og lige pludselig så skal de her medarbejderressourcer, altså det er jo medarbejderne, de skal jo til at forvalte sig selv. Og dvs. så bliver lederen n $\phi d t$ til at trade i baggrunden og lade medarbejderne komme til, (...) at den enkelte medarbejder, eller ansvarligheden og beslutningerne skal lagges sådan langt ud til medarbejderne som overhovedet muligt. Og dvs. at jeg som leder skal jo vare klar til at give de medarbejdere som kan tage ansvarligheden på sig, og som har lyst til det, give dem mere og mere frie tøjler, give dem den frihed og det rum som skal til, sådan så de agerer bedst muligt i deres job. (...)” (s. 113)

For gartnerne er selvledelse forbundet med at have indflydelse på prioritering og strukturering af eget arbejde i form af koordination af opgaveløsning og med muligheden for brug af faglighed i relation til ydelsesområdet, dvs. medbestemmelse på, hvordan kommunens grønne områder skal serviceres. Afdelingens funktion er pleje, vedligeholdelse og beplantning af Kommunens parker, natur og skov områder - kort sagt; Kommunens grønne områder. Funktion kan på den måde beskrives som, hvad gartnerne skal arbejde med. Ydelse kan forstås som, hvordan de kan arbejde med det, de skal. Endelig kan refleksion forstås som deres iagttagelses af forholdet mellem hvad og hvordan, dvs. overvejelser over muligheder og begrænsninger for, hvordan de kan arbejde med det, de skal arbejde med.

Afdelingen har ca. 50 medarbejdere (flest gartnere) fordelt på en række teams af varierende størrelse (fra 2-5) (s. 121). Ifølge medarbejderne har man $\mathrm{i}$ årevis arbejdet efter de principper, som ligger i uddelegeret ledelse, idet 
både den tidligere og nutidige organiseringsform samt konditioneringen af arbejdets tilrettelæggelse ude i 'marken' har været bestemt af teamene selv.

"3: (...) folk har faktisk $i$ mange år haft ret sådan frie tøjler ude $i$ marken altså det er begranset hvor meget jeg kommer ud og siger du skal gфre det og du skal gфre det. Det finder de selv ud af." (s.132) "5: Hvis vi går ind og snakker kompetencer så den her denne grønne afdeling så kan du så sige at selvledelseskompetencen er meget stor i denne afdeling (...)" (s.133; jf. s.113-114)

Gartnerne oplever ikke i det daglige arbejde den store forskel på baggrund af VBL, men de henviser ved refleksioner over funktion og ydelse til andre strukturelle forhold, som begrænsende i forhold til selvledelsen (jf. s.147). Disse strukturelle begrænsninger har ikke nødvendigvis noget med VBL at gøre, men bliver synlige i kraft af VBL, fordi de opleves som i modstrid med ideerne og intentionerne bag konceptet om VBL, som blandt andet defineres som i forskel til regelbaseret ledelse (jf. s. 9; $31 \& 34$; s.135; s.114-115).

"L: (...) Det er egentlig for at forklare, (...) det er ikke så mange år siden, og vi arbejder stadigvak $i$ arbejdshold, $i$ sjak, 2-3-4 måske 5 medarbejdere, de har et geografisk område at passe. For et par år siden da var det sådan, at der var lagt nogle rammer, nogle plejeniveauer $i$ de områder som, og det var nogle kendte rammer, altså det var medarbejdere der kendte de plejeniveauer og rammer, dvs. de kunne frit agere indenfor de her rammer. I dag er det sådan, at nu er hver enkelt bed type beskrevet, hvad skal man gøre ved et rosenbed der skal se sådan og sådan ud, det er meget nфje beskrevet, hvor mange gange skal man nippe hovederne af roserne og hvor mange gange skal der (kultiveres?) for ukrudt osv. Dvs. at $i$ princippet så kan medarbejderen tage hovedet under armen og skuffejernet under den anden arm, og så kan der vare en der holder bogen, og så laser man hvordan man gфr. M: Las manualen. L: $\mathrm{Ja}$. $\mathrm{Og}$ det er det, som (medarbejderen) siger, at der er altså noget handlefrihed der er taget fra os her. For da kunne vi arbejde meget mere frit, nu arbejder vi efter en bog." (s.121)

Som det fremgår, oplever gartnerne, at de over tid er gået fra en form for selvbestemmelse angående ydelsesområdet, dvs. hvordan de vil arbejde med de områder, de passer, til i dag at være 'styret' af regelbaserede beskrivelser af, hvad der skal gøres, og hvordan det skal gøres. Dette betyder en styring af 
gartnernes ydelsesområde i form af de grønne områder, de arbejder med, og det betyder altså helt grundlæggende mindre selvledelse hos gartnerne.

"L: (...) Den faglige udfoldelse for den enkelte gartner og prøve nogle ting af, det er slut, det er mere sådan mekanisk arbejde." (s.122)

Muligheden for at bruge sin egen gartnerfaglighed i forhold til arbejdet, f.eks. ved at lave eksperimenter og danne erfaringer på baggrund af dette, oplever de ikke længere som mulig på en række områder, da deres arbejde handler om og er styret af at skulle opfylde kontraktlige forhold bestemt af andre (arkitekterne).

"4. For vi virkelig kan få det organisatoriske med her ved os, så skal vi vak (...) fra det begreb kontraktstyring (...) så skal vi samme vej som resten af kommunen, (...) hvor aftalerne virker på dialogen. Hvor man aftaler de store rammer, altså i fär driften af de grønne anlag og (...) tat samarbejde med landskabsarkitekterne deroppe, (...) hvor man mødtes decideret ude i skuret med landskabsarkitekterne en gang om året og (...) vi tagermed ud, hvad har i gang $i, h v a d$ sker der, hvad kan i drømme om, (...) for grundlaeggende har grønne folk altid en stolthed de føler for deres område. (...) Det ejerskab til området, til det man holder, det er ved at forsvinde nu. Fordi fundamentet forsvinder under os, vi bliver decideret entrepren $\phi r e r$, du skal ikke gфre noget som helst du skal bare udfфre det der står skrevet. (...)" (s.146)

Begrundelserne for den manglende dialog er i følge gartnerne den politisk besluttede BUM-model (Bestiller-Udfører-Modtager-model) (s.115), og arkitekters og gartneres geografiske adskillelse, som betyder, at de ikke 'naturligt' mødes med hinanden. Gartnerne iagttager kommunikationen med arkitekterne ud fra distinktionen +/- samarbejde som udgangspunkt for styring, og oplever den som frustrerende, fordi de selv har en semantik om dialog som konditionering af kommunikation i eget system og som semantik for kommunikation/samarbejde med andre systemer. En semantik som de også knytter til kommunikationen, eller manglen på dialog til andre af kommunens systemer, f.eks. afdelinger inde på Rådhuset. Ved refleksion over sig selv som system i forskel til andre systemer i kommunen oplever gartnerne at 3: (...) det er lettere at gennemføre noget i små enheder." (s.161). Med dette henviser gartnerne til, at de oplever det som nemmere at ændre noget 
i deres egen enhed. Helt grundlæggende handler det om, at de gennem dialogen i egne teams og grupper oplever muligheden for at få snakket om tingene og derigennem finde de løsninger, som de mener, er bedst, og på baggrund af disse dialoger gennemføre ændringer. Deres problem i forhold til f.eks. BUM-modellen og muligheden for dialog med andre systemer i kommunen hviler på, at de ikke har beslutningskompetencen, hvilket betyder, at de oplever, at muligheden for at gøre en forskel på ydelsesområdet ikke er til stede. Der er med andre ord en oplevelse af, at der er grænser for deres egen beslutningskompetencer i forhold til dem selv som system og i forhold til andre af kommunens systemer. Gartnerne oplever grænserne for deres egen beslutningskompetence over sig selv, idet de oplever, at beslutninger taget $\mathrm{i}$ andre af kommunens systemer (byråd og andre aftalestyrede enheder) griber ind i og har begrænsende indflydelse på gartnernes beslutningskompetencer i form af muligheder for selvledelse af eget arbejde, og at disse styrende omverdensbeslutninger er svære at ændre på (jf. s.160-161). Denne oplevelse er paradoksalt nok opstået som følge af kommunens systemkonditionering af dens interne differentiering, dvs. uddelegering af beslutningskompetencer.

Som alternativ til styringskommunikation mellem kommunens interne differentieringer knyttes gartnernes semantik om dialog positivt til tre forhold; gartnernes motivation og til funktions- og ydelsesområdet. Gartnernes motivation knyttes til semantikken om mulighed for indflydelse på eget arbejde, og dermed til mulighederne for at påvirke funktions og ydelsesområdet (jf. s.118). I den udstrækning gartnerne ikke oplever dialog med andre systemer, som har indflydelse på konditionering/styring af deres arbejde, oplever de mindre motivation, og de vurderer, at det har negative konsekvenser for funktions- og ydelsesområdet, idet deres faglige viden ikke kan forbindes til og gøre en forskel i forhold til pleje, vedligeholdelse og beplantning af kommunens grønne områder. De mener ikke, at f.eks. landskabsarkitekterne har tilstrækkelig og aktuel viden om de grønne områder, som de beslutter over, og derfor ikke kan tage/tager de rigtige beslutninger i forhold til, hvordan de ud fra gartnernes faglige skøn bedste muligt skal serviceres. Gartnerne $\emptyset$ nsker at fravælge styringskommunikation (BUM-modellen) som medie for kommunikation med arkitekterne til fordel for dialog, som gartnerne mener, er mere i overensstemmelse med VBL. Det begrundes yderlige med henvisning til distinktionen +/- helhed, hvor de vælger helhedskoden som refleksions- og iagttagelsesform. Med henvisning til distinktionen helhed henviser gartnernes refleksioner til tre forskellige forhold. Det ene gælder refleksionen over ydelsesområdet, dvs. kommunens grønne områder. 
"1: Jeg synes også man kan se det på områderne i forhold til førhen, der ikke så flotte anlaeg som der var førhen"

"2: Hvis der skal arbejdes efter de der retningslinjer så siger de også at du kun må gøre den ting 6 gange om året selv om den måske burde gфres 10 gange om året. Og det er det igen at borgerne de kan måske ikke rigtig forstå, at vi faktisk ikke må gфre tingene bedre. Der er vi måske bare nogle sjuske nogen." (s. 141-142; jf. s. 136)

Grundlæggende mener gartnerne ikke, at den service, de som kommunalt ansatte har mulighed for at yde over for de grønne områder lever op til, hvad områderne har brug for. Deres opfattelse er, at dette kunne være anderledes, hvis beslutningskompetencen blev uddelegeret til gartnerne selv. Det andet helhedsforhold, som gartnerne reflekterer over, handler om deres funktion som kommunalt ansatte. De reflekterer over deres funktion med henvisning til borgene i kommunen, eller hvem der nu iagttager kommunens grønne arealer, dvs. samfundet. Med andre ord beskriver de sig som ansat af samfundet med det formål at vedligeholde og servicere kommunens offentlige grønne arealer. Ved refleksion over ydelsesområdet oplever de, at den kommunale organisering i form af den styrende kommunikation omkring deres afdeling potentielt kan have negative konsekvenser for de grønne arealer, dem selv, kommunen og borgerne, fordi de ikke kan leve op til deres funktionelle forpligtigelser/forventninger. Det tredje forhold som gartnerne reflekterer over kommer til udtryk på nedenstående måde.

"3: Det hanger også sammen med det med helheden, hvis kommunen skal vare en helhed og ikke bare den enkelte arbejdsplads så er vi nфdt til at lave nogen ting sammen.” (s.162)

Gartnerne har en semantik om kommunen og dens mange forskellige afdelinger/systemer som en helhed, der ideelt set helst skulle arbejde sammen. Dette oplever de ikke er tilfældet med den styrende kommunikation. Dette gælder ikke kun i relation til subsystemet arkitekterne, men også i forhold til andre af kommunens subsystemer, der enten direkte eller indirekte har indflydelse på konditionering af gartnernes arbejde, og som de arbejder sammen med eller kunne forestille sig at arbejde sammen med, f.eks. dem der har med idræt og veje at gøre. (jf. s. 138). Gartnerne har på flere måder forsøgt at få en anden ordning med arkitekterne, men indtil videre forgæves.

”2: Det er blevet taget op på vores medarbejdermфde masser af gange til vores driftsleder, men der er jo aldrig sket, og det bliver aldrig anderledes." (s.135; jf. s.137-138). 
Ud over inddragelse af egne ledere har gartnerne ikke nogen strategi/program for, hvordan de vil arbejde hen mod en ændring af kommunikationsformen med andre systemer, f.eks. Rådhuset, Politikerne og arkitekterne.

Spørgsmålet om selvledelse for gartnerne kan ud fra et didaktisk perspektiv skematisk beskrives på følgende måde:

\begin{tabular}{|l|l|}
\hline $\begin{array}{l}\text { Læringens } \\
\text { Hvad }\end{array}$ & $\begin{array}{l}\text { Opprioritering af dialogisk kommunikationsform, uddifferentiering af } \\
\text { beslutningskompetencer til kommunens subsystemer, og mere samarbe- } \\
\text { jde med andre systemer i kommunen så systemernes faglighed kan komme } \\
\text { i spil. }\end{array}$ \\
\hline $\begin{array}{l}\text { Læringens } \\
\text { Hvem }\end{array}$ & $\begin{array}{l}\text { Læring mellem gartnere, arkitekter, politikere og andre af kommunens } \\
\text { subsystemer. }\end{array}$ \\
\hline $\begin{array}{l}\text { Lvringens } \\
\text { Hvornår }\end{array}$ & $\begin{array}{l}\text { Skulle være sket, eftersom gartnerne mener det er en del af organisation- } \\
\text { sudviklingsprojektet VBL. }\end{array}$ \\
\hline Læringens & $\begin{array}{l}\text { Ud fra en semantik om helhed for iagttagelse af kommunen som organ- } \\
\text { isation fravælges andre systemers styrende kommunikationsformer for } \\
\text { konditionering af gartnernes arbejde, til fordel for dialog. Kommunika- } \\
\text { tionsformen dialogs funktion er forøgelse af motivation og sikring af } \\
\text { gartnernes faglighed for funktions og ydelseshåndtering i forhold til pleje, } \\
\text { vedligeholdelse og beplantning af kommunens grønne områder. Det vil } \\
\text { være bedre for gartnerne og de grønne områder. }\end{array}$ \\
\hline $\begin{array}{l}\text { Læringens } \\
\text { Hvordan }\end{array}$ & $\begin{array}{l}\text { Gartnerne forestiller sig generelt samarbejde (interaktionskommunika- } \\
\text { tion) med andre af kommunens subsystemer f.eks. i form af fælles } \\
\text { besigtigelse af de grønne områder sammen med landskabsarkitekterne. }\end{array}$ \\
\hline Funktion & $\begin{array}{l}\text { Funktionen af dialogisk kommunikationsform med andre af kommunens } \\
\text { systemer vil betyde forøgede muligheder for anvendelse af faglighed og } \\
\text { motivation i arbejdet. }\end{array}$ \\
\hline Ydelse & $\begin{array}{l}\text { Gartnernes motivation vil blive højnet, og kommunens grønne områder vil } \\
\text { få en bedre, dvs. mere aktuel og individuelt målrettet, behandling/service. }\end{array}$ \\
\hline
\end{tabular}

\section{Opsummering på Park og natur}

Ifølge Park og natur er der på baggrund af organisationsudviklingsprojektet VBL ikke sket de store forandringer i deres muligheder for selvledelse, dvs. bestemmelse eller medbestemmelse over organisering af eget arbejde. Gartnerne nævner selv kommunens anvendelse af BUM-modeller, dvs. modeller, hvor kommunens landskabsarkitekter detaljeret beskriver, hvad den enkelte gartner skal gøre, som den største hindring for selvledelse. Deres oplevelse af begrænsninger i forhold til selvledelse er således ikke så meget på grund af beslutninger i eget system, f.eks. hos ledere i deres eget system, men på grund af begrænsninger fra omverdenen af andre af kommunens systemer 
underforstået politiske beslutninger om anvendelse af BUM-modellen, men også landskabsarkitekternes praktiske anvendelse af den. På baggrund af kommunens egne beskrivelser af intentionerne med VBL, som f.eks. at beslutninger så vidt det er muligt, skal lægges ud til de enkelte afdelinger og ansatte, har gartnerne en semantik om dialog angående organisering og prioritering af deres eget arbejde. Ifølge deres forståelse må man kunne snakke om hvorfor og hvordan deres arbejde skal udføres. Dette forsøger de så vidt det er muligt at gøre internt $\mathrm{i}$ eget system, men de oplever, at dette ikke er muligt, når det gælder deres nærmeste samarbejdspartner nemlig landskabsarkitekterne. Selvom gartnerne selv og deres leder gentagne har fors $\emptyset \mathrm{gt}$ at komme i dialog med landskabsarkitekterne angående prioriteringer af gartnernes arbejde, har det ikke været muligt at få etableret et dialogbaseret samarbejde, hvor gartnerne kan bringe deres viden og kompetencer i forhold til f.eks. kommunens grønne arealer i spil. Gartnerne oplever det som en down grading af deres faglighed, kompetencer og ideer, eller som en af dem udtaler:

"i princippet så kan medarbejderen tage hovedet under armen og skuffejernet under den anden arm, og så kan der vare en der holder bogen, og så laeser man hvordan man gør.” (s. 121)

Denne detailstyring af deres arbejde betyder ud fra en organisationsdidaktisk tilgang, at gartnernes faglige ideer og intentioner om andre mulige måder at konditionere deres system på, og deres ideer om, hvordan dette kunne realiseres, begrænses.

Park og natur som system oplever, at de er fremmedstyret i en sådan grad, at organisationsdidaktiske ideer om læringens hvad, hvem, hvornår, hvorfor, og hvordan forbliver idealer uden praktisk mulighed for at blive realiseret. Dette bliver særlig tydeligt, når man iagttager deres refleksioner som funktionelle og ydelsesmæssige rationaliseringer, dvs. refleksioner, der dels tager udgangspunkt i deres funktion (nemlig at servicere kommunens grønne arealer) dels relaterer sig til ydelsesområdet i form af, hvad Park og natur som system kan gøre for at de grønne arealer trives og tager sig godt ud. For lige at præcisere, hvad jeg tidligere har skrevet, så er det sådan, at funktion og refleksion retter sig primært mod systemets - her det organisatoriske systems egen selvreference og selvkontrol, hvor ydelse retter sig mod iagttagelsen af omverdenen af øvrige systemer - det være sig sociale eller psykiske systemer (jf. Luhmann 1997 s. 757; Hagen 2006 s. 131). Når jeg derfor hævder, at Park og naturs refleksioner kan betegnes som rationelle, så refererer det til, at de ud fra begreberne om funktion og ydelse netop tager udgangspunkt $\mathrm{i}$ 
og reflekterer over, hvad systemet kan gøre ved sig selv, for at være noget for andre. I den her forbindelse er de andre af kommunens arealer og de borgere, som iagttager og anvender dem, og som det forventes at systemet samt systemets ansatte, dvs. gartnerne, gør noget for at pleje og vedligeholde. Det er selvsagt umuligt, og heller ikke denne afhandlings intention og funktion at afgøre, om kommunens grønne arealer har bedre af de ideer gartnerne måtte have til forbedring af arealerne end de foreskrifter, som fremkommer gennem landskabsarkitekternes beskrivelser i BUM-modellerne, og som styrer hvordan arealerne skal serviceres. Det kan blot iagttages, at gartnernes refleksioner og begrundelser for arbejdets organisering herunder begrundelser for selvledelse, tager udgangspunkt i refleksioner over deres funktion relateret til ydelsesområdet i form af kommunens grønne arealer.

Park og natur alias gartnerne mener, at en højere grad af uddelegering af ledelse til dem, vil resultere i en generel forbedring af kommunens grønne arealer (ydelsesområdet). Som det er fremgået, betyder fremmedstyringen på dette område imidlertid, at det ikke er muligt. I forhold til systemets selvkontrol, dvs. mulighed for med reference til funktion og ydelse at konstruere egne selvreferencer, er det uden for systemets rækkevidde. På grund af den fremmedbestemte styring har systemet med andre ord ikke mulighed for at styre sig selv i relation til opbygning af egen kompleksitet i egne meningshenvisninger og intern konditionering, hvilket betyder en begrænsning af dets autonomi. Systemet får derfor helt grundlæggende problemer med at lære, dvs. forandre sine egne forventningsstrukturer i betydningen egenkonditionering. Som det er fremgået i analysen, har systemet Park og natur ideer til, hvad der kunne læres og hvem, der skulle lære. Systemet har tillige ideer om, hvordan der skal læres og hvorfor, der skal læres, og alle disse didaktiske refleksioner er relateret til og begrundet med reference til systemets funktion og ydelse. Dette kan udlægges på den måde, at systemet i stedet for at agere og konditionere sig som en lærende organisation, som var et af kendetegnene og formålene ved VBL, i stedet for kommer til at fremstå som et frustreret system, der ikke kan anvende VBL og værdierne som handlingsanvisende. Dette har konkret kunnet iagttages ved, at først har medarbejderne forsøgt at komme i dialog med landskabsarkitekterne, så har man kontaktet sin egen ledelse for at få en dialog i gang, og eftersom disse tiltag og strategier ikke har kunnet ændre på noget, er det blevet til, at nogle medarbejdere i uformelle situationer og på grund af personligt kendskab til én af arkitekterne har skabt en mulighed for på enkelte områder at diskutere ideer til, hvordan nogle grønne områder skal prioriteres. Det er altså ikke på systemplan, der kan gøres en forskel, men på et latent plan, dvs. gennem uofficielle uformelle kontakter. 
Systemet kan altså iagttage, at den læring systemet gerne ser muliggjort, og som er en officielt udmeldt hensigt med organisationsudviklingsprojekt VBL for hele kommunen, ikke er mulig. Park og natur oplever sig som et element eller et system i et hierarkisk system, der bestemmer over og dikterer, hvad der skal laves, hvornår det skal laves, hvor meget det må koste, hvor meget tid der er afsat til de forskellige opgaver osv. Ud fra en systemteoretisk og organisationsdidaktisk betragtning er de omverdensvilkår, et system befinder sig i, af afgørende betydning for systemets muligheder for at agere i relation til og anvende organisationsdidaktiske refleksioner til forandring af sig selv.

\section{Områdecentret}

Områdecentret dækker 1500 pensionister, hvoraf centret har kontakt med ca. 300 om ugen. Områdecentrets funktion er tre former for hjælp. Den første er i form af traning, vedligeholdelsestraning og/eller genoptraning af ældre mennesker typisk efter operationer eller andre sygdomsforløb. Den anden er hjælp i form af bevilling af hjoelpemidler i form af kørestole, plejesenge, stokke, rollatorer men også boligændringer i eget hjem, f.eks. fjernelse af dørtrin, opsættelse af håndtag, toiletforhøjere osv., således at folk der har været indlagt på et hospital kan komme hjem og fungere uden at gå og falde og uden, at de bliver nødt til at flytte derfra. Den tredje form for hjælp er sociale aktiviteter $\mathrm{i}$ form af tilbud til borgerne om at deltage $\mathrm{i}$ alle mulige kreative ting, papirklip og silkemaling til fester, udflugter osv. De tre ting er ifølge lederen ligeligt vægtet. I Områdecenteret er der en personalegruppe på 16 personer, hvor halvdelen af dem er fysio- og ergoterapeuter. Den $\emptyset$ vrige gruppe er social- og sundhedsassistenter og beskæftigelsesvejledere samt folk i skånejob, fleksjob, jobtræning osv. (s.45; 80).

Ved iagttagelser af ydelsesområdet oplever Områdecentret kompleksitet og en kompleksitetstilvækst i flere forskellige former f.eks. flere ældre med funktionsnedsættelser, dvs. et $\emptyset$ get behov for centrets ydelser. Områdecentret er i visse tilfælde dårlig til eksklusion af ældre fordi, de vedbliver med at være svage, dvs. have funktionelle behov. En positiv omtale af områdecenteret har haft en selvforstærkende effekt på efterspørgslen af centrets ydelser samtidig med, at der er en juridisk begrundelse, der giver flere ret til centrets ydelser.

Et eksempel på den kompleksitet, Områdecentret oplever, er at der er blevet flere ældre, der har de behov, som funktionelt tilskrives deres system, og at behovene ikke forsvinder, selvom de ældre modtager områdecentrets ydelser, dvs. træning. De ældre bliver ved med at være 'svage', og de bliver 
derfor aldrig 'færdig' behandlet. Terapeuterne har derfor svært ved at 'afslutte' de ældre, som bliver 'hængende' i træningen (jf. s. 86 \& s. 201).

"M1: De har gået her i 10 år på det samme gymnastikhold, nogle afdem.

M2: Nogle har, ja.

M3: Og det gфr jo så også lige pludselig, at så bliver der altså pladsproblemer.

M2: Og så bliver de sure, når man afslutter dem.” (s. 83)

På trods af at Områdecentrets funktion er træning og genoptræning, og altså ikke en permanent ordning eller tilbud til ældre, er der tilfælde, hvor nogle ældre af forskellige grunde har modtaget Områdecentrets ydelser i over 10 år. Som et forsøg på at reducere denne kompleksitet, har områdecentret på deres to dages hyttetur besluttet nogle eksklusionskriterier for træningen af de ældre.

"M2: En anden ting vi har besluttet i forhold til de her dage vi har haft og (navn på sted for hyttetur) og sådan noget, det er at folk de kun får et tilbud 3 måneder som udgangspunkt, og så skal det revurderes. Der tror jeg også vi kommer til at ramle ind $i$ nogle barrierer og noget kultur der har eksisteret $i$ mange år og sådan noget, det tror jeg bliver rigtig, rigtig svart.” (s. 83)

"L: (...) men at det er i en tidsbegranset periode, som måske hedder max. tre måneder. Det, distriktslederne er bange for, det er hvis I får sat det her i gang, at I så ikke er hårde nok til at gå ud og sige, jamen det var så det. Nu var det den her genoptraningsperiode, 3 måneder eller den her periode, fordi det de ikke vil, de vil ikke sandes til med dem der, (...) Så hvis der er nogen af dem her I kan se, jamen det kunne egentlig lige så godt, der kommer vi kun én gang om ugen, og det er mere bare for at holde dem i gang, og der ved jeg ikke om det så kun er 3 måneder eller det er $i$ al evighed, men dem der er 3 måneder, (...) for det bliver vi immervaek nфdt til, fordi der kommer flere på ventelisten hele tiden ik', at dem vil plejerne gerne hjolpe med." (s. 201; jf. s. 204 \& s. 210)

Områdecentrets beslutning betyder, at de ældre som udgangspunktet tilbydes tre måneders genoptræning, hvorefter terapeuterne ud fra faglig viden skal 


\section{Analyse}

vurdere, hvorvidt den enkelte ældre skal afsluttes eller fortsætte, sidstnævnte f.eks. fordi de vurderer at vedkommende er for træningskrævende til at blive ekskluderet, eller som lederen udtrykker det "og der ved jeg ikke om det så kun er 3 måneder eller det er i al evighed". Beslutningen om at anvende dette beslutningsprogram for afslutning af de ældre til genoptræning løser imidlertid ikke hele centrets kompleksitetsproblem i forhold til eksklusion af de ældre, eller som der blev udtrykt i et af ovenstående citater: Der tror jeg også vi kommer til at ramle ind $i$ nogle barrierer og noget kultur der har eksisteret $i$ mange år og sådan noget, det tror jeg bliver rigtig, rigtig svaert (s. 83). Dette tematiserer nedenstående citater også:

"M: Men jeg tror det er rigtigt, vi fär ikke sluttet folk af, men man kan sige vi kan jo heller ikke bare slutte folk af fordi nu er de genoptranede, de har krav på at få vedligeholdelsestraning.

\section{M: Ja, det er nemlig det}

M: så hvordan skal vi så lige gфre? Fordi når de først kommer herind og føler sig godt tilpas, så vil de jo gerne fortsatte her, så vil de jo ikke hen et andet sted, hvor, jeg ved ikke lige hvor der er et tilbud." (s. 211)

Områdecentrets iagttagelse af de ældre er, at flere af dem har krav på og brug for vedligeholdelsestræning - ellers er de i risiko for at blive for svage til at kunne klare sig selv. En anden iagttagelse er desuden, at flere ældres sociale kontakter og netværk opretholdes ved Områdecentrets sociale aktiviteter, som de derfor også - selv om de er afsluttet til genoptræning eller vedligeholdelsestræning - skal have adgang til. Kompleksitetsproblemet med at afslutte de ældre resulterer derfor for Områdecentret $\mathrm{i}$ at afslutning eller eksklusion fra et af deres tilbud nærmest automatisk inkluderer den ældre i et andet af deres tilbud. I et fors $\emptyset \mathrm{g}$ på at reducere kompleksiteten af ældre, der bliver i systemet, reflekteres der over, om der i centrets omverden, dvs. kommunen eller andre steder, findes tilbud, som ud fra terapeuternes faglige vurdering er forsvarlige at sende de ældre til (s. 211).

Kompleksitetstilvæksten tilskrives også omverdenens positive oplevelser med centrets ydelser, der udlægges som noget, der har en selvforstærkende effekt på følgende måde: "M2: Så går de ud og siger til naboen og til fasteren og tanten og niecens kone osv." (s.84). Kompleksitetstilvæksten tilskrives yderligere en juridisk begrundelse: 
"M2: Det er også en konsekvens af den lovgivning der er kommet for $2 \frac{1}{2}$ år siden om at alle har ret til vedligeholdelsestraning $i$ kommunalt regi, når man er pensioneret, og egentlig også genoptraning efter sygdom udenfor sygehusregi. Det er jo nogle opgaver vi er blevet dikteret vi skal lave, hvorimod at man fra regeringens side, som det er nu, nedprioriterer sociale aktiviteter.” (s.85)

Det er derfor særligt i relation til træning, vedligeholdelsestraning og/eller genoptranings funktionen, at Områdecentret oplever en kompleksitetsforøgelse, som systemets didaktiske refleksioner er rettet mod at håndtere. Denne kompleksitetstilvækst har sat sig igennem internt i områdecentret ved, at aktivitetsfunktionen, som handler om sociale aktiviteter, oplever, at ergo- og fysioterapeuternes arbejde bliver opprioriteret. "M1: Aktivitetsmedarbejderne siger også, jamen det er altid os der skal gå ind og aflyse, det er altid vores arbejde det går ud over (...)" (s.79). Da netop det træningsområde ergo- og fysioterapeuterne funktionelt er tilknyttet fylder meget/mest for Områdecentret med hensyn til kompleksitetstilvækst, konstruktion af nye beslutningsprogrammer og konditionering af interne aktiviteter, og fordi langt størstedelen af den indhentede empiri omhandler og kommer fra interview med fysio- og ergoterapeuter, koncentrerer analysen sig om Områdecentrets refleksioner angående udvikling af beslutningsprogrammer og konditionering af terapeuternes arbejde ud fra den didaktiske tilgang. Som beskrevet oplever aktivitetsmedarbejderne, at deres arbejde/funktion reduceres til fordel for træningsområdet. Senere i analysen vil jeg forholde mig til hvorfor og hvordan deres funktionelle tilknytning til Områdecentret forsøges omformuleret til fordel for funktionen træning.

Ergo- og fysioterapeuternes arbejdsområder og arbejdsopgaver kan fordeles på individuel- og holdtræning, besøg og træning i de ældres hjem, sagsbehandling og instruktion/efteruddannelse af personalet på et plejehjem, der ligger i samme bygning som deres egen afdeling (s.49-51).

På et overordnet og generelt plan forløber Områdecentrets refleksioner og beslutninger i relation til konstruktionen af beslutningsprogrammer for selvledelse som læring i form af omverdens- og selvtilpasning. Omverdenstilpasning forløber via differencen system/omverden og henviser i dette tilfælde til de tilfælde, hvor områdecentrets refleksioner knyttes til dets oplevelse af omverdenenskompleksitet, og hvor disse refleksioner fører til kompleksitetsreduktioner $\mathrm{i}$ form af systemstrukturelle forandringer. Selvtilpasning på den anden side er kompleksitetsreduktioner, der forløber via differencen mellem element/relation, dvs. ændring (reduktion) af Områdecentrets egen 
kompleksitet via tilpasning af interne forhold mellem dets elementer og relationer (som kan være en følge af tilpasning til omverdenen). For Områdecentrets vedkommende kan både omverdens- og selvtilpasnings refleksionerne relateres til refleksioner over centrets funktion og ydelse. Funktion kan her forstås som områdecentrets relation til omverdenen, dvs. centrets relation til de ældre, systemet er sat i verden for at arbejde med, og ydelse kan forstås som, hvad terapeuterne gør for, at de mennesker, de arbejder med, har mulighed for at opfylde deres egne mål.

\section{Områdecentrets refleksioner over selvledelse}

Områdecentrets Var Med kurser faldt sammen med en generel sparerunde i kommunen, som - på trods af den øgede efterspørgsel på Områdecentrets ydelser - betød, at der skulle afskediges én fra afdelingen. Ifølge afdelingslederen og medarbejderne betød dette et dyk i motivationen blandt medarbejderne på afdelingen, hvorfor afdelingslederen besluttede at udsætte det videre arbejde med VBL, til fyringen var overstået (s. 49; s. 73). Efterfølgende arbejdede Områdecentret, bl.a. på personalemøder og på en to dages hyttetur, med at kommunikere om og beslutte, hvordan temaerne fleksibel arbejdstid, de fem kernevardier og teams skulle forstås og give muligheder og begrænsninger for arbejdet på centret (s.55). Det er specielt i relation til terapeuterne, at uddelegering af ledelse og fleksibel arbejdstid, eller selvledelse, kommer til udtryk i empirien (s.50).

For terapeuterne er det ikke noget nyt at arbejde med selvledelse og teams, faktisk har de, som jeg senere kommer ind på, af faglige og ledelsesmæssige grunde arbejdet sådan gennem længere tid (jf. s.51-52; s. 55; s. 72). Helt generelt fremgår det af empirien, at terapeuterne er motiverede og glade for afdelingens politik om uddelegering af forskellige ledelses- og arbejdsopgaver til dem. Selvom det ikke er noget nyt for terapeuterne at arbejde med uddelegeret ledelse og egen arbejdstilrettelæggelse, giver terapeuterne udtryk for, at for dem er det netop uddelegeringen af ledelse til selvledelse, der har været det mest markante og forskelsbetydende i VBL-projektet.

"M1: Altså, jeg synes måske, at (lederen) han har trukket sig meget.

M2: Ja.

H: Altså som leder?

M1: Ja. Men også i det, at han har fået andre opgaver, så han er ikke, jeg tror også han bevidst har trukket sig. 
M2: Han har uddelegeret meget er mit indtryk. Men det synes jeg også var før jeg kom, altså jeg er to år gammel $i$ gårde nu.

(...)

M1: Men det er så også en udvikling som måske var sat i gang, men han har så gjort det endnu mere, og det er nok også de her var-med-tanker, der har varet med til at gøre det. Men altså vi ved jo godt, hvor gransen er, den marker vi også somme tider.

M2: Men altså det giver, altså i og med at han ikke sådan satter meget hårde rammer op for os, at vi sådan meget bliver bedt om at vurdere selv, så får man jo frie rammer, og så tager man sig mere frihed til at vare ansvarlig for det man gør, altså.” (s. 76)

Med bemærkningen "han ikke sådan satter meget hårde rammer op for os, at vi sådan meget bliver bedt om at vurdere selv" giver terapeuterne udtryk for, at uddifferentieringen af ledelse til terapeuterne på Områdecentret ikke bare foregår ved, at f.eks. lederen uddelegerer i betydningen overlader bestemte beslutninger til terapeuterne, men at det helt generelt forgår ved at der sættes nogle nye refleksionskriterier op, som terapeuterne skal forholde sig til i forhold til de beslutninger, der uddifferentieres til dem. Som jeg vil vise i det efterfølgende, foregår refleksioner over uddifferentiering og konstruktionen af nye beslutningsprogrammer for selvledelse som refleksioner over Områdecentrets funktion og ydelse. F.eks. kan dette konkret iagttages ved, at Områdecentret i relation til beslutninger relateret til fleksibel arbejdstid foretager funktionelt orienterede refleksioner. Områdecentret tager udgangspunkt i systemets relation til omverdenen og reflekterer over ydelsesområdet, dvs. omverdenens forventninger som de kommer til udtryk blandt de ældre, andre subsystemer i kommunen, politikerne og kommunens borgere (s.54). Det betyder blandt andet, at medarbejderne beslutter, at træningshold ikke må aflyses, fordi det kan lede til dårlig omtale. (s.53; s. 77). Områdecentret refleksioner forløber i vid udstrækning over og anvender funktionelle og ydelsesmæssige begrundelser for beslutninger relateret til arbejdsopgaver og systeminterne forhold, dvs. som refleksioner knyttet til iagttagelsen af andre systemer.

Ovenstående er et eksempel på, at beslutninger relateret til selvledelse kan beskrives som læring i form af selvtilpasning. Denne læring som selvtilpasning kommer til udtryk i refleksioner, der er knytter sig til iagttagelsen af systemets egen konstruktion af relationer mellem elementer i systemet, dvs. 
hvordan beslutninger om den interne organisering af forholdet mellem ansatte og arbejdsopgaver er konstrueret. Selvtilpasning tematiserer systemets egen muliggørelse af sig selv som system, og den benytter sig af den form for iagttagelse, der giver systemet adgang til sig selv, så det som mulighed kan forholde sig til sin egen interne ordning, relatering og konditionering, dvs. måde at reducere kompleksitet på.

Med henvisning til ydelsesområdet (iagttagelsen af systemer i omverdenen) beslutter Områdecentret, at træningshold ikke må aflyses, og denne beslutning kan betragtes som et udtryk for og resulterer i systemets læring som selvtilpasning. Selvtilpasningen og den læring, der er indbygget heri, fremkommer via iagttagelsen af systemer i omverdenen men muliggøres gennem justeringer og ændringer af systemets egne beslutninger og beslutningsprogrammer, dvs. via ændringer af relationer mellem elementer i systemet.

\section{Selvledelse som kilde til reduktion af og dannelse af ny kompleksitet}

Selvledelse står, som det fremgår af ovenstående, som et centralt ledelsestema for områdecentrets organisering af terapeuterne og beslutningerne relateret til opgavehåndtering og koordinering af arbejdsopgaver. Ændringerne i Områdecentrets ledelsesform er både terapeuterne og lederen (s. 52) glade for. En medarbejder udtrykker det på følgende måde:

"M2: (...) den der proces vi har gennemgået det sidste års tid, der synes jeg vi arbejder lige lidt mere falles, men der hvor jeg synes det skinner igennem i hverdagen, det synes jeg faktisk meget er den måde vi arbejder på, at jeg har meget frie tøjler $i$ forhold til at planlagge min egen arbejdsdag, og jeg selv er ansvarlig for langt det meste. Der er ikke nogen der siger til mig hvad det er jeg skal og hvad det er jeg skal prioritere, det gør jeg selv. Det synes jeg, det giver ansvarlighed for mig, og helhed synes jeg." ( $s .72)$

Ud fra en didaktisk iagttagelse af Områdecentret kan en stor del af det, som læringsmæssigt har været på dagsordenen, beskrives som forskellige subtemaer relateret til uddifferentieringen af ledelse til mere udstrakt selvledelse. Jeg forklarer i nedenstående hvorfor og hvordan, jeg ser dette. Analysen er struktureret således, at uddifferentiering af ledelse til selvledelse står som overbegreb eller hovedtema for en række andre sub-temaer. Analysen tager udgangspunkt i den funktionelle tilgang ved først at analysere, hvilke former 
for kompleksitet Områdecentret selv tilskriver, at udviklingen af beslutningsprogrammerne for selvledelse funktionelt skal reducere. Efterfølgende forholder jeg mig til hvert subtema ud fra en didaktisk iagttagelse.

Ud fra en funktionel betragtning bruges selvledelse af Områdecentret til reduktion af flere former for kompleksitet. Samtidigt med reduktion af kompleksitet produceres en ny form for interdependens mellem områdecentret som system og medarbejderne. Et tema for analysen af Områdecentret og for terapeuternes læring er derfor ikke bare hvordan udvikling af kompleksitetsreducerende beslutningsprogrammer sker f.eks. i første ordens forstand, men også hvordan Områdecentrets refleksioner iagttager udviklingen af beslutningsprogrammerne $\mathrm{i}$ et anden ordensperspektiv, dvs. som refleksion.

Med anden ordensperspektiv henvises der til at Områdecentret selv gør sine nye beslutningsprogrammer til genstand for iagttagelse med henblik på at iagttage funktionelle muligheder og begrænsninger relateret til distinktionerne $\mathrm{i}$ de nye beslutningsprogrammer, herunder håndteringen af beslutningsprogrammernes produktion af interdependens.

'Som det fremgår senere, reflekterer Områdecentret over funktion og ydelse i relation til hvorfor og hvad, der skal læres, og disse refleksioner indføjes i beslutningsprogrammerne for prioriteringer af terapeuternes arbejde.

- For det første anvendes selvledelse til reduktion af forskellige former for kompleksitet i relation til forholdet mellem Områdecentrets funktion og medarbejdernes 'fritid'. Dette kommer f.eks. til udtryk i den flekstidsordning, som konditionerer arbejdet.

- For det andet reducerer flekstidsordningen kompleksitet i form af, hvad man kunne betegne 'spildt arbejdstid'. Som beskrevet tidligere oplever områdecentret en funktionelt begrundet kompleksitetsforøgelse relateret til ydelsesområdet, idet flere efterspørger træning, vedligeholdelsestræning og genoptræning. I et forsøg på at reducere den kompleksitet er der fokus på, at terapeuterne ikke er på arbejde med mindre, der er noget at lave.

- For det tredje betyder arbejdet i teams, at terapeuterne selv planlægger og tilrettelægger hvordan og hvem, der løser teamets forskellige opgaver og hvornår. Dvs. at de enkelte teams selv tilrettelægger arbejdstiderne herunder vagt- og ferieplaner. Som en konsekvens heraf arbejder fysioog ergoterapeuterne meget tværfagligt (s. 74-75).

- For det fjerde fors $\emptyset$ ger områdecentret at løse kompleksitetsproblemet ved brug af vidensdeling - specielt mellem ergo- og fysioterapeuter. 
- For det femte kan det iagttages, at ergo- og fysioterapeuterne er meget ydelsesorienterede. Forud for handlinger reflekterer de, hvad der fagligt set er hensigtsmæssigt ud fra iagttagelse af omverdenen af ældre som individuelle mennesker med hver deres særlige karakteristika og behov. Hvad, der skal gøres for den ældre, er afhængigt af individuelle forhold ved den ældre. Dette resulterer i differentierede og komplekse iagttagelser af omverdenen af ældre, som betyder, at hvad der skal gøres i første omgang fremstår som kontingent, eftersom en ældre ikke bare er en ældre. Denne kontingens bliver til kompleksitet som bestandigt møder systemet, og resulterer i et beslutningspres. Her kan man tale om, at de ældre som omverdenskompleksitet udgør vilde cases, som ikke kan behandles ud fra entydige generelle foreskrifter.

Funktionen af selvledelse i form af flekstidsordningen for terapeuterne anvendes som ovenfor beskrevet til at håndtere flere former for kompleksitet. Som jeg vil komme ind på, henviser reduktionen af disse kompleksitetsformer til Områdecentrets organisatoriske læring, som altså på den ene side reducerer kompleksitet, men samtidigt producerer ny kompleksitet og kontingens i form at nye mulige problemer, som Områdecentret funktionelt ved anden ordens iagttagelser forsøger at reducere på forskellige måder.

I forhold til uddelegering af ledelse og flekstidsordningen kommenterer lederen af Områdecentret det på følgende:

"C: (...) hvad kunne passe her ind til, og hvad var det jeg egentlig så af muligheder $i$ VM-projektet, der kunne gøre at medarbejderne de blomstrede i deres job og syntes det var skide lakkert at gå på job, fordi vi har en god arbejdsdag, og jeg har den indflydelse jeg vil have, og jeg kan tilpasse det lidt i forhold til min fritid og familie. Så den der fleksible arbejdstid den kom ind, (...) det er simpelthen at, $i$ stedet for at jeg har den der kontrolfunktion, at jeg hele tiden skal se om folk de er på arbejde osv. og at de holder den tid de skal osv. osv., så gik vi over til sige, at det må vi virkelig tro på, at medarbejderne selv gфr, indtil det modsatte er bevist. Og dvs. alt det med, de fik en fast arbejdstid, for den skal registreres $i$ systemet, så folk kan få deres løn, men møder de ind tidligere fordi de har nogle (uf) opgaver, så g $\phi r$ de bare det, og bliver de langere fordi de skal mødes med aftenvagter eller der er nogle arrangementer $i$ huset, eller skal de ind $i$ weekenden osv. osv. så styrer de selv det. Og vi lavede så en margen på en uges overarbejde, de må arbejde en uge over, en uge plus eller en uge minus, de må faktisk også hold en 
uges fri, hvor deres afspadsering (...) Vi ved alle sammen hvad vores arbejdsopgaver er, og vi har nogle forskellige grupper af aeldre, og vi har noget individuel traning og vi har noget holdtraning osv., og det skal stadigvaek køre. Så har vi noget ledig tid ind imellem, hvor vi har noget sagsbehandling, hvis vi får nogle henvendelser fra nogle aldre ude fra eget hjem, så har vi tid til at tage ud og besøge dem og finde ud af, hvad det er de gerne vil og få dem startet op her $i$ aktivitetscentret. Så vi har noget tid og kan flytte lidt rundt med på den måde der, således at folk også har lidt mulighed for afspadsering. Så nogle dage kører folk nogle lange dage, og andre dage, jamen så gik de til middag eller 2 dage fri. Og det koordinerer vi så på vores morgenm $\phi d e r . ~ O g$ hvis man ved man gerne vil have en fridag den dag i naeste uge, så siger man det så snart man ved det. Og det har faktisk gjort, synes jeg, at alle de hopper med på den, det er jo frivilligt, og aftalen var så at aftalen bliver annulleret hvis den misligholdes. Hvis jeg får en fornemmelse af, at det her kører helt af sporet, fordi at du moder altid kl. halv otte om morgenen, fordi det passer bedst med din mand, fär ham til at kфre herind, men du har reelt ikke noget at lave før $\mathrm{kl}$. 9, fordi der kommer de aeldre først, så synes jeg du misligholder aftalen fordi der sidder du og fyrer 11/2 time af hver morgen, som kunne bruges på de aldre. Det er jo ikke sådan den skal bruges, at så kan man møde lidt tidligere og gå hjem tidligere. Det er jo netop med sigte på at kunne vare her når brugeren var her, og det er også sådan at hvis de skulle et eller andet, skulle de til tandlage eller til lage, hvad man nu nogle gange skal, så har det tidligere varet sådan at de skulle komme og aflevere en tjenestefri-seddel til mig, om det var okay at de gik den der tid. Den er vi hoppet helt fra, den styrer I selv, for I ved godt vi har en personalepolitik der siger, at man får tjenestefri til det, og man fär med løn og uden løn. Den er folk klar over hvad der er, så det koordinerer de også i forhold til deres arbejdstid. De går til laege eller tandlage fra halv et til et osv. osv., det finder de selv ud af. Så tager de så den halve time på et, det, jeg synes det virker.” (s. 49-50)

Som det fremgår af citatet, opererer Områdecentret med en række temaer relateret til udviklingen af beslutningsprogrammer om selvledelse. Ud fra citatet kan funktionen af uddifferentieringen af arbejdstidsbestemmelserne i form af flekstidsordningen til terapeutteamene beskrives som iagttagelse, 


\section{Analyse}

håndtering og reduktion af fire forskellige former for kompleksitet relateret til ledelse, arbejds- og mødetid, vidensdeling og effektivitet. I det følgende vil jeg analysere disse temaer særskilt.

\section{Reduktion af ledelseskompleksitet}

Uddifferentieringen af ledelse, som også er en del af VBL, begrundes i et behov for reduktion af ledelseskompleksitet, som konkret blev aktuelt, da lederen på et tidspunkt blev leder for en ekstra afdeling (s.45 \& 55), og derfor fik brug for at reducere bestemte forhold knyttet til ledelsesfunktionen. I tæt tilknytning til uddifferentieringen af ledelse på afdelingen findes også flekstidsordningen, som gælder for alle afdelingens terapeuter. I analysen analyseres både beslutninger relateret til reduktion af ledelsesmæssig kompleksitet og beslutninger relateret til flekstidsordningen.

Uddifferentieringen af ledelsesfunktionen er kort sagt gået fra, at lederen tidligere havde viden om medarbejdernes daglige arbejde og tog koordinerende beslutninger relateret hertil, til at lederen nu har en mere vejledende og coachende tilgang til afdelingens medarbejdere og arbejdsopgaver (s. 53). Dette skal i en vis udstrækning ses i lyset af, at en stor del af beslutningerne for terapeuternes daglige arbejde tages med udgangspunkt $\mathrm{i}$ terapeutfaglig viden, som afdelingslederen ikke har, da vedkommende ikke er uddannet indenfor området. Afdelingslederen har med andre ord ikke den faglige viden, som kræves for at tage beslutninger på en række af de områder, terapeuterne arbejder med. Lederen udviser generelt stor respekt for terapeuternes faglige viden og blander sig ikke i beslutninger, han ikke har faglig indsigt $i$, men forholder sig til mere ledelses- og koordineringsmæssige forhold relateret Områdecentret og terapeuternes arbejde.

"C: (...) jeg har jo ikke nogen uddannelse indenfor det her område. Hvis man tager alle andre indenfor det her område, de har jo en eller anden sundhedsfaglig uddannelse, terapeut eller sygeplejerske eller andet, så det jeg arbejder med det er ledelse, altså det er simpelthen at få folk til at fungere godt i deres job, give de muligheder de har for at løse deres job bedst muligt." (s.53)

Selvledelse indføres funktionelt af to grunde, dels som aflastning af ledelsesfunktionen (s. 52), dels for at Områdecentrets 'reaktionsevne' optimeres. Dette sker ved, at beslutningerne gennem uddifferentieringen tages af den eller de terapeuter, som har faglig indsigt i de områder, der skal besluttes om. Grundlæggende handler dette om at kunne tage fagligt forsvarlige og 
hurtigere beslutninger (s.51-52). Mange beslutninger, som førhen lå hos lederen, er nu uddifferentieret til den enkelte medarbejder eller det enkelte team af medarbejdere, og lederen inddrages retrospektivt $\mathrm{i}$ forhold til at evaluere, om selvledelsen lever op til afdelingens beslutninger om f.eks. afdelingens $\varnothing$ konomi og andre beslutningsprogrammer. Imidlertid knyttes der en række ledelsesiagttagelser til uddifferentieringen af ledelse. For det første en ledelsesiagttagelse af terapeuterne ud fra forskellen kontrollerende/ikke kontrollerende samt tillid/mistillid.

"L: (...) aftalen bliver annulleret hvis den misligholdes. Hvis jeg får en fornemmelse af, at (...) du misligholder aftalen fordi der sidder du og fyrer 11/2 time af hver morgen, som kunne bruges på de aeldre." (s.50)

I relation til uddifferentiering af daglige beslutninger samt løbende kontrol og information om terapeuternes vagtplaner, arbejdstid osv. til terapeuterne (s. 52), anvender lederen en semantik om tillid til reduktion af kompleksitet, i det han går ud fra, at terapeuterne kan leve op til de forventninger, som er knyttet hertil.

"Den er folk klar over hvad der er, så det koordinerer de også $i$ forhold til deres arbejdstid. De går til lage eller tandlage fra halv et til et osv. osv., det finder de selv ud af. Så tager de så den halve time på et, det, jeg synes det virker.” (s. 50)

Som det fremgår af nedenstående citat, er det ikke lige let for alle at leve op til det nye kriterium for arbejdstid. I et fors $\emptyset \mathrm{g}$ på at få dem til at lære dette, beder lederen dem om at gå hjem, med mindre der er ydelsesmæssige opgaver.

"C: (...) der er stadigvaek et par stykker som hanger lige lidt, som ikke er gode til at gå hjem selv om der ikke er noget at lave, altså der er altid et eller andet der lige kan ryddes op eller lige ordnes, så nogle gange siger jeg, det ordner vi i morgen. (...) som har lidt den gamle kultur stadigvak hangende, og det tror jeg mange vil have lidt endnu (uf), som vil sige, min arbejdsseddel siger til kl. 4, så er jeg her til kl. 4, jeg kan ikke lide at gå kl. 3, for så føler jeg at jeg snyder." (s. 51)

Men som det også er fremgået, iagttager lederen en risiko ved uddelegeringen af arbejdstidsbestemmelserne til terapeuterne/teams, fordi det potentielt kan 


\section{Analyse}

give Områdecentret problemer i forhold til dets trænings- og genoptræningsfunktion og dermed dets ydelser til de ældre. Da områdecentret har mange forskellige og løbende arbejdsopgaver samt udfordringer i forhold til koordinering af systemets mange funktioner og ydelser, iagttages 'spildt arbejdstid' (der sidder du og fyrer 11/2 time af hver morgen, som kunne bruges på de aeldre), samt størrelsen af den enkelte terapeuts over/underarbejde ud fra en semantik om risiko. Risikosemantikken baserer sig på iagttagelsen af, at uddifferentieringen af arbejdstidsbestemmelser potentielt kan give problemer for systemet. Ifølge lederen kan problemerne opstå, hvis der er for få terapeuter på arbejde. For få på arbejde kan potentielt betyde udskydelse eller aflysning af terapeuternes arbejdsopgaver, dvs. problemer på ydelsesområdet. Ud fra legitimitetsgrunde, der handler om, at Områdecentret er afhængig af opbakning og positiv tilslutning fra omverdenen af andre systemer, er lederen meget opmærksom på, at problemer på ydelsesområdet helst ikke må ske, fordi det potentielt kan blive et problem for områdecentret (s. 53). Eller som lederen beskriver det:

"C: (...) vi lever meget af at vi har god omtale blandt de aldre, at de siger det her er et sted der er rart at komme, at man møder nogle positive mennesker, og de holder deres aftaler, og vi aflyser ikke $i$ tide og utide, og de informationer vi får dem kan vi stole på, og det tager lang tid at oparbejde sådan et ry (...) Men vi kan meget hurtigt фdelagge det, (...) Altså den går altså ikke, fordi så gider folk bare ikke at komme her. (...) fär vi ret meget dårlig omtale så får vi også opmarksomhed fra politisk side, der siger: de aeldre gider ikke komme der, hvorfor skal vi så have det, osv. (...)” (s. 55; jf. s. $62 \&$ s. 66)

De nye beslutninger angående den enkelte terapeuts flekstidsordning konditioneres gennem oprettelsen af et nyt beslutningsprogram, som består i, at den enkelte terapeut skal iagttage sine flekstidsprioriteringer ud fra forventninger om, at vedkommende højst må have +/- én uge i over/underarbejde, og at aftalte arbejdsopgaver helst ikke må aflyses. Beslutningsprogrammet rummer ligeledes en forventning om at i tilfælde, hvor der er risiko for aflysning af arbejdsopgaver, skal den enkelte terapeut forsøge at lave en aftale med en anden terapeut, som eventuelt kan overtage opgaven. Det er ligeledes en forventning, at terapeuterne kontinuerligt informerer hinanden om og koordinerer hinandens flekstidsprioriteringer således, at der ikke sker 'uheldige' aflysninger osv. Disse beslutninger handler om at undgå den potentielle risiko for skuffede omverdensforventninger, som kan medvirke til at producere 'dårlig' omtale af Områdecentret. 
Flekstidsordningen begrundes yderligere med muligheden for at kunne bistå, dvs. hjælpe, vejlede og uddanne specielt plejepersonalet på et plejehjem med forflytningsteknik m.m. Flekstidsordningens funktion er i den forbindelse specielt rettet mod de opgaver, som ligger uden for 'normal' arbejdstid og skal sikre at beslutningerne -qua uddifferentiering til terapeuterne - kan tages hurtigt, dvs. uden, at afdelingslederen skal involveres.

"C: (...) Men det jeg oplever med tilbagemeldingerne fra, altså vi har meget samarbejde med plejen, hvor vi skal mødes med aftenvagter om aftenen, og om morgenen osv. osv., hvor at det er lidt blomstret, fordi nu gør man det bare, hvis man fär en henvendelse, fordi man kan godt se at, i plejen deres arbejdsområde er meget tungt, det er meget med løft og slid og meget belastende, der er så mine terapeuter inde og finde ud af, hvordan gør man nu det bedst lige pracis med fru Hansen her, som skal forflyttes eller loftes på den og den måde, således at vi undgår arbejdsskader. Når de går ind kl. 7 om morgenen, jamen så, skal man snakke med nattevagten så skal man jo vare der kl. halv 7 om morgenen og få koordinering med dem. Og det oplever jeg, at det gør de bare.” (s. 50-51)

"H: Vil du sige, koordinationen med andre afdelinger, det er så også blevet bedre?

$C: J a$, men den har varet meget god altid, men der er kommet mere efterspфrgsel på brugen $i$ de der vagter udenfor normal 8-16, altså om aftenen og tidlig morgen, fordi de ved at de bare kan kontakte os, og så skal vi nok vare der.” (s. 52)

I relation til plejepersonalet fungerer terapeuterne som vejledere eller lærer, dvs. de 'uddanner' plejepersonalet i arbejdsstillinger, forflytning og badning af de ældre, således at personalet ikke selv kommer til skade (s. 93).

Nedenstående er en skematisk opsummering af analysens konklusioner i forhold til afhandlingens didaktiske analysemodel.

\section{Læring relateret til flekstidsordningen}

\begin{tabular}{|l|l|}
\hline Læringens & $\begin{array}{l}\text { Terapeuterne skal lære at leve op til forventningerne i nye beslutninger } \\
\text { angående prioriteringer for deres arbejde. Dette handler f.eks. om kun at } \\
\text { være på arbejde, hvis der er noget at lave, at de kun i særlige tilfælde må } \\
\text { aflyse aftaler med ydelsesområdet i form af de ældre, at de højst må have } \\
\text { én uges over- eller underarbejde, samt at de forventes at informere om } \\
\text { arbejdsopgaver og koordinere afspadsering med de andre terapeuter. }\end{array}$ \\
\hline
\end{tabular}




\begin{tabular}{|c|c|}
\hline $\begin{array}{l}\text { Læringens } \\
\text { Hvem }\end{array}$ & $\begin{array}{l}\text { Afdelingslederen og terapeuterne skal lære at prioritere deres arbejde i } \\
\text { forhold til forventningerne i de nye beslutninger. Terapeuterne 'under- } \\
\text { viser' i en vis udstrækning plejepersonale, hvorfor de også iagttages som } \\
\text { nogle, der skal eller kommer til at lære på baggrund af beslutningerne på } \\
\text { Områdecentret. }\end{array}$ \\
\hline $\begin{array}{l}\text { Læringens } \\
\text { Hvornår }\end{array}$ & $\begin{array}{l}\text { Er stort set sket, dog er der et par af de ældre terapeuter, som har svært } \\
\text { ved at vænne sig til, at de skal tage hjem, hvis der ikke er noget at lave. }\end{array}$ \\
\hline $\begin{array}{l}\text { Læringens } \\
\text { Hvorfor }\end{array}$ & $\begin{array}{l}\text { Eftersom lederen har fået mere travlt efter at være blevet leder for endnu } \\
\text { en afdeling reduceres ledelsesopgaver ved at blive uddifferentieret til } \\
\text { terapeuterne. } \\
\text { Ud fra en semantik om, at terapeuternes arbejdstid er bedst givet ud } \\
\text { ved at arbejde med ydelsesområdet i form af de ældre, besluttes en } \\
\text { effektivisering af arbejdstiden (flekstidsordning), som betyder, at de kun } \\
\text { forventes at være på arbejde, hvis de har arbejde, der relaterer sig direkte } \\
\text { til ydelsesområdet. } \\
\text { Flekstidsordningen besluttes også, for at terapeuterne får bedre mulighed } \\
\text { for at koordinere forholdet mellem arbejde og privatliv (fritid, familien, } \\
\text { andre aftaler osv.). } \\
\text { Flekstidsordningen besluttes endvidere for at Områdecentret kan støtte } \\
\text { op om og leve op til forventninger fra andre subsystemer i kommunen - } \\
\text { specielt yde hjælp til og 'uddanne' plejepersonale i forbindelse med f.eks. } \\
\text { forflytningsteknik o.a. } \\
\text { Ved uddelegering af ledelse og beslutningskompetence til terapeuterne } \\
\text { kan beslutninger tages hurtigere. }\end{array}$ \\
\hline $\begin{array}{l}\text { Læringens } \\
\text { Hvordan }\end{array}$ & $\begin{array}{l}\text { Terapeuterne og lederen forventes at lære gennem møde og dagligdags } \\
\text { kommunikation og information om ændringer, og deres implikationer for } \\
\text { den enkelte terapeut og lederen. I den udstrækning terapeuterne ikke lever } \\
\text { op til de nye forventninger, minder lederen dem om det, og de forventes } \\
\text { derved gradvist at gøre forventningerne til præmis for egen adfærd. }\end{array}$ \\
\hline Funktion & $\begin{array}{l}\text { Beslutningen om uddifferentiering af ledelse og flekstidsordningen har } \\
\text { flere funktioner: } \\
\text { - At sikre en reduktion af lederens arbejdsopgaver, } \\
\text { - At sikre effektiv udnyttelse af terapeuternes arbejdstid (de forventes } \\
\text { kun at være på arbejde, hvis det er ydelsesorienteret), } \\
\text { - At give terapeuterne bedre mulighed for at planlægge forholdet } \\
\text { mellem arbejde og privatliv (andre aftaler), } \\
\text { - At give bedre og mere fleksibel mulighed for at støtte op om og leve } \\
\text { op til forventninger fra andre subsystemer i kommunen - specielt } \\
\text { yde hjælp til og 'uddanne' plejepersonale i forbindelse med f.eks. } \\
\text { forflytningsteknik o.a. }\end{array}$ \\
\hline Ydelse & $\begin{array}{l}\text { Terapeuterne får mulighed for at holde fleksibelt fri, således at de bedre } \\
\text { kan koordinere forholdet mellem arbejde og fritid. Lederens opgaver } \\
\text { reduceres. Der frigives mere tid til de ældre, og der vil være færre } \\
\text { aflysninger. }\end{array}$ \\
\hline
\end{tabular}




\section{Semantik om ydelsesområdet som et beslutningsproblem}

Beslutningsprogrammer $\mathrm{i}$ forhold til flekstidsordningen såvel som andre forhold på Områdecentret, f.eks. 'fri' i forbindelse med kursus eller efteruddannelse, er på baggrund af VBL blevet gjort til genstand for iagttagelse og refleksion, og på den baggrund er det blevet besluttet at ændre programmerne specielt med henblik på at styrke Områdecentrets funktionsudfoldelse og ydelsesområde, dvs. ydelser til de ældre. For at få en forståelse for hvilken læring forventningsændringerne i beslutningsprogrammerne er udtryk for og hvorfor, dette er tilfældet, vil jeg tage udgangspunkt i Områdecentrets forståelse eller semantik om de ældre som et særligt ydelsesområde.

Som det vil fremgå, tager områdecentrets refleksioner stort set altid udgangspunkt i en funktionel iagttagelse af ydelsesområdet. Refleksionerne handler om hvad Områdecentret kan gøre ved sig selv - ikke bare for at hjælpe de ældre, men som oftest også for at kunne forbedre ydelsen til de ældre. Som det også vil fremgå af analysen opererer Områdecentret med en relativ kompleks iagttagelse af de ældre. Der er tale om en flerkodet iagttagelse, der udtrykker, at udviklingen af nye beslutningsprogrammer må være sådan indrettet, at de tager mange hensyn. Det betyder i en række tilfælde, at ydelsesområdet fremstår som et beslutningsproblem for Områdecentret, specielt når det gælder en eller anden form for eksklusion fra Områdecentrets aktiviteter, f.eks. forskellige former for træning.

I forbindelse med temaet: Under hvilke omstcendigheder må terapeuterne tage 'fri', dvs. aflyse traningsopgaver, anvender afdelingslederen en semantik om Områdecentrets funktion som har betydning for refleksionen over ydelsesområdet, og som betyder en ændring af beslutningsprogrammer og dermed de forventninger, der relaterer sig til terapeuternes arbejdstidsprioriteringer, dvs. flekstidsordningen.

"C: (...) så lukker man ned for traninger for de aldre, de må så blive hjemme den dag, eller kan man gøre lidt af begge dele. Der har jeg det sådan, at det er lidt af begge dele, fordi mange aeldre kommer måske kun en gang om ugen, det eneste de kommer til ude af deres hjem det er herinde, og hvis vi så går ind og aflyser den (latter), jamen det har en omkostning for den aldre, der er større end man lige regner med. For dig og mig er det jo lige meget, vi kan bare gå et eller andet andet sted hen, men lige at tanke den ind og sige, hvad for nogle aldre, som ikke kommer herind fordi at jeg nu tager på et kursus $i$ (bynavn) eller, og skal vi aflyses, er der en 
268 Analyse

anden en der skal have den, eller skal vi tilbyde dem at komme ind til noget andet, og vil de så det? Nogle af dem er meget angste og meget nervøse og er kun trygge ved dig." (s. 57)

Som det fremgår af afdelingslederens udtalelser, reflekterer han funktionelt over områdecentrets forskellige prioriteringer og deres mulige konsekvenser for de ældre (ydelsesområdet). Som det også fremgår iagttages de ældre som et 'skrøbeligt' ydelsesområde, der er særligt følsomt overfor centrets ændringer og aflysninger, og som centret derfor har et særligt ansvar og særlige forpligtigelser overfor. Denne semantik om ydelsesområdet betyder, at terapeuternes kursusaktivitet, hvor de som medarbejdere ind i mellem skal have fri, kommer i fokus:

"C: Ja, hvis det er dig ik', og du skal på et kursus, jamen hvad faen gфr man så? Er det rimeligt at de så ikke skal komme? Og naeste uge har vi ferie, så går der faktisk (latter), så det kraver prioriteringer. Og vi har også lige de aldre herinde og vende engang imellem, jamen er det en gruppe fordi du ikke er her, som nu kan komme til noget andet, således at de stadigvaek for (uf), så er der en anden en der kan overtage det. Hvad faen gør vi?" (s. 58)

Lederens beskrivelse af de ældre kan som nævnt ses som udtryk for en funktionelt ledet refleksion over centrets ydelsesområde, der kan beskrives som en semantik om de ældre som skrøbelige og særligt følsomme overfor visse af Områdecentrets prioriteringer og beslutninger. Denne semantik kan ligeledes iagttages hos terapeuterne, og giver på baggrund af VBLen række udfordringer for Områdecentret i relation til udvikling af beslutningsprogrammer for, hvordan ydelsesområdet i form af de ældre skal håndteres. Nedenstående citat er fra en terapeut, som fortæller om en ældre, der er visiteret til hjemmebes $\varnothing \mathrm{g}$. Terapeuten reflekterer over den ældres problematiske adfærd, hvis ikke der er mere eller mindre kontinuerlig kontakt til og hjælp fra kommunens personale, herunder Områdecentrets.

"M: Og hele ideen med det har varet, at der kommer en hjoelper én gang om ugen, og så du kom den anden gang om ugen. Hvis der ikke kommer nogen hjem til hende, så drikker hun, og så går hun fuldstondig i hundene. Derfor kan du ikke give slip på hende. Men når ikke der kommer noget nyt ind, så kan vi jo ikke slippe dem. Jo, det kan vi godt, men det er bare ikke sarlig rart.” (s. 202) 
Som det fremgår, vurderer terapeuten, at den ældre er afhængig af hjælp, og at bl.a. Områdecentret har et ansvar overfor den ældre. Andre steder anvendes en semantik, som betyder, at Områdecentret oplever de ældre som nogle, de har et ansvar for, der rækker ud over 'bare' træning.

En anden gruppe af ældre, der ligeledes iagttages ud fra semantikken om at være skrøbelige, og som der skal tages særlige hensyn til, er gruppen af ældre demente. Denne gruppe er ifølge Områdecentret specielle. De kan f.eks. ikke 'tåle' pludselige forandringer, og ofte er de demente kun trygge ved én bestemt terapeut (jf. s. 57 \& s. 78-79). Dette betyder en høj grad af individualisering af ydelsesområdet på to måder, dels har nogle af de ældre individuelle problemstillinger, som betyder, at de skal have individuelt tilpassede ydelser, dels er nogle af de ældre demente som nævnt kun 'trygge' ved en bestemt terapeut. Denne differentierede iagttagelse af ydelsesområdet har den konsekvens, at flekstidsprioriteringerne, så vidt det er muligt, skal ske og sker i en refleksion over ydelsesområdet - ofte i form af en iagttagelse af meget individualiserede forhold hos den ældre, f.eks. den ældres 'tilstand' og behov, samt hvorvidt den ældre kan være tryg ved andre, eller kun ved én bestemt terapeut.

Semantikken betyder, at de ældre ikke bare iagttages som nogen, der kommer eller er inkluderet på centret for at få hjemmebes $\emptyset$ g, træning osv., men som mennesker i en særlig situation, hvor f.eks. træning måske er den eneste ud-af-huset aktivitet, de har hen over ugen. De reflekteres også som personer, der har svære problemer, eller er skrøbelige i forhold til at blive henvist til andre tilbud. Selvom de ikke har brug for træningen, ønsker de måske ikke at blive flyttet til et andet hold. For nogles vedkommende vil det resultere i, at de bare holder sig væk, og i Områdecenterets perspektiv er dette ikke godt for den ældre (jf. s. 201-202). Nogle ældre iagttages yderligere som værende alene, dvs. uden socialt netværk, og med forskellige problemer, som terapeuterne oplever de skal tage sig af. Alle disse 'problemer' Områdecentret iagttager ved de ældre, gør arbejdet med dem komplekst og vanskeligt atbeslutte i forhold til.

Områdecentrets semantik om de ældre som særligt 'skrøbelige' betyder, at centret anvender en differentieret iagttagelse af ydelsesområdet, der - som jeg tidligere har været inde på - generelt leder til et problem vedrørende beslutning. Beslutningsproblemet består i, at de mange 'hensyn', der skal afbalanceres i forhold til hinanden, ikke er afklaret og ikke i sig selv angiver hvilke iagttagelser eller kriterier, der skal være udslagsgivende for, hvordan Områdecentret skal beslutte i relation til den enkelte ældre. Problemet vedrørende beslutning opstår, når det er beslutninger, der efter Områdecentrets opfattelse 
(semantik) kan lede til problemer for den ældre, f.eks. når det handler om eksklusion, afvisning eller aflysning af aktiviteter for de ældre. På et generelt plan har terapeutgruppen for lidt kapacitet til at tage sig af alle, som har de behov, de selv oplever funktionelt falder indenfor deres område. De finder det derfor lettere at tage inkluderende end ekskluderende beslutninger.

"M: Jeg tror nemlig også, at diskussionen er på et helt andet plan (uf) de her navne, hvad kan vi gore ved dem, fordi vi sander til lynhurtigt igen, og problemet er, at vi fär ikke afsluttet folk, jeg har sagt det før nu siger jeg det igen, får ikke afsluttet folk når først vi har taget dem herind, og vi sander til fordi vi kommer til at sige, ja send dem ind på mit hold, send dem ind på mit hold, så vi får ikke afsluttet folk, og der bliver bare stфrre og større byrde fra (det andet center) lige nu, altså 4 af dem jeg har det er fra (det andet center) område, til hjemmetraning ik', så det (...)

M: så det er noget med prioriteringer i forhold til, hvad er kvalitet, altså jeg tror det er helt oppe med mål egentlig, mere end det er lige at lose de 5 mennesker. Vi får ikke afsluttet folk, vi tager bare ind og tager ind og tager ind, sådan oplever jeg det.” (s. 209-210)

På et mere operationelt og konkret plan opstår beslutningsproblemet, når f.eks. terapeuterne skal på ferie, har andre aftaler og gøremål, fordi det potentielt kan betyde aflysninger eller udskydelser af ydelser til de ældre. Beslutningsproblemet kan også opstå, når terapeuterne for at få nedbragt ventelisten af ældre som er berettigede til hjemmebesøg, træning osv. er nødsaget til at ekskludere ældre fra træningshold osv. Fordi terapeuterne ikke har mulighed for at indkalde forstærkning i form af afløsere eller vikarer i pressede perioder, er de afhængige af hinanden i relation til at løse disse beslutningsproblemer (s. 58).

Den semantiske iagttagelse af de ældre anvender en flerhed af iagttagelsesformer til iagttagelse af de ældre, og denne flerhed anvendes tillige som beslutningsgrundlag for at ekskludere eller aflyse en aktivitet for en ældre, dvs. den konkrete ældre må ikke have de problemer, som flerheden af semantikkens iagttagelsesformer iagttager. Ud over at skulle forholde sig til en flerhed af iagttagelsesformer, er et andet beslutningsproblem, at grænsedragningen i forhold til flere af iagttagelsesformerne ikke er entydig. Med entydig menes der, at det kan være svært entydigt at definere, hvornår en ældre er genoptrænet til at kunne 'klare' sig selv, eller hvornår en ældre med psykiske problemer f.eks. kan 'overføres' fra at modtage individuelhjemmetræning - hvilket 
er meget tidskrævende for terapeuterne - til at starte op på et hold (jf. s. 201-202). Semantikken rummer også iagttagelsen af de ældre som nogle, der for en stor dels vedkommende er meget svage og derfor har brug for kontinuerlig træning. Dette gør dem svære at afslutte, fordi de ud fra den semantik hele tiden er i en 'tilstand', som betyder, at de fra de inkluderes på Områdecentret er kontinuerligt relevante for Områdecentret (jf. s. 207-214).

Opsummerende om dette analyseafsnit skal det for det første fremhæves, at semantikken om de ældre som skrøbelige og følsomme for forandring på ydelsesområdet giver et problem vedrørende beslutning, og at iagttagelse af dette forstærkes i og med VBL. VBL bidrager til at tydeliggøre at Områdecenteret står overfor en række udfordringer i forhold til udvikling af beslutningsprogrammer for, hvordan ydelsesområdet i form af de ældre skal håndteres, og at dette er udfordringer, som de som følge af uddifferentieringen af ledelse selv må løse.

Nedenstående er en skematisk opsummering af analysens konklusioner i forhold til afhandlingens didaktiske analysemodel.

\section{Læring relateret til semantik om ydelsesområdet som et beslutningsproblem}

\begin{tabular}{|l|l|}
\hline Læringens & $\begin{array}{l}\text { Terapeuterne skal lære at anvende de nye beslutningsprogrammer for } \\
\text { flekstidsordningen, samt eksklusion og omfordeling i en refleksion over } \\
\text { ydelsesområdet. Det vil sige, at prioriteringer skal reflekteres i relation til } \\
\text { potentielle konsekvenser for de ældre, der berøres af dem. Terapeuterne } \\
\text { skal lære, hvordan de kan balancere og grænsesætte de mange forskellige } \\
\text { hensyn, som ligger i afdelingens semantik om ydelsesområdet i form af de } \\
\text { ældre, således at det bliver muligt for dem at tage beslutninger om f.eks. } \\
\text { at ekskludere ældre, som de ikke selv oplever som afsluttet, til fordel for } \\
\text { at inkludere nye ældre i deres aktiviteter. }\end{array}$ \\
\hline $\begin{array}{l}\text { Læringens } \\
\text { Hvem }\end{array}$ & $\begin{array}{l}\text { Afdelingslederen og terapeuterne skal lære at anvende de nye og ikke } \\
\text { helt entydige og konditionerede beslutningsprogrammer for anvendelsen } \\
\text { af flekstidsordningen, samt eksklusion og omfordeling af ældre fra deres } \\
\text { aktiviteter. }\end{array}$ \\
\hline $\begin{array}{l}\text { Læringens } \\
\text { Hvornår }\end{array}$ & $\begin{array}{l}\text { Der er taget en række beslutninger som det forekommer som om, at } \\
\text { terapeuterne har lært, men der er ligeledes områder, som der er en vis } \\
\text { uklarhed over, og som formentlig i fremtiden vil blive diskuteret og } \\
\text { løbende reflekteret som mulige områder for læring. }\end{array}$ \\
\hline $\begin{array}{l}\text { Læringens } \\
\text { Hvorfor }\end{array}$ & $\begin{array}{l}\text { Områdecentret oplever en større efterspørgsel på deres ydelser, end det } \\
\text { er muligt at honorere med det antal ansatte de har, eftersom de ikke har } \\
\text { mulighed for at indkalde vikarer o. lign. De har ligeledes generelt svært } \\
\text { ved at afslutte, dvs. ekskludere og omfordele ældre fra deres aktiviteter. }\end{array}$ \\
\hline
\end{tabular}




\section{Analyse}

\begin{tabular}{|l|l|}
\hline & $\begin{array}{l}\text { Områdecenteret skal lære at reducere kompleksitet, som konkret består } \\
\text { i, at der er ældre, der skal ekskluderes eller flyttes fra deres aktiviteter, } \\
\text { således at der kan skabes plads til nye, der opfylder inklusionskriterierne } \\
\text { for at modtage ydelser. Læringens hvorfor er i denne forbindelse relateret } \\
\text { til Områdecentrets semantik om ydelsesområdet i form af de ældre, som } \\
\text { skrøbelige og særligt følsomme overfor ændringer i centrets ydelser } \\
\text { hvilket betyder, at der er brug for at finde eksklusionskriterier, som } \\
\text { terapeuterne finder fagligt forsvarlige. }\end{array}$ \\
\hline Læringens & $\begin{array}{l}\text { Terapeuterne og lederen forventes at lære gennem møder og daglig } \\
\text { kommunikation og information samt gennem refleksion over ændringer } \\
\text { og disses implikationer for den enkelte terapeut og lederen, således at de } \\
\text { over tid kan gøres til præmis for egen adfærd. }\end{array}$ \\
\hline Funktion & $\begin{array}{l}\text { Funktionen af de mange kriterier, som område centret anvender til iagt- } \\
\text { tagelse af ydelsesområdet i form af de ældre, er reduktion af kompleksitet } \\
\text { ved ydelsesområdet, således at det bliver muligt at tage beslutninger } \\
\text { relateret hertil. Kriteriernes funktion er grundlæggende at muliggøre } \\
\text { eksklusion og omfordeling af ældre, således at systemet ikke 'sander til', } \\
\text { dvs. fårformange ældre, somikke afsluttes (ekskluderes) eller omfordeles } \\
\text { til andre aktiviteter, således Områdecentret ikke har mulighed for at tage } \\
\text { nye ind. } \\
\text { I den sammenhæng har Områdecentret brug for at udvikle en række } \\
\text { faglige kriterier der kan danne grundlag for fagligt forsvarlige beslut- } \\
\text { ninger, når det handler om omfordeling og eksklusion af de ældre } \\
\text { (ydelsesområdet). }\end{array}$ \\
\hline Ydelse & $\begin{array}{l}\text { Ved at muliggøre eksklusion eller omfordeling af ældre fra Område- } \\
\text { centrets ydelsesområde, kan 'nye' ældre, der funktionelt lever op til } \\
\text { centrets inklusionskriterier inkluderes og modtage centrets ydelser i form } \\
\text { af hjemmebesøg, hjælpemidler, træning osv. }\end{array}$ \\
\hline
\end{tabular}

Områdecentrets læring retter sig mod at udvikle beslutningsprogrammer, der kan aflaste lederen, og som på bedre vis er i stand til at håndtere omverdenens forventninger fra det politiske system, brugerne og kommunens borgere. Uddelegering af ledelse eller selvledelses kan funktionelt beskrives som den løsning Områdecentret anvender til at reducere ledelseskompleksiteten og omverdens- og ydelseskompleksiteten. Grundlæggende kan dette beskrives ved, at det sker som funktionelle refleksioner over ydelsesområdet på en sådan måde, at ydelsen bliver opprioriteret - de ældre må f.eks. ikke opleve 'vilkårlige' aflysninger osv.

\section{Reduktion af arbejds- og arbejdstidskompleksitet}

Et andet område som gøres til genstand for iagttagelse ud fra selvledelse, og som resulterer i ændrede beslutningsprogrammer, er iagttagelsen af medarbejderne ud fra enheden af forskellen mellem arbejde/'fritid'. Iagttagelsens 
funktion er reduktion af kompleksitet i forhold til arbejds- og mødetid samt arbejdseffektivitet.

Som beskrevet tidligere oplever Områdecentret helt generelt en kompleksitetstilvækst i efterspørgslen af deres ydelser. På Områdecentret har man besluttet, så vidt det er muligt, at forsøge at leve op til disse efterspørgselsforventninger, hvilket blandt andet har betydet, at nogle arbejdsopgaver til forskel fra tidligere ligger mere spredt ud over ugens dage og døgnets timer.

$C:(. .$.$) der er kommet mere efterspфrgsel på brugen i de der vagter$ udenfor normal 8-16, altså om aftenen og tidlig morgen, fordi de ved at de bare kan kontakte os, og så skal vi nok vare der." (s. 52)

Områdecentrets orientering mod og beslutning om at forsøge at leve op til omverdenens forventninger fører til en refleksion over dets interne konditionering og beslutningsprogrammer. Der bliver behov for beslutninger om at organisere sig på en anden måde, der muliggør en ny arbejdsorganisering. Terapeuternes tidligere relativt faste arbejdstider gøres ved indførelsen af en flekstidsordning mere kontingente, dvs. det bliver nu muligt at organisere arbejdet på andre og mere fleksible måder. Terapeuternes arbejdstid individualiseres, idet den enkelte terapeut indenfor visse rammer, som jeg beskriver senere, selv får mulighed for at planlægge sin arbejdstid. For ikke at få for meget kontingens i systemet, f.eks. at terapeuterne kun er på arbejde, når det passer ind i deres egne individuelle gøremål, udvikles et nyt beslutningsprogram, hvis funktion er håndtering af og dannelse af nye forventninger til terapeuternes arbejdstidsprioriteringer. Beslutningsprogrammet består af en række nye kriterier, som terapeuterne skal lære at reflektere over og medinddrage i deres arbejdstidsprioriteringer, og som samtidigt betyder, at medarbejderne iagttages ud fra en ny forskel, som tematiserer om medarbejderen har omstillet sig og lært at leve op til det nye beslutningsprogram, nemlig enheden af forskellen mellem +/- ændret adfærd. Eller udtrykt på en anden måde; der opstår en ny iagttagelse, der skelner mellem dem, der har lart og lever op til de nye beslutninger, dvs. har gjort dem til præmis for egen adfærd, og dem som ikke har lart og ikke lever op til beslutningerne, dvs. ikke har gjort dem til præmis for egen adfærd. Ifølge lederen har de fleste lært dette, mens andre har sværere ved det.

"C: Ja. Og der er stadigvaek et par stykker som haenger lige lidt, som ikke er gode til at gå hjem selv om der ikke er noget at lave, altså der er altid et eller andet der lige kan ryddes op eller lige ordnes, så nogle gange siger jeg, det ordner vi i morgen. Som nogle gange, 


\section{Analyse}

som har lidt den gamle kultur stadigvaek haengende, og det tror jeg mange vil have lidt endnu (uf), som vil sige, min arbejdsseddel siger til kl. 4, så er jeg her til kl. 4, jeg kan ikke lide at gå kl. 3, for så føler jeg at jeg snyder. (...)Det er aldre medarbejdere, som har varet her i mange år.

C: Ja. For de unge, dem synes jeg, de fanger det med det samme, og det er også typisk dem som møder ind tidligere om morgenen eller går ind $i$ en aftenvagt fordi kl. 21 aften der skal fru Hansen $i$ seng, og der er altså nogle problemer med at få hende $i$ seng, fordi hun skal altså løftes eller forflyttes på en eller anden speciel måde. Så er det så også dem, der er inde og vare her på de tidspunkter." (s. 51)

Funktionelt tjener flekstidsordning til at give den enkelte terapeut mere autonomi i planlægning af forholdet mellem arbejde og fritid, herunder at øge terapeuternes motivation. Og ud fra iagttagelsen effektiv/ikke effektiv arbejdstid iagttages terapeuternes arbejdstidsprioriteringer ud fra en semantik om, at arbejdstid skal begrundes med reference til funktions- og ydelsesområdet, dvs. med funktionelle begrundelser. Dette betyder, at der etableres en forventning om, at terapeuterne kun forventes at være på arbejde, hvis der er konkrete arbejdsopgaver - ellers forventes de at tage fri eller at afspadsere (s. 49-50). Iagttagelsen af terapeuterne ud fra enheden af forskellen mellem effektiv/ikke effektiv arbejdstid sker med reference til ydelsesområdet

"C: (...) der er stadigvaek et par stykker (...) som ikke er gode til at gå hjem selv om der ikke er noget at lave (...)” (s. 51) ”C: (...) fordi der sidder du og fyrer 11/2 time af hver morgen, som kunne bruges på de celdre.(...)” (s. 50)

Det nye beslutningsprogram for arbejdstidsprioriteringer tjener på den måde funktionelt til og med samme antal ansatte at reducere den kompleksitetsforøgelse, der følger med flere og nye arbejdsopgaver. Samtidig har det den funktion at styrke iagttagelsen af ydelsesområdet, idet terapeuternes arbejdstid altid søges relateret til servicering af de ældre.

\section{Vidensdeling som differentieringsstrategi}

Et forhold, der ikke er et direkte 'produkt' af VBL, men som afdelingslederen og terapeuterne på Områdecentret er fokuseret på, og som søges 'styrket' og udbygget ved hjælp af VBL, er orienteringen mod viden og vidensdeling. 
Interessen for og anvendelsen af viden og vidensdeling kan beskrives som grundlæggende for, hvordan og hvorfor Områdecentrets beslutninger tages, som de gør. Tilsvarende er interessen grundlæggende for Områdecentret integrationspolitik i forhold til medarbejdere med forskellige faglige profiler der bidrager til afdelingens arbejdsopgaver. Dette handler mere konkret om medarbejdernes muligheder og begrænsninger for at kunne håndtere flere forskellige arbejdsopgaver på og for Områdecentret.

Som det vil fremgå er viden et centralt fænomen for at forstå, hvordan og hvorfor beslutninger tages som de gør herunder hvilke kriterier, der lægges til grund for mange af Områdecentrets beslutninger.

Faglig viden, der vurderes som relevant for bestemte arbejdsopgaver, udgør grundlaget for beslutningstagen, og denne får derfor også afgørende betydning for, hvem arbejdsopgaver og selvledelse uddelegeres til, samt hvordan arbejdsopgaverne søges løst. Som det også vil fremgå, kan den strategi, som Områdecentret anvender i relation til udbredelse af viden som vidensdeling mellem de forskellige medarbejdere, beskrives som udtryk for en didaktisk tilgang. Man kan sige, at Områdecentret foretager didaktiske refleksioner i relation til at sikre eller leve op til sine egne vidensmæssige kriterier for uddelegering af arbejdsopgaver.

Ifølge terapeuterne opleves det at blive ansat på Områdecentret som en anderledes oplevelse. Den forståelse og tildeling af arbejdsopgaver, der præger Områdecenteret opleves som anderledes end andre steder (s. 76). Områdecentrets interne organisering af terapeuterne er karakteriseret ved en særlig differentieret tilgang til viden og deraf betinget allokering af arbejdsopgaver. Dette er noget af det første, som en ny ansat terapeut skal lære at mestre.

"M2: Altså når man kommer som ny i gruppen, så studser man lidt, og så tanker man, nå er det også min opgave, og så når man har varet her et par måneder, så er det bare helt naturligt. Så er det man studser, når de ringer fra sygehuset og beder om at snakke med en ergoterapeut, og siger, jamen kan du ikke bruge mig? Jamen jeg kan altså godt. I forhold til de rammer vi har $i$ hvert fald, $i k$ '.

M3: Det er klart, at vi har to forskellige uddannelser, selvfølgelig har vi nogle forskellige specialer, men meget af det vi laver det noget hvor begge grupper kan gå ind og lave det. Men hvis man kan se, at det er noget hvor en ergoterapeut vil vare bedre, jamen så giver man det så videre eller omvendt, altså i forhold til de kompetencer 
man har, og det synes jeg også vi gør. Vi bruger hinanden, eller hvis jeg har en, og der kommer noget mere ergoterapeutisk, så går jeg hen og spørger i forhold til det, så på den måde der bruger vi hinanden, arbejder sammen." (s. 75)

Som nævnt tidligere er en stor del af Områdecentrets funktion relateret til og afhængig af den viden og de kvalifikationer og kompetencer, som ergo- og fysioterapeuter har. Som det fremgår af citatet, har Områdecentret besluttet at foretage en særlig intern differentiering i relation til løsning af centrets opgaver. Denne differentiering beskrives af terapeuterne på følgende måde.

"M2: Men det er usadvanligt, tror jeg." (s. 75)

M3: Det er i hvert fald ikke alle steder, at, altså det er nogle steder, hvis man tager til Århus, så ergoterapeuter de tager sig af alle hjoelpemidler, mere eller mindre, ik', eller hvad, i hvert fald mange steder.

M2: Sådan er det også bare ude på (et andet center), et andet sted $i$ byen, der er det også ergoterapeuterne der tager sig af alle hjalpemidlerne, og fys'erne de traner med folk, sådan er det bare." (s. 76)

Ifølge terapeuterne er denne differentierede form for organisering af ergoog fysioterapeuter ikke særligt udbredt andre steder. Differentieringsformen betyder, at f.eks. nye medarbejdere ikke kun iagttages som nye kollegaer men tillige iagttages ud fra en pædagogisk didaktisk optik, dvs. som mulige 'objekter' for 'uddannelse' og undervisning. Funktionen af den didaktiske iagttagelse og forventningerne om, at medarbejderne 'uddanner' sig, så de kan leve op til områdecentrets interne forventninger om videns-, kompetence- og kvalifikationsdifferentiering kan beskrives som centrets strategi for at undgå en for høj grad af dependens knyttet til bestemte fagligheder. Funktionelt har Områdecentret brug for medarbejdere med en så funktionelt og ydelsesmæssigt begrundet bred faglig profil som muligt, således at de kan anvendes fleksibelt til løsning af centrets forskellige arbejdsopgaver. Strategien med vidensdifferentiering kan beskrives som en strategi, der hjælper centret med at reducere den kompleksitet, der ligger $i$ at have mange forskelligartede opgaver og relativt få ansatte, som internt er afhængige af hinanden i relation til kunne afløse hinanden, eller at kunne bytte arbejdsopgaver. Dette gælder f.eks., når de skal på kursus eller skal have 'fri' til andre gøremål. 
Overordnet kan vidensdelingen iagttages som en særlig vidensmæssig differentieringsstrategi, der muliggør løsning af Områdecentrets opgaver på måder, som ellers ikke havde været mulige. Funktionelt kan dette beskrives som en nivellering af centrets vidensdependens af i første omgang de to terapeutgrupper, samt en 'rationel' udnyttelse af centrets økonomiske midler, som Områdecentret har til rådighed til kurser og efteruddannelse af sine medarbejdere. (s. 58-59).

\section{Områdecentrets didaktik til vidensdifferentiering}

Ud fra en mere operationel didaktisk iagttagelse er Områdecentrets didaktiske refleksioner og strategier rettet mod at foretage disponeringer, der muliggør relevant og strategisk målrettet vidensdeling til centrets egne aktører. Aktørerne er mere præcist de to afdelinger (Områdecentret og det andet center lederen også er leder for), ergo- og fysioterapeuterne, og aktivitetsmedarbejderne, samt andre aktører der vurderes at være relevante at inddrage i løsning af centrets opgaver, f.eks. personale på et plejehjem, som de arbejder en del sammen med.

På et generelt plan beskriver afdelingslederen og terapeuterne sig selv som opsat og fokuseret på fagligudvikling.

"C: (...) Jamen udvikling det kraver prioriteringer, fordi vi har en gruppe heroppe der skide gerne vil ud, vil vare på forkant med alt muligt, og rigtigt gerne vil på kurser, og de vil, jamen hvis vi tager terapeutgruppen, alle 8 de vil jo gerne på det samme kursus. $O g$ så kommer der et nyt kursus, de vil egentlig også gerne alle 8 på det kursus, fordi det er fandeme vigtigt, også at vi alle sammen ved det, hvad der bliver sagt omkring en ny forflytningsteknik, hvordan underviser vi plejepersonalet $i$ sådan noget. Jamen det er rigtigt siger jeg så ik', men så er der så bare ingen terapeuter heroppe, og så er der jo aflysninger på alting.” (s. 57; jf. s. 55)

Det fremgår flere steder, at både afdelingslederen og terapeutgruppen er, hvad man kan betegne som omstillingsparate og læringsorienterede, og dette gælder i særlig grad, når det handler om faglig opkvalificering, dvs. viden, der kan tilegnes gennem specialiserede kurser på faglige områder, som funktionelt er relateret til Områdecentrets ydelsesområde. For eksempel skal centret til at være praktiksted for ergoterapeutstuderende, og for Områdecentret iagttages dette - ud over at give økonomi til afdelingen - som en mulighed for at få adgang til og at tilegne sig ny viden indenfor deres faglige områder - noget der anses at kunne blive til gavn for ydelsesområdet i form af de ældre. 
"C: (..) Her der får vi faktisk nogle penge, og hvis vi snakker udvikling ik'os', så kommer vores sjetteårsstuderende (6. semester), som har den nyeste teori med inde og kan vare med til at holde os a jour og holde vejlederne på dupperne, (...) vi sidder faktisk med sådan en udviklingsopgave både rent fagligt, men også at vi både får nogle op i tid, men også at vi får nogle ind og inspirere med ny viden, som vi kan bruge" (s. 59; jf. s. 66)

En af metoderne til fagligudvikling, vidensdeling og læring er daglig kommunikation mellem de forskellige terapeuter og andre medarbejdere. Medarbejdergruppen på Områdecentret er ikke større, end at de kender hinanden og hinandens faglige profiler. Afdelingslederen udtaler sig således om dette:

"C: Jamen det synes jeg. Altså vi har sådan lidt nogle, et par stykker, de er specielt gode til demente mennesker, de har en god viden om det, og når de andre de så ryger ind i et problem, hvis man skal trane en dement, med noget fysisk traning, selv om man er fysioterapeut osv. så er det ikke verdens nemmeste opgave, fordi de forstår måske ikke det man siger osv. osv. Og hvis man kommer som ny fysioterapeut og ikke ved ret meget om demente, (...) så må du hente den viden, og vi har så nogen der har den viden. Så kører der noget sparring der, ik', og vi har noget omkring noget alkohol, der er gode til nogen der misbruger alkohol, og psykisk syge osv., sådan nogle ressourcepersoner indenfor gruppen, som vi så egentlig g $\phi r$ meget ud af ved introduktion af folk at sige: du vil på et tidspunkt komme ud for nogle, der har, der enten sådan og sådan, og det skal du ikke lade dig slå ud af, fordi vi har nogen, der ved noget om sådan noget. Så enten så giver du bare hele opgaven over, eller også så får du bare den viden fra dem som du har brug for. Så sådan er det." (s. 57)

Hvis den enkelte står med en opgave men oplever, at vedkommendes faglige viden ikke er tilstrækkelig til at løse opgaven fagligt forsvarligt, tages der kontakt til ressourcepersonen, dvs. den person i medarbejdergruppen, som på netop det område har den faglige viden, som menes at kunne afhjælpe problemet (s. 57; s. 75). En anden metode er bes $\phi g$ og deltagelse på 'hinandens' hold, således at de forskellige medarbejdere gennem, sparring, observation og deltagelse bliver inspireret af hinandens måske forskellige måder at løse den samme opgave på (jf. s. 55; s. 57). En tredje undervisningsmetode er oplaeg for hinanden. Eftersom der ikke er kapacitet til, mulighed for samt midler til 
at alle eller flere af terapeuterne kommer af sted på samme kursus, er der lavet en beslutning om, at dem, der har været på kursus, holder oplæg for de andre på centret, der vurderes at have gavn af denne viden (s. 57).

"C: (...) Nogle har svarere ved at hive pointer ud fra deres kurser end andre. Specielt terapeutgruppen er meget gode til det. Der er også forskel på uddannelsesniveauet heroppe, hvor god man er til at formidle sig, men terapeutgruppen er specielt god til at, f.eks. om traning eller hjoelpemidler, hvad nye ting der er kommet, det er de faktisk gode til.” (s. 56)

På den måde og ved hjælp af disse undervisningsmetoder forsøger Områdecentret at praktisere en didaktisk tilgang til medarbejderne, hvor formålet er at muliggøre større fleksibilitet og mindske dependensen af medarbejdernes monofaglige viden, kvalifikationer og kompetencer såvel som centrets opdeling (jf. s. 55). Den didaktiske tilgang til terapeuterne kan således ses som Områdecentrets strategi til vidensdifferentiering såvel som effektivisering eller optimering med henblik på reduktion af kompleksitet i relation til centrets arbejdsopgaver.

I det følgende vil jeg uddybe, hvordan Områdecentrets udvikling, opkvalificering eller 'uddannelse' af egne medarbejdere foregår på et mere operationelt plan.

Områdecentrets terapeuter deltager i og 'uddanner' ny ansatte terapeuter i form af introduktion til og 'undervisning' i de forskellige arbejdsopgaver, der er på afdelingen, herunder viden fra den 'anden' terapeutprofession samt specifik viden relateret til udførelse af arbejdsopgaver på faglig forsvarlig vis. Helt generelt foregår uddannelsen af den enkelte medarbejder (og her er der ikke kun tale om de nyansatte) ved anvendelse af forskellige undervisningsmetoder. En af metoderne er det, som populært kendes som sidemandsoplæring, dvs. hvor kollegaer oplærer hinanden (spiller rollen som underviser over for andre kollegaer), og dette foregår typisk ved instruktion og afprøvning/efterprøvning af læringsindholdet $i$ en arbejdsmæssig sammenhæng (s. 98). For eksempel kan eleven (den ikke-vidende kollega) deltage i en holdtræning hos laereren (den vidende kollega). Et andet eksempel er beslutningen om at anvende en anden undervisningsmetode med et særligt indhold, nemlig det ergoterapeutiske 'måleredskab' COPM (Canadian Occupational Performance Measure). COPM er et reliabelt, responsivt og individualiseret ergoterapeutisk redskab til resultatmåling af en klients egen vurdering af tilfredshed med udøvelsen af vigtige daglige aktiviteter. COPM er således 
ideelt set et redskab, der skal fremme og sikre en klientcentreret praksis (http://www.etf.dk/copm/).

"M2: Det er en ergoterapeutisk arbejdsmodel, som vi synes at vi kan bruge ret bredt heroppe. Vi synes den er god, fordi den netop er brugerorienteret, (...) men alt det her med COPM og sådan noget, det kommer også af Var-med-projektet, det kommer af at vi har sagt, vi synes at vi vil arbejde på en anden måde for at vi skal vare mere, vi mener vi får mere kvalitet ved at gå ind og arbejde mere målrettet, og vi mener vi er blevet mere brugerorienterede ved at gфre det på denne her måde. Så det er sådan lige så stille, ud af alle de her temadage vi har fået, og efter vores (hytte)-tur, har vi arbejdet hen imod at komme $i$ gang med det her koncept. Det er noget vi har bestemt vi vil, hvor (leder) han synes vi skal have en let og overskuelig, let tilgangelig måde at satte målene for brugerne på, ikke. Og det bliver det nok aldrig, men det er en made”.

Intentionen med COPM er for det første at få et redskab, der er bedre til at identificere individuelle problemstillinger, behov og mål for områdecentrets ydelser relateret til den ældre. For det andet er intentionen at give mere kontinuitet, progression og sammenhæng i centrets ydelser til den ældre ved at samstemme forventningerne til ydelsen mellem de forskellige terapeuter og den enkelte ældre.

M1: Men jeg tror at selve traningen, eller selve aktiviteterne for brugerne bliver nemme at gå i gang med, når vi nu har nogle klare mål for den enkelte bruger. Så ved vi hvad det er de vil, så er det ikke at (navn på terapeut) mener et og (navn på terapeut) mener noget andet, og hun mener noget tredje, (uf) så når brugeren endelig er her, så er det ikke sådan helt klart hvad det egentlig er, altså hvis brugeren også selv er klar over, at det der er vigtigt for mig det er at kunne laere at pudse mine briller, jamen så ved alle det, og så er det det man gør.” (s. 81-82)

Beslutningen om at anvende COPM kan således ses som Områdecentrets fors $\emptyset \mathrm{g}$ på at styrke ydelsesområdet, dvs. give bedre service til de ældre. Det kan også ses som en mulighed for at skabe bedre koordinering indad til i afdelingen, ved at terapeuterne har mere umiddelbart tilgængelig viden om den enkelte ældre og dermed et bedre fagligt udgangspunkt for at kunne tilrettelægge relevante ydelser. Samlet set kan det ses som et udtryk for, at 
terapeutgruppen er orienteret mod at udvikle deres arbejde i faglige retninger, som kan begrundes funktionelt og i relation til styrkelse af ydelsesområdet.

Som jeg tidligere har været inde på, er viden, efteruddannelse og vidensdeling noget, som terapeuterne og Områdecentret er optaget af. Dette gælder specielt når det drejer sig om styrkelse af centrets funktion og ydelsesområde. Medarbejderne, specielt terapeuterne, forsøger derfor så meget, som det er muligt, at deltage i arbejdsrelevante kurser (s. 55-59).

\section{Kompleksitetsreduktion, faglighed, autonomi og hierarki}

Som jeg tidligere har været inde på i analysen, er et helt centralt tema for Områdecentret, at de oplever et kompleksitetsproblem i forhold til behovet for centrets ydelser i form af hjemmebesøg, visitering til hjælpemidler, og de forskellige former for træning og vedligeholdelses/genoptræning, som centrets terapeuter tager sig af. For afdelingslederen fremstår det som vigtigt at få ventelisten på adgangen til Områdecenterets ydelser ned.

"L: Lad os nu sige, jeg kommer tilbage noeste uge og siger at det er okay, (...) hvis I skal vare rigtig hårde, fordi det tror jeg nasten I skal vare fordi I skal have lidt luft $i$ ventelisten, (...)” (s. 204)

Lederen og terapeuterne er enige $i$, at der skal findes nogle løsninger på dette problem angående ventelisten. Lederen og terapeuterne er også enige i, at terapeuterne gennem længere tid har haft meget svært ved at afslutte de ældre. Terapeuterne kommunikerer på følgende måde om strategier for reduktion af kompleksitet relateret til ydelsesområdet.

"M: Men vi skubber stadigvak problemet,

M: Ja, det gфr vi

M: fordi problemet det vil komme igen på et eller andet tidspunkt, medmindre vi finder et eller andet mere fundamentalt vi kan lave om, ellers så vil vi bare blive ved med at skubbe det foran os, så kommer det igen." (s. 215)

Hele dette møde mellem afdelingslederen og terapeuterne om, hvordan det er muligt at skabe mere luft og plads i terapeuternes arbejdsopgaver, handler om at forsøge at finde strukturelle løsninger på problemet med for lang venteliste, for få ansatte, og for mange tidskrævende arbejdsopgaver. 


\section{Analyse}

Rollefordelingen til mødet kan i store træk defineres ved, at lederen holder fokus på, at det skal ske, men overlader det til terapeuterne at definere hvorfor og hvordan ydelsesområdet skal håndteres i relation til at skabe mere plads i deres arbejdsopgaver. I et fors $\emptyset \mathrm{g}$ på at reducere denne kompleksitet arbejder terapeuterne med en række forskellige problemløsninger. En af de mest markante problemløsningsstrategier er et fors $\emptyset \mathrm{g}$ på - via differentiering af ydelsesområdet - at gøre det til en håndterbar størrelse, som terapeuter med deres egen faglighed i behold kan forsvare. I forsøget på at reducere kompleksiteten ved ydelsesområdet er en grundlæggende strategi blandt terapeuterne således, at de orienterer sig mod deres egen faglige viden og med udgangspunkt i dette diskuterer forskellige muligheder for at differentiere ydelsesområdet bl.a. gennem intern uddifferentiering. Som det vil fremgå af analysen, kan differentiering af ydelsesområdet som problemløsningsstrategi kædes sammen med terapeuternes faglige tilgang til ydelsesområdet, som betyder, at de generelt har problemer med at afslutte, eller på anden måde reducere kompleksiteten på ydelsesområdet.

I bestræbelserne på at finde mulige faglige problemløsningsstrategier i forhold til differentieringen af ydelsesområdet forsøger terapeuterne at hente inspiration fra kurser og tiltag fra andre kommuner, f.eks. diskuteres det i hvilken udstrækning, det er muligt at anvende frivillige til at initiere og stå for motionsprogrammer for ældre (jf. s. 192-193). Terapeuterne forkaster dog frivillighedsinitiativet ( $g \varnothing \mathrm{r}$ det til omverden) med den begrundelse, at de frivillige ikke har den fornødne faglig indsigt og kompetencer, som de vurderer, er påkrævet for f.eks. at kunne stå for genoptræning af de ældre (s. 193). Terapeuterne mener ikke, at de kan eller skal være ansvarlige for, eller skal lægge navn til noget, som de vurderer muligvis kan skade de ældre:

"M: Der er mange med osteoporose f.eks. der vil blive overbelastet sådan her (knipser)" (s. 195)

Lederen udtrykker det således:

"L: For jer der handler det om at have den tryghed $i$ at det de nu gфr det er ikke noget der $\phi$ delagger noget." ( $s .196)$

Det diskuteres om, der kan differentieres mellem de ældre, således at f.eks. dem med osteoporose skal holdes ude af uddifferentieringen til de frivillige, mens andre grupper af ældre muligvis kunne have gavn af de frivilliges tilbud. Nedenstående passage er et udpluk af en diskussion mellem terapeuterne og lederen, hvor muligheden for uddifferentiering af ydelser til frivillige reflekteres: 
"M: (...) For mig der handler det om, at det de så kommer ud og $g \phi r$, det er det bedste de overhovedet kunne finde på, hvis de selv skal finde på noget, og ikke bare at, nå men det går jo nok. Så jeg tanker, (...) når jeg ser konklusionen, altså jeg synes ikke der er noget overførselsvardi $i$ at stå med en håndvagt derhjemme på en eller anden måde, det er der ikke for mig, altså. Men der kunne vare noget $i$ at sige, nu går vi ned $i$ (en park), ik', sammen, og fodrer ander, og taler sammen på vejen og har noget sammen og går tilbage igen, og så har fået noget motion der er brugbart, som

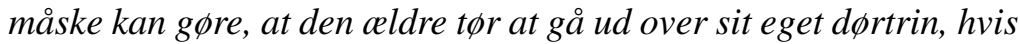
de ikke tør. Jeg synes ikke, altså, så synes jeg lige så godt man kunne knalde en motionsvideo på naesten, groft sagt."

$(\ldots)$

M: Jamen det er det, at man jeg tror bare det er vigtigt, at man så tager stilling til, hvad det sådan er man vil med det frivillighed der. Fordi det vil jo også tage arbejdet fra os, altså hvis man tanker sig om, hvis der er nogen der går ud og går tur med folk, det er jo ikke sådan, det er ikke så meget det jeg tonker over.

L: Jeg tror ikke, I skal tonke på, at arbejdet bliver taget fra jer, I skal nok

M: Nej, det gør jeg heller ikke.

\section{(...)}

M: Ja, fordi små ting ved osteoporose-folk, et lille vrid der er forkert, altså der er mange фvelser hvor der er en eller anden form for vrid i ryggen, så kan det jo gå meget galt.

L: Man kan jo spфrge, om osteoporose-folk skal vare med i det her, om de skal

M: Nej, men jeg siger bare

M: Nej, men hvis de skal frasorteres, så frasorterer man jo rigtig mange.

M: Det er ikke fordi, jeg synes også det er en god ide 
284 Analyse

M: Og man skal også vide de har det, det er nok narmest det

M: For det er ikke nok, at man larer om motion, hvordan man gфr

M: Nej, det er det nemlig ikke

M: Der skal også vare sygdoms

\section{M: Men nu har vi også brugt $31 \frac{1}{2}$ år på at uddanne os til det}

L: Men omvendt, så skal vi heller ikke vare terapeuter eller lager for at kunne gå ud og lave det, altså, vi skal finde et eller leje, hvor vi kan sige, nu har de en viden som vi synes er tilstrakkelig, og vi tror egentlig godt nok på, at de holder sig indenfor de rammer. Selv om vi siger, det er rammen, så kan vi jo ikke garantere de ikke går udenfor rammen og laver 50 gentagelser af noget de kun må lave 10 gentagelser med. Altså jeg ved med min far, hvis han skulle gøre det, han får aldrig en skid motion, hvis han får en håndvagt, jamen så bliver han bare ved, og bagefter så kan han

M: Og lige pracis, $i$ sådan et tilfaelde der er vi uddannet til at se på folks trathedstegn, ik', når musklerne begynder at sitre, og hvordan ser de ud i фjnene og hvordan har de det, hele tiden lige tage pulsen på hvordan de har det, det vil en anden jo ikke vare. Der ville din far jo kunne have siddet og taget $100 \mathrm{og}$ så vil de bare sige, åh det er flot du bliver ved, måske." (s. 196-197)

Med lederens bemærkning om, at terapeuterne ikke skal være bange for, at arbejdet bliver taget fra dem, hvis de uddelegerer bestemte arbejdsopgaver til de frivillige, fravælges denne antagelse. Terapeuterne argumenterer herefter for, at hvis ældre med osteoporose ikke indgår i gruppen, som de frivillige kan arbejde med, så frasorterer man jo rigtig mange, underforstået at så vil effekten af uddifferentieringen være for lille, hvorfor man ligeså godt kan lade være. Terapeuternes iagttagelse af ydelsesområdet kan beskrives ud fra en semantik om, at deres sundhedsuddannelse gør en forskel i relation til iagttagelsen af de ældre. Semantikken om sundhedsuddannelse ligger til grund for argumentationen om, at de til forskel fra andre er bedre til at iagttage og tage højde for eventuelle risici ved træning af de ældre, f.eks. om den ældre bliver overbelastet eller kan komme til skade. Eftersom de frivillige ingen sundhedsuddannelse har og derfor, ifølge terapeuterne, 
ikke kan iagttage eventuelle overbelastninger forkastes uddifferentieringen til de frivillige. Terapeuterne fravælger ligeledes tidsdimensionen (automatisk eksklusion efter tre måneder) som afslutningsstrukturel løsningsalternativ med henvisning til den kontingente virkning, den kan have overfor den enkelte ældres situation. Det giver efter terapeuternes mening ikke mening at gå ud fra, at den enkelte ældre automatisk er trænet færdig efter tre måneder. Terapeuternes fagligt begrundede differentieringsblik betyder, at de ikke iagttager de ældre som en homogen gruppe, der automatisk kan afsluttes efter tre måneders træning. Terapeuterne iagttager de ældre som mennesker med individuelle behov og problemer og som nogle, der har krav på og brug for individuelle træningsforløb. Afslutning efter tre måneder iagttages derfor som kontingent og fagligt uforsvarlig, da den enkelte ældre kan have behov, som ikke er tilstrækkeligt dækket efter tre måneders træning (jf. s. 83; s. 86; s. 201; s. 216).

Terapeuterne accepterer imidlertid i begrænset omfang den tidsstrukturelle løsning ud fra den faglige betragtning, at den enkelte ældres afslutning efter de tre måneder tages op til vurdering. Det kan vurderes, om det er forsvarligt at afslutte den ældre helt, eller om den ældre skal overtræde til en anden af Områdecentrets ydelser, f.eks. fra genoptræning til vedligeholdelsestræning (jf. s. 211). En anden mulighed, som overvejes, er muligheden for at gå fra individuel hjemmetræning til holdtræning, eftersom det er en mindre ressourcekrævende ydelse for Områdecentret, idet terapeuterne her har mulighed for at levere ydelser til flere ældre på en gang.

Efter diskussioner om hvilke muligheder og begrænsninger der er for at flytte ældre fra tidskrævende hjemmetræning til holdtræning, og om der findes tilbud andre steder i byen, som det er muligt at henvise de ældre til, når de afsluttes på Områdecentret f.eks. med økonomisk støtte til privat praktiserende fysioterapeuter (s. 227-228), peger terapeuterne på en mulighed for at uddifferentiere ydelser til personalet på et plejehjem (s. 215; s. 217; s. 220; s. 223-224; s. 227).

Nedenstående er en del af lederen og terapeuternes diskussion om uddifferentiering af vedligeholdelsestræning til plejehjemmet.

"L: Altså, jeg har stadigvak den her lyserøde tanke, som jeg også havde på den der inspirationsdag, at $i$ plejen og $i$ aldreboliger, jamen vedligeholdelsestraning kan laves af personalet på afdelingerne, hvis de bliver uddannet $i$ det, så kan de lave noget vedligeholdende traning på det niveau de nu de oeldre er dernede. 
(...)

M: Det startede min elev jo op nede på (afdeling) f.eks., så var det meningen at noget af personalet dernede skulle overtage, men det kraver at det kommer fra deres leder, som siger det her det skal I, det er en del af jeres arbejde, og jeg ser det som vores opgave at vi laver vedligeholdelsestraning med vores beboere 2 gange om ugen, og det er dit ansvar, og hvem har ellers lyst, så er det også dit ansvar. Fordi de skal se det som deres opgave, som det er nu ser de det som vores, det kraver en holdningsandring." (s. 218)

(...)

"M: Men jeg tror også, det har jeg sagt før, at vi skal tanke mere vedligeholdelsestraning, det kan altså også vare at lave nogle aktiviteter nede $i$ aktivitetslokalet

\section{M: Mm, det kan det nemlig}

M: Det kan stille større krav end det kan at gøre så meget andet, men så skal vi bare vare bedre til at bakke op omkring personalet dernede, så de også ser at det er traning, så de ikke bare kommer derned og sidder og drikker kaffe

M: Og det er nok det der lidt sker, ik'os'

\section{$M: J o$}

M: Ja, netop også at hvis man skal lave et silketфrklaede f.eks., at man bliver stillet et sted hvor man skal stå og lave et silketфrklade, og at man selv skal gå hen og hente tingene f.eks., sådan at man ikke bliver sat $i$ en stol med en kop kaffe, og så bliver der ellers et silketфrklaede-kit stillet foran en, og så kan man ellers lave et silketфrklade, for så er der jo ikke meget traning i det vel

M: Og også som du sagde nede på afdelingen, jeg toenker da også at vedligeholdelsestraning dernede det er jo også at de selv begynder at gå hen til middagsmaden i stedet for at det lige bliver 'sjup' $i$ en kørestol ik', eller, altså at det er sådan, at de behøver ikke lige at blive banket $i$ en rundkreds på stole og så skal de lave noget, men at de begynder at toenke det ind 
L: (uf) traening ind $i \operatorname{det}(u f)$

M: Hjalper med at dakke bord

M: Hjalper med at dakke bord, ik', det der kampe.” (s. 224)

(...)

"M: Men det er også fordi folk ikke kan se en sammenhang mellem det at trane og så det at dakke bord, men så skal vi med vores faglighed gå ind og sige at det er fordi det og det og det har hun brug for, og det er lige netop det hun opnår der, og så er det det tager tid, og så er det man ikke skal gøre det en fredag eftermiddag hvor de står og” (s. 225)

Som det fremgår, iagttager afdelingslederen og terapeuterne de ældre, og de ansatte i Områdecentrets aktivitetscenter, samt personalet på plejehjemmet ud fra en funktionelt ledet terapeutfaglig tilgang, der i det her tilfælde handler om vedligeholdelsestræning. Iagttagelsen ud fra enheden af forskellen traning/ikke traning leder til, at de ældre ses som mennesker med behov for træning, og at aktivitetsmedarbejderne og personalet på plejehjemmet iagttages ud fra enheden af forskellen mellem viden om traning/ikke viden om traening. Eftersom aktivitetsmedarbejderne og personalet på plejehjemmet iagttages som ikke vidende om træning bliver de for terapeuterne genstand for pædagogisk didaktisk intervention. Terapeuterne beslutter derfor at udvikle et særligt uddannelses- og undervisningsprogram, som har til hensigt at lære aktivitetsmedarbejderne og plejehjemspersonalet at iagttage og forholde sig til de ældre ud fra viden om træning. Læringsmålet eller læringens hvad er, at aktivitetsmedarbejderne og plejehjemspersonalet bliver i stand til at iagttage de ældre på en ny måde, som muliggør, at træningsfunktionen integreres i plejefunktionen af de ældre.

Baggrunden for ovenstående udspringer af Områdecentrets bestræbelser på at reducere kompleksitet ved at uddifferentiere dele af ydelsesområdet vedligeholdelsestraening til subsystemet plejehjemmet. Men fordi terapeuterne iagttagelser er funktionelt ledet, dvs. reflekterer træningsrelateret over ydelsesområdet, er uddifferentiering kun mulig i den udstrækning, at den lever op til terapeuterne egne faglige kriterier. Dette betyder flere ting. For det første betyder det, at VBL resulterer i mere pædagogisk didaktisk kodet kommunikation i begge subsystemer - Områdecentret og plejehjemmet. Terapeuterne tilskrives eller tilskriver sig selv rollen som undervisere, 
og at aktivitetsmedarbejderne og personale på plejehjemmet iagttages som elever/studerende, dvs. iagttages ud fra en pædagogisk didaktisk tilgang. For det andet betyder det en ny funktionstilskrivning til aktivitetsmedarbejderne og plejehjemspersonalet, idet de til forskel fra tidligere forventes at hjælpe terapeuterne med træning, og mere generelt iagttage og anvende viden om træning til iagttagelse og aktivering af de ældre i deres daglige arbejde. De ældres aktiviteter som f.eks. at gå selv, dække bord og andre dagligdagsaktiviteter, skal iagttages og behandles som potentielle træningsmuligheder, hvorfor personalet forventes at fremme dette så meget som muligt (jf. 218-220).

Der er knyttet to iagttagelser til uddifferentieringen af vedligeholdelsestræningen. Den ene handler om aflastning. Aflastningen består i, at nogle ældre, som pt. deltager på Områdecentrets hold, uddifferentieres således, at de ikke længere optager plads. Den anden knytter sig til terapeuternes iagttagelse af de ældre på plejehjemmet ud fra en risikosemantik. Risikosemantikken udspringer af terapeuternes faglige tilgang til de ældre, og deres oplevelse af ansvar overfor dem. Helt konkret iagttager terapeuterne dem som ældre mennesker med kontinuerlig brug for træning, ellers er de i risiko for at få fysiske funktionsnedsættelser. Semantikken om risiko har således to væsentlige iagttagelser knyttet til sig, dels en slags omsorgsiagttagelse, som består i, at terapeuterne gerne vil have, at det går de ældre godt, dvs. at de ikke får fysiske problemer. Den anden iagttagelse består i, at hvis ikke de ældre trænes, udgør de potentiel kompleksitet på ydelsesområdet, dvs. kommer til at optage plads på Områdecentret.

Risikosemantikken betyder forebyggelse og indbefatter i den form, som der her er tale om, at terapeuterne via personalet på plejehjemmet inkluderer flere ældre, end de ekskluderer. Der er altså ikke nødvendigvis tale om beslutningen fører til mere arbejde for terapeuterne, men beslutningen viser noget om deres forhold til ydelsesområdet, dvs. de ældre. Jeg kommer tilbage til dette senere, men kort sagt er uddifferentieringen og den medfølgende uddannelse af plejepersonalet et udtryk for terapeuternes funktionelt begrundede iagttagelser af de ældre. De udviser, hvad man kan betegne som en stor ansvarlighed for de ældre, der betyder, at de stort set altid reflekterer over, hvad de kan gøre ved sig selv, for at blive bedre til at hjælpe de ældre. I tilfældet med plejehjemspersonalet handler det også om, hvordan de kan få andet personale i kommunen til at indrette sig sådan, at de bliver bedre til at hjælpe de ældre. Man kan udlede, at med uddifferentieringen af ydelsen vedligeholdelsestrcening til plejehjemmets personale udbredes terapeuternes træningsfunktion til en ny funktionsbeskrivelse for plejepersonalet. 
Den samme tendens, som ovenfor er beskrevet i relationen mellem terapeuterne og plejepersonalet, kan iagttages internt på Områdecentret i relationen mellem terapeuterne og aktivitetsmedarbejderne. Nedenstående citater handler om, hvordan de overordnede prioriteringer og disponeringer på områdecentret har konsekvenser for aktivitetsmedarbejdernes funktionsbeskrivelse.

"M2: Noget andet jeg synes vi er begyndt på efter de her Varmed-kurser, det er at arbejde i teams, og gå ind og beskrive hvad er det for nogle opgaver, der ligger i de forskellige teams omkring sammenholdet, omkring deres indhold, omkring. Vi forsøgte at få op at kore nogle teams på tvars af fys'en og aktiviteten, fordi at brugerne gik begge veje, altså de var både det ene og det andet sted på den samme formiddag, så det blev én aktivitet at de både tranede og var i aktiviteten. Det var svart.” (s. 74)

"M1: Aktivitetsmedarbejderne siger også, jamen det er altid os der skal gå ind og aflyse, det er altid vores arbejde det går ud over, og man kan sige, jamen det er da også vigtigt at komme ud og få købt nogle gevinster, så vi har nogle gevinster, når der skal vare banko, og de har jo også nogle ting som er vigtige at lave, de kan også have nogle brugere som kommer, som de skal tage sig af, som de så bliver nodt til at aflyse eller få nogle andre igen til at tage sig af, og det kan godt give nogle konflikter også mellem de to grupper: Er det nu terapeuterne der skal aflyse hjemmebes $\phi$, eller er det aktivitetsmedarbejderne der skal finde ud at få det til at køre ind $i$ aktivitets-(uf)

H: Altså fordi aktivitetsmedarbejderne bliver sat på noget som terapeuterne ellers skulle varetage?

M1: Ja.

M2: F.eks. Eller som skal gå ind og vikariere for hinanden i forhold til at hjalpe på et hold. Man er altid to i fys'en, en terapeut og en hjoelper.

M1: Altså jeg tror nok, at (lederen) han ville hellere have at der var to aktivitetsmedarbejdere der gik ind og havde det inde ifys'en end at det blev aflyst. Ja, men sådan er det. 
290 Analyse

M2: Men det synes jeg ikke man kan.

M1: Nej, og det er den diskussion (uf)” (s. 79)

Som det fremgår af ovenstående, er et centralt tema for Områdecentrets VBLdiskussioner om kriterier for konditionering af arbejdet i og samarbejdet mellem teams. Arbejdet mellem terapeuterne og aktivitetsmedarbejderne besluttes og konditioneres dermed primært ud fra terapeuternes faglige tilgang til de ældre. Dette betyder, at iagttagelsen af sammenhæng i den ældres forl øb på Områdecentret iagttages som sammenhæng i den terapeutfaglige tilgang til træning. Dette betyder endvidere to ting, dels at aktivitetsmedarbejderne skal lære at forholde sig til den ældres problem og reflektere det ind $\mathrm{i}$ forhold til de aktiviteter der foregår hos dem - i aktivitetscentret, dels at aktivitetsmedarbejderne skal lære at vikariere, dvs. bistå terapeuterne $\mathrm{i}$ deres arbejde. Den nye konditionering af Områdecentret betyder også, at beslutningen om helst ikke at aflyse terapeuternes træning af de ældre får den konsekvens, at aktivitetsmedarbejderne i pressede situationer skal aflyse deres opgaver til fordel for at assistere terapeuterne. Der er således tale om, at Områdecentret generelt $\emptyset$ nsker mere fokus på at styrke og løse problemer i relation til centrets træningsfunktion.

\section{Opsummering på Områdecentret}

Som det er fremgået af analysen ovenfor, forsøger Områdecentrets leder og terapeuterne på baggrund af VBL at komme med forskellige ideer til reduktion af Områdecentrets kompleksitet på ydelsessiden. Strategien kan beskrives som en vidensbaseret differentieringsstrategi, der ved hjælp af terapeutfaglig viden har til formål at differentierer de ældre, som mennesker med forskellige behov. Differentieringen $\mathrm{g} ø \mathrm{r}$ det muligt for Områdecentret at tage beslutninger om hvilke ydelser den enkelte ældre skal modtage, og hvornår det er fagligt forsvarligt at afslutte den ældre, dvs. ekskludere vedkommende fra Områdecentrets ydelser, og alternativt tilbyde fagligt forsvarlige ydelser fra andre systemer. Ud fra en organisationsdidaktisk tilgang kan det iagttages at specielt Områdecentrets terapeuter i løsninng af egne arbejdsmæssige problemstillinger og til forbedring af ydelsesområdet, dvs. tilbud til de ældre, anvender organisationsdidaktiske refleksioner. Dette beskrives nærmere i nedenstående skema. 


\begin{tabular}{|c|c|}
\hline $\begin{array}{l}\text { Laringens } \\
\text { Hvad }\end{array}$ & $\begin{array}{l}\text { Områdecentret } \mathrm{i} \text { form af terapeuterne og afdelingslederen skal lære } \\
\text { hvordan reduktion af kompleksitet på ydelsesområdet kan ske gennem } \\
\text { konstruktion af differentieringsprogrammer. Differentieringsprogram- } \\
\text { mernes strukturelle funktion er at kunne afslutte ældre fra f.eks. } \\
\text { tidskrævende hjemmetræning, så de kan overgå til ressource besparende } \\
\text { holdtræning. Et andet forhold, som skal læres, er ny konditionering } \\
\text { for uddifferentiering af dele af ydelsesområdet til andre systemer, } \\
\text { f.eks. vedligeholdelsestræning til plejehjemspersonale. Områdecentrets } \\
\text { terapeuter skal ligeledes konstruere et undervisnings og uddannelses- } \\
\text { forløb for personalet på plejehjemmet, således at de fagligt er i stand } \\
\text { til at varetage funktionen vedligeholdelsestræning af de ældre på } \\
\text { plejehjemmet. }\end{array}$ \\
\hline $\begin{array}{l}\text { Læringens } \\
\text { Hvem }\end{array}$ & $\begin{array}{l}\text { De lærende i denne sammenhæng er Områdecentret, plejehjemmet, og } \\
\text { en række ansatte på begge afdelinger (alle ansatte på Områdecentret, } \\
\text { og lederen på plejehjemmet samt det plejepersonale, som skal varetage } \\
\text { den uddifferentierede funktion vedligeholdelsestrcening). }\end{array}$ \\
\hline $\begin{array}{l}\text { Laringens } \\
\text { Hvornår }\end{array}$ & $\begin{array}{l}\text { For Områdecentrets vedkommende foregår læringen løbende med, at } \\
\text { nye beslutninger angående arbejdsprioriteringer besluttes. For pleje- } \\
\text { hjemmet handler det om en potentiel fremtidig læring. Denne består for } \\
\text { det første i deltagelse i terapeuternes undervisning/uddannelse om hvor- } \\
\text { for og hvordan, vedligeholdelsestræning potentielt kan implementeres } \\
\text { og integreres i deres fremtidige arbejdspraksis med de ældre. For det } \\
\text { andet består den i, at de under supervision af terapeuterne, skal opnå } \\
\text { erfaring med anvendelsen af viden om vedligeholdelsestræning af de } \\
\text { ældre i deres daglige arbejdsrutiner, dvs. arbejdspraksis. }\end{array}$ \\
\hline $\begin{array}{l}\text { Laringens } \\
\text { Hvorfor }\end{array}$ & $\begin{array}{l}\text { For Områdecentret er funktionen af læringen strukturelle løsninger på } \\
\text { kompleksitetsproblemet relateret til ydelsesområdet. Centret skal blive } \\
\text { bedre til at afslutte ældre, dvs. ekskludere ældre, når den ældres behov } \\
\text { for træning vurderes at være opfyldt. Områdecentret oplever, at de } \\
\text { har problemer med at leve op til egne og omverdenens funktionelle } \\
\text { forventninger i forhold til inklusion af nye ældre med inklusionsbe- } \\
\text { hov. Områdecentrets ændringer af sin interne konditionering vedrører } \\
\text { ligeledes forsøg på at indrette sine ydelser efter den enkelte ældres } \\
\text { individuelle behov (klientcentreret tilgang). }\end{array}$ \\
\hline $\begin{array}{l}\text { Læringens } \\
\text { Hvordan }\end{array}$ & $\begin{array}{l}\text { For Områdecentrets terapeuter forventes det, at de lærer i takt med, at } \\
\text { beslutningerne tages. For aktivitetsmedarbejderne forventes det, at de } \\
\text { lærer gennem instruktion og vejledning af terapeuterne, når de assisterer } \\
\text { som hjælper i træningssituationer af de ældre. Plejepersonalet forventes } \\
\text { at lære dels gennem terapeuternes undervisning, dels efterfølgende via } \\
\text { terapeuternes supervision og vejledning i det daglige arbejde/pasning } \\
\text { af de ældre. }\end{array}$ \\
\hline Funktion & $\begin{array}{l}\text { Funktionen af Områdecentrets differentiering af ydelsesområdet (de } \\
\text { ældre) er muliggørelse af plads i systemet med henblik på at kunne } \\
\text { tilbyde centrets ydelser til nye ældre. En yderligere funktion er at det } \\
\text { skal muliggøre fordeling af de ældre på de ydelsesaktiviteter, som passer } \\
\text { til deres behov, dvs. mere differentieret ydelseshåndtering. }\end{array}$ \\
\hline
\end{tabular}




\section{Analyse}

\begin{tabular}{|l|l|}
\hline Ydelse & $\begin{array}{l}\text { Med henblik på styrkelse af ydelsesområdet beslutter Områdecentret på } \\
\text { baggrund af selviagttagelse at ændre sin interne konditionering, således } \\
\text { at der skabes plads til nye ældre med inklusionsbehov. Områdecentret } \\
\text { forsøger ligeledes at skærpe iagttagelsen af den enkelte ældres indi- } \\
\text { viduelle behov (klientcentrering), således at Områdecentrets ydelser i } \\
\text { højere grad bliver indrettet efter at servicere den enkelte ældres behov. }\end{array}$ \\
\hline
\end{tabular}

Som det er fremgået i analysen, kan Områdecentret iagttages som differentieret i to forskellige subsystemer. Et subsystem bestående af terapeuter, hvis funktion er træning af og hjælpemidler til de ældre, og et subsystem af aktivitetsmedarbejdere, hvis funktion er initiering og varetagelse af forskellige former for sociale og håndarbejdsmæssig aktiviteter. Analysen har koncentreret sig om at analysere subsystemet af terapeuter. Lederen giver udtryk for at alle tre funktioner (træning, hjælpemidler og aktiviteter) og begge subsystemer vægtes ligeligt. Analysen viser imidlertid på et overordnet plan, at organisationsudviklingskonceptet VBL har resulteret $i$ en styrkelse og opprioritering af centrets træningsfunktion og ydelser relateret hertil, dvs. den viden, funktion og de ydelser terapeuterne står for. Ud fra et didaktisk perspektiv handler læringens hvad for Områdecentret om reduktions af kompleksitet ved andringer af arbejdets organisering, og anvendelse af og formidling affaglig viden i relation til styrkelse af troningsfunktionen af og ydelsen til de celdre. Og i den forbindelse iagttages terapeuternes faglige viden som den, der på en forsvarlig måde kan reducere Områdecentrets kompleksitet, dvs. den viden der funktionelt kan anvendes til at løse Områdecentrets problemer. VBL har derfor overordnet betydet en øget efterspørgsel på terapeutfaglig viden, og på en række områder en øget autonomi til terapeuterne.

For Områdecentrets vedkommende har organisationsudviklingsprojektet VBL betydet forandringer af forskellig karakter. I udgangspunktet har centret allerede før VBL arbejdet efter en del af de principper, visioner og ideer, som ligger i dette organisationsudviklingskoncept. Mange af ændringerne, og den læring som kan iagttages hos Områdecentret, kan derfor beskrives som videreførelser af en række initiativer, som allerede var i gang. Ligesom hos Park og natur er det særligt temaet om uddelegering af ledelse til selvledelse, som er i fokus på Områdecentret. Uddifferentieringen af ledelse er sket dels som fors $\emptyset \mathrm{g}$ på reduktion af lederens ledelseskompleksitet del ved at flere beslutninger bliver uddelegeret til terapeuterne og deres teams, dels som fors $\emptyset \mathrm{g}$ på opprioritering og effektivisering af funktionsudfoldelsen træningen af de ældre med medblik på styrkelse af ydelsesområde, dvs. at hjælpe de ældre med deres problemer. 
På et generelt plan oplever specielt terapeuterne og deres teams en udstrakt selvledelse i forhold til planlægning og prioriteringer af eget arbejde. I takt med uddifferentieringen af ledelse til selvledelse blev der besluttet en række konditionerende kriterier, som terapeuterne forventes at reflektere over i deres arbejdsprioriteringer. Dette gælder f.eks. i forhold til mængden af over/underarbejde. Aflysning af holdtræning skal undgås. Der er forventninger om, at de kun skal være på arbejde, hvis det kan begrundes med henvisning til funktionsudfoldelse og ydelsesområdet i form af træning af ældre, dvs. en generel effektivisering af terapeuternes arbejdsprioriteringer relateret til funktionsudfoldelse og ydelsesområdet. Den organisatoriske læring består i ændrede beslutningskriterier og konditioneringer for arbejdets organisering, således at systemets funktion og ydelse styrkes. En helt grundlæggende viden for denne læring har været med udgangspunkt i systemets funktion og terapeuternes faglige viden om og tilgang til ydelsesområdet. Ud fra en organisationsdidaktisk betragtning betyder dette, at eftersom terapeuternes viden iagttages som væsentlig for styrkelse af systemets funktion og ydelse, har deres tanker og ideer i samråd med afdelingslederens været udslagsgivende for læringens hvad, hvem, hvornår, hvorfor og hvordan. Terapeuternes øgede autonomi og deraf opprioriterede beslutningskompetence i forhold til de organisationsdidaktiske prioriteringer koblet med deres meget faglige og engagerede tilgang til ydelsesområdet, kan iagttages som væsentlig idet det har haft betydning på flere områder. Helt grundlæggende udlægger jeg det som en slags konsekvens af karakteren af og forandringer i Områdecentrets ydelsesområde, dvs. de ældre.

Det første jeg vil fremhæve er terapeuternes generelle problem med at tage beslutninger. Terapeuternes faglige tilgang til arbejdet og iagttagelse af ydelsesområdet - de ældre, betyder at de ser et kontinuerligt behov for deres assistance, dvs. ydelser i form af træning og genoptræning. Terapeuterne iagttager de ældre som mennesker med varierende problemer af fysisk, psykisk og social karakter, og for hvem det gælder, at der ikke er udsigt til bedring, dvs. mennesker som har et kontinuerligt og i visse tilfælde stigende behov for hjælp og assistance. For det andet er det sådan, at flere af de ældre har været i systemet i flere år, altså har modtaget træning, hvorfor terapeuterne har et relativt indgående kendskab til den enkelte ældre og vedkommendes situation. Et tredje forhold er, at nogle af de ældre protesterer, hvis de afsluttes, altså ekskluderes fra træning. Protesterne kan antage forskellige former som f.eks. at de begynder at græde, bliver vred og skælder ud, begynder at drikke, isolerer sig socialt osv. Terapeuterne giver derfor udtryk for, at det kan være hårdt at afslutte dem, fordi de rent følelsesmæssigt bliver berørt af det. Jeg udleder, at 


\section{Analyse}

summen af terapeuternes faglige tilgang og kendskabet til den enkelte ældre som mennesker med et kontinuerligt behov for træning, samt at de ældre på forskellige måder protesterer hvis de afsluttes, gør det meget svært for terapeuterne at tage en række afgørende beslutninger i forhold til ydelsesområdet. Konsekvensen har over tid været, at terapeuterne har taget flere ældre ind, men at de ikke i samme tempo afsluttet nogen. Terapeuterne, forstået som psykiske systemer med følelser, og Områdecentret som organisationssystem har med andre ord brug for systemets konditionering, dvs. generelle regler eller institutionelle kriterier de kan henvise til ved afslutning af ældre, ellers personligg $\phi$ res beslutningerne om afslutning, dvs. bliver til en beslutning den enkelte terapeut har taget. Netop denne personliggørelse når det gælder trcelse eller svare beslutninger har terapeuterne qua psykisk kompleksitet i form af følelser, svært ved at håndtere.

Områdecentrets organisatoriske læring på baggrund af VBL har været orienteret mod at løse arbejdsmæssige problemstillinger som f.eks. ovenstående, altså at gøre det muligt for systemet at tage beslutninger som reducerer systemet kompleksitet på ydelsesområdet. Områdecentrets fokusering på styrkelse af funktion og ydelsesområdet ud fra den terapeutfaglige tilgang har videre betydet, at andre medarbejdergrupper, som arbejder med de ældre, er blevet inddraget i træningen, dvs. fået en ekstra funktionstilskrivning. Internt på Områdecentret gælder dette nye funktionelle forventninger til aktivitetsmedarbejderne om at assistere terapeuterne i træningen af de ældre, når der er behov for det. Eksternt $i$ et andet subsystem i kommunen, gælder det i forhold til plejehjemspersonale, som forventes at integrere og varetage en træningsfunktion i refleksionen over dagligdags interventioner med de ældre på plejehjemmet. Plejehjemspersonalet skal med andre ord lære at iagttage de ældres dagligdagsaktiviteter som potentielle træningsmuligheder. Eftersom disse nye forventninger til aktivitetsmedarbejderne og plejehjemspersonalet er baseret på terapeutfaglig viden, har terapeuterne fået en central rolle i formuleringen af organisationsdidaktiske prioriteringer. Det er terapeuterne som i did udstrækning formulerer lærings hvad, hvem, hvornår, hvorfor og hvordan i forhold til de to andre medarbejdsgrupper. Områdecentrets og plejehjemmets iagttagelse og annerkendelse af terapeuternes viden som en, der kan bruges funktionelt til at løse problemer relateret til ydelsesområdet, har generelt haft to betydninger. For det første har terapeuterne fået mere autonomi. Dette skyldes at deres viden anses som værdifuld i relation til faglig forsvarlig reduktion af kompleksitet i forbindelse med beslutningstagen, og til generel styrkelse af funktionsudfoldelse og forbedring af ydelsesområdet.

For det andet at terapeuterne har fået en ny funktion som undervisere for 
de to andre medarbejdergrupper, der som en konsekvens heraf iagttages som elever. Jeg mener ikke, man kan betragte det forhold, at terapeuternes viden, og kompetencer får større udbredelse i de to subsystemer, som udtryk for udøvelse af magt, eller decideret indførelse af hierarki. Dette vidensforhold angående styrkelse af funktionsudfoldelse og forbedring af ydelsesområdet er for mig at se ikke udtryk for et nulsumsspil, i betydningen at nogen afgiver magt til andre, altså at f.eks. plejehjemspersonalet afgiver magt som tilfalder terapeuterne. Men udtryk for at systemerne kan styrke, og forbedre funktionsudfoldelsen og ydelsesområdet gennem anvendelse af en bestemt viden, dvs. noget begge systemer er interesseret i, og som i sidste ende gøres med henblik på styrkelse af systemernes ydelser til de ældre. Det kan nærmere betragtes som at systemerne forsøger at gøre noget godt, dvs. yde en form for hjælp til ydelsesområdet gennem anvendelsen af den terapeutfaglige viden. I denne bestræbelse får terapeuterne rollen som underviser i relation til andre medarbejdergrupper. Det kan dog ikke afvises, at netop opprioriteringen af terapeuternes viden som vigtig, og noget der skal udbredes ændrer på relationerne mellem medarbejdergrupperne, og som muligvis kan udvikle sig til at fungere som hierarkiske former, i betydningen at terapeuterne som undervisere af uddannelsesmæssige grunde kan blande sig i plejehjemspersonalets varetagelse af deres jobfunktion. Det samme gør sig gældende overfor aktivitetsmedarbejderne som terapeuterne derudover har fået muligheden for at trække på dem når der er behov for det. I den udlægning er terapeuternes beslutningskompetence udvidet, ikke kun i relation til planlægning og udførelse af eget arbejde, men tillige i forhold til to andre medarbejdergrupper, som de har fået beføjelser til at beslutte i relation til. Samtidigt har både plejehjemspersonalet og aktivitetsmedarbejderne qua at være en del af lærende systemer fået andre forventninger knyttet til deres arbejdsfunktion med træning, som giver dem andre job muligheder end de har haft før. 



\section{Konklusion}

Inden selve konklusionen vil jeg præsentere afhandlingens problemformulering, der består af tre spørgsmål, og som vil blive besvaret i den opstillede rækkefølge:

Hvordan begrebsliggфres organisatorisk laring i eksisterende teorier, og hvilke muligheder/problemer er der forbundet med det i forhold til at beskrive organisationers udfordringer som 'larende organisationer' $i$ et moderne samfund, og kan man på den baggrund (og med den moderne systemteori) udvikle en organisationsdidaktik, der kan anvendes til at forstå og analysere organisatorisk laering $i$ konkrete organisationsudviklingsprojekter?

1. Hvordan begrebsligg $\phi r$ eksisterende teorier om organisatorisk laering samfund og organisation og hvilke muligheder/problemer er der forbundet med det $i$ relation til organisatorisk laring?

2. Er det muligt på den baggrund med den moderne systemteori at udvikle en organisationsdidaktik, der kan anvendes til at forstå og analysere organisatorisk laring i konkrete organisationsudviklingsprojekter?

3. Hvordan kan man ud fra ovenstående organisationsdidaktik forstå organisatorisk laring $i$ et konkret organisationsudviklingsprojekt?

Det første spørgsmål er blevet besvaret gennem kapitlerne 3, 4 og 6: Hvordan begrebsligg $\phi r$ eksisterende teorier om organisatorisk laring samfund og organisation og hvilke muligheder/problemer er der forbundet med det $i$ relation til organisatorisk laring?

I kapitel 3, 4 og 6 begrunder jeg, med udgangspunkt i litteratur om organisationer, forskningsspørgsmålet om i hvilken udstrækning, teorier om organisatorisk læring har et begreb om samfundet. Dette forskningsspørgsmål forfølges i relation til tre teorier om organisatorisk læring: Argyris og Schöns teori om Organisational Learning, Peter M. Senges Den femte disciplin, og Etienne Wengers teori om Praksisfællesskaber. Her konkluderes det, at Argyris og Schön grundlæggende interesserer sig for interorganisatoriske forhold, og i den udstrækning omverdenen eller samfundet teoretisk kommer til syne i deres teori sker det ud fra en $\emptyset$ konomisk iagttagelse, som de ikke mener, 
har relevans for intraorganisatoriske forhold, og dermed fraskriver de sig i en eller anden udstrækninger refleksioner over samfundet som relevant for organisatorisk læring. Argyris og Schön beskriver organisatorisk læring som noget, der foregår i organisationer, og i en vis grad afviser sociologiske teorier og analyser, der i deres optik opererer med en udefra tilgang til organisationer. Senge har til forskel herfra begreber om organisationers omverden. Samfundet iagttages som udtryk for kontingent dynamisk kompleksitet, hvorfor det med hensyn til konsekvens kontrol og styring er uberegneligt. Senge argumenterer imidlertid for, at samfundet - gennem hans systemtænkning kan transformeres til variable, der kan kontrolleres og håndteres fra et organisatorisk perspektiv. Samfundet er med andre ord komplekst, men ikke mere komplekst end at det kan styres og kontrolleres af organisationer ved hjælp af hans egen systemtænkning. I relation til spørgsmålet om i hvilken udstrækning teorien om praksisfælleskaber rummer betragtninger over omverden/samfundet, så er det ikke et spørgsmål teorien interesserer sig for og forholder sig til. Teorien interesserer sig for praksisfælleskaber, og for at der findes forskellige praksisfælleskaber med hver deres erkendelsesinteresse, både internt i organisationer, og mellem praksisfællesskaber situeret i forskellige organisationer. Ud af dette være interesse forskelle og potentielle konflikter kan opstå. Luhmanns sociologiske systemteori har et væsentligt anderledes syn på samfundet, organisationer, læring og muligheder for styring og kontrol. For systemteorien er samfundet komplekst og kontingent, og genuint ustyrligt fra en hvilken som helst organisatorisk position. Forholdet mellem organisation og samfund beskrives gennem den grundlæggende system/omverden-difference og henviser til, at omverdenen altid er mere kompleks end systemet. Dette betyder, at et systems mulighed for reduktion af omverdenskompleksitet ligger i opbygning af egenkompleksitet (læring). Jo mere komplekst et system er, desto flere muligheder har det for at reagere på en passende måde i forhold til udfordringerne fra omverdenen. Dette laver dog ikke om på den grundlæggende definition af kompleksitetsforholdet mellem system og omverden, nemlig at omverdenen altid er mere kompleks end systemet. Tværtimod betyder kompleksitetstilvæksten i et system, som for dette system betyder mulighed for reduktion af systemets omverdens kompleksitet, samtidig en tilvækst $i$ kompleksitet $i$ andre systemers omverden. Luhmann beskriver organisationer som samfundets handlesystemer, og med den placering i og for samfundet bliver organisationerne helt naturligt adressat for samfundets nye og stadigt stigende, ukoordinerede og forskellige forventninger (asymmetriserede kommunikationer). Disse forventninger kan deles op $i$ to forskellige forventningstilskrivninger. På den ene side drejer det sig om 
de samfundsmæssige forventninger om en vis form for stabilitet, struktur og kontinuitet. På den anden side drejer det sig om forventninger om muliggørelse af samfundsmæssige ændringer og transformationer. I dette krydsfelt kan organisationers problem som sagt beskrives som et problem vedrørende iagttagelse, selektion, koordinering og beslutning. Organisationer skal være i stand til at iagttage kompleksiteten af samfundets forskellige forventninger og afgøre hvilke, der er relevante/ikke relevante for organisationen og ikke mindst hvordan. Samtidigt skal organisationer også motivere og specificere, hvad det betyder for individet f.eks. de ansatte eller de personer, organisationens ydelse retter sig mod.

Det andet spørgsmål i problemformuleringen besvares med kapitlerne 2, 4, 5, 7 og 8: Er det muligt på den baggrund med den moderne systemteori at udvikle en organisationsdidaktik, der kan anvendes til at forstå og analysere organisatorisk laring i konkrete organisationsudviklingsprojekter?

I denne afhandling iagttages undervisnings- og uddannelseskommunikation som kommunikation, der har intentioner om at uddanne og forandre personer og organisation(er). Afhandlingen tager udgangspunkt i en almen didaktik, og definerer organisationsdidaktik som teorier og refleksioner om undervisningens praksis nærmere betegnet læringens hvem, hvad, hvornår, hvorfor og hvordan. Organisationsdidaktikken rummer på den måde flere elementer end bare konkret kommunikation med intentioner om forandring af personer og organisationssystemer. Organisationsdidaktikken $\emptyset$ nsker at iagttage organisatorisk kommunikation, der kan betegnes som undervisningskommunikation, og at reflektere og analysere denne med udgangspunkt i læringens hvem, hvad, hvornår, hvorfor og hvordan. Ud fra en sociologisk refleksion iagttages organisationer som samfundets handlesystemer. De er situeret i en kompleks og kontingent omverden af andre systemer, som hver især har mere eller mindre præcise forventninger til det pågældende system, hvilket giver et problem vedrørende styring. Problemer med at styre kan altså direkte lokaliseres til et samfund, hvis form udstyrer dets systemer med et grundlæggende styringsproblem, nemlig at ingen kan styre samfundet som total system. Samfundets styring er henlagt til dets autopoietiske subsystemer, der ikke kan styre hinanden, men styrer sig selv ved hjælp af deres respektive binære mediekoder og programmer - videnskaben som funktionssystem kan ikke styre det politiske funktionssystem, uddannelsessystemet kan ikke styre $\emptyset$ konomien som funktionssystem osv. Det samme gælder organisationer. Organisationer er autopoietiske systemer der ikke kan styre andre systemer, men styrer sig selv gennem og ved beslutninger, medlemskab og beslutningsprogrammer. I relation til organisationssystemer betyder dette, at den 
samfundsmæssige kompleksitet og kontingens leder til et problem vedrørende iagttagelse. Organisatorisk læring som organisationsdidaktik er et svar på netop dette problem vedrørende selvstyring og iagttagelse. Organisatorisk læring har på baggrund af denne samfundsanalyse til formål - ikke at styre men at udstyre organisationer med mere komplekse evner til at lære eller former for læring. Gennem en organisation didaktisk optik, tænkes det, at organisationer kan lære at lære nye måder, hvorpå de kan iagttage sig selv og organisationens omverden, og kan lære at inkorporere og integrere disse nye iagttagelsesformer i organisationens iagttagelses- og beslutningsprogrammer (konditionering). Vel og mærke iagttagelsesformer som skal omsættes til beslutninger der efterfølgende leder til anderledes kommunikation/handlinger.

Den systemteoretiske tilgang til forholdet mellem organisation og samfund betyder, at man må betragte organisationer som systemer, der betjener sig af tre grundoperationer med henblik på at mestre kompleksitetsproblemet nemlig: funktion, ydelse og refleksion. Funktion er knyttet til system/ omverden-distinktionen og har med systemets iagttagelse af hele samfundssystemet at gøre. Ydelse har med systemets iagttagelse af eller forhold til andre systemer at gøre. Refleksion er knyttet til systemets selviagttagelse, dvs. refleksion vedrører systemets forhold til sig selv. Funktion og refleksion retter sig altså primært mod systemets - her det organisatoriske systems egen selvreference og selvkontrol, hvor ydelse retter sig mod iagttagelsen af omverdenen af $\varnothing$ vrige systemer - det være sig sociale eller psykiske systemer. Denne tredeling i funktion, ydelse og refleksion gælder alle systemtyper, og mere specifikt i relation til interorganisatoriske forhold, dvs. organisationer og deres subsystemer (afdelinger) så står en afdeling i en organisation i et forhold til hele organisationen (funktion), til andre afdelinger (ydelse) og til sig selv (refleksion).

Funktion og refleksion retter sig altså primært mod systemets - her det organisatoriske systems - egen selvreference og selvkontrol, hvor ydelse retter sig mod iagttagelsen af omverdenen af $\emptyset$ vrige systemer - det være sig sociale eller psykiske systemer. Organisatoriske refleksioner over funktion og ydelse kan tilsammen give retning til den pædagogiske didaktiks begreber om: Hvem der skal laere? Hvad der skal laeres? Hvornår der skal laeres? Hvorfor der skal laeres? og Hvordan der skal laeres?

Det tredje spørgsmål blev besvaret gennem kapitel 9. Hvordan kan man ud fra ovenstående organisationsdidaktik forstå organisatorisk laring $i$ et konkret organisationsudviklingsprojekt?

Det konkrete organisationsudviklingsprojekt - og således afhandlingens empiri - stammer fra en større dansk kommune, som arbejdede med 
værdibaseret ledelse. Udgangspunktet er således en organisationsdidaktisk iagttagelse og analyse af den organisatoriske kommunikation om værdibaseret ledelse i to afdelinger i denne kommune. Forholdet mellem værdier, organisatorisk kommunikation og læring blev behandlet særskilt og teoretisk i kapitel 8 som en optakt til den empiriske analyse. Konklusionen på denne teoretiske analyse var, at man kan antage, at kommunikation om værdier primært finder sted i form af et systems refleksion over, hvorvidt dét, systemet er sat i verden for at gøre - dets funktion - gøres godt nok. Kommunikationer om værdier aktualiserer på denne måde forskellens anden side, nemlig om funktionsopfyldelsen kunne gøres anderledes som regel i forståelsen bedre. Iagttagelsesformen kunne beskrives som en iagttagelse ud fra distinktionen tilstrakkeligt/utilstrakkeligt, eller godt nok/ikke godt nok. Det er den forandringskommunikation, der opstår på baggrund af systemernes arbejde med værdierne, som afhandlingen iagttager med organisationsdidaktikken.

I kapitel 10 analyserede jeg de to afdelinger i kommunen Park og natur og Områdecentret. Analysen tog udgangspunkt i deres arbejde med uddifferentiering af ledelse til selvledelse.

Hos Park og natur er der ikke sket de store forandringer i deres muligheder for selvledelse. Som system oplever det, at det er fremmedstyret i en sådan grad, at organisationsdidaktiske ideer om læringens hvad, hvem, hvornår, hvorfor, og hvordan forbliver idealer uden praktisk mulighed for at blive realiseret. Systemet oplever, at det bliver styret af det politiske systems beslutning om brugen af og landskabsarkitekternes anvendelse af BUM-modellen. Denne detailstyring af arbejdet betyder ud fra en organisationsdidaktisk tilgang, at gartnerfagligheden samt ideer og intentioner om andre mulige måder at konditionere systemet på begrænses. Systemet får derfor helt grundlæggende problemer med at lære, dvs. forandre dets egne forventningsstrukturer i betydningen egenkonditionering. Medarbejdernes oplevelse er derfor, at de ikke kan forbedre deres funktion og ydelse, og systemet fremstår derfor som et 'frustreret' system. Park og natur oplever sig som et element eller system i et hierarkisk system, der bestemmer over og dikterer, hvad der skal laves, hvornår det skal laves, hvor meget det må koste, hvor meget tid der er afsat til de forskellige opgaver osv. Ud fra en systemteoretisk og organisationsdidaktisk betragtning er de omverdensvilkår, et system befinder sig i, af afgørende betydning for systemets muligheder for at anvende organisationsdidaktiske refleksioner til forandring af sig selv.

Ud fra en organisationsdidaktisk tilgang har læringens hvad samt forandringer på Områdecentret i væsentlig grad været rettet mod funktionen af og ydelser relateret til centrets ergo- og fysioterapeuter, herunder deres 
selvledelse. Læringens hvad kan inddeles i fire temaer: 1) reduktion af ledelseskompleksitet og uddelegering af ledelse til terapeuterne, 2) reduktion af kompleksitet på ydelsesområdet, 3) styrkelse af centrets træningsfunktion og ydelser, samt 4) udbredelse af terapeuternes faglige viden til andre personalegrupper.

Reduktionen af ledelseskompleksitet er sket ved, at en række beslutninger, som før var ledelsesbeslutninger, er lagt ud til terapeuterne og deres teams, f.eks. fleksibel arbejdstidsplanlægning. Læringens hvad har været konstruktion af nye beslutningskriterier til konditionering af terapeuternes selvledelse. Som en konsekvens af dette, har terapeuterne fået mere autonomi i forhold til beslutninger relateret til egen funktionsudfoldelse og ydelse. Terapeuternes tilgang til arbejdets funktionelle og ydelsesmæssige betydning sker ud fra terapeutfaglige og omsorgsmæssige kriterier, hvilket gennem tiden har givet dem et generelt problem med at tage ekskluderende beslutninger. Konsekvensen har været, at de ældre ikke er blevet afsluttet i samme tempo, som nye skulle inkluderes, hvorfor systemet har fået for meget kompleksitet på ydelsessiden. Terapeuterne, som også repræsenterer psykiske systemer med følelser, og Områdecentret som socialt system har derfor brug for nye og systemkonditionerede beslutningskriterier til afslutning af ældre, ellers forbliver beslutninger om eksklusion individualiserede, terapeutafhængige og personliggjorte. En anden strategi for kompleksitetsreduktion af ydelsesområdet er inddragelse og uddifferentiering af træningsfunktionen og ydelsen til to andre personalegrupper. Aktivitetsmedarbejderne på Områdecentret forventes fremover at assistere terapeuterne i pressede situationer, og plejehjemspersonalet tilskrives en træningsfunktion i relation til deres daglige arbejde med de ældre på plejehjemmet. Styrkelsen af centrets træningsfunktion og ydelser skal således ske gennem inddragelse og uddifferentiering af træningsfunktionen og ydelsen til to de to andre personalegrupper, og dette kan ses som en konsekvens af den uddifferentierede ledelse til terapeuterne. Uddifferentieringen af flekstidsbestemmelser til terapeuterne har desuden betydet, at de kan varetage nye opgaver udenfor normal arbejdstid. Den nye konditionering af terapeuternes arbejdsbegrundelser, hvor de kun forventes at være på arbejde, hvis det kan begrundes med henvisning til deres træningsfunktion og ydelser, har ligeledes betydet en effektivisering af deres arbejdstid. Som det er fremgået har Områdecentret brugt VBL til at forbedre dets funktion og ydelser, og denne organisatoriske læring er grundlæggende muliggjort qua systemets muligheder og begrænsninger for autonomi. Systemautonomien har betydet, at systemet har kunnet anvende egne refleksioner til forandring af sig selv. Denne form for forandringskommunikation betegner jeg systemteorietisk som 
undervisnings- og uddannelseskommunikation idet det er kommunikation, som aktualiseres med henblik på at forandre personer og systemer, hvorfor det kan betegnes organisatorisk uddannelse med det formål at producere læring.

Den viden og de kompetencer, som terapeuterne repræsenterer, iagttages af systemet som et afsæt for forbedring af centrets funktion og ydelser. Terapeuterne får dermed en undervisende funktion overfor de to andre medarbejdergrupper, der iagttages som elever, der skal lære at anvende terapeutfaglig viden i relation til deres nye træningsfunktioner. Organisatorisk læring, uddannelses- og undervisningskommunikation samt didaktiske refleksioner og prioriteringer vedrører dermed hele Områdecentret og en medarbejdergruppe på et plejehjem. Selvom terapeuternes viden og kompetencer iagttages som vigtige og som løftestang i forhold til styrkelse af begge systemers funktion og ydelser, og selvom de således har en central funktion set ud fra en organisationsdidaktisk iagttagelse, betyder det ikke, at andres viden og kompetencer ikke anses som vigtige. Således har både plejehjemspersonalet og aktivitetsmedarbejderne, qua det, at de indgår i lærende systemer, fået andre forventninger knyttet til deres arbejdsfunktion i form af træning, hvilket har givet dem andre læringsmuligheder, end de har haft før (nye udfordringer).

Som beskrevet flere steder i afhandlingen, er der lagt op til en komparativ analyse, og det er her jeg vil lave sammenligningen mellem de to subsystemer, herunder hvilke muligheder og begrænsninger der kan iagttages i forhold til organisationsudviklingsprojektet VBL ud fra en organisationsdidaktisk betragtning.

En første opsummerende sammenligning mellem de to systemer er, at de begge $\emptyset$ nsker at være lærende systemer. Læringsindholdet og -målet hos begge systemer handler om deres egne iagttagelser af muligheder og begrænsninger for at styrke deres funktion og ydelser. Begge systemer bruger her refleksion til iagttagelse af sig selv, og fors $\varnothing$ ger at forholde sig til sin egen selvregulering i relation til andre systemer i omverdenen. Det interessante er imidlertid, at mulighederne og begrænsningerne relateret til systemernes egen indflydelse på funktion og ydelse er meget forskellig. Park og natur oplever, at være fremmedstyret og dermed begrænset $\mathrm{i}$ dets egen autonomi $\mathrm{i}$ forhold til at beslutte at handle anderledes, dvs. lære. Områdecentret som system har udstrakt autonomi, og det kan derfor anvende egne refleksioner over sig selv til at formulere og igangsætte forandringer. Forandringerne kan iagttages og beskrives som organisationsdidaktiske, dvs. som refleksioner, der vedrører hvad der skal laeres? hvem der skal laere? hvornår der skal laeres? hvorfor der skal laeres? og hvordan der skal laeres? Afhandlingens organisationsdidaktiske analyse viser således, at organisationssystemers læring er både afhængig af 


\section{Konklusion}

deres omverden (og relationer hertil) $o g$ af systemets autonomi. Jo mere autonomi systemet har, jo større muligheder har det for at realisere den læring, og den måde at lære på, som systemet selv ønsker i forhold til at være noget for omverdenen! Samlet set viser det, at læringens form og mulighed udfolder sig i refleksionen over ikke blot systemet selv eller omverdenen, men over system/omverden-differencen. 


\section{English Summary - Abstract}

This Ph.D. thesis is about and inscribes it self in the field of organizational learning. There has for many years been a lot of research within the field of organizational learning. Most people are familiar with the concept of organizational learning or the learning organization. The whole basic premise of talking about organizational learning is that organizations learn! But how does an organization learn, and how does it learn to learn? Or in other words, how does an organization teach itself to learn? This pedagogical issue cannot only be answered with a concept of learning. It includes reflections on the relationship between teaching and learning. With this issues or problem, one might prefer to talk about the educational organization! Or the teaching organization! It is this pedagogical "something", this thesis is interested in and want to develop knowledge about. This dissertation is more precisely about developing an idea about organizational didactics.

The aim of the thesis is on the basis of theoretical and empirical analyzes to discuss, develop and present a sociological and pedagogical perspective on organizational learning. The dissertation's intention can be described as to develop a sociologically inspired perspective on organizational didactics. Fundamental questions for the sociology of knowledge are on the one hand how thinking, ideas and beliefs are always influenced by the society in which they are formed, and on the other hand, what role knowledge plays in society and organizational functioning and development.

The dissertation is based on tree questions (Chapter 1).

How is organizational learning conceptualized in existing theories, and what possibilities and limitations is associated with these conceptualizations in relation to describe the challenges 'learning organizations' are faced with within a modern society, and is it possible on this basis (and with the modern systems theory) possible to develop an organizational didactic, which can be used to understand and analyze organizational learning in specific organizational projects? 
1. How does existing theories about organizational learning conceptualize society and organization and what possibilities and limitations are associated with these conceptualizations in relation to organizational learning?

2. Is it possible on the basis of the modern system theory to develop an organizational didactic that can be used to understand and analyze organizational learning in specific organizational projects?

3. In what way is this organizational didactic meaningful in regard to understand and analyze organizational learning within a specific organizational project?

In chapter 2 didactics is presented and reflected into organizational theory about organizational learning. In chapter 3 the dissertation discusses theories of organizational learning and shows that they don't have an anvanced elaborated idea about the modern society they are situated in. The modern sociological theory on social systems developed by Niklas Luhmann is used to describe the modern society, and to argue for an understanding about organizations as operating through the observation of function, performance and reflection (Chapter 4). In chapter 5 different theories about organizational learning as communication are discussed, and this discussion serves as an argument for choosing Niklas Luhmannś theory about social systems. The insight from previous chapters, combined with theory about didactics, and of organizations as differentiated social systems made up of communication, leads to an understanding of organizational learning that can be analysed with a didactical theory combined with the organizations understanding of its function and performance (Chapter 2, 5 and 6). In chapter 6 the theory of Niklas Luhmannś social systems is unfolded in order to comprehend how it can be used to understand organizational learning in a different way than existing theories. In chapter 7 a discussion of values, organization and society is carried out as a preparation of the empirical case which is a large municipally in Denmark going through a value-based management project. The discussion on values serves the purpose to identify what can be expected from a theoretical perspective, when organizations are expected to learn from a value-based management project. The theoretical conclusion is that it is an empirical question which is related to the form of communication produced within the subsystems of the organization. In chapter 9 the empirical case and the analytical model are presented. The analysis of the dissertation focuses on two different departments within the municipally (Chapter 9). 
One of the conclusions is that theories on organizational learning have different ideas, but generally suffer from a lack of a concept of the modern society, and that Niklas Luhmannś grand theory gives concepts not only to an understanding about modern society, but also about organizations and how they orient themselves in modern society. The conclusion is that through the concepts of function, performance and reflection, organizations learn, and that organizational didactics is related to these concepts.

Another conclusion is that seen from a sociological and systems theoretical perspective organizations are perceived as action systems of modern society. They are situated in a complex and contingent world of other systems, each with more or less accurate expectations of the system, resulting in a problem of management. Problems in managing society can be addressed to and thus explained by a society which in its shape equips systems with a common basic management problem: a problem of observation. Organizational learning as a didactic organization is a response to this particular problem concerning the management and observation of society. Therefore on the basis of this social analysis organizational learning has the function of - not to manage - but to equip organizations with more complex abilities to learn, and to initate different complex forms of learning. Through an organizational teaching perspective, it is assumed that organizations can learn to learn new ways of observing themselves and their surroundings, and can learn to incorporate and integrate these new observations in their own observation and decision programs (conditioning).

Finally a conclusion - based on the empirical analysis and comparison between the two departments or subsystems in the municipally - is that both deparments want to be learning systems. The content and objective of learning is in each system concerned with observations of their own opportunities and the constraints related to the enhancement of their function and performance. Both systems use this reflection to observe and regulate its own decisions. What is interesting is that the possibilities and limitations related to the systems own influence on the function and performance are very different. The one subsystem experiences them selves as foreign-controlled and thus limited in their autonomy act differently and based on their own decisions - that is to learn. The other subsystem has substantial autonomy and can therefore use its own reflections upon itself to formulate and initiate change. These changes can be observed and described as organizational didactics as reflections concerning: What should be learned? Who should learn? Where and when to learn? Why to learn? And finally: How to learn? The organizational didactical analysis of the dissertation shows that organizational learning systems are 
both dependent on their environment (and the relationship to it) and the autonomy of the system itself. The more autonomy a system has, the more opportunities it has to realize processes of learning and the way it wants to learn in relationship to be something to the world! Overall, it shows that the form of learning and opportunities for learning are unfolded in the reflection over not only the system itself or the outside world but over the system / environment difference.

This contribution of the dissertation to the field of organizational learning is that it offers a different perspective on organizational learning; a perspective which emphasizes the pedagogical dimension of organizational learning namely the didactical dimensions. It also shows that organizational learning only makes sense and is possible when systems have the autonomy to identify what they want to learn and have the autonomy to act on behalf of them selves. 


\section{Litteraturliste}

Alrø, Helle \& Marianne Kristiansen (1992): Kan du se hvad jeg sagde? - mennesker ansigt til ansigt. Holistic.

Andersen, Torben, Inger Jensen \& Arne Prahl (red.) (2000): Kompetence - $i$ et organisatorisk perspektiv. Roskilde Universitetsforlag, Frederiksberg.

Andersen, Heine (2005): Funktionalisme og neofunktionalisme. I Heine Andersen og Lars Bo Kaspersen (red.): Klassisk og moderne samfundsteori, Hans Reitzels Forlag, København K. s. 240-272.

Andersen, Niels Åkerstrøm (1999): Diskursive analysestrategier Foucault, Koselleck, Laclau, Luhmann, Nyt fra Samfundsvidenskaberne, København N.

Andersen, Niels Åkerstrøm (2001): Beslutningens ubesluttelighed. MPP Working Paper No. 3, Department of Management, Politics and Philosophy, Kbh. http://www.cbs.dk/departments/mpp

Andersen, Niels Åkerstrøm \& Asmund Born (2001): Karlighed og omstilling - italesattelsen af den offentligt ansatte. Nyt fra Samfundsvidenskaberne, Frederiksberg.

Andersen, Niels Åkerstrøm (2002): Medarbejderens padagogisering, MPP Working Paper, No. 20. 30 sider.

Andersen, Niels Åkerstrøm (2003): The undecidability of decision, pp. 235258 in Autopoietic organization theory - Drawing on Niklas Luhmannś Social Systems Perspective. Edited by Tore Bakken and Tor Hernes, Abstrakt forlag, Oslo.

Andersen, Niels Åkerstrøm (2003): Polyphonic organisations, pp. 151-182 in Autopoietic organization theory - Drawing on Niklas Luhmannś Social Systems Perspective, Edited by Tore Bakken and Tor Hernes, Abstrakt forlag, Oslo.

Antonsen, Marianne \& Jørgensen, Torben Beck (red.) (2000): Forandringer i teori og praksis - skiftende billeder fra den offentlige sektor, Juristog Økonomforbundets Forlag, København.

Archibugi, Daniele \& Bengt-Åke Lundvall (red.) (2001): The Globalizing Learning Economy. Oxford University Press, Oxford. 
Argyris, Chris (1990a): Overcoming Organizational Defenses: Facilitating Organizational Learning - Facilitating Organizational learning, Allyn \& Bacon.

Argyris, Chris (1990b): Bryt forsvarsrutinene - Hvordan lette organisasjonslcering, Oversat af Kevin M. J. Quirk, Universitetsforlaget/Prentice Hall International, Oslo.

Argyris, Chris (1997): Initiating change that perseveres, American Behavioral Scientist, January 01.

Argyris, Chris \& Schön, Donald A. (1978): Organizational Learning - A theory of action perspective, Addison-Wesley Publishing Company, Inc.

Argyris, Chris \& Schön, Donald A. (1996): Organizational Learning II Theory, Method, and Practice, Addison-Wesley Publishing Company, Inc.

Armstrong, Michael (2006): A Handbook of Human Resource Management Practice (10th ed.). London: Kogan Page.

Baecker, Dirk (1994): Sociale Hilfe als Funktionssystem der gesellschaft. Zeitschrift für Soziologie 23:93-110.

Baecker, Dirk (2003): Organisation som begreb: Niklas Luhmann om beslutningens graenser. I Holger Højlund \& Morten Knudsen (red.): Organiseret kommunikation - systemteoretiske analyser. Samfundslitteratur, Frederiksberg C.

Bakken, Tore (2000): System og iakttagelse - Teorien om autopoietiske systemer og dens implikationer for moral og etikk, Avhandling for dr. polit.-graden, Unipub forlag, Oslo.

Baraldi, C., Giancarlo, C., Esposito, E. (1999): GLU - Glossar zu Niklas Luhmanns Theorie sozialer Systeme, 3. Aufl. - Frankfurt am Main, Suhrkamp. Bateson, Gregory (1984): Ånd og Natur - En Nødvendig enhed. Rosinante Forlag, København.

Beck, Ulrich (1994): The reinvention of politics - Towards a Theory of Reflexive Modernization. In Ulrich Beck, Anthony Giddens \& Scott Lash: Reflexive Modernization: Politics, Traditions and Aestetics in the Modern Social order. Stanford University Press, California.

Beck, Ulrich (1997): The Reinvention of Politics: Rethinking Modernity in the Global Social Order. Polity Press.

Berger, Peter L. \& Luckmann, Thomas (1999): Den samfundsskabte virkelighed - En videnssociologisk afhandling, Lindhardt og Ringhof.

Berniker, E. (1987): Understanding Technical Systems. Paper presented at Symposium on Management Training Programs: Implications of New technologies, Geneva, Switzerland, November. 
Bisgaard, Niels Jørgen (red.) (1998): Padagogiske Teorier. Billes $\emptyset$ \& Baltzer.

Borch, Christian (2000): Former der kommer i form - om Luhmann og Spencer-Brown. I Distinktionen - tidsskrift for samfundsteori, temanummer om Niklas Luhmanns samfundsteori, c/o Institut for Statskundskab, Aarhus Universitet, Århus C.

Borch, Christian (2009): Niklas Luhmann - En verden af systemer, i Mogens Hansen (red.): '50 Samfundstænkere', Gyldendalske Boghandel Nyt Nordisk Forlag A/S, København.

Borch, Christian (2011): Niklas Luhmann. Routledge Taylor \& Francis Group, London and New York.

Bordum, Anders (2003): Institutionel Ledelse og Det Etiske Regnskab, i Jacob Dahl Rendtorff (red.): Værdier, etik og socialt ansvar i virksomheder: brudflader og konvergens. Roskilde, s. 122-127 (Skriftserie; 2003-4).

Bordum, Anders (2009): Jürgen Habermas og Pierre Bourdieu: Etik eller magt som forståelsesramme for kommunikation? I Jørn Helder, Torbjörn Bredenlöw og Jens Lautrup Nørgaard (red.): Kommunikation - en grundbog, Hans Reitzels Forlag, s. 215-238.

Bordum, Anders (2010): Vardibaseret Ledelse: Når vardier forankrer og forandrer strategier, i Thomson HR, Vol. 1, Nr. 1, 2010, s. 12-17

Borum, Finn (1995): Strategier for organisationsandringer, Handelshøjskolens Forlag.

Bramming, Pia (2001): Kompetence-i-praksis, Samfundslitteratur, Ph.d.serie 8 .

Bredsdorff, Nils (2002): Diskurs og konstruktion - En samfundsvidenskabelig kritik af diskursanalyser og socialkonstruktivismer. Forlaget Sociologi, Frederiksberg C.

Brown, George Spencer (1969): Laws of Form, George Allen and Unwin LTD, London.

Cangelosi, V. \& W. R. Dill (1995): Organizational Learning. Observations toward a theory. In Administrative Science Quarterly, 10 (2): s. 175-203.

Chaize, J. (1994): D $\phi r e n$ til forandring åbnes indefra, Danfoss og Ankerhus. Christensen, Allan (red.) (1997): Den laerende organisations begreber og praksis. Aalborg Universitetsforlag, Aalborg.

Christensen, Allan (red.) (2000): Det laerende perspektiv. Aalborg Universitetsforlag, Aalborg.

Cohen, Michael D. \& Lee Sproull (1996): Organizational learning. Sage Publications. 


\section{Litteraturliste}

Collins, Randall (1994): Four Sociological Traditions. Oxford University Press, Oxford.

Collins, Randall (2000): Max Weber - personen og forfatterskabet. Hans Reitzels Forlag.

Cour, Anders la (2002): Frivillighedens pris, Ph.d. afhandling Sociologisk Institut, Københavns Universitet.

Cour, Anders la (2005): Er de frivillige organisationers teknologiunderskud et problem? I DANSK SOCIOLOGI, Nr. 2/16. årg.

Dahl, Poul Nørgaard, Kenneth Mølbjerg Jørgensen, Erik Laursen, Jørgen Gulddahl Rasmussen og Palle Rasmussen (2002): Perspektiver på organisatorisk laering, Institut for Uddannelse, Læring og Filosofi, Aalborg Universitet.

Dahl, Poul Nørgaard; Jørgensen, Kenneth Mølbjerg; Laursen, Erik; Rasmussen, Jørgen Gulddahl; Rasmussen, Palle. (2005): Organisatorisk lacring: resultater fra forskningen i Center for Organisatorisk Laering. Aalborg Universitetsforlag, Aalborg.

Dahler-Larsen, Peter (2009): Den Rituelle Refleksion - om evaluering $i$ organisationer. Syddansk Universitetsforlag, Odense.

Dale, Erling Lars (1999): Padagogik og professionalitet. Forlaget Klim.

Dixon, Nancy (1999): Learning Across Organizational Boundaries: a case Study of canadian Museums. In Mark Easterby-Smith, John Burgoyne and Luis Araujo (red.): Organizational Learning and the Learning Organization - Developments in theory and practice. SAGE Publications Inc., London.

Duncen, R. B. \& Weiss, A. (1979): Organizational Learning: Implications for Organizational Design. In B. M. Staw (Red.): Research in Organizational Behavior (Vol. 1, pp. 75-123), Greenwich, CT: JAI Press.

Easterby-Smith, M. \& Araujo, L. (1999): Organizational learning: current debates and opportunities. In Mark Easterby-Smith, John Burgoyne and Luis Araujo (Red.): Organizational Learning and the Learning Organization: Developments in Theory and Practice. Sage, London, pp. 1-21. Easterby-Smith, Mark \& Marjorie A. Lyles (2005): Introduction: Watershed of Organizational Learning and Knowledge Management. In Mark Easterby-Smith and Marjorie A. Lyles (red.): Handbook of Organizational Learning and Knowledge Management. Blackwell Publishing Ltd.

Eide, Hilde \& Tom Eide (2007): Kommunikasjon i relasjoner - Samhandling, konfliktlфsning og etikk. Gyldendal akademisk. 
Elkjær, Bente \& Lysgaard A.G. (1998): Med lareprocessens blik-en undersøgelse af konsulentprojekter $i$ mindre virksomheder. Samfundslitteratur, Frederiksberg.

Elklær, Bente (1999a): Det er laenge siden, at nogen har talt om den laerende organisation. www.nyt-om-arbejdsliv.dk/artikel.asp?itemID=27. Oprindeligt fra: 'Tidsskrift for Arbejdsliv', nr. 4. s. 85-101.

Elkjær, Bente (1999b): In search of a Social Learning Theory, in Organizational Learning and the Learning Organization - Development in theory and practice. In Mark Easterby-Smith, John Burgoyne and Luis Araujo (red.): Organizational Learning and the Learning Organization - Developments in thepry and practice, SAGE Publications Inc., London.

Elkjær, Bente (2005a): Når laring går på arbejde - et pragmatisk blik på laering $i$ arbejdslivet, Forlaget Samfundslitteratur, Frederiksberg C.

Elkjær, Bente (2005b): Social Learning Theory: Learning as Participation in Social Processes. In Mark Easterby-Smith and Marjorie A. Lyles (red.): Handbook of Organizational Learning and Knowledge Management. Blackwell Publishing Ltd.

Elting, Mette (2009): Forandring og ledelsestankning - fra klassisk forandringsteori til teori U. I Mette Elting \& Sverri Hammer (red.): Ledelse og organisation - Forandringer og udfordringer. Samfundslitteratur.

Enderud, Harald (2003): Beslutninger i organisationer $-i$ adfcerdsteoretisk perspektiv, Samfundslitteratur.

Eriksen, Erik Oddvar \& Jarle Weigård (2003): Kommunikativt demokrati - Jürgen Habermas' teori om politik og samfund, Hans Reitzels Forlag, København K.

Easterby-Smith, Mark, John Burgoyne \& Luis Araujo (red.) (1999): Organizational Learning and the Learning Organization - Developments in thepry and practice. SAGE Publications Inc., London.

Easterby-Smith, Mark \& Marjorie A. Lyles (red.) (2005): Handbook of Organizational Learning and Knowledge Management. Blackwell Publishing Ltd.

Easterby-Smith, Mark \& Marjorie A. Lyles (2005): Introduction: Watersheds of Organizational Learning and Knowledge Management. In Mark Easterby-Smith \& Marjorie A. Lyles (red.): Handbook of Organizational Learning and Knowledge Management. Blackwell Publishing Ltd.

Finansministeriet (1983): Redegørelse til folketinget om regeringens program for modernisering af den offentlige sektor.

Finansministeriet (2002): Velfard og valgfrihed - et reformprogram. København. 


\section{Litteraturliste}

Finansministeriet (2003): En mere borgernar service. København.

Fiol, C. M. \& M. A. Lyles (1985): Organizational learning. In Academy of Management Review, 10 (4): s. 803-813.

Fisher, Colin M. \& Alan Lovell (2003): Business Ethics and Values: Individual, Corporate and International Perspectives. Pearson Education Limited, England, Essex.

Fiske, John (1993): Introduction to communication studies, Routledge, London and New York.

Floris, Toini S. \& Charlotte Bidsted (1996): Brugerbestyrelser på tvars - erfaringer fra kommuner og amter. AKF - Amternes og Kommunernes Forskningsinstitut, AKF Forlaget.

Foucault, Michel (1998): The Will to Knowledge - The History of Sexuality. Penguin Books.

Foucault, Michel (2001): Talens forfatning. In: Talens forfatning: Nietzsche - genealogien, historien. Hans Reitzels Forlag, København.

Foucault, Michel (2002): Overvågning og straf: Fangslets fødsel. Det lille Forlag, Frederiksberg.

Foerster, Heinz von \& Bernhard Pörksen (2003): Sandhed - opfundet af en løgner - samtaler for skeptikere, Billes $\varnothing$ \& Baltzer.

Gadamer, Hans-Georg (2004): Sandhed og metode - Grundtrak til en filosofisk hermeneutik, Gyldendals Bogklubber.

Geist, Uve (1996): Etik og kommunikation, i MedieKultur, Nr. 24, s. 43-60.

Gherardi, S. \& Nicolini, D. (2001): 'The Sociological Foundations of Organizational Learning, in M. Dierkes \& A. B. Antal \& J. Child \& I. Nonaka (red.): Handbook of organizational Learning and Knowledge, pp. 35-60. Oxford, Oxford University Press.

Giddens, Anthony (1995): Sociologi - En kort men kritisk introduktion, Hans Reitzels Forlag, København.

Giddens, Anthony (1996): Modernitetens konsekvenser. Hans Reitzels Forlag, København.

Giddens, Anthony (1997): Modernitet og selvidentitet - Selvet og samfundet under sen-moderniteten. Hans Reitzels Forlag, København.

Gilje, Nils og Harald Grimen (2002): Samfundsvidenskabernes forudsatninger - Indføring $i$ samfundsvidenskabernes videnskabsfilosofi. Hans Reitzels Forlag, København K.

Goodman, Paul S. \& Lee S. Sproull (red.) (1990): Technology and Organizations. Jossey-Bass Publishers, San Francisco.

Goffman, Erving (1992): Vore rollespil i hverdagen, Hans Reitzels Forlag. 
Guneriussen, Willy (1996): Emile Durkheim. I Heine Andersen \& Lars Bo Kaspersen (red.): Klassisk og moderne samfundsteori. Hans Reitzels Forlag, København K.

Habermas, Jürgen (1989): Hvad er universalpragmatik? I Mogens Pahuus (red.): Mennesket og dets udtryksformer - Fra bevids- thedsparadigme til kommunikationsparadigme - en antologi, Philosophia.

Habermas, Jürgen (1996): Teorien om den kommunikative handlen. Aalborg Universitetsforlag, Institut for pædagogik og uddannelsesforskning, Danmarks Lærerhøjskole.

Hagen, Roar (1997): Vitenskapssystemets refleksjon - fra identitet til differens, IN Sosiologisk tidsskrift - Journal of Sociology, Årg. 5, nr.1, Scandinavian University Press.

Hagen, Roar (1999): Rasjonell solidaritet. Avhandling for dr. philos. -graden, Det Blå Bibliotek, Universitetsforlaget, Oslo.

Hagen, Roar (2006): Nyliberalismen og samfunnsvitenskapene, Universitetsforlaget, Oslo.

Hansen, Bjarne Gorm \& Annalisa Tams (red.) (2006): Almen didaktik Relationer mellem undervisning og laring, Billesø \& Baltzer, Værløse.

Harste, Gorm (1997): Modernitet og organisation, Forlaget politisk revy, København.

Harste, Gorm \& Nils Mortensen (1996): Sociale samhandlingsteorier. I Heine Andersen og Lars Bo Kaspersen (red.): Klassisk og moderne samfundsteori, Hans Reitzels Forlag, København K.

Hatch, Mary jo (1993): The dynamics of organizational culture, pp. 657-663 in Academy of Management Review 18/4.

Hatch, Mary jo (2002): Organisationsteori - Moderna, symbolska och postmoderna perspektiv, Studentlitteratur.

Hermansen, Mads (1998): Laringens univers. Forlaget Klim, Århus.

Hermansen, Mads, Elsebeth jensen \& John Krejsler (2005): Didaktikken og individet - Når senmoderne elever skal laere. Forlaget Alinea.

Hermann, Stefan (2003): Fra styring til ledelse - om kompetencebegrebets udvikling. Undervisningsministeriets tidsskrift Uddannelse nr. 1.

Hildebrandt, Steen \& Erik Johnsen (1994): Ledelse Nu. 10 danske professorers bud på aktuel ledelse. Børsens Forlag. København.

Hildebrandt, Steen og Søren Brandi (1998): Larende organisationer - med erfaringer fra danske virksomheder. Børsens Forlag, København.

Hulin, C. L. \& M. Roznowski (1985): Organizational Technologies: Effects on Organizations 'Characteristics and Individuals' Responses. 


\section{Litteraturliste}

In L. L. Cummins \& B. M. Staw (red.): research in Organizational Behavior. Vol 7. Greenwich, Conn.: JAI Press.

Huber, G. P. (1991): Organisational learning: the contributing processes and the litteratur. In Organization Science, 2 (2): s. 88-115.

Høyrup, S. og Ellström, P.-E. (2007): Arbejdspladslaering forudsæetninger, strategi/metoder og resultater. Tema Nord 2007:576 (C)Nordisk Ministerråd.

Illeris, Knud (2000): Laring - aktuel laringsteori i spandingsfeltet mellem Piaget, Freud og Marx, Roskilde Universitetsforlag/Samfundslitteratur, Frederiksberg C.

Illeris, Knud (2003): Voksenuddannelse og voksenlæring, Roskilde Universitetsforlag Learning Lab Denmark.

Illeris, Knud (2004): Laring i arbejdslivet. Roskilde Universitetsforlag.

Illeris, Knud og Signe Berri (red.) (2005): Tekster om voksenlaring, Roskilde Universitetsforlag.

Illeris, Knud (2006): Laring. Roskilde Universitetsforlag, Frederiksberg C. Isaacs, W. N. (1993): Taking Flight: Dialogue, Collective Thinking, and Organizational Learning, A report from the Center for Organizational Learning's Dialogue Project, pp. 1-16.

Jacobsen, Jens Christian (red.) (1997): Refleksive laereprocesser, Forlaget politisk revy, København K.

Jacobsen, Dag Ingvar og Jan Thorsvik (2002): Hvordan organisationer fungerer-en indføring i organisationsteori og ledelse. Hans Reitzels Forlag. Jank, Werner \& Hilbert Meyer (2010): Didaktiske Modeller - grundbog i didaktik, Gyldendals lærerbibliotek, København.

Johansen, Karsten Friis (1991): Den europaiske filosofis historie -Antikken, Nyt Nordisk Forlag Arnold Busck, København K.

Just, Eva (2005): Viden og laring i sundhedsfaglige praksisfallesskaber: Fortallinger om lagers og sygeplejerskers laering i praksis. Et feltstudie. $\mathrm{Ph}$. D. afhandling. Institut for Uddannelse, Læring og Filosofi, Aalborg Universitet, 2005. $358 \mathrm{~s}$.

Jönhill, Jan Inge (1997): Samhället som system och dess ekologiska omväld - En studie i Niklas Luhmanns sociologiska systemteori, Lund Dissertations in Sociology 17, Sociologiska institutionen, Lund Universitet, Lund.

Jönhill, Jan Inge (2003): Communications with decisions as medium and form - some notes on Niklas Luhmanns̀ theory of organization, pp. 23-30 in Autopoietic organization theory - Drawing on Niklas Luhmannś Social Systems Perspective, Edited by Tore Bakken and Tor Hernes, Abstrakt forlag, Oslo. 
Jönhill, Jan Inge (2012): Inklusion och exclusion - En distinction som gör skillnad i det mångkulturella samhället. Liber AB, Malmö.

Jørgensen, Marianne W. \& Louise Phillips (1999): Diskursanalyse som teori og metode. Samfundslitteratur/Roskilde Universitetsforlag, Frederiksberg.

Jørgensen, Torben Beck \& Melander, Preben (red.) (1999): Livet $i$ offentlige organisationer - Institutionsdrift i spcendingsfeltet mellem stat, profession og marked, Jurist- og Økonomforbundets Forlag, København.

Jørgensen, Kenneth Mølbjerg (2005): Serieproduktion eller kundeorientering? - organisatorisk på en produktionsvirksomhed. IKenneth Mølbjerg Jørgensen og Palle Rasmussen (red.): Forandringsprojekter som organisatorisk læring. Aalborg Universitetsforlag, Aalborg Ø.

Jørgensen, Kenneth Mølbjerg og Palle Rasmussen (red.) (2005): Forandringsprojekter som organisatorisk laering, Aalborg Universitetsforlag, Aalborg Ø.

Jørgensen, Kenneth Mølbjerg (2007): Forandringsledelse igennem kommunikation, Milestone, $91 \mathrm{~s}$. (Den nye Industriarbejdsplads/medarbejder).

Kant, Immanuel (2002): Kritik af den rene fornuft, Det lille Forlag, Frederiksberg.

Kaspersen, Lars Bo (1995): Anthony Giddens - introduktion til en samfundsteoretiker, Hans Reitzels Forlag, København.

Keller, Hanne Dauer (2004): Kvinder mellem uddannelse og arbejde. Hvidbog om barrierer for kortuddannede kvinders deltagelse i erhvervsfaglig uddannelse. Institut for Uddannelse, Læring og Filosofi, Aalborg Universitet. Keller, Hanne Dauer (2009): Social arbejdernes læringsrum. I Annie Aarup Jensen \& Palle Rasmussen (red.): Læring og forandring - Tværfaglige prspektiver. Aalborg Universitetsforlag, Aalborg.

Kim, Daniel H. (1993): The Link between Individual and Organizational Learning. Sloan Management Review Association (Fall). (pp 37-50).

Klafki, Wolfgang (2004): Skole, teori, forskning, udvikling. Hans Reitzels Forlag.

Klausen, Kurt Klaudi (2001): Skulle det vare noget sarligt? - organisation og ledelse i det offentlige, Børsens forlag A/S, København.

Kneer, Georg \& Armin Nassehi (1997): Niklas Luhmann - introduktion til teorien om sociale systemer, Hans Reitzels Forlag, København.

Knudsen, Morten (2012): Surprised by Method: Functional Method and Systems Theory. I: Forum Qualitative Sozialforschung, Vol. 11, Nr. 3, Art. 12, 2010 
Korsnes, Olav, Andersen, Heine, Brante, Thomas (red.) (1997): Sosiologisk Leksikon, Universitetsforlaget, Oslo.

Krevi (Det Kommunale og regionale Evalueringsinstitut) \& Morten Eriksen (2009): Evaluering og laring - Vejen til en evalueringskultur. ISBN 978-87-92258-26-7 (elektronisk version). http://krevi.dk/files/Notat_ Evaluering_og_laering.pdf

Künzli, Rudolf (2000): German Didaktik: Models of Re-presentation, of Intercourse, and of Experience, In Ian Westbury, Stefan Hopmann and Kurt Riquarts (red.): Teaching as a Reflecrive Practice - The German Didaktik Tradition. Lawrence Erlbaum Associates, Publishers. Mahwah, New Jersey London.

Larsen, Henrik Holt et al. (2006): Kompetenceudvikling og videnmedarbejdere i staten - praksis, problemer og perspektiver. Forlaget Valmuen.

Larsen, Henrik Holt (2007): Laringsmilj $i$ staten - hvad, hvorfor og hvordan? København: CFU - Statens Center for Kompetence- og Kvalitetsudvikling.

Laursen, Per Fibæk (1997): Refleksivitet $i$ didaktikken, i Jens Christian Jacobsen (red.): Refleksive lacreprocesser, Forlaget politisk revy, København K.

Law, J. (1987): Technology and Heterogeneous Engineering. The Case of Portuguese Expansion. In W. E. Bijker, T. P. Hughes \& T. J. Pinch (red.): The Social Construction of Technological Systems. Cambridge, Mass.: MIT Press. Leymann, Heinz \& H. Kornbluh (Red.) (1989): Socialization and Learning at Work. A new approach to the Learning Process in the Workplace and Society. Aldershot Hants: Gower Publishing Avebury.

Lave, Jean \& Etienne Wenger (1994): Situated learning - Legitimate peripheral participation, Cambridge University Press.

Lave, Jean (1999): Laering, mesterlare og social praksis. I Klaus Nielsen \& Steinar Kvale (red.): Mesterlære: Læring som social praksis. Hans Reitzels Forlag A/S.

Levitt, B. \& March, J. G. (1988): Organizational learning, Annual Review of Sociology, 14, s. 319-340.

Luhmann, Niklas \& Karl Eberhard Schorr (1979): Das Technologiedefizit der Erziehung und die Pädagogik. I Zeitschrift für Pädagogik, Heft 3.

Luhmann, Niklas (1982): The Differentiation of Society, Columbia University Press, New York.

Luhmann, Niklas (1989): Ecological Communication, Polity Press, Cambridge. 
Luhmann, Niklas (1990a): Essays on Self-Reference, Columbia University Press, New York.

Luhmann, Niklas (1990b): Political theory in the welfarestate, Berlin; New York: de Gruyter \& Co.

Luhmann, Niklas (1990c): Technology, environment and social risk: a systems perspective. In Organization Environment September 1990 vol. 4 no. 3 223-231.

Luhmann, Niklas (1991): Soziologische Aufklärung 1. Opladen, Westdeutscher Verlag.

Luhmann, Niklas (1992): Die Wissenschaft der Gesellschaft. Suhrkamp Taqschenbuch Verlag, Frankfurt am Main.

Luhmann, Niklas (1993): Soziologische Aufkläring 5 - Konstruktivistische Perspektiven, Westdeutscher Verlag, Opladen.

Luhmann, Niklas (1995a): Autopoesis II - udvalgte tekster af Niklas Luhmann, Redigeret af Jens Christian Jacobsen, Forlaget Politisk Revy, København.

Luhmann, Niklas (1995b): Inklusion og Eksklusion, oversættelse af Nils Mortensen af Niklas Luhmann, Inklusion und Exclusion, pp. 237-264 in Sociologische Aufklärung 6, Opladen, West Deutscher Verlag.

Luhmann, Niklas (1995c): Økologisk kommunikation. Kan det moderne samfund indstille sig på фkologiske farer? I Jens Christian Jacobsen (Red.): Autopoiesis II - udvalgte tekster af Niklas Luhmann. Politisk Revy, København.

Luhmann, Niklas (1995d): Soziologische Autklärung 6-Die Soziologie und der Mensch, Westdeutscher Verlag, Opladen.

Luhmann, Niklas (1995e): The paradox of system differentiation and the evolution of society. In Alexander \& Colomy (eds.): Differentiation Theory and Social Change. New York: Colombia University Press.

Luhmann, Niklas (1996): Complexity, Structural Contingencies and Value Conflicts, pp. 59-71 In Detraditionalization-Critical Reflections on Authority and Identity, Edited by Paul Hellas, Scott Lash and Paul Morris, Blackwell Publishers Ltd., Cambridge, Massachusetts.

Luhmann, Niklas (1997a): Die Gesellschaft der Gesellschaft, bd. 1-2. Frankfurt an Main, Suhrkamp.

Luhmann, Niklas (1997b): Limits of Steering. I Theory, Culture \& Society - Explorations in Critical Social Science - Volume 14, Number 1.

Luhmann, Niklas (1997c): Globalization or World society: How to concieve of modern society? International Review of Sociology, mar 97, vol. 7 issue 1, p.67, 13p. 
Luhmann, Niklas (1997d): Barnet som medie for opdragelsen" i Cederstrøm et al. (red.): Laring, Samtale, Organisation - Luhmann og skolen, Unge pædagoger, København.

Luhmann, Niklas (1998): Observations of modernity, Standford University press, California

Luhmann, Niklas (2000a): Sociale systemer - Grundris til en almen teori, Hans Reitzels forlag, København.

Luhmann, Niklas (2000b): Organisation und Entscheidung, Westdeutscher Verlag GmbH, Opladen/Wiesbaden.

Luhmann, Niklas \& Karl-Eberhardt Schorr (2000c): Problems of reflection in the System of Education. Waxmann, Münster.

Luhmann, Niklas (2002a): Theories of Distinktion - Redescribing the descriptions of modernity, Edited by William Rasch, Stanford University Press, California.

Luhmann, Niklas (2002b): What is Communication?, pp. 155-168 In Theories of Distinktion - Redescribing The Descriptions of Modernity, Edited by William Rasch, Stanford University Press, California.

Luhmann, Niklas (2002c): How Can the Mind Participate in Communication?, pp. 169-186 In Theories of Distinktion - Redescribing The Descriptions of Modernity, Edited by William Rasch, Stanford University Press, California. Luhmann, Niklas (2003a): Organization, pp. 31-52 in Autopoietic organization theory, Edited by Tore Bakken and Tor Hernes, Abstrakt forlag, Oslo.

Luhmann, Niklas (2003b): Beslutningens paradoks, pp. 35-61 in Organiseret kommunikation - systemteoretiske analyser, Redigeret af Holger Højlund og Morten Knudsen, Samfundslitteratur, København.

Luhmann, Niklas (2006): Samfundets uddannelsessystem, Hans Reitzels Forlag, Kфbenhavn.

Luhmann, Niklas (2007): Indføring $i$ systemteorien. Unge Pædagoger. København $\varnothing$.

Luhmann, Niklas (2008): Risk: A Sociological Theory. Walter de Gruyter. Berlin, New York.

Luhmann, Niklas (2009): Økologisk kommunikasjon, Cappelens upopulære skrifter, Cappelen Akademisk Forlag.

Lübcke, Poul (1995): Politikens bog om Politiske Ideer. En grundbog om liberalisme og socialisme. Politikens Forlag, København.

Lyon, David (1995): Postmodernitet - en introduktion. Det lille Forlag, Frederiksberg. 
Lyotard Jean-Francois (1982): Viden og det postmoderne samfund. København.

Lyotard Jean-Francois (1984): The Postmoern Condition.University of Minnesota Press edition.

Mannaz (2010): Effektive laringsformer - der skaber bedre laringsformer for din virksomhed. http://www.effektivelaeringsformer.dk/wpcontent/uploads/dea-noca-mannaz-brochure-web.pdf

March, James G. and Olsen, Johan P. (1988): The Uncertainty of the Past: Organizational Learning under Ambiguity. Decisions and Organizations. Basil Blackwell Inc. Oxford.

March, James G. (1995): Fornuft og forandring - ledelse i en verden beriget af uklarhed, Samfundslitteratur, København.

March, James G. (2005): Valg, vane og vision - perspektiver på aspiration og adfcerd, Forlaget Samfundslitteratur, Frederiksberg C.

Maturana, Humberto og Francisco Varela (1987): Kundskabens trae - Den menneskelige erkendelses biologiske rødder. Forlaget Ask.

Mejlby, P., Nielsen, K.U., \& Schultz, M. (1999): Introduktion til organisationsteori-med udgangspunkt i Scotts perspektiver, Samfundslitteratur.

Moe, Sverre (1995): Sosiologisk Betraktning - en systemteoretisk innføring, Universitetsforlaget, Oslo.

Moe, Sverre (1998): Den moderne hjelpens sosiologi: velferd $i$ systemteoretisk perspektiv. Sandnes: Apeiros.

Moe, Sverre (1999): Luhmanns evolusjonsteori, forelæsning ved forskerkurs Troms $\varnothing$ september 1999.

Moe, Sverre (2003): Tid for Luhmann - En studie av tidens betydning $i$ Niklas Luhmanns systemteori og samfundsanalyse. Avhandling for Dr. philos.graden, ISBN 82-91636-10-9, Institut for sosiologi, Det samfundsvitenskabelige fakultet, Universitetet i Troms $\varnothing$.

Morgan, Garreth (1993): Images of organizations. Sage Publications, Inc.

Morsing, M. and Schultz, M. (2006): Corporate social responsibility communication: stakeholder information, response and involvement strategies. Business Ethics: a European Review, 15(4), pp. 323-338

Mortensen, Nils (1996): Narcissisme og autopoiesis - et Luhmannsk blik på den moderne individualitet. Grus, Årg. 17, nr. 50. s. 25-41.

Mortensen, Nils (1997): Struktur- og aktørproblemet $i$ systemteoretisk belysning, Dansk Sociologi, 8. årgang, nr. 2, s. 21-36.

Mortensen, Nils (2004): Det paradoksale samfund, Hans Reitzels Forlag, København k. 
Moesby-Jensen, Cecilie K. (2010): Social lacing og faelles praksis Et mixed method studie, der belyser laringskonsekvenser af et lederkursus for et praksisfallesskab af offentlige mellemledere, Handelshøjskolen, Frederiksberg.

Munk, Merete (2002): Mesterlaere retur, Unge Pædagoger, København Ø. Naisbitt, John (1982): Megatrends. Ten New Directions Transforming Our Lives, Warner Books.

Nielsen, Søren Overgaard \& Steen Vallentin(2003): Organisation og samfund - mellem systemteori og neoinstitutionel teori. I Højlund, Holger \& Morten Knudsen (red.): Organiseret kommunikation - systemteoretiske analyser. Samfundslitteratur, Frederiksberg C.

Nielsen, Kent (2005): Effekten af en erhvervspolitisk satsning - Effektevaluering af Viborg Amts erhvervspolitiske programmer - Udviklingskompas og Chef til leje. Udgivet af Viborg Amt Erhvervsfremmekontoret.

Nielsen, Klaus og Steiner Kvales (red.) (1999): Mesterlare - Laring som social praksis. Hans reitzels Forlag A/S, København.

Nielsen, Klaus \& Steinar Kvale (red.) (2003): Praktikkens laringslandskab - at cere grennem arbejde. Akademisk Forlag A/S, København.

Nielsen, Klaus (1998): Mesterlære som læringsform. Billes $\emptyset$ og Baltzer, Værløse.

Nielsen, Klaus (1999): Musikalsk mesterlare. I Klaus Nielsen \& Steinar Kvale (red.) Mesterlære: Læring som social praksis. Hans Reitzels Forlag A/S. s. 130-147.

Nielsen, Klaus (2008): Laring og udvikling: situeret laring og ledelse. I Erik Elgaard, Lise Hounsgaard, Birgit Ryberg og Frode Boye Andersen (red.): Ledelse og laring - $i$ organisationer. Hans Reitzels Forlag, København K.

Nissen, Maria Appel \& Henrik Vardinghus-Nielsen (2007): Diskurs eller ekskurs - diskursanalysens sociologiske muligheder og begransninger, i Rasmus Antoft, Michael Hviid Jacobsen, Anja Jørgensen \& Søren Kristiansen (red.) 'Håndværk og horisonter-Tradition og nytænkning i kvalitativ metode', Syddansk Universitetsforlag, Odense M.

Nonaka, I., \& H. Takeuchi (1995): The Knowledge-Creating Company - How Japanese Companies Create the Dynamics of Innovation, Oxford University Press, New York.

Normann, R. (1985): Developing capabilities for organizational learning, In J. M. Pennings (red.), Organizational Strategy and Change (pp. 217-48). San Francisco, CA: Jossey-Bass.

Nørager, Troels (1995): System og Livsverden - Habermas' konstruktion af det moderne, Forlaget ANIS, Aarhus. 
Oettingen, Alexander von (2010): Almen paedagogik - paedagogikkens grundlaggende spфrgsmål. Gyldendalske Boghandel, Nordisk Forlag A/S, København.

Outhwaite, William (1997): Habermas - en kritisk introduktion, Hans Reitzels Forlag, København.

Pahuus, Mogens (1989): Mennesket og dets udtryksformer - Fra bevidsthedsparadigme til kommunikationsparadigme - en antologi, Philosophia.

Parsons, Talcott (1935): The Place of Ultimate Values in Sociological Theory, International Journal of Ethics, Vol.45. pp. 282-316.

Parsons, Talcott (1951a): The Social System, Free Press, New York.

Parsons, T., \& E. Shils (red.) (1951): Toward a General Theory of Action, Harvard University Press, Cambridge, Mass.

Paulsen, Michael (2008): Laring og organisation, i Jesper Tække og Michael Paulsen (red.): Luhmann og organisation. Forlaget UP - Unge Pædagoger, København.

Pedersen, Lene Tanggaard (2003): Laeringsbaner igennem elektronikken. I Klaus Nielsen \& Steinar Kvale (red.): Praktikkens læringslandskab - at lære gennem arbejde. Akademisk Forlag, København.

Polanyi, M. (1966): The Tacit Dimension, Glouchester, Mass: Peter Smith. Prange, C. (1999): Organizational learning - desperately seeking theory? In Mark Easterby-Smith, John Burgoyne and Luis Araujo (red.): Organizational Learning and the Learning Organization - Developments in thepry and practice, SAGE Publications Inc., London.

Qvortrup, Lars (1996): Mellem kedsomhed og dannelse - variationer over et tema af Pico, Odense Universitetsforlag.

Qvortrup, Lars (1998): Det Hyperkomplekse Samfund - 14 fortcellinger om informationssamfundet, Gyldendalske Boghandel, Nordisk forlag A/S København.

Qvortrup, Lars (1998a): Den laerende organisation, pp. 201-226 in Padagogiske teorier, Redigeret af Niels Jørgen Bisgaard, Billes $\varnothing$ \& Baltzer, Værløse.

Qvortrup, Lars (2001): Det laerende samfund - Hyperkompleksitet og viden, Gyldendalske Boghandel, Nordisk Forlag A/S, København.

Qvortrup, Lars (2006): Introduktion til Niklas Luhmanns padagogiske teori, i Niklas Luhmann samfundets uddannelsessystem, Hans Reitzels Forlag, København.

Rasborg, Klaus (1996): Det sociologiske paradigme - sociologien om det moderne og postmoderne samfund, Forlaget Sociologi, København K. 
Rasmussen, Jens (1996): Socialisering og laring $i$ det refleksivt moderne, Unge Pædagoger, København.

Rasmussen, jens (1999): Mesterlare og den almene padagogik, i Steiner Kvale \& Klaus Nielsen (red.): Mesterlære - Læring som social praksis, Hans Reitzels Forlag, København. (s. 199-218)

Rasmussen, Jens (2000): En introduktion, i Niklas Luhmann Sociale systemer - Grundrids til en almen teori, Hans Reitzels Forlag, København K.

Rasmussen, Jens (2004): Undervisning $i$ det refleksivt moderne - Politik, profession, paedagogik, Hans Reitzels forlag, København.

Rasmussen, Jens, Søren Kruse \& Claus Holm (2007): Viden om uddannelse - Uddannelsesforskning, padagogik og paedagogisk praksis, Hans Reitzels Forlag, København.

Rennison, Betina Wolfgang (2003): Polyfonisk lønkommunikation. I Holger Højlund \& Morten Knudsen (red.) Organiseret kommunikation: systemteoretiske analyser. Samfundslitteratur, København. s. 207-231.

Roth, George L. (1996): Laerehistorier: Dokumentation som middel til bedømmelse af stфtte for laring i organisationer. I Mette Morsing og Bolette Christensen (Red.): Lærings processer i virksomheden. Dansk Industri.

Røvik, Kjell Arne (1998): Moderne organisasjoner - Trender i organisasjonstenkningen ved tusenårsskiftet. Fagbokforlaget Vigmostad \& Bjørke A/S.

Schein, Edgar H. (1993): Organisationskultur og ledelse - et dynamisk perspektiv, Forlaget Valmuen, København.

Schein, Edgar H. (1996): Three Cultures of Management: The Key to Organizational Learning, MIT Sloan Management Review 14 pages. Publication date: Oct 01, 1996. Prod. \#: SMR022-PDF-ENG

Schein, Edgar H. (2010): Three Cultures of Management: The Key to Organizational Learning. In Barbara Bertagni, Michele La Rosa, Fernando Salvetti (red.): Glocal working - Living and working across the world with cultural intelligence, Sociology of work, Franco Angeli.

Schnack, Karsten (2001): Didaktik. I Muschinsky, L \& Schnack, K (red.): Pædagogisk opslagsbog. København.

Schultz, Maiken (1993): Kultur i organisationer - Funktion eller symbol, Handelshøjskolens Forlag, København.

SCKK (Statens Center for Kompetence- og Kvalitetsudvikling) \& Henrik Holt Larsen (red.) (2007): Effektive laringsformer - En guide til praktikeren der skaber bedre resultater for din virksomhed. DEA, NOCA og 
MannazA/S. http://www.mannaz.com/wp-content/uploads/2011/02/effektivelaeringsformer.pdf

Scott, Richard W. (2003): Organizations - Rational, Natural, and Open Systems, Prentice Hall, New Jersey.

Senge, Peter M. (2000): Den Femte Disciplin - Den laerende organisations teori og praksis. Klim, Århus N.

Simon, Herbert A. (1991): Bounded rationality and Organizational Learning. In Organization Vol. 2, No. 1, Special issue: Organizational Learning: Paper in Honor of (and by) James G. March, pp. 125-134.

Swiringa, J. \& A. Wierdsma (1994): Becoming a Learning Organization. Addison-Wesley Publishing Company.

Säljö, Roger (2003): Laring i praksis - et sociokulturelt perspektiv, Hans Reitzels Forlag, København.

Tangen, J. O. (1997): Samfunnets idrett. En sosiologisk analyse av idrett som sosialt system, dets evolusjon og funksjon fra arkaisk til moderne tid. Dr. philos. avhandling, Inst for sosiologi og samfunnsgeografi, Universitetet i Oslo.

Taylor, Frederick Winslow (1998): The Principles of Scientific Management. Courier Dover Publications Inc.

Thygesen, Niels Thyge \& Niels Åkerstrøm Andersen (2007): The Polyphonic Effects of Technological Changes in Public Sector Organizations: A System Theoretical Approach. In ephemera - theory \& politics in organization, volume 7(2): 326-345.

Thyssen, Ole (1991): Penge, magt og kaelighed - Teorien om symbolsk generaliserede medier hos Parsosns, Luhmann og Habermas. Rosinante/Munksgaard, København.

Thyssen, Ole (1994): Kommunikation, kultur og etik, handelshøjskolens Forlag, København.

Thyssen, Ole (1995): I hinandens фjne - Bidrag til en kynisk etik, Gyldendal, København.

Thyssen, Ole (1997): Hjørnesten i Niklas Luhmanns systemteori. In iagttagelse og paradoks, Oversættelse af udvalgte essays og uddrag fra forfatterskab ved H.C. Fink, Jan Katlev og Ole Thyssen i serien Moderne Tænkere, Gyldendalske Boghandel, Nordisk Forlag A.S. København.

Thyssen, Ole (1997a): Vardiledelse - om organisationer og etik, Gyldendalske Boghandel, Nordisk forlag, København.

Thyssen, Ole (2000a): Iagttagelse og blindhed, Copenhagen Business School Press, handelshøjskolens Forlag. 
Thyssen, Ole (2000b): Luhmann og sporten. In: Distinktion: Scandinavian Journal of Social Theory, No. 1, 2000, p. 49-65.

Thyssen, Ole (2006): Vardier og dannelse i folkeskolen. I Bjarne Gorm Hansen \& Annalisa Tams (red.): Almen didaktik - Relationer mellem undervisning og læring. Billes $\varnothing$ \& Baltzer, Værløse.

Tsang, Eric W. K. (1997): Organizational Learning and the Learning Organization: A Dichotomy between Descriptive and Prescriptive Research. Human Relations, 50 (1) : s. 73-89.

Undervisningsministeriet (2007): Danmarks strategi for livslang læring Uddannelse og livslang opkvalificering for alle, Redegørelse til EU-kommissionen april 2007. http://pub.uvm.dk/2007/livslanglaering/livslanglaering.pdf

Weber, Max (2003): Max Weber - Udvalgte tekster - Bind $1 \&$ 2. Hans Reitzels Forlag, København K.

Weick, Karl E. (1990): Technology as Equivoque: Sensemaking in new technologies. InPaul S. Goodman \& Lee S. Sproull (red.): Technology and Organizations. Jossey-Bass Publishers, San Francisco. (s. 1-44)

Weick, Karl E. \& K. H. Roberts (1993): Collective mind in organizations: heedful interrelating on flight decks. In Administrative Science Quarterly, 38/3: s. 357-381.

Weick, Karl E. \& Frances Westley (1996): Organizational Learning Affirming an Oxymoron, pp. 440-458 in Handbook of organization studies, Edited by Steward R. Clegg, Cynthia Hardy, Walter R. Nord.

Wenger, Etienne (2004): Praksis fallesskaber - Laring, mening og identitet. Hans Reitzels Forlag, København.

Wenger, Etienne (2009): Social laeringsteori - aktuelle temaer og udfordringer, i Knud Illeris (red.): Laringsteorier - 6 aktuelle forståelser, Roskilde Universitetsforlag, Frederiksberg C.

Windinge, Henrik (2006): Skole og skoleudvikling som ramme om didaktikken, i Bjarne Gorm Hansen \& Annalisa Tams (red.): Almen didaktik Relationer mellem undervisning og laring, Billesø \& Baltzer, Værløse.

Vardinghus-Nielsen, H. \& Nissen, Maria Appel (2002): Hvad skabes der $i$ skolebestyrelserne? - En analysemodel til iagttagelse af sociale systemers meningsdannelse, pp. 145-162. In Jens Rasmussen (red.): Luhmann anvendt. Unge Pædagoger, København.

Vera, Dusya \& Mary Crossan (2005): Organizational learning and Knowledge Management: Toward an Integrative Framework. In Mark EasterbySmith and Marjorie A. Lyles (red.): Handbook of Organizational Learning and Knowledge Management. Blackwell Publishing Ltd. 
Ziehe, Thomas (1989): Ambivalenser og mangfoldighed - en artikelsamling om ungdom, skole, astetik og kultur, redigeret af Johan Fornäs og Elo Nielsen, oversat af Hans Christian Fink, Forlaget Politisk revy, København.

Ziehe, Thomas (1997): Om prisen på selv-relationel viden - Afmystificeringseffekter for padagogik, skole og identitetsdannelse. I Jens Christian Jacobsen (red.): Refleksive læreprocesser, Forlaget Politisk revy, København K.

Aasen, Peter (1997): Pedagogikk og refleksiv modernitet, i Jens Christian Jacobsen (red.): Refleksive læreprocesser, Forlaget politisk revy, København K. 
